\title{
Copper-Hydride-Catalyzed Enantioselective Processes with Allenyl Boronates. Mechanistic Nuances, Scope, and Utility in Target-Oriented Synthesis
}

\author{
Yu Sun, ${ }^{1}$ Yuebiao Zhou, ${ }^{1}$ Ying Shi, ${ }^{1}$ Juan del Pozo, ${ }^{1}$ Sebastian Torker ${ }^{1,2} \&$ Amir H. Hoveyda*1,2 \\ ${ }^{I}$ Department of Chemistry, Merkert Chemistry Center, Boston College, Chestnut Hill, Massachusetts 02467, USA \\ ${ }^{2}$ Supramolecular Science \& Engineering Institute, University of Strasbourg, CNRS, 67000 Strasbourg, France \\ e-mail: $\underline{\text { amir.hoveyda@bc.edu or ahoveyda@unistra.fr }}$
}

\section{SuPPLEMENTARY INFORMATION}

\section{Table of Contents}

1 General

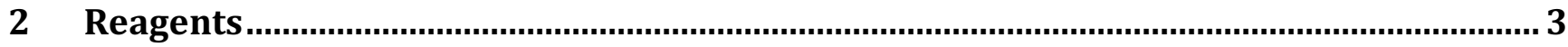

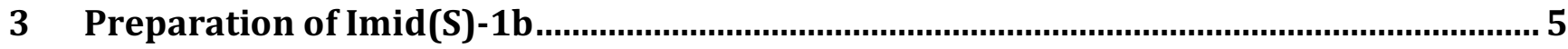

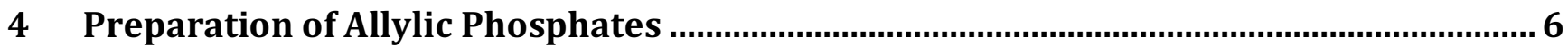

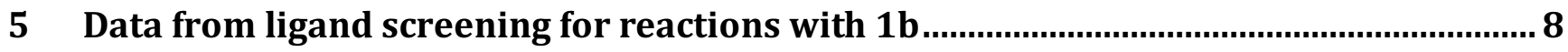

6 Procedure for $\mathrm{Cu}-\mathrm{H}-$-Catalyzed Multicomponent Allylic Substitutions............................... 8

7 Products with a Tertiary Carbon Stereogenic Center............................................................ 8

8 Products with a Quaternary Carbon Stereogenic Center.....................................................19

9 Procedure for Polar Functional Group Compatibility Experiments.................................25

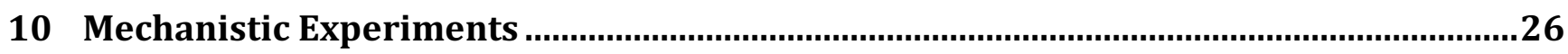

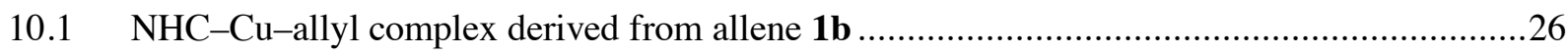

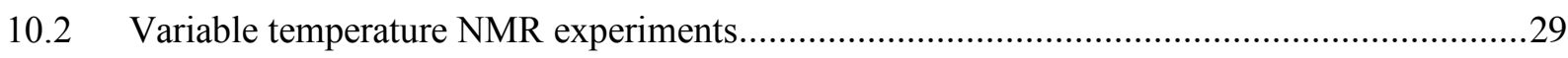

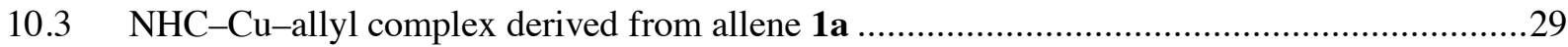

$10.4 \mathrm{~B} / \mathrm{Cu}$ exchange between organoboron compounds and $\mathrm{NHC}-\mathrm{Cu}-\mathrm{O} t-\mathrm{Bu}$ complexes ..............32

10.5 Competition experiments between vinyl-B(pin) and allenyl-B(pin) compounds 1a and $\mathbf{1 b}$....35

10.6 Reactions with varying quantities of metal-alkoxide and PMHS ........................................37

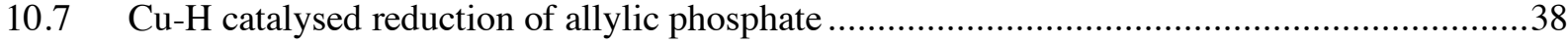

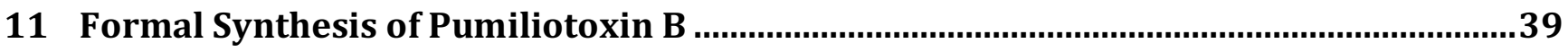


12 Synthesis of and Stereochemical Assignment for Netamine C

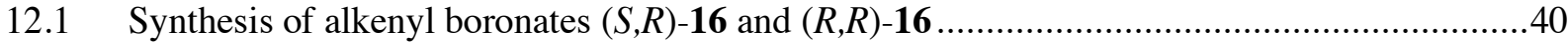

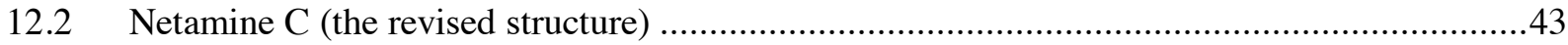

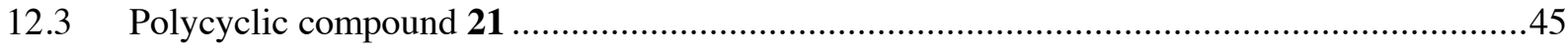

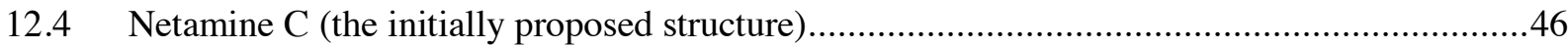

13 Comparison of Analytical Data for Natural and Synthetic Netamine C..........................49

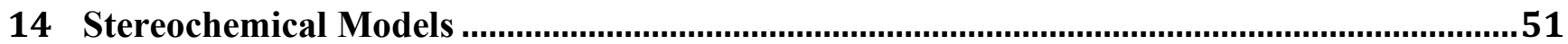

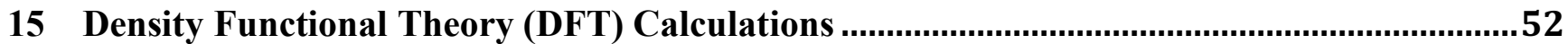

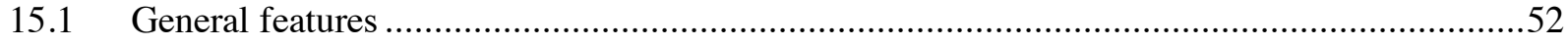

15.2 Comparison of background reactivity with enantioselective pathways ...............................53

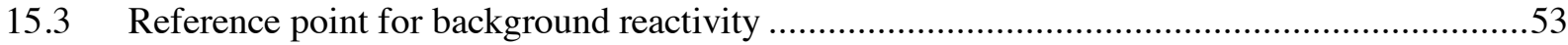

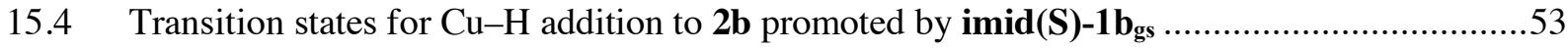

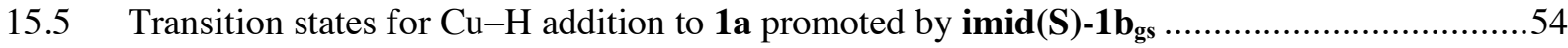

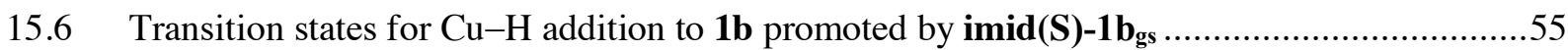

15.7 Transition states for reduction and $\mathrm{Cu}-\mathrm{H}$ addition to allenes $\mathbf{1 a}$ and $\mathbf{1 b}$ promoted by imid(S)-1ags 55

15.8 Comparison of $\mathbf{C u}-\mathrm{H}$ additions promoted by catalysts derived from imid(S)-1 $\mathbf{b}_{\mathbf{g s}}$ and $\mathbf{i m i d}(\mathbf{S})-\mathbf{1} \mathbf{a}_{\mathrm{gs}} 62$

15.9 Summary for investigation with functionals MN15, M06L, $\omega B$ 97MD, $\omega B$ 97XD and $\omega$ B97X67

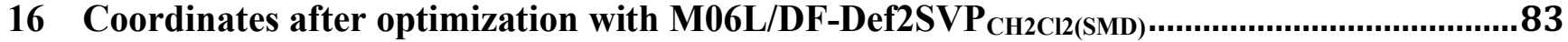

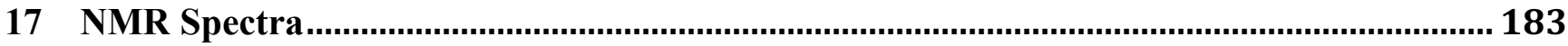

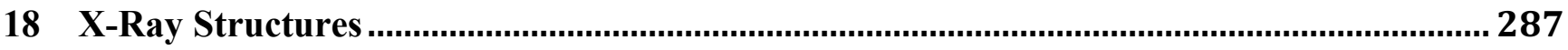

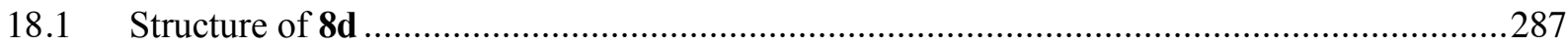

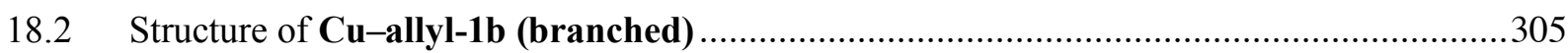

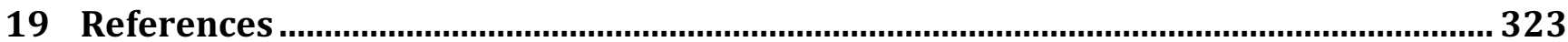




\section{General}

Infrared (IR) spectra were recorded on a Bruker FT-IR Alpha (ATR mode) spectrophotometer, $\lambda_{\max }$ in $\mathrm{cm}^{-1}$. Bands are characterized as broad (br), strong (s), medium (m), and weak (w). ${ }^{1} \mathrm{H}$ NMR spectra were recorded on a Varian Unity INOVA $400(400 \mathrm{MHz})$, Varian Unity INOVA 500 (500 MHz) or Varian Unity INOVA $600(600 \mathrm{MHz})$ spectrometer. Chemical shifts are reported in ppm from tetramethylsilane with the solvent resonance as the internal standard $\left(\mathrm{CDCl}_{3}: \delta 7.26 \mathrm{ppm}\right.$, thf $-d_{s:} \delta 3.58$ $\mathrm{ppm})$. Data are reported as follows: chemical shift, multiplicity $(\mathrm{s}=$ singlet, $\mathrm{d}=$ doublet, $\mathrm{t}=$ triplet, $\mathrm{q}=$ quartet, $\mathrm{br}=$ broad, $\mathrm{m}=$ multiplet), coupling constant $(\mathrm{Hz})$, and integration. ${ }^{13} \mathrm{C}$ NMR spectra were recorded on a Varian Unity INOVA $400(100 \mathrm{MHz})$ spectrometer, Varian Unity INOVA $500(125 \mathrm{MHz})$ or a Varian Unity INOVA 600 (150 MHz) with complete proton decoupling. Chemical shifts are reported in ppm from tetramethylsilane with the solvent resonance as the internal standard $\left(\mathrm{CDCl}_{3}: \delta 77.16 \mathrm{ppm}\right)$. High-resolution mass spectrometry was performed on a JEOL AccuTOF DART (positive mode) or ESI (positive mode) at the Mass Spectrometry Facility at Boston College. Enantiomeric ratios were determined by GC analysis (Alltech Associated alpha dex (30 m x $0.25 \mathrm{~mm}$ ) or HPLC analysis (Chiral Technologies Chiralpak AZ-H (4.6 x $250 \mathrm{~mm})$, Chiralcel OD-H (4.6 x $250 \mathrm{~mm})$, Chiralpak AD-H (4.6 x $250 \mathrm{~mm})$, Chiralcel OJ-H (4.6 x $250 \mathrm{~mm})$, Chiralcel OK (4.6 x $250 \mathrm{~mm})$, Chiralcel OZ-H (4.6 x 250 $\mathrm{mm})$, and Chiralcel OZ-3 $(4.6 \times 150 \mathrm{~mm})$ in comparison with authentic racemic materials. Specific rotations were measured on an ATAGO ${ }^{\circledR}$ AP-300 Automatic Polarimeter or a Rudolph Research Analytical Autopol IV Polarimeter.

Unless otherwise noted, all reactions were carried out with distilled and degassed solvents under an atmosphere of dry $\mathrm{N}_{2}$ in oven- $\left(135^{\circ} \mathrm{C}\right)$ or flame-dried glassware with standard dry box or vacuum-line techniques. Solvents were purified under a positive pressure of dry Ar by a modified Innovative Technologies purification system: toluene, benzene and hexanes were purified through a copper oxide and alumina column; $\mathrm{CH}_{2} \mathrm{Cl}_{2}$ and $\mathrm{Et}_{2} \mathrm{O}$ were purged with $\mathrm{Ar}$ and purified by passage through two alumina columns. Tetrahydrofuran (THF, Fisher Scientific, Inc., THF- $d_{8}$, Oakwood) was purified by distillation from sodium benzophenone ketyl immediately prior to use unless otherwise specified. Ethanol (Fisher Scientific, Inc.) was purified by distillation from Mg (Fisher Scientific) prior to use. All work-up and purification procedures were carried out in air and with reagent grade solvents (purchased from Fisher Scientific, Inc.). The glove box used was $\mathrm{N}_{2}$-filled.

\section{Reagents}

Allenylboronic acid pinacol ester (1b): purchased from TCI and used as received.

Benzylhydrazine: prepared according to previously reported procedures. ${ }^{1}$

(R)-(-)-5,5'-Bis[di(3,5-di-t-butyl-4-methoxyphenyl)phosphino]-4,4'-bi-1,3-benzodioxole (phos-1): purchased from Strem and used as received.

(-)-1,2-Bis[(2R,5R)-2,5-dimethylphospholano]benzene (phos-4): purchased from Strem and used as received. 
(-)-1,2-Bis((2R, 5R)-2,5-diphenylphospholano)ethane (phos-3): purchased from Strem and used as received.

2-(Buta-2,3-dien-2-yl)-4,4,5,5-tetramethyl-1,3,2-dioxaborolane (1a): prepared according to previously reported procedures. ${ }^{2}$

$n$-Butyllithium ( $n$-BuLi, 2.5 M in hexane): as purchased from Aldrich and used as received.

$N$-Cbz-guanidine: purchased from Combi-Blocks and used as received.

Chloroiodomethane: purchased from Oakwood and used as received.

Copper (I) chloride $(\mathbf{C u C l})$ : purchased from Strem and used as received.

1,2-Dibromoethene: purchased from TCI and used as received.

Cyanogen bromide (BrCN): purchased from Aldrich and used as received.

Dichloro(2-isopropoxyphenylmethylene) （tricyclohexylphosphine)ruthenium(II) (Ru-1): purchased from AK Scientific and used as received.

Diethyl chlorophosphate: purchased from Alfa Aesar and used as received.

$(R)-1-\left[\left(S_{\mathrm{P}}\right)\right.$-2-(Diphenylphosphino)ferrocenyl]ethyldicyclohexylphosphine (phos-2): purchased from Strem and used as received.

Diisobutylaluminum hydride (dibal-H): purchased (neat) from Aldrich and used as received.

4-Dimethylaminopyridine (DMAP): purchased from Oakwood and used as received.

$\boldsymbol{n}$-Hexylzinc bromide (0.5 M in THF): purchased from Alfa Aesar and used as received.

Hydrazine monohydrate: purchased from Aldrich and used as received.

Hydrochloric acid (HCI): purchased from Fisher and used as received.

Hydrogen peroxide (30 wt \% in $\mathrm{H}_{2} \mathrm{O}$ ): purchased from Oakwood and used as received.

Imidazolinium salt imid(O)-1: prepared according to previously reported procedures. ${ }^{3}$

Imidazolinium salt imid(S)-1b: prepared according to previously reported procedures. ${ }^{4}$

Lithium $t$-butoxide ( $\mathrm{LiO} t$-Bu): purchased from Strem and used as received.

Lithium diisopropylamide (LDA, 1.0 M in THF/hexane): purchased from Aldrich and used as received.

Lithium 2,2,6,6-tetramethylpiperidide (LTMP): purchased from Aldrich and used as received.

Complex Mo-1: prepared according to previously reported procedures. ${ }^{5}$

Platinum(IV) oxide $\left(\mathbf{P t O}_{2}\right)$ : purchased from Acros and used as received.

Poly(methylhydrosiloxane) (PMHS): purchased from Alfa Aesar and used as received.

$(\boldsymbol{R})-(+)$-Propylene oxide: purchased from TCI and used as received.

Complex Ru-2: prepared according to previously reported procedures. ${ }^{6}$

Sodium bicarbonate $\left(\mathrm{NaHCO}_{3}\right)$ : purchased from Fisher Scientific and used as received.

Sodium hydroxide (NaOH): purchased from Fisher Scientific and used as received.

Sodium methoxide (NaOMe): purchased from Strem and used as received. 
Titanium(IV) ethoxide: purchased from Strem and used as received.

Triethyl phosphonoacetate: purchased from Oakwood and used as received.

Triethylamine: purchased from Fisher Scientific and distilled over $\mathrm{CaH}_{2}$ prior to use.

p-Toluenesulfonic acid monohydrate: purchased from Oakwood and used as received.

\section{Preparation of $\operatorname{Imid}(S)-1 b$}

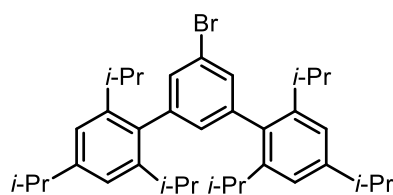

S1

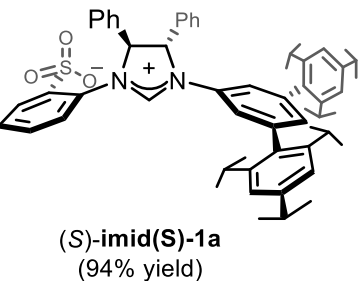

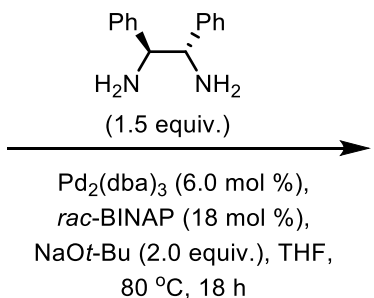

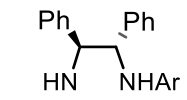

$\left(\mathrm{Ar}=3,5-(\operatorname{Trip})_{2} \mathrm{C}_{6} \mathrm{H}_{3}\right)$

S2

$(88 \%$ yield $)$
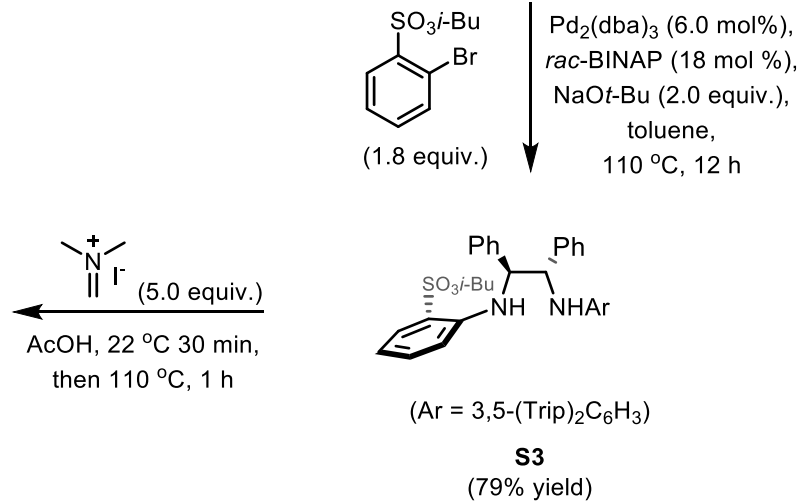

Imidazolinium salt imid(S)-1a was prepared through a gram-scale procedure, which was modified from established methods. ${ }^{7}$ Note: Although the sequence illustrated in the above scheme has been previously reported, the three-step protocol described below is significantly superior (i.e., $65 \%$ vs. $8 \%$ overall yield). Characterization data are fully consistent with those reported previously.

3,5-Bis(2,4,6-tri-iso-propylbenzene)-((1S,2S)-2-amino-1,2-diphenylethylamino)benzene (S2): A (4.24 g, $7.55 \mathrm{mmol})$, (-)-(S,S)-1,2-diphenylethylenediamine (2.41 g, $11.3 \mathrm{mmol}), \mathrm{Pd}_{2}(\mathrm{dba})_{3}(415 \mathrm{mg}$, $0.453 \mathrm{mmol}$ ), rac-BINAP (846 mg, $1.36 \mathrm{mmol})$ and $\mathrm{NaO} t$-Bu $(1.31 \mathrm{~g}, 13.6 \mathrm{mmol})$ were weighed out into a flame-dried $100 \mathrm{~mL}$ round-bottom flask in a glove box. THF (20 mL) was added, after which the flask was fitted with a reflux condenser and removed from the glove box. The mixture was allowed to stir for $18 \mathrm{~h}$ at $80{ }^{\circ} \mathrm{C}$, then allowed to cool to $22^{\circ} \mathrm{C}$. The volatiles were removed in vacuo, and the resulting red oil was loaded onto silica gel, and purified by silica gel chromatography (1:5 EtOAc:hexanes, $\left.\mathrm{R}_{\mathrm{f}} 0.2\right)$ to afford $4.61 \mathrm{~g}(6.64 \mathrm{mmol}, 88 \%)$ of $\mathbf{S 2}$ as pale yellow solid.

\section{3,5-Bis(2,4,6-tri-iso-propylbenzene)-((1S,2S)-2-((2-iso-butylsulfonyl)benzene)-amino-1,2-}

diphenylethylamino)benzene $\quad(\mathbf{S 3}): \quad$ Diamine $\quad \mathbf{S 2} \quad(5.14 \quad \mathrm{~g}, \quad 7.42 \mathrm{mmol})$, isobutyl-2bromobenzenesulfonate $(3.96 \mathrm{~g}, 13.5 \mathrm{mmol}), \quad \mathrm{Pd}_{2}(\mathrm{dba})_{3}(407 \mathrm{mg}, 0.445 \mathrm{mmol}), \mathrm{rac}$-BINAP (739 mg, $1.19 \mathrm{mmol})$ and $\mathrm{NaO} t$-Bu $(1.43 \mathrm{~g}, 14.8 \mathrm{mmol})$ were weighed out into a flame-dried $100 \mathrm{~mL}$ round- 
bottom flask in a glove box. Toluene $(40 \mathrm{~mL})$ was added to the mixture. The flask was fitted with a reflux condenser and removed from the glove box. The mixture was allowed to stir for $12 \mathrm{~h}$ at reflux $\left(110{ }^{\circ} \mathrm{C}\right)$; it was then allowed to cool to $22{ }^{\circ} \mathrm{C}$ and then directly loaded onto silica gel, and the resulting red oil was purified by silica gel chromatography (1:9 Et $\mathrm{t}_{2} \mathrm{O}$ :hexanes, $\left.\mathrm{R}_{\mathrm{f}}=0.18\right)$ to afford $5.31 \mathrm{~g}(5.86$ mmol, 79\%) of $\mathbf{S 3}$ as pale yellow solid.

Imidazolinium salt $(\boldsymbol{S})$-imid(S)-1b: Diamine S3 (1.52 g, $1.68 \mathrm{mmol})$ and Eschenmoser's salt (1.55 g, $8.39 \mathrm{mmol}$ ) were weighed out into a screw cap vial, which was sealed with a septum and purged with $\mathrm{N}_{2}$. Acetic acid $(10.0 \mathrm{~mL})$ was added to the mixture. The mixture was allowed to stir vigorously for 30 min at $22{ }^{\circ} \mathrm{C}$ (CAUTION: the pre-stir at $22{ }^{\circ} \mathrm{C}$ is crucial for high yield and reproducibility) before it was heated to $110^{\circ} \mathrm{C}$ (the mixture becomes an orange homogeneous solution). After $1 \mathrm{~h}$, the mixture was allowed to cool to $22^{\circ} \mathrm{C}$ and diluted with $\mathrm{Et}_{2} \mathrm{O}(10 \mathrm{~mL})$ and water $(10 \mathrm{~mL})$. The solution was neutralized by slow addition of a saturated solution of aqueous $\mathrm{K}_{2} \mathrm{CO}_{3}$ solution until gas evolution ceased. The aqueous layer was washed with $\mathrm{CH}_{2} \mathrm{Cl}_{2}(4 \times 100 \mathrm{~mL})$ and the combined organic layers were dried over $\mathrm{MgSO}_{4}$, filtered, and concentrated under reduced pressure. The red oil was purified by silica gel chromatography (10:1 EtOAc:hexanes $\rightarrow 5: 1 \mathrm{CH}_{2} \mathrm{Cl}_{2}$ :acetone, $\mathrm{R}_{\mathrm{f}}=0.30$ in 3:1 EtOAc:hexanes) to afford $1.36 \mathrm{~g}(1.58 \mathrm{mmol}, 94 \%)$ of $(S)$-imid(S)-1b as white solid.

\section{Preparation of Allylic Phosphates}

Allylic alcohols were synthesized from the corresponding esters by Horner-Wadsworth-Emmons olefin synthesis/dibal-H reduction sequence. Subsequently, allylic alcohols were converted to the corresponding allylic phosphates by established methods. ${ }^{8,9}$ The following substrates were prepared according to the above sequence. Characterization data are fully consistent with those reported previously.

(E)-But-2-en-1-yl diethyl phosphate (2a) ${ }^{10}$

$(E)$-Diethyl 3-phenylprop-2-enyl phosphate (2b) ${ }^{11}$

(E)-Diethyl (3-(4-(trifluoromethyl)phenyl)allyl) phosphate (2c) ${ }^{7}$

(E)-3-(3-Bromophenyl)allyl diethyl phosphate (2d) ${ }^{12}$

(E)-Diethyl (3-(3-methoxyphenyl)allyl) phosphate (2e) ${ }^{13}$

(E)-Diethyl (3-(naphthalen-1-yl)allyl) phosphate (2f) $)^{14}$

(E)-Diethyl (3-(2-methoxyphenyl)allyl) phosphate (2g) ${ }^{12}$

(E)-Diethyl (3-(furan-2-yl)allyl) phosphate (2h): IR (neat): 2982 (w), 2930 (w), 2907 (w), 1488 (w), 1391 (w), 1269 (s), 1152 (w), 1027 (s), 963(s), 798 (w), 740 (w) cm ${ }^{-1} ;{ }^{1} \mathbf{H}$ NMR (500 MHz, CDCl $): \delta$ $7.36(\mathrm{~s}, 1 \mathrm{H}), 6.49(\mathrm{~d}, J=15.8 \mathrm{~Hz}, 1 \mathrm{H}), 6.37(\mathrm{~s}, 1 \mathrm{H}), 6.29(\mathrm{~d}, J=3.0 \mathrm{~Hz}, 1 \mathrm{H}), 6.22$ (dt, $J=15.8,6.1 \mathrm{~Hz}$, $1 \mathrm{H}), 4.66(\mathrm{t}, J=7.2 \mathrm{~Hz}, 2 \mathrm{H}), 4.13(\mathrm{p}, J=7.1 \mathrm{~Hz}, 4 \mathrm{H}), 1.34(\mathrm{t}, J=6.7 \mathrm{~Hz}, 6 \mathrm{H}) ;{ }^{13} \mathbf{C}$ NMR (151 MHz, $\left.\mathbf{C D C l}_{3}\right): \delta 142.6,122.2,122.2,121.9,111.5,109.2,67.6\left(\mathrm{~d}, J_{\mathrm{CP}}=5.2 \mathrm{~Hz}\right), 63.96\left(\mathrm{~d}, J_{\mathrm{CP}}=5.8 \mathrm{~Hz}\right), 16.27$ $\left(\mathrm{d}, J_{\mathrm{CP}}=6.8 \mathrm{~Hz}\right)$; HRMS (ESI+): Calcd for $\mathrm{C}_{11} \mathrm{H}_{17} \mathrm{PO}_{5}[\mathrm{M}+\mathrm{H}]^{+}:$260.0808; Found: 260.0808 .

(E)-Diethyl (3-(1-tosyl-1H-indol-3-yl)allyl) phosphate (2i) ${ }^{15}$

(E)-Diethyl (5-phenylpent-2-en-1-yl) phosphate $(2 \mathrm{j} \text {, precursor to } 3 \mathrm{j} \text { and } 5 \mathrm{~b})^{7}$ 
Cyclopent-1-en-1-ylmethyl diethyl phosphate (2k): IR (neat): 2979 (w), 2933 (w), 2847 (w), 1261 (m), 1164 (w), 1021 (s), 977 (s), 800 (w), 515 (w) cm ${ }^{-1},{ }^{1}$ H NMR (600 MHz, CDCl $)$ ): $\delta 5.72$ (d, $J=1.9$ $\mathrm{Hz}, 1 \mathrm{H}), 4.57$ (d, J=7.3 Hz, 2H), 4.10 (p, J=7.2 Hz, 4H), 2.35 (t, J=7.4 Hz, 4H), 1.91 (p, J=7.5 Hz, 2H), $1.33(\mathrm{t}, J=7.1 \mathrm{~Hz}, 6 \mathrm{H}) ;{ }^{13} \mathbf{C}$ NMR (151 MHz, $\left.\mathbf{C D C l}_{3}\right): \delta 139.6\left(\mathrm{~d}, J_{\mathrm{CP}}=7.0 \mathrm{~Hz}\right), 129.2,66.3(\mathrm{~d}$, $\left.J_{\mathrm{CP}}=5.8 \mathrm{~Hz}\right), 63.8\left(\mathrm{~d}, J_{\mathrm{CP}}=5.8 \mathrm{~Hz}\right), 32.6,32.5,23.4,16.3\left(\mathrm{~d}, J_{\mathrm{CP}}=6.7 \mathrm{~Hz}\right)$; HRMS (ESI+): Calcd for $\mathrm{C}_{10} \mathrm{H}_{20} \mathrm{PO}_{4}[\mathrm{M}+\mathrm{H}]^{+}:$235.1094; Found: 235.1093 .

Cyclohex-1-en-1-ylmethyl diethyl phosphate (2l, precursor to 31 and $5 h)^{16}$

(E)-3-Cyclohexylallyl diethyl phosphate $(2 \mathrm{~m} \text {, precursor to } 5 \mathrm{c})^{12}$

(E)-Diethyl (3-(thiophen-2-yl)allyl) phosphate (2n, precursor to 5g) $)^{17}$

(S)-Diethyl ((4-(prop-1-en-2-yl)cyclohex-1-en-1-yl)methyl) phosphate (2o, precursor to 5i and 5j) ${ }^{16}$

(E)-Diethyl (3-phenylbut-2-en-1-yl) phosphate (11a, precursor to 8 b and 12a) ${ }^{18}$

(E)-3,7-Dimethylocta-2,6-dien-1-yl diethyl phosphate (11b, precursor to 8a $)^{18}$

(E)-3-(3-Chlorophenyl)but-2-en-1-yl diethyl phosphate (11c, precursor to 8c): IR (neat): 2980 (w), 2905 (w), 1591 (w), $1561(\mathrm{w}), 1475$ (w), 1371 (w), 1260 (m), 1165 (w), 1005 (s), 972 (s), 877 (m), 779

(m), $690(\mathrm{~m}) \mathrm{cm}^{-1} ;{ }^{1} \mathbf{H}$ NMR (400 MHz, $\left.\mathbf{C D C l}_{3}\right): \delta 7.36(\mathrm{~s}, 1 \mathrm{H}), 7.27-7.21(\mathrm{~m}, 3 \mathrm{H}), 5.93(\mathrm{t}, J=6.83$ $\mathrm{Hz}, 1 \mathrm{H}), 4.73(\mathrm{t}, J=7.63 \mathrm{~Hz}, 2 \mathrm{H}), 4.16-4.07(\mathrm{~m}, 4 \mathrm{H}), 2.07(\mathrm{~s}, 3 \mathrm{H}), 1.35-1.30(\mathrm{~m}, 6 \mathrm{H}) ;{ }^{13} \mathrm{C}$ NMR (101 $\left.\mathbf{M H z}, \mathbf{C D C l}_{3}\right): \delta 144.3,139.1,134.4,129.6,127.7,126.2,124.1,123.2\left(\mathrm{~d}, J_{\mathrm{CP}}=7.0 \mathrm{~Hz}\right), 64.2\left(\mathrm{~d}, J_{\mathrm{CP}}=\right.$ $5.4 \mathrm{~Hz}), 63.9\left(\mathrm{~d}, J_{\mathrm{CP}}=5.9 \mathrm{~Hz}\right), 16.2,16.2\left(\mathrm{~d}, J_{\mathrm{CP}}=6.7 \mathrm{~Hz}\right)$; HRMS (ESI+): Calcd for $\mathrm{C}_{14} \mathrm{H}_{20} \mathrm{PNaClO}_{4}$ $[\mathrm{M}+\mathrm{Na}]^{+}:$341.0680; Found: 341.0685 .

(E)-Diethyl (3-(4-(trifluoromethyl)phenyl)but-2-en-1-yl) phosphate (11d, precursor to 8d and 12b) ${ }^{18}$

(E)-Diethyl (3-(thiophen-2-yl)but-2-en-1-yl) phosphate (11e, precursor to 8e) ${ }^{19}$

(E)-Diethyl (3-methyl-5-phenylpent-2-en-1-yl) phosphate (11f, precursor to 8f and 12c) ${ }^{20}$

(E)-3-Cyclohexylbut-2-en-1-yl diethyl phosphate (11g, precursor to $8 \mathrm{~g}$ and $12 \mathrm{~d})^{18}$ 


\section{Data from ligand screening for reactions with $\mathbf{1 b}$}

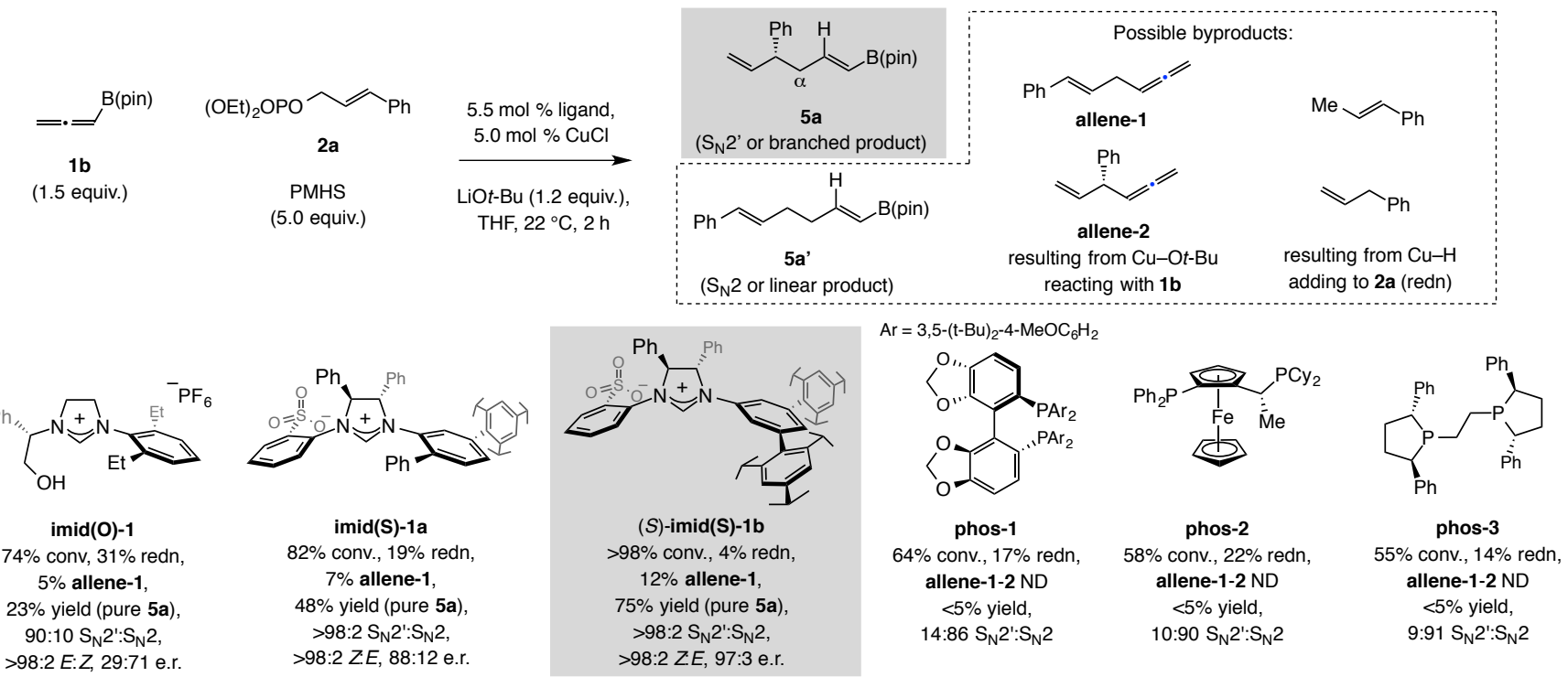

As observed with the transformations that involve 1,1-disubstituted allenyl-B(pin) 1a, the only the $\mathrm{Cu}$ complex derived from imid(S)-1b proved to be effective. Under these conditions, resulting in only $4 \%$ of the reduction byproduct, the desired 1,5-diene 5a was obtained in 75\% yield, as a single alkene isomer, and in 97:3 er Also as before, various chiral P-based ligands proved to be entirely ineffective, generating 5a' as the major product.

\section{Procedure for $\mathrm{Cu}-\mathrm{H}-\mathrm{Catalyzed} \mathrm{Multicomponent} \mathrm{Allylic} \mathrm{Substitutions}$}

In a $\mathrm{N}_{2}$-filled glove box, an oven-dried 2-dram vial with magnetic stir bar was charged with $\mathrm{CuCl}(0.5$ $\mathrm{mg}, 0.005 \mathrm{mmol})$, (S)-imid(S)-1b (4.7 mg, $0.0055 \mathrm{mmol}), \mathrm{LiO} t$-Bu (9.6 mg, $0.12 \mathrm{mmol})$, and freshly distilled tetrahydrofuran (THF, $0.5 \mathrm{~mL}$ ). The mixture was premixed for $30 \mathrm{~min}$ before PMHS (30.0 mg, $0.50 \mathrm{mmol})$, allenyl boronic acid pinacol ester $1 \mathrm{a}(27.0 \mathrm{mg}, 0.15 \mathrm{mmol})$ and additional THF $(0.5 \mathrm{~mL})$ were added, causing the solution to turn dark-red immediately. After $10 \mathrm{~min}$, allylic phosphate $\mathbf{2 b}$ (27.3 $\mathrm{mg}, 0.10 \mathrm{mmol}$ ) was added (at $22^{\circ} \mathrm{C}$ ). The vial was sealed with electrical tape before removal from the glove box, and the mixture was allowed to stir for $2 \mathrm{~h}$ at $22{ }^{\circ} \mathrm{C}$, after which it was passed through a short plug of oven-dried silica gel and eluted with $\mathrm{Et}_{2} \mathrm{O}$. The organic layer was concentrated under reduced pressure, affording yellow oil, which was purified by silica gel chromatography $(3: 1 \rightarrow 1: 1 \rightarrow 1: 3$ hexanes: $\mathrm{CH}_{2} \mathrm{Cl}_{2}$ ) to afford $\mathbf{3 b}$ as colorless oil (20.6 mg, $0.0643 \mathrm{mmol}, 64 \%$ yield).

Please note: For the reactions in preparation of $\mathbf{1 2 a - 1 2 d}$, if the reaction is quenched with a saturated aqueous solution of $\mathrm{NH}_{4} \mathrm{Cl}$ the $\mathrm{S}_{\mathrm{N}} 2$ byproduct can be made to decompose readily, and thus the yield reported correspond to pure $\mathrm{S}_{\mathrm{N}} 2$ ' addition isomers.

\section{Products with a Tertiary Carbon Stereogenic Center}

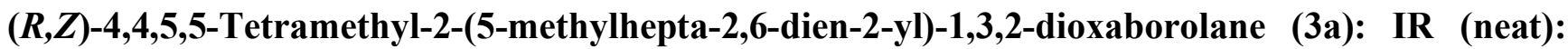
2973 (w), 2154 (w), 1368 (w), 1269 (w), 1040 (s), 902 (m), 765 (m) cm ${ }^{-1}$; ${ }^{1}$ H NMR (600 MHz, CDCl $)$ : $\delta 6.32(\mathrm{t}, J=6.3 \mathrm{~Hz}, 1 \mathrm{H}), 5.79(\mathrm{ddd}, J=17.2,10.4,6.8 \mathrm{~Hz}, 1 \mathrm{H}), 5.02-4.85(\mathrm{~m}, 2 \mathrm{H}), 2.31-2.23(\mathrm{~m}, 1 \mathrm{H})$, 
2.20-2.08 (m, 1H), $1.67(\mathrm{~s}, 3 \mathrm{H}), 1.26(\mathrm{~s}, 12 \mathrm{H}), 1.01(\mathrm{~d}, J=6.7 \mathrm{~Hz}, 3 \mathrm{H}) ;{ }^{13} \mathbf{C}$ NMR (151 MHz, CDCl$)$ : $\delta$ 144.6, 144.4, 112.5, 83.2, 37.3, 35.8, $24.9(\mathrm{~d}, J=2.2 \mathrm{~Hz}), 19.7,14.2$; HRMS (DART): Calcd for $\mathrm{C}_{14} \mathrm{H}_{26} \mathrm{BO}_{2}[\mathrm{M}+\mathrm{H}]^{+}:$237.2020. Found: 237.2020; Specific rotation: $[\alpha]_{\mathrm{D}}{ }^{20}+3.7\left(c 0.29, \mathrm{CHCl}_{3}\right)$ for a 92:8 er sample. Enantiomeric purity of 3a was determined by HPLC analysis of the corresponding methyl ester produced through carbonylation of alkenyl $\mathrm{B}(\mathrm{pin})^{21}$ in comparison with authentic racemic material; Chiralpak AZ-H, 100\% hexanes, $0.3 \mathrm{~mL} / \mathrm{min}, 220 \mathrm{~nm}$.
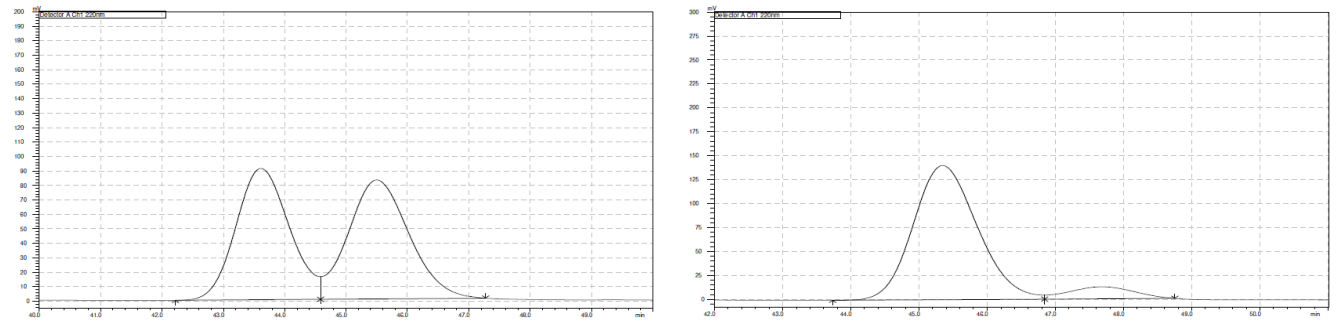

\begin{tabular}{|c|c|c|c|c|c|}
\hline Retention Time & Area & Area\% & Retention Time & Area & Area\% \\
\hline 43.612 & 5495339 & 49.288 & 45.346 & 9151573 & 91.669 \\
\hline 45.500 & 5654120 & 50.712 & 47.682 & 831674 & 8.331 \\
\hline
\end{tabular}

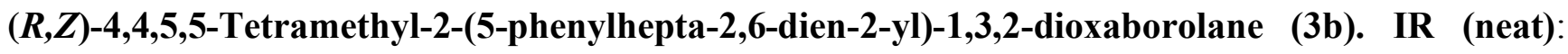
3028 (w), 2977 (s), 2930 (w), 2154 (w), 1632 (m), 1601 (w), 1493 (w), 1370 (s), 1341 (s), 1303 (w),

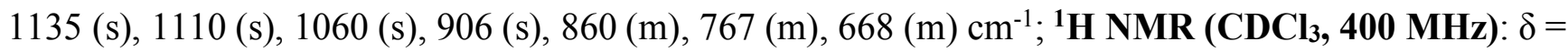
$7.29(\mathrm{t}, J=7.6 \mathrm{~Hz}, 2 \mathrm{H}), 7.23-7.16(\mathrm{~m}, 3 \mathrm{H}), 6.30(\mathrm{dt}, J=6.8,3.4 \mathrm{~Hz}, 1 \mathrm{H}), 5.99$ (ddd, $J=17.4,10.3,7.3$ $\mathrm{Hz}, 1 \mathrm{H}), 5.07-5.01(\mathrm{~m}, 2 \mathrm{H}), 3.41$ (q, $J=7.3 \mathrm{~Hz}, 1 \mathrm{H}), 2.61-2.49(\mathrm{~m}, 2 \mathrm{H}), 1.65(\mathrm{~s}, 3 \mathrm{H}), 1.24(\mathrm{~s}, 12 \mathrm{H})$; ${ }^{13} \mathbf{C ~ N M R ~ ( C D C l} 3,151$ MHz): $\delta=144.2,143.9,141.7,128.5,127.8,126.4,114.6,83.2,49.2,34.7,24.9$ $\left(\mathrm{d}, J=2.6 \mathrm{~Hz}\right.$ ), 14.3; HRMS (ESI ${ }^{+}$): Calcd for $\mathrm{C}_{19} \mathrm{H}_{31} \mathrm{BO}_{2} \mathrm{~N}\left[\mathrm{M}+\mathrm{NH}_{4}\right]^{+}$: 316.2483 . Found: 316.2475; Specific rotation: $[\alpha]_{\mathrm{D}}^{20}+2.1\left(c 1.2, \mathrm{CHCl}_{3}\right)$ for an enantiomerically enriched sample of 99:1 er Enantiomeric purity of $\mathbf{3 b}$ was determined by HPLC analysis in comparison with authentic racemic material; Chiralcel OD-H, 100\% hexanes, $0.5 \mathrm{~mL} / \mathrm{min}, 220 \mathrm{~nm}$.
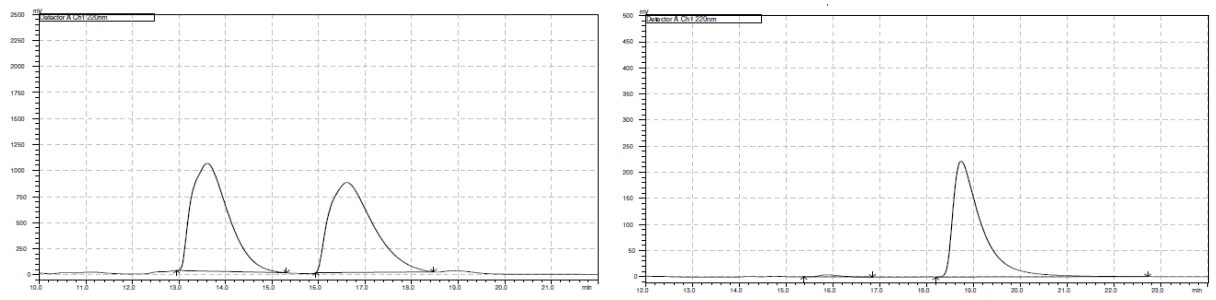

\begin{tabular}{|c|c|c|c|c|c|}
\hline Retention Time & Area & Area $\%$ & Retention Time & Area & Area\% \\
\hline 13.610 & 56788053 & 50.163 & 15.871 & 116709 & 1.241 \\
\hline 16.610 & 56419903 & 49.837 & 18.790 & 9286946 & 98.759 \\
\hline
\end{tabular}

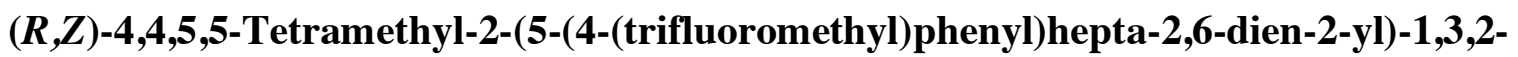

dioxaborolane (3c): IR (neat): 2926 (w), $1716(\mathrm{~m}), 1325$ (s), $1164(\mathrm{~m}), 1123(\mathrm{~m}), 1068(\mathrm{~s}), 1017(\mathrm{w})$, $841(\mathrm{w}) \mathrm{cm}^{-1} ;{ }^{1} \mathbf{H}$ NMR (600 MHz, $\left.\mathbf{C D C l}_{3}\right): \delta 7.54(\mathrm{~d}, J=7.9 \mathrm{~Hz}, 2 \mathrm{H}), 7.31(\mathrm{~d}, J=7.9 \mathrm{~Hz}, 2 \mathrm{H}), 6.24$ $(\mathrm{t}, J=6.2 \mathrm{~Hz}, 1 \mathrm{H}), 5.97(\mathrm{ddd}, J=17.3,10.2,7.1 \mathrm{~Hz}, 1 \mathrm{H}), 5.12-5.00(\mathrm{~m}, 2 \mathrm{H}), 3.47(\mathrm{q}, J=7.2 \mathrm{~Hz}, 1 \mathrm{H})$,

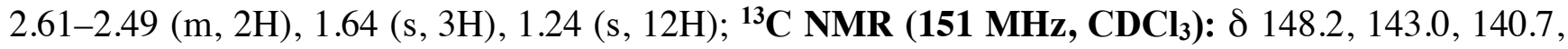


$128.7(\mathrm{q}, J=32.2 \mathrm{~Hz}), 128.2,125.5(\mathrm{q}, J=3.8 \mathrm{~Hz}), 115.5,83.3,49.0,34.5,24.9(\mathrm{~d}, J=2.6 \mathrm{~Hz}), 14.3$; ${ }^{19}$ F NMR (376 MHz, CDCl 3 ): $\delta-62.11$; HRMS (DART): Calcd for $\mathrm{C}_{20} \mathrm{H}_{30} \mathrm{BF}_{3} \mathrm{O}_{2} \mathrm{~N}\left[\mathrm{M}+\mathrm{NH}_{4}\right]^{+}$: 384.2322. Found: 384.2306; Specific rotation: $\left.[\alpha]_{\mathrm{D}}{ }^{20}+3.3(c) 1.2, \mathrm{CHCl}_{3}\right)$ for a 99:1 er sample. Enantiomeric purity of 3c was determined by HPLC analysis in comparison with authentic racemic material; Chiralcel OD-H, 100\% hexanes, $0.5 \mathrm{~mL} / \mathrm{min}, 220 \mathrm{~nm}$.
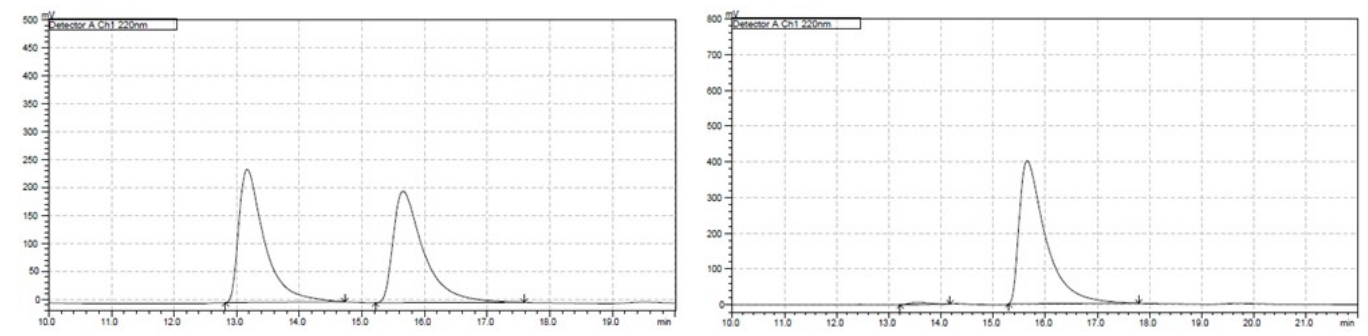

\begin{tabular}{|c|c|c|c|c|c|}
\hline Retention Time & Area & Area\% & Retention Time & Area & Area\% \\
\hline 13.169 & 6795907 & 50.307 & 13.551 & 136085 & 0.957 \\
\hline 15.658 & 6712839 & 49.693 & 15.653 & 14080904 & 99.043 \\
\hline
\end{tabular}

(R,Z)-2-(5-(3-Bromophenyl)hepta-2,6-dien-2-yl)-4,4,5,5-tetramethyl-1,3,2-dioxaborolane (3d): IR (neat): 2974 (w), 1712 (w), 1472 (m), 1438 (m), 1370 (m), 1329 (m), 1143 (s), 1072 (m), 981 (m), 850(m), $762(\mathrm{w}), 672(\mathrm{~m}) \mathrm{cm}^{-1} ;{ }^{1} \mathbf{H}$ NMR (600 MHz, $\left.\mathbf{C D C l}_{3}\right): \delta 7.36-7.30(\mathrm{~m}, 2 \mathrm{H}), 7.18-7.10(\mathrm{~m}, 2 \mathrm{H})$, 6.28-6.21 (m, 1H), 5.94 (ddd, $J=17.3,10.3,7.1 \mathrm{~Hz}, 1 \mathrm{H}), 5.11-5.01(\mathrm{~m}, 2 \mathrm{H}), 3.37(\mathrm{q}, J=7.3 \mathrm{~Hz}, 1 \mathrm{H})$, 2.60-2.43 (m, 2H), 1.63 (s, 3H), 1.24 (s, 12H); ${ }^{13} \mathbf{C}$ NMR (151 MHz, CDCl $): \delta$ 146.5, 143.2, 140.8, 131.0, 130.1 , 129.5, 126.5, 122.6, 115.3, 83.3, 48.8, 34.5, 24.9 (d, $J=2.6$ Hz), 14.3; HRMS (DART): Calcd for $\mathrm{C}_{19} \mathrm{H}_{30} \mathrm{BBrO}_{2} \mathrm{~N}\left[\mathrm{M}+\mathrm{NH}_{4}\right]^{+}: 394.1553$; Found: 394.1551 ; Specific rotation: $[\alpha]_{\mathrm{D}}{ }^{20}+3.5(c$ 1.2, $\mathrm{CHCl}_{3}$ ) for a 99:1 er sample. Enantiomeric purity of $\mathbf{3 d}$ was determined by HPLC analysis in comparison with authentic racemic material; Chiralcel OD-H, 100\% hexanes, $0.5 \mathrm{~mL} / \mathrm{min}, 220 \mathrm{~nm}$.
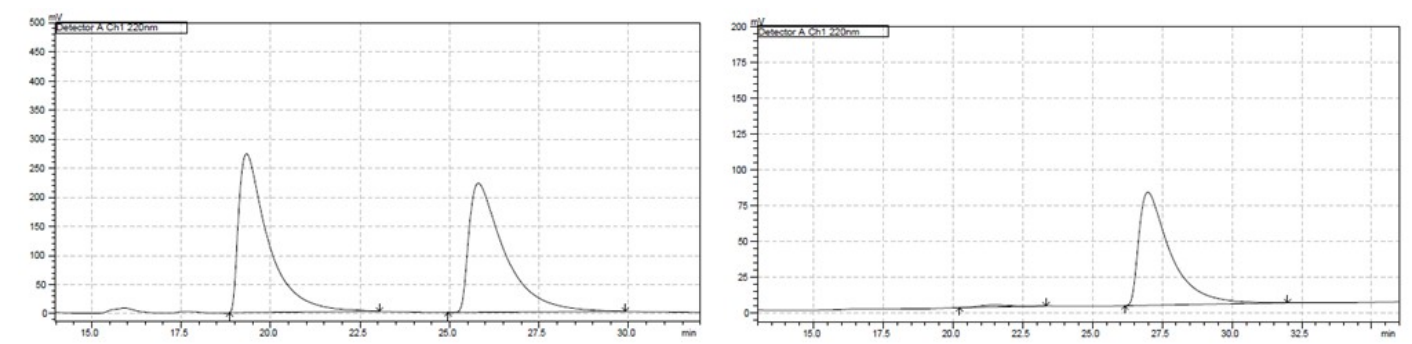

\begin{tabular}{|c|c|c|c|c|c|}
\hline Retention Time & Area & Area\% & Retention Time & Area & Area\% \\
\hline 19.327 & 15693182 & 50.477 & 21.499 & 94077 & 1.478 \\
\hline 25.803 & 15396630 & 49.523 & 26.984 & 6272069 & 98.522 \\
\hline
\end{tabular}

(R,Z)-2-(5-(3-Methoxyphenyl)hepta-2,6-dien-2-yl)-4,4,5,5-tetramethyl-1,3,2-dioxaborolane (3e): IR (neat): $2974(\mathrm{w}), 1714(\mathrm{w}), 1630(\mathrm{w}), 1368(\mathrm{~m}), 1260(\mathrm{~m}), 1041(\mathrm{~s}), 905(\mathrm{~s}), 859(\mathrm{~m}), \quad$ (m), $765(\mathrm{~s})$, $1699(\mathrm{w}), 668(\mathrm{~s}) \mathrm{cm}^{-1} ;{ }^{1} \mathbf{H}$ NMR (600 MHz, $\left.\mathbf{C D C l}_{3}\right): \delta 7.21(\mathrm{t}, J=7.6 \mathrm{~Hz}, 1 \mathrm{H}), 6.81(\mathrm{~d}, J=7.5 \mathrm{~Hz}$, $1 \mathrm{H}), 6.78-6.70(\mathrm{~m}, 2 \mathrm{H}), 6.30(\mathrm{td}, J=6.9,6.0,3.5 \mathrm{~Hz}, 1 \mathrm{H}), 5.97$ (dddd, $J=17.3,10.3,7.3,1.5 \mathrm{~Hz}, 1 \mathrm{H})$, 5.08-4.97 (m, 2H), 3.80 (s, 3H), 3.37 (q, $J=7.4 \mathrm{~Hz}, 1 \mathrm{H}), 2.61-2.45$ (m, 2H), 1.65 (s, 3H), $1.24(\mathrm{~s}, 12 \mathrm{H})$; 
${ }^{13}$ C NMR (151 MHz, CDCl $)$ ): $\delta$ 159.8, 145.9, 143.9, 141.4, 129.5, 120.2, 114.7, 113.7, 111.6, 83.2, 55.3, 49.2 , 34.7, 24.9 (d, $J=2.6 \mathrm{~Hz}$ ), 14.3; HRMS (DART): Calcd for $\mathrm{C}_{20} \mathrm{H}_{30} \mathrm{BO}_{3}[\mathrm{M}+\mathrm{H}]+: 329.2288$. Found: 329.2297; Specific rotation: $[\alpha]_{\mathrm{D}}{ }^{20}+2.9\left(c 0.77, \mathrm{CHCl}_{3}\right)$ for a $99: 1$ er sample. Enantiomeric purity of 3e was determined by HPLC analysis in comparison with authentic racemic material; Chiralcel OD-H, $99.9 \%$ hexanes, $0.3 \mathrm{~mL} / \mathrm{min}, 220 \mathrm{~nm}$.
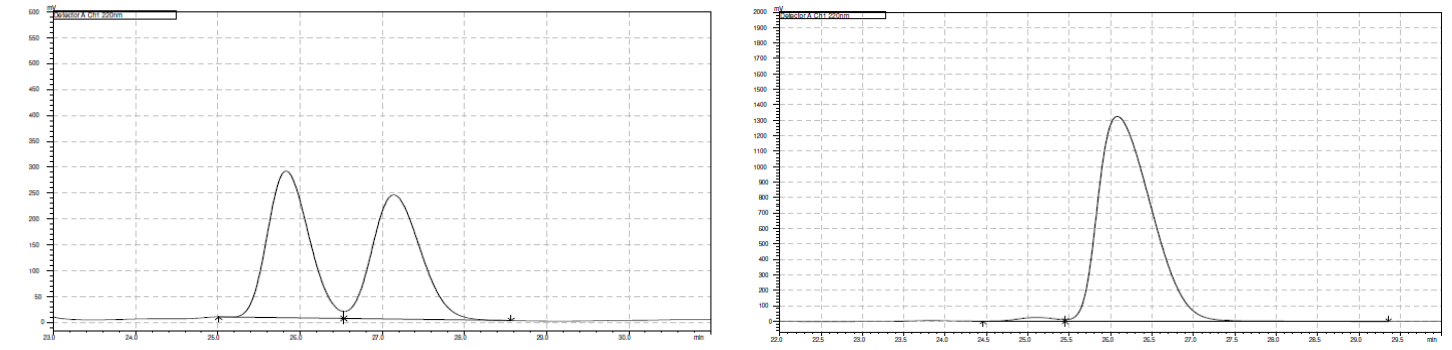

\begin{tabular}{|c|c|c|c|c|c|}
\hline Retention Time & Area & Area $\%$ & Retention Time & Area & Area\% \\
\hline 25.830 & 9919852 & 50.312 & 25.105 & 764854 & 1.286 \\
\hline 27.140 & 9796740 & 49.688 & 26.080 & 58707230 & 98.714 \\
\hline
\end{tabular}

(R,Z)-4,4,5,5-Tetramethyl-2-(5-(naphthalen-1-yl)hepta-2,6-dien-2-yl)-1,3,2-dioxaborolane (3f): IR (neat): 2973 (w), 2929 (w), 1714 (w), 1598 (w), 1410 (w), $1810(\mathrm{w}), 1340$ (m), 1213 (m), 1041 (s), 905 (m), 859 (s), 765 (m), 699 (m), $668(\mathrm{w}) \mathrm{cm}^{-1}$; ${ }^{1} \mathbf{H}$ NMR (400 MHz, CDCl $\left.\mathbf{~}_{3}\right): \delta 8.10$ (d, J = 8.2 Hz, 1H), $7.88-7.83(\mathrm{~m}, 1 \mathrm{H}), 7.73(\mathrm{~d}, J=8.0 \mathrm{~Hz}, 1 \mathrm{H}), 7.54-7.36(\mathrm{~m}, 4 \mathrm{H}), 6.40(\mathrm{t}, J=6.8 \mathrm{~Hz}, 1 \mathrm{H}), 6.12(\mathrm{ddd}, \mathrm{J}=$ $17.1,10.3,6.7 \mathrm{~Hz}, 1 \mathrm{H}), 5.12(\mathrm{~d}, J=10.3 \mathrm{~Hz}, 1 \mathrm{H}), 5.06(\mathrm{~d}, J=17.4 \mathrm{~Hz}, 1 \mathrm{H}), 4.26(\mathrm{q}, J=7.0 \mathrm{~Hz}, 1 \mathrm{H})$, 2.79-2.65 (m, 2H), $1.68(\mathrm{~s}, 3 \mathrm{H}), 1.24(\mathrm{~s}, 12 \mathrm{H}) ;{ }^{13} \mathbf{C}$ NMR (101 MHz, $\left.\mathbf{C D C l}_{3}\right): \delta 144.2,141.1,140.1$, 134.1, 131.7, 129.0, 127.0, 125.9, 125.7, 125.5, 124.3, 123.7, 115.3, 83.3, 43.7, 34.4, 24.9 (d, J = 2.6 $\mathrm{Hz}$ ), 14.4; HRMS (DART): Calcd for $\mathrm{C}_{23} \mathrm{H}_{30} \mathrm{BO}_{2}[\mathrm{M}+\mathrm{H}]^{+}:$349.2333. Found: 349.2334; Specific rotation: $[\alpha]_{\mathrm{D}}{ }^{20}-7.5\left(c 0.08, \mathrm{CHCl}_{3}\right)$ for a 98:2 er sample. Enantiomeric purity of $\mathbf{3 f}$ was determined by HPLC analysis in comparison with authentic racemic material; Chiralpak AD-H, 100\% hexanes, 0.3 $\mathrm{mL} / \mathrm{min}, 220 \mathrm{~nm}$.
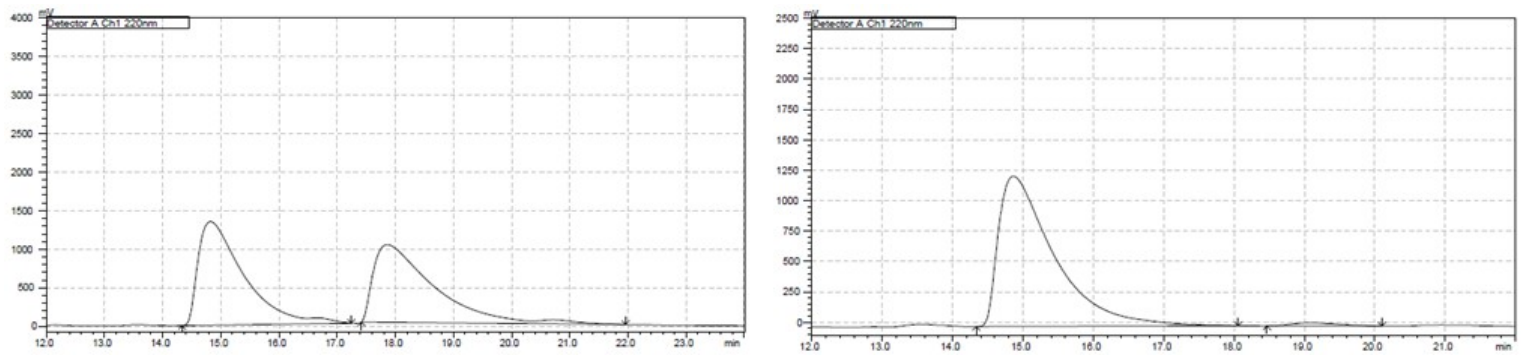

\begin{tabular}{|c|c|c|c|c|c|}
\hline Retention Time & Area & Area\% & Retention Time & Area & Area\% \\
\hline 14.821 & 73355520 & 50.189 & 14.864 & 67929251 & 98.220 \\
\hline 17.862 & 72804224 & 49.811 & 19.085 & 1230913 & 1.780 \\
\hline
\end{tabular}

(R,Z)-2-(5-(2-Methoxyphenyl)hepta-2,6-dien-2-yl)-4,4,5,5-tetramethyl-1,3,2-dioxaborolane (3g): IR (neat): 2973 (m), 2930 (w), 2163 (w), 1714 (w), 1490 (m), 1368 (m), 1030 (s), 905 (m), 859 (w), $752(\mathrm{~s}), 668(\mathrm{w}) \mathrm{cm}^{-1}{ }^{1} \mathbf{H}$ NMR (600 MHz, $\left.\mathbf{C D C l}_{3}\right): \delta 7.22-7.10(\mathrm{~m}, 2 \mathrm{H}), 6.91(\mathrm{t}, J=7.4 \mathrm{~Hz}, 1 \mathrm{H}), 6.85$ $(\mathrm{d}, J=8.0 \mathrm{~Hz}, 1 \mathrm{H}), 6.34(\mathrm{t}, J=6.7 \mathrm{~Hz}, 1 \mathrm{H}), 6.03$ (ddd, $J=17.2,10.4,7.0 \mathrm{~Hz}, 1 \mathrm{H}), 5.08-4.96(\mathrm{~m}, 2 \mathrm{H})$, 
3.89 (q, $J=7.3 \mathrm{~Hz}, 1 \mathrm{H}), 3.81(\mathrm{~s}, 3 \mathrm{H}), 2.61-2.46(\mathrm{~m}, 2 \mathrm{H}), 1.65(\mathrm{~s}, 3 \mathrm{H}), 1.24(\mathrm{~s}, 12 \mathrm{H}) ;{ }^{13} \mathbf{C}$ NMR (151 MHz, $\left.\mathbf{C D C l}_{3}\right): \delta 157.0,144.8,141.0,132.8,128.1,127.2,120.7,114.5,110.8,83.2,55.5,41.7,33.8$, $24.9(\mathrm{~d}, J=2.6 \mathrm{~Hz}), 14.2$; HRMS (DART): Calcd for $\mathrm{C}_{20} \mathrm{H}_{30} \mathrm{BO}_{3}[\mathrm{M}+\mathrm{H}]^{+}:$329.2282. Found: 329.2279; Specific rotation: $[\alpha]_{\mathrm{D}}{ }^{20}+2.8\left(c 0.82, \mathrm{CHCl}_{3}\right)$ for a $99: 1$ er sample. Enantiomeric purity of $\mathbf{3 g}$ was determined by HPLC analysis in comparison with authentic racemic material; Chiralcel OZ-H, 100\% hexanes, $0.5 \mathrm{~mL} / \mathrm{min}, 220 \mathrm{~nm}$.
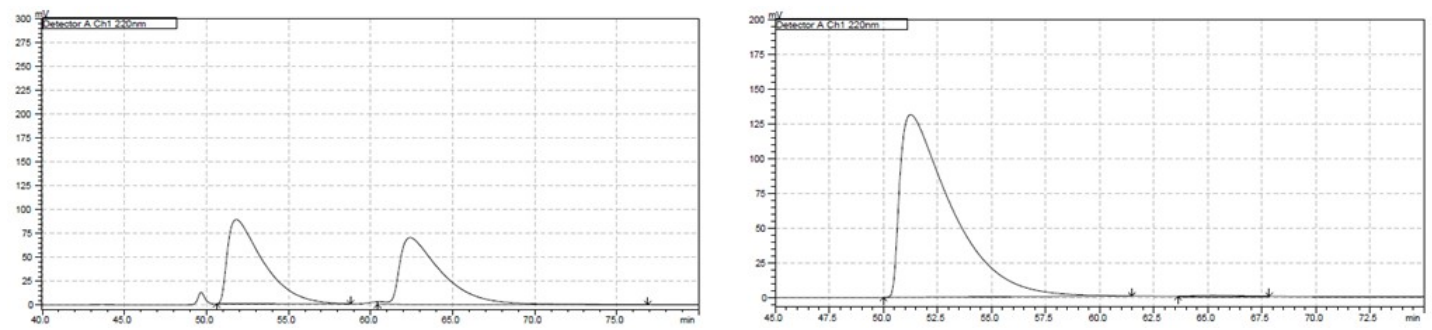

\begin{tabular}{|c|c|c|c|c|c|}
\hline Retention Time & Area & Area\% & Retention Time & Area & Area\% \\
\hline 51.810 & 13395214 & 52.038 & 51.252 & 21900263 & 99.510 \\
\hline 62.409 & 12345992 & 47.962 & 65.139 & 107797 & 0.490 \\
\hline
\end{tabular}

(R,Z)-2-(5-(Furan-2-yl)hepta-2,6-dien-2-yl)-4,4,5,5-tetramethyl-1,3,2-dioxaborolane $\quad(3 \mathrm{~h}): \quad$ IR (neat): $2975(\mathrm{~m}), 2924$ (w), $2858(\mathrm{w}), 1631$ (w), 1409 (w), 1369 (s), $1344(\mathrm{~m}), 1303$ (m), 1145 (m), 860 (w), $730(\mathrm{w}), 668$ (w) cm ${ }^{-1}$; ${ }^{1} \mathbf{H}$ NMR (600 MHz, $\left.\mathbf{C D C l}_{3}\right): \delta 7.33$ (s, 1H), 6.34-6.23 (m, 2H), 6.03 (d, $J$ $=2.9 \mathrm{~Hz}, 1 \mathrm{H}), 5.89(\mathrm{ddd}, J=17.4,10.2,7.7 \mathrm{~Hz}, 1 \mathrm{H}), 5.14-5.01(\mathrm{~m}, 2 \mathrm{H}), 3.50(\mathrm{q}, J=7.4 \mathrm{~Hz}, 1 \mathrm{H}), 2.63$ $(\mathrm{dt}, J=14.2,6.6 \mathrm{~Hz}, 1 \mathrm{H}), 2.49(\mathrm{dt}, J=15.1,7.5 \mathrm{~Hz}, 1 \mathrm{H}), 1.68(\mathrm{~s}, 3 \mathrm{H}), 1.25(\mathrm{~s}, 12 \mathrm{H}) ;{ }^{13} \mathbf{C}$ NMR (151 MHz, $\left.\mathbf{C D C l}_{3}\right): \delta 157.0,143.1,141.4,138.8,115.8,110.2,105.1,83.3,42.9,32.6,24.9$ (d, $J=2.4 \mathrm{~Hz}$ ), 14.3; HRMS (DART): Calcd for $\mathrm{C}_{17} \mathrm{H}_{26} \mathrm{BO}_{3}[\mathrm{M}+\mathrm{H}]^{+}$: 289.1975. Found: 289.1975; Specific rotation: $[\alpha]_{\mathrm{D}^{20}}-11.8\left(c 0.090, \mathrm{CHCl}_{3}\right)$ for a 99:1 er sample. Enantiomeric purity of $\mathbf{3 h}$ was determined by HPLC analysis in comparison with authentic racemic material; Chiralcel OD-H, 100\% hexanes, $0.3 \mathrm{~mL} / \mathrm{min}$, $220 \mathrm{~nm}$.
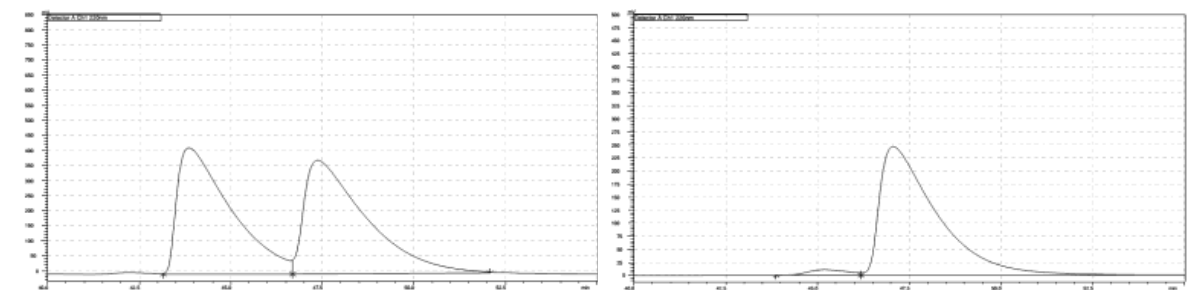

\begin{tabular}{|c|c|c|c|c|c|}
\hline Retention Time & Area & Area\% & Retention Time & Area & Area\% \\
\hline 43.852 & 42723043 & 49.210 & 45.194 & 800521 & 2.920 \\
\hline 47.368 & 44095022 & 50.790 & 47.058 & 26614809 & 97.080 \\
\hline
\end{tabular}

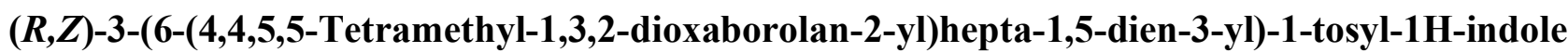
(3i): IR (neat): 2974 (w), 2925 (w), 1630 (w), 1596 (w), 1446 (m), 1368 (s), 1303 (m), 1274 (m), 1172 (s), 1130 (s), 1094 (m), 986 (w), 745 (m), 664 (m), 581 (m), 537 (m) cm ${ }^{-1}$; ${ }^{1}$ H NMR (400 MHz, CDCl $)$ : $\delta$ 8.03-7.87 (m, 1H), $7.73(\mathrm{~d}, J=8.2 \mathrm{~Hz}, 2 \mathrm{H}), 7.49(\mathrm{~d}, J=7.8 \mathrm{~Hz}, 1 \mathrm{H}), 7.35(\mathrm{~s}, 1 \mathrm{H}), 7.32-7.25(\mathrm{~m}, 1 \mathrm{H})$, $7.24-7.15(\mathrm{~m}, 3 \mathrm{H}), 6.34(\mathrm{t}, J=6.5 \mathrm{~Hz}, 1 \mathrm{H}), 5.95(\mathrm{ddd}, J=17.2,10.3,7.1 \mathrm{~Hz}, 1 \mathrm{H}), 5.11-4.99(\mathrm{~m}, 2 \mathrm{H})$, 
$3.62(\mathrm{q}, J=7.2 \mathrm{~Hz}, 1 \mathrm{H}), 2.69-2.53(\mathrm{~m}, 2 \mathrm{H}), 2.33(\mathrm{~s}, 3 \mathrm{H}), 1.66(\mathrm{~s}, 3 \mathrm{H}), 1.25(\mathrm{~s}, 12 \mathrm{H}) ;{ }^{13} \mathbf{C}$ NMR (100 MHz, $\left.\mathbf{C D C l}_{3}\right): \delta 144.8,143.4,139.9,135.6,135.4,130.6,129.9,126.9,125.1,124.7,123.0,122.9$, 120.3, 115.5, 113.9, 83.3, 40.1, 33.5, 25.0, 24.9, 21.7, 14.4; HRMS (DART): Calcd for $\mathrm{C}_{28} \mathrm{H}_{35} \mathrm{BNO}_{4} \mathrm{~S}$ $[\mathrm{M}+\mathrm{H}]^{+}:$492.2374. Found: 492.2383; Specific rotation: $[\alpha]_{\mathrm{D}}{ }^{20}-12.0$ (c $0.26, \mathrm{CHCl}_{3}$ ) for a $99: 1$ er sample. Enantiomeric purity of $\mathbf{3 i}$ was determined by HPLC analysis in comparison with authentic racemic material; Chiralpak AZ-H, 98\% hexanes, $0.3 \mathrm{~mL} / \mathrm{min}, 220 \mathrm{~nm}$.
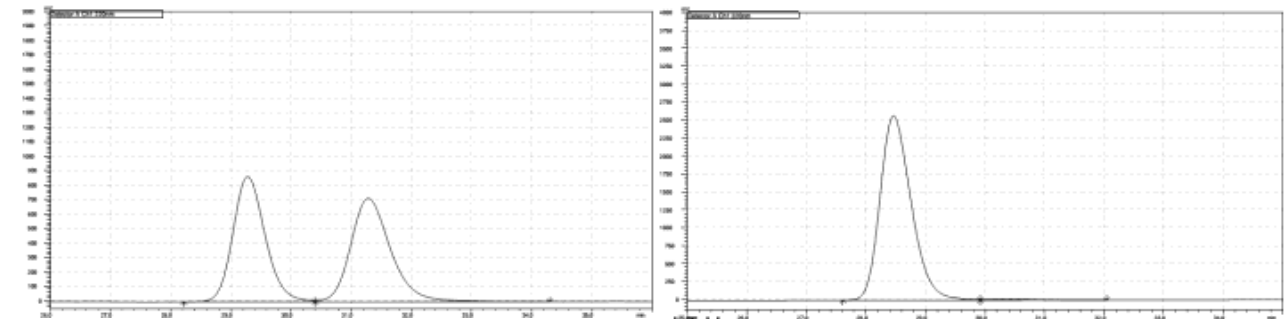

\begin{tabular}{|c|c|c|c|c|c|}
\hline Retention Time & Area & Area\% & Retention Time & Area & Area\% \\
\hline 29.279 & 32323881 & 49.484 & 28.461 & 93581085 & 98.892 \\
\hline 31.283 & 32998485 & 50.516 & 30.392 & 1048410 & 1.108 \\
\hline
\end{tabular}

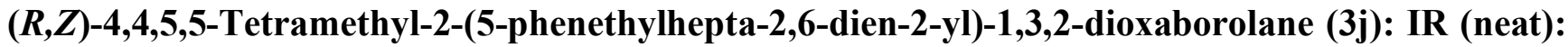
3026 (w), 2975 (m), 2922 (m), 1630 (m), 1409 (m), 1369 (s), 1344 (m), 1302 (m), 1077 (m), 860 (w), $698(\mathrm{w}), 666(\mathrm{w}) \mathrm{cm}^{-1} ;{ }^{1} \mathbf{H}$ NMR (500 $\left.\mathbf{M H z}, \mathbf{C D C l}_{3}\right): \delta 7.27(\mathrm{dd}, J=9.0,5.8 \mathrm{~Hz}, 2 \mathrm{H}), 7.18(\mathrm{~d}, J=6.7$ $\mathrm{Hz}, 3 \mathrm{H}), 6.31(\mathrm{t}, J=5.6 \mathrm{~Hz}, 1 \mathrm{H}), 5.69(\mathrm{dt}, J=17.0,8.6 \mathrm{~Hz}, 1 \mathrm{H}), 5.08-5.00(\mathrm{~m}, 2 \mathrm{H}), 2.72-2.62(\mathrm{~m}, 1 \mathrm{H})$, 2.58-2.49 (m, 1H), 2.30-2.13 (m, 3H), 1.81-1.72 (m, 1H), $1.68(\mathrm{~s}, 3 \mathrm{H}), 1.64-1.57(\mathrm{~m}, 1 \mathrm{H}), 1.26(\mathrm{~s}$, 12H); ${ }^{13}$ C NMR (101 MHz, $\left.\mathbf{C D C l}_{3}\right): \delta 144.2,142.8,142.5,128.6,128.4,125.8,114.9,83.2,43.2,36.2$, 34.3, 33.6, 24.9, 14.3; HRMS (DART): Calcd for $\mathrm{C}_{21} \mathrm{H}_{32} \mathrm{BO}_{2}[\mathrm{M}+\mathrm{H}]^{+}$: 327.2490. Found: 327.2489; Specific rotation: $[\alpha]_{\mathrm{D}}{ }^{20}+10.1\left(c 0.19, \mathrm{CHCl}_{3}\right)$ for a $91: 9$ er sample. Enantiomeric purity of $\mathbf{3 j}$ was determined by HPLC analysis in comparison with authentic racemic material; Chiralcel OD-H, 99.5\% hexanes, $0.5 \mathrm{~mL} / \mathrm{min}, 220 \mathrm{~nm}$.
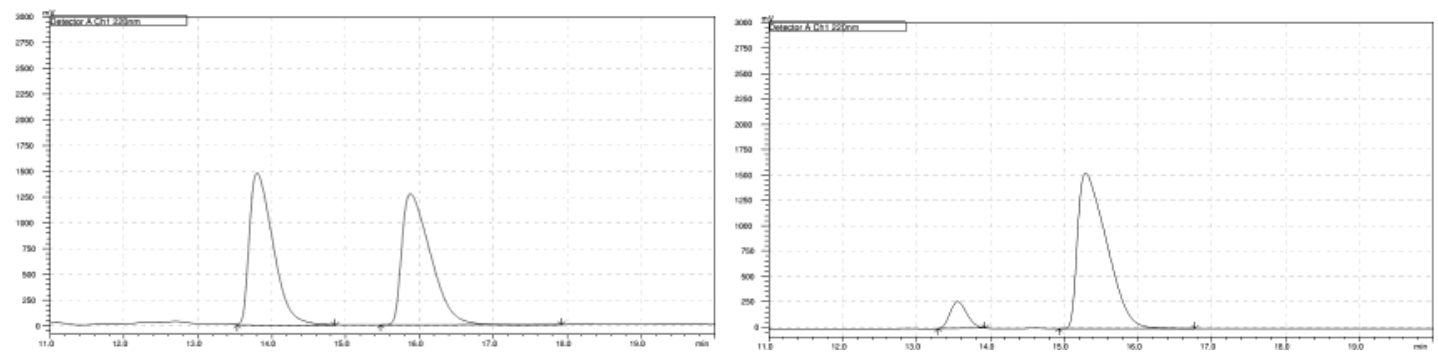

\begin{tabular}{|c|c|c|c|c|c|}
\hline Retention Time & Area & Area\% & Retention Time & Area & Area\% \\
\hline 13.802 & 32930384 & 49.034 & 13.556 & 4186099 & 9.122 \\
\hline 15.878 & 34228544 & 50.966 & 15.290 & 14702312 & 90.878 \\
\hline
\end{tabular}




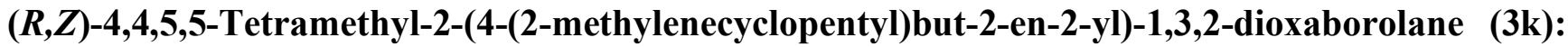
IR (neat): 2953 (m), 2922 (s), 2853 (w), 1369 (s), 1301 (w), 1138 (m), 1269 (m), 1060 (w), 907 (w), $766(\mathrm{w}) \mathrm{cm}^{-1} ;{ }^{1} \mathbf{H}$ NMR (400 MHz, CDCl $): \delta 6.37(\mathrm{t}, J=6.9 \mathrm{~Hz}, 1 \mathrm{H}), 4.89(\mathrm{~s}, 1 \mathrm{H}), 4.83(\mathrm{~s}, 1 \mathrm{H}), 2.45-$ $2.32(\mathrm{~m}, 3 \mathrm{H}), 2.16-2.06(\mathrm{~m}, 1 \mathrm{H}), 1.93-1.84(\mathrm{~m}, 1 \mathrm{H}), 1.69(\mathrm{~s}, 3 \mathrm{H}), 1.34-1.28(\mathrm{~m}, 4 \mathrm{H}), 1.26(\mathrm{~s}, 12 \mathrm{H}) ;{ }^{13} \mathrm{C}$ NMR (151 MHz, $\left.\mathbf{C D C l}_{3}\right): \delta 156.7,145.2,104.5,83.2,43.7,33.6,33.3,32.9,25.0,24.2,14.2$; HRMS (DART): Calcd for $\mathrm{C}_{16} \mathrm{H}_{28} \mathrm{BO}_{2}[\mathrm{M}+\mathrm{H}]^{+}: 263.2177$. Found: 263.2186 ; Specific rotation: $[\alpha]_{\mathrm{D}}^{20}+8.3(c$ $0.73, \mathrm{CHCl}_{3}$ ) for a $92: 8$ er sample. Enantiomeric purity of $\mathbf{3 k}$ was determined by HPLC analysis of the corresponding methyl ester produced through carbonylation of alkenyl $\mathrm{B}(\mathrm{pin})^{21}$ in comparison with authentic racemic material; Chiralcel OK, $100 \%$ hexanes, $0.8 \mathrm{~mL} / \mathrm{min}, 220 \mathrm{~nm}$.
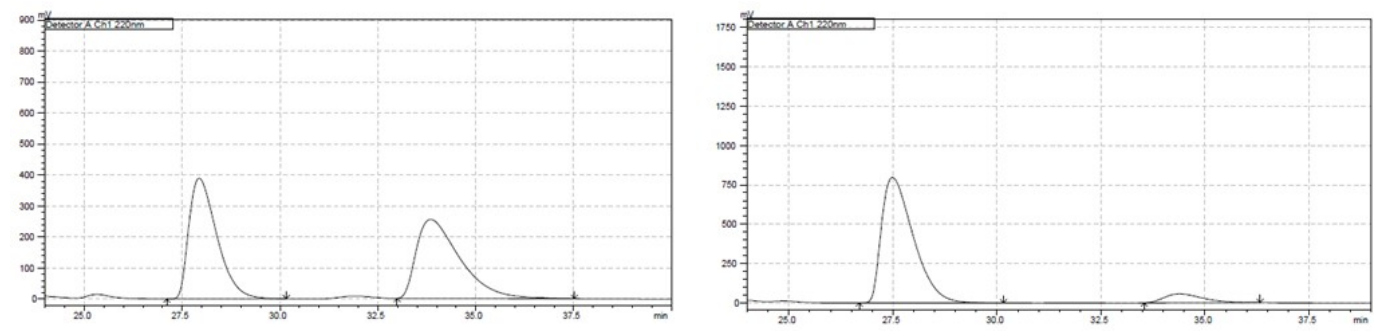

\begin{tabular}{|c|c|c|c|c|c|}
\hline Retention Time & Area & Area\% & Retention Time & Area & Area\% \\
\hline 27.933 & 19349561 & 49.522 & 27.488 & 42245430 & 92.253 \\
\hline 33.846 & 19699635 & 50.448 & 34.385 & 3547539 & 7.747 \\
\hline
\end{tabular}

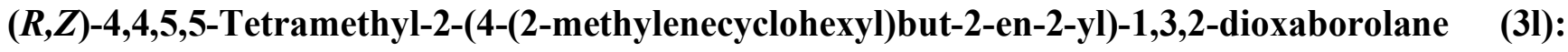
IR (neat): 2974 (w), 2924 (s), 2852 (m), 1631 (w), 1369 (s), 1340 (w), 1301 (m), 1146 (w), 1133 (m), $1111(\mathrm{w}) \mathrm{cm}^{-1} ;{ }^{1} \mathbf{H}$ NMR (600 MHz, $\left.\mathbf{C D C l}_{3}\right): \delta 6.32(\mathrm{t}, J=6.7 \mathrm{~Hz}, 1 \mathrm{H}), 4.66(\mathrm{~s}, 1 \mathrm{H}), 4.57(\mathrm{~s}, 1 \mathrm{H}), 2.38-$ $2.32(\mathrm{~m}, 1 \mathrm{H}), 2.28(\mathrm{dd}, J=12.6,4.4 \mathrm{~Hz}, 1 \mathrm{H}), 2.20(\mathrm{dt}, J=15.5,7.9 \mathrm{~Hz}, 1 \mathrm{H}), 2.12$ (dt, $J=9.5,4.8 \mathrm{~Hz}$, $1 \mathrm{H}), 2.04-1.98(\mathrm{~m}, 1 \mathrm{H}), 1.80(\mathrm{dd}, J=12.3,5.0 \mathrm{~Hz}, 1 \mathrm{H}), 1.69(\mathrm{~s}, 3 \mathrm{H}), 1.68-1.63(\mathrm{~m}, 1 \mathrm{H}), 1.47-1.38(\mathrm{~m}$, 2H), 1.32-1.26 (m, 1H), 1.26 (s, 12H), 1.19-1.12 (m, 1H); ${ }^{13} \mathbf{C}$ NMR (151 MHz, CDCl $\left.\mathbf{3}\right): \delta$ 153.1, 145.5, 105.4, 83.2, 42.8, 35.8, 33.9, 31.9, 28.9, 25.3, 25.0, 24.9 (d, $J=4.1 \mathrm{~Hz}), 14.3$; HRMS (DART): Calcd for $\mathrm{C}_{17} \mathrm{H}_{30} \mathrm{BO}_{2}[\mathrm{M}+\mathrm{H}]^{+}:$277.2334. Found: 277.2335; Specific rotation: $[\alpha]_{\mathrm{D}}^{20}+2.1$ (c 0.62 , $\mathrm{CHCl}_{3}$ ) for a 95:5 er sample. Enantiomeric purity of $\mathbf{3 l}$ was determined by HPLC analysis of the corresponding methyl ester produced through carbonylation of alkenyl $\mathrm{B}(\mathrm{pin})^{21}$ in comparison with authentic racemic material; Chiralcel OK, 100\% hexanes, $0.5 \mathrm{~mL} / \mathrm{min}, 220 \mathrm{~nm}$.
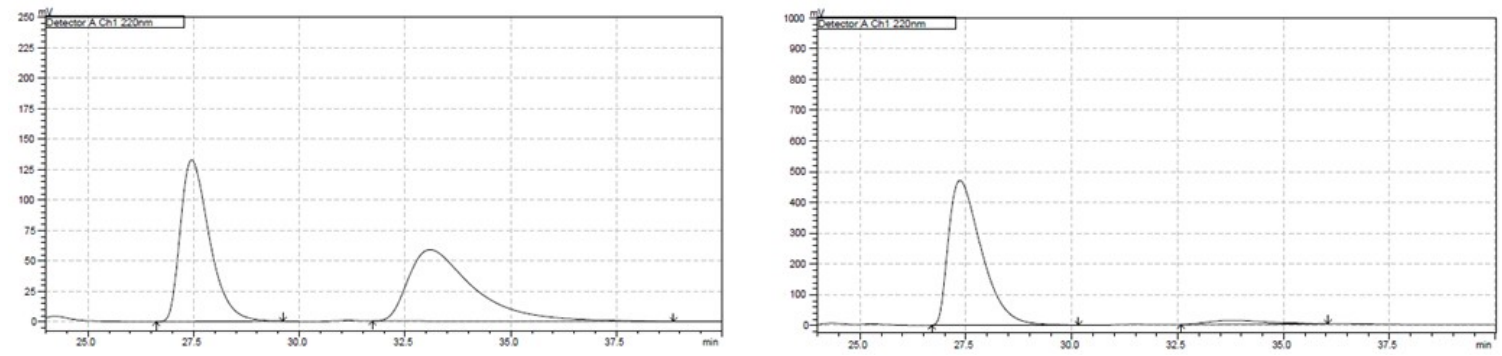

\begin{tabular}{|c|c|c|c|c|c|}
\hline Retention Time & Area & Area\% & Retention Time & Area & Area\% \\
\hline 27.452 & 6360018 & 50.308 & 27.358 & 25489024 & 95.369 \\
\hline 33.094 & 6282121 & 49.692 & 33.785 & 1237738 & 4.631 \\
\hline
\end{tabular}


$(R, E)-4,4,5,5-T e t r a m e t h y l-2-(4-m e t h y l h e x a-1,5-d i e n-1-y l)-1,3,2$-dioxaborolane (5a): IR (neat): 2975 (m), 2925 (w), 1637 (m), $1455(\mathrm{w}), 1396$ (w), 1359 (s), 1318 (m), 1265 (w), 1237 (w), 1213 (w), 1143 (s), 995 (w), 969 (w), 909 (w), 849 (m) cm ${ }^{-1} ;{ }^{1} \mathbf{H}$ NMR (600 MHz, CDCl $)$ ): $\delta 6.58$ (dt, $J=17.9$, $6.7 \mathrm{~Hz}, 1 \mathrm{H}), 5.76$ (ddd, $J=17.3,10.4,6.8 \mathrm{~Hz}, 1 \mathrm{H}), 5.44(\mathrm{~d}, J=17.9 \mathrm{~Hz}, 1 \mathrm{H}), 5.03-4.87$ (m, 2H), 2.36$2.19(\mathrm{~m}, 2 \mathrm{H}), 2.11(\mathrm{dt}, J=14.1,7.1 \mathrm{~Hz}, 1 \mathrm{H}), 1.56(\mathrm{~s}, 3 \mathrm{H}), 1.26(\mathrm{~s}, 12 \mathrm{H}), 1.00(\mathrm{~d}, J=6.6 \mathrm{~Hz}, 3 \mathrm{H}) ;{ }^{13} \mathrm{C}$ NMR (151 MHz, CDCl $\mathbf{3}): \delta 152.7,144.1,112.8,83.2,43.2,36.9,24.9,19.7$; HRMS (DART): Calcd

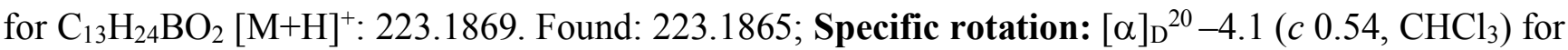
a 93:7 er sample. Enantiomeric purity of $\mathbf{5 a}$ was determined by GC analysis in comparison with authentic racemic material; alpha dex, $15 \mathrm{psi}, 75^{\circ} \mathrm{C}$.
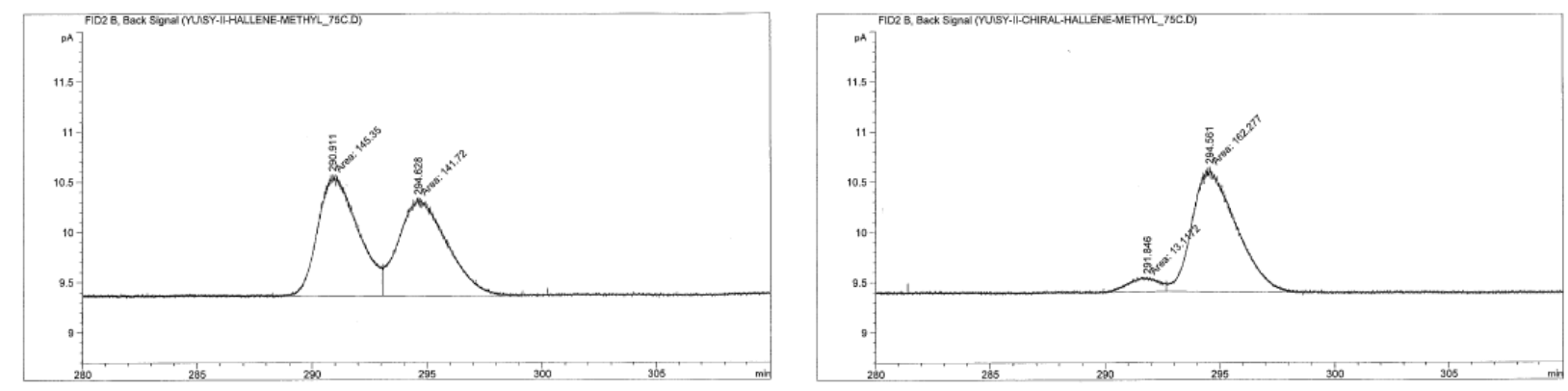

\begin{tabular}{|c|c|c|c|c|c|}
\hline Retention Time & Area & Area\% & Retention Time & Area & Area\% \\
\hline 290.911 & 145.34981 & 50.63217 & 291.846 & 13.11721 & 7.47871 \\
\hline 294.628 & 141.72029 & 49.36783 & 294.561 & 162.27673 & 92.52129 \\
\hline
\end{tabular}

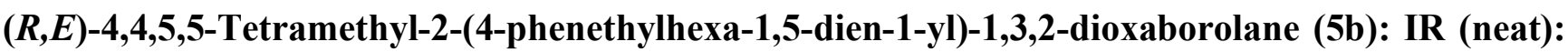
3023 (w), 2975 (w), 2924 (w), 1636 (m), 1359 (s), 1318 (m), 1143 (s), 995 (w), 970 (w), 911 (w), 849 (w), 637 (w) cm ${ }^{-1} ;{ }^{1} \mathbf{H}$ NMR (400 MHz, $\left.\mathbf{C D C l}_{3}\right): \delta 7.31-7.22(\mathrm{~m}, 2 \mathrm{H}), 7.20-7.13(\mathrm{~m}, 3 \mathrm{H}), 6.56(\mathrm{dt}, J=$ $17.9,6.6 \mathrm{~Hz}, 1 \mathrm{H}), 5.66(\mathrm{ddd}, J=17.2,10.3,8.0 \mathrm{~Hz}, 1 \mathrm{H}), 5.43(\mathrm{~d}, J=18.1 \mathrm{~Hz}, 1 \mathrm{H}), 5.12-4.92(\mathrm{~m}, 2 \mathrm{H})$, 2.65 (ddd, $J=13.9,10.4,5.3 \mathrm{~Hz}, 1 \mathrm{H}), 2.52$ (ddd, $J=13.8,10.3,6.4 \mathrm{~Hz}, 1 \mathrm{H}), 2.27-2.13(\mathrm{~m}, 3 \mathrm{H}), 1.79$ 1.69 (m, 1H), 1.62-1.51 (m, 2H), 1.26 (s, 12H); ${ }^{13} \mathbf{C}$ NMR (126 MHz, $\left.\mathbf{C D C l}_{3}\right): \delta$ 152.3, 142.7, 142.2, 128.6, 128.4, 125.8, 120.7 (br), 115.1, 83.2, 42.8, 41.8, 36.1, 33.5, 24.9; HRMS (DART): Calcd for $\mathrm{C}_{20} \mathrm{H}_{30} \mathrm{BO}_{2}[\mathrm{M}+\mathrm{H}]^{+}: 313.2333$. Found: 313.2335 ; Specific rotation: $[\alpha]_{\mathrm{D}}^{20}+11.2\left(c 0.38, \mathrm{CHCl}_{3}\right)$ for a 95:5 er sample. Enantiomeric purity of $\mathbf{5 b}$ was determined by HPLC analysis in comparison with authentic racemic material; Chiralcel OD-H, 99.9\% hexanes, $0.8 \mathrm{~mL} / \mathrm{min}, 220 \mathrm{~nm}$.
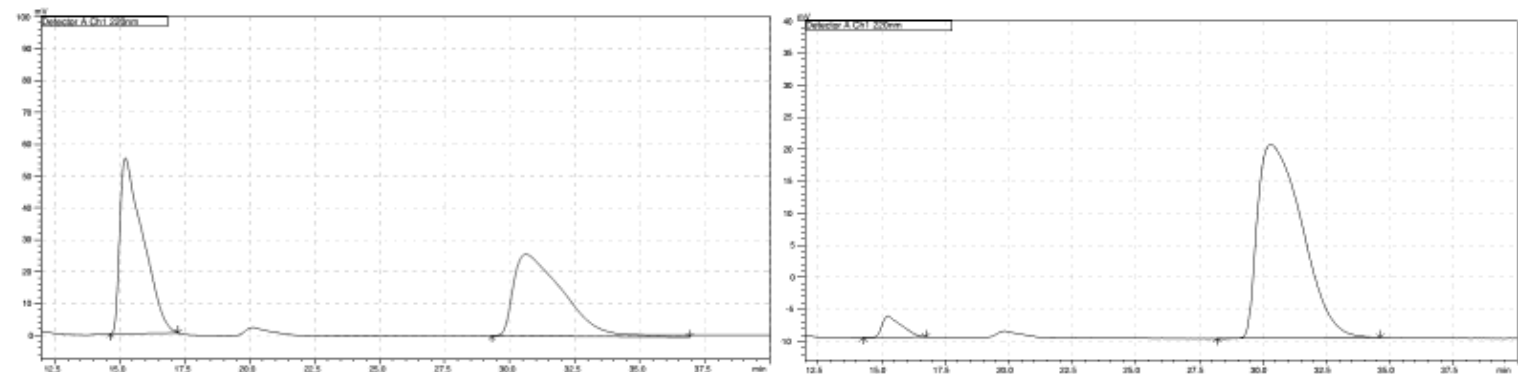

Retention Time Area Area\% Retention Time Area Area\% 


\begin{tabular}{|c|c|c|c|c|c|}
\hline 15.225 & 3405720 & 50.081 & 15.235 & 177097 & 4.591 \\
\hline 30.624 & 3394754 & 49.919 & 30.331 & 3679973 & 95.409 \\
\hline
\end{tabular}

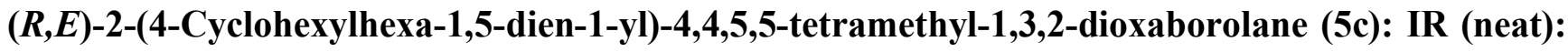
2974 (w), 2920 (s), 2850 (m), 1636 (s), 1446 (m), 1360 (s), 1318 (m), 1268 (w), 1143 (s), 1106 (m), 1057 (m), 996 (w), 970 (m), 909 (m), 849 (m), 770 (w), 674 (w) cm $\left.{ }^{-1} ;{ }^{1} \mathbf{H ~ N M R ~ ( 6 0 0 ~ M H z , ~ C D C l}_{3}\right): \delta$ $6.55(\mathrm{dt}, J=17.9,6.8 \mathrm{~Hz}, 1 \mathrm{H}), 5.60(\mathrm{dt}, J=18.9,9.9 \mathrm{~Hz}, 1 \mathrm{H}), 5.41(\mathrm{~d}, J=17.9 \mathrm{~Hz}, 1 \mathrm{H}), 5.04-4.85$ (m, 2H), 2.38-2.23 (m, 1H), 2.18 (dt, $J=14.3,7.2 \mathrm{~Hz}, 1 \mathrm{H}), 2.04-1.89(\mathrm{~m}, 1 \mathrm{H}), 1.76-1.59(\mathrm{~m}, 5 \mathrm{H}), 1.26$ (s, 12H), 1.24-1.04 (m, 4H), 1.00 (qd, $J=12.6,2.4 \mathrm{~Hz}, 1 \mathrm{H}), 0.94-0.85$ (m, 1H); ${ }^{13}$ C NMR (151 MHz, $\left.\mathbf{C D C l}_{3}\right): \delta 153.4,140.7,115.4,83.1,49.1,41.1,38.6,31.2,29.4,26.8,26.75,26.70,24.9$ (d, $\left.J=1.6 \mathrm{~Hz}\right)$; HRMS (DART): Calcd for $\mathrm{C}_{18} \mathrm{H}_{32} \mathrm{BO}_{2}[\mathrm{M}+\mathrm{H}]^{+}:$291.2495. Found: 291.2498; Specific rotation: $[\alpha]_{\mathrm{D}}{ }^{20}$ $+9.1\left(\mathrm{c}_{1.38}, \mathrm{CHCl}_{3}\right)$ for a 98:2 er sample. Enantiomeric purity of $\mathbf{5 c}$ was determined by HPLC analysis of the corresponding methyl ester produced through carbonylation of alkenyl $\mathrm{B}(\mathrm{pin})^{21}$ in comparison with authentic racemic material; Chiralpak AS-H, 100\% hexanes, $0.5 \mathrm{~mL} / \mathrm{min}, 220 \mathrm{~nm}$.
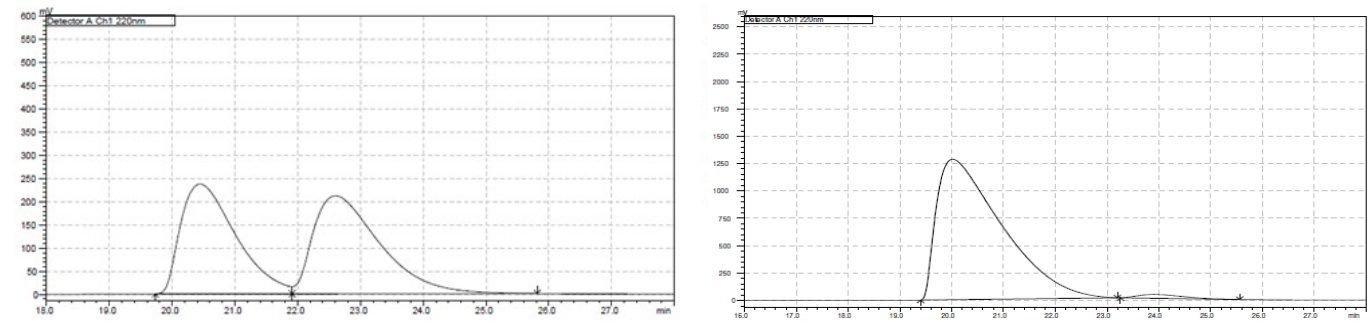

\begin{tabular}{|c|c|c|c|c|c|}
\hline Retention Time & Area & Area\% & Retention Time & Area & Area\% \\
\hline 20.446 & 14453470 & 48.183 & 20.017 & 11295585 & 98.149 \\
\hline 22.600 & 15543486 & 51.817 & 23.909 & 2119280 & 1.851 \\
\hline
\end{tabular}

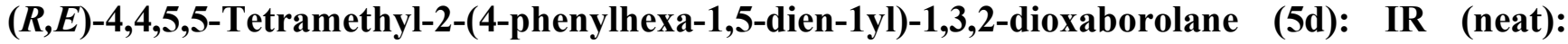
2975 (m), 2925 (w), 1724 (w), 1636 (w), 1447 (m), 1360 (m), 1322 (m), 1269 (m), 1141 (s), 908 (m), 849 (m), 759 (m), 699 (s), 672 (w) cm ${ }^{-1}$; ${ }^{1}$ H NMR (600 MHz, CDCl $): \delta 7.29$ (t, J= 7.7 Hz, 2H), $7.21-$ $7.17(\mathrm{~m}, 3 \mathrm{H}), 6.55(\mathrm{dt}, J=17.9,6.6 \mathrm{~Hz}, 1 \mathrm{H}), 5.96(\mathrm{ddd}, J=17.2,10.3,7.3 \mathrm{~Hz}, 1 \mathrm{H}), 5.46(\mathrm{~d}, J=17.9$ $\mathrm{Hz}, 1 \mathrm{H}), 5.08-4.98(\mathrm{~m}, 2 \mathrm{H}), 3.42(\mathrm{q}, J=7.3 \mathrm{~Hz}, 1 \mathrm{H}), 2.60(\mathrm{t}, J=7.1 \mathrm{~Hz}, 2 \mathrm{H}), 1.25(\mathrm{~s}, 12 \mathrm{H}) ;{ }^{13} \mathbf{C}$ NMR (151 MHz, CDCl $\mathbf{3}): \delta 152.0,143.9,141.5,128.6,127.8,126.4,114.8,83.2,48.9,41.9,24.9$; HRMS (DART): Calcd for $\mathrm{C}_{18} \mathrm{H}_{29} \mathrm{BO}_{2} \mathrm{~N}\left[\mathrm{M}+\mathrm{NH}_{4}\right]^{+}: 302.2291$. Found: 302.2283 . Specific rotation: $[\alpha]_{\mathrm{D}}{ }^{20}+3.3$ $\left(c 1.1, \mathrm{CHCl}_{3}\right)$ for a 97:3 er sample. Enantiomeric purity of $\mathbf{5 d}$ was determined by HPLC analysis in comparison with authentic racemic material; Chiralcel OD-H, 100\% hexanes, $0.5 \mathrm{~mL} / \mathrm{min}, 220 \mathrm{~nm}$.
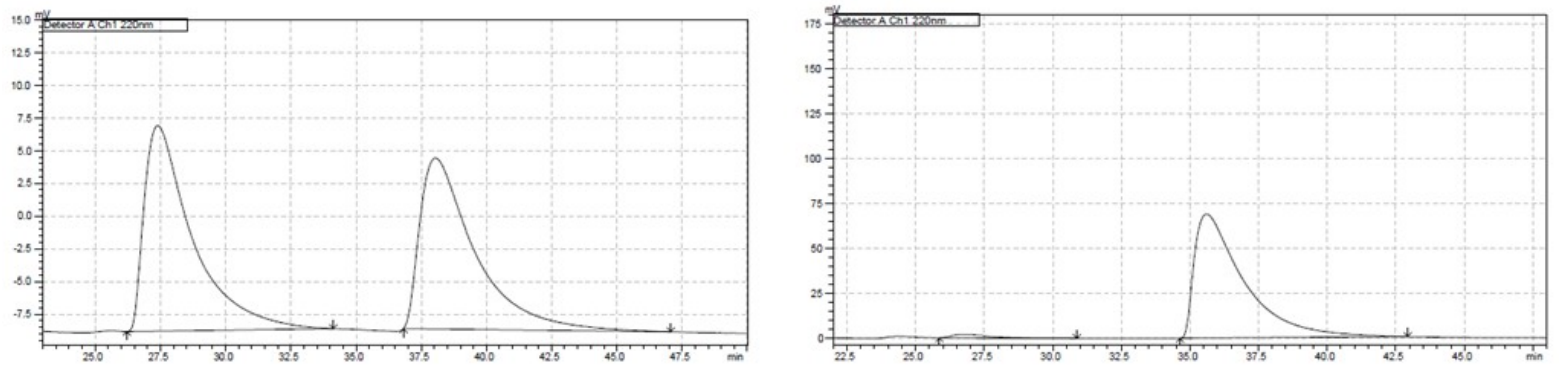


\begin{tabular}{|c|c|c|c|c|c|}
\hline Retention Time & Area & Area\% & Retention Time & Area & Area\% \\
\hline 27.401 & 2016218 & 51.271 & 26.740 & 187144 & 2.852 \\
\hline 38.044 & 1916264 & 48.729 & 35.606 & 8670259 & 97.148 \\
\hline
\end{tabular}

(R,E)-2-(4-(3-Bromophenyl)hexa-1,5-dien-1-yl)-4,4,5,5-tetramethyl-1,3,2-dioxaborolane (5e): IR (neat): $2974(\mathrm{w}), 2924(\mathrm{w}), 1725(\mathrm{w}), 1637(\mathrm{w}), 1566(\mathrm{w}), 1472(\mathrm{~m}), 1361(\mathrm{~m}), 1323(\mathrm{~m}), 1268(\mathrm{~m})$, 1215 (m), 1141 (s), 1071 (m), 907 (m), 849 (m), 781 (s), 695 (m), 671 (m) cm ${ }^{-1}$; ${ }^{1}$ H NMR (400 MHz, $\left.\mathbf{C D C l}_{3}\right): \delta 7.34-7.30(\mathrm{~m}, 2 \mathrm{H}), 7.19-7.07(\mathrm{~m}, 2 \mathrm{H}), 6.51$ (dt, $\left.J=17.9,6.6 \mathrm{~Hz}, 1 \mathrm{H}\right), 5.91$ (ddd, $J=17.5$, $10.1,7.3 \mathrm{~Hz}, 1 \mathrm{H}), 5.44$ (d, $J=17.9 \mathrm{~Hz}, 1 \mathrm{H}), 5.08$ (d, $J=10.3 \mathrm{~Hz}, 1 \mathrm{H}), 5.02$ (d, $J=17.1 \mathrm{~Hz}, 1 \mathrm{H}), 3.39$ (q, $J=7.3 \mathrm{~Hz}, 1 \mathrm{H}), 2.64-2.50(\mathrm{~m}, 2 \mathrm{H}), 1.25(\mathrm{~s}, 12 \mathrm{H}) ;{ }^{13} \mathbf{C}$ NMR (101 MHz, CDCl $\left.\mathbf{3}\right): \delta 151.2,146.1$, 140.7, 130.9, 130.2, 129.6, 126.5, 122.7, 115.4, 83.2, 48.6, 41.6, 24.9; HRMS (DART): Calcd for $\mathrm{C}_{18} \mathrm{H}_{28} \mathrm{BBrO}_{2} \mathrm{~N}\left[\mathrm{M}+\mathrm{NH}_{4}\right]^{+}: 380.1396$. Found: 380.1385 ; Specific rotation: $[\alpha]_{\mathrm{D}}{ }^{20}+4.6\left(c 1.2, \mathrm{CHCl}_{3}\right)$ for a 99:1 er sample. Enantiomeric purity of 5e was determined by HPLC analysis in comparison with authentic racemic material; Chiralcel OD-H, 100\% hexanes, $0.5 \mathrm{~mL} / \mathrm{min}, 220 \mathrm{~nm}$.
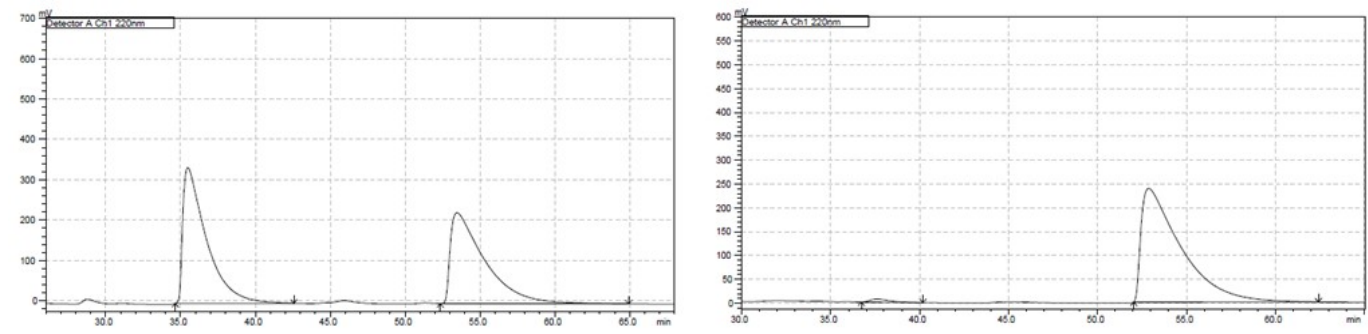

\begin{tabular}{|c|c|c|c|c|c|}
\hline Retention Time & Area & Area\% & Retention Time & Area & Area\% \\
\hline 35.482 & 36803489 & 50.588 & 37.608 & 500035 & 1.328 \\
\hline 53.472 & 35948195 & 49.412 & 52.877 & 37146073 & 98.672 \\
\hline
\end{tabular}

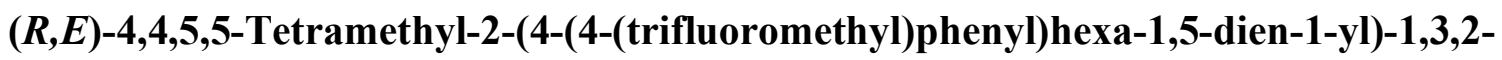

dioxaborolane (5f): IR (neat): 2976 (w), 2924 (w), 1725 (w), 1438 (w), 1371 (w), 1322 (s), 1269 (s), 1162 (m), 1119 (s), 1066 (s), 1016 (m), 908 (w), 843 (m), 769 (w), 672 (w), 605 (w) cm ${ }^{-1}$; ${ }^{1}$ H NMR (600 MHz, CDCl $): \delta 7.55(\mathrm{~d}, J=8.0 \mathrm{~Hz}, 2 \mathrm{H}), 7.29(\mathrm{~d}, J=8.0 \mathrm{~Hz}, 2 \mathrm{H}), 6.50$ (dt, $J=17.9,6.6 \mathrm{~Hz}, 1 \mathrm{H})$, $5.94(\mathrm{ddd}, J=17.3,10.3,7.1 \mathrm{~Hz}, 1 \mathrm{H}), 5.45(\mathrm{dt}, J=17.7,1.6 \mathrm{~Hz}, 1 \mathrm{H}), 5.15-4.98(\mathrm{~m}, 2 \mathrm{H}), 3.49(\mathrm{q}, J=$ $7.3 \mathrm{~Hz}, 1 \mathrm{H}), 2.65-2.54(\mathrm{~m}, 2 \mathrm{H}), 1.24(\mathrm{~s}, 12 \mathrm{H}) ;{ }^{13} \mathbf{C}$ NMR (101 MHz, CDCl $\left.\mathbf{3}\right): \delta 151.0,147.8,140.6$, $128.7(\mathrm{q}, J=32.4 \mathrm{~Hz}), 128.2,125.5(\mathrm{q}, J=3.7 \mathrm{~Hz}), 124.4(\mathrm{q}, J=270.4 \mathrm{~Hz}), 115.6,83.3,48.7$, 41.6, 24.9; ${ }^{19}$ F NMR (376 MHz, $\mathbf{C D C l}_{3}$ ): $\delta$-62.33; HRMS (DART): Calcd for $\mathrm{C}_{19} \mathrm{H}_{28} \mathrm{BF}_{3} \mathrm{O}_{2} \mathrm{~N}\left[\mathrm{M}+\mathrm{NH}_{4}\right]^{+}$: 370.2165. Found: 370.2175; Specific rotation: $[\alpha]_{\mathrm{D}}{ }^{20}+3.2\left(c 0.81, \mathrm{CHCl}_{3}\right)$ for a $99: 1$ er sample. Enantiomeric purity of $\mathbf{5 f}$ was determined by HPLC analysis in comparison with authentic racemic material; Chiralcel OD-H, 100\% hexanes, $0.5 \mathrm{~mL} / \mathrm{min}, 220 \mathrm{~nm}$. 

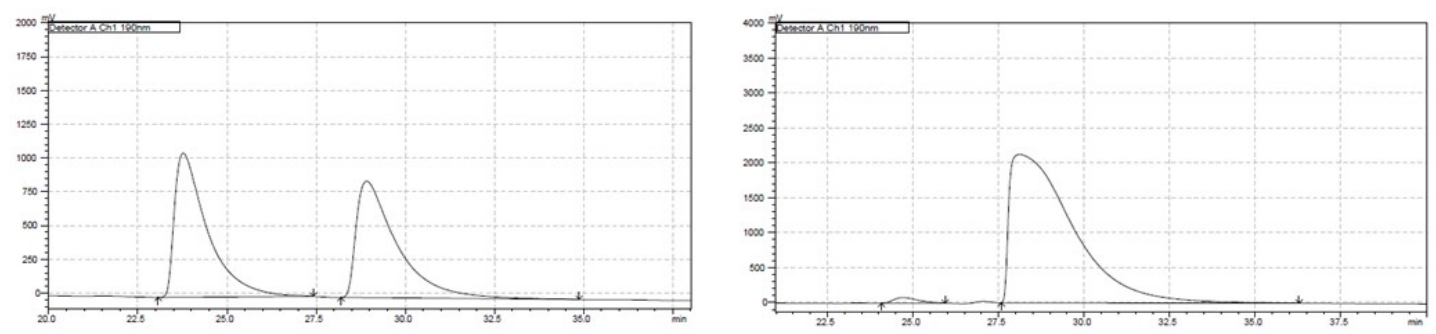

\begin{tabular}{|c|c|c|c|c|c|}
\hline Retention Time & Area & Area\% & Retention Time & Area & Area\% \\
\hline 23.772 & 68659412 & 49.998 & 24.708 & 4082671 & 1.468 \\
\hline 28.914 & 68665282 & 50.002 & 28.113 & 274087000 & 98.532 \\
\hline
\end{tabular}

(R,E)-4,4,5,5-Tetramethyl-2-(4-(thiophen-2-yl)hexa-1,5-dien-1-yl)-1,3,2-dioxaborolane (5g): IR (neat): 2975 (w), 2925 (w), 1637 (m), 1437 (w), 1360 (s), 1322 (m), 1232 (w), 1144 (s), 970 (w), 849 $(\mathrm{w}), 695$ (w) cm ${ }^{-1} ;{ }^{1} \mathbf{H}$ NMR (400 MHz, $\left.\mathbf{C D C l}_{3}\right): \delta 7.15$ (dd, $\left.J=5.2,1.2 \mathrm{~Hz}, 1 \mathrm{H}\right), 6.93$ (dd, $J=5.1,3.5$ $\mathrm{Hz}, 1 \mathrm{H}), 6.83(\mathrm{~d}, J=3.5 \mathrm{~Hz}, 1 \mathrm{H}), 6.57$ (dt, $J=17.9,6.6 \mathrm{~Hz}, 1 \mathrm{H}), 5.92$ (ddd, $J=17.4,9.9,7.7 \mathrm{~Hz}, 1 \mathrm{H})$, 5.49 (dt, $J=17.9,1.5 \mathrm{~Hz}, 1 \mathrm{H}), 5.17-5.02(\mathrm{~m}, 2 \mathrm{H}), 3.71(\mathrm{q}, J=7.4 \mathrm{~Hz}, 1 \mathrm{H}), 2.74-2.54(\mathrm{~m}, 2 \mathrm{H}), 1.25$ (s, 12H); ${ }^{13}$ C NMR (101 MHz, $\left.\mathbf{C D C l}_{3}\right): \delta 151.1,147.6,140.8,126.8,123.8,123.6,115.4,83.2,44.3,42.8$, 24.9; HRMS (DART): Calcd for $\mathrm{C}_{28} \mathrm{H}_{35} \mathrm{BNO}_{4} \mathrm{~S}[\mathrm{M}+\mathrm{H}]^{+}:$291.1585. Found: 291.1597; Specific rotation: $[\alpha]_{\mathrm{D}}{ }^{20}-11.5\left(c 0.73, \mathrm{CHCl}_{3}\right)$ for a 97:3 er sample. Enantiomeric purity of $\mathbf{5 g}$ was determined by HPLC analysis in comparison with authentic racemic material; Chiralcel OD-H, 99.9\% hexanes, $0.5 \mathrm{~mL} / \mathrm{min}$, $220 \mathrm{~nm}$.
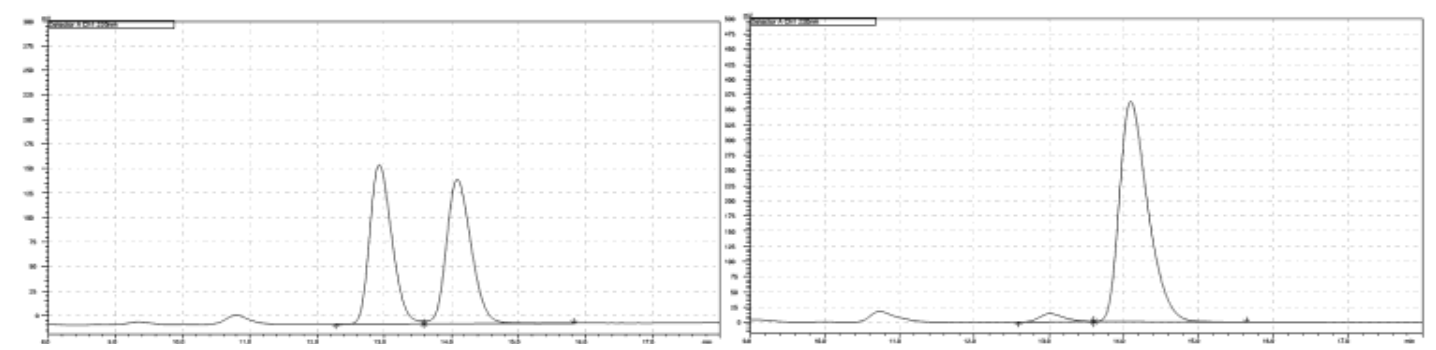

\begin{tabular}{|c|c|c|c|c|c|}
\hline Retention Time & Area & Area\% & Retention Time & Area & Area\% \\
\hline 12.925 & 3738109 & 49.870 & 13.012 & 317387 & 3.206 \\
\hline 14.087 & 3757643 & 50.130 & 14.094 & 9582728 & 96.794 \\
\hline
\end{tabular}

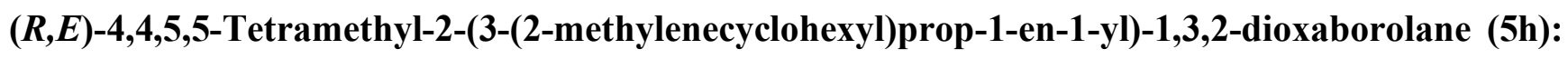
IR (neat): 2975 (w), 2925 (m), 1852 (w), 1636 (m), 1445 (w), 1358 (s), 1319 (m), 1268 (w), 1145 (s), $971(\mathrm{w}), 849(\mathrm{w}) \mathrm{cm}^{-1}{ }^{1} \mathbf{H}$ NMR (500 MHz, $\left.\mathbf{C D C l}_{3}\right): \delta 6.61(\mathrm{dt}, J=17.9,6.4 \mathrm{~Hz}, 1 \mathrm{H}), 5.45(\mathrm{~d}, J=18.0$ $\mathrm{Hz}, 1 \mathrm{H}), 4.66(\mathrm{~s}, 1 \mathrm{H}), 4.57(\mathrm{~s}, 1 \mathrm{H}), 2.52-2.42(\mathrm{~m}, 1 \mathrm{H}), 2.30-2.21(\mathrm{~m}, 1 \mathrm{H}), 2.21-2.08(\mathrm{~m}, 2 \mathrm{H}), 2.05-$ $1.95(\mathrm{~m}, 1 \mathrm{H}), 1.85-1.75(\mathrm{~m}, 1 \mathrm{H}), 1.73-1.60(\mathrm{~m}, 2 \mathrm{H}), 1.47-1.36(\mathrm{~m}, 2 \mathrm{H}), 1.26(\mathrm{~s}, 12 \mathrm{H}), 1.20-1.08(\mathrm{~m}$, 1H); ${ }^{13} \mathbf{C}$ NMR (126 MHz, $\left.\mathbf{C D C l}_{3}\right): \delta$ 153.5, 152.7, 105.6, 83.2, 42.4, 39.2, 35.7, 33.8, 28.9, 25.1, 24.9, 24.9; HRMS (DART): Calcd for $\mathrm{C}_{16} \mathrm{H}_{28} \mathrm{BO}_{2}[\mathrm{M}+\mathrm{H}]^{+}$: 263.2177. Found: 263.2175; Specific rotation: $[\alpha]_{\mathrm{D}}{ }^{20}+6.9\left(c 0.43, \mathrm{CHCl}_{3}\right)$ for a 97:3 er sample. Enantiomeric purity of $\mathbf{5 h}$ was determined by HPLC analysis in comparison with authentic racemic material; Chiralcel OZ-H, $100 \%$ hexanes, $0.5 \mathrm{~mL} / \mathrm{min}$, $220 \mathrm{~nm}$. 

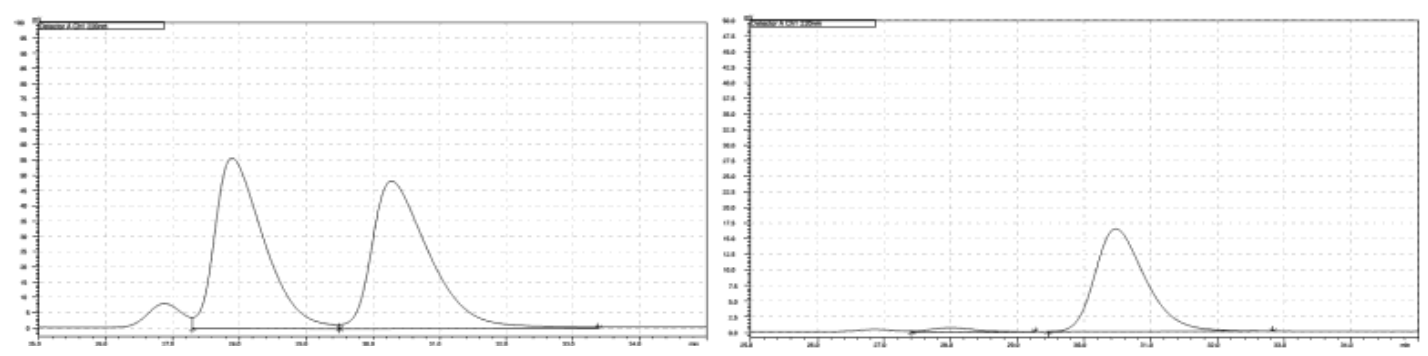

\begin{tabular}{|c|c|c|c|c|c|}
\hline Retention Time & Area & Area\% & Retention Time & Area & Area\% \\
\hline 27.888 & 2825960 & 49.542 & 28.000 & 27880 & 3.135 \\
\hline 30.278 & 2878176 & 50.458 & 30.471 & 861449 & 96.865 \\
\hline
\end{tabular}

4,4,5,5-Tetramethyl-2-((E)-3-((1S,5S)-2-methylene-5-(prop-1-en-2-yl)cyclohexyl)prop-1-en-1-yl)1,3,2-dioxaborolane (5i): IR (neat): 3080 (w), 2975 (m), 2926 (m), 2852 (w), 1637 (m), 1440 (w), 1357 (s), 1319 (m), 1144 (s), 996 (w), 970 (w), 888 (m), 848 (w) cm ${ }^{-1} ;{ }^{1}$ H NMR (400 MHz, CDCl $): \delta 6.63$ (dt, $J=17.9,6.3 \mathrm{~Hz}, 1 \mathrm{H}), 5.47(\mathrm{~d}, J=17.8 \mathrm{~Hz}, 1 \mathrm{H}), 4.74-4.56(\mathrm{~m}, 4 \mathrm{H}), 2.62-2.50(\mathrm{~m}, 1 \mathrm{H}), 2.38$ (dt, $J$ $=13.0,3.4 \mathrm{~Hz}, 1 \mathrm{H}), 2.16-2.01(\mathrm{~m}, 4 \mathrm{H}), 1.96-1.79(\mathrm{~m}, 2 \mathrm{H}), 1.69(\mathrm{~d}, J=1.2 \mathrm{~Hz}, 3 \mathrm{H}), 1.30-1.24(\mathrm{~m}, 13 \mathrm{H})$, 0.95 (q, $J=12.1 \mathrm{~Hz}, 1 \mathrm{H}) ;{ }^{13} \mathbf{C}$ NMR (101 MHz, $\left.\mathbf{C D C l}_{3}\right): \delta 153.3,152.1,150.1,108.8,105.2,83.2,45.7$, 41.5, 39.34, 39.30, 36.9, 33.9, 25.0, 24.9, 20.9; HRMS (DART): Calcd for $\mathrm{C}_{19} \mathrm{H}_{32} \mathrm{BO}_{2}[\mathrm{M}+\mathrm{H}]^{+}$: 303.2490. Found: 303.2491; Specific rotation: $[\alpha]_{\mathrm{D}}{ }^{20}+4.0\left(c 0.15, \mathrm{CHCl}_{3}\right)$ for a $96: 4 \mathrm{dr}$ sample.

\section{4,4,5,5-Tetramethyl-2-((E)-3-((1R,5S)-2-methylene-5-(prop-1-en-2-yl)cyclohexyl)prop-1-en-1-yl)-} 1,3,2-dioxaborolane (5j): IR (neat): 3066 (w), 2975 (m), 2927 (m), 2852 (w), 1637 (m), 1444 (w), 1360 (s), 1319 (m), 1144 (s), 1000 (w), 971 (w), 889 (m), 848 (w) cm ${ }^{-1}$; ${ }^{1}$ H NMR (400 MHz, CDCl $)$ : $\delta 6.54(\mathrm{dt}, J=17.9,6.8 \mathrm{~Hz}, 1 \mathrm{H}), 5.42(\mathrm{~d}, J=17.8 \mathrm{~Hz}, 1 \mathrm{H}), 4.73-4.46(\mathrm{~m}, 4 \mathrm{H}), 2.53-2.44(\mathrm{~m}, 1 \mathrm{H}), 2.40$ $2.29(\mathrm{~m}, 2 \mathrm{H}), 2.27-2.08(\mathrm{~m}, 3 \mathrm{H}), 1.88-1.71(\mathrm{~m}, 2 \mathrm{H}), 1.69(\mathrm{~s}, 3 \mathrm{H}), 1.53-1.39(\mathrm{~m}, 1 \mathrm{H}), 1.31-1.23(\mathrm{~m}$, 13H); ${ }^{13} \mathbf{C}$ NMR (101MHz, $\left.\mathbf{C D C l}_{3}\right): \delta$ 153.1, 150.9, 150.0, 108.8, 108.2, 83.2, 42.6, 39.3, 39.1, 36.5, 33.2, 31.2, 24.9 (d, $J=2.7 \mathrm{~Hz}), 21.1$; HRMS (DART): Calcd for $\mathrm{C}_{19} \mathrm{H}_{32} \mathrm{BO}_{2}[\mathrm{M}+\mathrm{H}]^{+}: 303.2490$. Found: 303.2502; Specific rotation: $[\alpha]_{\mathrm{D}}{ }^{20}-30.8\left(c 0.40, \mathrm{CHCl}_{3}\right)$ for a $>98: 2 \mathrm{dr}$ sample.

\section{Products with a Quaternary Carbon Stereogenic Center}

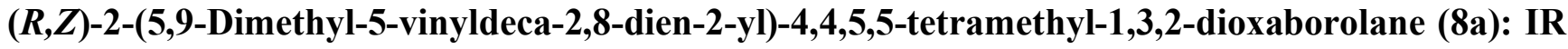
(neat): 2968 (w), 1714 (w), 1445 (w), 1365 (w), 1268 (m), 1034 (s), 902 (s), 872 (w), 762 (s) cm ${ }^{-1} ;{ }^{1} \mathbf{H}$ NMR (600 MHz, CDCl $): \delta 6.33(\mathrm{t}, J=7.3 \mathrm{~Hz}, 1 \mathrm{H}), 5.76(\mathrm{dd}, J=17.5,10.7 \mathrm{~Hz}, 1 \mathrm{H}), 5.09$ (t, $J=7.5$ $\mathrm{Hz}, 1 \mathrm{H}), 5.02-4.89(\mathrm{~m}, 2 \mathrm{H}), 2.17(\mathrm{dd}, J=14.8,7.6 \mathrm{~Hz}, 1 \mathrm{H}), 2.11(\mathrm{dd}, \mathrm{J}=14.7,6.9 \mathrm{~Hz}, 1 \mathrm{H}), 1.87(\mathrm{q}, J$ $=7.9 \mathrm{~Hz}, 2 \mathrm{H}), 1.67(\mathrm{~s}, 6 \mathrm{H}), 1.58(\mathrm{~s}, 3 \mathrm{H}), 1.36-1.31(\mathrm{~m}, 2 \mathrm{H}), 1.25(\mathrm{~s}, 12 \mathrm{H}), 1.00(\mathrm{~s}, 3 \mathrm{H}) ;{ }^{13}$ C NMR (151 MHz, $\left.\mathbf{C D C l}_{3}\right): \delta 147.0,142.6,131.2,125.2,111.9,83.2,40.6,40.2,39.7,25.8,24.9$ (d, J = 3.4 Hz), 23.1, 23.0, 17.7, 14.3; HRMS (DART): Calcd for $\mathrm{C}_{20} \mathrm{H}_{36} \mathrm{BO}_{2}[\mathrm{M}+\mathrm{H}]^{+}$: 319.2803. Found: 319.2803; Specific rotation: $[\alpha]_{\mathrm{D}}{ }^{20}+4.7\left(c 0.38, \mathrm{CHCl}_{3}\right)$ for a $95: 5$ er sample. Enantiomeric purity of 8a was determined by HPLC analysis of the corresponding methyl ester produced through carbonylation of alkenyl $\mathrm{B}(\text { pin })^{21}$ in comparison with authentic racemic material; Chiralpak AD-H, 100\% hexanes, 0.5 $\mathrm{mL} / \mathrm{min}, 220 \mathrm{~nm}$. 

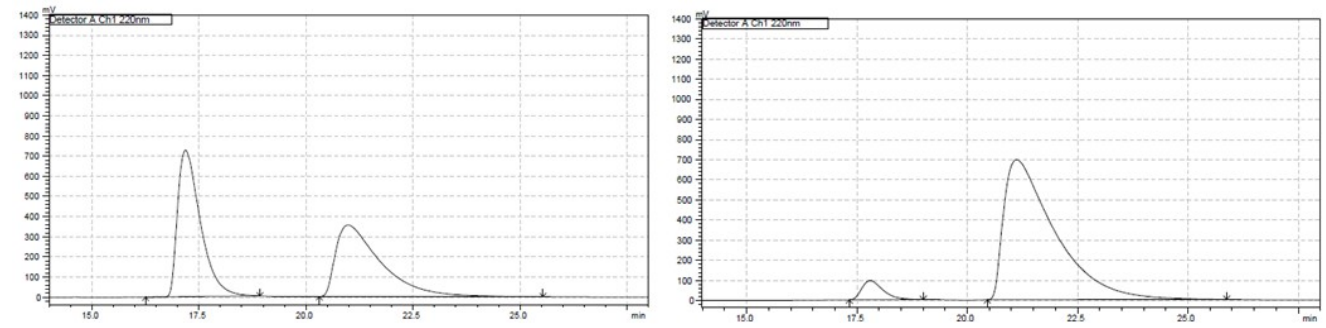

\begin{tabular}{|c|c|c|c|c|c|}
\hline Retention Time & Area & Area\% & Retention Time & Area & Area\% \\
\hline 17.184 & 27020752 & 50.942 & 17.800 & 3168060 & 5.351 \\
\hline 20.983 & 26021487 & 49.058 & 21.118 & 56034616 & 94.649 \\
\hline
\end{tabular}

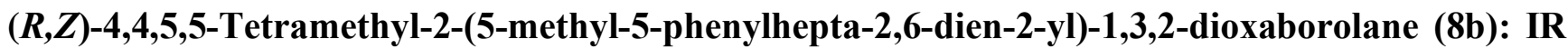
(neat): $2973(\mathrm{w}), 2925$ (w), $1716(\mathrm{w}), 1444(\mathrm{w}), 1410(\mathrm{w}), 1369(\mathrm{~m}), 1303$ (w), 1269 (m), 1077 (s), 906 (s), $764(\mathrm{~m}), 700(\mathrm{w}) \mathrm{cm}^{-1} ;{ }^{1} \mathbf{H}$ NMR (500 MHz, $\left.\mathbf{C D C l}_{3}\right)$ : $\delta$ 7.36-7.27 (m, 4H), 7.18 (tt, J=6.7, $1.4 \mathrm{~Hz}$, $1 \mathrm{H}), 6.24(\mathrm{td}, J=7.0,1.7 \mathrm{~Hz}, 1 \mathrm{H}), 6.06(\mathrm{dd}, J=17.5,10.7 \mathrm{~Hz}, 1 \mathrm{H}), 5.12(\mathrm{dd}, J=10.7,1.2 \mathrm{~Hz}, 1 \mathrm{H}), 5.05$ $(\mathrm{dd}, J=17.5,1.2 \mathrm{~Hz}, 1 \mathrm{H}), 2.67-2.55(\mathrm{~m}, 2 \mathrm{H}), 1.66(\mathrm{~s}, 3 \mathrm{H}), 1.39(\mathrm{~s}, 3 \mathrm{H}), 1.23(\mathrm{~s}, 12 \mathrm{H}) ;{ }^{13}$ C NMR (126 MHz, CDCl 3$): \delta 147.5,146.6,142.3,128.2,126.8,126.0,112.4,83.2,44.6,39.9,25.3,24.9,14.4$; HRMS (DART): Calcd for $\mathrm{C}_{20} \mathrm{H}_{30} \mathrm{BO}_{2}[\mathrm{M}+\mathrm{H}]^{+}: 313.2339$. Found: 313.2349; Specific rotation: $[\alpha]_{\mathrm{D}}{ }^{20}$ $+5.6\left(c 0.53, \mathrm{CHCl}_{3}\right)$ for a 94:6 er sample. Enantiomeric purity of $\mathbf{8 b}$ was determined by HPLC analysis in comparison with authentic racemic material; Chiralpak AD-H, 100\% hexanes, $0.2 \mathrm{~mL} / \mathrm{min}, 220 \mathrm{~nm}$.
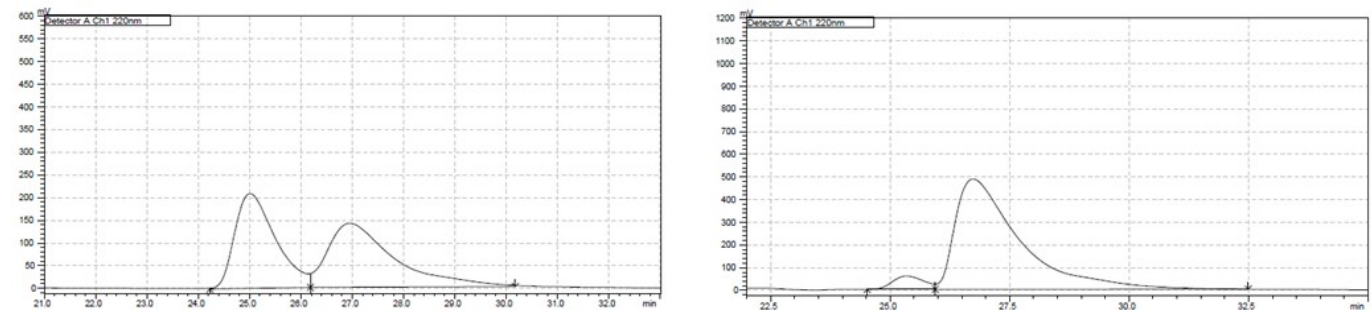

\begin{tabular}{|c|c|c|c|c|c|}
\hline Retention Time & Area & Area\% & Retention Time & Area & Area\% \\
\hline 25.007 & 11560948 & 47.765 & 25.343 & 2662403 & 5.527 \\
\hline 26.950 & 12642626 & 52.235 & 26.733 & 45509942 & 94.473 \\
\hline
\end{tabular}

\section{(R,Z)-2-(5-(3-Chlorophenyl)-5-methylhepta-2,6-dien-2-yl)-4,4,5,5-tetramethyl-1,3,2-}

dioxaborolane (8c): IR (neat): 2974 (m), 2929 (w), 1629 (w), 1593 (w), 1466 (w), 1410 (m), 1369 (m), 1344 (m), 1303 (m), 1145 (m), 918 (w), 860 (w), 784 (w), 666 (w) cm ${ }^{-1}$; ${ }^{1}$ H NMR (400 MHz, CDCl $\mathbf{~ M M}_{3}$ : $\delta 7.31-7.29(\mathrm{~m}, 1 \mathrm{H}), 7.24-7.20(\mathrm{~m}, 2 \mathrm{H}), 7.19-7.14(\mathrm{~m}, 1 \mathrm{H}), 6.18(\mathrm{td}, J=7.0,1.8 \mathrm{~Hz}, 1 \mathrm{H}), 6.02(\mathrm{dd}, J=$ $17.4,10.7 \mathrm{~Hz}, 1 \mathrm{H}), 5.15$ (dd, $J=10.7,1.1 \mathrm{~Hz}, 1 \mathrm{H}), 5.07$ (dd, $J=17.5,1.1 \mathrm{~Hz}, 1 \mathrm{H}), 2.64-2.50(\mathrm{~m}, 2 \mathrm{H})$, 1.64 (s, 3H), 1.37 (s, 3H), 1.23 (s, 12H); $\left.{ }^{13} \mathbf{C ~ N M R ~ ( 1 0 1 ~ M H z , ~ C D C l ~} \mathbf{3}\right): \delta$ 149.6, 145.8, 141.6, 134.1, 129.4, 127.3, 126.2, 125.1, 113.0, 83.3, 44.7, 39.8, 25.3, 24.9 (d, $J=3.3 \mathrm{~Hz}$ ), 14.4; HRMS (DART): Calcd for $\mathrm{C}_{20} \mathrm{H}_{29} \mathrm{BO}_{2} \mathrm{Cl}[\mathrm{M}+\mathrm{H}]^{+}: 347.1944$. Found: 347.1934 ; Specific rotation: $[\alpha]_{\mathrm{D}}{ }^{20}+17.8$ (c 0.30, $\mathrm{CHCl}_{3}$ ) for a $96: 4$ er sample. Enantiomeric purity of $\mathbf{8 c}$ was determined by HPLC analysis in comparison with authentic racemic material; Chiralcel OJ-H, 100\% hexanes, $0.3 \mathrm{~mL} / \mathrm{min}, 220 \mathrm{~nm}$. 

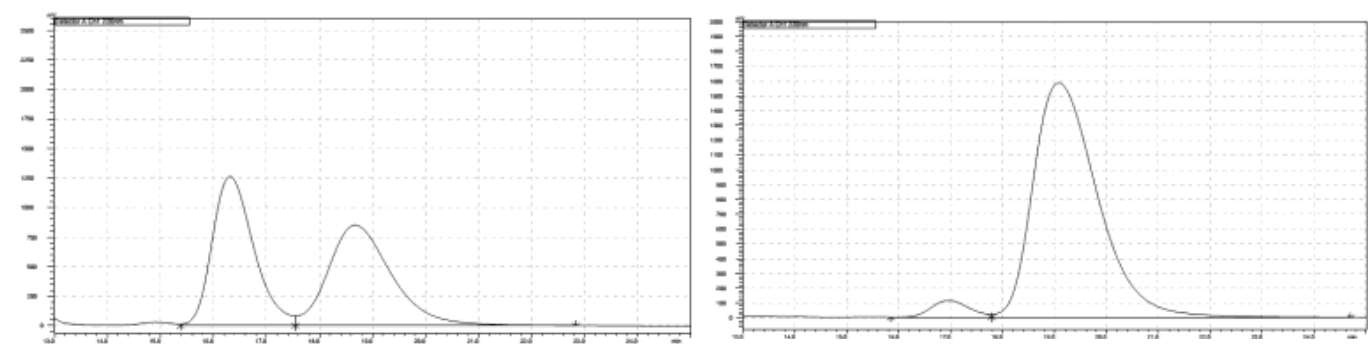

\begin{tabular}{|c|c|c|c|c|c|}
\hline Retention Time & Area & Area\% & Retention Time & Area & Area\% \\
\hline 16.313 & 68552140 & 49.246 & 16.957 & 5809718 & 4.097 \\
\hline 18.671 & 70651389 & 50.754 & 19.079 & 136011666 & 95.903 \\
\hline
\end{tabular}

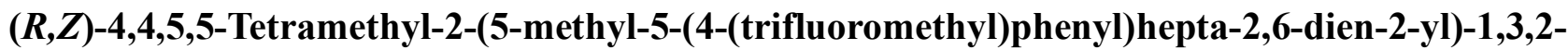
dioxaborolane (8d): M. P.: 53-55 ${ }^{\circ} \mathrm{C}$; IR (neat): 2976 (w), 2931 (w), 1629 (w), 1410 (w), 1369 (w), 1326 (s), 1165 (m), 1123 (m), 1078 (m), 1015 (w), 837 (w) cm ${ }^{-1} ;{ }^{1}$ H NMR (400 MHz, CDCl $\left.\mathbf{3}\right): \delta 7.55$ $(\mathrm{d}, J=8.4 \mathrm{~Hz}, 2 \mathrm{H}), 7.44(\mathrm{~d}, J=8.3 \mathrm{~Hz}, 2 \mathrm{H}), 6.17(\mathrm{td}, J=7.0,1.8 \mathrm{~Hz}, 1 \mathrm{H}), 6.04(\mathrm{dd}, J=17.5,10.7 \mathrm{~Hz}$, $1 \mathrm{H}), 5.16(\mathrm{dd}, J=10.8,1.1 \mathrm{~Hz}, 1 \mathrm{H}), 5.07(\mathrm{dd}, J=17.4,1.1 \mathrm{~Hz}, 1 \mathrm{H}), 2.67-2.54(\mathrm{~m}, 2 \mathrm{H}), 1.66-1.63(\mathrm{~m}$, 3H), 1.41 (s, 3H), 1.22 (s, 12H); ${ }^{13} \mathbf{C}$ NMR (101 MHz, $\left.\mathbf{C D C l}_{3}\right): \delta 151.5,145.8,141.3,128.3$ (q, $J=32.4$ $\mathrm{Hz}), 127.3,125.1$ (q, $J=3.8 \mathrm{~Hz}), 124.5$ (q, $J=270.4 \mathrm{~Hz}) 113.2,83.3,44.8,39.8,25.3,24.9$ (d, $J=1.9$ $\mathrm{Hz}$ ), 14.4; ${ }^{19} \mathbf{F}$ NMR (376 MHz, CDCl$): ~ \delta-62.37$; HRMS (DART): Calcd for $\mathrm{C}_{21} \mathrm{H}_{29} \mathrm{BO}_{2} \mathrm{~F}_{3}[\mathrm{M}+\mathrm{H}]^{+}$: 381.2207. Found: 381.2199; Specific rotation: $[\alpha]_{\mathrm{D}}{ }^{20}+11.1\left(c 0.21, \mathrm{CHCl}_{3}\right)$ for a 94:6 er sample. Enantiomeric purity of $\mathbf{8 d}$ was determined by HPLC analysis in comparison with authentic racemic material; Chiralcel OZ-3, 100\% hexanes, $1.0 \mathrm{~mL} / \mathrm{min}, 220 \mathrm{~nm}$.
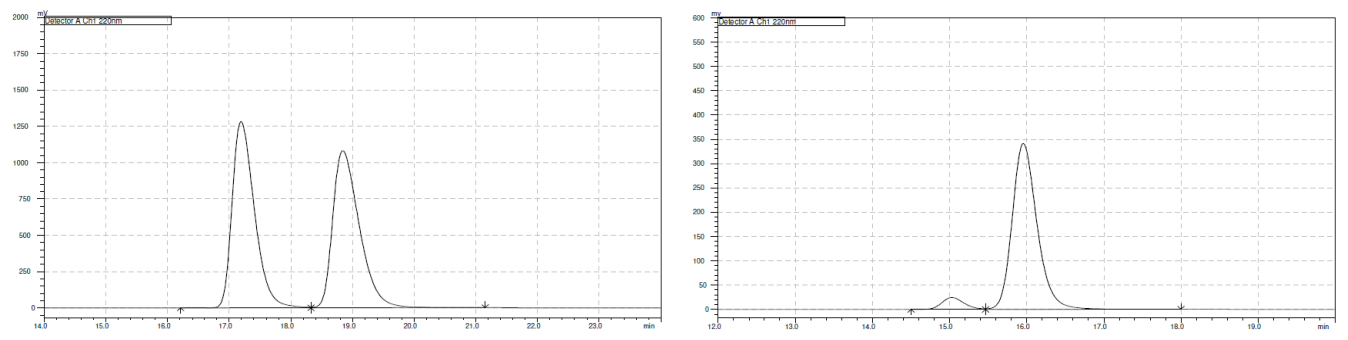

\begin{tabular}{|c|c|c|c|c|c|}
\hline Retention Time & Area & Area\% & Retention Time & Area & Area\% \\
\hline 17.191 & 32340850 & 50.056 & 15.031 & 488779 & 6.024 \\
\hline 18.842 & 32268593 & 49.944 & 15.956 & 7625033 & 93.976 \\
\hline
\end{tabular}

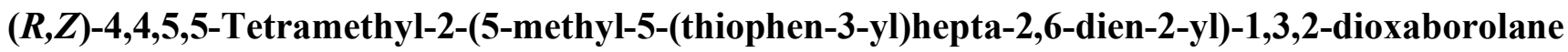
(8e): IR (neat): 2974 (m), 2929 (w), 1629 (w), 1409 (w), 1368 (s), 1342 (m), 1302 (m), 1144 (m), 912 (w), 859 (w), 780 (w), 666 (w) cm ${ }^{-1}$; ${ }^{1} \mathbf{H}$ NMR (500 MHz, CDCl $): \delta$ 7.26-7.23 (m, 1H), 7.03-7.00 (m, $1 \mathrm{H}), 7.00-6.97(\mathrm{~m}, 1 \mathrm{H}), 6.26(\mathrm{tt}, J=7.1,1.7 \mathrm{~Hz}, 1 \mathrm{H}), 6.05(\mathrm{dd}, J=17.4,10.6 \mathrm{~Hz}, 1 \mathrm{H}), 5.06(\mathrm{~d}, J=10.6$ $\mathrm{Hz}, 1 \mathrm{H}), 4.99$ (d, $J=17.4 \mathrm{~Hz}, 1 \mathrm{H}), 2.62-2.50(\mathrm{~m}, 2 \mathrm{H}), 1.66(\mathrm{~s}, 3 \mathrm{H}), 1.39(\mathrm{~s}, 3 \mathrm{H}), 1.24(\mathrm{~s}, 12 \mathrm{H}) ;{ }^{13} \mathrm{C}$ NMR (126 MHz, CDCl $)$ ): $\delta$ 149.1, 146.2, 142.0, 127.2, 125.1, 119.6, 112.2, 83.2, 43.0, 40.3, 25.2, 24.9, 14.4; HRMS (DART): Calcd for $\mathrm{C}_{18} \mathrm{H}_{28} \mathrm{BO}_{2} \mathrm{~S}$ [M+H] ${ }^{+}: 319.1898$. Found: 319.1901; Specific rotation: $[\alpha]_{\mathrm{D}}^{20}+2.8\left(c 0.57, \mathrm{CHCl}_{3}\right)$ for a 93:7 er sample. Enantiomeric purity of $\mathbf{8 e}$ was determined by HPLC 
analysis in comparison with authentic racemic material; Chiralcel OZ-H, 100\% hexanes, $1.0 \mathrm{~mL} / \mathrm{min}$, $220 \mathrm{~nm}$.
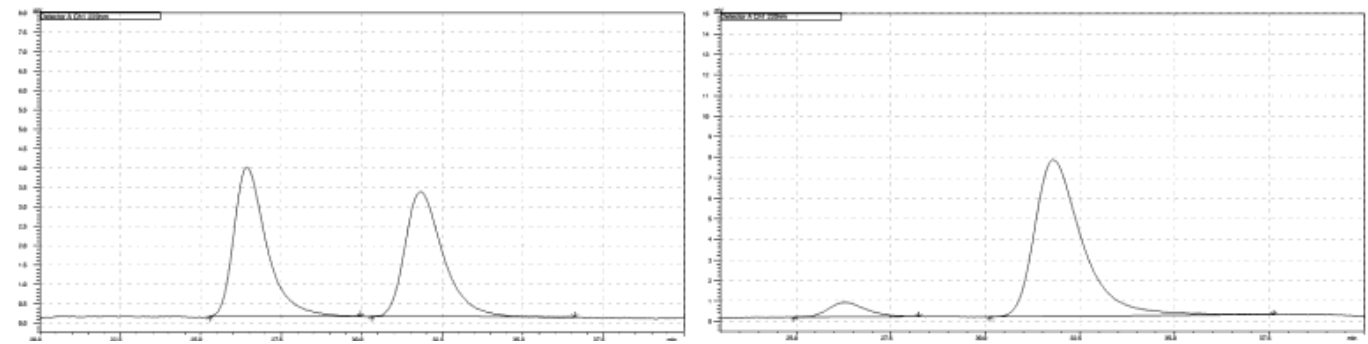

\begin{tabular}{|c|c|c|c|c|c|}
\hline Retention Time & Area & Area\% & Retention Time & Area & Area\% \\
\hline 26.433 & 270877 & 50.703 & 26.299 & 48364 & 6.773 \\
\hline 31.816 & 263363 & 49.297 & 31.772 & 665662 & 93.227 \\
\hline
\end{tabular}

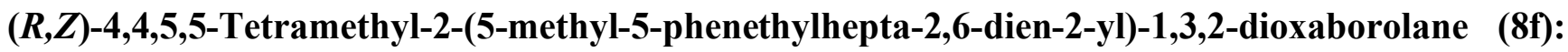
IR (neat): 3023 (w), 2974 (m), 2929 (w), 1629 (w), 1454 (w), 1369 (s), 1347 (m), 1302 (m), 1144 (m), 1100 (w), 911 (w), 859 (w) cm ${ }^{-1} ;{ }^{1} \mathbf{H}$ NMR (400 MHz, CDCl $)$ : $\delta$ 7.29-7.23 (m, 2H), 7.19-7.12 (m, 3H), $6.36(\mathrm{td}, J=7.3,1.8 \mathrm{~Hz}, 1 \mathrm{H}), 5.83(\mathrm{dd}, J=17.5,10.8 \mathrm{~Hz}, 1 \mathrm{H}), 5.07(\mathrm{dd}, J=10.8,1.4 \mathrm{~Hz}, 1 \mathrm{H}), 5.00(\mathrm{dd}$, $J=17.5,1.4 \mathrm{~Hz}, 1 \mathrm{H}), 2.55-2.46(\mathrm{~m}, 2 \mathrm{H}), 2.29-2.12(\mathrm{~m}, 2 \mathrm{H}), 1.69(\mathrm{~s}, 3 \mathrm{H}), 1.67-1.59$ (m, 2H), 1.26 (s, 12H), 1.07 (s, 3H); ${ }^{13} \mathbf{C}$ NMR (101 MHz, $\left.\mathbf{C D C l}_{3}\right): \delta 146.7,143.4,142.3,128.5,128.4,125.7,112.3,83.2$, 42.8, 40.4, 39.7, 30.9, 25.0, 24.9, 23.1, 14.4; HRMS (DART): Calcd for $\mathrm{C}_{22} \mathrm{H}_{34} \mathrm{BO}_{2}[\mathrm{M}+\mathrm{H}]^{+}: 341.2646$. Found: 341.2643; Specific rotation: $[\alpha]_{\mathrm{D}}{ }^{20}-1.7\left(c 0.73, \mathrm{CHCl}_{3}\right)$ for a $96: 4$ er sample. Enantiomeric purity of $\mathbf{8 f}$ was determined by HPLC analysis in comparison with authentic racemic material; Chiralpak AD-H, 100\% hexanes, $0.5 \mathrm{~mL} / \mathrm{min}, 220 \mathrm{~nm}$.
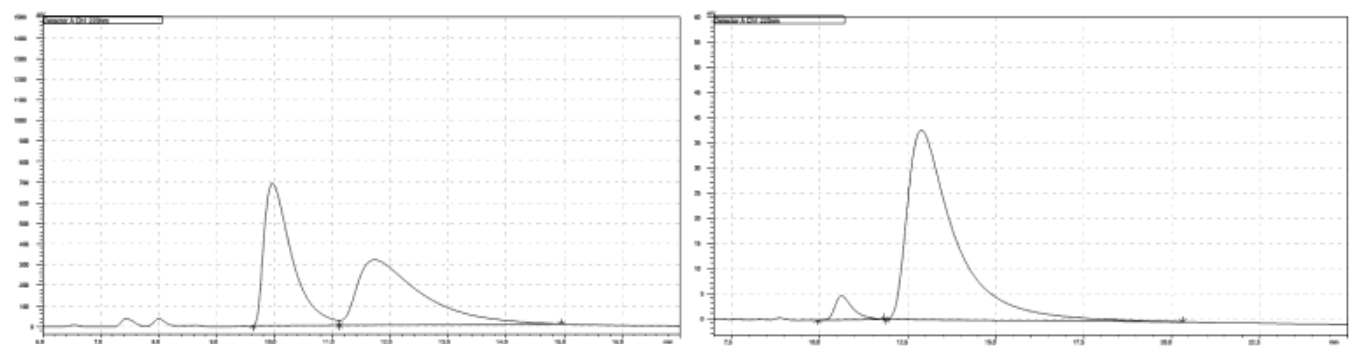

\begin{tabular}{|c|c|c|c|c|c|}
\hline Retention Time & Area & Area\% & Retention Time & Area & Area\% \\
\hline 9.959 & 23148172 & 48.665 & 10.625 & 168144 & 4.488 \\
\hline 11.724 & 24417862 & 51.335 & 12.890 & 3578699 & 95.512 \\
\hline
\end{tabular}

(R,Z)-2-(5-Cyclohexyl-5-methylhepta-2,6-dien-2-yl)-4,4,5,5-tetramethyl-1,3,2-dioxaborolane (8g): IR (neat): 2974 (m), 2923 (s), 2850 (m), 1627 (w), 1410 (w), 1369 (s), 1301 (m), $1145(\mathrm{~m}), 666(\mathrm{w}) \mathrm{cm}^{-}$ 1; ${ }^{1}$ H NMR (400 MHz, CDCl $): \delta 6.31(\mathrm{t}, J=6.3 \mathrm{~Hz}, 1 \mathrm{H}), 5.75(\mathrm{dd}, J=17.6,10.9 \mathrm{~Hz}, 1 \mathrm{H}), 5.01(\mathrm{dd}, J$ $=10.9,1.6 \mathrm{~Hz}, 1 \mathrm{H}), 4.88(\mathrm{dd}, J=17.6,1.6 \mathrm{~Hz}, 1 \mathrm{H}), 2.25(\mathrm{dd}, J=14.9,7.8 \mathrm{~Hz}, 1 \mathrm{H}), 2.10(\mathrm{dd}, J=14.9$, $6.6 \mathrm{~Hz}, 1 \mathrm{H}), 1.80-1.69(\mathrm{~m}, 4 \mathrm{H}), 1.69-1.59(\mathrm{~m}, 4 \mathrm{H}), 1.25(\mathrm{~s}, 12 \mathrm{H}), 1.21-1.02(\mathrm{~m}, 4 \mathrm{H}), 1.02-0.85$ (m, 5H); ${ }^{13} \mathbf{C}$ NMR (151 MHz, $\left.\mathbf{C D C l}_{3}\right): \delta 146.2,143.2,112.3,83.1,46.1,42.8,37.6,27.9,27.4,27.3,26.9$, 25.0, 24.9, 19.6, 14.4; HRMS (DART): Calcd for $\mathrm{C}_{22} \mathrm{H}_{34} \mathrm{BO}_{2}[\mathrm{M}+\mathrm{H}]^{+}:$319.2803. Found: 319.2798; 
Specific rotation: $[\alpha]_{\mathrm{D}}{ }^{20}+5.9\left(c 0.14, \mathrm{CHCl}_{3}\right)$ for a $94: 6$ er sample. Enantiomeric purity of $\mathbf{8 g}$ was determined by HPLC analysis in comparison with authentic racemic material; Chiralcel OZ-3, 100\% hexanes, $0.5 \mathrm{~mL} / \mathrm{min}, 220 \mathrm{~nm}$.
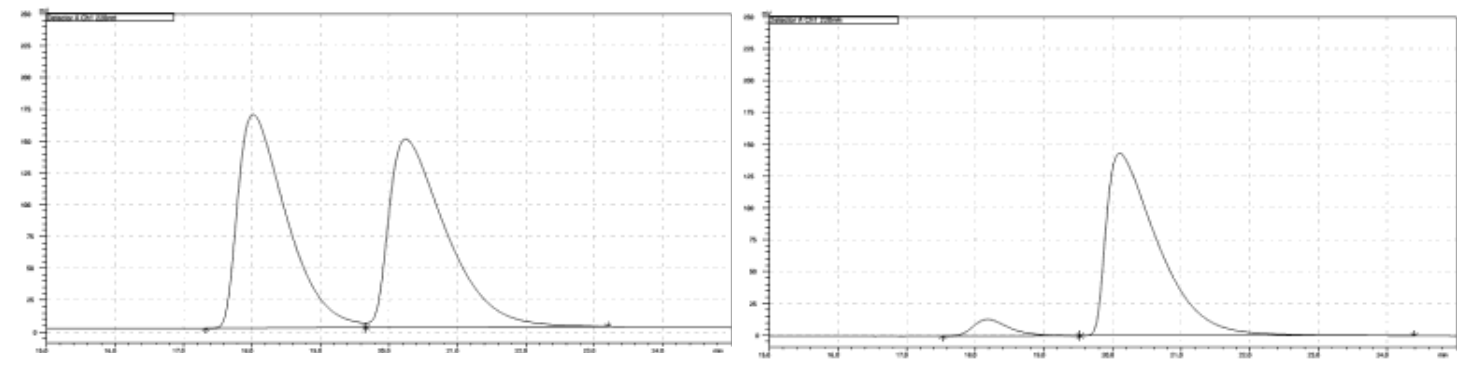

\begin{tabular}{|c|c|c|c|c|c|}
\hline Retention Time & Area & Area\% & Retention Time & Area & Area\% \\
\hline 18.017 & 8331115 & 49.180 & 18.177 & 475870 & 5.954 \\
\hline 20.247 & 8609089 & 50.820 & 20.107 & 7516910 & 94.046 \\
\hline
\end{tabular}

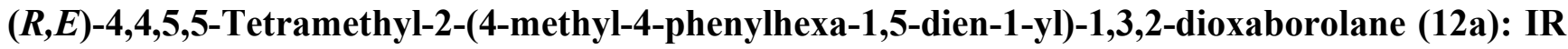
(neat): 2975 (m), 2927 (w), 1635 (m), 1444 (m), 1359 (s), 1324 (s), 998 (w), 849 (w), 763 (w), 699 (m) $\mathrm{cm}^{-1}$; ${ }^{1} \mathbf{H}$ NMR (400 MHz, $\left.\mathbf{C D C l}_{3}\right): \delta 7.37-7.27$ (m, 4H), 7.22-7.15 (m, 1H), 6.44 (dt, J = 17.9, 7.0 Hz, $1 \mathrm{H}), 6.03(\mathrm{dd}, J=17.5,10.7 \mathrm{~Hz}, 1 \mathrm{H}), 5.46(\mathrm{~d}, J=17.8 \mathrm{~Hz}, 1 \mathrm{H}), 5.12(\mathrm{dd}, J=10.7,1.2 \mathrm{~Hz}, 1 \mathrm{H}), 5.04$ $(\mathrm{dd}, J=17.4,1.2 \mathrm{~Hz}, 1 \mathrm{H}), 2.65(\mathrm{~d}, J=7.0 \mathrm{~Hz}, 2 \mathrm{H}), 1.37(\mathrm{~s}, 3 \mathrm{H}), 1.24(\mathrm{~d}, J=0.7 \mathrm{~Hz}, 12 \mathrm{H}) ;{ }^{13} \mathbf{C} \mathbf{N M R}$ (101 MHz, CDCl $): \delta$ 150.6, 147.1, 146.4, 128.3, 126.7, 126.1, 112.4, 83.1, 47.9, 44.3, 25.3, 24.9; HRMS (DART): Calcd for $\mathrm{C}_{19} \mathrm{H}_{28} \mathrm{BO}_{2}[\mathrm{M}+\mathrm{H}]^{+}:$299.2177. Found: 299.2180; Specific rotation: $[\alpha]_{\mathrm{D}}{ }^{20}$ $+8.4\left(c 0.50, \mathrm{CHCl}_{3}\right)$ for a 92:8 er sample. Enantiomeric purity of $\mathbf{1 2 a}$ was determined by HPLC analysis in comparison with authentic racemic material; Chiralpak AD-H, 100\% hexanes, $0.4 \mathrm{~mL} / \mathrm{min}, 220 \mathrm{~nm}$.
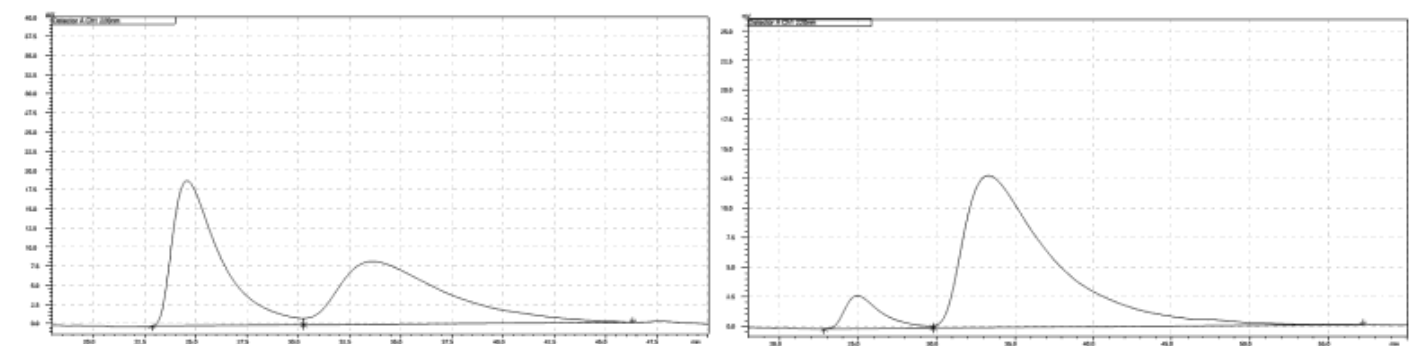

\begin{tabular}{|c|c|c|c|c|c|}
\hline Retention Time & Area & Area\% & Retention Time & Area & Area\% \\
\hline 24.563 & 3102576 & 50.784 & 24.936 & 451117 & 8.159 \\
\hline 33.557 & 3006776 & 49.216 & 33.332 & 5077621 & 91.841 \\
\hline
\end{tabular}

(R,E)-4,4,5,5-tetramethyl-2-(4-methyl-4-(4-(trifluoromethyl)phenyl)hexa-1,5-dien-1-yl)-1,3,2dioxaborolane (12b): IR (neat): 2976 (w), 2928 (w), 1636 (m), 1396 (m), 1360 (m), 1325 (s), 1165 (m), 1124 (m), 1179 (w), 1014 (w), 919 (w), 839 (w) cm ${ }^{-1} ;{ }^{1} \mathbf{H}$ NMR (600 MHz, CDCl $\left.\mathbf{3}\right): \delta 7.55$ (d, $J=$ $8.1 \mathrm{~Hz}, 2 \mathrm{H}), 7.43(\mathrm{~d}, J=8.1 \mathrm{~Hz}, 2 \mathrm{H}), 6.38(\mathrm{dt}, J=17.8,7.0 \mathrm{~Hz}, 1 \mathrm{H}), 6.01(\mathrm{dd}, J=17.5,10.8 \mathrm{~Hz}, 1 \mathrm{H})$, $5.46(\mathrm{~d}, J=17.8 \mathrm{~Hz}, 1 \mathrm{H}), 5.16(\mathrm{~d}, J=10.7 \mathrm{~Hz}, 1 \mathrm{H}), 5.06(\mathrm{~d}, J=17.5 \mathrm{~Hz}, 1 \mathrm{H}), 2.65(\mathrm{~d}, J=7.0 \mathrm{~Hz}, 2 \mathrm{H})$, 1.39 (s, 3H), 1.23 (s, 12H); ${ }^{13} \mathbf{C}$ NMR (101 MHz, CDCl 3 ): $\delta 151.1,149.6,145.6,128.4$ (q, J= 32.5 Hz), 127.2, 125.2 (q, $J=3.7 \mathrm{~Hz}), 124.5(\mathrm{q}, J=270.5 \mathrm{~Hz}), 113.2,83.2,47.8,44.5,25.3,24.9(\mathrm{~d}, J=1.5 \mathrm{~Hz})$; 
${ }^{19}$ F NMR (376 MHz, CDCl $)$ ): $\delta$-62.40; HRMS (DART): Calcd for $\mathrm{C}_{20} \mathrm{H}_{27} \mathrm{BO}_{2} \mathrm{~F}_{3}[\mathrm{M}+\mathrm{H}]^{+}: 367.2051$. Found: 367.2047; Specific rotation: $[\alpha]_{\mathrm{D}}{ }^{20}+18.1\left(c 0.34, \mathrm{CHCl}_{3}\right)$ for a $92: 8$ er sample. Enantiomeric purity of $\mathbf{1 2 b}$ was determined by HPLC analysis in comparison with authentic racemic material; Chiralcel OZ-H, 99.9\% hexanes, $0.5 \mathrm{~mL} / \mathrm{min}, 220 \mathrm{~nm}$.
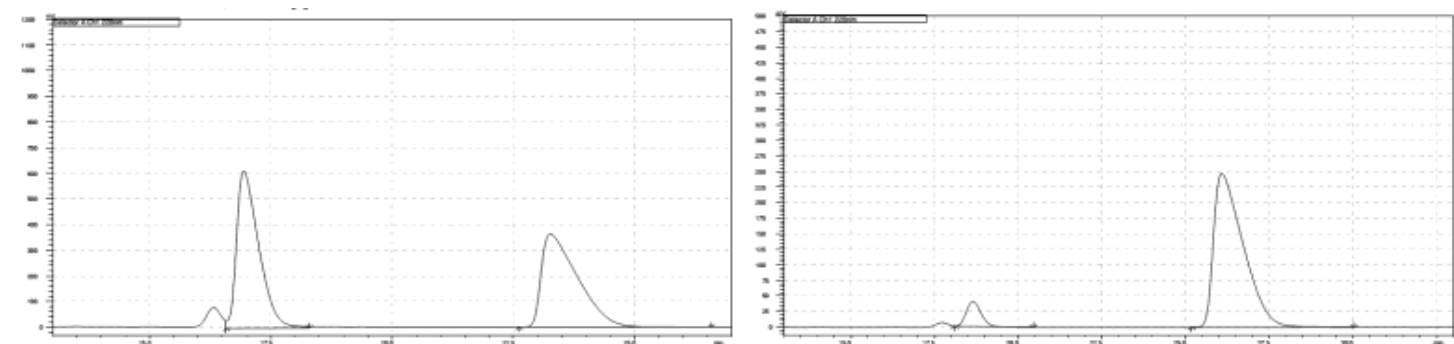

\begin{tabular}{|c|c|c|c|c|c|}
\hline Retention Time & Area & Area\% & Retention Time & Area & Area\% \\
\hline 16.940 & 19408791 & 50.778 & 18.645 & 1208999 & 7.360 \\
\hline 23.262 & 18813867 & 49.222 & 26.079 & 15217248 & 92.640 \\
\hline
\end{tabular}

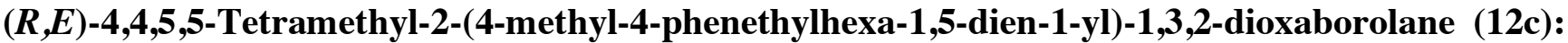
IR (neat): 3023 (w), 2974 (m), 2928 (w), 1636 (m), 1454 (w), 1360 (s), 1321 (m), 1144 (m), 999 (w), 970 (w), 912 (w), 849 (w), 698 (w) cm ${ }^{-1} ;{ }^{1} \mathbf{H}$ NMR (500 MHz, CDCl $\mathbf{~ I}_{3}$ : $\delta$ 7.29-7.23 (m, 2H), 7.19-7.13 $(\mathrm{m}, 3 \mathrm{H}), 6.59(\mathrm{dt}, J=17.8,7.2 \mathrm{~Hz}, 1 \mathrm{H}), 5.81(\mathrm{dd}, J=17.5,10.8 \mathrm{~Hz}, 1 \mathrm{H}), 5.47$ (d, $J=17.8 \mathrm{~Hz}, 1 \mathrm{H}), 5.07$ $(\mathrm{d}, J=10.8 \mathrm{~Hz}, 1 \mathrm{H}), 4.99(\mathrm{~d}, J=17.5 \mathrm{~Hz}, 1 \mathrm{H}), 2.55-2.48(\mathrm{~m}, 2 \mathrm{H}), 2.29-2.20(\mathrm{~m}, 2 \mathrm{H}), 1.65-1.57(\mathrm{~m}$, 2H), 1.26 (s, 12H), 1.06 (s, 3H); ${ }^{13} \mathbf{C}$ NMR (126 MHz, CDCl 3 ): $\delta$ 150.7, 146.5, 143.3, 128.5, 128.4, 125.7, 112.5, 83.2, 47.8, 42.8, 40.0, 30.8, 24.9, 23.2; HRMS (DART): Calcd for $\mathrm{C}_{21} \mathrm{H}_{32} \mathrm{BO}_{2}[\mathrm{M}+\mathrm{H}]^{+}$: 327.2490. Found: 327.2492; Specific rotation: $[\alpha]_{\mathrm{D}}{ }^{20}-56.7\left(c 0.04, \mathrm{CHCl}_{3}\right)$ for a 94:6 er sample. Enantiomeric purity of 12c was determined by HPLC analysis in comparison with authentic racemic material; Chiralcel OZ-H, 99.5\% hexanes, $0.5 \mathrm{~mL} / \mathrm{min}, 220 \mathrm{~nm}$.
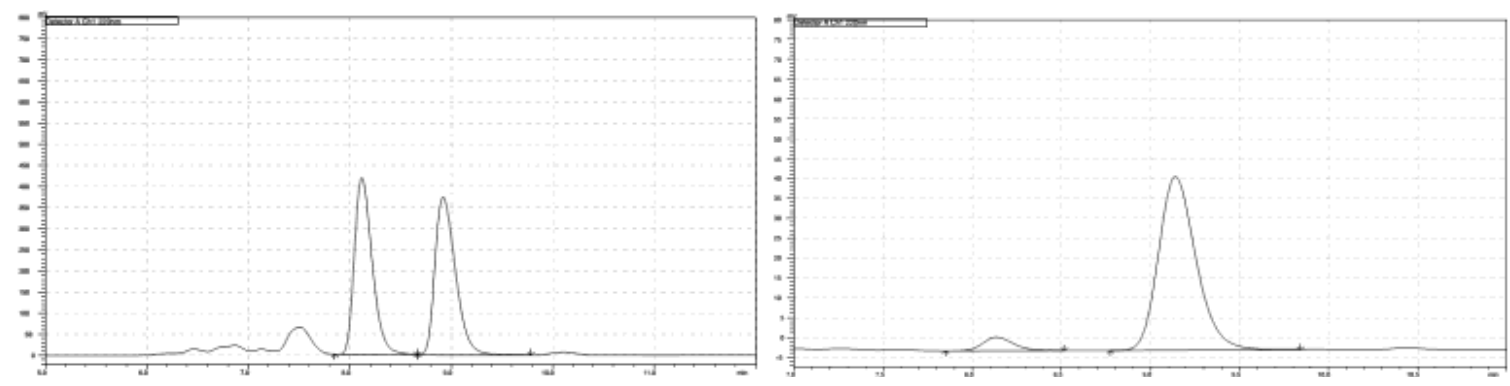

\begin{tabular}{|c|c|c|c|c|c|}
\hline Retention Time & Area & Area\% & Retention Time & Area & Area\% \\
\hline 8.118 & 5118308 & 49.522 & 8.136 & 40162 & 5.891 \\
\hline 8.920 & 5217034 & 50.478 & 9.140 & 641580 & 94.109 \\
\hline
\end{tabular}

(R,E)-2-(4-Cyclohexyl-4-methylhexa-1,5-dien-1-yl)-4,4,5,5-tetramethyl-1,3,2-dioxaborolane (12d): IR (neat): 2976 (m), 2924 (s), 2851 (m), 1635 (m), 1448 (w), 1359 (s), 1321 (m), 1213 (w), 1145 (s), 1000 (w), 971 (w), 910 (w), 849 (w) cm ${ }^{-1} ;{ }^{1} \mathbf{H}$ NMR (400 MHz, CDCl $\left.\mathbf{3}\right): \delta 6.55$ (dt, $J=17.8,7.1 \mathrm{~Hz}$, 1H), $5.74(\mathrm{dd}, J=17.6,10.9 \mathrm{~Hz}, 1 \mathrm{H}), 5.41(\mathrm{~d}, J=17.7 \mathrm{~Hz}, 1 \mathrm{H}), 5.02(\mathrm{dd}, J=10.9,1.5 \mathrm{~Hz}, 1 \mathrm{H}), 4.88$ 
$(\mathrm{dd}, J=17.6,1.5 \mathrm{~Hz}, 1 \mathrm{H}), 2.21(\mathrm{~d}, J=7.1 \mathrm{~Hz}, 2 \mathrm{H}), 1.80-1.57(\mathrm{~m}, 5 \mathrm{H}), 1.26(\mathrm{~s}, 12 \mathrm{H}), 1.22-0.99(\mathrm{~m}$, 4H), 0.99-0.85 (m, 5H); ${ }^{13} \mathbf{C}$ NMR (101 MHz, $\left.\mathbf{C D C l}_{3}\right): \delta 151.6,145.9,112.5,83.1,45.9,45.8,42.5$, 27.8, 27.3, 27.2, 26.9, 24.9, 19.8; HRMS (DART): Calcd for $\mathrm{C}_{19} \mathrm{H}_{34} \mathrm{BO}_{2}[\mathrm{M}+\mathrm{H}]^{+}:$305.2646. Found: 305.2642; Specific rotation: $[\alpha]_{\mathrm{D}}{ }^{20}+7.2\left(c 0.19, \mathrm{CHCl}_{3}\right)$ for a 95:5 er sample. Enantiomeric purity of 12d was determined by HPLC analysis in comparison with authentic racemic material; Chiralcel OZ-H, $100 \%$ hexanes, $0.8 \mathrm{~mL} / \mathrm{min}, 220 \mathrm{~nm}$.
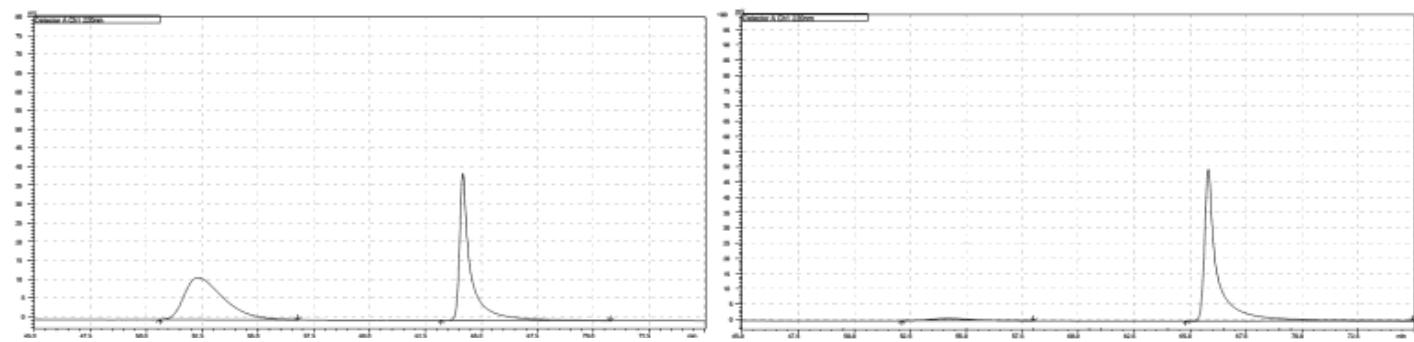

\begin{tabular}{|c|c|c|c|c|c|}
\hline Retention Time & Area & Area\% & Retention Time & Area & Area\% \\
\hline 52.322 & 1369972 & 50.269 & 54.158 & 93006 & 4.470 \\
\hline 64.166 & 1355307 & 49.731 & 65.810 & 1987537 & 95.530 \\
\hline
\end{tabular}

\section{Procedure for Polar Functional Group Compatibility Experiments}

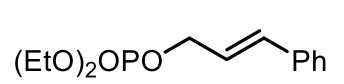

2b

(1.0 equiv.)<smiles>COC(=O)c1ccccc1</smiles><smiles>O=C(Nc1ccccc1)OCc1ccccc1</smiles><smiles>CC(C)(C)c1ccc(N)cc1</smiles>

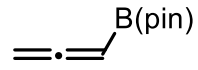

$1 b$

(1.5 equiv.)

$>98 \%$ conv., $76 \%$ yield

$>98: 2 S_{N} 2: S_{N} 2,>98: 2 E: Z$

97:3 e.r.

$>98 \%$ probe recovered

$>98 \%$ conv., $73 \%$ yield

$>98: 2 S_{N} 2: S_{N} 2,>98: 2 E: Z$

98:2 e.r.

$>98 \%$ probe recovered

PMHS

(5.0 equiv.)

$>98 \%$ conv., $68 \%$ yield

$>98: 2 \mathrm{~S}_{\mathrm{N}} 2^{\prime}: \mathrm{S}_{\mathrm{N}} 2,>98: 2 \mathrm{E:Z}$

97:3 e.r.

$92 \%$ probe recovered

$5.5 \mathrm{~mol} \%(S)$-imid(S)-1b $5.0 \mathrm{~mol} \% \mathrm{CuCl}$ 1.2 equiv. $\mathrm{LiOt}$-Bu 1.0 equiv. probe $\mathrm{THF}, 22{ }^{\circ} \mathrm{C}, 2 \mathrm{~h}$

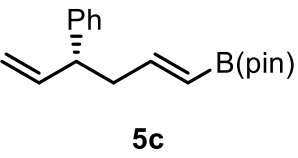

$>98 \%$ conv., $54 \%$ yield<smiles>CC(=O)c1ccccc1</smiles>
$>98: 2 S_{N} 2^{\prime}: S_{N} 2,>98: 2 E: Z$ 97:3 e.r.

$<2 \%$ probe recovered $56 \% 2^{\circ}$ alcohol

$>98 \%$ conv., $65 \%$ yield $>98: 2 S_{N} 2 ': S_{N} 2,>98: 2 E: Z$ 98:2 e.r.

$87 \%$ probe recovered $10 \% 2^{\circ}$ alcohol

$>98 \%$ conv., $56 \%$ yield

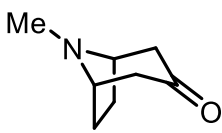

tropinone
$>98: 2 \mathrm{~S}_{\mathrm{N}} 2^{\prime}: \mathrm{S}_{\mathrm{N}} 2,>98: 2 \mathrm{E}: \mathrm{Z}$

97:3 e.r.

$24 \%$ probe recovered

$72 \% 2^{\circ}$ alcohol 
In a $\mathrm{N}_{2}$-filled glove box, an oven-dried 2-dram vial with magnetic stir bar was charged with $\mathrm{CuCl}(0.5$ mg, $0.005 \mathrm{mmol})$, (S)-imid(S)-1b (4.7 mg, $0.0055 \mathrm{mmol}), \mathrm{LiO}$-Bu (9.6 mg, $0.12 \mathrm{mmol})$, and freshly distilled tetrahydrofuran (THF, $0.5 \mathrm{~mL}$ ). The mixture was premixed for $30 \mathrm{~min}$ before PMHS (30.0 $\mathrm{mg}$, $0.50 \mathrm{mmol})$, allenyl boronic acid pinacol ester $\mathbf{1 b}(24.9 \mathrm{mg}, 0.15 \mathrm{mmol})$ and additional THF $(0.5 \mathrm{~mL})$ were added, causing the solution to turn dark-red immediately. After $10 \mathrm{~min}$, a solution of allylic phosphate $2 \mathbf{b}(27.3 \mathrm{mg}, 0.10 \mathrm{mmol})$ and probe $(0.10 \mathrm{mmol})$ in THF $(0.5 \mathrm{~mL})$ was added to the reaction (at $22{ }^{\circ} \mathrm{C}$ ). The vial was sealed with electrical tape before removal from the glove box, and the mixture was allowed to stir for $2 \mathrm{~h}$ at $22{ }^{\circ} \mathrm{C}$, after which it was quenched with an aqueous solution of sat. $\mathrm{NH}_{4} \mathrm{Cl}$ $(0.1 \mathrm{~mL})$. The mixture was stirred for $15 \mathrm{~min}$ before it was passed through a short plug of oven-dried silica gel and eluted with EtOAc. The organic layer was concentrated under reduced pressure, affording yellow oil, which was purified by silica gel chromatography (1:1 hexanes: $\mathrm{CH}_{2} \mathrm{Cl}_{2} \rightarrow 1: 1$ hexanes: EtOAc) to afford $\mathbf{5 c}$ and recovered probe as colorless oil .

\section{Mechanistic Experiments}

To gain insight regarding the ground state structure of the intermediate generated by $\mathrm{Cu}-\mathrm{H}$ addition to allenes $\mathbf{1 a}$ and $\mathbf{1 b}$, we carried out the experiments described below.

\subsection{NHC-Cu-allyl complex derived from allene $1 \mathrm{~b}$}
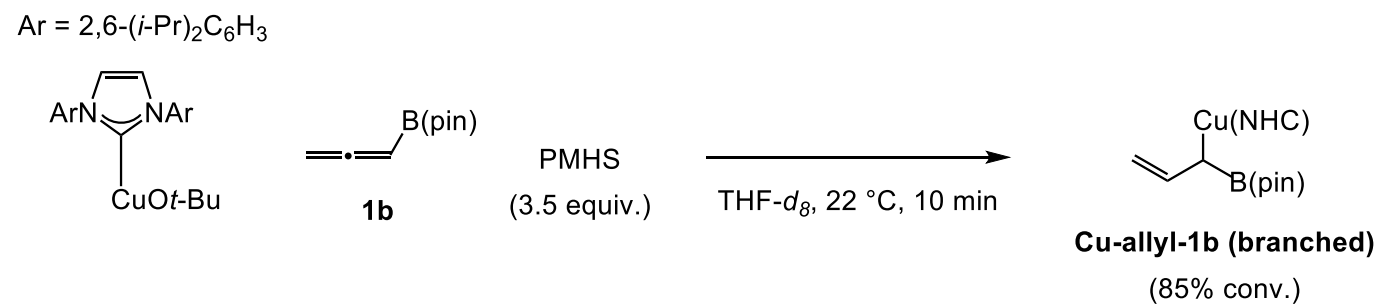

In a glove box, an oven-dried 2-dram vial equipped with a stir bar was charged with [1,3-bis(2,6diisopropylphenyl)imidazol-2-ylidene]CuOt-Bu${ }^{22}(10.6 \mathrm{mg}, 0.02 \mathrm{mmol})$ and thf- $d_{8}$. This mixture was charged with PMHS ( $4.3 \mathrm{mg}, 0.07 \mathrm{mmol}$ ) and the mixture was allowed to stir for $1 \mathrm{~min}$, after which $\mathbf{1 b}$ (4.0 mg, $0.024 \mathrm{mmol}$ ) was added and the mixture was allowed to stir for $10 \mathrm{~min}$. Suitable crystals for Xray diffraction were obtained by vapor diffusion of hexanes into a saturated solution of the $\mathrm{Cu}-\mathrm{allyl}$ complex in a hexanes: $\mathrm{Et}_{2} \mathrm{O}$ mixture $(1: 2)$ in a freezer of a glovebox at $-40{ }^{\circ} \mathrm{C}$. Analysis of ${ }^{1} \mathrm{H} \mathrm{NMR}$ of the unpurified mixture indicated that there was $85 \%$ conversion, and the identity of the product was ascertained by ${ }^{1} \mathrm{H}$ NMR, HH-COSY and nOe experiments, indicating it to be $\mathbf{C u}-\mathbf{a l l y l}-\mathbf{1 b}$ (branched) or Cu-allyl-1b (linear), depending on the temperature (see below). ${ }^{1}$ H NMR (500 MHz, THF-d8 at 25 ${ }^{\circ}$ C) $\delta 7.42(\mathrm{t}, J=7.7 \mathrm{~Hz}, 2 \mathrm{H}), 7.40(\mathrm{~s}, 2 \mathrm{H}), 7.30(\mathrm{~d}, J=7.7 \mathrm{~Hz}, 4 \mathrm{H}), 5.84(\mathrm{q}, J=12.8 \mathrm{~Hz}, 1 \mathrm{H}), 3.27(\mathrm{~d}$, $J=13.1 \mathrm{~Hz}, 2 \mathrm{H}), 2.69-2.50(\mathrm{~m}, 4 \mathrm{H}), 1.73-1.69(\mathrm{~m}, 1 \mathrm{H}), 1.32(\mathrm{~d}, J=6.8 \mathrm{~Hz}, 12 \mathrm{H}), 1.22(\mathrm{~d}, J=4.7 \mathrm{~Hz}$, 12H), 0.79 (s, 12H). ${ }^{1} \mathbf{H}$ NMR (500 MHz, THF-d at $\left._{-10}{ }^{\circ} \mathbf{C}\right) \delta 7.55(\mathrm{~d}, J=2.4 \mathrm{~Hz}, 2 \mathrm{H}), 7.44(\mathrm{t}, J=7.7$ $\mathrm{Hz}, 2 \mathrm{H}), 7.32$ (d, $J=7.7 \mathrm{~Hz}, 4 \mathrm{H}), 5.81$ (q, $J=12.9 \mathrm{~Hz}, 1 \mathrm{H}), 3.27$ (d, $J=13.2 \mathrm{~Hz}, 2 \mathrm{H}), 2.62-2.45$ (m, 4H), 1.66 (d, $J=12.2 \mathrm{~Hz}, 1 \mathrm{H}), 1.32$ (d, $J=6.8 \mathrm{~Hz}, 12 \mathrm{H}), 1.21$ (d, $J=7.0 \mathrm{~Hz}, 12 \mathrm{H}), 0.75$ (s, 12H). 
The presence of two identical terminal alkene protons in the ${ }^{1} \mathrm{H}$ NMR spectrum indicate that there is rapid equilibrium between $\mathbf{C u}$-allyl-1b (branched a) and $\mathbf{C u}$-allyl-1b (branched b). This olefin isomerization process probably proceeds, as shown below, via $\mathbf{C u}-\mathbf{a l l y l - 1 b}$ (linear $\mathbf{a - b}$ ) through a
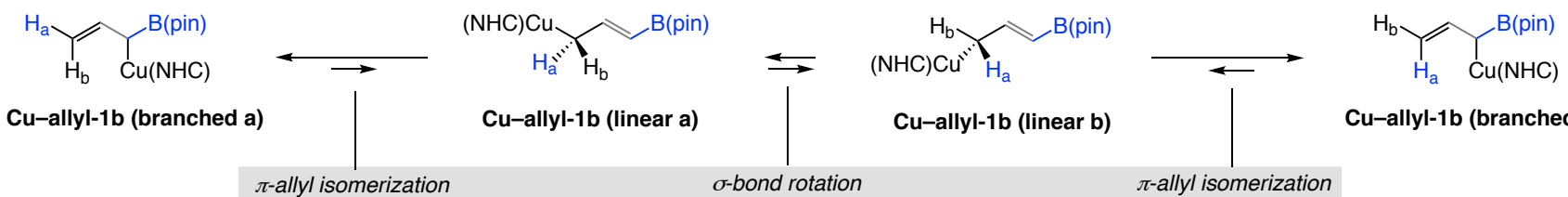

Cu-allyl-1b (branched b)

sequence of $\pi$-allyl isomerization and $\sigma$-bond rotation. The step that separate $\mathbf{C u}-\mathbf{a l l y l}-\mathbf{1 b}$ (branced a) and $\mathbf{C u}-\mathbf{a l l y l - 1 b}$ (branced b) are likely fast, and since only $\mathbf{C u}-\mathbf{a l l y l - 1 b}$ (branched) can be detected, it is at least $3 \mathrm{kcal} / \mathrm{mol}$ lower in energy than $\mathbf{C u}-\mathbf{a l l y l}-\mathbf{1 b}$ (linear). To confirm this hypothesis and gain additional insight, we carried out the variable temperature spectroscopic experiments, described below.

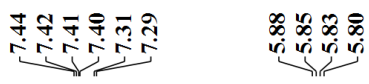

${ }^{1} \mathrm{H}$ NMR $\left(500 \mathrm{MHz}, \mathrm{THF}-d_{8}, 25^{\circ} \mathrm{C}\right)$

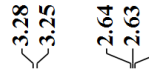

(

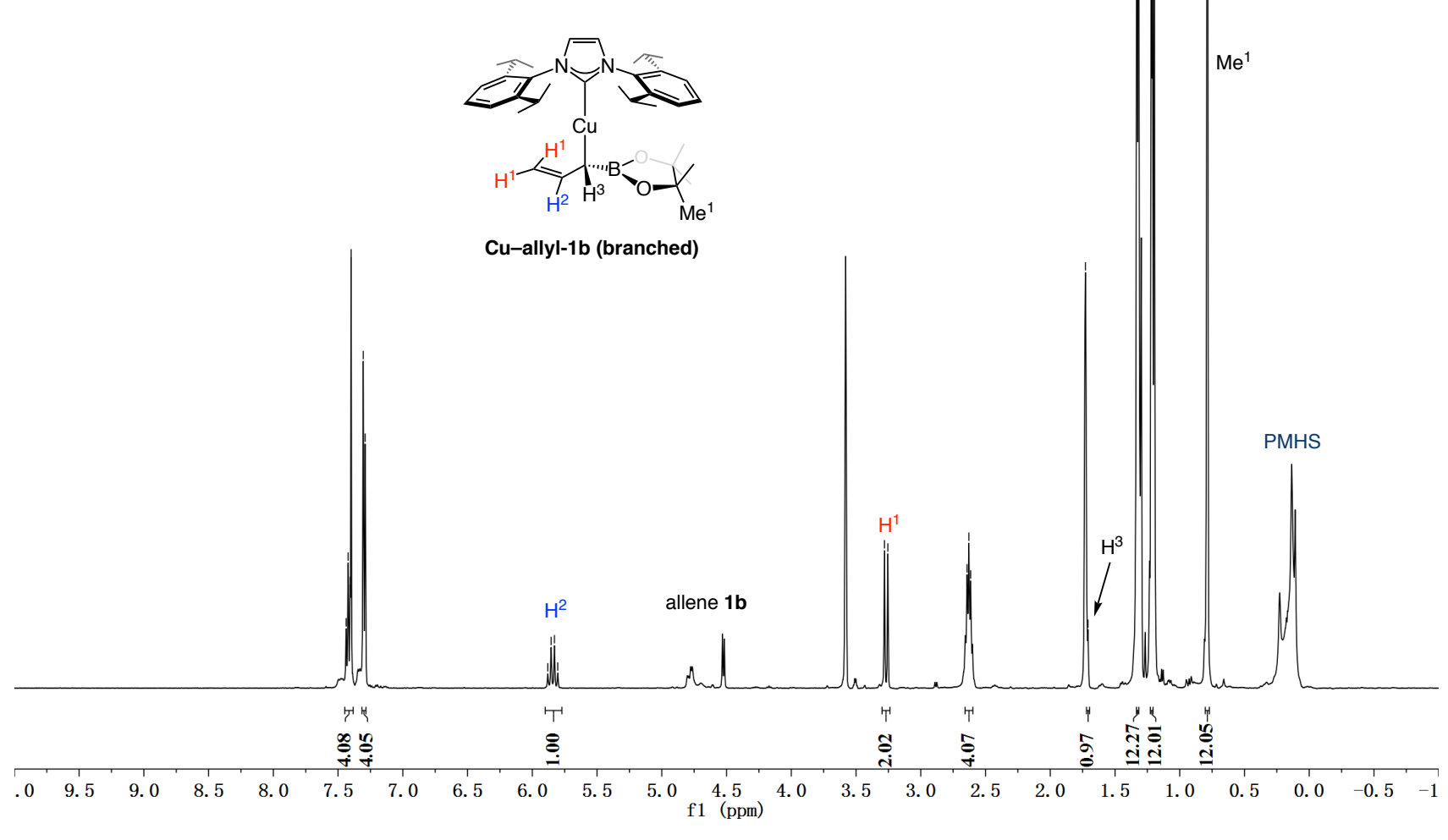




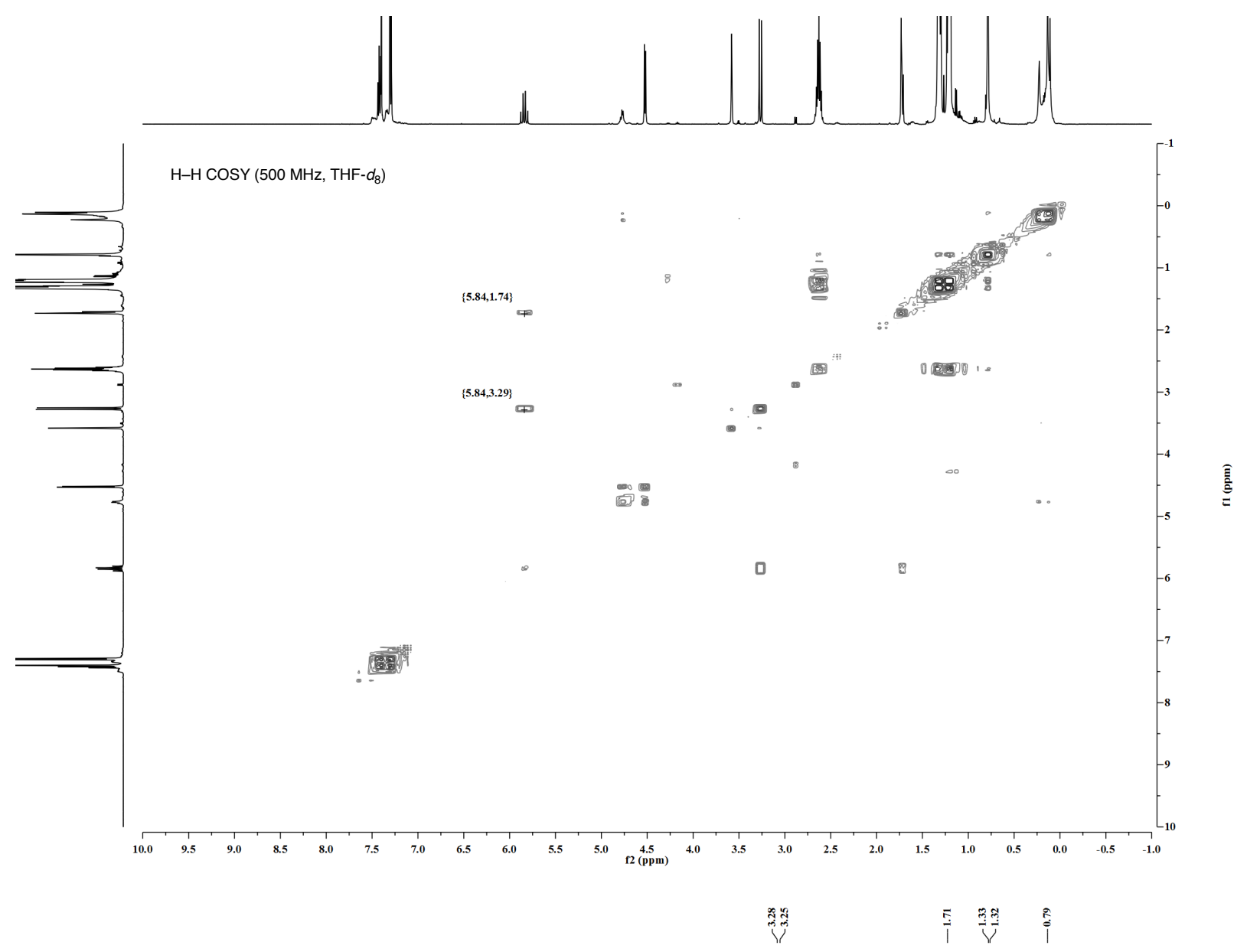

1D NOSEY (500 MHz, THF- $d_{8}$ )

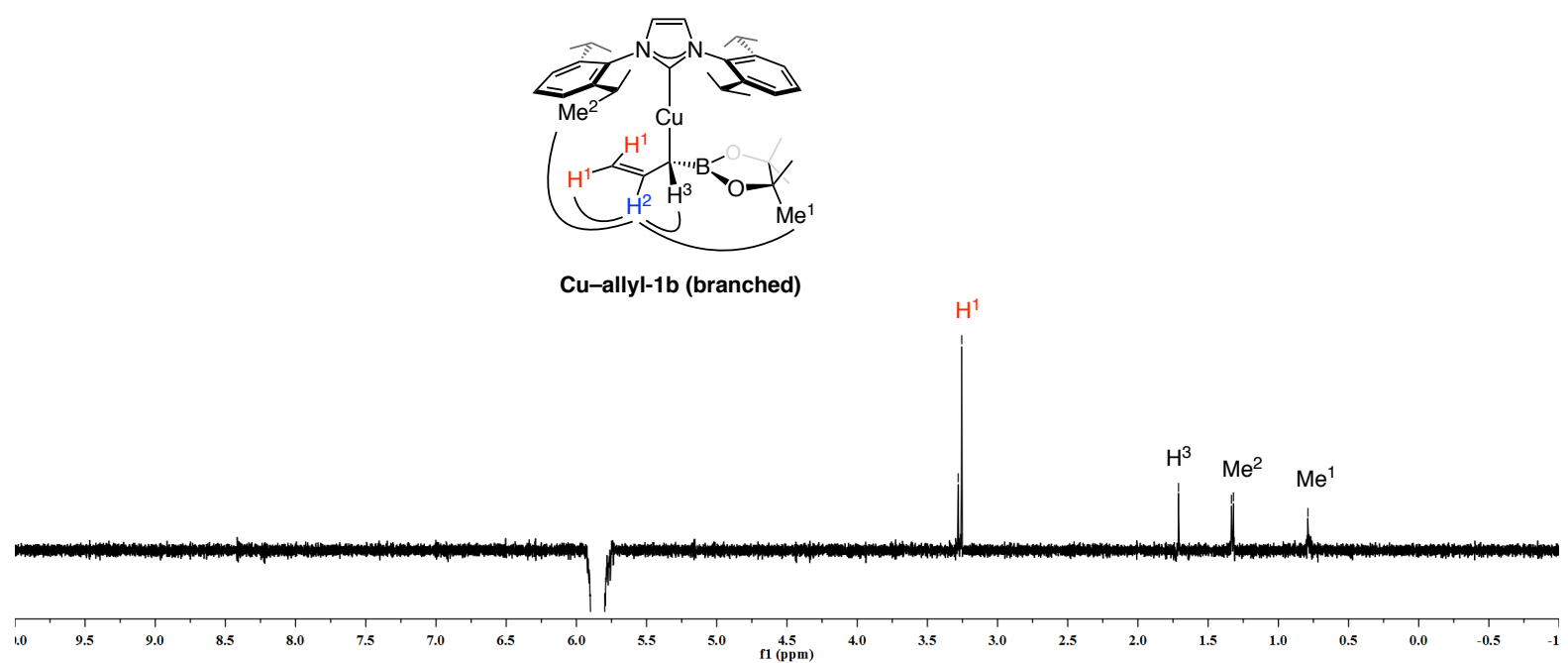




\subsection{Variable temperature NMR experiments}

A sample of Cu-allyl-1b (branched) in THF- $d_{8}$ was placed in a J-Young NMR tube, which was then placed in the pre-cooled probe $\left(-75^{\circ} \mathrm{C}\right)$ of a $500 \mathrm{MHz}$ NMR spectrometer. The sample was allowed to warm in $10-30{ }^{\circ} \mathrm{C}$ intervals, for each of which a spectrum was recorded. Prior to each acquisition the probe temperature was allowed to equilibrate for $\sim 15 \mathrm{~min}$.

The spectra acquired at $-75{ }^{\circ} \mathrm{C}$ did not reveal the presence of any other isomer, indicating that, as predicted, the abovementioned equilibrium involving $\mathbf{C u}-$ allyl-1b (branched) and $\mathbf{C u}-\mathbf{a l l y l - 1 b}$ (linear) is rapid. However, the dissymmetric signal at $\delta 3.27 \mathrm{ppm}$ implies that equilibriation is slower at $-75^{\circ} \mathrm{C}$, and the terminal protons appear to be in different chemical environments.

Conclusion: $\mathbf{C u}-\mathbf{a l l y l}-1 \mathbf{b}$ (branched) is likely the energetically favored ground state isomer, which is in rapid equilibrium with $\mathbf{C u}-\mathbf{a l l y l} \mathbf{l} \mathbf{1 b}$ (linear) isomers.

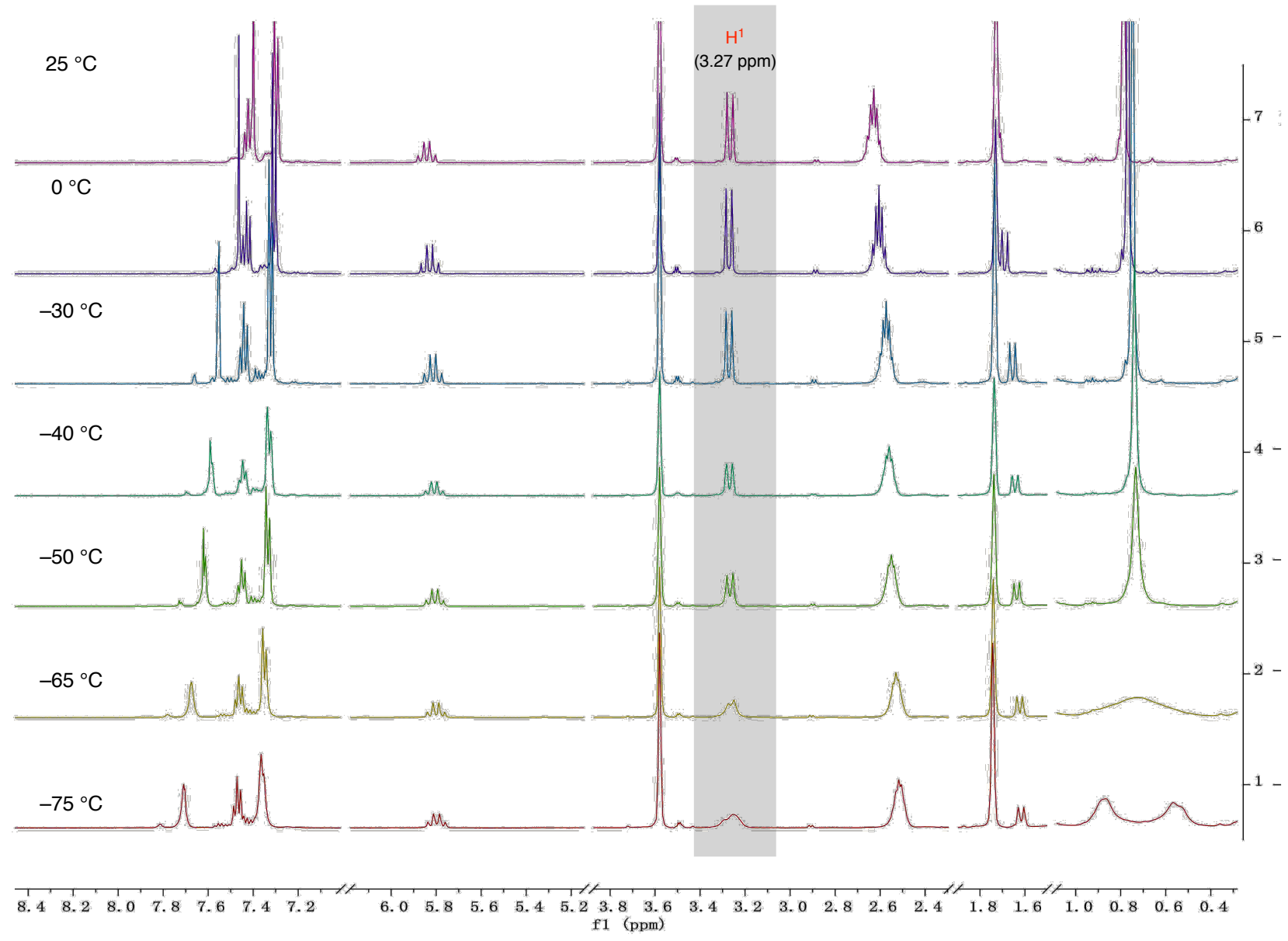

\subsection{NHC-Cu-allyl complex derived from allene 1a}

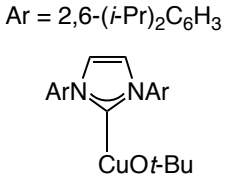<smiles>C=C(C)Br</smiles>

PMHS

(3.5 equiv.)
THF- $d_{8}, 22^{\circ} \mathrm{C}, 10 \mathrm{~min}$

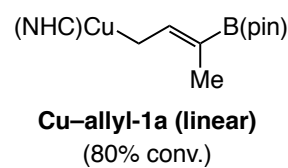


In a glove box, an oven-dried 2-dram vial equipped with a stir bar was charged with [1,3-bis(2,6diisopropylphenyl)imidazol-2-ylidene $] \mathrm{CuOt}$ - $\mathrm{Bu}(5.3 \mathrm{mg}, 0.01 \mathrm{mmol})$ and THF- $d_{8}$. PMHS $(2.1 \mathrm{mg}$, $0.035 \mathrm{mmol}$ ) was added at $22{ }^{\circ} \mathrm{C}$ and the mixture was allowed to stir for $1 \mathrm{~min}$, after which it was charged with 1,1-disubstituted allene $1 \mathrm{a}(2.2 \mathrm{mg}, 0.012 \mathrm{mmol})$ and the mixture was allowed to stir for $10 \mathrm{~min}$. Analysis of ${ }^{1} \mathrm{H}$ NMR spectrum of the unpurified mixture indicated that $80 \%$ conversion to $\mathbf{N H C}-\mathbf{C u}-$ allyl-1a $\left(\mathbf{1}^{\circ}\right)$. The identity of the copper complex was established through ${ }^{1} \mathrm{H}$ NMR, HH-COSY and nOe experiments involving the unpurified mixture. In the $1 \mathrm{D}$ nOe experiment, irradiation of $\mathrm{H}^{2}$ led to enhancement of signals at $\mathrm{Me}^{2}$ (at the $\mathrm{B}$ (pin)) as well as $\mathrm{Me}^{1}$ (at the NAr unit of the NHC ligand) suggesting the existence of rapid equilibrium between $\mathbf{N H C}-\mathbf{C u}-$ allyl-1a $\left(1^{\circ} Z\right)$ and $\mathbf{N H C}-\mathbf{C u}-\mathbf{a l l y l}-1 \mathbf{a}$ $\left(1^{\circ} \boldsymbol{E}\right)$ via NHC-Cu-allyl-1a $\left(2^{\circ} \mathbf{a}-\mathbf{b}\right)$, as illustrated above. ${ }^{1} \mathrm{H}$ NMR (500 MHz, THF-ds) $\delta 7.46(\mathrm{t}, J=$ $7.7 \mathrm{~Hz}, 2 \mathrm{H}), 7.38$ (s, 2H), 7.31 (d, $J=7.6 \mathrm{~Hz}, 4 \mathrm{H}), 6.64$ (t, $J=10.0 \mathrm{~Hz}, 1 \mathrm{H}), 2.67-2.57$ (m, 4H), 1.29 (d, $J=6.8 \mathrm{~Hz}, 12 \mathrm{H}), 1.22(\mathrm{~d}, J=5.7 \mathrm{~Hz}, 12 \mathrm{H}), 1.09$ (s, 12H), $0.98(\mathrm{~d}, J=10.0 \mathrm{~Hz}, 2 \mathrm{H}), 0.93(\mathrm{~s}, 3 \mathrm{H})$.
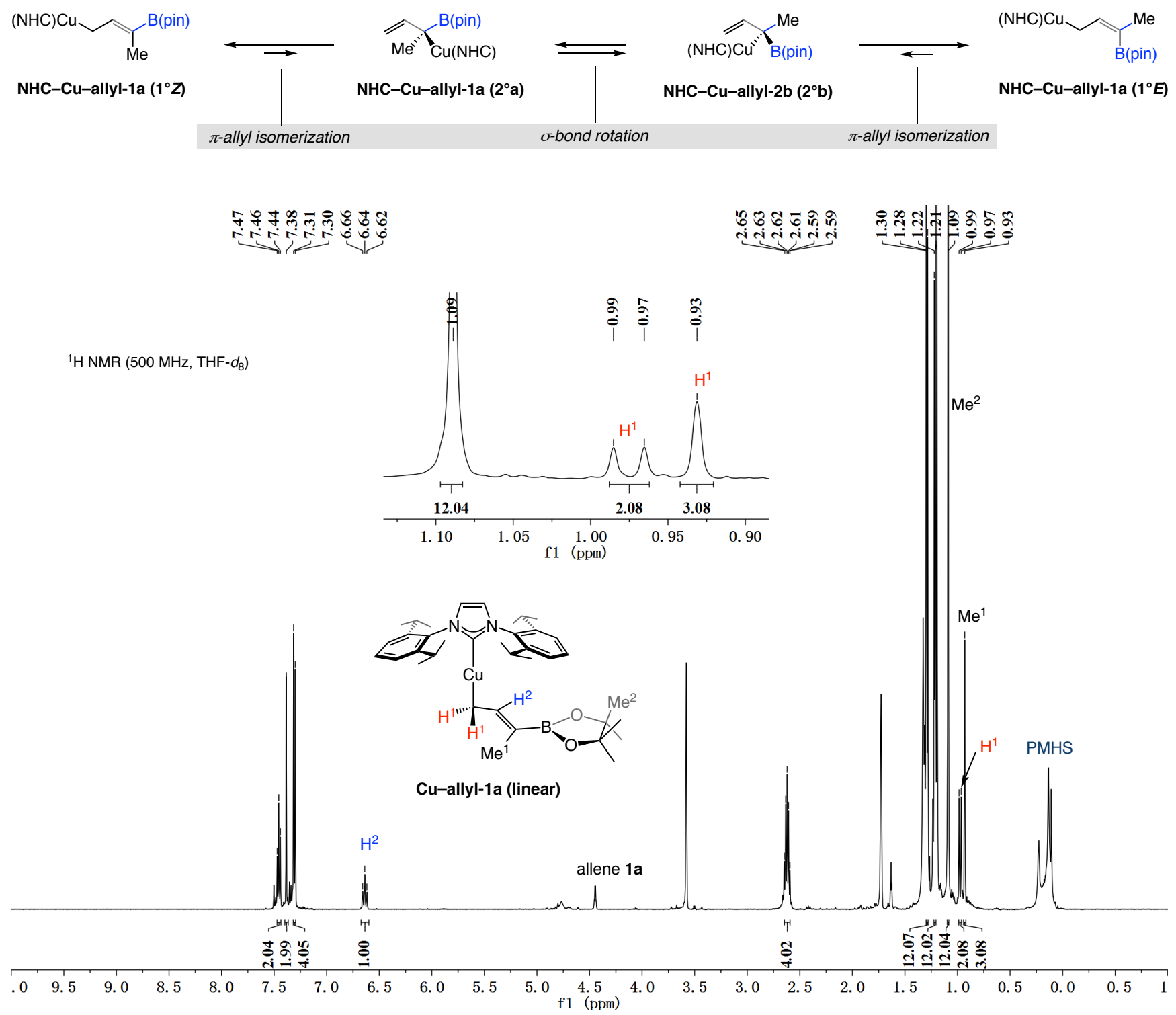

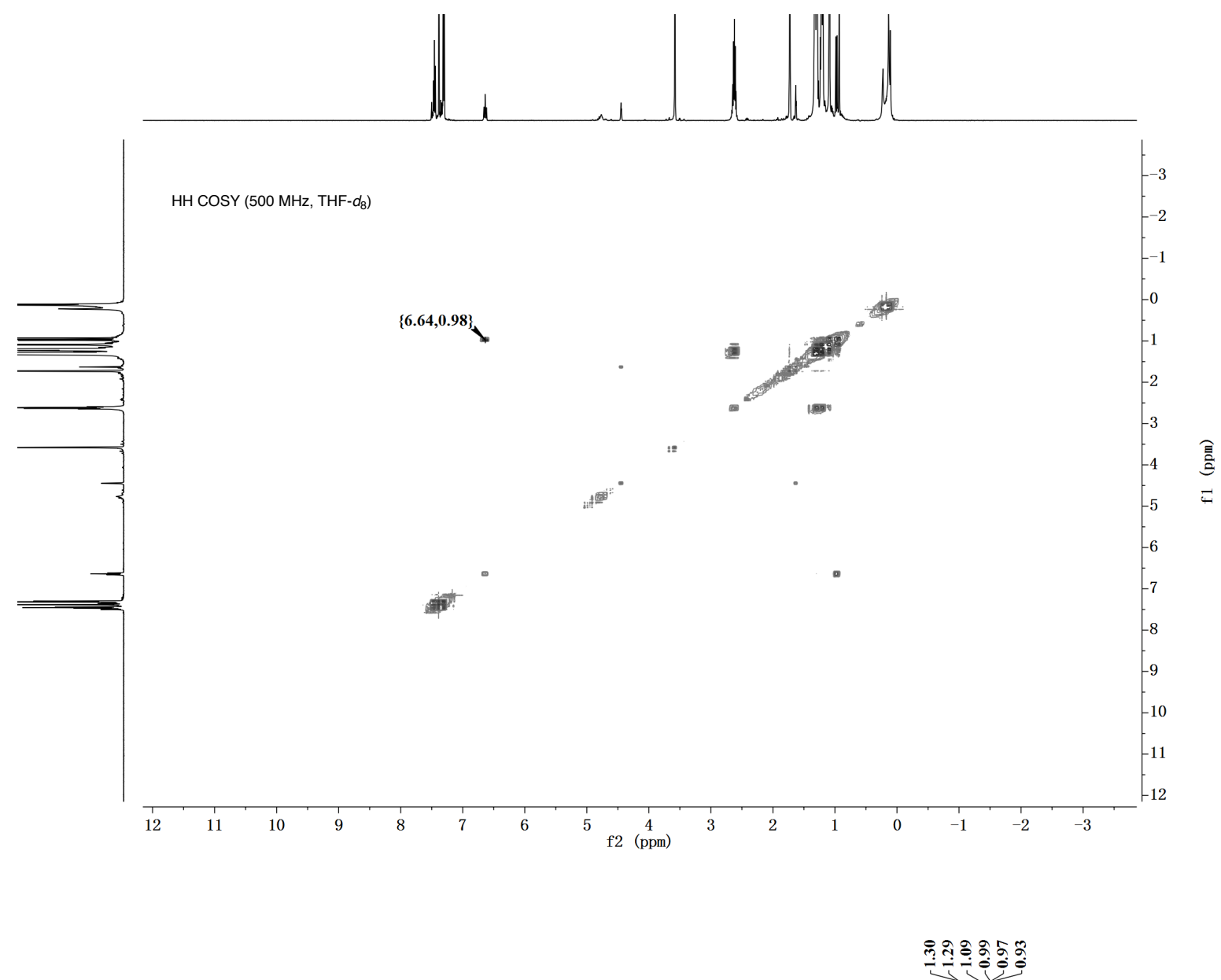

1D NOESY (500 MHz, THF- $\left.d_{8}\right)$

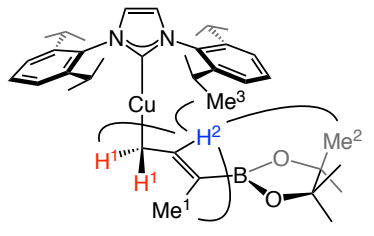

Cu-allyl-1a (linear)

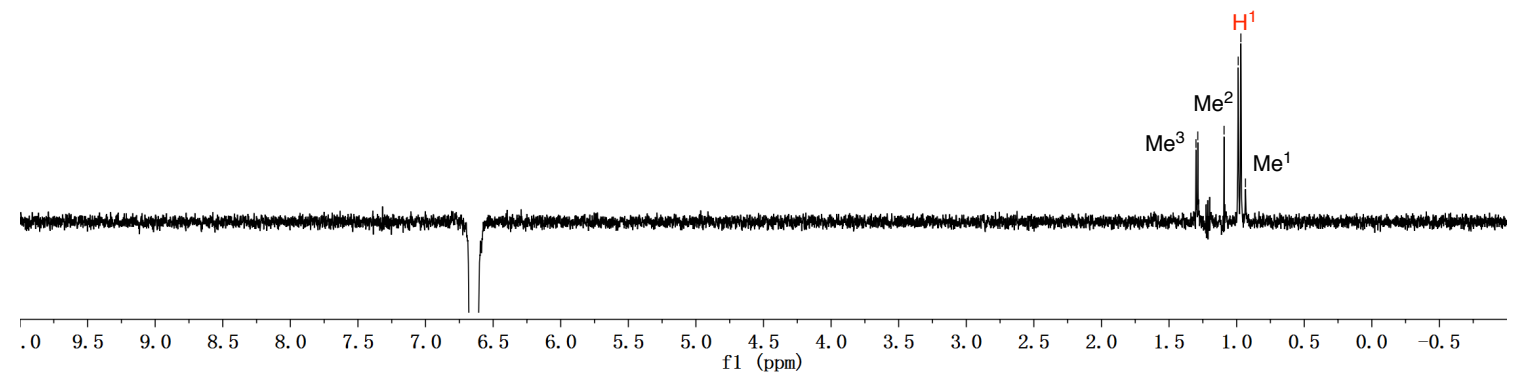




\section{$10.4 \mathrm{~B} / \mathrm{Cu}$ exchange between organoboron compounds and $\mathrm{NHC}-\mathrm{Cu}-\mathrm{O} t-\mathrm{Bu}$ complexes}

In an $\mathrm{N}_{2}$-filled glove box, an oven-dried 2-dram vial was charged with [1,3-bis(2,6diisopropylphenyl)imidazol-2-ylidene]CuOt-Bu $(10.0 \mathrm{mg}, 0.019 \mathrm{mmol})$. The mixture was charged with THF- $d_{8}(0.5 \mathrm{~mL})$ and allowed to stir for five min, resulting in a clear colorless solution. Allenyl-B(pin) 1a, (6.9 mg, $0.038 \mathrm{mmol})$ was then added through syringe and the resulting colorless solution was transferred to a J-young NMR tube. Reaction progress was monitored by ${ }^{1} \mathrm{H}$ NMR spectroscopy. Key signals are highlighted below.

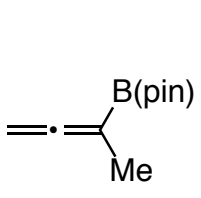

$1 \mathrm{a}$

(2.0 equiv.)

$\mathrm{Ar}=2,6-(i-\mathrm{Pr})_{2} \mathrm{C}_{6} \mathrm{H}_{3}$<smiles>CCOC(=O)c1nccn1Br</smiles>

NHC-Cu-1
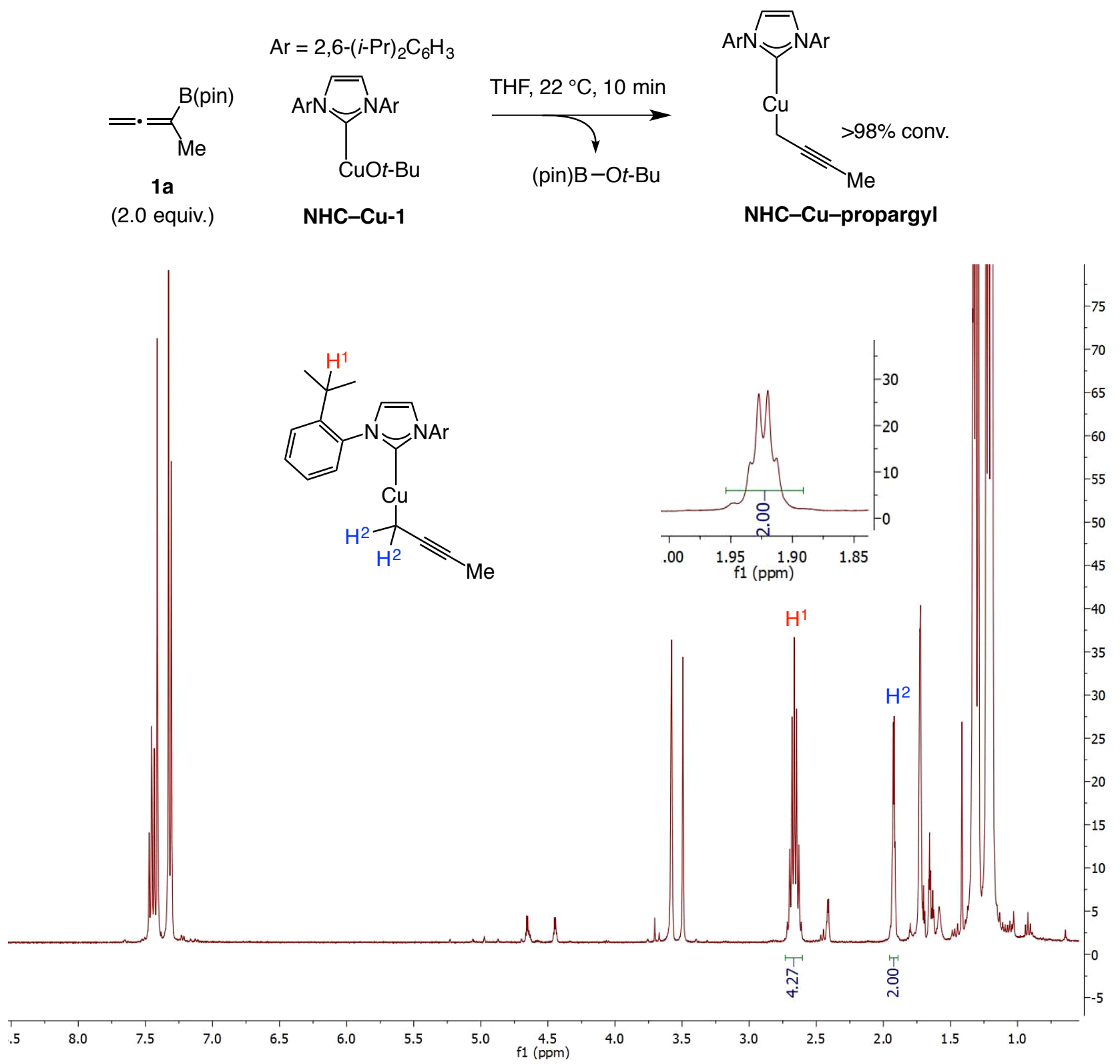

NHC-Cu-propargyl 
In an $\mathrm{N}_{2}$-filled glove box, an oven-dried 2-dram vial was charged with [1,3-bis(2,6diisopropylphenyl)imidazol-2-ylidene $] \mathrm{CuOt}$-Bu $(10 \mathrm{mg}, 0.019 \mathrm{mmol})$. The mixture was charged with THF $-d_{8}(0.5 \mathrm{~mL})$ and then allowed to stir for five min, resulting in a clear colorless solution. At this point, allenyl-B(pin) $\mathbf{1 b},(6.8 \mu \mathrm{L}, 0.038 \mathrm{mmol})$ was added by syringe and the resulting colorless solution was transferred to a J-young NMR tube. Reaction progress was monitored by ${ }^{1} \mathrm{H}$ NMR spectroscopy. Key signals are highlighted below.

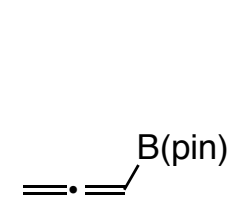

$1 \mathrm{~b}$ (2.0 equiv.)

$$
\operatorname{Ar}=2,6-(i-\operatorname{Pr})_{2} \mathrm{C}_{6} \mathrm{H}_{3}
$$<smiles>CCCCc1nccn1Br</smiles>

NHC-Cu-1

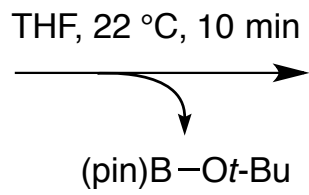

(pin)B-Ot-Bu

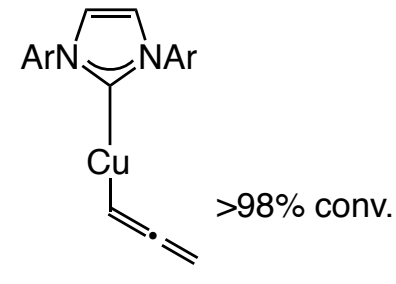

NHC-Cu-allenyl

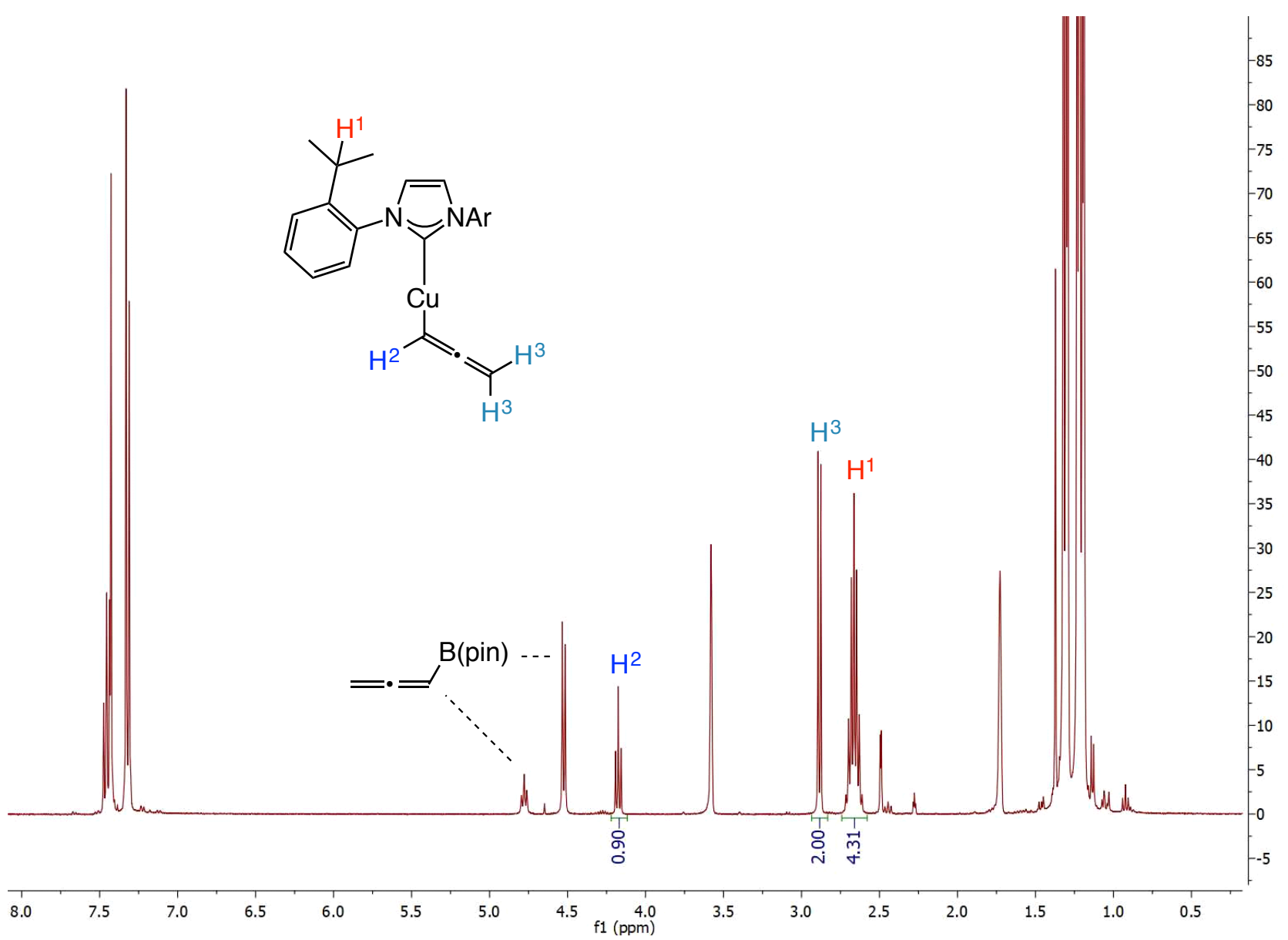


In an $\mathrm{N}_{2}$-filled glove box, an oven-dried 2-dram vial was charged with [1,3-bis(2,6diisopropylphenyl)imidazol-2-ylidene $] \mathrm{CuOt}$-Bu $(10 \mathrm{mg}, 0.019 \mathrm{mmol})$. The mixture was charged with $\mathrm{THF}-d_{8}(0.5 \mathrm{~mL})$ and allowed to stir for five min, resulting in a clear colorless solution. Vinyl-B(pin), $(6.5 \mu \mathrm{L}, 0.038 \mathrm{mmol})$ was added through syringe and the resulting colorless solution was transferred to a J-young NMR tube. Reaction progress was monitored by ${ }^{1} \mathrm{H}$ NMR spectroscopy. Key signals are highlighted below.
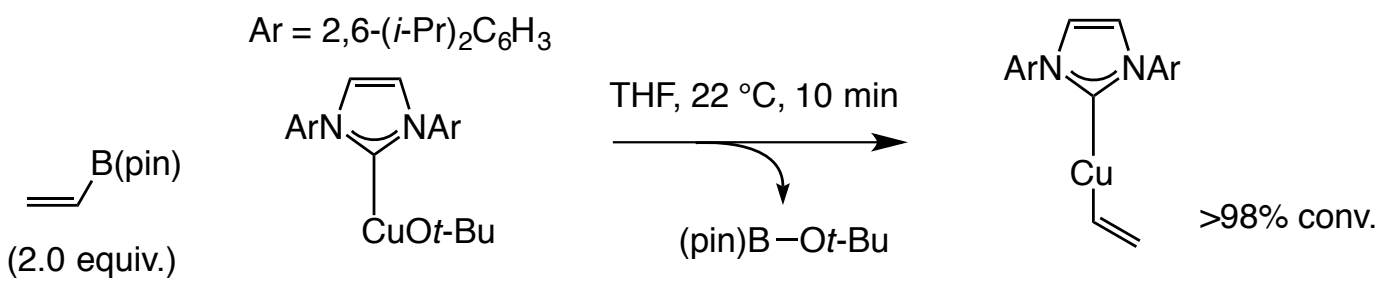

$$
\text { NHC-Cu-1 }
$$

\section{NHC-Cu-vinyl}

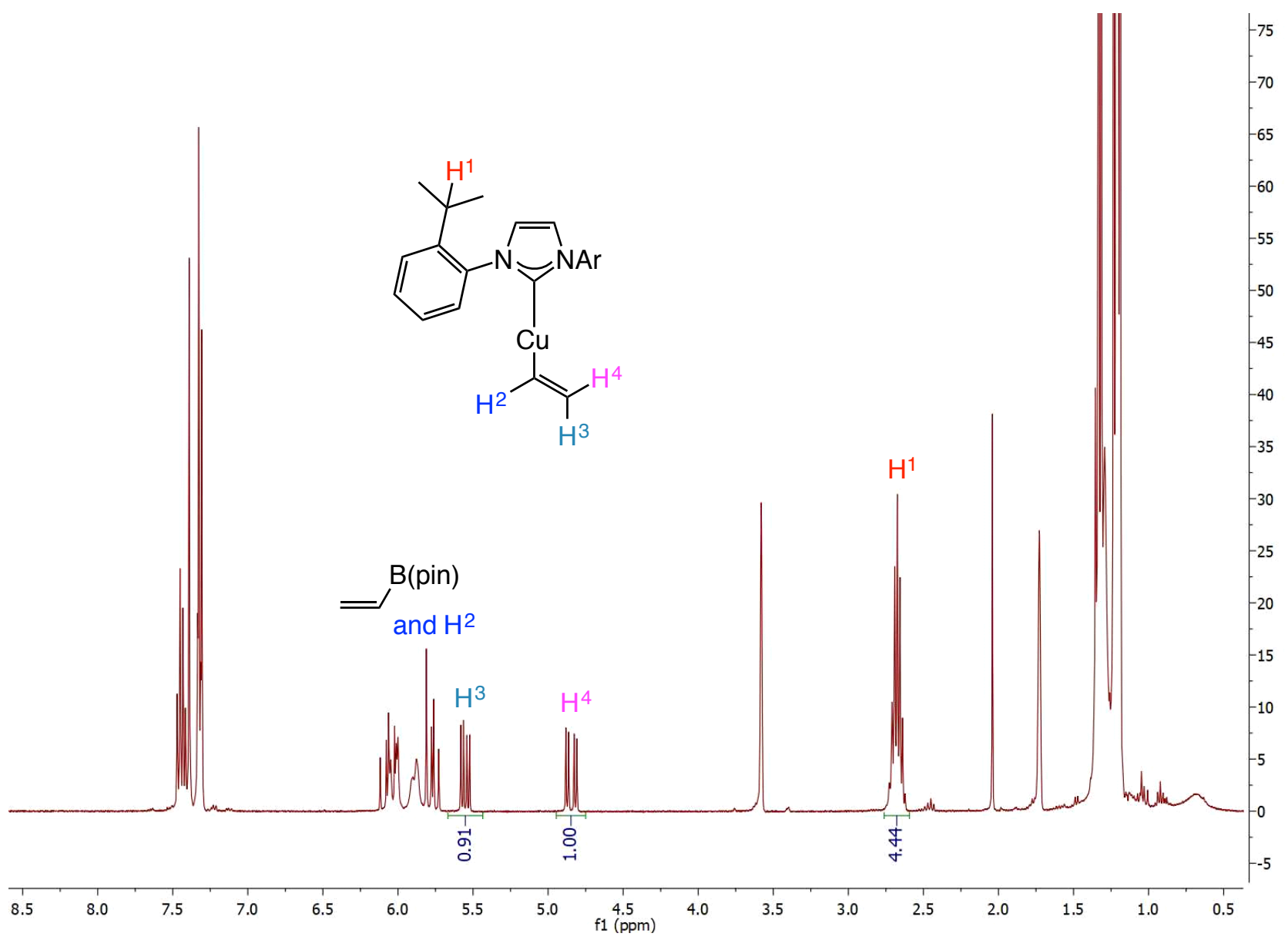

Control experiments show that allenyl-B(pin) compounds $\mathbf{1 a}$ and $\mathbf{1 b}$ as well as vinyl-B(pin) undergo $\mathrm{B} / \mathrm{Cu}$ exchange with a $\mathrm{NHC}-\mathrm{Cu}-$ alkoxide complex in less than 10 minutes. 


\subsection{Competition experiments between vinyl-B(pin) and allenyl-B(pin) compounds $1 \mathrm{a}$ and $1 \mathrm{~b}$}

In an $\mathrm{N}_{2}$-filled glove box, an oven-dried 2-dram vial was charged with [1,3-bis(2,6diisopropylphenyl)imidazol-2-ylidene]CuOt-Bu $(10.0 \mathrm{mg}, 0.019 \mathrm{mmol})$. The mixture was charged with THF- $d_{8}(0.25 \mathrm{~mL})$ and allowed to stir for five min, resulting in a clear colorless solution. A separate vial was charged with allenyl-B(pin) $\mathbf{1 b}(6.8 \mu \mathrm{L}, 0.038 \mathrm{mmol})$ and vinyl-B(pin) $(6.5 \mu \mathrm{L}, 0.038 \mathrm{mmol})$, and the mixture was dissolved in THF- $d_{8}(0.25 \mathrm{~mL})$ resulting colorless solution. Both solutions were mixed and transferred to a J-young NMR tube. Reaction progress was monitored by ${ }^{1} \mathrm{H}$ NMR spectroscopy.
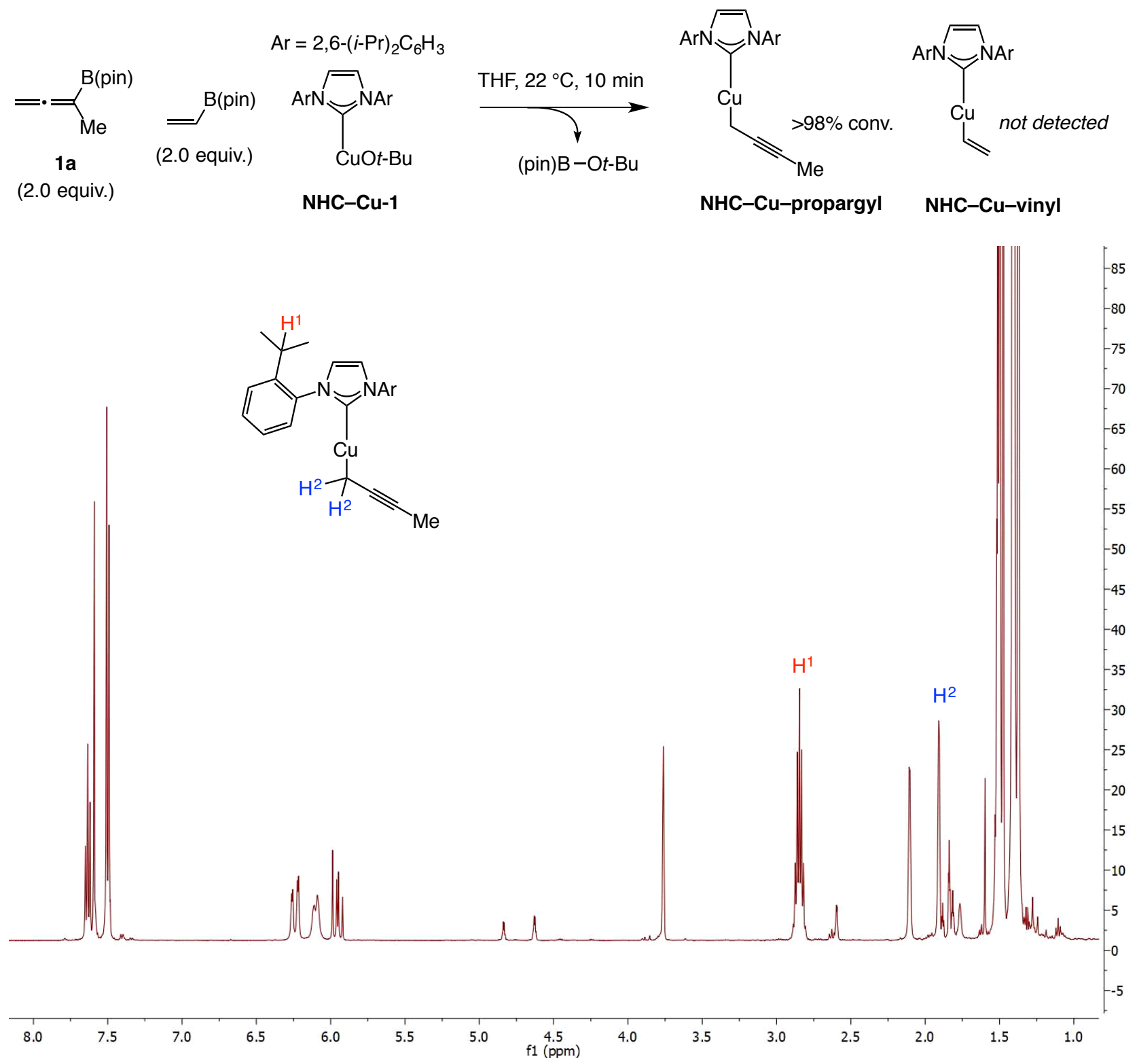
In an $\mathrm{N}_{2}$-filled glove box, an oven-dried 2-dram vial was charged with [1,3-bis(2,6diisopropylphenyl)imidazol-2-ylidene $] \mathrm{CuOt}$-Bu $(10.0 \mathrm{mg}, 0.019 \mathrm{mmol})$. The mixture was charged with THF $-d_{8}(0.25 \mathrm{~mL})$ and allowed to stir for five min, resulting in a clear colorless solution. A separate vial was charged with allenyl-B(pin) $\mathbf{1 b}(6.8 \mu \mathrm{L}, 0.038 \mathrm{mmol})$ and vinyl-B(pin) $(6.5 \mu \mathrm{L}, 0.038 \mathrm{mmol})$, and the mixture was dissolved in THF- $d_{8}(0.25 \mathrm{~mL})$, resulting colorless solution. Both solutions were mixed and transferred to a J-young NMR tube. Reaction progress was monitored by ${ }^{1} \mathrm{H}$ NMR spectroscopy.
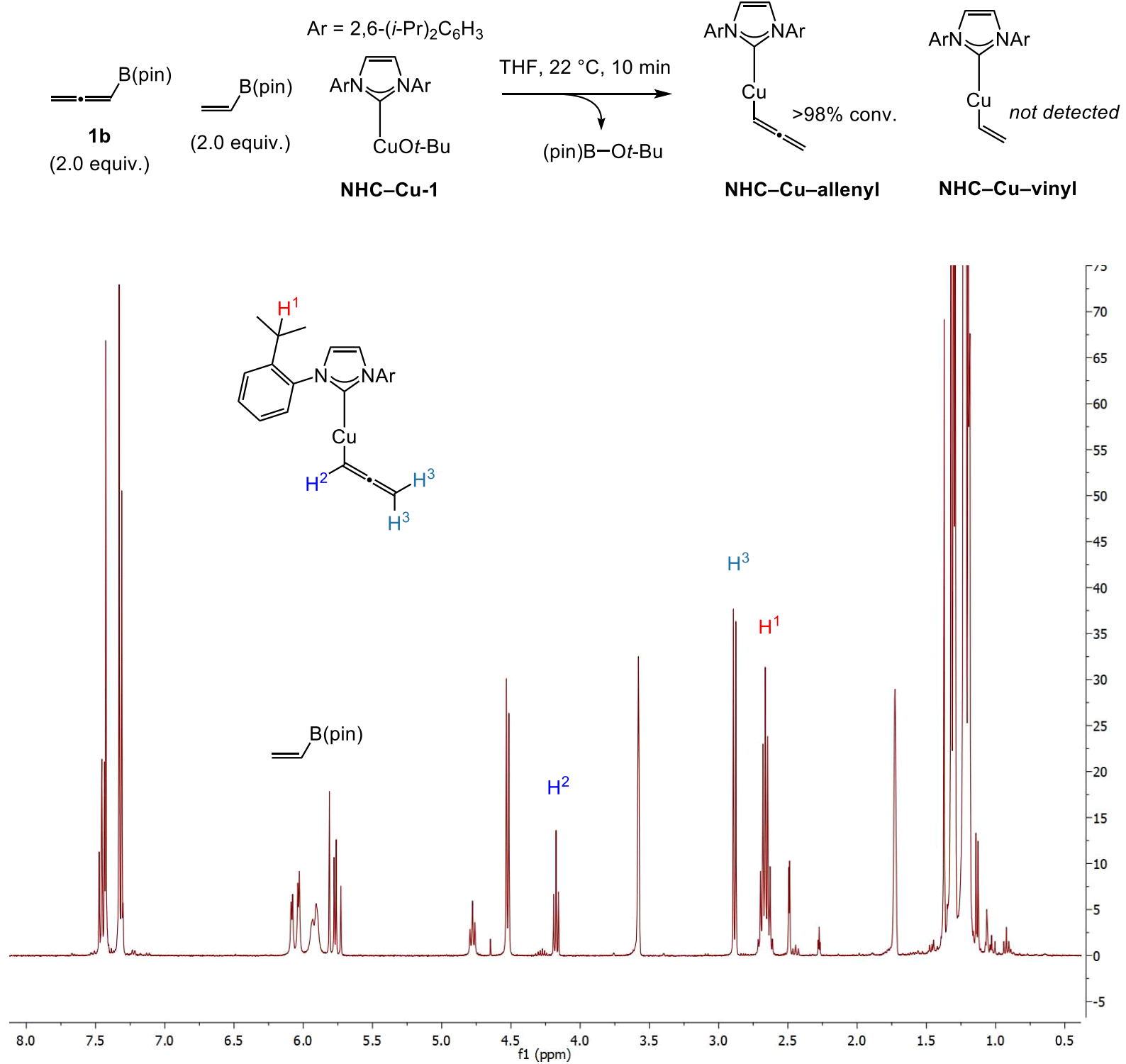

The above experiments show that, although 1a, $\mathbf{1 b}$ and vinyl-B(pin) undergo $\mathrm{B} / \mathrm{Cu}$ exchange with an $\mathrm{NHC}-\mathrm{Cu}$-alkoxide complex in just $10 \mathrm{~min}$ at room temperature, when an equal mixture of $\mathbf{1 a}$ or $\mathbf{1 b}$ and vinyl-B(pin) are subjected to the same conditions, only the allenyl boronates react and there is no detectable transformation to the $\mathrm{Cu}-$-vinyl species. Undesired $\mathrm{B} / \mathrm{Cu}$ exchange is thus significantly more of a complication when allenyl-B(pin) compounds are involved. 


\subsection{Reactions with varying quantities of metal-alkoxide and PMHS}

Table S1. The Impact of Different Amounts of Metal-Alkoxide and PMHS on a Reaction with Allenyl-B(pin) 1a
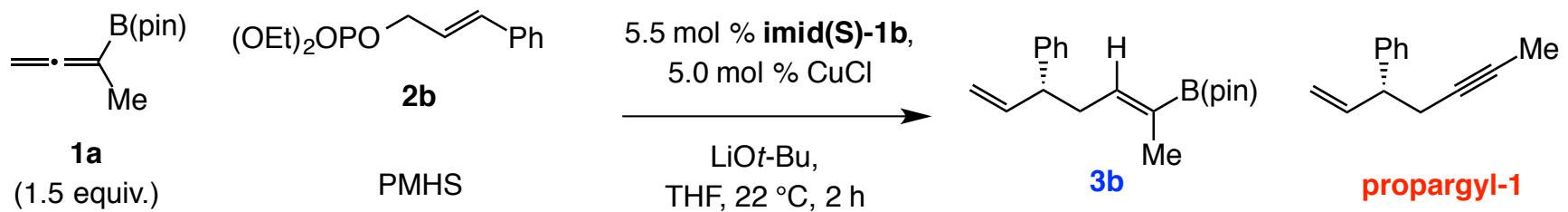

\begin{tabular}{cccc}
\hline Entry & Equiv. (LiOt-Bu; PMHS) & Conv. $(\%) ; b$ Yield (\%) & 3b: propargyl-1 \\
\hline 1 & $2.5 ; 3.0$ & $>98 ; 8$ & $14: 86$ \\
2 & $1.5 ; 3.0$ & $>98 ; 53$ & $74: 26$ \\
3 & $1.2 ; 3.0$ & $>98 ; 64$ & $89: 11$ \\
4 & $1.2 ; 5.0$ & $>98 ; 69$ & $96: 4$ \\
\hline
\end{tabular}

Table S2. The Impact of Different Amounts of Metal-Alkoxide and PMHS on a Reaction with Allenyl-B(pin) 1b

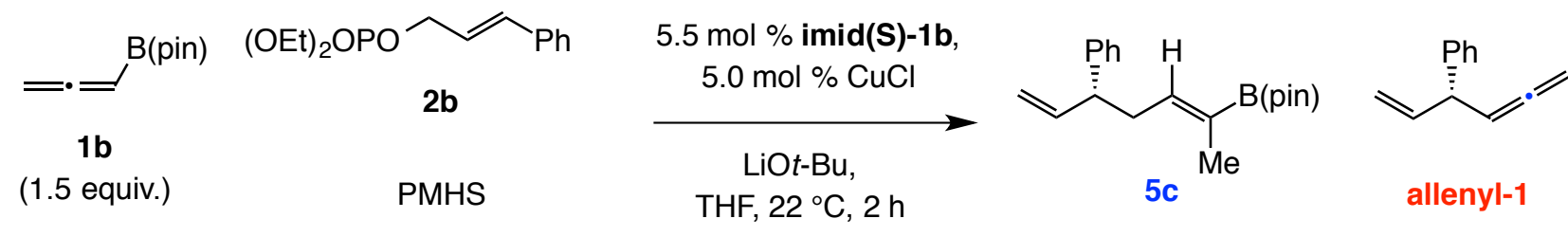

\begin{tabular}{cccc}
\hline Entry & Equiv. (LiOt-Bu; PMHS) & Conv. (\%); ${ }^{b}$ Yield $(\%)^{c}$ & 5c:allenyl-1 \\
\hline 1 & $2.5 ; 3.0$ & $>98 ;$ ND & $<2:>98$ \\
2 & $1.5 ; 3.0$ & (allenyl-1, $87 \%$ yield) & $61: 39$ \\
3 & $1.2 ; 3.0$ & $>98 ; 54$ & $82: 18$ \\
4 & $1.2 ; 5.0$ & $>98 ; 71$ & $88: 12$ \\
\hline
\end{tabular}

${ }^{a}$ Reactions were permed under $\mathrm{N}_{2}$ atm. ${ }^{b}$ Conv. and product ratios determined by analysis of the $400 \mathrm{MHz}{ }^{1} \mathrm{H} \mathrm{NMR}$ spectra of unpurified product mixtures. ${ }^{c}$ Yield of purified product. ND, not determined. 


\section{7 $\mathrm{Cu}-\mathrm{H}$ catalysed reduction of allylic phosphate}

1. Kinetic study of reduction with imid(S)-1a and imid(S)-1b
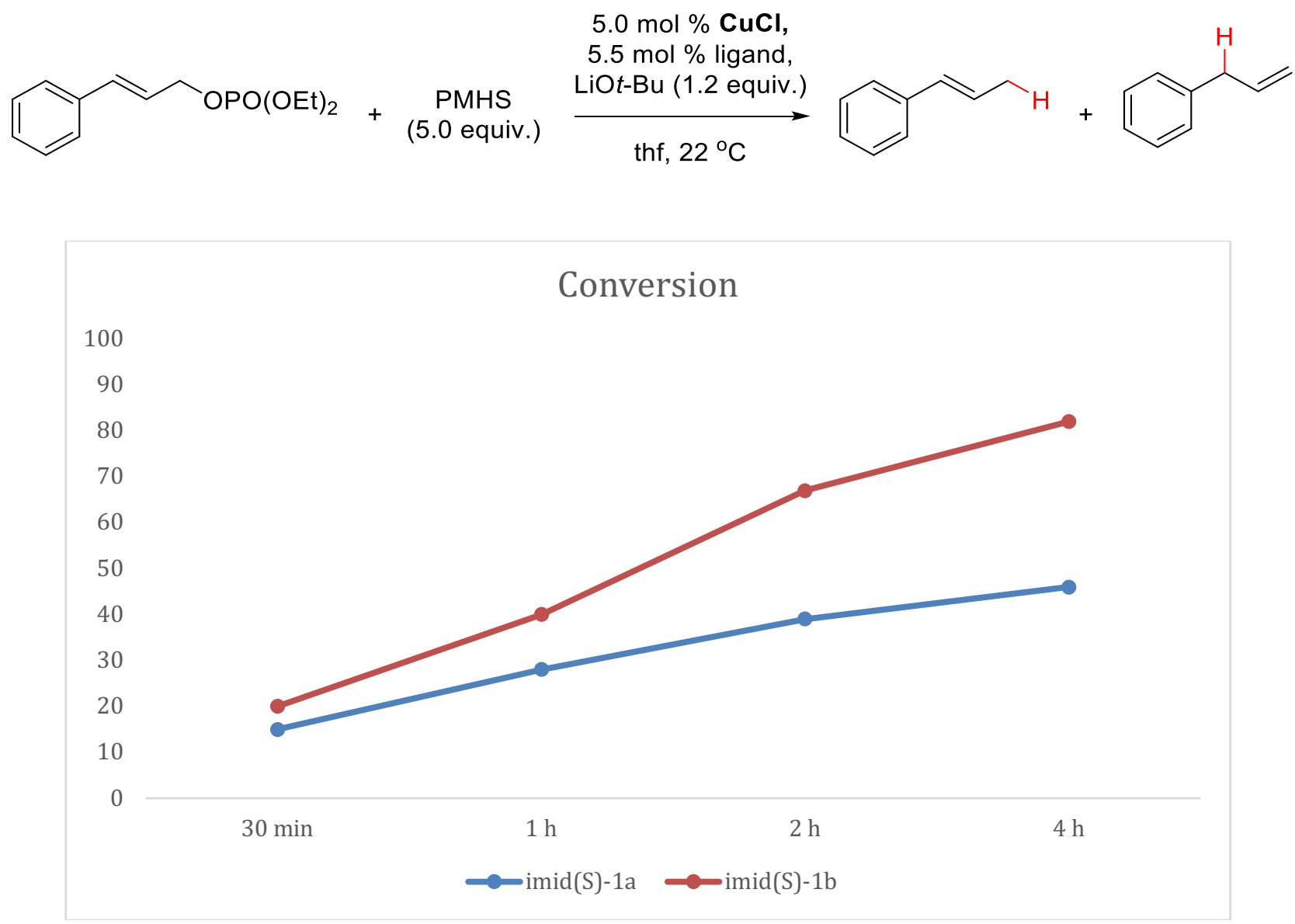

2. Control experiment

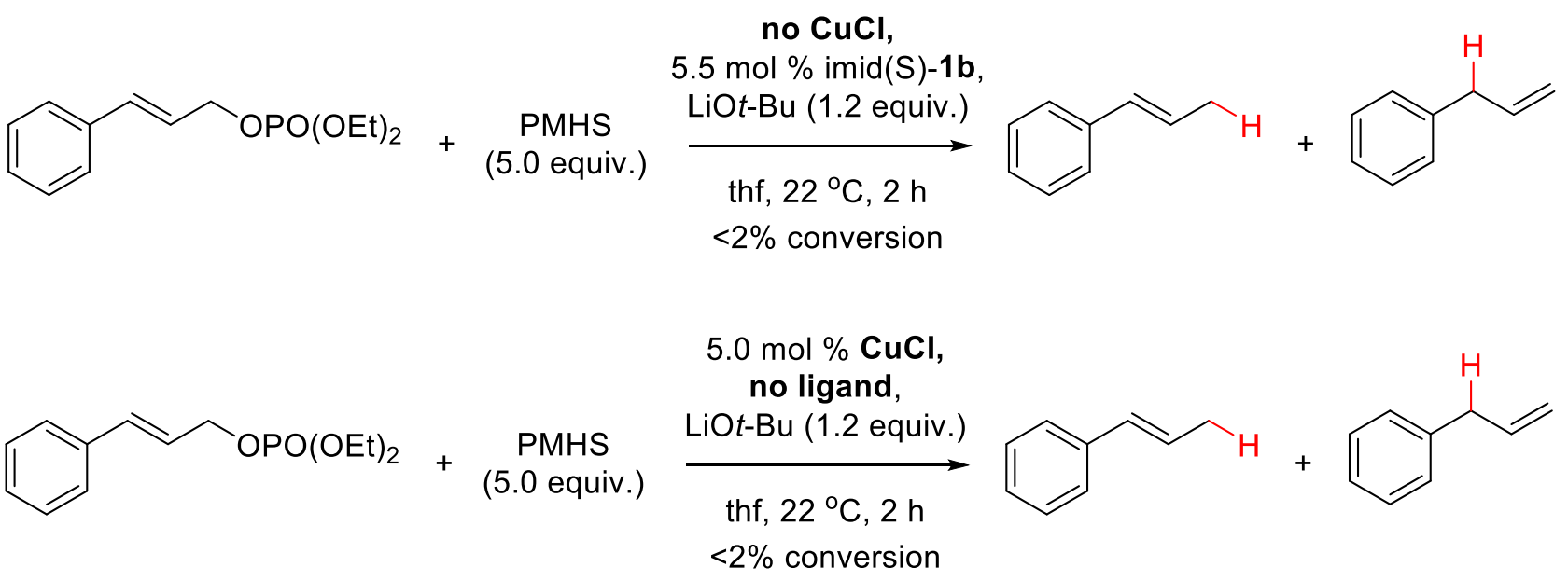




\section{Formal Synthesis of Pumiliotoxin B}

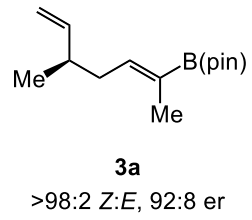

$>98: 2$ Z:E, $92: 8$ er

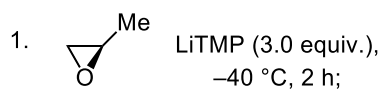

$$
\text { (3.0 equiv.) }
$$

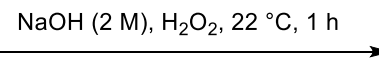

2. 2,2-dimethoxypropane (1.5 equiv.), $20 \mathrm{~mol} \% p-\mathrm{TsOH}$, acetone, $22{ }^{\circ} \mathrm{C}, 1 \mathrm{~h}$

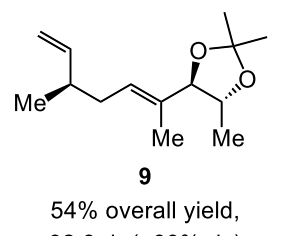

$92: 8 \mathrm{dr}(>99 \% \mathrm{ds})$

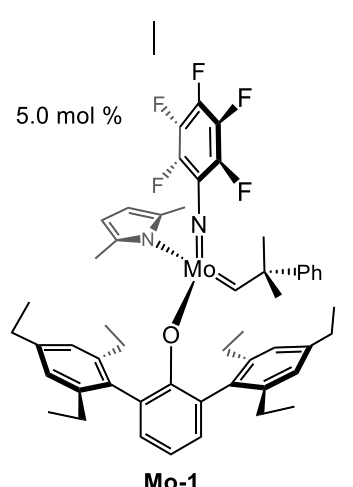

$86 \%$ overall yield

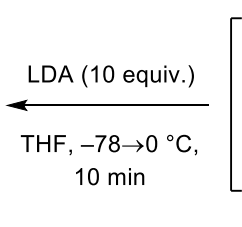

$$
\text { - }
$$

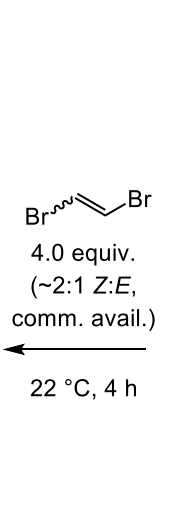

(4R,5R)-2,2,4-Trimethyl-5-((R,E)-5-methylhepta-2,6-dien-2-yl)-1,3-dioxolane (9): In a glove box, an oven-dried vial containing a stir bar was charged with LiTMP (132 mg, $0.900 \mathrm{mmol}$ ) and THF (5.0 mL). The vial was sealed with a septum and electrical tape, and removed from the glove box. The mixture was allowed to stir for $30 \mathrm{~min}$ at $22^{\circ} \mathrm{C}$, after which it was allowed to cool to $-40{ }^{\circ} \mathrm{C}$. To this solution was added sequentially $(R)-(+)$-propylene oxide $(52.3 \mathrm{mg}, 0.900 \mathrm{mmol})$ and $3 \mathbf{a}(70.8 \mathrm{mg}, 0.300 \mathrm{mmol})$ (at $-40{ }^{\circ} \mathrm{C}$ ). The solution was allowed to stir for $2 \mathrm{~h}$ at $-40{ }^{\circ} \mathrm{C}$ before it was allowed to warm to $0{ }^{\circ} \mathrm{C}$ at which time the reaction was quenched by the addition of a saturated solution of aqueous $\mathrm{NaOH}(3.0 \mathrm{~mL}$, $2 \mathrm{M})$ and $\mathrm{H}_{2} \mathrm{O}_{2}\left(100 \mu \mathrm{L}, 30 \%\right.$ wt. in $\left.\mathrm{H}_{2} \mathrm{O}\right)$. The mixture was then allowed to warm to $22{ }^{\circ} \mathrm{C}$ and stir for $1 \mathrm{~h}$, after which an aqueous solution of saturated $\mathrm{Na}_{2} \mathrm{~S}_{2} \mathrm{O}_{3}(2.0 \mathrm{~mL})$ was added. The mixture was allowed to stir for $10 \mathrm{~min}$ at $22{ }^{\circ} \mathrm{C}$. The layers were separated and the aqueous layer was washed with $\mathrm{Et}_{2} \mathrm{O}(3 \mathrm{x}$ $20 \mathrm{~mL}$ ). The combined organic layers were dried over $\mathrm{Na}_{2} \mathrm{SO}_{4}$ and concentrated in vacuo. The resulting orange oil was purified by a short column of silica gel. To a solution of the diol at $22{ }^{\circ} \mathrm{C}$ in acetone $(5.0$ $\mathrm{mL}$ ) were sequentially added 2,2-dimethoxypropane (46.9 $\mathrm{mg}, 0.450 \mathrm{mmol}$ ) and $p$-toluenesulfonic acid monohydrate $(11.4 \mathrm{mg}, 0.0600 \mathrm{mmol})$. The mixture was allowed to stir for $1 \mathrm{~h}$ at $22{ }^{\circ} \mathrm{C}$ and then it was charged with an aqueous solution of saturated $\mathrm{NaHCO}_{3}(50 \mu \mathrm{L})$. The mixture was allowed to pass through a short plug of silica gel and eluted with EtOAc. The volatiles were removed in vacuo and the resulting yellow oil was purified by silica gel chromatography $(30: 1 \rightarrow 10: 1$ hexanes:EtOAc) to afford 9 as pale yellow oil (36.2 mg, $0.161 \mathrm{mmol}, 54 \%$ overall yield). IR (neat): 3076 (s), 2982 (m), 2931 (m), 2877 (m), 1640 (w), 1455 (m), 1377 (s), 1370 (s), 1238 (s), 1175 (m), 1098 (s), 1065 (w), 1036 (s), 993 $(\mathrm{w}), 911(\mathrm{~m}), 863(\mathrm{w}) \mathrm{cm}^{-1}$; ${ }^{1} \mathbf{H}$ NMR (600 MHz, CDCl $): \delta 5.75(\mathrm{ddd}, \mathrm{J}=17.3,10.4,7.1 \mathrm{~Hz}, 1 \mathrm{H}), 5.51$ $(\mathrm{t}, \mathrm{J}=7.4 \mathrm{~Hz}, 1 \mathrm{H}), 5.00-4.90(\mathrm{~m}, 2 \mathrm{H}), 3.90-3.82(\mathrm{~m}, 2 \mathrm{H}), 2.21(\mathrm{p}, \mathrm{J}=6.4 \mathrm{~Hz}, 1 \mathrm{H}), 2.14-2.02(\mathrm{~m}, 2 \mathrm{H})$, $1.64(\mathrm{~s}, 3 \mathrm{H}), 1.42(\mathrm{~s}, 6 \mathrm{H}), 1.21(\mathrm{~d}, \mathrm{~J}=5.0 \mathrm{~Hz}, 3 \mathrm{H}), 0.99(\mathrm{~d}, \mathrm{~J}=7.1 \mathrm{~Hz}, 3 \mathrm{H}) ;{ }^{13} \mathbf{C}$ NMR (151 MHz, $\left.\mathbf{C D C l}_{3}\right): 144.1,131.8,128.5,112.8,108.1,88.9,74.5,37.8,34.8,27.7,27.1,19.5,17.1,11.7$; HRMS 
(DART): Calcd for $\mathrm{C}_{14} \mathrm{H}_{25} \mathrm{O}_{2}[\mathrm{M}+\mathrm{H}]^{+}:$225.1849. Found: 225.1853; Specific rotation: $[\alpha]_{\mathrm{D}}{ }^{20}-1.9$ (c 1.7, $\left.\mathrm{CHCl}_{3}\right)$.

$(4 R, 5 R)-2,2,4-T r i m e t h y l-5-((R, E)-5-m e t h y l h e p t-2-e n-6-y n-2-y l)-1,3-d i o x o l a n e ~(4): ~ I n ~ a ~ \mathrm{~N}_{2}$-filled glove box, an oven-dried 2-dram vial equipped with a stir bar was charged with 9 (22.4 mg, $0.100 \mathrm{mmol})$, 1,2-dibromoethylene (74.3 mg, $0.4 \mathrm{mmol}$ ), and Mo-1 (50 $\mu \mathrm{L}, 0.1 \mathrm{M}$ in benzene, $5.0 \mu \mathrm{mol}$ ) were added. The vial was capped, sealed, and removed from the glove box. The mixture was allowed to stir for $4 \mathrm{~h}$ at $22{ }^{\circ} \mathrm{C}$, after which it was charged with THF $(1.0 \mathrm{~mL})$ and allowed to cool to $-78^{\circ} \mathrm{C}$. To this solution at $-78{ }^{\circ} \mathrm{C}$ was added LDA in a dropwise manner $(1.0 \mathrm{~mL}, 1.0 \mathrm{M}$ in THF, $1.0 \mathrm{mmol})$. The resulting solution was allowed to warm to $0{ }^{\circ} \mathrm{C}$ and stir for $10 \mathrm{~min}$ before the addition of an aqueous solution of saturated $\mathrm{NH}_{4} \mathrm{Cl}(50 \mu \mathrm{L})$. The mixture was passed through a short plug of silica gel and eluted with $\mathrm{Et}_{2} \mathrm{O}$. The volatiles were concentrated in vасио and and the resulting yellow oil was purified by silica gel chromatography $\left(30: 1 \rightarrow 10: 1\right.$ hexanes: $\left.\mathrm{Et}_{2} \mathrm{O}\right)$ to afford 4 as colorless oil $(19.1 \mathrm{mg}, 0.0860 \mathrm{mmol}, 86 \%$ yield). IR (neat): 3342 (w), 2996 (m), 2914 (w), 2123 (m), 1477 (s), 1412(w), 1362 (m), 1223 (m), 1134 (w), 1004 (m), $772(\mathrm{w}) \mathrm{cm}^{-1} ;{ }^{1} \mathbf{H}$ NMR (600 MHz, $\left.\mathbf{C D C l}_{3}\right): \delta 5.60(\mathrm{t}, J=7.3 \mathrm{~Hz}, 1 \mathrm{H}), 3.91(\mathrm{~d}, J=8.6$ $\mathrm{Hz}, 1 \mathrm{H}), 3.88-3.83(\mathrm{~m}, 1 \mathrm{H}), 2.51(\mathrm{q}, J=6.7 \mathrm{~Hz}, 1 \mathrm{H}), 2.31-2.19(\mathrm{~m}, 2 \mathrm{H}), 2.04(\mathrm{~d}, J=2.1 \mathrm{~Hz}, 1 \mathrm{H}), 1.67$ $(\mathrm{s}, 3 \mathrm{H}), 1.43(\mathrm{~s}, 6 \mathrm{H}), 1.23$ (d, $J=5.7 \mathrm{~Hz}, 3 \mathrm{H}), 1.18$ (d, $J=6.8 \mathrm{~Hz}, 3 \mathrm{H}) ;{ }^{13} \mathbf{C}$ NMR (101 MHz, CDCl$):$ $\delta$ 133.2, 126.9, 108.2, 88.7, 88.6, 74.7, 68.6, 34.7, 27.7, 27.1, 25.9, 20.5, 17.2, 11.9; HRMS (DART): Calcd for $\mathrm{C}_{14} \mathrm{H}_{23} \mathrm{O}_{2}[\mathrm{M}+\mathrm{H}]^{+}: 223.1693$. Found: 223.1688 ; Specific rotation: $[\alpha]_{\mathrm{D}}{ }^{20}-11.4\left(c 1.0, \mathrm{CHCl}_{3}\right)$.

\section{Synthesis of and Stereochemical Assignment for Netamine C}

\subsection{Synthesis of alkenyl boronates $(S, R)-16$ and $(R, R)-16$}

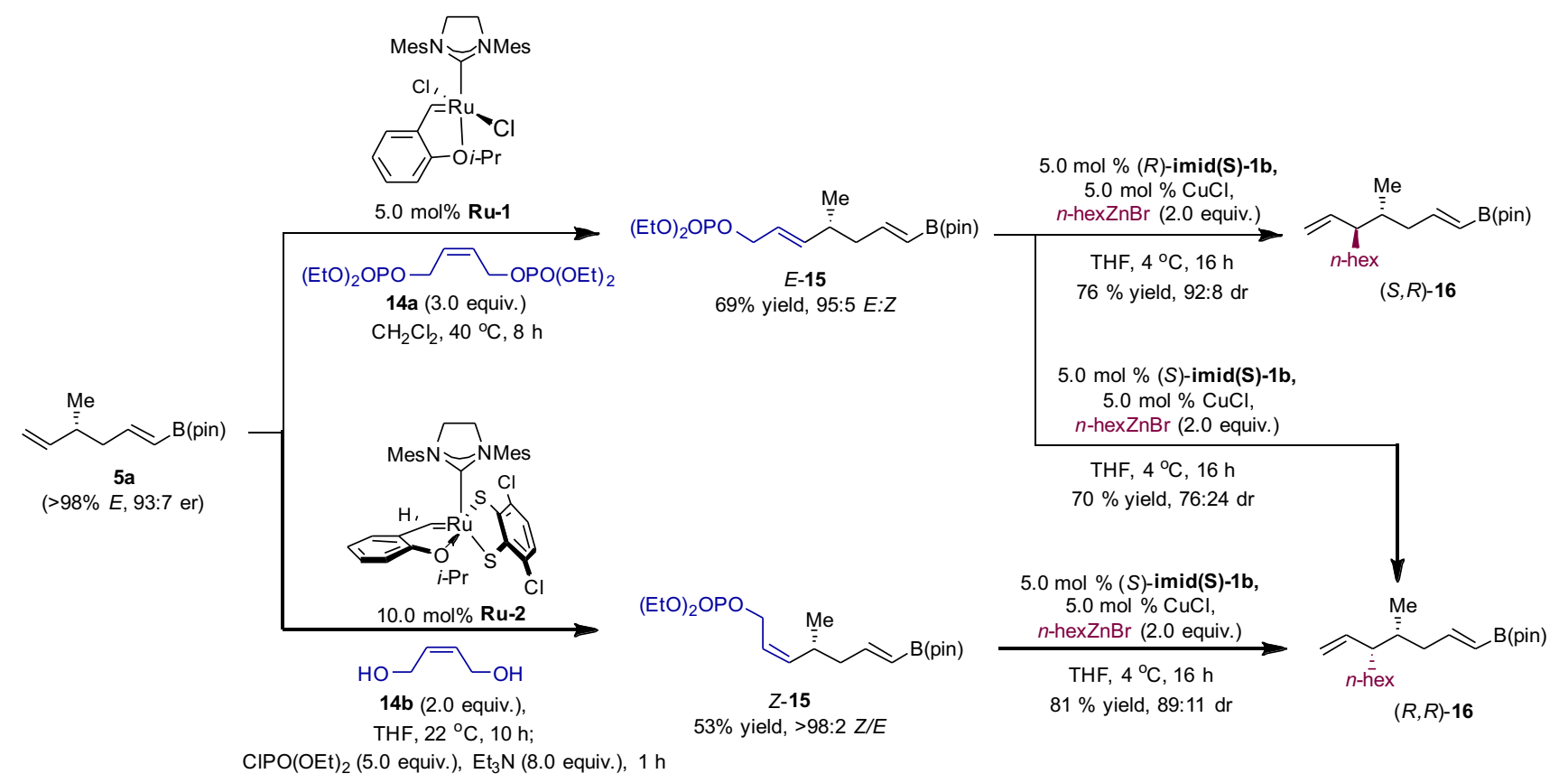

Diethyl ((R,2E,6E)-4-methyl-7-(4,4,5,5-tetramethyl-1,3,2-dioxaborolan-2-yl)hepta-2,6-dien-1-yl) phosphate (E-15): In a glove box, an oven-dried vial equipped containing a stir bar was charged with 
5a (555 mg, $2.50 \mathrm{mmol})$ and $\mathbf{1 4 a}(2.70 \mathrm{~g}, 7.50 \mathrm{mmol})$. To this mixture was added Ru-1 (78.3 mg, 2.07 mmol) in $\mathrm{CH}_{2} \mathrm{Cl}_{2}(0.5 \mathrm{~mL})$. The vial was sealed with a cap and electrical tape, and removed from the glove box. The solution was allowed to stir for $8 \mathrm{~h}$ at $40{ }^{\circ} \mathrm{C}$ and then allowed to cool to $22{ }^{\circ} \mathrm{C}$. The volatiles were removed under reduced pressure and the resulting red oil residue was purified by silica gel chromatography $(10: 1 \rightarrow 2: 1 \rightarrow 1: 1$ hexanes:EtOAc) to afford $\boldsymbol{E}-\mathbf{1 5}$ as red oil (667 $\mathrm{mg}, 1.72 \mathrm{mmol}, 69 \%$ yield). IR (neat): 2976 (s), 2926 (s), 1637 (s), 1456 (s), 1391 (w), 1360 (s), 1321 (m), 1264 (m), 1165

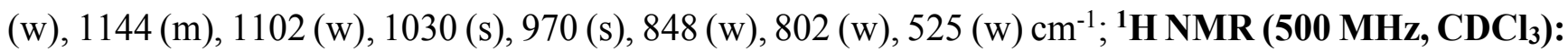
$\delta 6.54(\mathrm{dt}, J=17.8,6.8 \mathrm{~Hz}, 1 \mathrm{H}), 5.74(\mathrm{dd}, J=15.5,6.9 \mathrm{~Hz}, 1 \mathrm{H}), 5.57(\mathrm{dtd}, J=15.5,6.3,1.3 \mathrm{~Hz}, 1 \mathrm{H})$, $5.43(\mathrm{~d}, J=17.9 \mathrm{~Hz}, 1 \mathrm{H}), 4.51-4.45(\mathrm{~m}, 2 \mathrm{H}), 4.11(\mathrm{p}, J=7.1 \mathrm{~Hz}, 4 \mathrm{H}), 2.32(\mathrm{p}, J=6.8 \mathrm{~Hz}, 1 \mathrm{H}), 2.23$ $(\mathrm{dtd}, J=13.0,6.5,1.5 \mathrm{~Hz}, 1 \mathrm{H}), 2.15-2.09(\mathrm{~m}, 1 \mathrm{H}), 1.33(\mathrm{td}, J=7.1,1.1 \mathrm{~Hz}, 6 \mathrm{H}), 1.26(\mathrm{~s}, 12 \mathrm{H}), 1.01(\mathrm{~d}$, $J=6.7 \mathrm{~Hz}, 3 \mathrm{H}) ;{ }^{13} \mathbf{C}$ NMR (126 MHz, $\left.\mathbf{C D C l}_{3}\right): \delta 152.1,141.1,123.1$ (d, $\left.J=6.7 \mathrm{~Hz}\right), 83.2,68.3(\mathrm{~d}, J=$ $5.6 \mathrm{~Hz}), 63.8(\mathrm{~d}, J=5.8 \mathrm{~Hz}), 43.1,35.5,24.9,19.6,16.3(\mathrm{~d}, J=6.8 \mathrm{~Hz})$; HRMS (DART): Calcd for $\mathrm{C}_{18} \mathrm{H}_{35} \mathrm{BO}_{6} \mathrm{P}[\mathrm{M}+\mathrm{H}]^{+}: 389.2259$. Found: 389.2250; Specific rotation: $[\alpha]_{\mathrm{D}}^{20}-13.7\left(c 0.30, \mathrm{CHCl}_{3}\right)$.

Diethyl $\quad((R, 2 Z, 6 E)-4-m e t h y l-7-(4,4,5,5-t e t r a m e t h y l-1,3,2-d i o x a b o r o l a n-2-y l) h e p t a-2,6-d i e n-1-y l)$ phosphate (Z-15): In a glove box, an oven-dried vial equipped with a stir bar was charged with 5a (444 $\mathrm{mg}, 2.00 \mathrm{mmol})$ and $\mathbf{1 4 b}(352 \mathrm{mg}, 4.00 \mathrm{mmol})$. To this mixture was added Ru-2 (76.5 mg, $0.10 \mathrm{mmol})$ in THF $(0.1 \mathrm{~mL})$. The solution was allowed to stir for $5 \mathrm{~h}$ at $22^{\circ} \mathrm{C}$ and an additional aliquot of $\mathbf{R u}-2$ (76.5 $\mathrm{mg}, 0.10 \mathrm{mmol})$ in THF $(0.1 \mathrm{~mL})$ was added. The vial was sealed with a cap and electrical tape, and removed from the glove box. The solution was allowed to stir for $5 \mathrm{~h}$ at $22{ }^{\circ} \mathrm{C}$ and then cooled to $0{ }^{\circ} \mathrm{C}$. To this mixture was sequentially added at $0{ }^{\circ} \mathrm{C} \mathrm{Et}_{3} \mathrm{~N}(2.20 \mathrm{~mL}, 16.0 \mathrm{mmol}), \mathrm{ClPO}(\mathrm{OEt})_{2}(1.45 \mathrm{~mL}$, $10.0 \mathrm{mmol})$, and 4-dimethylaminopyridine $(12.2 \mathrm{mg}, 0.1 \mathrm{mmol})$. The solution was allowed to warm to $22{ }^{\circ} \mathrm{C}$ and stir for $1 \mathrm{~h}$ before the addition of an aqueous solution of saturated $\mathrm{NaHCO}_{3}(50 \mu \mathrm{L})$. The mixture was passed through a short plug of silica gel and eluted with EtOAc. The volatiles were removed in vacuo and the resulting red oil was purified by silica gel chromatography $(10: 1 \rightarrow 2: 1 \rightarrow 1: 1$ hexanes:EtOAc) to afford $\mathbf{Z - 1 5}$ as orange oil (413 mg, $1.06 \mathrm{mmol}, 53 \%$ yield). IR (neat): 2958 (m), 2936 (m), 2925 (m), 2871 (w), 1732 (s), 1637 (w), 1394 (w), 1360 (m), 1317 (m), 1268 (m), 1165 (w), 1144 (w), 1036 (s), 992 (m), 981 (m) cm ${ }^{-1} ;{ }^{1} \mathbf{H}$ NMR (500 MHz, CDCl$): \delta 6.50$ (dt, $J=17.8,6.9 \mathrm{~Hz}$, $1 \mathrm{H}), 5.53(\mathrm{dt}, J=11.2,6.8 \mathrm{~Hz}, 1 \mathrm{H}), 5.48-5.37(\mathrm{~m}, 2 \mathrm{H}), 4.66-4.47(\mathrm{~m}, 2 \mathrm{H}), 4.10$ (p, $J=7.4 \mathrm{~Hz}, 4 \mathrm{H})$, $2.59(\mathrm{dq}, J=9.7,6.8 \mathrm{~Hz}, 1 \mathrm{H}), 2.13(\mathrm{t}, J=6.9 \mathrm{~Hz}, 2 \mathrm{H}), 1.33(\mathrm{t}, J=7.1 \mathrm{~Hz}, 6 \mathrm{H}), 1.25(\mathrm{~s}, 12 \mathrm{H}), 0.98(\mathrm{~d}, J$ $=6.7 \mathrm{~Hz}, 3 \mathrm{H}) ;{ }^{13} \mathbf{C}$ NMR (126 MHz, $\left.\mathbf{C D C l}_{3}\right): \delta 151.7,140.3,123.2(\mathrm{~d}, \mathrm{~J}=6.8 \mathrm{~Hz}), 83.2,63.8(\mathrm{~d}, J=$ $5.9 \mathrm{~Hz}), 63.3(\mathrm{~d}, J=5.7 \mathrm{~Hz}), 43.6,31.9,24.9,20.8,16.3(\mathrm{~d}, J=6.7 \mathrm{~Hz})$; HRMS (DART): Calcd for $\mathrm{C}_{18} \mathrm{H}_{35} \mathrm{BO}_{6} \mathrm{P}[\mathrm{M}+\mathrm{H}]^{+}: 389.2259$. Found: 389.2252; Specific rotation: $[\alpha]_{\mathrm{D}}{ }^{20}+24.1\left(c 0.61, \mathrm{CHCl}_{3}\right)$.

4,4,5,5-Tetramethyl-2-((4R,5S,E)-4-methyl-5-vinylundec-1-en-1-yl)-1,3,2-dioxaborolane $\quad((S, R)$ 16): In a glove box, an oven-dried vial equipped with a stir bar was charged with $\mathrm{CuCl}(5.0 \mathrm{mg}, 0.050$ mmol), $(R)$-imid(S)-1b (43.0 mg, $0.05 \mathrm{mmol}), n$-hexylzinc bromide (4.0 mL, 0.5 M in THF, $2.0 \mathrm{mmol}$ ). The solution was allowed to stir for $1 \mathrm{~h}$ at $22{ }^{\circ} \mathrm{C}$ and then to cool to $-40{ }^{\circ} \mathrm{C}$. To this mixture at $-40{ }^{\circ} \mathrm{C}$ was added $E-15(388 \mathrm{mg}, 1.0 \mathrm{mmol})$. The vial was sealed with electrical tape before removal from the glove box, and the mixture was allowed to stir for $16 \mathrm{~h}$ at $4{ }^{\circ} \mathrm{C}$, after which it was diluted with $\mathrm{CH}_{2} \mathrm{Cl}_{2}$ $(20.0 \mathrm{~mL})$ followed by a saturated solution of aqueous $\mathrm{NH}_{4} \mathrm{Cl}(0.5 \mathrm{~mL})$. The mixture was then passed through a short plug of oven-dried silica gel and eluted with $\mathrm{Et}_{2} \mathrm{O}$. The organic layer was concentrated 
in vacuo and the resulting yellow oil was purified by silica gel chromatography (1:3 hexanes: $\left.\mathrm{CH}_{2} \mathrm{Cl}_{2}\right)$ to afford $(S, R)$-16 as pale yellow oil ( $242 \mathrm{mg}, 0.0757 \mathrm{mmol}, 76 \%$ yield, $92: 8 \mathrm{dr})$. IR(neat) $2956(\mathrm{~m}), 2923$ (s), 2854 (m), $2358(\mathrm{~m}), 1636(\mathrm{~s}), 1456(\mathrm{w}), 1388$ (w), $1361(\mathrm{~s}), 1318(\mathrm{~m}), 1145$ (s), 996 (m), $970(\mathrm{~m})$, $910(\mathrm{~m}), 848(\mathrm{w}) \mathrm{cm}^{-1},{ }^{1} \mathbf{H}$ NMR (600 MHz, $\left.\mathbf{C D C l}_{3}\right): \delta 6.58(\mathrm{dt}, \mathrm{J}=18.0,6.9 \mathrm{~Hz}, 1 \mathrm{H}), 5.54(\mathrm{ddd}, \mathrm{J}=$ 17.1, 10.3, $9.2 \mathrm{~Hz}, 1 \mathrm{H}), 5.41(\mathrm{~d}, \mathrm{~J}=17.9 \mathrm{~Hz}, 1 \mathrm{H}), 5.00$ (dd, J = 10.3, $2.3 \mathrm{~Hz}, 1 \mathrm{H}), 4.93$ (dd, J = 17.1, 2.2 $\mathrm{Hz}, 1 \mathrm{H}), 2.19$ (dt, J = 12.7, $5.5 \mathrm{~Hz}, 1 \mathrm{H}), 1.97-1.89(\mathrm{~m}, 2 \mathrm{H}), 1.60(\mathrm{td}, \mathrm{J}=12.7,6.5 \mathrm{~Hz}, 1 \mathrm{H}), 1.35-1.12$ (m, 22H), 0.88-0.85 (m, 3H), 0.80 (d, J = 6.9 Hz, 3H); ${ }^{13} \mathbf{C}$ NMR (151 MHz, CDCl $\left.\mathbf{3}\right): \delta 153.9,140.1$, 115.8, 83.1, 48.3, 41.9, 36.3, 32.5, 32.0, 29.6, 27.5, 24.9 (d, J = 1.8 Hz), 22.8, 15.5, 14.2; HRMS (DART): Calcd for $\mathrm{C}_{20} \mathrm{H}_{38} \mathrm{BO}_{2}[\mathrm{M}+\mathrm{H}]^{+}$: 321.2959. Found: 321.2959; Specific rotation: $[\alpha]_{\mathrm{D}}^{20}-31.4$ (c 0.32, $\left.\mathrm{CHCl}_{3}\right)$.

Catalytic substitution with $\boldsymbol{E - 1 5}((\boldsymbol{R}, \boldsymbol{R})-16)$ : In a glove box, an oven-dried vial equipped with a stir bar was charged with $\mathrm{CuCl}(0.5 \mathrm{mg}, 5.0 \mu \mathrm{mol}),(S)$-imid(S)-1b $(4.3 \mathrm{mg}, 5.0 \mu \mathrm{mol})$, and $n$-hexylzinc bromide (0.4 mL, $0.5 \mathrm{M}$ in THF, $0.2 \mathrm{mmol}$ ). The solution was allowed to stir for $1 \mathrm{~h}$ at $22{ }^{\circ} \mathrm{C}$ and then to cool to $-40{ }^{\circ} \mathrm{C}$. To this mixture at $-40{ }^{\circ} \mathrm{C}$ was added $E-15(38.8 \mathrm{mg}, 0.1 \mathrm{mmol})$. The vial was sealed with electrical tape before removal from the glove box, and the resulting mixture was allowed to stir for $16 \mathrm{~h}$ at $4{ }^{\circ} \mathrm{C}$. The mixture was diluted with $\mathrm{CH}_{2} \mathrm{Cl}_{2}(2.0 \mathrm{~mL})$ and the reaction was quenched by the addition of a saturated solution of aqueous $\mathrm{NH}_{4} \mathrm{Cl}(50 \mu \mathrm{L})$. The mixture was passed through a short plug of ovendried silica gel and eluted with $\mathrm{Et}_{2} \mathrm{O}$. The organic layer was concentrated under reduced pressure and the resulting yellow oil was purified by silica gel chromatography $\left(1: 3\right.$ hexanes: $\left.\mathrm{CH}_{2} \mathrm{Cl}_{2}\right)$ to afford $(R, R)-\mathbf{1 6}$ as pale yellow oil ( $24.2 \mathrm{mg}, 0.0756 \mathrm{mmol}, 76 \%$ yield, $76: 24 \mathrm{dr})$.

Catalytic substitution with $Z-15((\boldsymbol{R}, \boldsymbol{R})-16)$ : In a glove box , an oven-dried vial equipped with a stir bar was charged with $\mathrm{CuCl}(5.0 \mathrm{mg}, 0.050 \mathrm{mmol}),(S)$-imid(S)-1b $(43.0 \mathrm{mg}, 0.05 \mathrm{mmol})$, and $n$-hexylzinc bromide $\left(4.0 \mathrm{~mL}, 0.5 \mathrm{M}\right.$ in THF, $2.0 \mathrm{mmol}$ ). The mixture was allowed to stir for $1 \mathrm{~h}$ at $22{ }^{\circ} \mathrm{C}$ and then to ccol to $-40{ }^{\circ} \mathrm{C}$. To this mixture at $-40{ }^{\circ} \mathrm{C}$ was added $Z-15$ (388 $\left.\mathrm{mg}, 1.0 \mathrm{mmol}\right)$. The vial was sealed with electrical tape before removal from the glove box, and the resulting mixture was allowed to stir for $16 \mathrm{~h}$ at $4{ }^{\circ} \mathrm{C}$. The solution was diluted with $\mathrm{CH}_{2} \mathrm{Cl}_{2}(20.0 \mathrm{~mL})$ and the reaction was quenched by the addition of an aqueous solution of saturated $\mathrm{NH}_{4} \mathrm{Cl}(0.5 \mathrm{~mL})$. The mixture passed through a short plug of oven-dried silica gel and eluted with $\mathrm{Et}_{2} \mathrm{O}$. The organic layer was concentrated under reduced pressure and the resulting yellow oil was purified by silica gel chromatography (1:3 hexanes: $\left.\mathrm{CH}_{2} \mathrm{Cl}_{2}\right)$ to afford $(R, R)$-16 as pale yellow oil (259 mg, $0.809 \mathrm{mmol}, 81 \%$ yield, 89:11 dr). IR(neat): $2973(\mathrm{~m}), 2956(\mathrm{~m})$, 2924 (s), 2854 (s), 1636 (s), 1457 (w), 1397 (w), 1362 (s), 1319 (m), 1268 (w), 1145 (s), 996 (w), 970 (w), $910(\mathrm{w}), 848(\mathrm{w}) \mathrm{cm}^{-1} ;{ }^{1} \mathrm{H}$ NMR (400 MHz, $\left.\mathbf{C D C l}_{3}\right): \delta 6.57$ (ddd, $\left.J=17.8,7.5,6.2 \mathrm{~Hz}, 1 \mathrm{H}\right), 5.54$ (ddd, $J=17.1,10.2,9.2 \mathrm{~Hz}, 1 \mathrm{H}), 5.40(\mathrm{dt}, J=17.9,1.4 \mathrm{~Hz}, 1 \mathrm{H}), 5.00(\mathrm{dd}, J=10.3,2.2 \mathrm{~Hz}, 1 \mathrm{H}), 4.92$ (dd, $J=16.9,1.8 \mathrm{~Hz}, 1 \mathrm{H}), 2.31$ (dddd, $J=14.0,5.8,4.0,1.5 \mathrm{~Hz}, 1 \mathrm{H}), 1.88-1.77(\mathrm{~m}, 2 \mathrm{H}), 1.62-1.50(\mathrm{~m}$, 1H), $1.41-1.16(\mathrm{~m}, 22 \mathrm{H}), 0.87(\mathrm{t}, J=6.8 \mathrm{~Hz}, 3 \mathrm{H}), 0.85(\mathrm{~d}, J=6.8 \mathrm{~Hz}, 3 \mathrm{H}) ;{ }^{13} \mathrm{C} \mathbf{N M R}\left(\mathbf{1 0 1} \mathbf{M H z}, \mathbf{C D C l}_{3}\right)$ : $\delta$ 154.2, 141.5, 115.4, 83.1, 49.5, 40.3, 36.5, 32.0, 31.2, 29.6, 27.6, 24.9 (d, $J=1.7 \mathrm{~Hz}), 22.8,17.3,14.2$; HRMS (DART): Calcd for $\mathrm{C}_{20} \mathrm{H}_{38} \mathrm{BO}_{2}[\mathrm{M}+\mathrm{H}]^{+}: 321.2959$. Found: 321.2953 ; Specific rotation: $[\alpha]_{D}{ }^{20}$ $-6.9\left(\right.$ c $\left.1.0, \mathrm{CHCl}_{3}\right)$. 


\subsection{Netamine $C$ (the revised structure)}
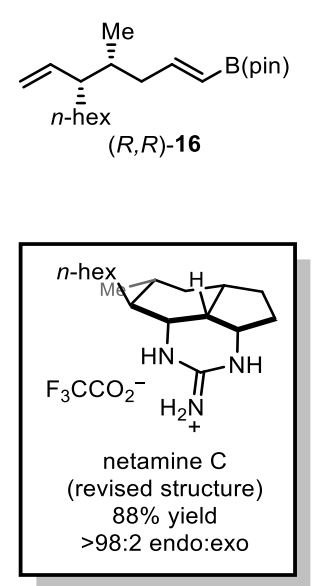

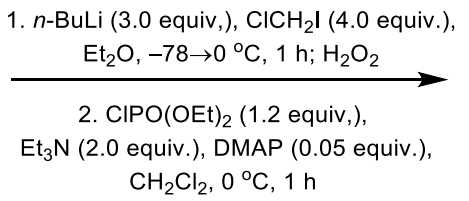

1. $n$-BuLi (3.0 equiv,), $\mathrm{CICH}_{2} \mathrm{I}$ (4.0 equiv.), $\mathrm{Et}_{2} \mathrm{O},-78 \rightarrow 0^{\circ} \mathrm{C}, 1 \mathrm{~h} ; \mathrm{H}_{2} \mathrm{O}_{2}$ 2. $\mathrm{CIPO}(\mathrm{OEt})_{2}(1.2$ equiv, $)$, $\mathrm{Et}_{3} \mathrm{~N}$ (2.0 equiv.), DMAP ( 0.05 equiv.), $\mathrm{CH}_{2} \mathrm{Cl}_{2}, 0^{\circ} \mathrm{C}, 1 \mathrm{~h}$

$$
\begin{gathered}
\mathrm{NH}_{2} \mathrm{NHBn}(1.5 \text { equiv. }) \text {, } \\
\text { conc. } \mathrm{HCl}(5.0 \text { equiv.), } \\
\mathrm{EtOH}, 100^{\circ} \mathrm{C}, 4 \mathrm{~h} ; \\
\text { then } \mathrm{PtO}_{2}(0.2 \text { equiv.), } \\
\mathrm{H}_{2}, 60^{\circ} \mathrm{C}, 12 \mathrm{~h} ; \\
\text { then } \mathrm{BrCN}(2.0 \text { equiv.), } \\
\mathrm{NaOMe}(10.0 \text { equiv.) }
\end{gathered}
$$

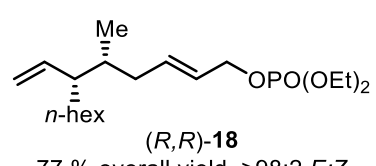

$77 \%$ overall yield, $>98: 2 \mathrm{E}: Z$

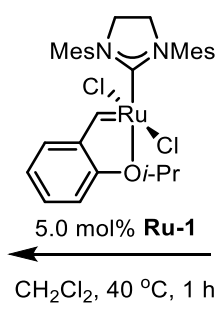

$(R, R, S)-7$ $93 \%$ yield
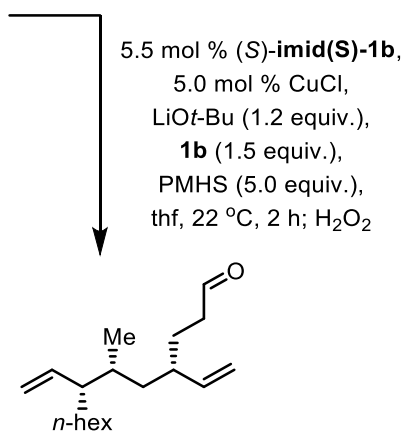

$(R, R, S)-6$

$65 \%, 96: 4 d r$

Diethyl $((5 R, 6 R, E)-5-m e t h y l-6-v i n y l d o d e c-2-e n-1-y l)$ phosphate $(R, R)-18$ : To a vial equipped with a stir bar was added $(R, R)-16(271 \mathrm{mg}, 0.846 \mathrm{mmol})$, chloroiodomethane $(246 \mu \mathrm{L}, 3.38 \mathrm{mmol})$ and $\mathrm{Et}_{2} \mathrm{O}$ $(5.0 \mathrm{~mL})$. To this solution at $-78^{\circ} \mathrm{C}$ in a dropwise manner was added $n$-BuLi (1.0 mL, $2.5 \mathrm{M}$ in hexanes, $2.50 \mathrm{mmol})$. The mixture was allowed to warm to $0{ }^{\circ} \mathrm{C}$ over the course of $1 \mathrm{~h}$ after which the reaction was quenched by the addition of an aqueous solution of $1 \mathrm{M} \mathrm{NaOH}(2.0 \mathrm{~mL})$ and $\mathrm{H}_{2} \mathrm{O}_{2}(300 \mu \mathrm{L}, 30 \%$ wt. in $\mathrm{H}_{2} \mathrm{O}$ ). The mixture was allowed to warm to $22^{\circ} \mathrm{C}$ and stir for $1 \mathrm{~h}$, after which an aqueous solution of saturated $\mathrm{Na}_{2} \mathrm{~S}_{2} \mathrm{O}_{3}(2.0 \mathrm{~mL})$ was added. The mixture was allowed to stir at $22{ }^{\circ} \mathrm{C}$ for $30 \mathrm{~min}$. The layers were separated, and the aqueous layer was washed with $\mathrm{Et}_{2} \mathrm{O}(3 \times 10 \mathrm{~mL})$. The combined organic layers were dried over $\mathrm{Na}_{2} \mathrm{SO}_{4}$ and concentrated in vacuo. The resulting yellow oil was purified by a short column. To a solution of the the allyl alcohol in $\mathrm{CH}_{2} \mathrm{Cl}_{2}(5.0 \mathrm{~mL})$ were sequentially added at $0{ }^{\circ} \mathrm{C} \mathrm{Et} 3 \mathrm{~N}$ (235 $\mu \mathrm{L}, 1.69 \mathrm{mmol}), \mathrm{ClPO}(\mathrm{OEt})_{2}(147 \mu \mathrm{L}, 1.02 \mathrm{mmol})$ and 4-dimethylaminopyridine $(5.17 \mathrm{mg}, 0.0423$ $\mathrm{mmol})$. The mixture was allowed to stir for $1 \mathrm{~h}$ at $0{ }^{\circ} \mathrm{C}$ after which the reaction was quenched by the addition of an aqueous solution of saturated $\mathrm{NaHCO}_{3}(50 \mu \mathrm{L})$. The mixture was passed through a short plug of silica gel and eluted with EtOAc. The volatiles were removed under reduced pressure and the yellow oil was purified by silica gel chromatography $(10: 1 \rightarrow 1: 1$ hexanes:EtOAc) to afford $(R, R)-18$ as colorless oil (235 mg, $0.652 \mathrm{mmol}, 77 \%$ overall yield). IR (neat): 2955 (w), $2923(\mathrm{~m}), 2853$ (w), 1457 (w), $1377(\mathrm{w}), 1263(\mathrm{~m}), 1165(\mathrm{w}), 1031$ (s), 1005 (s), $971(\mathrm{~s}), 910(\mathrm{w}), 817(\mathrm{w}), 807(\mathrm{w}), 526(\mathrm{w}) \mathrm{cm}^{-1}$; ${ }^{1}$ H NMR (400 MHz, CDCl $)$ ): $\delta 5.75(\mathrm{dt}, J=14.4,7.0 \mathrm{~Hz}, 1 \mathrm{H}), 5.63-5.49(\mathrm{~m}, 2 \mathrm{H}), 5.01$ (dd, $J=10.3$, $2.1 \mathrm{~Hz}, 1 \mathrm{H}), 4.93(\mathrm{dd}, J=17.1,2.0 \mathrm{~Hz}, 1 \mathrm{H}), 4.50-4.46(\mathrm{~m}, 2 \mathrm{H}), 4.10(\mathrm{q}, J=7.4 \mathrm{~Hz}, 4 \mathrm{H}), 2.24-2.16(\mathrm{~m}$, 1H), 1.87-1.72 (m, 2H), 1.53-1.46 (m, 1H), 1.35-1.17 (m, 16H), 0.91-0.82 (m, 6H); ${ }^{13} \mathrm{C}$ NMR (126 MHz, $\left.\mathbf{C D C l}_{3}\right): \delta 141.5,135.7,125.7(\mathrm{~d}, J=6.6 \mathrm{~Hz}), 115.5,68.3(\mathrm{~d}, J=5.6 \mathrm{~Hz}), 63.8(\mathrm{~d}, J=5.8 \mathrm{~Hz})$, 49.4, 37.0, 36.5, 32.0, 31.2, 29.6, 27.6, 22.8, 17.0, 16.30 (d, $J=6.7 \mathrm{~Hz}$ ), 14.2; HRMS (DART): Calcd for $\mathrm{C}_{19} \mathrm{H}_{38} \mathrm{O}_{4} \mathrm{P}[\mathrm{M}+\mathrm{H}]+:$ 361.2502. Found: 361.2498; Specific rotation: $[\alpha]_{\mathrm{D}}{ }^{20}+4.2\left(c 0.48, \mathrm{CHCl}_{3}\right)$.

(4S,6R,7R)-6-Methyl-4,7-divinyltridecanal $(R, R, S)-6:$ In a glove box, an oven-dried vial equipped with a magnetic stir bar was charged with $\mathrm{CuCl}(2.5 \mathrm{mg}, 0.025 \mathrm{mmol}),(S)$-imid(S)-1b (23.6 mg, 0.0275 $\mathrm{mmol}), \mathrm{LiO} t-\mathrm{Bu}(48.0 \mathrm{mg}, 0.12 \mathrm{mmol})$, and freshly distilled THF (2.5 mL). The solution was premixed for $30 \mathrm{~min}$ before PMHS (150 mg, $2.50 \mathrm{mmol}$ ), allenyl boronic acid pinacol ester $\mathbf{1 b}$ (135 $\mathrm{mg}, 0.75$ 
mmol) and additional THF (2.5 mL) were added. The solution immediately turned dark-red. After 10 min, at $22{ }^{\circ} \mathrm{C}$ allylic phosphate $(R, R)-18(180 \mathrm{mg}, 0.50 \mathrm{mmol})$ was added. The vial was sealed with electrical tape before removal from the glove box, and the resulting mixture was allowed to stir for $2 \mathrm{~h}$ at $22{ }^{\circ} \mathrm{C}$, after which the reaction was quenched by the addition of an aqueous solution of $1 \mathrm{M} \mathrm{NaOH}$ ( $1.0 \mathrm{~mL})$ and $\mathrm{H}_{2} \mathrm{O}_{2}\left(200 \mu \mathrm{L}, 30 \%\right.$ wt. in $\left.\mathrm{H}_{2} \mathrm{O}\right)$ at $0{ }^{\circ} \mathrm{C}$. The mixture was allowed to warm to $22{ }^{\circ} \mathrm{C}$ and stir for $1 \mathrm{~h}$, after which an aqueous solution of saturated $\mathrm{Na}_{2} \mathrm{~S}_{2} \mathrm{O}_{3}(1.0 \mathrm{~mL})$ was added. The mixture was allowed to stir at $22{ }^{\circ} \mathrm{C}$ for $30 \mathrm{~min}$ and then the layers were separated, and the aqueous layer was washed with $\mathrm{Et}_{2} \mathrm{O}(3 \times 10 \mathrm{~mL})$. The combined organic layers were dried over $\mathrm{Na}_{2} \mathrm{SO}_{4}$ and concentrated in vacuo. The resulting yellow oil was purified by silica gel chromatography $(20: 1 \rightarrow 1: 1$ hexanes:Et $2 \mathrm{O})$ to afford $(R, R, S)-6$ as colorless oil (86.1 mg, $0.326 \mathrm{mmol}, 65 \%$ yield). IR (neat): $2954(\mathrm{~m}), 2922(\mathrm{~s}), 2853(\mathrm{~m})$, 1726 (s), 1638 (w), 1457 (w), 1418 (w), 1377 (w), 1047 (w), 910 (s) cm ${ }^{-1}$; ${ }^{1}$ H NMR (500 MHz, CDCl $)$ : $\delta 9.76(\mathrm{~s}, 1 \mathrm{H}), 5.53(\mathrm{dt}, J=17.2,9.8 \mathrm{~Hz}, 1 \mathrm{H}), 5.37(\mathrm{dt}, J=17.2,9.7 \mathrm{~Hz}, 1 \mathrm{H}), 5.06-4.88(\mathrm{~m}, 4 \mathrm{H}), 2.49-$ $2.35(\mathrm{~m}, 2 \mathrm{H}), 2.02(\mathrm{dtd}, J=13.5,9.2,3.6 \mathrm{~Hz}, 1 \mathrm{H}), 1.78(\mathrm{tt}, J=8.7,3.8 \mathrm{~Hz}, 1 \mathrm{H}), 1.69(\mathrm{td}, J=13.4,7.9$ $\mathrm{Hz}, 1 \mathrm{H}), 1.54-1.42(\mathrm{~m}, 2 \mathrm{H}), 1.39-1.16(\mathrm{~m}, 11 \mathrm{H}), 1.07-1.00(\mathrm{~m}, 1 \mathrm{H}), 0.88(\mathrm{t}, J=6.8 \mathrm{~Hz}, 3 \mathrm{H}), 0.81(\mathrm{~d}, J$ = 6.7 Hz, 3H); $\left.{ }^{13} \mathbf{C ~ N M R ~ ( 1 2 6 ~ M H z , ~} \mathbf{C D C l}_{3}\right)$ : $\delta$ 202.8, 142.0 141.5, 116.1, 115.3, 50.3, 42.1, 41.8, 38.7, $34.0,32.0,31.5,29.6,28.3,27.7,22.8,17.1,14.2$; HRMS (DART): Calcd for $\mathrm{C}_{18} \mathrm{H}_{33} \mathrm{O}[\mathrm{M}+\mathrm{H}]^{+}$: 265.2526. Found: 265.2520; Specific rotation: $[\alpha]_{\mathrm{D}}{ }^{20}+13.7\left(c 1.0, \mathrm{CHCl}_{3}\right)$.

3-((1S,4S,5R)-4-Hexyl-5-methylcyclohex-2-en-1-yl)propanal $(\boldsymbol{R}, \boldsymbol{R}, S)-7:$ In a glove box, an ovendried 2-dram vial equipped with a stir bar was charged with $(R, R, S)-6(81.3 \mathrm{mg}, 0.307 \mathrm{mmol})$. To this was added Ru-1 $(9.6 \mathrm{mg}, 0.0154 \mathrm{mmol})$ in $\mathrm{CH}_{2} \mathrm{Cl}_{2}(1.0 \mathrm{~mL})$. The vial was sealed with a cap and electrical tape, and removed from the glove box. The mixture was allowed to stir for $1 \mathrm{~h}$ at $40{ }^{\circ} \mathrm{C}$ and then cool to $22{ }^{\circ} \mathrm{C}$. The volatiles were removed under reduced pressure and the resulting red oil was purified by silica gel chromatography $\left(20: 1 \rightarrow 1: 1\right.$ hexanes: $\left.\mathrm{Et}_{2} \mathrm{O}\right)$ to afford $(R, R, S)-7$ as colorless oil $(67.7 \mathrm{mg}, 0.286 \mathrm{mmol}$, 93\% yield). IR (neat): 2952 (m), 2922 (s), $2853(\mathrm{~m}), 1725(\mathrm{~m}), 1456(\mathrm{w}), 1376(\mathrm{w}), 724(\mathrm{w}) \mathrm{cm}^{-1} ;{ }^{1} \mathbf{H}$ NMR (600 MHz, CDCl$): \delta 9.78(s, 1 H), 5.60(\mathrm{~d}, J=10.0 \mathrm{~Hz}, 1 \mathrm{H}), 5.48(\mathrm{~d}, J=10.4 \mathrm{~Hz}, 1 \mathrm{H}), 2.47(\mathrm{t}$, $J=7.6 \mathrm{~Hz}, 2 \mathrm{H}), 2.15$ (br s, 1H), 1.72-1.49 (m, 5H), 1.38-1.18 (m, 11H), $0.96(\mathrm{~d}, J=6.6 \mathrm{~Hz}, 3 \mathrm{H}), 0.88$ $(\mathrm{t}, J=6.7 \mathrm{~Hz}, 3 \mathrm{H}) ;{ }^{13} \mathbf{C}$ NMR (151 MHz, $\left.\mathbf{C D C l}_{3}\right): \delta 202.9,132.3,130.4,43.2,41.3,38.8,35.7,33.6$, 33.0, 32.0, 29.9, 28.5, 26.1, 22.8, 20.5, 14.3; HRMS (DART): Calcd for $\mathrm{C}_{16} \mathrm{H}_{29} \mathrm{O}[\mathrm{M}+\mathrm{H}]^{+}: 237.2213$. Found: 237.2207; Specific Specific rotation: $[\alpha]_{\mathrm{D}}{ }^{20}-47.6\left(c 0.58, \mathrm{CHCl}_{3}\right)$.

Netamine C (revised structure): In a glove box, an oven-dried 2-dram vial equipped with a stir bar was charged with $(R, R, S)-7(37.8 \mathrm{mg}, 0.160 \mathrm{mmol})$, benzyl hydrazine $(29.3 \mathrm{mg}, 0.240 \mathrm{mmol})$, and ethanol $(2.0 \mathrm{~mL})$ and stirred at $22{ }^{\circ} \mathrm{C}$ for $10 \mathrm{~min}$. To this solution was added hydrochloric acid $(67 \mu \mathrm{L}, 36.5 \%$ wt, $0.800 \mathrm{mmol}$ ). The vial was sealed with a cap and electrical tape, and removed from the glove box. The resulting mixture was allowed to stir for $4 \mathrm{~h}$ at $100{ }^{\circ} \mathrm{C}$ and then cool to $22^{\circ} \mathrm{C}$. To this solution was added $\mathrm{PtO}_{2}\left(7.4 \mathrm{mg}, 0.032 \mathrm{mmol}\right.$ ), after which the vial was purged with $\mathrm{H}_{2}$ and then a $\mathrm{H}_{2}$-filled ballon was attached. ${ }^{23}$ The mixture was allowed to stir for $16 \mathrm{~h}$ at $60{ }^{\circ} \mathrm{C}$. The mixture was then allowed to cool to $22{ }^{\circ} \mathrm{C}$ and $\mathrm{MeONa}(86.4 \mathrm{mg}, 1.6 \mathrm{mmol})$ and $\mathrm{BrCN}\left(33.9 \mathrm{mg}, 0.32 \mathrm{mmol}\right.$ ) were added sequentially..$^{24}$ The solution was allowed to stir for $1 \mathrm{~h}$ and then filtered through cotton and eluted with $\mathrm{MeOH}(10 \mathrm{~mL})$. The volatiles were removed under reduced pressure and the resulting yellow oil was purified by $\mathrm{C} 18$ silica gel chromatography $\left(3: 1: 0.01 \rightarrow 1: 5: 0.01 \mathrm{H}_{2} \mathrm{O}: \mathrm{MeOH}\right.$ :trifluoroacetic acid) to afford netamine $\mathrm{C}$ 
(trifluoroacetate salt) as colorless oil (54.8 mg, $0.140 \mathrm{mmol}, 88 \%$ yield). Please Note: Despite extensive efforts to achieve a completely pure sample, because guanidine-containing compounds are highly polar, $1-5 \%$ impurity is invariably present.

Netamine C (revised structure): IR (neat): 3268 (br), 2952 (m), 2926 (s), 2855(m), 1674 (s), 1636 (s), 1457 (w), 1425 (w), 1200 (s), 1179 (s), 1135 (m), 635 (w), 801 (w), 760 (w) cm ${ }^{-1}$; ${ }^{1}$ H NMR (500 MHz, $\left.\mathbf{C D C l}_{3}\right): \delta 7.49$ (br s, 1H), 7.28 (br s, $\left.1 \mathrm{H}\right), 6.86$ (br s, $\left.1 \mathrm{H}\right), 3.86(\mathrm{dd}, J=6.5,4.0 \mathrm{~Hz}, 1 \mathrm{H}), 3.51$ (dd, $J=$ $5.1,1.5 \mathrm{~Hz}, 1 \mathrm{H}), 2.32(\mathrm{dt}, J=11.5,5.7 \mathrm{~Hz}, 1 \mathrm{H}), 2.13-2.02(\mathrm{~m}, 1 \mathrm{H}), 1.94(\mathrm{dt}, J=13.9,7.3 \mathrm{~Hz}, 1 \mathrm{H}), 1.83$ $(\mathrm{dd}, J=13.3,6.0 \mathrm{~Hz}, 1 \mathrm{H}), 1.69-1.58(\mathrm{~m}, 2 \mathrm{H}), 1.38-1.17(\mathrm{~m}, 13 \mathrm{H}), 1.08-1.03(\mathrm{~m}, 1 \mathrm{H}), 1.01(\mathrm{~d}, J=6.8$ $\mathrm{Hz}, 3 \mathrm{H}), 0.88(\mathrm{t}, J=6.9 \mathrm{~Hz}, 3 \mathrm{H}) ;{ }^{13} \mathbf{C} \mathbf{N M R}\left(\mathbf{1 0 1} \mathbf{M H z}, \mathbf{C D C l}_{3}\right): \delta 154.8,53.8,49.9,45.1,35.8,35.1$, 34.8, 34.7, 34.5, 33.4, 31.7, 30.4, 29.4, 27.5, 23.1, 22.6, 14.0; HRMS (DART): Calcd for $\mathrm{C}_{17} \mathrm{H}_{32} \mathrm{~N}_{3}$ $[\mathrm{M}+\mathrm{H}]^{+}:$278.2591. Found: 278.2600; Specific rotation: $[\alpha]_{\mathrm{D}}{ }^{20}+6.9(c 0.50, \mathrm{MeOH})$.

\subsection{Polycyclic compound 21}

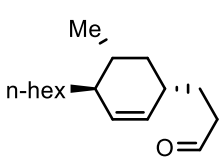

$(R, R, S)-7$
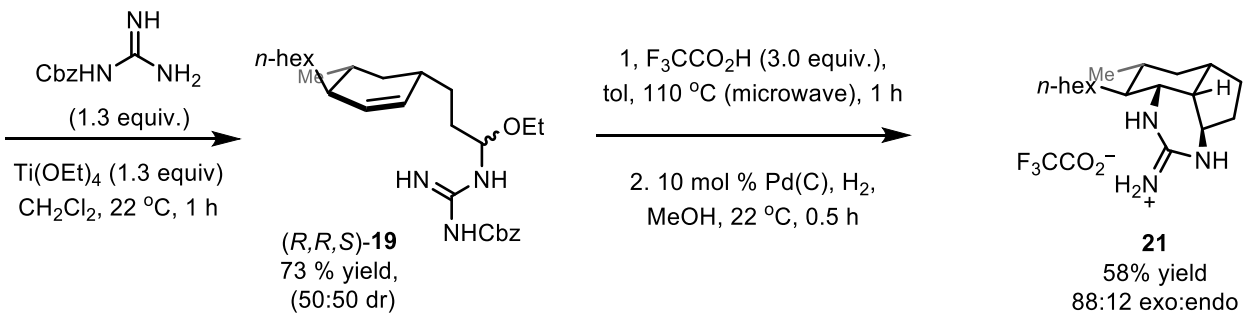

$\boldsymbol{N}$-Guanidinyl acetal $(\boldsymbol{R}, \boldsymbol{R}, \boldsymbol{S})$-19: To an oven-dried 2-dram vial equipped with a stir bar were sequentially added $(R, R, S)-7(18.4 \mathrm{mg}, 0.0778 \mathrm{mmol}), N-\mathrm{Cbz}$ guanidine $(19.5 \mathrm{mg}, 0.101 \mathrm{mmol})$ and $\mathrm{CH}_{2} \mathrm{Cl}_{2}(1.0 \mathrm{~mL})$. To this solution at $0{ }^{\circ} \mathrm{C}$ and in a dropwise manner was added $\mathrm{Ti}(\mathrm{OEt})_{4}(23 \mu \mathrm{L}, 0.101$ $\mathrm{mmol})$. The mixture was allowed to warm to $22^{\circ} \mathrm{C}$ and stir for $1 \mathrm{~h}$, after which it was loaded onto a short column of silica gel; subsequent silica gel chromatography $(5: 1 \rightarrow 1: 2$ hexanes:EtOAc) afforded $(R, R, S)$ 19 as pale white foam $(26.3 \mathrm{mg}, 0.0574 \mathrm{mmol}, 73 \%$ yield). IR (neat): 2952 (m), 2923 (s), $2853(\mathrm{~m})$, 1649 (s), 1621 (s), 1584 (s), 1454 (m), 1377 (m), 1283 (s), 1103 (s), 802 (w), 730 (w), 697 (w) cm ${ }^{-1} ;{ }^{1} \mathbf{H}$ NMR (600 MHz, CDCl 3$): \delta 7.70$ (br s, 1H), 7.41-7.24 (m, 5H), $6.73(\mathrm{~s}, 2 \mathrm{H}), 5.58(\mathrm{~d}, J=10.3 \mathrm{~Hz}, 1 \mathrm{H})$, $5.47(\mathrm{~d}, J=9.7 \mathrm{~Hz}, 1 \mathrm{H}), 5.10(\mathrm{~s}, 2 \mathrm{H}), 4.66(\mathrm{~s}, 1 \mathrm{H}), 3.58(\mathrm{dt}, J=14.2,7.1 \mathrm{~Hz}, 1 \mathrm{H}), 3.46-3.38(\mathrm{~m}, 1 \mathrm{H})$, $2.10(\mathrm{~s}, 1 \mathrm{H}), 1.89-1.79(\mathrm{~m}, 1 \mathrm{H}), 1.78-1.70(\mathrm{~m}, 1 \mathrm{H}), 1.70-1.62(\mathrm{~m}, 2 \mathrm{H}), 1.56-1.50(\mathrm{~m}, 1 \mathrm{H}), 1.45-1.20$ $(\mathrm{m}, 13 \mathrm{H}), 1.17(\mathrm{t}, J=7.0 \mathrm{~Hz}, 3 \mathrm{H}), 0.97(\mathrm{~d}, J=6.6 \mathrm{~Hz}, 3 \mathrm{H}), 0.90(\mathrm{t}, J=6.6 \mathrm{~Hz}, 3 \mathrm{H}) ;{ }^{13} \mathbf{C ~ N M R}(\mathbf{1 5 1}$ MHz, $\left.\mathbf{C D C l}_{3}\right): \delta 164.2,162.4,137.7,132.1,130.8,130.8,128.5,128.1,127.8,84.0,66.6,61.0,43.4$, 39.2, 36.1 , 36.0, 33.9, 33.3, 32.1 , 31.8, 31.8, 29.9, 26.3, 22.8, 20.5, 15.2, 14.1; HRMS (ESI): Calcd for $\mathrm{C}_{27} \mathrm{H}_{44} \mathrm{~N}_{3} \mathrm{O}_{3}[\mathrm{M}+\mathrm{H}]^{+}:$458.3377. Found: 458.3378; Specific rotation: $[\alpha]_{\mathrm{D}}{ }^{20}-35.2\left(c 0.50, \mathrm{CHCl}_{3}\right)$.

Polycyclic compound 21: In a glove box, an oven-dried microwave pressure vessel was charged with $(R, R, S)-19(13.3 \mathrm{mg}, 0.029 \mathrm{mmol})$, toluene $(1.0 \mathrm{~mL})$ and trifluoroacetic acid $(9.9 \mathrm{mg}, 0.087 \mathrm{mmol})$. The vessel was sealed with a cap and removed from the glove box, and the solution was allowed for $10 \mathrm{~min}$ to stir at $22{ }^{\circ} \mathrm{C}$. The mixture was placed in a microwave synthesizer $(200 \mathrm{~W})$ for $1 \mathrm{~h}$ at $100{ }^{\circ} \mathrm{C}$, after which the volatiles were removed in vacuo. The resulting pale-yellow oil was dissolved in $\mathrm{MeOH}(1.0$ $\mathrm{mL})$ and $\mathrm{Pd} / \mathrm{C}(1.3 \mathrm{mg}, 10 \% \mathrm{wt})$ was added to the resulting solution was added. The solution was purged 
with $\mathrm{H}_{2}$ and the vial was affixed with a $\mathrm{H}_{2}$-filled ballon. The mixture was allowed to stir for $30 \mathrm{~min}$ at $22{ }^{\circ} \mathrm{C}$. The volatiles were removed in vacuo and the resulting yellow oil was purified by $\mathrm{C} 18$ silica gel chromatography $\left(3: 1: 0.01 \rightarrow 1: 5: 0.01 \mathrm{H}_{2} \mathrm{O}: \mathrm{MeOH}:\right.$ trifluoroacetic acid) to afford 21 (trifluoroacetate salt) as colorless oil (6.6 mg, $0.0169 \mathrm{mmol}, 58 \%$ yield, 88:12 exo/endo). IR (neat): 2952 (m), 2925 (s), 2870 (m), 1683 (s), 1610 (m), 1459 (w), 1377 (w), 1201 (s), 1280 (m), $1135(\mathrm{w}), 836(\mathrm{w}), 801$ (w), $721(\mathrm{w})$ $\mathrm{cm}^{-1} ;{ }^{1} \mathbf{H}$ NMR (600 MHz, $\left.\mathbf{C D C l}_{3}\right): \delta 8.17(\mathrm{~s}, 1 \mathrm{H}), 8.09(\mathrm{~s}, 1 \mathrm{H}), 7.03(\mathrm{~s}, 1 \mathrm{H}), 3.52-3.44(\mathrm{~m}, 2 \mathrm{H}), 2.23$ $(\mathrm{dt}, J=14.4,7.0 \mathrm{~Hz}, 1 \mathrm{H}), 2.19-2.12(\mathrm{~m}, 2 \mathrm{H}), 1.88(\mathrm{dt}, J=12.1,6.5 \mathrm{~Hz}, 1 \mathrm{H}), 1.66-1.60(\mathrm{~m}, 1 \mathrm{H}), 1.54-$ $1.49(\mathrm{~m}, 1 \mathrm{H}), 1.48-1.41(\mathrm{~m}, 2 \mathrm{H}), 1.34-1.22(\mathrm{~m}, 10 \mathrm{H}), 1.20-1.12(\mathrm{~m}, 2 \mathrm{H}), 0.91-0.86(\mathrm{~m}, 6 \mathrm{H}) ;{ }^{13} \mathbf{C} \mathbf{N M R}$ (151 MHz, $\left.\mathbf{C D C l}_{3}\right): \delta 155.8,52.7,48.7,46.4,43.9,40.4,33.7,32.6,32.0,30.0,29.7,29.1,26.8,23.8$, 22.8, 19.2, 14.2; HRMS (DART): Calcd for $\mathrm{C}_{17} \mathrm{H}_{32} \mathrm{~N}_{3}[\mathrm{M}+\mathrm{H}]^{+}:$278.2591. Found: 278.2585; Specific rotation: $[\alpha]_{\mathrm{D}}^{20}+23.9\left(c 0.16, \mathrm{CHCl}_{3}\right)$.

\subsection{Netamine $\mathrm{C}$ (the initially proposed structure)}
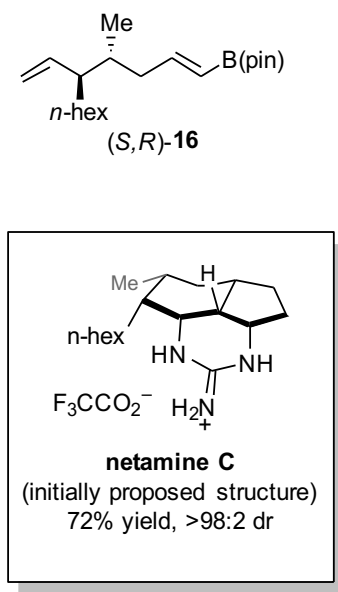

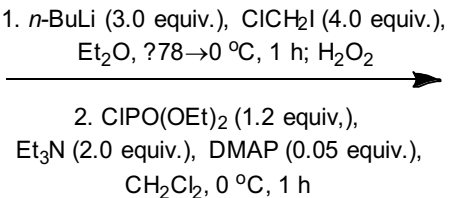
$\mathrm{CH}_{2} \mathrm{Cl}_{2}, 0^{\circ} \mathrm{C}, 1 \mathrm{~h}$

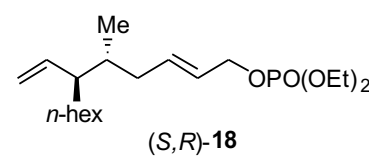

$74 \%$ overall yield, $>98: 2 E: Z$

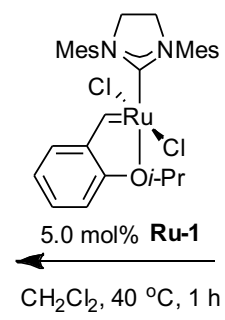

$(S, R, S)-7$
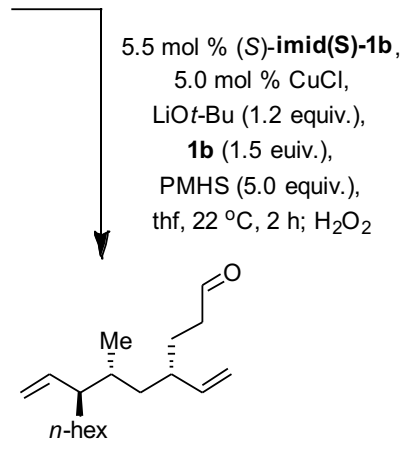

$(S, R, S)-6$ $71 \%, 95.5 d r$

$((5 R, 6 S, E)-5-M e t h y l-6-v i n y l d o d e c-2-e n-1-y l)((S, R)-18):$ The same procedure as described above for synthesis of $(R, R)-\mathbf{1 8}$ was followed to obtain $(S, R)-\mathbf{1 8}$ as colorless oil (286 $\mathrm{mg}, 0.794 \mathrm{mmol}, 74 \%$ overall yield). IR (neat): 2956 (m), 2924 (s), 2853 (m), 1276 (m), 1034 (s), 1007 (s), 973 (s) cm ${ }^{-1} ;{ }^{1}$ H NMR (500 MHz, $\left.\mathbf{C D C l}_{3}\right): \delta 5.75(\mathrm{dt}, J=14.8,7.2 \mathrm{~Hz}, 1 \mathrm{H}), 5.63-5.49(\mathrm{~m}, 2 \mathrm{H}), 5.01(\mathrm{~d}, J=10.8 \mathrm{~Hz}, 1 \mathrm{H}), 4.93$ $(\mathrm{d}, J=17.1 \mathrm{~Hz}, 1 \mathrm{H}), 4.48(\mathrm{t}, J=7.4 \mathrm{~Hz}, 2 \mathrm{H}), 4.10(\mathrm{p}, J=7.2 \mathrm{~Hz}, 4 \mathrm{H}), 2.09(\mathrm{dt}, J=13.6,6.5 \mathrm{~Hz}, 1 \mathrm{H})$, $1.96-1.83(\mathrm{~m}, 2 \mathrm{H}), 1.54$ (hept, $J=7.6,7.1 \mathrm{~Hz}, 1 \mathrm{H}), 1.36-1.20(\mathrm{~m}, 16 \mathrm{H}), 0.87$ (t, $J=6.8 \mathrm{~Hz}, 3 \mathrm{H}), 0.80$ $(\mathrm{d}, J=6.9 \mathrm{~Hz}, 3 \mathrm{H}) ;{ }^{13} \mathbf{C}$ NMR (126 $\left.\mathbf{~ M H z}, \mathbf{C D C l}_{3}\right): \delta 140.0,135.6,125.8(\mathrm{~d}, J=6.6 \mathrm{~Hz}), 115.9,68.3(\mathrm{~d}$, $J=5.5 \mathrm{~Hz}), 63.8(\mathrm{~d}, J=5.9 \mathrm{~Hz}), 48.3,38.0,36.7,32.6,32.0,29.6,27.7,22.8,16.3(\mathrm{~d}, J=6.7 \mathrm{~Hz}), 15.3$, 14.2; HRMS (DART): Calcd for $\mathrm{C}_{19} \mathrm{H}_{38} \mathrm{O}_{4} \mathrm{P}[\mathrm{M}+\mathrm{H}]^{+}: 361.2502$. Found: 361.2508; Specific rotation: $[\alpha]_{\mathrm{D}}{ }^{20}-2.3\left(c 0.32, \mathrm{CHCl}_{3}\right)$.

$(4 S, 6 R, 7 S)-6-M e t h y l-4,7-d i v i n y l t r i d e c a n a l ~((S, R, S)-6):$ In a glove box, an oven-dried vial with magnetic stir bar was charged with $\mathrm{CuCl}(2.5 \mathrm{mg}, 0.025 \mathrm{mmol}),(S)$-imid(S)-1a (23.6 mg, $0.0275 \mathrm{mmol})$, $\mathrm{LiO} t$-Bu (48.0 mg, $0.12 \mathrm{mmol}$ ), freshly distilled THF (2.5 mL). The solution was pre-mixed for $30 \mathrm{~min}$ before PMHS (150 mg, $2.50 \mathrm{mmol}$ ), allenyl boronic acid pinacol ester $\mathbf{1 b}$ (135 $\mathrm{mg}, 0.75 \mathrm{mmol}$ ) and more THF $(2.5 \mathrm{~mL})$ were added. The solution immediately turned dark-red. After $10 \mathrm{~min}$ at $22{ }^{\circ} \mathrm{C}$, allylic 
phosphate $(S, R)-18$ (180 mg, $0.50 \mathrm{mmol})$ was added. The vial was sealed with electrical tape before removal from the glove box, and stirring was allowed to continue for $2 \mathrm{~h}$ at $22^{\circ} \mathrm{C}$ after which the reaction was quenched by the addition at $0{ }^{\circ} \mathrm{C}$ of an aqueous solution of $1 \mathrm{M} \mathrm{NaOH}(1.0 \mathrm{~mL})$ and $\mathrm{H}_{2} \mathrm{O}_{2}(200 \mu \mathrm{L}$, $30 \%$ wt. in $\mathrm{H}_{2} \mathrm{O}$ ). The mixture was allowed to warm to $22^{\circ} \mathrm{C}$ and stir for $1 \mathrm{~h}$, after which it was charged with an aqueous solution of saturated $\mathrm{Na}_{2} \mathrm{~S}_{2} \mathrm{O}_{3}(1.0 \mathrm{~mL})$. The resulting mixture was allowed to stir for $30 \mathrm{~min}$ at $22{ }^{\circ} \mathrm{C}$. The layers were separated, and the aqueous layer was washed with $\mathrm{Et}_{2} \mathrm{O}(3 \times 10 \mathrm{~mL})$. The combined organic layers were dried over $\mathrm{Na}_{2} \mathrm{SO}_{4}$ and concentrated in vacuo. The resulting yellow oil was purified by silica gel chromatography $\left(20: 1 \rightarrow 1: 1\right.$ hexanes: $\left.\mathrm{Et}_{2} \mathrm{O}\right)$ to afford $(S, R, S)-\mathbf{6}$ as colorless oil (93.3 mg, $0.353 \mathrm{mmol}, 71 \%$ yield). IR (neat): 2968 (m), 2924 (s), 2953 (m), 1719 (m), 1458 (w), 1410 (w), 1365 (w), 1044 (w), 910 (s) cm ${ }^{-1}$; ${ }^{1} \mathbf{H}$ NMR (400 MHz, CDCl $\left.\mathbf{3}\right): \delta 9.76$ (t, $\left.J=1.6 \mathrm{~Hz}, 1 \mathrm{H}\right)$, $5.55(\mathrm{ddd}, J=17.1,10.3,9.2 \mathrm{~Hz}, 1 \mathrm{H}), 5.40(\mathrm{ddd}, J=17.0,10.2,9.2 \mathrm{~Hz}, 1 \mathrm{H}), 5.05-4.87$ (m, 4H), 2.42 $(\operatorname{tdd}, J=8.6,6.4,1.7 \mathrm{~Hz}, 2 \mathrm{H}), 2.04(\mathrm{ddq}, J=14.1,9.5,4.4 \mathrm{~Hz}, 1 \mathrm{H}), 1.82(\mathrm{tt}, J=9.0,4.6 \mathrm{~Hz}, 1 \mathrm{H}), 1.75-$ $1.62(\mathrm{~m}, 1 \mathrm{H}), 1.54-1.43(\mathrm{~m}, 2 \mathrm{H}), 1.35-1.07(\mathrm{~m}, 12 \mathrm{H}), 0.87(\mathrm{t}, J=6.8 \mathrm{~Hz}, 3 \mathrm{H}), 0.77(\mathrm{~d}, J=6.8 \mathrm{~Hz}, 3 \mathrm{H})$; ${ }^{13}$ C NMR (126 MHz, $\left.\mathbf{C D C l}_{3}\right)$ : $\delta$ 202.8, 142.1, 140.6, 115.8, 115.4, 49.7, 42.1, 41.6, 40.8, 33.9, 32.4, 32.0, 29.6, 27.9, 27.7 , 22.8, 14.9, 14.2; HRMS (DART): Calcd for $\mathrm{C}_{18} \mathrm{H}_{33} \mathrm{O}[\mathrm{M}+\mathrm{H}]^{+}: 265.2526$. Found: 265.2525; Specific rotation: $[\alpha]_{\mathrm{D}}{ }^{20}+5.7\left(c 0.60, \mathrm{CHCl}_{3}\right)$.

3-((1S,4R,5R)-4-Hexyl-5-methylcyclohex-2-en-1-yl)propanal $((S, R, S)-7)$ : In a glove box, an ovendried 2-dram vial equipped with a stir bar was charged with $(S, R, S)-6(89.2 \mathrm{mg}, 0.337 \mathrm{mmol})$. To this compound was added $\mathbf{R u}-1$ (10.6 $\mathrm{mg}, 0.0169 \mathrm{mmol})$ in $\mathrm{CH}_{2} \mathrm{Cl}_{2}(1.0 \mathrm{~mL})$. The vial was sealed with a cap and electrical tape, and removed from the glove box. The mixture was allowed to stir for $1 \mathrm{~h}$ at $40^{\circ} \mathrm{C}$ and then cooled to $22{ }^{\circ} \mathrm{C}$. The volatiles were removed under reduced pressure and the residue was purified by silica gel chromatography $\left(20: 1 \rightarrow 1: 1\right.$ hexanes: $\left.\mathrm{Et}_{2} \mathrm{O}\right)$ to afford $(S, R, S)-7$ as colorless oil $(71.9$ mg, 0.304 mmol, 90\% yield). IR (neat): 2952 (m), 2922 (s), 2854 (m), 1726 (s), 1452 (w), 1376 (w), 1119 (w), 1049 (w), 771 (w), 736 (w) cm ${ }^{-1} ;{ }^{1} \mathbf{H}$ NMR (500 MHz, CDCl $)$ ): $\delta 9.78$ (s, 1H), 5.83 (ddd, $J$ $=10.1,5.1,2.5 \mathrm{~Hz}, 1 \mathrm{H}), 5.47(\mathrm{~d}, J=9.1 \mathrm{~Hz}, 1 \mathrm{H}), 2.46(\mathrm{t}, J=7.6 \mathrm{~Hz}, 2 \mathrm{H}), 2.20-2.11(\mathrm{~m}, 1 \mathrm{H}), 1.98-1.89$ $(\mathrm{m}, 1 \mathrm{H}), 1.83(\mathrm{dqd}, J=14.4,7.0,2.5 \mathrm{~Hz}, 1 \mathrm{H}), 1.68(\mathrm{tt}, J=13.0,6.0 \mathrm{~Hz}, 2 \mathrm{H}), 1.57$ (dq, $J=15.9,7.6 \mathrm{~Hz}$, $1 \mathrm{H}), 1.49-1.16(\mathrm{~m}, 10 \mathrm{H}), 1.07-0.99(\mathrm{~m}, 1 \mathrm{H}), 0.91(\mathrm{~d}, J=7.0 \mathrm{~Hz}, 3 \mathrm{H}), 0.88(\mathrm{t}, J=6.8 \mathrm{~Hz}, 3 \mathrm{H}) ;{ }^{13} \mathbf{C}$

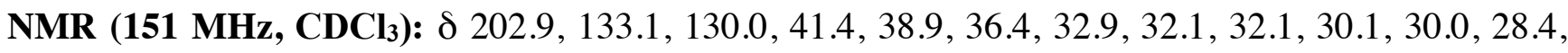
27.7, 22.8, 19.3, 14.3; HRMS (DART): Calcd for $\mathrm{C}_{16} \mathrm{H}_{29} \mathrm{O}[\mathrm{M}+\mathrm{H}]^{+}$: 237.2213. Found: 237.2213; Specific rotation: $[\alpha]_{\mathrm{D}}{ }^{20}+96.7\left(c 1.3, \mathrm{CHCl}_{3}\right)$.

Netamine C (initially proposed structure): In a glove box, an oven-dried 2-dram vial equipped with a stir bar was charged with $(S, R, S)-7(10.9 \mathrm{mg}, 0.0461 \mathrm{mmol})$, hydrazine monohydrate $(11.5 \mathrm{mg}, 0.230$ $\mathrm{mmol})$, and $\mathrm{EtOH}(1.0 \mathrm{~mL})$ and stirred at $22{ }^{\circ} \mathrm{C}$ for $10 \mathrm{~min}$. To the solution was added $\mathrm{HCl}(39 \mu \mathrm{L}, 36.5 \%$ wt, $0.46 \mathrm{mmol}$ ). The vial was sealed with a cap and electrical tape, and removed from the glove box. The solution was allowed to stir for $4 \mathrm{~h}$ at $100{ }^{\circ} \mathrm{C}$ and then cool to $22{ }^{\circ} \mathrm{C}$. To this solution was added $\mathrm{PtO}_{2}(2.1 \mathrm{mg}, 9.2 \mu \mathrm{mol}){ }_{, 23}$ after which the solution was purged with $\mathrm{H}_{2}$ and the vial was affixed with a $\mathrm{H}_{2}$-filled ballon; the mixture was allowed to stir for $16 \mathrm{~h}$ at $60{ }^{\circ} \mathrm{C}$, and then was allowed to cool to $22^{\circ} \mathrm{C}$ and sequentially charged with $\mathrm{MeONa}(49.7 \mathrm{mg}, 0.92 \mathrm{mmol})$ and $\mathrm{BrCN}(24.4 \mathrm{mg}, 0.23 \mathrm{mmol}) .^{24}$ The mixture was allowed to stir for $1 \mathrm{~h}$ and then filtered through cotton and eluted with $\mathrm{MeOH}$. The volatiles were removed in vacuo and the resulting yellow oil was purified by C18 silica gel chromatography 
(3:1:0.01 $\rightarrow$ 1:5:0.01 $\mathrm{H}_{2} \mathrm{O}: \mathrm{MeOH}$ :trifluoroacetic acid) to afford netamine $\mathrm{C}$ (initially proposed structure, trifluoroacetate salt) as colorless oil (12.9 mg, $0.0331 \mathrm{mmol}, 72 \%$ yield). Please Note: Despite extensive efforts to achieve a completely pure sample, because guanidine-containing compounds are highly polar, $1-5 \%$ impurity is invariably present.

Netamine C (initially proposed structure): IR (neat): 3198 (br), 2953 (m), 2924 (s), 2854 (m), 1671 (s), $1456(\mathrm{w}), 1427(\mathrm{w}), 1377$ (w), $1339(\mathrm{w}), 1201$ (s), $1181(\mathrm{~m}), 1135(\mathrm{~m}), 834(\mathrm{w}), 800(\mathrm{w}), 721(\mathrm{w})$ $\mathrm{cm}^{-1}$; ${ }^{1} \mathbf{H}$ NMR (600 MHz, CDCl $): \delta 8.49(\mathrm{~s}, 1 \mathrm{H}), 7.59(\mathrm{~s}, 1 \mathrm{H}), 7.16(\mathrm{~s}, 1 \mathrm{H}), 3.77(\mathrm{t}, J=4.4 \mathrm{~Hz}, 1 \mathrm{H})$, $3.68(\mathrm{~d}, J=6.4 \mathrm{~Hz}, 1 \mathrm{H}), 2.29(\mathrm{dt}, J=11.3,5.7 \mathrm{~Hz}, 1 \mathrm{H}), 2.20-2.13(\mathrm{~m}, 1 \mathrm{H}), 2.03(\mathrm{dt}, J=13.1,8.0 \mathrm{~Hz}$, $1 \mathrm{H}), 1.93-1.84(\mathrm{~m}, 2 \mathrm{H}), 1.70-1.59(\mathrm{~m}, 2 \mathrm{H}), 1.46-1.38(\mathrm{~m}, 1 \mathrm{H}), 1.36-1.16(\mathrm{~m}, 12 \mathrm{H}), 0.93(\mathrm{~d}, J=6.7 \mathrm{~Hz}$, $3 \mathrm{H}), 0.89(\mathrm{t}, J=6.7 \mathrm{~Hz}, 3 \mathrm{H}) ;{ }^{13} \mathbf{C} \mathbf{N M R}\left(\mathbf{1 2 6} \mathbf{M H z}, \mathbf{C D C l}_{3}\right): \delta 154.7,119.1\left(\mathrm{CF}_{3} \mathrm{CO}_{2}\right), 53.0,50.0,40.3$, 39.4, 38.6, 33.7, 32.8, 31.9, 31.9, 30.0, 29.9, 29.8, 29.6, 29.5, 29.0, 28.2, 28.2, 22.8, 22.7, 18.3, 14.2; HRMS (DART): Calcd for $\mathrm{C}_{17} \mathrm{H}_{32} \mathrm{~N}_{3}[\mathrm{M}+\mathrm{H}]^{+}:$278.2591. Found: 278.2579 ; Specific rotation: $[\alpha]_{\mathrm{D}}{ }^{20}$ -19.9 ( $c 0.16, \mathrm{MeOH})$. 


\section{Comparison of Analytical Data for Natural and Synthetic Netamine C}

Table S3. ${ }^{1} \mathrm{H}$ NMR data $\left(\mathrm{CDCl}_{3}\right)$

\begin{tabular}{|c|c|c|c|c|}
\hline \multicolumn{2}{|c|}{$\begin{array}{c}\text { Natural } \\
\delta_{\mathrm{H}}\left[\mathrm{ppm}, \text { mult, } J(\mathrm{~Hz})^{*}\right] \\
500 \mathrm{MHz}\end{array}$} & \multicolumn{2}{|c|}{$\begin{array}{c}\text { Synthetic } \\
\text { (revised structure) } \\
\delta_{\mathrm{H}}[\mathrm{ppm}, \text { mult, } J(\mathrm{~Hz})] \\
500 \mathrm{MHz}\end{array}$} & \multirow{2}{*}{$\begin{array}{c}\text { Difference } \\
\text { (Natural-Synthetic) } \\
\Delta \delta_{\mathrm{H}}(\mathrm{ppm}) \\
0.18\end{array}$} \\
\hline 7.67 & $1 \mathrm{H}$, br s & 7.49 & $1 \mathrm{H}$, br s & \\
\hline 7.53 & $1 \mathrm{H}$, br s & 7.28 & $1 \mathrm{H}$, br s & 0.25 \\
\hline 6.93 & $2 \mathrm{H}$, br s & 6.86 & $2 \mathrm{H}$, br s & 0.07 \\
\hline 3.86 & $1 \mathrm{H}, \mathrm{m},(6.2,3.9)$ & 3.86 & $1 \mathrm{H}, \mathrm{dd}, 6.5,4.0$ & 0 \\
\hline 3.51 & $1 \mathrm{H}$, br d, $(5.0,1.5)$ & 3.51 & $1 \mathrm{H}, \mathrm{dd}, 5.1,1.5$ & 0 \\
\hline 2.32 & $1 \mathrm{H}, \mathrm{m},(11.1,5.9)$ & 2.32 & $1 \mathrm{H}, \mathrm{dt}, 11.5,5.7$ & 0 \\
\hline 2.08 & $1 \mathrm{H}, \mathrm{m}$ & $2.13-2.02$ & $1 \mathrm{H}, \mathrm{m}$ & - \\
\hline 1.94 & $1 \mathrm{H}, \mathrm{m}$ & 1.94 & $1 \mathrm{H}, \mathrm{dt}, 13.9,7.3$ & 0 \\
\hline 1.84 & $1 \mathrm{H}, \mathrm{dd},(13.0,5.0)$ & 1.83 & $1 \mathrm{H}, \mathrm{dd}, 13.3,6.0$ & 0.01 \\
\hline 1.63 & $2 \mathrm{H}, \mathrm{m}$ & $1.69-1.58$ & $2 \mathrm{H}, \mathrm{m}$ & - \\
\hline 1.36 & $1 \mathrm{H}, \mathrm{m}$ & & & \\
\hline 1.31 & $2 \mathrm{H}, \mathrm{m}$ & & & \\
\hline 1.30 & $1 \mathrm{H}, \mathrm{m}$ & $1.38-1.17$ & $13 \mathrm{H}, \mathrm{m}$ & - \\
\hline 1.28 & $6 \mathrm{H}, \mathrm{m}$ & & & \\
\hline 1.27 & $2 \mathrm{H}, \mathrm{m}$ & & & \\
\hline 1.21 & $1 \mathrm{H}, \mathrm{m}$ & & & \\
\hline 1.06 & $1 \mathrm{H}, \mathrm{m}$ & $1.08-1.03$ & $1 \mathrm{H}, \mathrm{m}$ & - \\
\hline 1.02 & $3 \mathrm{H}, \mathrm{d}$ & 1.01 & $3 \mathrm{H}, \mathrm{d}, 6.8$ & 0.01 \\
\hline 0.89 & $3 \mathrm{H}, \mathrm{t}(7.0)$ & 0.88 & $3 \mathrm{H}, \mathrm{t}, 6.9$ & 0.01 \\
\hline
\end{tabular}

* Coupling constants given in parentheses are for netamine $\mathrm{A}$ because coupling constants for netamine $\mathrm{C}$ were not provided. 
Table S4. ${ }^{13} \mathrm{C}$ NMR data $\left(\mathrm{CDCl}_{3}\right)$

\begin{tabular}{|c|c|c|}
\hline $\begin{array}{l}\text { Natural } \\
\delta_{\mathrm{C}}(\mathrm{ppm}) \\
126 \mathrm{MHz}\end{array}$ & $\begin{array}{c}\text { Synthetic } \\
\text { (revised structure) } \\
\delta_{\mathrm{C}}(\mathrm{ppm}) \\
126 \mathrm{MHz}\end{array}$ & $\begin{array}{c}\text { Difference } \\
\text { (Natural-Synthetic) } \\
\Delta \delta_{\mathrm{C}}(\mathrm{ppm})\end{array}$ \\
\hline 154.9 & 154.8 & 0.1 \\
\hline 53.7 & 53.8 & -0.1 \\
\hline 49.8 & 49.9 & -0.1 \\
\hline 45.0 & 45.1 & -0.1 \\
\hline 35.8 & 35.8 & 0 \\
\hline 35.1 & 35.1 & 0 \\
\hline 34.8 & 34.8 & 0 \\
\hline 34.7 & 34.7 & 0 \\
\hline 34.5 & 34.5 & 0 \\
\hline 33.4 & 33.4 & 0 \\
\hline 31.7 & 31.7 & 0 \\
\hline 30.4 & 30.4 & 0 \\
\hline 29.4 & 29.4 & 0 \\
\hline 27.5 & 27.5 & 0 \\
\hline 23.1 & 23.1 & 0 \\
\hline 22.6 & 22.6 & 0 \\
\hline 14.0 & 14.0 & 0 \\
\hline
\end{tabular}




\section{Stereochemical Models}

The stereochemical models presented in Scheme 1 address the following questions: a) Why the same diastereomer is generated regardless of whether an $E$ or a $Z$ allylic phosphate is used, and b) why a reaction involving a $Z$ allylic phosphate is more stereoselective. Based on previous mechanistic investigations regarding related systems ${ }^{4}$, it may be suggested that transformation via $\mathbf{I}$ (for an $E$ substrate) and II (for a $Z$ substrate) are energetically preferred. Furthermore, these models suggest that the energy gap separating I and III is smaller, compared to II and IV; this is because in the former case, mode of addition I, despite being lower in energy, suffers from a destabilizing steric pressure between the allylic phosphate methylene and an iso-propyl moiety of the chiral NHC ligand.

\section{Scheme S1}
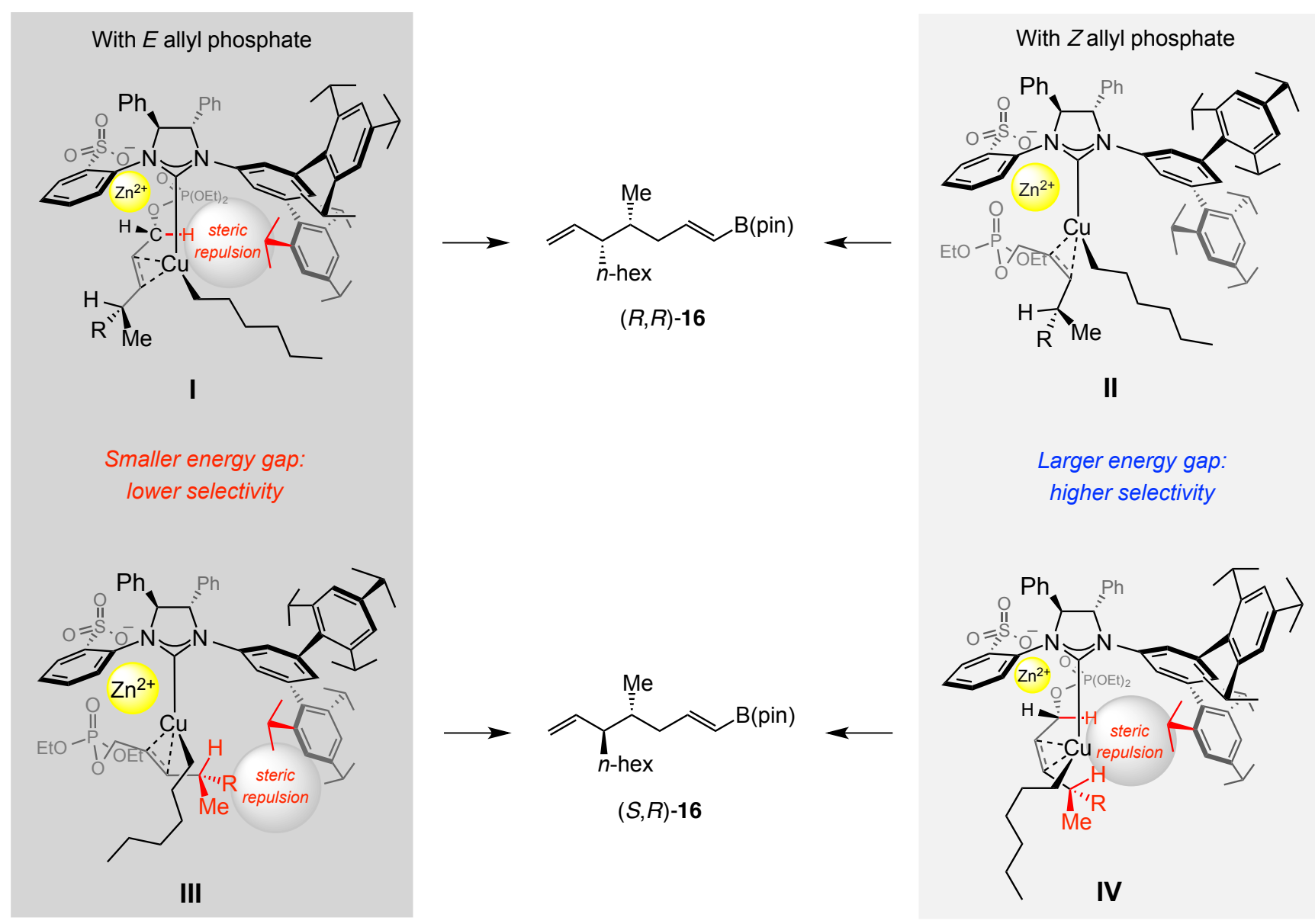


\section{Density Functional Theory (DFT) Calculations}

DFT computations ${ }^{25,26,27}$ were performed with the Gaussian 09/Gaussian 16 suite of programs ${ }^{28}$ and the 4.1.1 version of $\mathrm{ORCA}^{29}$ (for $\omega \mathrm{B}^{2} 9 \mathrm{MV}^{30}$ single-point energies). Geometries were optimized with the M06- $\mathrm{L}^{31}$ functional and the Def2SVP basis set ${ }^{32}$ in conjunction with the corresponding Coulomb fitting basis set to speed up calculations. ${ }^{33}$ The effect of a polar reaction medium (dichloromethane, $\mathrm{CH}_{2} \mathrm{Cl}_{2}$ ) was approximated by means of the SMD solvation model. ${ }^{34}$ Stationary points were probed through vibrational analysis and Gibbs free energy corrections were performed under standard conditions (298.15 K, $1.0 \mathrm{~atm})$. Transition states have been verified through Intrinsic Reaction Coordiante calculations (IRC) employing the L(ocal) Q(uadratic) A(approximation) method, ${ }^{35,36}$ followed by subsequent optimization of the end points with the abovementioned optimization method. We furthermore probed the performance of various density functionals through single-point energy calculations at the geometries optimized with the level described above by means of the SMD solvation model with $\mathrm{CH}_{2} \mathrm{Cl}_{2}$ as solvent and the larger def2-TZVPP ${ }^{\sharp}$ or def2-QZVPP ${ }^{32}$ basis set. Several state-ofthe-art DFT approaches ${ }^{37,38,39,40,41,42}$ have been developed over the past decade with particular focus on treatment of dispersion interactions and employed, for example, in modeling the olefin metathesis reaction. ${ }^{43,44,45,46} \mathrm{~A}$ notable impact of dispersion relates to the correct description of ligand association/dissociation steps in a catalytic cycle. Nonetheless, there have been concerns raised regarding the accurate modeling of dispersion interactions in solution. ${ }^{47,48}$ In particular, although structural information of precatalysts is available through $\mathrm{x}$-ray christallography ${ }^{46}$ there is little extant information regarding their structure and that of related reactive intermediates in solution. Here, we include the evaluation with MN15/Def2-TZVPP, ${ }^{42}$ M06-L/Def2-TZVPP, ${ }^{33} \quad \omega B$ 97MV/Def2-QZVPP, $\omega B$ 97XD/Def2-TZVPP ${ }^{49}$ and $\omega$ B97X/Def2-TZVPP." ${ }^{s 1}$ All density functionals accounting for disperison provided qualitatively similar results and we use the MN15/Def2TZVPP $\mathrm{CH}_{2 \mathrm{Cl} 2 \mathrm{SMD}} / / \mathrm{M} 06 \mathrm{~L} / \mathrm{DF}$ Def2SVP ${ }_{\mathrm{CH} 2 \mathrm{Cl} 2(\mathrm{SMD})}$ energies for discussion (Charts S1-1-S2-6). A file for convenient viewing of computed geometries with the program Mercury 3.3 is appended as separate "coordinates.xyz" file in Section $2 .{ }^{50}$ The "coordinates.xyz" file can be generated by copying all the coordinates in Section 2 into a text file without empty lines and changing the extension to (.xyz).

\subsection{General features}

The fundamental mechanistic features considered are consistent within the recently reviewed framework of reactions promoted by nucleophilic $\mathrm{Cu}(\mathrm{I})$ complexes. ${ }^{51}$ Examples involving enantioselective allylic substitution promoted by a sulfonate containing $\mathrm{NHC}-\mathrm{Cu}$ complex have previously been investigated and the significant role of the sulfonate group has been elucidated. ${ }^{4,14,52}$ These investigations illustrate that the sulfonate mioety probably coordinates with a cation, assisting the displacement of the phosphate anion to establish of an ionic bridge.Mechanistically related are cases for enantioselective 1,4- and 1,6-conjugate additions that are promoted by $\mathrm{NHC}-\mathrm{Cu}$ complexes bearing an alcohol moiety. ${ }^{53,54,55}$ 


\subsection{Comparison of background reactivity with enantioselective pathways}

As noted above, a salt bridge between the sulfonate group within a Cu-based complex and the phosphate

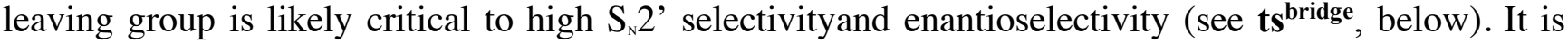
unlikely that the same is required during competitive $\mathrm{Cu}-\mathrm{H}$ addition to allyl phosphate $\mathbf{2 b}$ (a side reaction). We therefore chose to model this latter transformation as proceeding via an "open transition state" (ts $\left.\mathbf{s}^{\text {open }}\right)$. Such a pathway can lead to the formation of linear as well as branched products. We believe that the actual structure in solution is more complex and will presumably involve additional counter-ions that are bound to the "naked" sulfonate (see $\mathbf{t s}^{\mathbf{o p e n}}$ ). Since a direct comparison of $\mathbf{t s}^{\text {bridge }}$ and ts $^{\text {open }}$ would be exceptionally and subject to considerable computational error, we chose to omit a solvated second counterion (i.e., $\mathrm{M}_{2}^{+}$). Rather than viewing the investigated transition states for reduction as the true representation of what transpires in solution, they should more appropriately considered as a measure of accessability of the substrate to the active site based on steric factors.

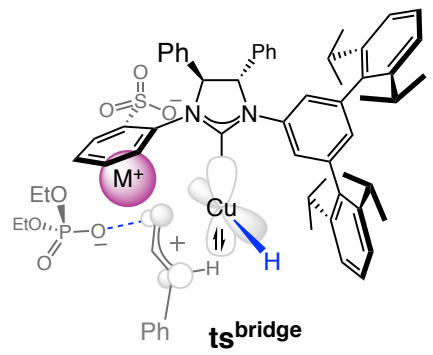

transition state involving a cationic bridge between sulfonate and phosphate

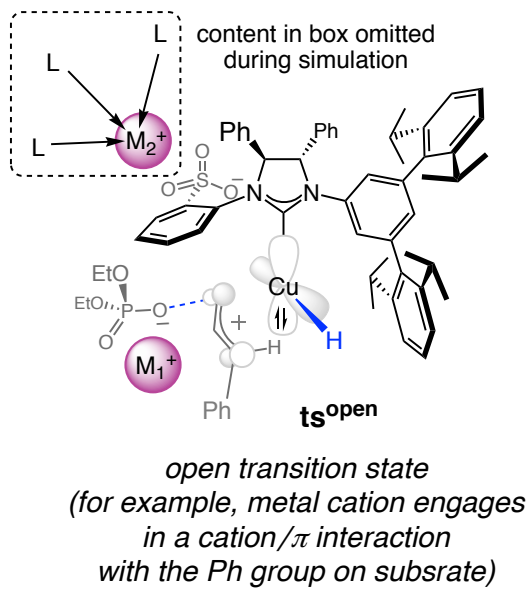

\subsection{Reference point for background reactivity}

Considering the challenge associated with an appropriate description of the transition state associated with reduction, we chose the following reference point relative to the ground state imid(S)$\mathbf{1 b}_{\mathbf{g s}}$ (see the equation shown below).

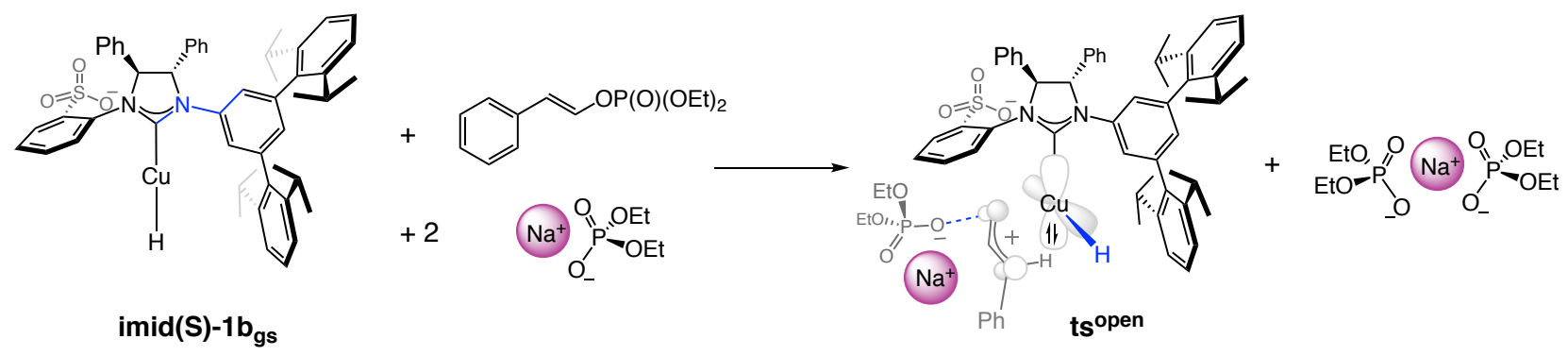

\subsection{Transition states for $\mathrm{Cu}-\mathrm{H}$ addition to $2 \mathrm{~b}$ promoted by imid(S)-1 $\mathrm{b}_{\mathrm{gs}}$}

The following transition states have been investigated for reduction promoted by $\mathbf{i m i d}(\mathbf{S})-\mathbf{1 b}_{\mathrm{gs}}$ (Chart S1). In imid-1b(ts1.1)-imid-1b(ts2.2) the hydride is situated at the rear, while in imid- 
1b(ts3.1)-imid-1b(ts4.2) it is pointing to the front (Chart S1). Energy values in Chart S1 correspond to

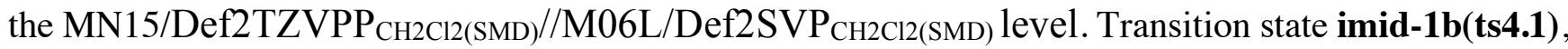
leading to formation of the $\mathrm{S}_{\mathrm{N}} 2$ isomer, is predicted to be lowest in energy ( $\left.\Delta \mathrm{G}=9.5 \mathrm{kcal} / \mathrm{mol}\right)$. In contrast, transition state imid-1b(ts3.2), which leads to the $S_{N} 2$ ' isomer and involves the preferred orientation of the substrate, typically predicted in presence of a cationic bridge between the phosphate and the sulfonate group, Error! Bookmark not defined. is marginally higher in energy $(\Delta \mathrm{G}=12.0 \mathrm{kcal} / \mathrm{mol})$. This comparison suggests that formation of a cationic bridge might come at the cost of formation of a sterically more demanding complex.

\subsection{Transition states for $\mathrm{Cu}-\mathrm{H}$ addition to $1 \mathrm{a}$ promoted by imid(S)-1 $\mathrm{b}_{\mathrm{gs}}$}

Unlike a highly enantioselective allylic substitution (EAS), Error! Bookmark not defined. although proposed originally, Error! Bookmark not defined. $\mathrm{Cu}-\mathrm{H}$ addition to allenyl-B(pin) 1a probably does not need the involvement of a cationic bridge. Therefore, we considered the pendant sulfonate anion as an "innocent" bystander (Chart S2). In imid-1b(tsA1)-imid-1b(tsA4) the Cu centre initially associates with the more substituted allenyl carbon, whereas the regioselectivity is reversed in imid1b(tsB1)-imid-1b(tsB4). Transition state imid-1b(tsA4) is predicted to be most favored $(\Delta \mathrm{G}=9.8$ $\mathrm{kcal} / \mathrm{mol}$ ) with the transition states leading to a reversal of the initial regioselectivity being at least 8 $\mathrm{kcal} / \mathrm{mol}$ higher in energy. DFT studies reveal that $\mathrm{Cu}-\mathrm{H}$ addition to the sterically more demanding site of an allenyl-B(pin) compound is favored. This is likely because of the stabilization of the electron density at the carbon atom of the incipient $\mathrm{Cu}-\mathrm{C}$ bond by the Lewis acidic $\mathrm{B}$ atom. For further discussion, please refer to the main manuscript.
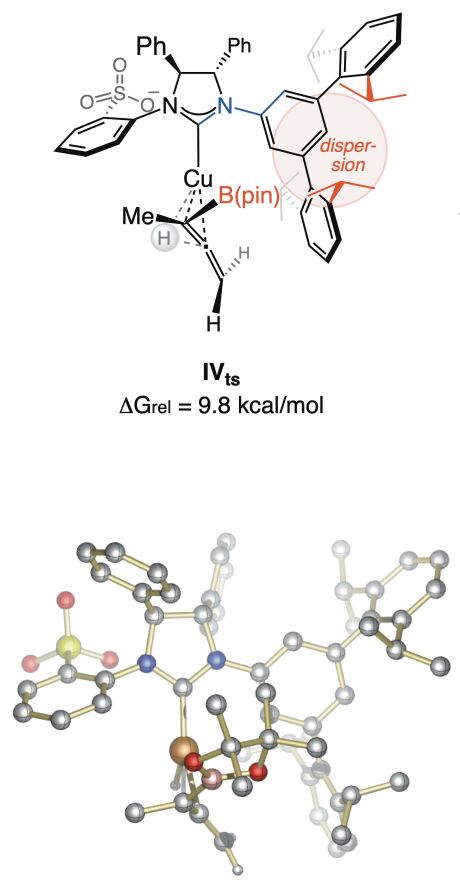

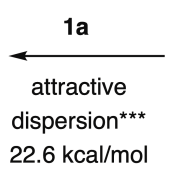

$22.6 \mathrm{kcal} / \mathrm{mol}$

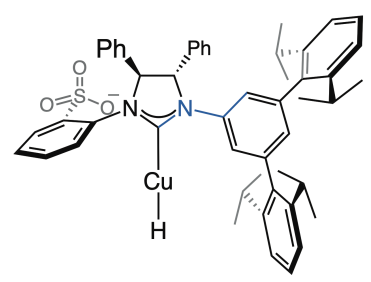

$\begin{aligned} & \mathbf{I V}_{\mathbf{g s}} \\ \Delta \mathrm{Grel}= & 0.0 \mathrm{kcal} / \mathrm{mol}\end{aligned}$

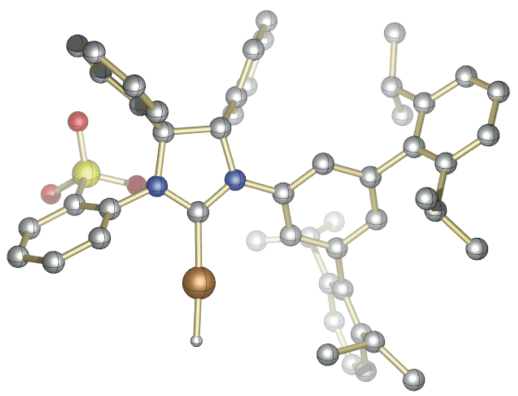

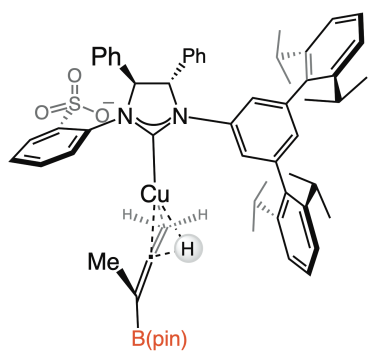

$\Delta \mathrm{Grel}_{\mathrm{rel}}=17.7 \mathrm{kcal} / \mathrm{mol}$

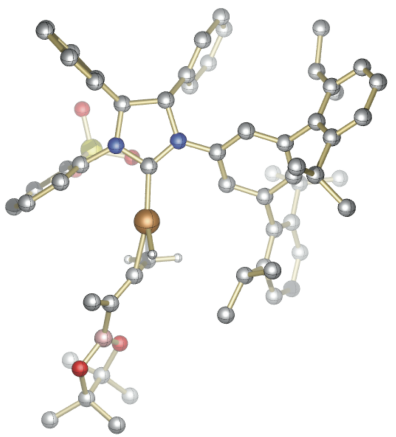




\subsection{Transition states for $\mathrm{Cu}-\mathrm{H}$ addition to $1 \mathrm{~b}$ promoted by imid(S)-1 $\mathbf{b}_{\mathrm{gs}}$}

The transition states for $\mathrm{Cu}-\mathrm{H}$ addition to allenyl-B(pin) $\mathbf{1 b}$ are displayed in Chart S3. Again, in imid-1b(tsC1)-imid-1b(tsC4) the $\mathrm{Cu}$ initially associates with the more substituted allene carbon, whereas the regioselectivity is reversed in imid-1b(tsD1)-imid-1b(tsD4). Transition state imid$\mathbf{1 b}(\mathbf{t s C 1})$ is predicted to be most favored $(\Delta \mathrm{G}=9.5 \mathrm{kcal} / \mathrm{mol})$, consistent with a previous investigation

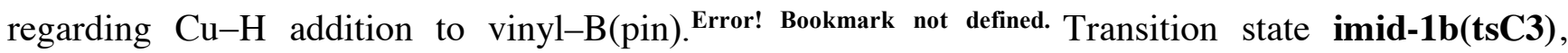
predicted to be the most favorable with other density functionals (see Section 1.8 below), is only marginally higher in free energy $(\Delta \mathrm{G}=11.7 \mathrm{kcal} / \mathrm{mol})$, particularly if one considers the inherent errors of $\sim 1-2 \mathrm{kcal} / \mathrm{mol}$.

\subsection{Transition states for reduction and $\mathrm{Cu}-\mathrm{H}$ addition to allenes $1 \mathrm{a}$ and $1 \mathrm{~b}$ promoted by $\operatorname{imid}(\mathbf{S})-1 a_{g s}$}

The transition states for the transformation with imid(S)-1a $\mathbf{a}_{\mathrm{s}}$ are displayed in Charts S4-S6. During $\mathbf{C u}-\mathrm{H}$ addition to $\mathbf{2 b}$, as in the case of imid(S)-1 $\mathbf{b}_{\mathbf{g s}}$, imid-1a(ts4.1), leading to formation of the $\mathrm{S}_{\mathrm{N}} 2$ isomer, is predicted to be lowest in energy $(\Delta \mathrm{G}=10.3 \mathrm{kcal} / \mathrm{mol}$; Chart $\mathrm{S} 4)$, though transition state imid1a(ts3.2) is slightly higher in energy $(\Delta \mathrm{G}=12.3 \mathrm{kcal} / \mathrm{mol})$. Regarding $\mathrm{Cu}-\mathrm{H}$ addition to allene $1 \mathbf{a}$ it is imid-1a(tsA3) that is most favored in this case $(\Delta \mathrm{G}=12.4 \mathrm{kcal} / \mathrm{mol}$; Chart S5). In the case of $\mathrm{Cu}-\mathrm{H}$ addition to $\mathbf{1 b}$ it is again imid-1a(tsC1) that is preferred with density functional $\mathrm{MN} 15(\Delta \mathrm{G}=11.4$ $\mathrm{kcal} / \mathrm{mol}$; Chart S6), while with other functionals imid-1a(tsC3) is lower in energy (see Section 1.8 below). 
Chart S1. Reduction of allyl phosphate $\mathbf{2 b}$ with $\mathrm{Cu}-\mathrm{H}$ derived from imid(S)-1b

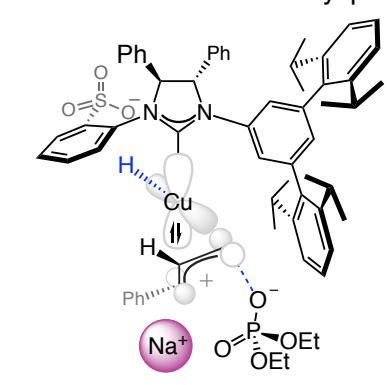

imid-1b(ts1.1)

$\Delta \mathrm{E}_{\mathrm{rel}}=-8.3 \mathrm{kcal} / \mathrm{mol}$ $\Delta \mathrm{G}_{\mathrm{rel}}=17.9 \mathrm{kcal} / \mathrm{mol}$
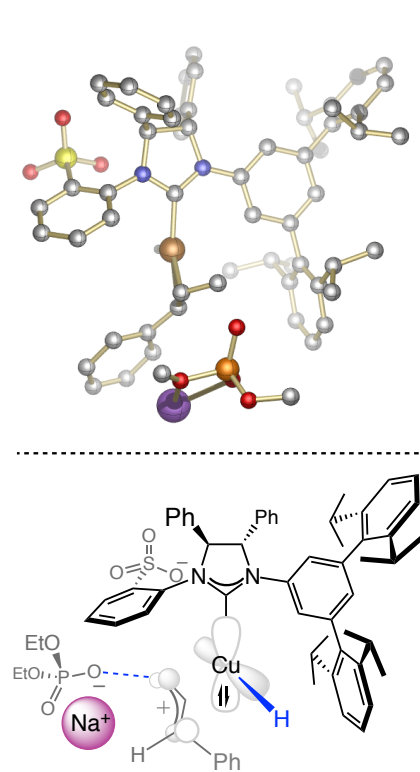

imid-1b(ts3.1)

$\Delta \mathrm{E}_{\text {rel }}=-16.9 \mathrm{kcal} / \mathrm{mol}$ $\Delta \mathrm{G}_{\mathrm{rel}}=12.0 \mathrm{kcal} / \mathrm{mol}$

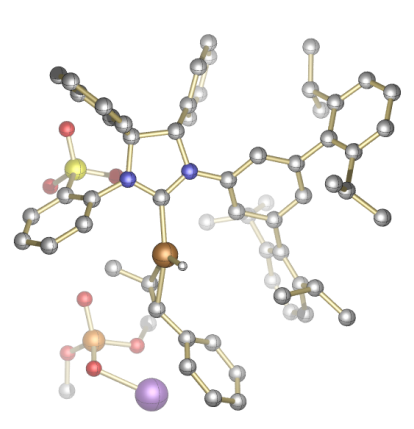

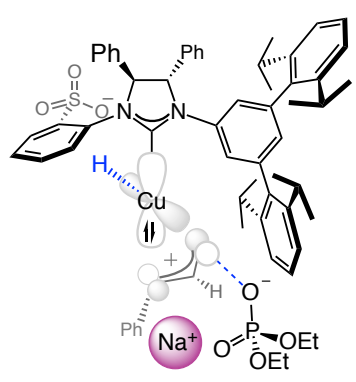

imid-1b(ts1.2)

$\Delta \mathrm{E}_{\mathrm{rel}}=-11.2 \mathrm{kcal} / \mathrm{mol}$ $\Delta G_{\mathrm{rel}}=17.3 \mathrm{kcal} / \mathrm{mol}$
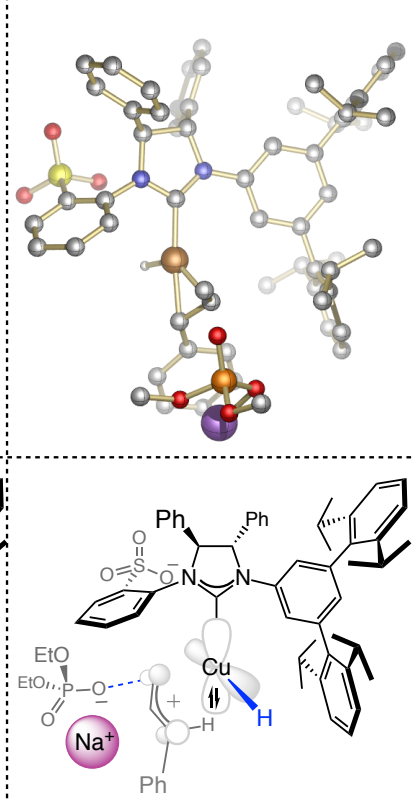

imid-1b(ts3.2)

$\Delta \mathrm{E}_{\mathrm{rel}}=-15.2 \mathrm{kcal} / \mathrm{mol}$ $\Delta \mathrm{G}_{\mathrm{rel}}=12.0 \mathrm{kcal} / \mathrm{mol}$

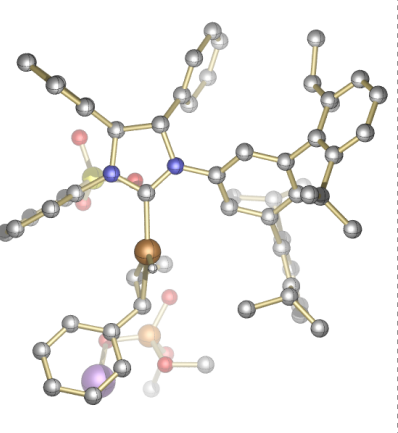

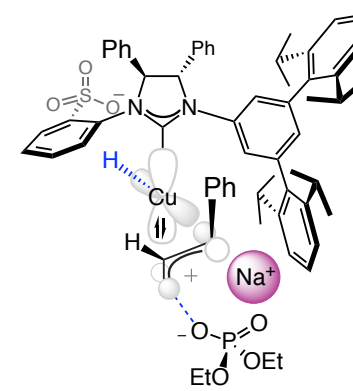

imid-1b(ts2.1)

$\Delta \mathrm{E}_{\text {rel }}=-10.1 \mathrm{kcal} / \mathrm{mol}$ $\Delta \mathrm{G}_{\mathrm{rel}}=16.7 \mathrm{kcal} / \mathrm{mol}$
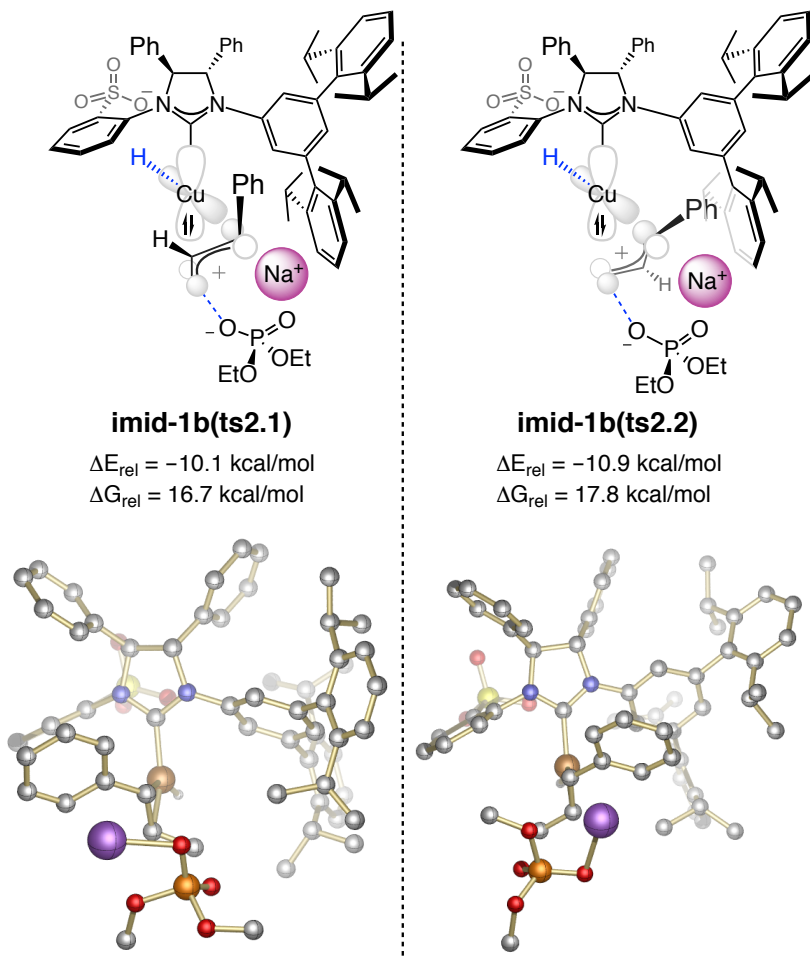

imid-1b(ts2.2)

$\Delta \mathrm{E}_{\mathrm{rel}}=-10.9 \mathrm{kcal} / \mathrm{mol}$ $\Delta \mathrm{G}_{\mathrm{rel}}=17.8 \mathrm{kcal} / \mathrm{mol}$
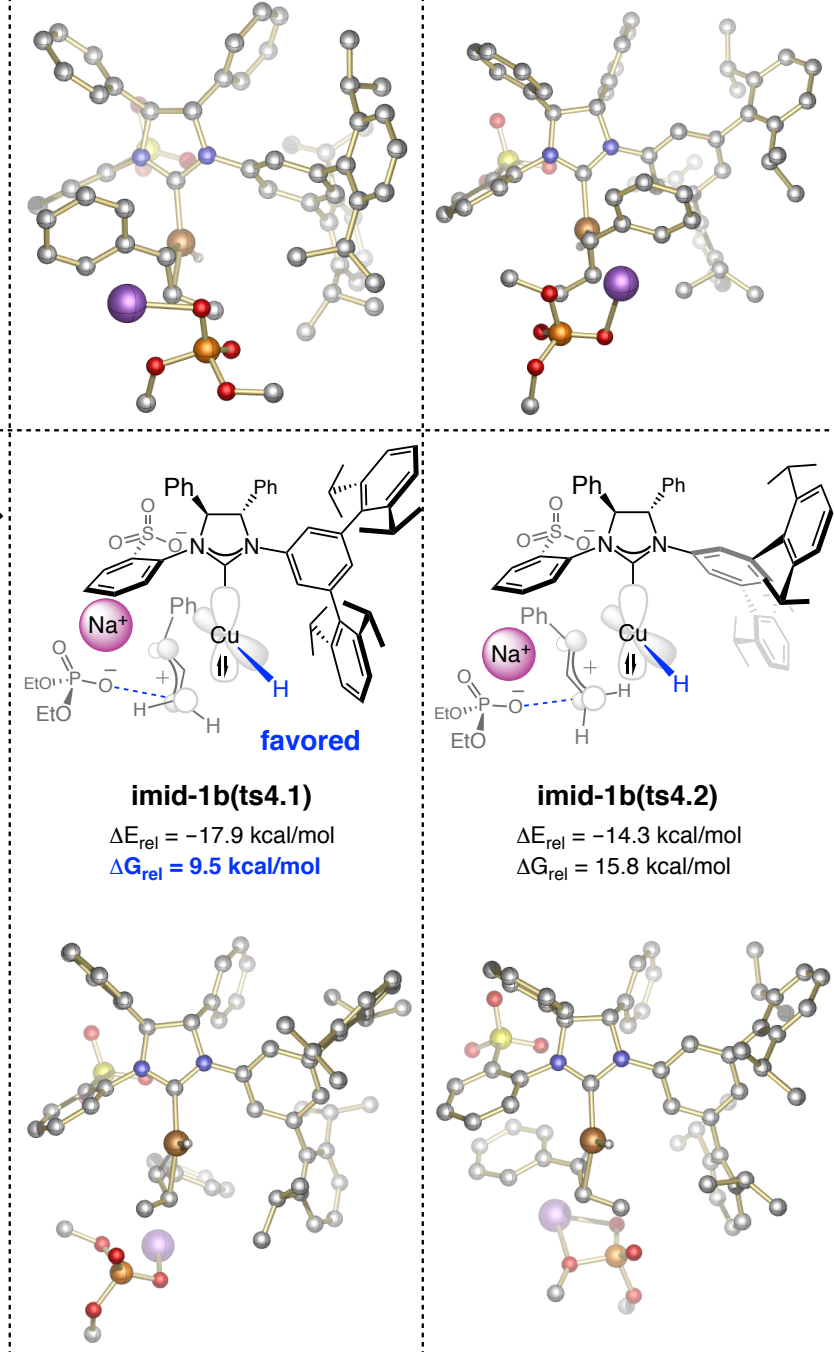

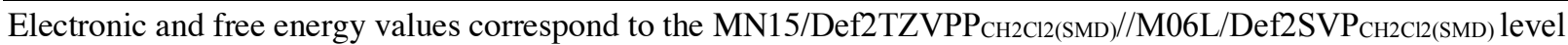


Chart S2. Cu-H additon to allenyl B(pin) 1a with $\mathrm{Cu}-\mathrm{H}$ derived from imid(S)-1b

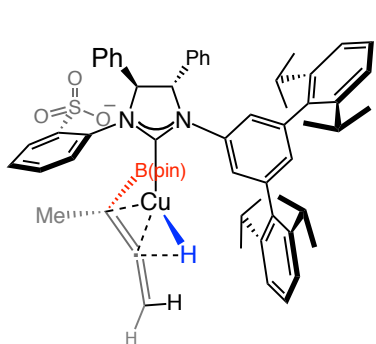

imid-1b(tsA1)

$\Delta \mathrm{E}_{\text {rel }}=-2.1 \mathrm{kcal} / \mathrm{mol}$ $\Delta \mathrm{G}_{\mathrm{rel}}=13.9 \mathrm{kcal} / \mathrm{mol}$
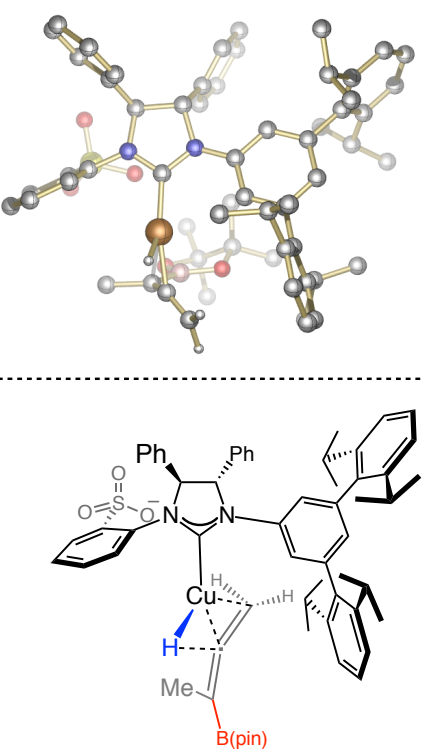

imid-1b(tsB1)

$\Delta \mathrm{E}_{\text {rel }}=4.4 \mathrm{kcal} / \mathrm{mol}$ $\Delta \mathrm{G}_{\mathrm{rel}}=17.7 \mathrm{kcal} / \mathrm{mol}$

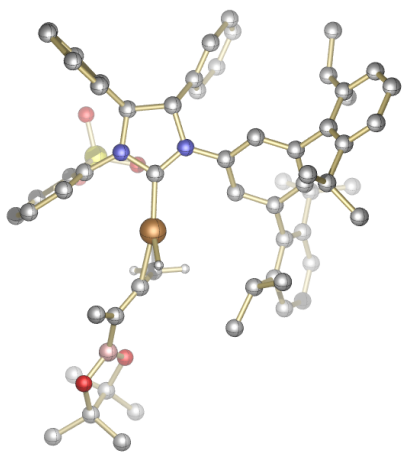

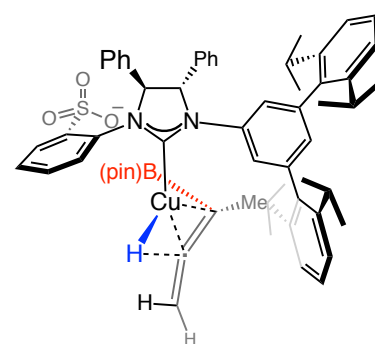

imid-1b(tsA2)

$\Delta \mathrm{E}_{\mathrm{rel}}=-4.3 \mathrm{kcal} / \mathrm{mol}$ $\Delta \mathrm{G}_{\mathrm{rel}}=14.4 \mathrm{kcal} / \mathrm{mol}$
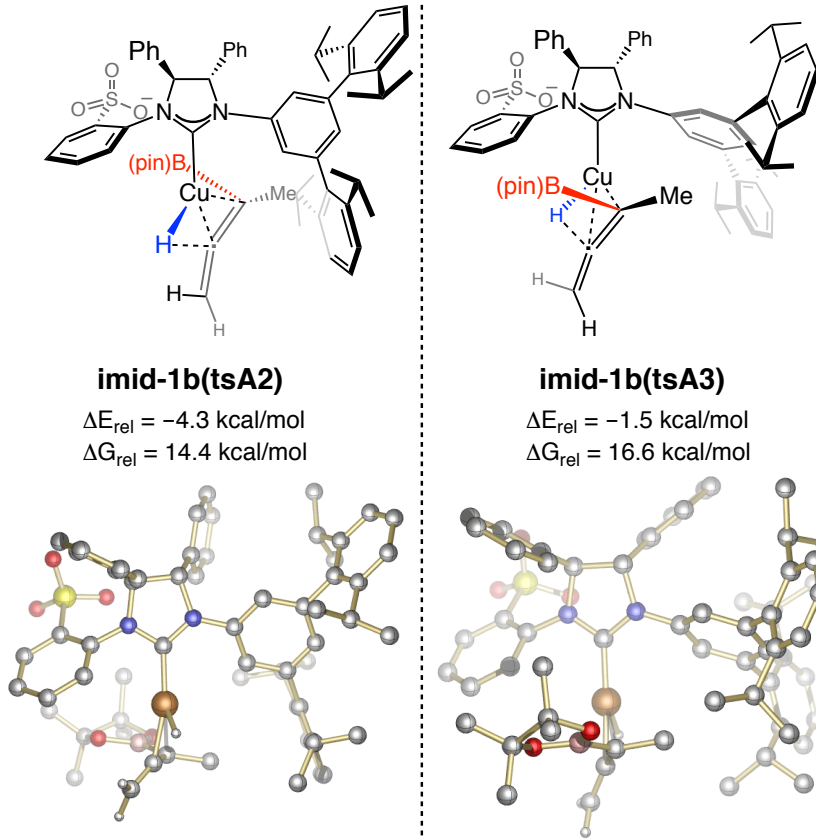

imid-1b(tsA3)

$\Delta \mathrm{E}_{\mathrm{rel}}=-1.5 \mathrm{kcal} / \mathrm{mol}$

$\Delta G_{\text {rel }}=16.6 \mathrm{kcal} / \mathrm{mol}$
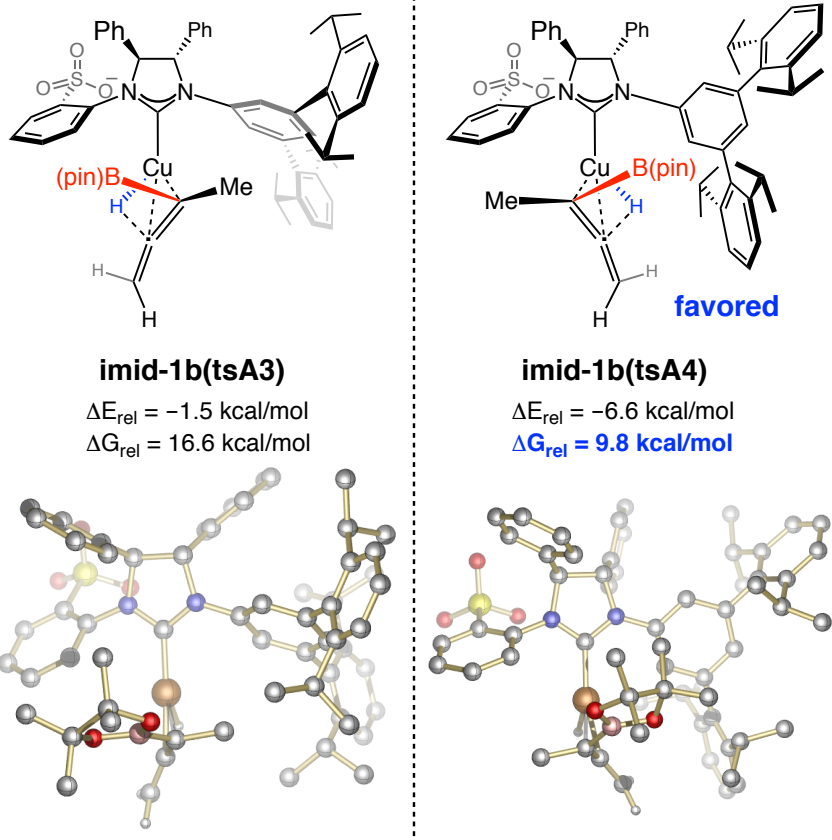

imid-1b(tsA4)

$\Delta \mathrm{E}_{\mathrm{rel}}=-6.6 \mathrm{kcal} / \mathrm{mol}$

$\Delta \mathrm{G}_{\mathrm{rel}}=9.8 \mathrm{kcal} / \mathrm{mol}$

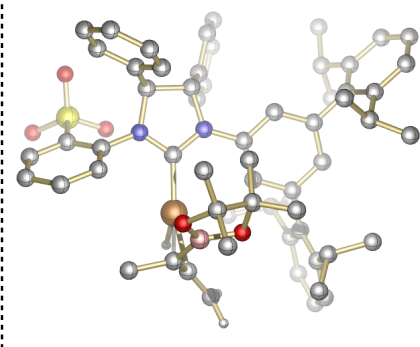

$\Delta \mathrm{E}_{\mathrm{rel}}=6.9 \mathrm{kcal} / \mathrm{mol}$

$\Delta \mathrm{G}_{\mathrm{rel}}=22.2 \mathrm{kcal} / \mathrm{mol}$

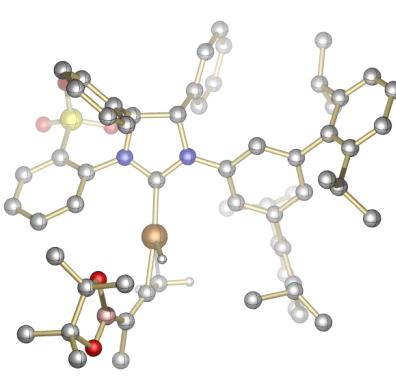

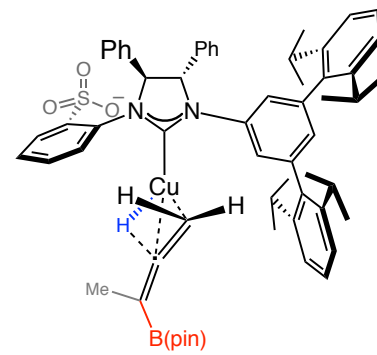

imid-1b(tsB3)

$\Delta \mathrm{E}_{\mathrm{rel}}=5.0 \mathrm{kcal} / \mathrm{mol}$

$\Delta G_{\mathrm{rel}}=19.5 \mathrm{kcal} / \mathrm{mol}$

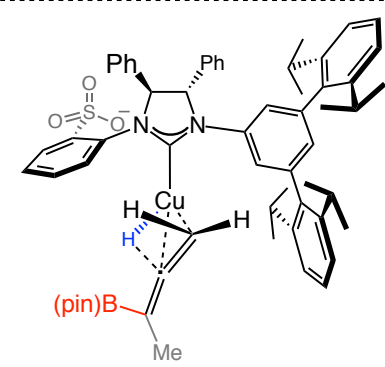

imid-1b(tsB4)

$\Delta \mathrm{E}_{\mathrm{rel}}=7.1 \mathrm{kcal} / \mathrm{mol}$ $\Delta \mathrm{G}_{\text {rel }}=23.0 \mathrm{kcal} / \mathrm{mol}$
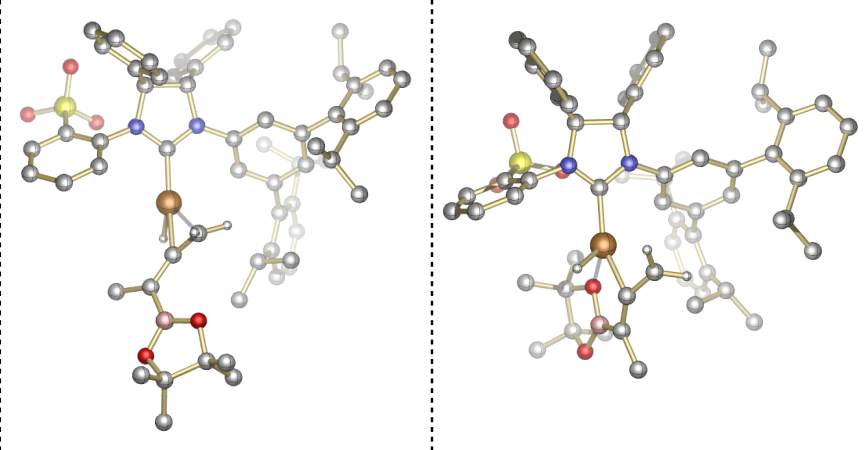

Electronic and free energy values correspond to the MN15/Def2TZVPP ${ }_{\mathrm{CH} 2 \mathrm{Cl} 2(\mathrm{SMD}) / / \mathrm{M} 06 \mathrm{~L} / \mathrm{Def}_{2} \mathrm{SVP}} \mathrm{CH}_{2 \mathrm{Cl}(\mathrm{SMD})}$ level $_{2}$ 
Chart S3. $\mathrm{Cu}-\mathrm{H}$ additon to allenyl $\mathrm{B}$ (pin) $\mathbf{1 b}$ with $\mathrm{Cu}-\mathrm{H}$ derived from imid(S)-1b
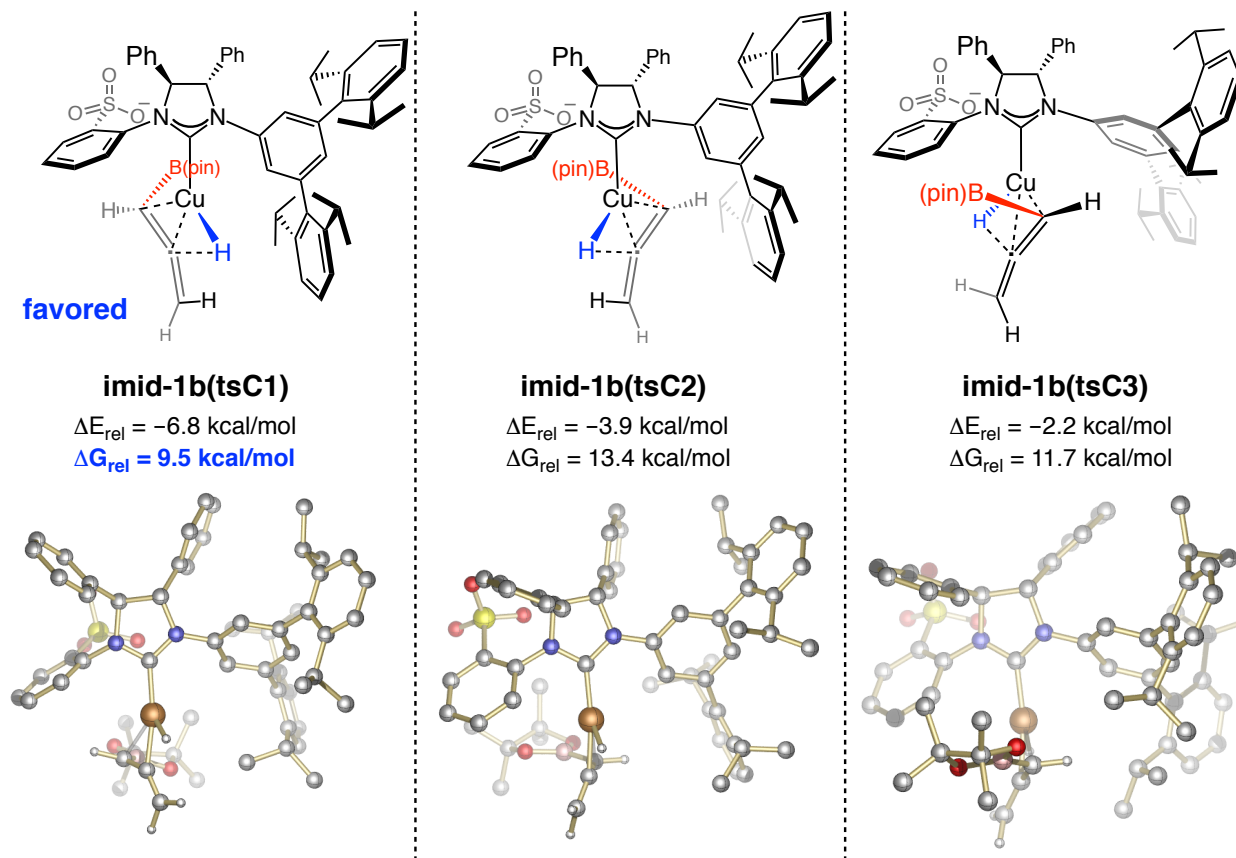

imid-1b(tsC3)

$\Delta \mathrm{E}_{\text {rel }}=-2.2 \mathrm{kcal} / \mathrm{mol}$

$\Delta \mathrm{G}_{\mathrm{rel}}=11.7 \mathrm{kcal} / \mathrm{mol}$
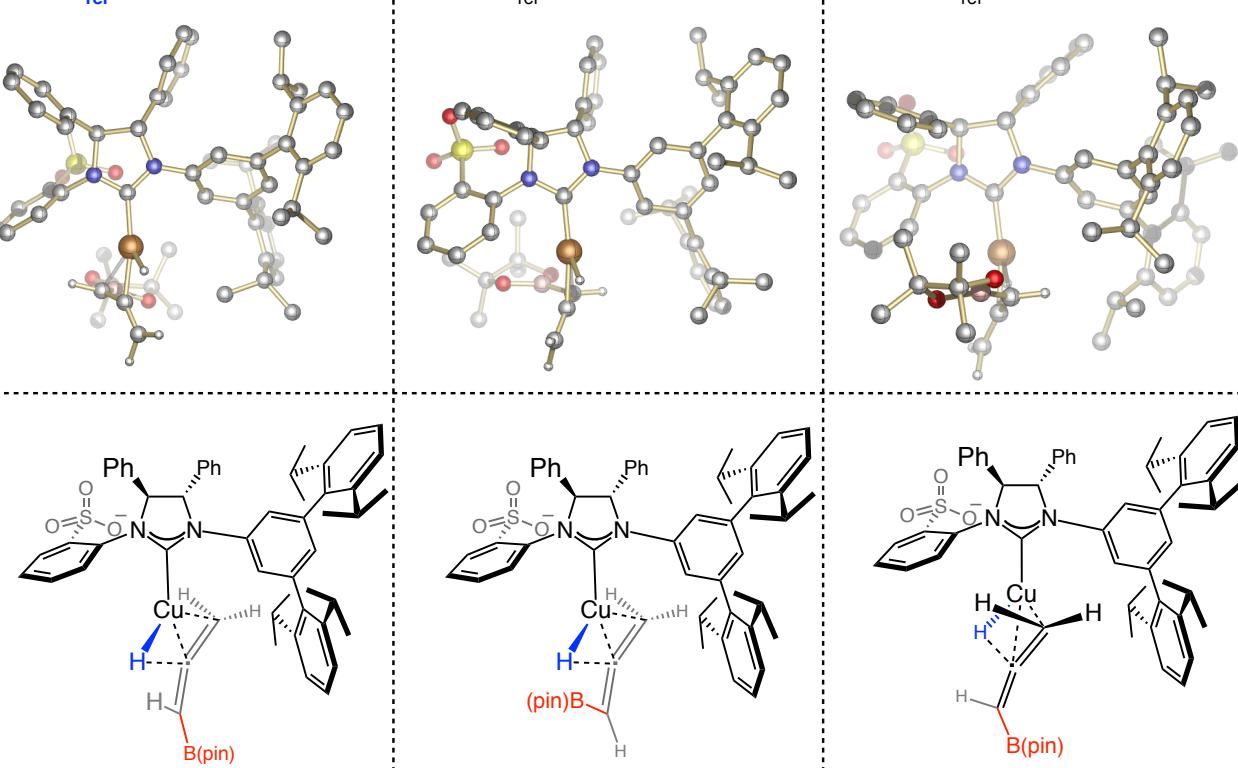

imid-1b(tsD1)

$\Delta \mathrm{E}_{\text {rel }}=6.1 \mathrm{kcal} / \mathrm{mol}$

$\Delta \mathrm{G}_{\mathrm{rel}}=20.5 \mathrm{kcal} / \mathrm{mol}$

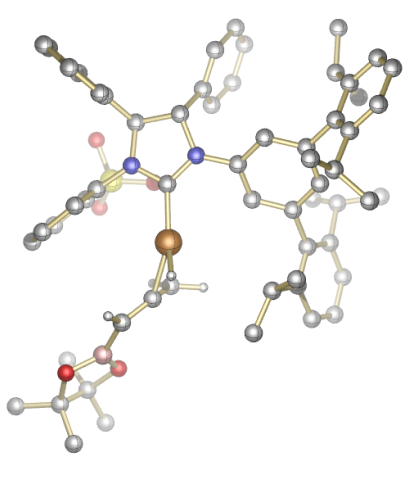

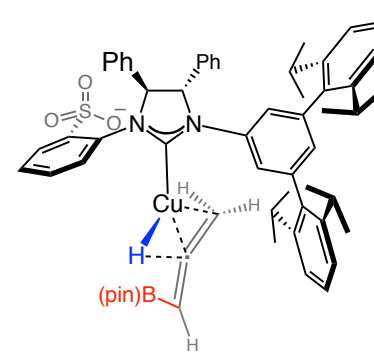

imid-1b(tsD2)

$\Delta \mathrm{E}_{\text {rel }}=6.3 \mathrm{kcal} / \mathrm{mol}$

$\Delta \mathrm{G}_{\mathrm{rel}}=20.7 \mathrm{kcal} / \mathrm{mol}$

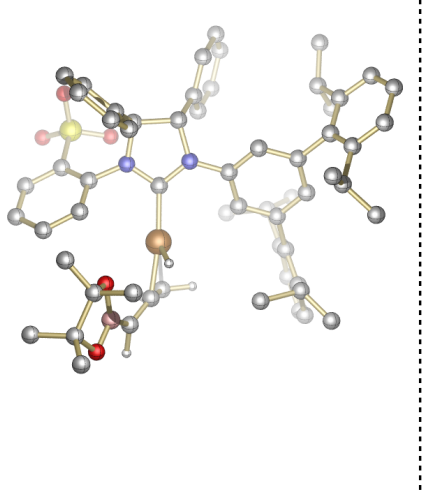

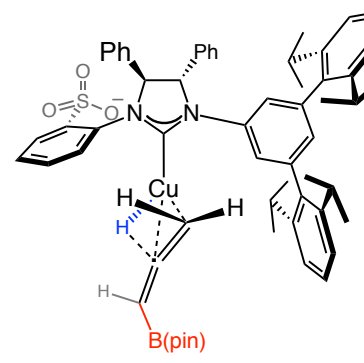

imid-1b(tsD3)

$\Delta \mathrm{E}_{\mathrm{rel}}=6.6 \mathrm{kcal} / \mathrm{mol}$

$\Delta \mathrm{G}_{\mathrm{rel}}=20.1 \mathrm{kcal} / \mathrm{mol}$

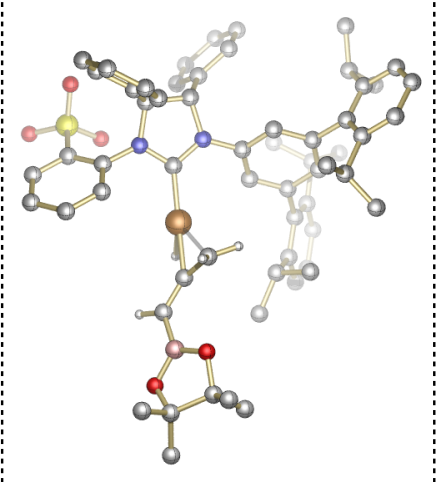

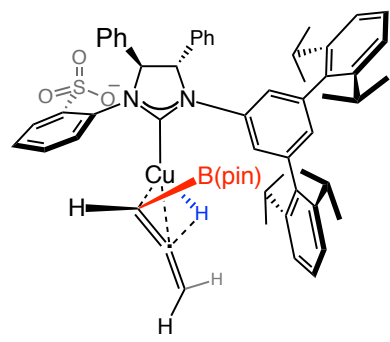

imid-1b(tsC4)

$\Delta \mathrm{E}_{\mathrm{rel}}=-6.2 \mathrm{kcal} / \mathrm{mol}$

$\Delta \mathrm{G}_{\mathrm{rel}}=11.0 \mathrm{kcal} / \mathrm{mol}$
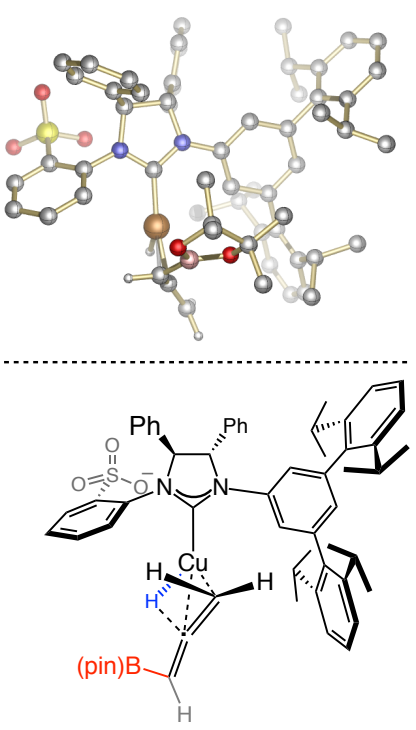

imid-1b(tsD4)

$\Delta \mathrm{E}_{\text {rel }}=5.6 \mathrm{kcal} / \mathrm{mol}$

$\Delta \mathrm{G}_{\mathrm{rel}}=21.2 \mathrm{kcal} / \mathrm{mol}$

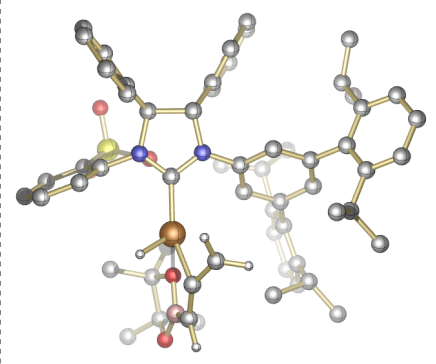

Electronic and free energy values correspond to the MN15/Def2TZVPP ${ }_{\mathrm{CH} 2 \mathrm{Cl} 2(\mathrm{SMD}) / / \mathrm{M} 06 \mathrm{~L} / \mathrm{Def} 2 \mathrm{SVP}} \mathrm{CH}_{2 \mathrm{Cl} \text { (SMD) }}$ level 
Chart S4. Reduction of allyl phosphate $\mathbf{2 b}$ with $\mathrm{Cu}-\mathrm{H}$ derived from imid(S)-1a

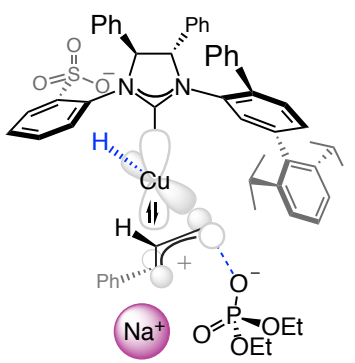

imid-1a(ts1.1)

$\Delta \mathrm{E}_{\text {rel }}=-12.7 \mathrm{kcal} / \mathrm{mol}$ $\Delta \mathrm{G}_{\mathrm{rel}}=16.9 \mathrm{kcal} / \mathrm{mol}$
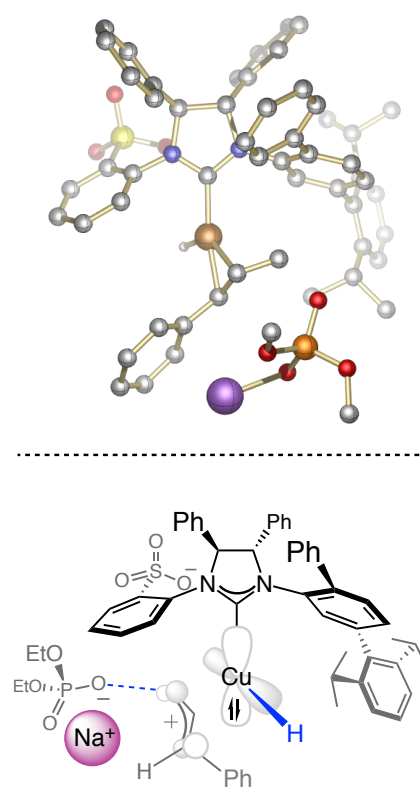

imid-1a(ts3.1)

$\Delta \mathrm{E}_{\mathrm{rel}}=-10.8 \mathrm{kcal} / \mathrm{mol}$ $\Delta \mathrm{G}_{\mathrm{rel}}=20.8 \mathrm{kcal} / \mathrm{mol}$

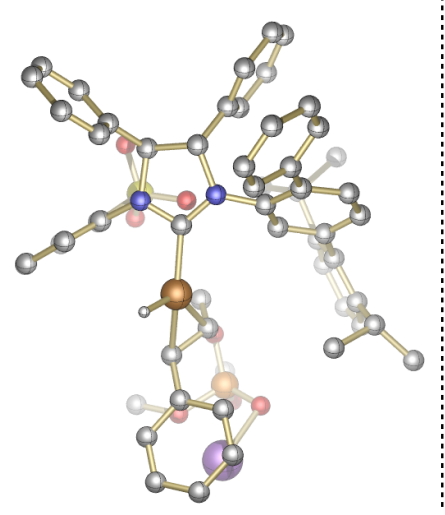

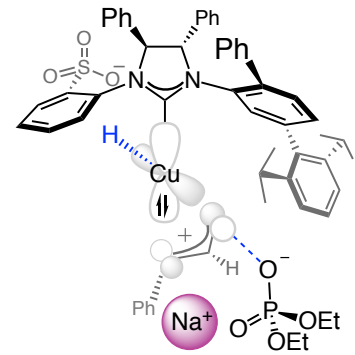

imid-1a(ts1.2)

$\Delta \mathrm{E}_{\mathrm{rel}}=-13.0 \mathrm{kcal} / \mathrm{mol}$ $\Delta \mathrm{G}_{\mathrm{rel}}=18.8 \mathrm{kcal} / \mathrm{mol}$

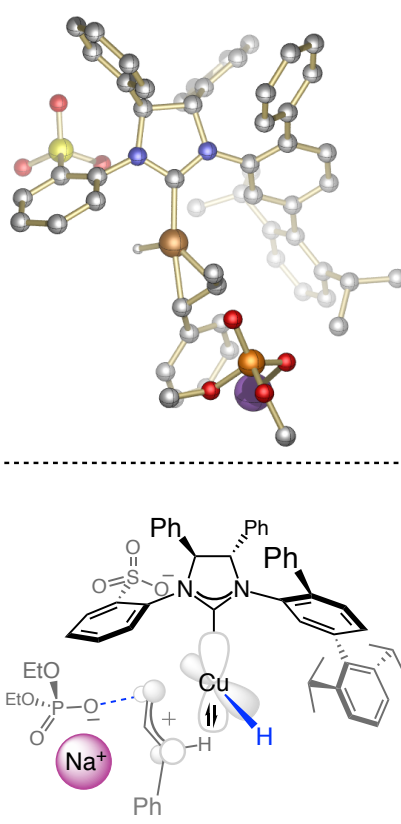

imid-1a(ts3.2)

$\Delta \mathrm{E}_{\mathrm{rel}}=-17.0 \mathrm{kcal} / \mathrm{mol}$ $\Delta G_{\text {rel }}=12.3 \mathrm{kcal} / \mathrm{mol}$

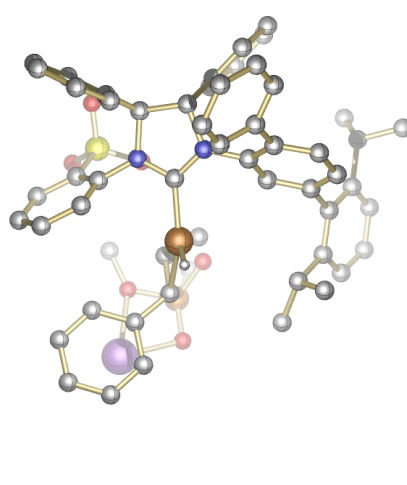

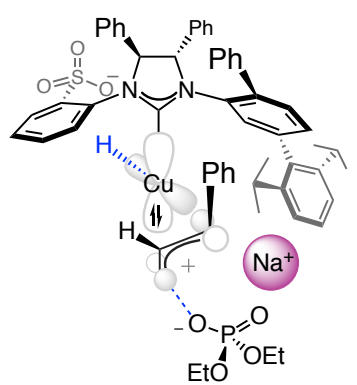

imid-1a(ts2.1)

$\Delta \mathrm{E}_{\mathrm{rel}}=-11.8 \mathrm{kcal} / \mathrm{mol}$ $\Delta \mathrm{G}_{\mathrm{rel}}=20.4 \mathrm{kcal} / \mathrm{mol}$
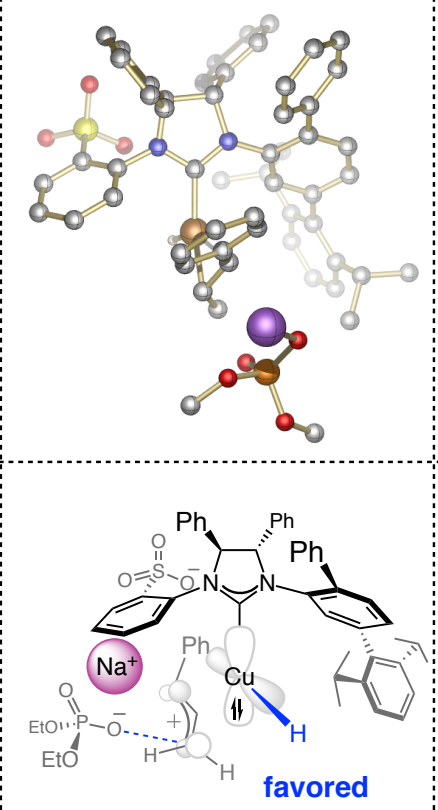

imid-1a(ts4.1)

$\Delta \mathrm{E}_{\text {rel }}=-19.9 \mathrm{kcal} / \mathrm{mol}$ $\Delta \mathrm{G}_{\mathrm{rel}}=10.3 \mathrm{kcal} / \mathrm{mol}$

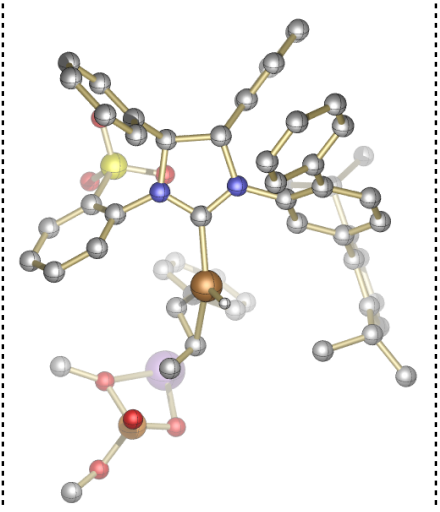

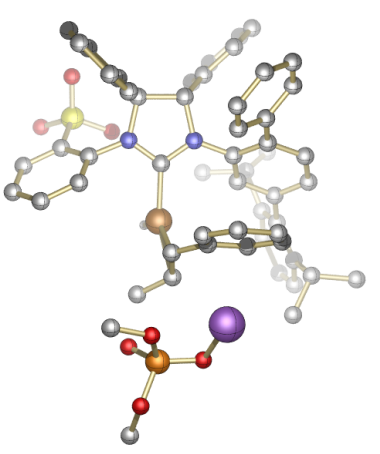

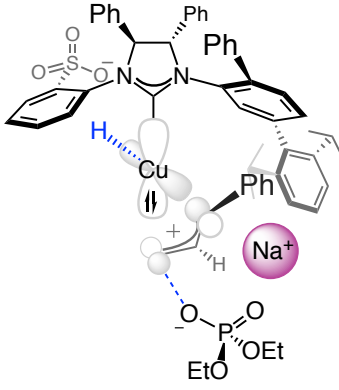

imid-1a(ts2.2)

$\Delta \mathrm{E}_{\mathrm{rel}}=-13.4 \mathrm{kcal} / \mathrm{mol}$ $\Delta \mathrm{G}_{\mathrm{rel}}=17.1 \mathrm{kcal} / \mathrm{mol}$

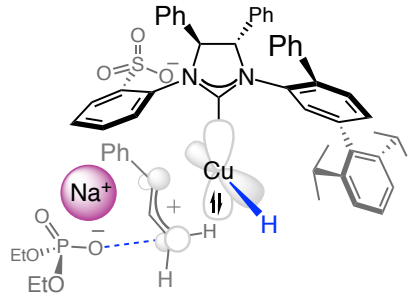

imid-1a(ts4.2)

$\Delta \mathrm{E}_{\mathrm{rel}}=-15.2 \mathrm{kcal} / \mathrm{mol}$ $\Delta \mathrm{G}_{\mathrm{rel}}=15.9 \mathrm{kcal} / \mathrm{mol}$

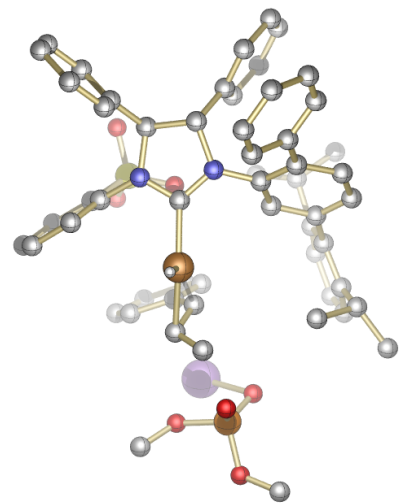

Electronic and free energy values correspond to the MN15/Def2TZVPP ${ }_{\mathrm{CH} 2 \mathrm{Cl} 2(\mathrm{SMD}) / / \mathrm{M} 06 \mathrm{~L} / \mathrm{Def} 2 \mathrm{SVP}} \mathrm{CH}_{2 \mathrm{Cl} \text { (SMD) }}$ level 
Chart S5. $\mathrm{Cu}-\mathrm{H}$ additon to allenyl $\mathrm{B}($ pin) $1 \mathrm{a}$ with $\mathrm{Cu}-\mathrm{H}$ derived from imid(S)-1a

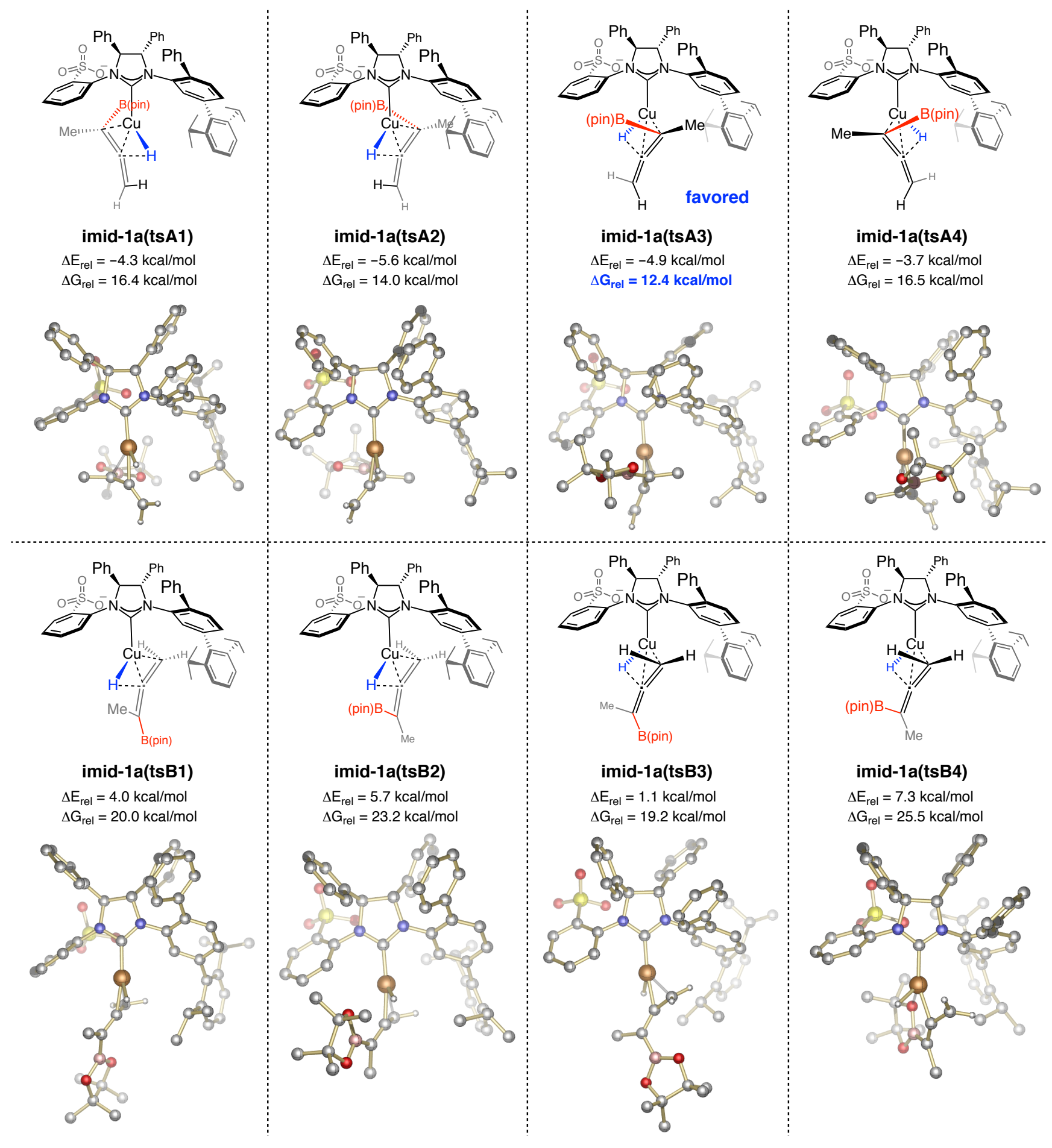

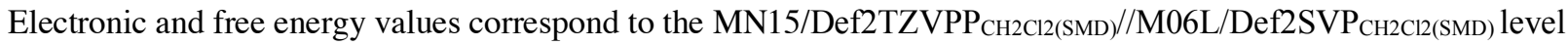


Chart S6. $\mathrm{Cu}-\mathrm{H}$ additon to allenyl $\mathrm{B}$ (pin) 1b with $\mathrm{Cu}-\mathrm{H}$ derived from imid(S)-1a

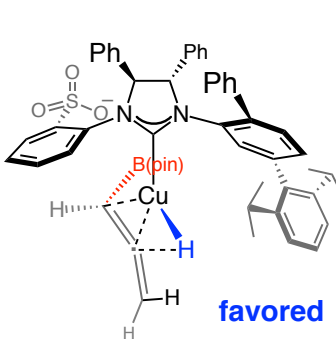

imid-1a(tsC1)

$\Delta \mathrm{E}_{\mathrm{rel}}=-7.2 \mathrm{kcal} / \mathrm{mol}$ $\Delta \mathrm{G}_{\mathrm{rel}}=11.4 \mathrm{kcal} / \mathrm{mol}$

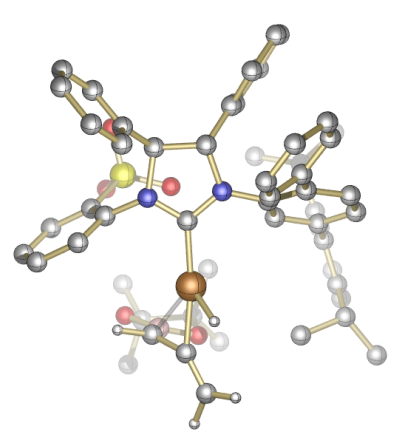

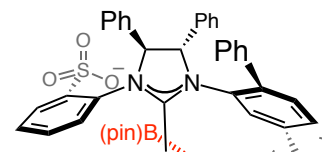
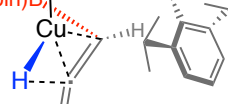

$\mathrm{H}-1$

imid-1a(tsC2)

$\Delta \mathrm{E}_{\text {rel }}=-4.9 \mathrm{kcal} / \mathrm{mol}$ $\Delta \mathrm{G}_{\mathrm{rel}}=15.9 \mathrm{kcal} / \mathrm{mol}$

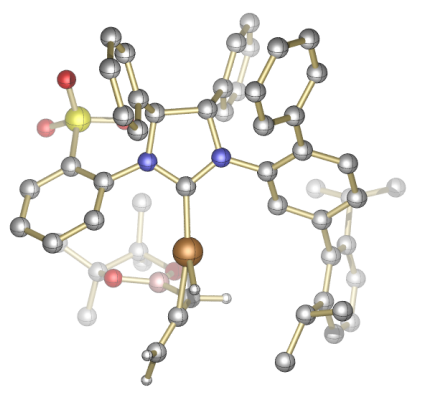

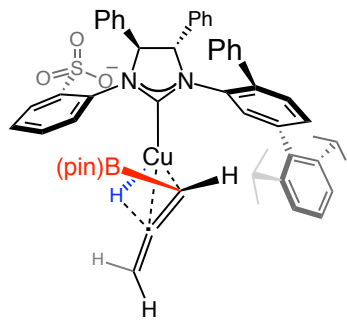

imid-1a(tsC3)

$\Delta \mathrm{E}_{\mathrm{rel}}=-4.7 \mathrm{kcal} / \mathrm{mol}$ $\Delta \mathrm{G}_{\mathrm{rel}}=12.1 \mathrm{kcal} / \mathrm{mol}$

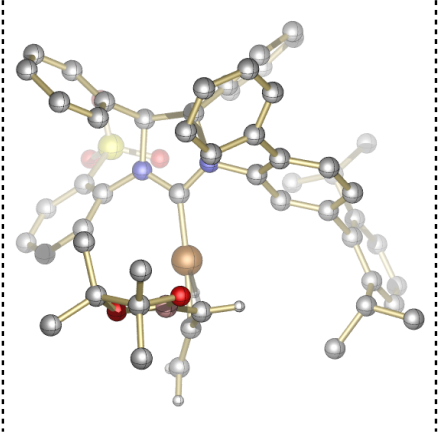

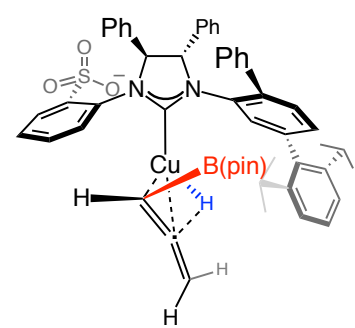

imid-1a(tsC4)

$\Delta \mathrm{E}_{\mathrm{rel}}=-4.1 \mathrm{kcal} / \mathrm{mol}$ $\Delta \mathrm{G}_{\mathrm{rel}}=15.4 \mathrm{kcal} / \mathrm{mol}$

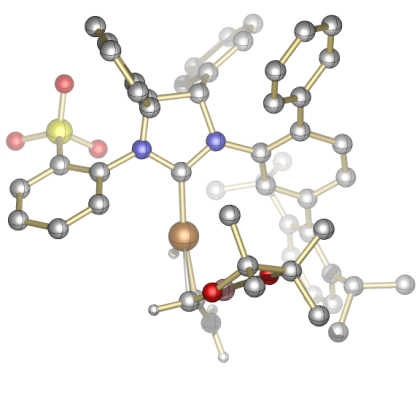

Electronic and free energy values correspond to the MN15/Def2TZVPP $\mathrm{CH}_{2 \mathrm{Cl}}$ (SMD)//M06L/Def2SVP $\mathrm{CH}_{2 \mathrm{Cl}(\mathrm{SMD})}$ level 


\subsection{Comparison of $\mathrm{Cu}-\mathrm{H}$ additions promoted by catalysts derived from imid(S)-1 $\mathrm{b}_{\mathrm{gs}}$ and imid(S)-1ags}

A summary of the pathways for $\mathrm{Cu}-\mathrm{H}$ addition to an allylic phosphate and allenes $\mathbf{1 a}$ and $\mathbf{1 b}$ promoted by a $\mathrm{Cu}$-based complex that is derived from imid(S)-1 b $\mathbf{b}_{\mathbf{g s}}$ is shown in Graph $\mathrm{S} 1.1$. Most notably, in the favored exteded transition state for addition to the allylic phosphate (i.e., reduction; cf. $\mathbf{t s}^{\mathbf{o p e n}}$; above) the $\mathrm{Cu}$ atom is delivered to $\mathrm{C} \alpha$ of the allyl electrophile $\mathbf{2 b}[9.5 \mathrm{kcal} / \mathrm{mol}$ for imid-1b(ts4.1) with MN15; Graph S1.1]. As noted above, it is likely that the $\mathrm{S}_{\mathrm{N}} 2$ ' reduction product (derived from $\mathrm{Cu}-$ $\mathrm{H}$ addition to the allylic phosphate) is formed through a transition state that involves a cationic bridge (cf. ts ${ }^{\text {bridge }}$ ). While $\mathrm{Cu}-\mathrm{H}$ addition to 1 a likely occurs when the $\mathrm{B}$ (pin) is oriented in the direction of the bulky NAr moiety [imid-1b(tsA4); Graph S1.1] when functionals accounting for dispersion are used (e.g., 9.8 and $17.0 \mathrm{kcal} / \mathrm{mol}$ with MN15 and $\omega \mathrm{B} 97 \mathrm{MV}$, repsectively), imid-1b(tsA3) (wherein the B(pin) group is pointing to the left) is predicted to be lower in energy when dispersion is omitted $(34.9 \mathrm{kcal} / \mathrm{mol}$ with $\omega \mathrm{B} 97 \mathrm{X})$. 556.5758 .59 Depending on the degree to which dispersion forces are operative in solution, the sizeable N-Ar group presumably functions as a dispersion energy donor (DED) and preferentially associates the large B(pin) moiety. Furthermore, the degree to which dispersion forces are relevant determines whether the $\mathrm{Cu}$ atom adds to the more substituted carbon of the allene $(9.8 \mathrm{vs} .17 .7 \mathrm{kcal} / \mathrm{mol}$ for imid-1b(tsA4) vs. imid-1b(tsB1), respectively with MN15), or prefers to react with alternative regioselectivity (34.9 vs. $30.7 \mathrm{kcal} / \mathrm{mol}$ for imid-1b(tsA3) vs imid-1b(tsB1), respectively with $\omega \mathrm{B} 97 \mathrm{X})$. Reaction with $\mathbf{1 b}$ is energetically more preferred compared to $\mathbf{1 a}$ and likely occurs through imid-1b(tsC1) $(9.5 \mathrm{kcal} / \mathrm{mol}$ with $\mathrm{MN} 15)$ or imid-1b(tsC3) $(14.8 \mathrm{kcal} / \mathrm{mol}$ with $\omega \mathrm{B} 97 \mathrm{MV})$. Transition state imid$\mathbf{1 b}(\mathbf{t s C 3})$ is also preferred with M06L and $\omega \mathrm{B} 97 \mathrm{XD}$ (see Graph S1-5, below).

In case of imid(S)-1a(Graph S2-1), $\mathbf{C u}-\mathrm{H}$ addition to $\mathbf{2 b}[10.3 \mathrm{kcal} / \mathrm{mol}$ for imid-1a(ts4.1) with MN15; Graph S2.1] requires a similar barrier compared to when the complex derived from imid(S)-1b [9.5 kcal/mol for imid-1b(ts4.1) with MN15; Graph S1.1]. It is difficult to predict, on the basis of computational studies alone, which of the two ligands promotes a faster $\mathrm{Cu}-\mathrm{H}$ addition to an allylic phosphate or whether such side reactions proceed at comparable rates. Regarding $\mathrm{Cu}-\mathrm{H}$ addition to allene 1a there appears to be a clear preference for transition state imid-1a(tsA3) $[12.4 \mathrm{kcal} / \mathrm{mol}$ with MN15; Graph S2-1)], wherein the B(pin) group is oriented to the left and away from the bulky NAr substitutent; this is likely owing to the absence of significant dispersion forces. Reaction with $\mathbf{1 b}$ is again energetically more preferred (vs. 1a) and likely transpired through imid-1a(tsC1) $(11.4 \mathrm{kcal} / \mathrm{mol}$ with MN15) or imid-1b(tsC3) $(15.9 \mathrm{kcal} / \mathrm{mol}$ with $\omega \mathrm{B} 97 \mathrm{MV})$.

In summary, $\mathrm{Cu}-\mathrm{H}$ addition to allenes $\mathbf{1 a}$ and $\mathbf{1 b}$ is likely more preferred in presence of imid(S)1b over imid(S)-1a based on the following data:

- 9.8 and $9.5 \mathrm{kcal} / \mathrm{mol}$ (with imid(S)-1b; Graph S1-1) vs 12.4 and $11.4 \mathrm{kcal} / \mathrm{mol}$ (with imid(S)-1a; Graph S2-1) with MN15

- 17.0 and $14.8 \mathrm{kcal} / \mathrm{mol}$ (with imid(S)-1b; Graph S1-1) vs 17.2 and $15.9 \mathrm{kcal} / \mathrm{mol}$ (with imid(S)-1a; Graph S2-1) with $\omega B$ 97MV 
$\operatorname{imid}(S)-1 b$

reduction of allyl

phosphate $2 b$

$\mathrm{Cu}-\mathrm{H}$ addition to allene $1 \mathrm{a} \quad \mathrm{Cu}-\mathrm{H}$ addition to allene $1 \mathrm{~b}$

110.0

90.0
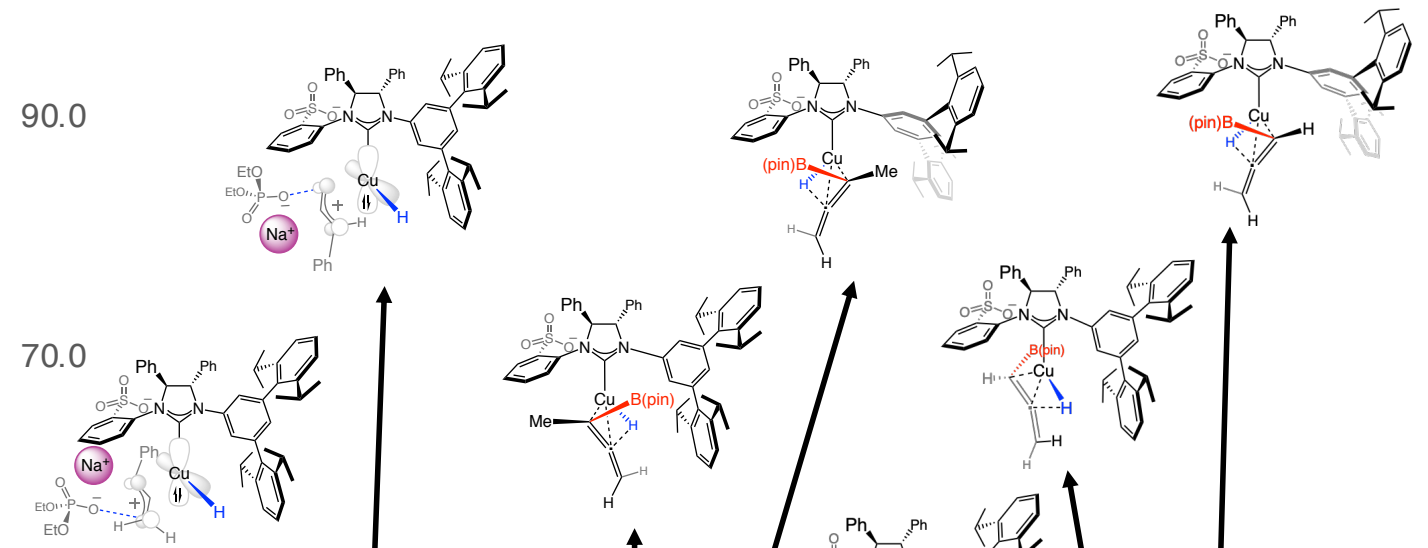

50.0

30.0

10.0
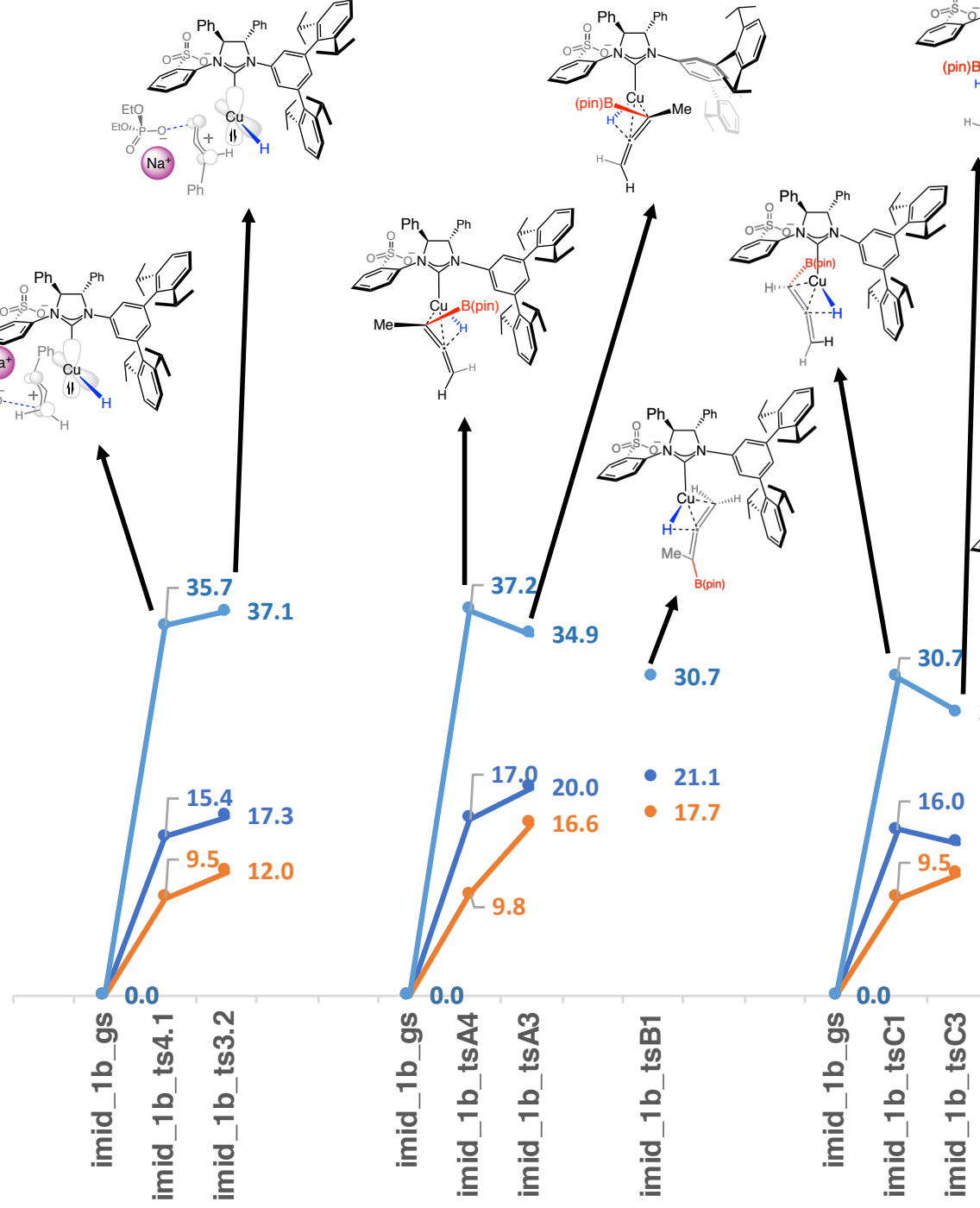

37.1

$-10.0$

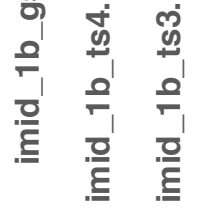

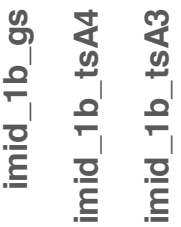

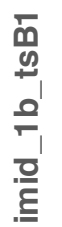

0
0
0
0
0
.0
.$\underline{\underline{E}}$

$-30.0$

Graph S1-1. Summary of Gibbs free energy values ( $\Delta \mathrm{G}$ relative to $\mathrm{Cu}-\mathrm{H}$ imid_1b_gs) for most favored transition states for reduction of allyl phosphate $\mathbf{2 b}$ (left) and $\mathrm{Cu}-\mathrm{H}$ addition to allenyl-B(pin) $\mathbf{1 a}$ (middle) and allenyl-B(pin)

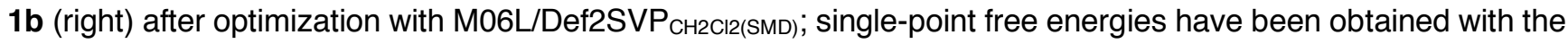
SMD model in $\mathrm{CH}_{2} \mathrm{Cl}_{2}$ and the Def2-TZVPP (MN15 and $\left.\omega \mathrm{B} 97 \mathrm{X}\right)$ or Def2-QZVPP basis set ( $\omega$ B97MV). 
$\operatorname{imid}(S)-1 b$

reduction of allyl

phosphate $2 b$

110.0

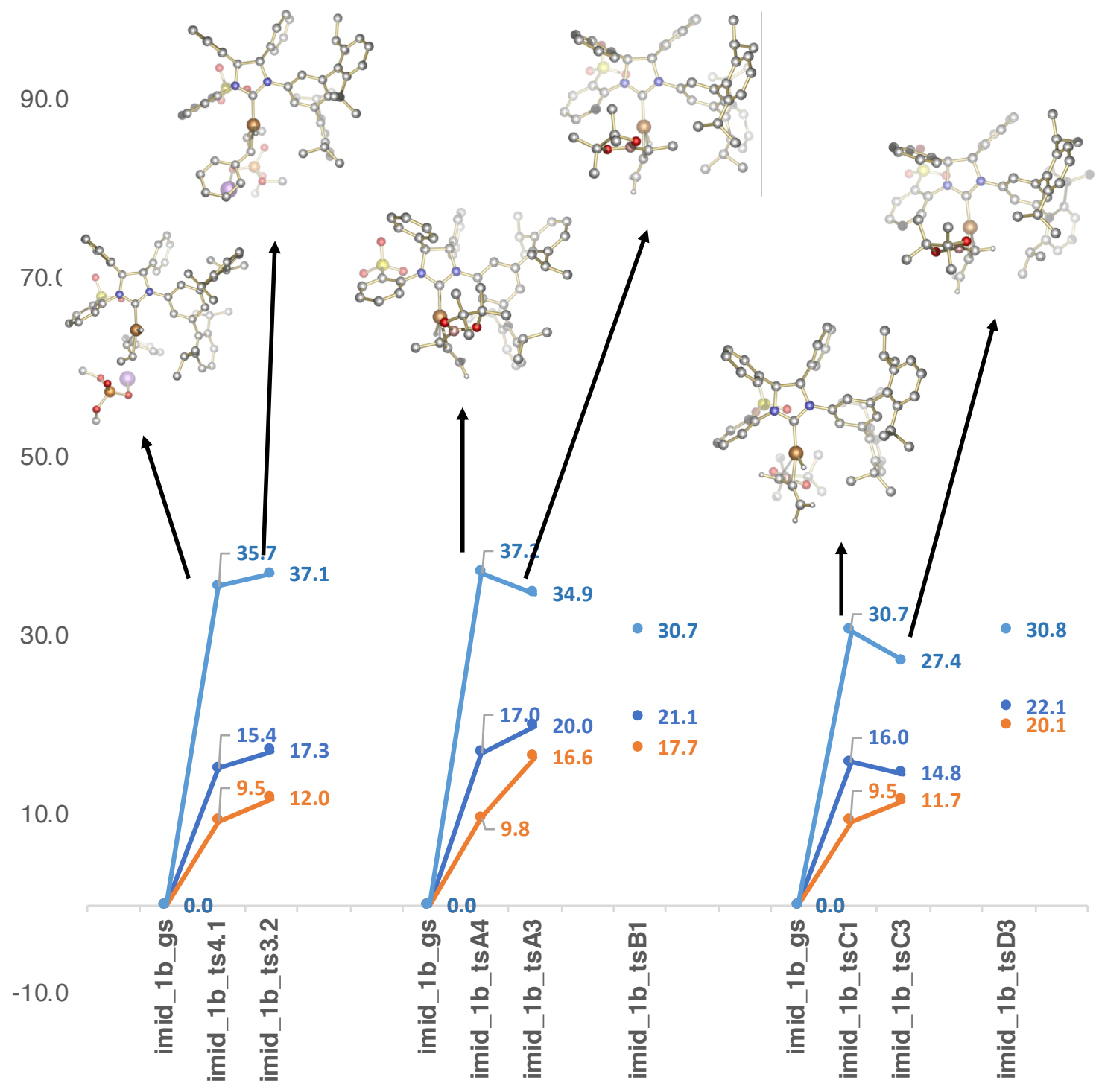

$-30.0$

Graph S1-2. Summary of Gibbs free energy values ( $\Delta \mathrm{G}$ relative to $\mathrm{Cu}-\mathrm{H}$ imid_1b_gs) for most favored transition states for reduction of allyl phosphate $\mathbf{2 b}$ (left) and $\mathrm{Cu}-\mathrm{H}$ addition to allenyl-B(pin) $\mathbf{1 a}$ (middle) and allenyl-B(pin)

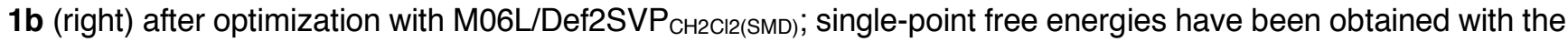
SMD model in $\mathrm{CH}_{2} \mathrm{Cl}_{2}$ and the Def2-TZVPP (MN15 and $\omega \mathrm{B97X}$ ) or Def2-QZVPP basis set ( $\omega$ B97MV). 
$\operatorname{imid}(S)-1 a$

reduction of allyl phosphate 2b
$\mathrm{Cu}-\mathrm{H}$ addition to allene $1 \mathrm{a}$

$\mathrm{Cu}-\mathrm{H}$ addition to allene $1 \mathrm{~b}$

110.0

90.0

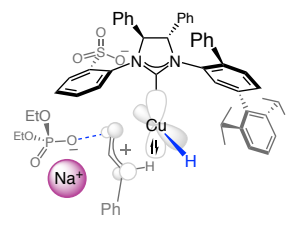

70.0

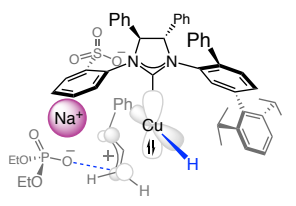

50.0

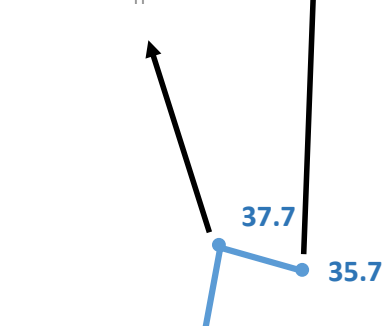

30.0

10.0
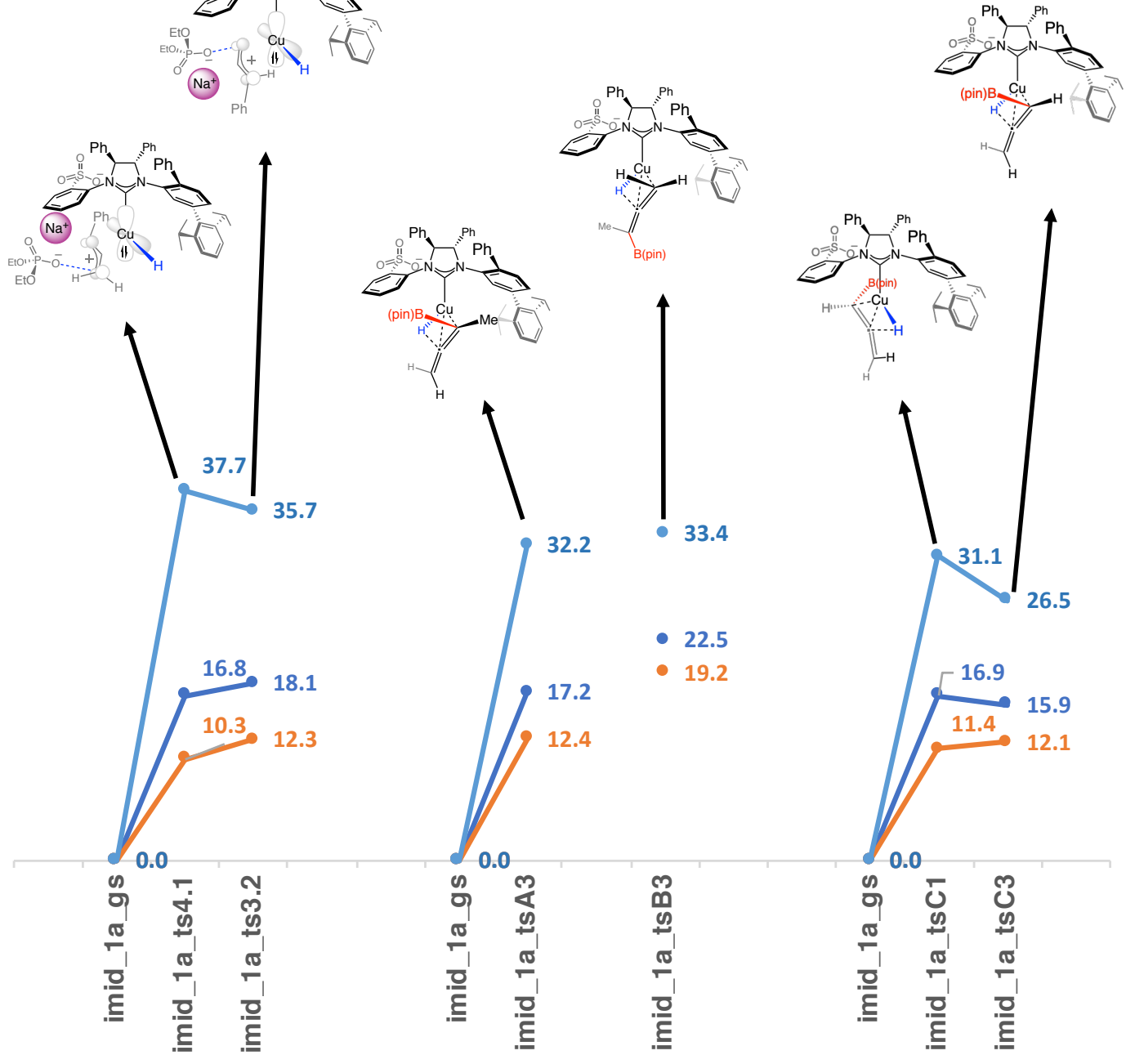

$-10.0$

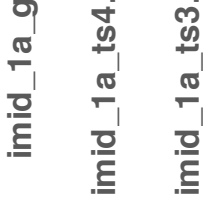

- 22.5

33.4

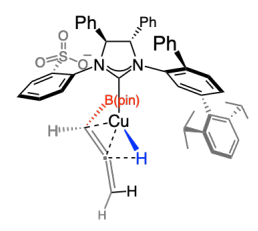

$$
\uparrow
$$
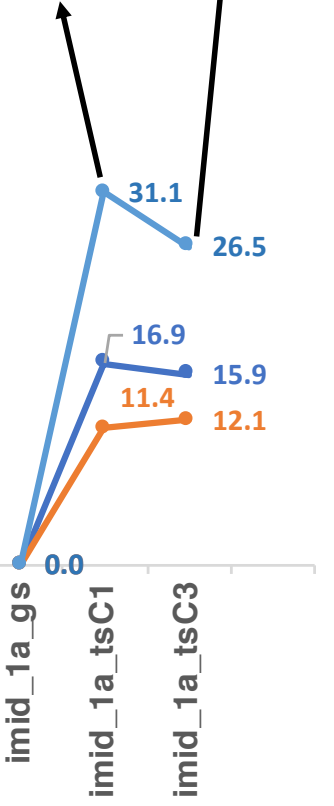

$-30.0$

Graph S2-1. Summary of Gibbs free energy values ( $\Delta \mathrm{G}$ relative to $\mathrm{Cu}-\mathrm{H}$ imid_1a_gs) for most favored transition states for reduction of allyl phosphate $\mathbf{2 b}$ (left) and $\mathrm{Cu}-\mathrm{H}$ addition to allenyl-B(pin) $\mathbf{1 a}$ (middle) and allenyl-B(pin)

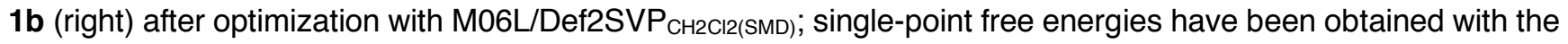
SMD model in $\mathrm{CH}_{2} \mathrm{Cl}_{2}$ and the Def2-TZVPP (MN15 and $\left.\omega \mathrm{B} 97 \mathrm{X}\right)$ or Def2-QZVPP basis set ( $\left.\omega \mathrm{B} 97 \mathrm{MV}\right)$. 
imid(S)-1a

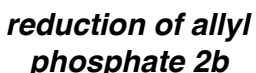

phosphate $2 b$

110.0

90.0

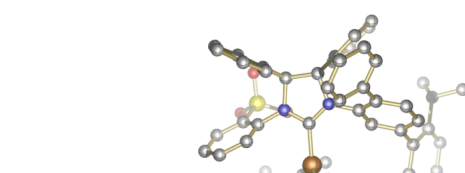

70.0

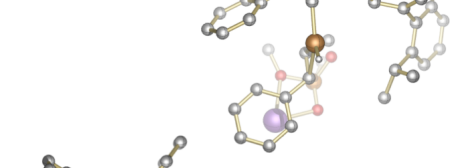

50.0
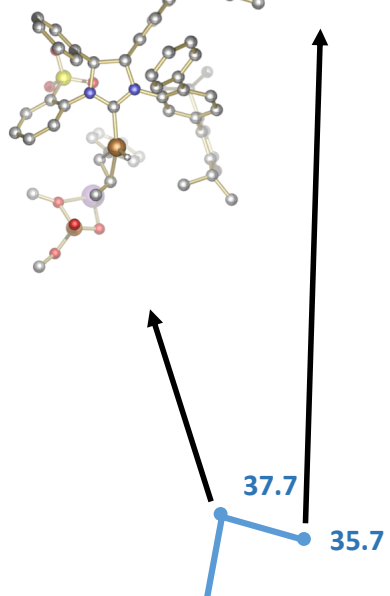

30.0

10.0

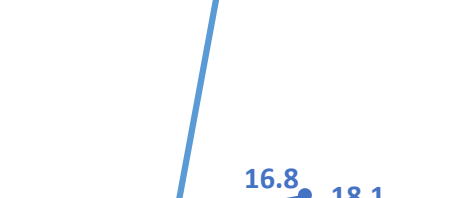

$-10.0$
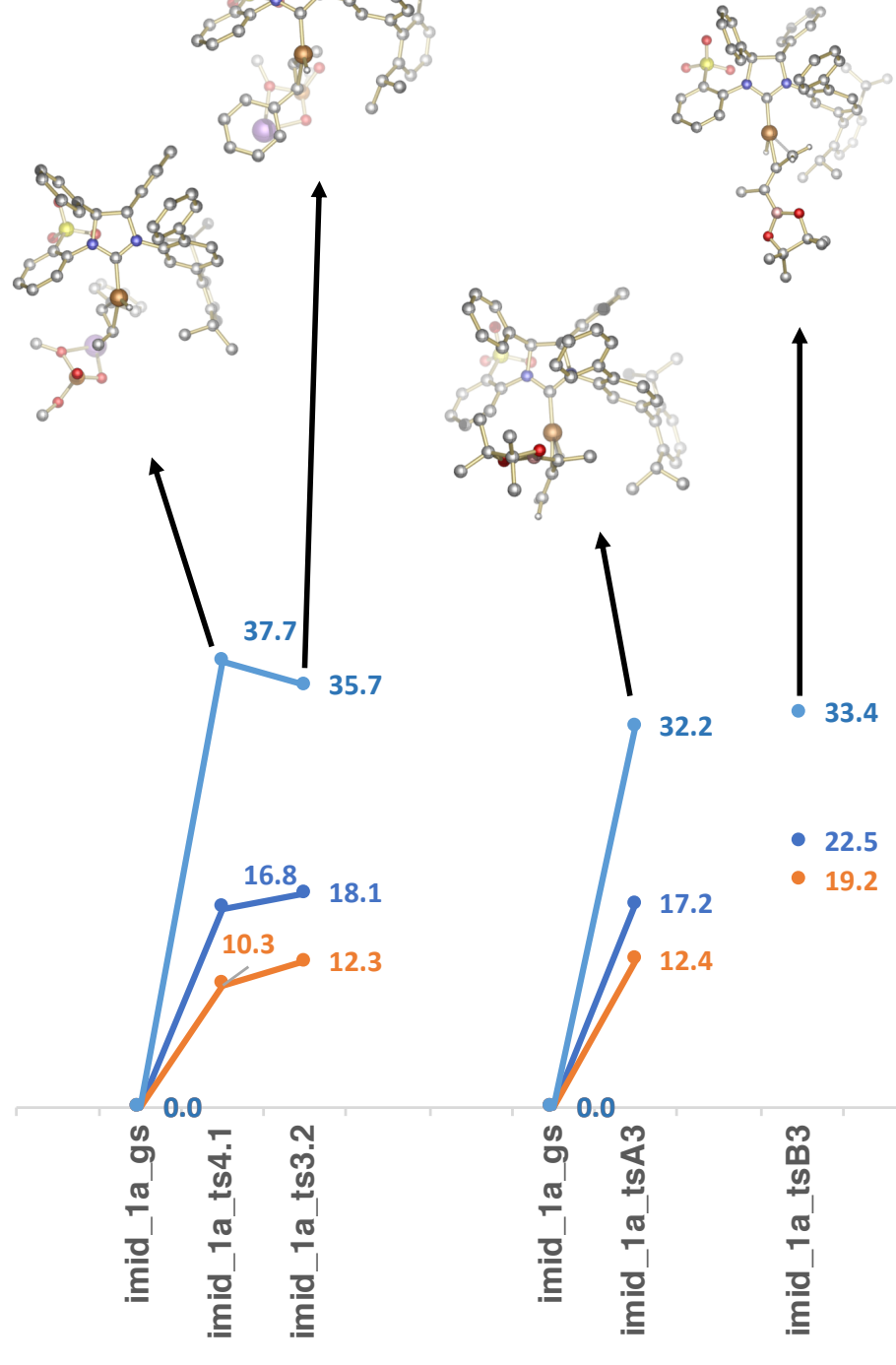

33.4

- 22.5

- 19.2
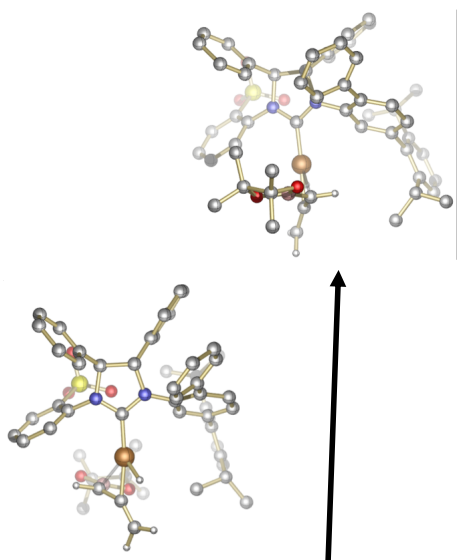

\section{$\mathrm{Cu}-\mathrm{H}$ addition to allene $\mathbf{1 b}$}




\title{
15.9 Summary for investigation with functionals MN15, M06L, $\omega B$ 97MD, $\omega B$ 97XD and $\omega B$ 97X
}

\author{
$\Delta G$ with imid-1b and allene $1 a$
}
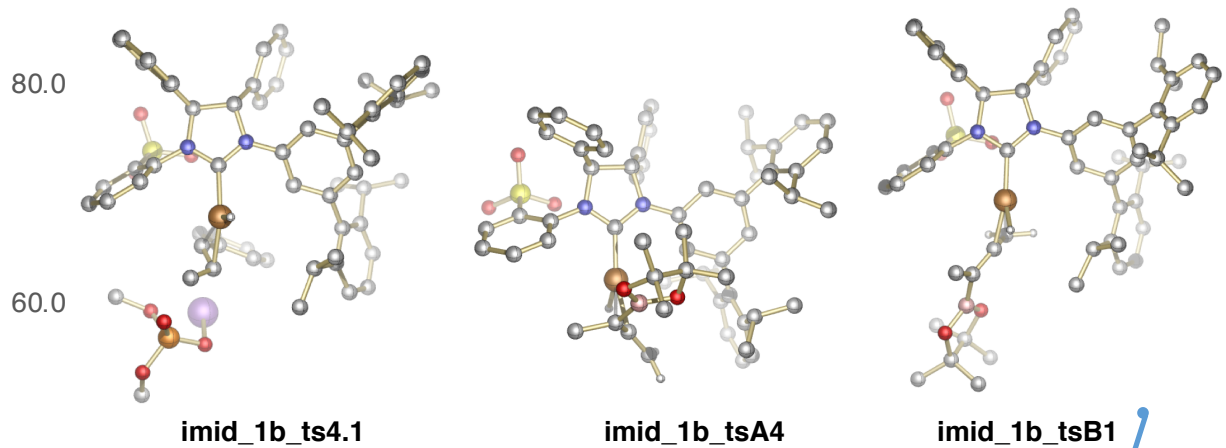

40.0
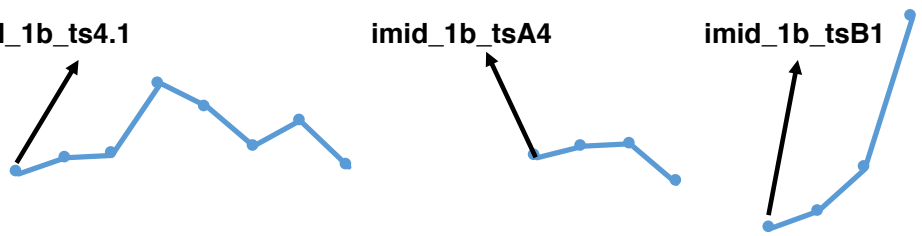

20.0
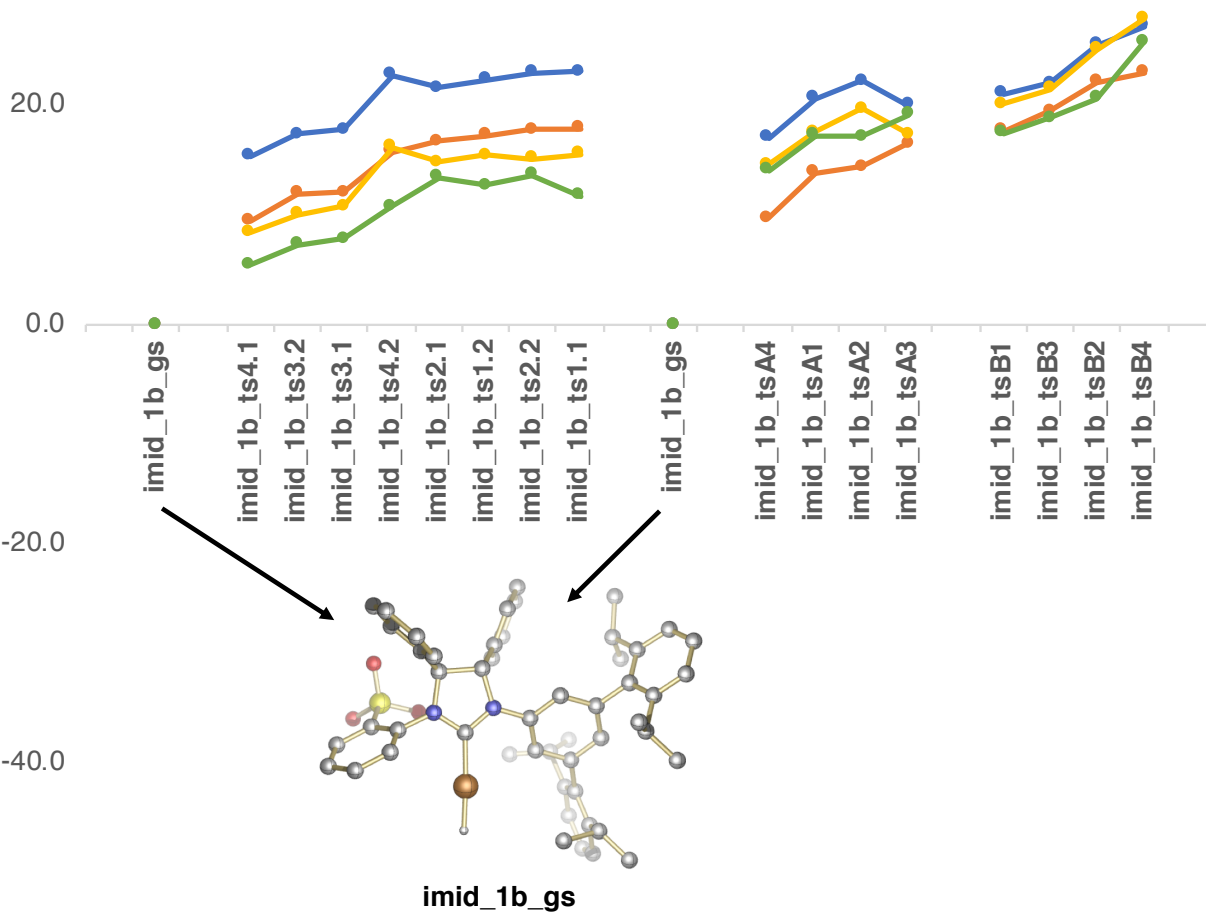

$-60.0$

Graph S1-3. Gibbs free energy values ( $\Delta \mathrm{G}$ relative to $\mathrm{Cu}-\mathrm{H}$ imid_1b_gs) for reduction of allyl phosphate (imid_1b_ts1.1 - imid_1b_ts4.2; left) and $\mathrm{Cu}-\mathrm{H}$ addition to allenyl-B(pin) 1a (imid_1b_tsA1 - imid_1b_tsB4;

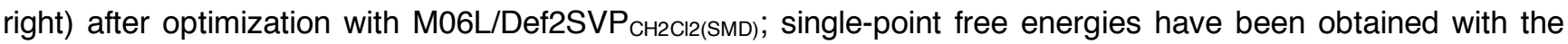
SMD model in $\mathrm{CH}_{2} \mathrm{Cl}_{2}$ and the Def2-TZVPP (MN15, M06L, $\omega \mathrm{B} 97 \mathrm{XD}$ and $\omega \mathrm{B} 97 \mathrm{X}$ ) or Def2-QZVPP basis set $(\omega \mathrm{B} 97 \mathrm{MV})$. 


\begin{tabular}{|c|c|c|c|c|c|}
\hline$\Delta \mathbf{G}$ values & MN15 & M06L & wB97MV & wB97XD & wB97X \\
\hline imid_1b_gs & 0.0 & 0.0 & 0.0 & 0.0 & 0.0 \\
\hline imid_1b_ts4.1 & 9.5 & 5.5 & 15.4 & 8.4 & 35.7 \\
\hline imid_1b_ts3.2 & 12.0 & 7.3 & 17.3 & 10.1 & 37.1 \\
\hline imid_1b_ts3.1 & 12.0 & 7.9 & 17.8 & 10.8 & 37.4 \\
\hline imid_1b_ts 4.2 & 15.8 & 10.8 & 22.8 & 16.2 & 43.9 \\
\hline imid_1b_ts2.1 & 16.7 & 13.4 & 21.7 & 14.9 & 41.8 \\
\hline imid_1b_ts1.2 & 17.3 & 12.8 & 22.3 & 15.5 & 38.2 \\
\hline imid_1b_ts2.2 & 17.8 & 13.6 & 23.0 & 15.1 & 40.5 \\
\hline imid_1b_ts1.1 & 17.9 & 11.7 & 23.1 & 15.6 & 36.3 \\
\hline imid_1b_gs & 0.0 & 0.0 & 0.0 & 0.0 & 0.0 \\
\hline imid_1b_tsA4 & 9.8 & 14.1 & 17.0 & 14.7 & 37.2 \\
\hline imid_1b_tsA1 & 13.9 & 17.3 & 20.7 & 17.6 & 38.1 \\
\hline imid_1b_tsA2 & 14.4 & 17.1 & 22.3 & 19.7 & 38.4 \\
\hline imid_1b_tsA3 & 16.6 & 19.2 & 20.0 & 17.4 & 34.9 \\
\hline imid_1b_tsB1 & 17.7 & 17.5 & 21.1 & 20.2 & 30.7 \\
\hline imid_1b_tsB3 & 19.5 & 18.8 & 22.0 & 21.6 & 32.2 \\
\hline imid_1b_tsB2 & 22.2 & 20.7 & 25.6 & 25.1 & 36.2 \\
\hline imid_1b_tsB4 & 23.0 & 25.9 & 27.2 & 27.9 & 50.0 \\
\hline
\end{tabular}

Table S1. Gibbs free energy values ( $\Delta \mathrm{G}$ relative to $\mathrm{Cu}-\mathrm{H}$ imid_1b_gs) for reduction of allyl phosphate (imid_1b_ts1.1 - imid_1b_ts4.2; left) and $\mathrm{Cu}-\mathrm{H}$ addition to allenyl-B(pin) 1a (imid_1b_tsA1 - imid_1b_tsB4;

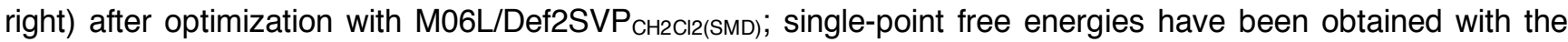
SMD model in $\mathrm{CH}_{2} \mathrm{Cl}_{2}$ and the Def2-TZVPP (MN15, M06L, $\omega$ B97XD and $\omega$ B97X) or Def2-QZVPP basis set $(\omega \mathrm{B} 97 \mathrm{MV})$. 
$\Delta \mathrm{E}$ with imid-1b and allene $1 \mathrm{a}$

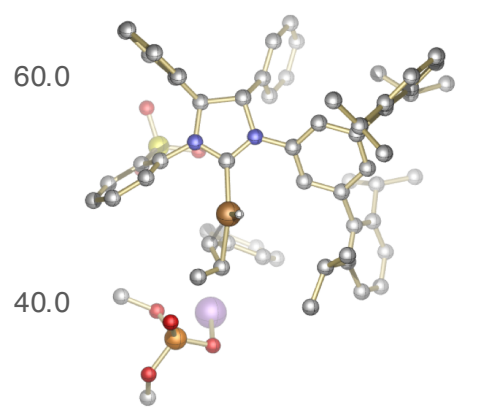

imid_1b ts 4.1

20.0

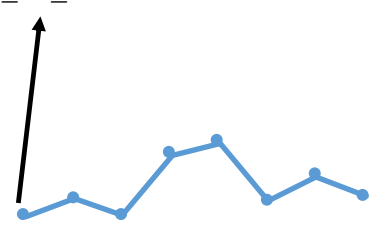

$-20.0$

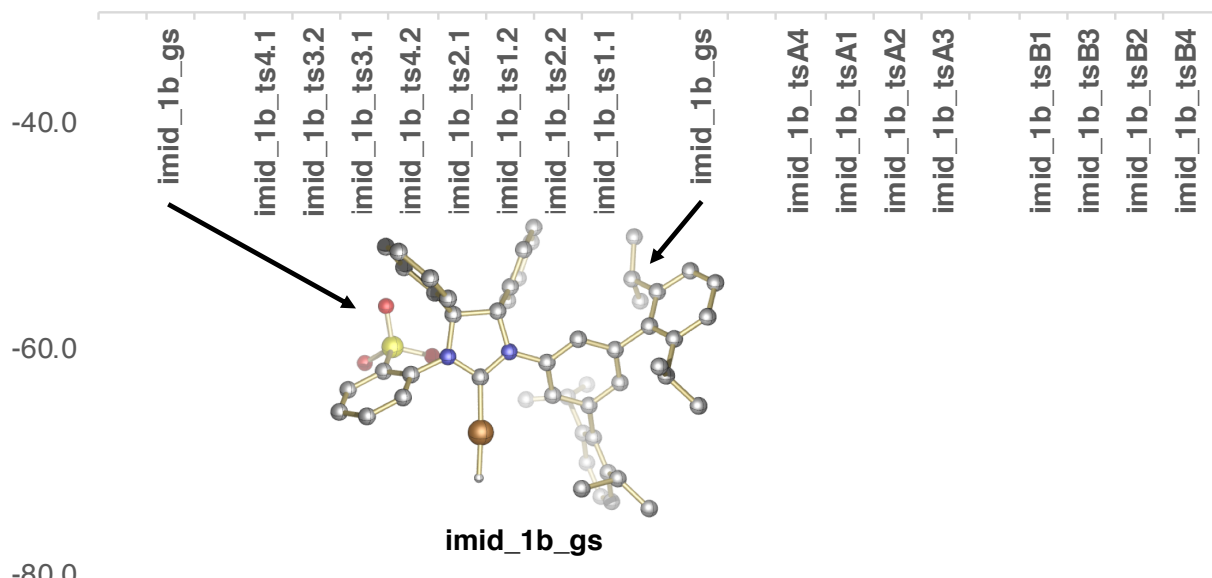

$-80.0$

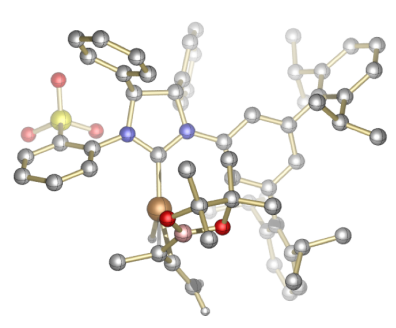

imid_1b_tsA4
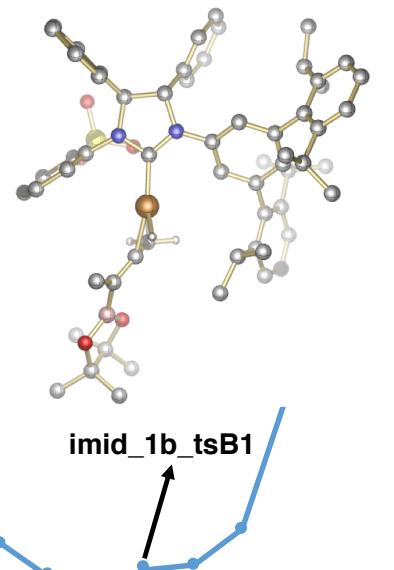

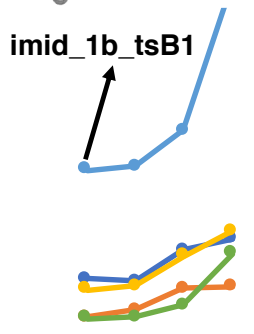

0.0
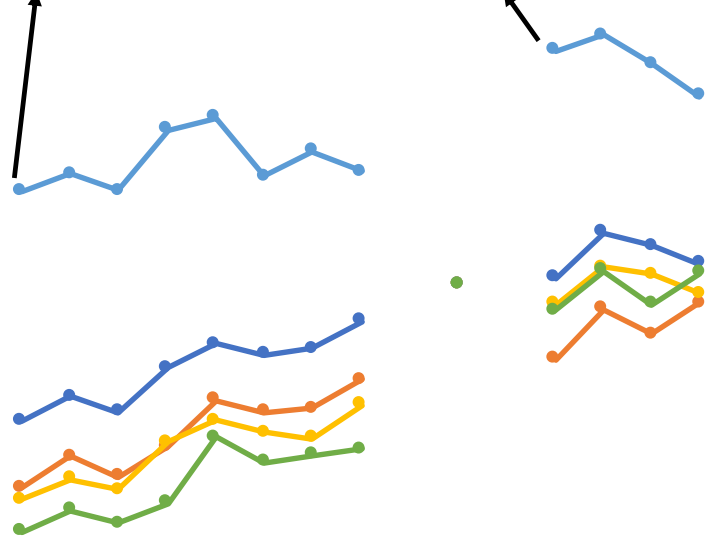

$$
\multimap \text { wB97MV } \multimap \text { MN15 } \multimap \text { WB97XD WB97X } \multimap \text { M06L }
$$

Graph S1-4. Electronic energy values ( $\Delta \mathrm{E}$ relative to $\mathrm{Cu}-\mathrm{H}$ imid_1b_gs) for reduction of allyl phosphate (imid_1b_ts1.1 - imid_1b_ts4.2; left) and $\mathrm{Cu}$-H addition to allenyl-B(pin) 1a (imid_1b_tsA1 - imid_1b_tsB4;

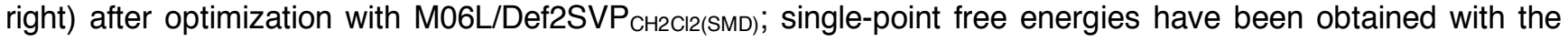
SMD model in $\mathrm{CH}_{2} \mathrm{Cl}_{2}$ and the Def2-TZVPP (MN15, M06L, $\omega$ B97XD and $\omega$ B97X) or Def2-QZVPP basis set $(\omega \mathrm{B} 97 \mathrm{MV})$. 


\begin{tabular}{|c|c|c|c|c|c|}
\hline$\Delta \mathrm{E}$ values & MN15 & M06L & wB97MV & wB97XD & wB97X \\
\hline imid_1b_gs & 0.0 & 0.0 & 0.0 & 0.0 & 0.0 \\
\hline imid_1b_ts4.1 & -17.9 & -21.9 & -12.0 & -18.9 & 8.3 \\
\hline imid_1b_ts3.2 & -15.2 & -19.9 & -9.8 & -17.1 & 9.9 \\
\hline imid_1b_ts3.1 & -16.9 & -21.1 & -11.2 & -18.1 & 8.4 \\
\hline imid_1b_ts4.2 & -14.3 & -19.2 & -7.3 & -13.8 & 13.9 \\
\hline imid_1b_ts2.1 & -10.1 & -13.4 & -5.2 & -12.0 & 14.9 \\
\hline imid_1b_ts1.2 & -11.2 & -15.7 & -6.1 & -13.0 & 9.7 \\
\hline imid_1b_ts2.2 & -10.9 & -15.0 & -5.6 & -13.5 & 11.9 \\
\hline imid_1b_ts1.1 & -8.3 & -14.5 & -3.1 & -10.6 & 10.1 \\
\hline imid_1b_gs & 0.0 & 0.0 & 0.0 & 0.0 & 0.0 \\
\hline imid_1b_tsA4 & -6.6 & -2.2 & 0.7 & -1.7 & 20.8 \\
\hline imid_1b_tsA1 & -2.1 & 1.3 & 4.7 & 1.6 & 22.2 \\
\hline imid_1b_tsA2 & -4.3 & -1.6 & 3.5 & 0.9 & 19.7 \\
\hline imid_1b_tsA3 & -1.5 & 1.1 & 1.9 & -0.8 & 16.8 \\
\hline imid_1b_tsB1 & 4.4 & 4.2 & 7.8 & 6.9 & 17.5 \\
\hline imid_1b_tsB3 & 5.0 & 4.3 & 7.5 & 7.1 & 17.7 \\
\hline imid_1b_tsB2 & 6.9 & 5.4 & 10.3 & 9.8 & 20.9 \\
\hline imid_1b_tsB4 & 7.1 & 10.0 & 11.3 & 12.0 & 34.1 \\
\hline
\end{tabular}

Table S2. Electronic energy values $(\Delta \mathrm{G}$ relative to $\mathrm{Cu}-\mathrm{H}$ imid_1b_gs) for reduction of allyl phosphate (imid_1b_ts1.1 - imid_1b_ts4.2; left) and $\mathrm{Cu}-\mathrm{H}$ addition to allenyl-B(pin) 1a (imid_1b_tsA1 - imid_1b_tsB4;

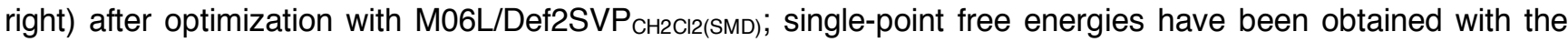
SMD model in $\mathrm{CH}_{2} \mathrm{Cl}_{2}$ and the Def2-TZVPP (MN15, M06L, $\omega$ B97XD and $\omega$ B97X) or Def2-QZVPP basis set $(\omega \mathrm{B} 97 \mathrm{MV})$. 


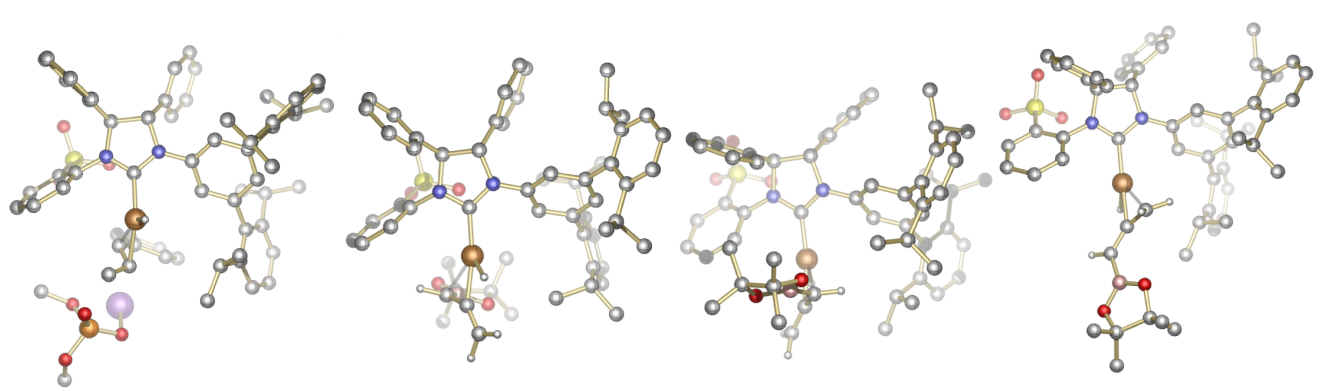

imid_1b_ts4.1 imid_1b_tsC1
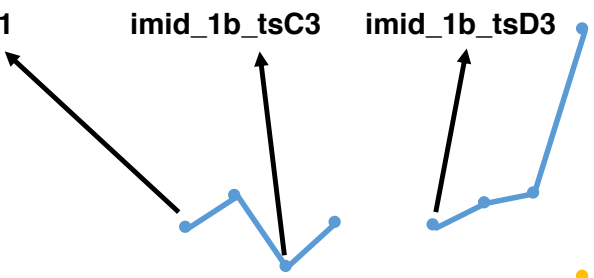

40.0

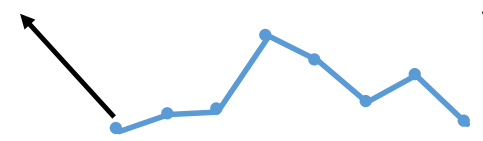

20.0
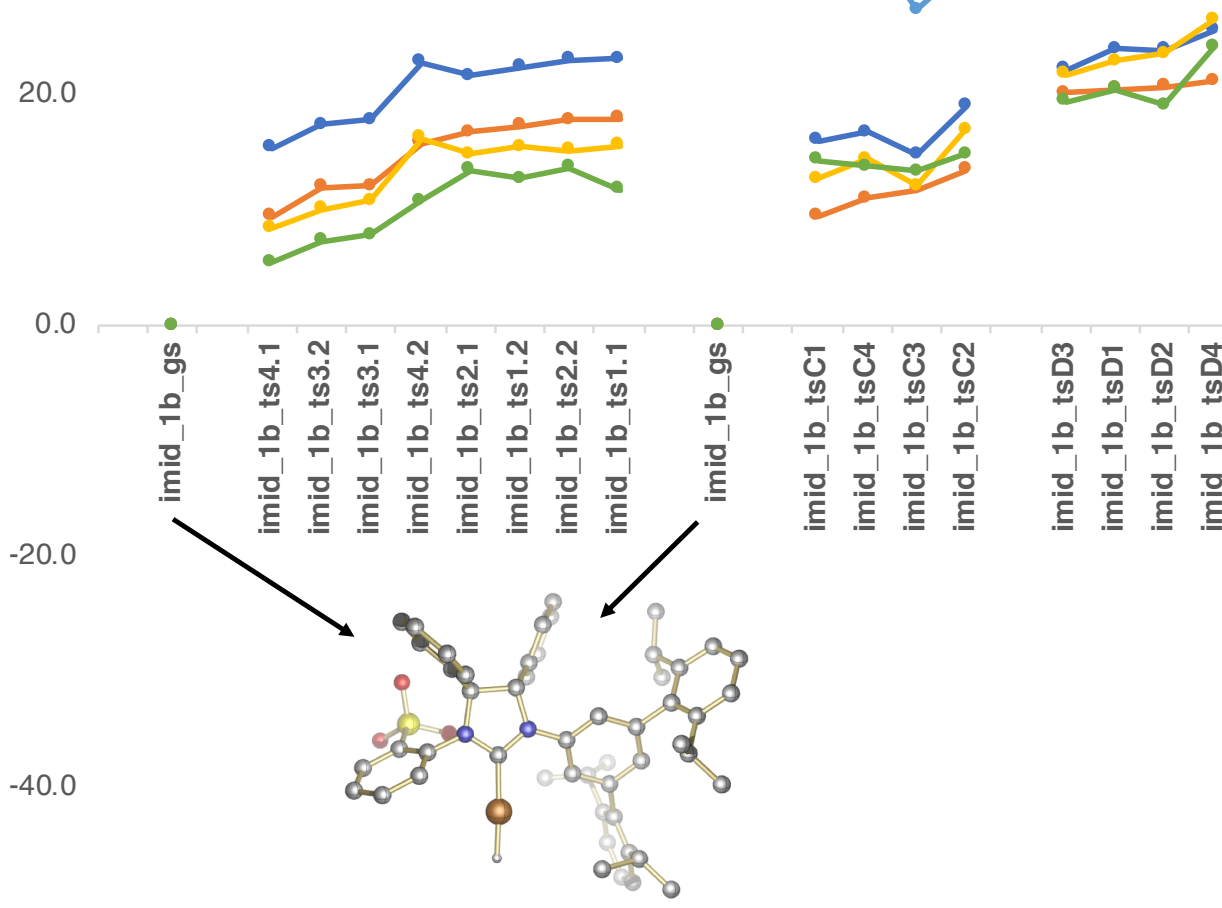

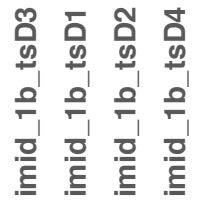

imid_1b_gs

$-60.0$

$\multimap$ wB97MV $\rightarrow$ MN15 $\multimap$ WB97XD $\multimap$ WB97X $\rightarrow$ M06L

Graph S1-5. Gibbs free energy values ( $\Delta \mathrm{G}$ relative to $\mathrm{Cu}-\mathrm{H}$ imid_1b_gs) for reduction of allyl phosphate (imid_1b_ts1.1 - imid_1b_ts4.2; left) and $\mathrm{Cu}-\mathrm{H}$ addition to allenyl-B(pin) 1b (imid_1b_tsC1 - imid_1b_tsD4;

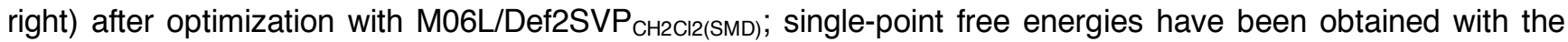
SMD model in $\mathrm{CH}_{2} \mathrm{Cl}_{2}$ and the Def2-TZVPP (MN15, M06L, $\omega \mathrm{B} 97 \mathrm{XD}$ and $\omega \mathrm{B} 97 \mathrm{X}$ ) or Def2-QZVPP basis set $(\omega \mathrm{B} 97 \mathrm{MV})$. 


\begin{tabular}{|c|c|c|c|c|c|}
\hline$\Delta \mathbf{G}$ values & MN15 & M06L & wB97MV & wB97XD & wB97X \\
\hline imid_1b_gs & 0.0 & 0.0 & 0.0 & 0.0 & 0.0 \\
\hline imid_1b_ts4.1 & 9.5 & 5.5 & 15.4 & 8.4 & 35.7 \\
\hline imid_1b_ts3.2 & 12.0 & 7.3 & 17.3 & 10.1 & 37.1 \\
\hline imid_1b_ts3.1 & 12.0 & 7.9 & 17.8 & 10.8 & 37.4 \\
\hline imid_1b_ts4.2 & 15.8 & 10.8 & 22.8 & 16.2 & 43.9 \\
\hline imid_1b_ts2.1 & 16.7 & 13.4 & 21.7 & 14.9 & 41.8 \\
\hline imid_1b_ts1.2 & 17.3 & 12.8 & 22.3 & 15.5 & 38.2 \\
\hline imid_1b_ts2.2 & 17.8 & 13.6 & 23.0 & 15.1 & 40.5 \\
\hline imid_1b_ts1.1 & 17.9 & 11.7 & 23.1 & 15.6 & 36.3 \\
\hline imid_1b_gs & 0.0 & 0.0 & 0.0 & 0.0 & 0.0 \\
\hline imid_1b_tsC1 & 9.5 & 14.4 & 16.0 & 12.7 & 30.7 \\
\hline imid_1b_tsC4 & 11.0 & 13.7 & 16.7 & 14.4 & 33.5 \\
\hline imid_1b_tsC3 & 11.7 & 13.3 & 14.8 & 12.1 & 27.4 \\
\hline imid_1b_tsC2 & 13.4 & 14.8 & 19.0 & 17.0 & 31.2 \\
\hline imid_1b_tsD3 & 20.1 & 19.4 & 22.1 & 21.7 & 30.8 \\
\hline imid_1b_tsD1 & 20.5 & 20.4 & 24.0 & 22.9 & 32.9 \\
\hline imid_1b_tsD2 & 20.7 & 19.1 & 23.9 & 23.5 & 33.7 \\
\hline imid_1b_tsD4 & 21.2 & 24.2 & 25.6 & 26.5 & 47.8 \\
\hline
\end{tabular}

Table S3. Gibbs free energy values ( $\Delta \mathrm{G}$ relative to $\mathrm{Cu}-\mathrm{H}$ imid_1b_gs) for reduction of allyl phosphate (imid_1b_ts1.1 - imid_1b_ts4.2; left) and $\mathrm{Cu}-\mathrm{H}$ addition to allenyl-B(pin) 1b (imid_1b_tsC1 - imid_1b_tsD4;

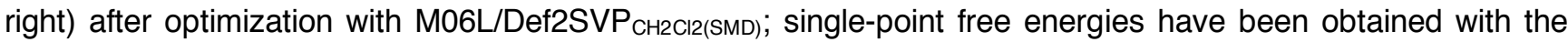
SMD model in $\mathrm{CH}_{2} \mathrm{Cl}_{2}$ and the Def2-TZVPP (MN15, M06L, $\omega$ B97XD and $\omega \mathrm{B} 97 \mathrm{X}$ ) or Def2-QZVPP basis set $(\omega \mathrm{B} 97 \mathrm{MV})$. 

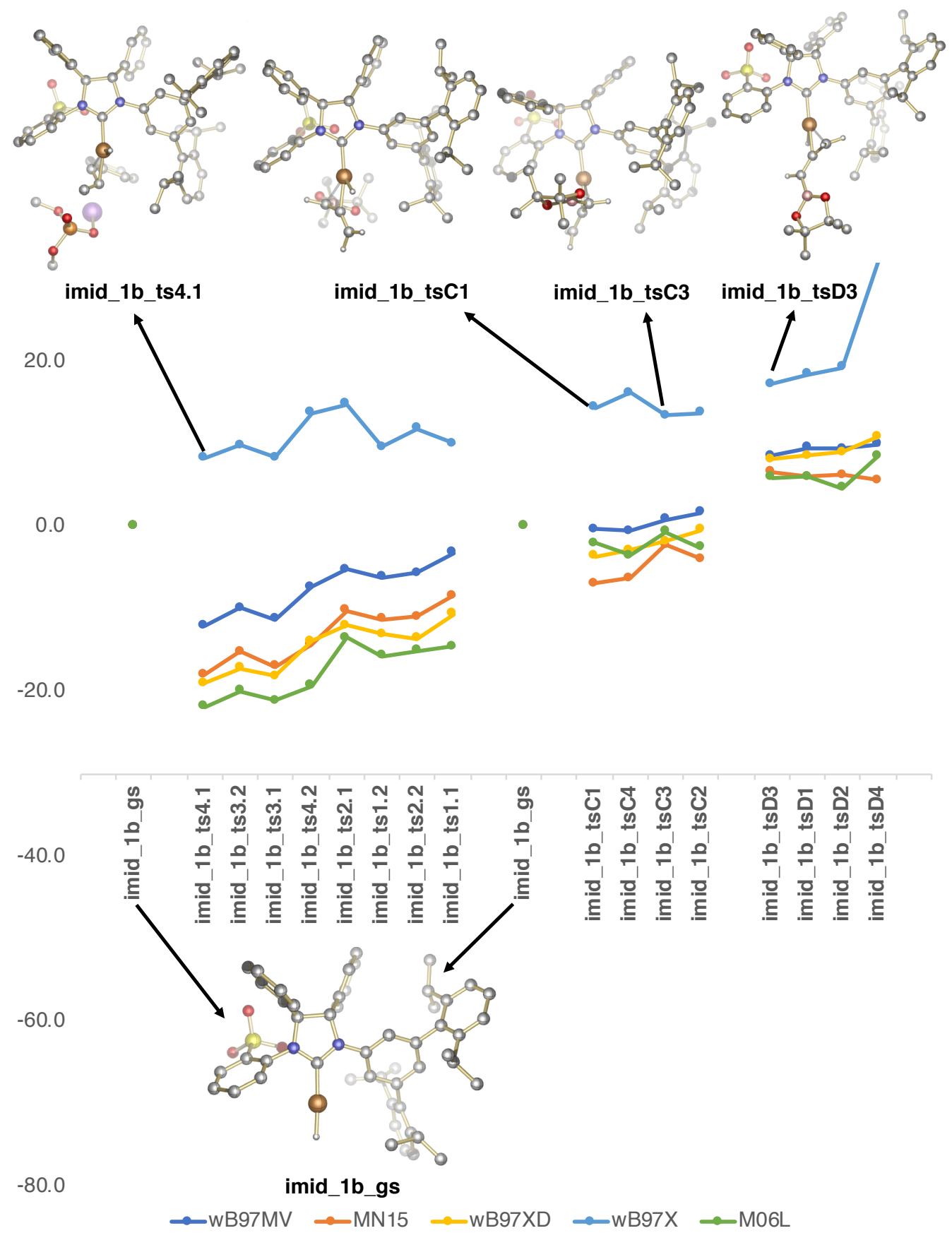

Graph S1-6. Electronic energy values ( $\Delta \mathrm{E}$ relative to $\mathrm{Cu}-\mathrm{H}$ imid_1b_gs) for reduction of allyl phosphate (imid_1b_ts1.1 - imid_1b_ts4.2; left) and $\mathrm{Cu}-\mathrm{H}$ addition to allenyl-B(pin) 1b (imid_1b_tsC1 - imid_1b_tsD4;

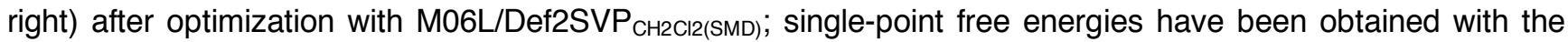
SMD model in $\mathrm{CH}_{2} \mathrm{Cl}_{2}$ and the Def2-TZVPP (MN15, M06L, $\omega \mathrm{B} 97 \mathrm{XD}$ and $\omega \mathrm{B} 97 \mathrm{X}$ ) or Def2-QZVPP basis set

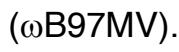




\begin{tabular}{|c|c|c|c|c|c|}
\hline$\Delta E$ values & MN15 & M06L & wB97MV & wB97XD & wB97X \\
\hline imid_1b_gs & 0.0 & 0.0 & 0.0 & 0.0 & 0.0 \\
\hline imid_1b_ts4.1 & -17.9 & -21.9 & -12.0 & -18.9 & 8.3 \\
\hline imid_1b_ts3.2 & -15.2 & -19.9 & -9.8 & -17.1 & 9.9 \\
\hline imid_1b_ts3.1 & -16.9 & -21.1 & -11.2 & -18.1 & 8.4 \\
\hline imid_1b_ts 4.2 & -14.3 & -19.2 & -7.3 & -13.8 & 13.9 \\
\hline imid_1b_ts2.1 & -10.1 & -13.4 & -5.2 & -12.0 & 14.9 \\
\hline imid_1b_ts1.2 & -11.2 & -15.7 & -6.1 & -13.0 & 9.7 \\
\hline imid_1b_ts2.2 & -10.9 & -15.0 & -5.6 & -13.5 & 11.9 \\
\hline imid_1b_ts1.1 & -8.3 & -14.5 & -3.1 & -10.6 & 10.1 \\
\hline imid_1b_gs & 0.0 & 0.0 & 0.0 & 0.0 & 0.0 \\
\hline imid_1b_tsC1 & -6.8 & -1.9 & -0.3 & -3.6 & 14.4 \\
\hline imid_1b_tsC4 & -6.2 & -3.5 & -0.5 & -2.8 & 16.2 \\
\hline imid_1b_tsC3 & -2.2 & -0.6 & 0.9 & -1.8 & 13.5 \\
\hline imid_1b_tsC2 & -3.9 & -2.5 & 1.7 & -0.3 & 13.9 \\
\hline imid_1b_tsD3 & 6.6 & 6.0 & 8.6 & 8.2 & 17.4 \\
\hline imid_1b_tsD1 & 6.1 & 6.1 & 9.6 & 8.6 & 18.5 \\
\hline imid_1b_tsD2 & 6.3 & 4.7 & 9.4 & 9.1 & 19.3 \\
\hline imid_1b_tsD4 & 5.6 & 8.6 & 10.0 & 11.0 & 32.2 \\
\hline
\end{tabular}

Table S4. Electronic energy values $(\Delta \mathrm{G}$ relative to $\mathrm{Cu}-\mathrm{H}$ imid_1b_gs) for reduction of allyl phosphate (imid_1b_ts1.1 - imid_1b_ts4.2; left) and $\mathrm{Cu}-\mathrm{H}$ addition to allenyl-B(pin) 1b (imid_1b_tsC1 - imid_1b_tsD4;

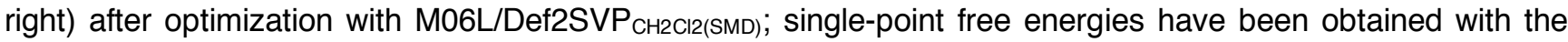
SMD model in $\mathrm{CH}_{2} \mathrm{Cl}_{2}$ and the Def2-TZVPP (MN15, M06L, $\omega$ B97XD and $\omega$ B97X) or Def2-QZVPP basis set $(\omega \mathrm{B} 97 \mathrm{MV})$. 

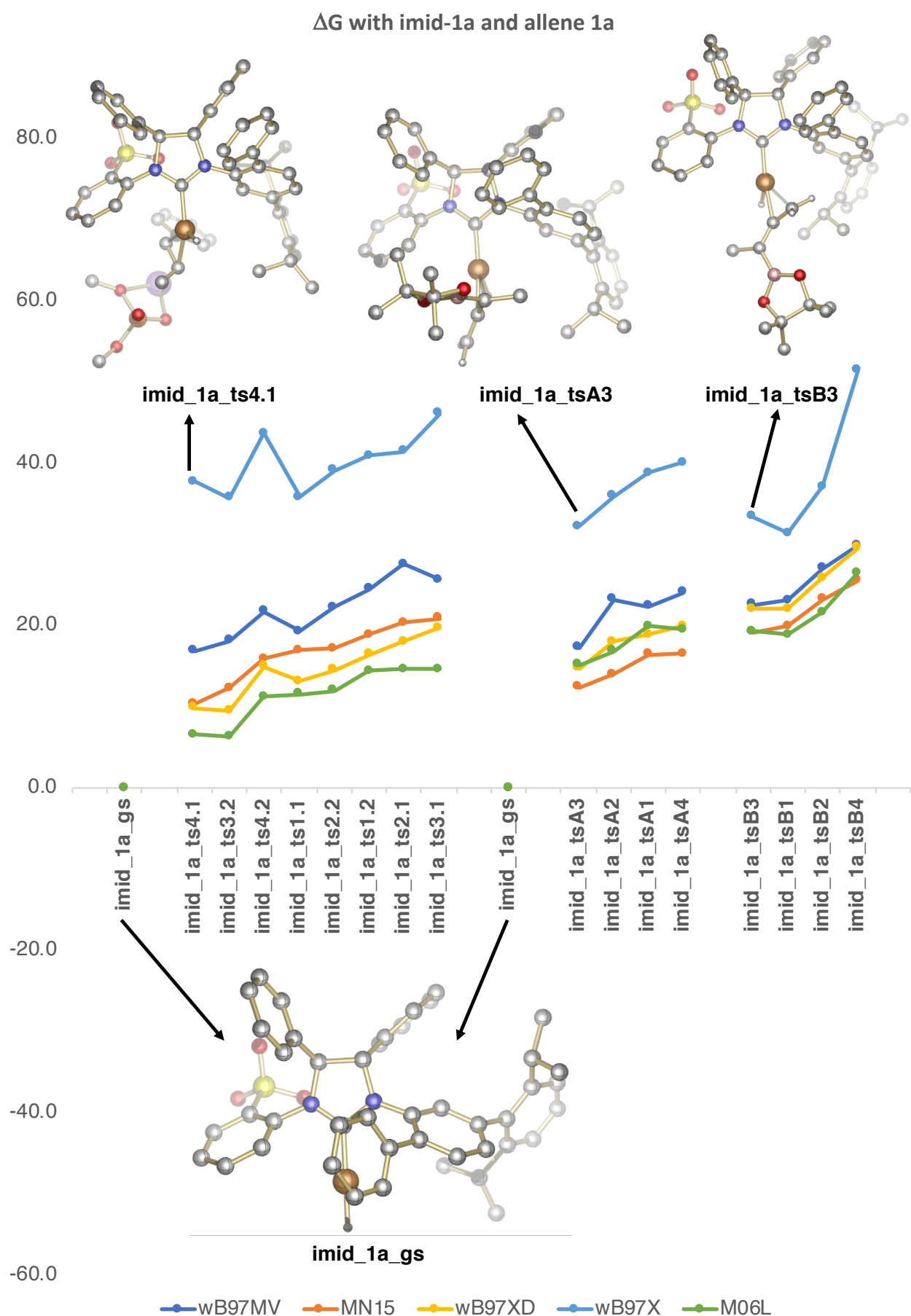

Graph S2-3. Gibbs free energy values ( $\triangle \mathrm{G}$ relative to $\mathrm{Cu}-\mathrm{H}$ imid_1a_gs) for reduction of allyl phosphate (imid_1a_ts1.1 - imid_1a_ts4.2; left) and $\mathrm{Cu}-\mathrm{H}$ addition to allenyl-B(pin) 1a (imid_1a_tsA1 - imid_1a_tsB4;

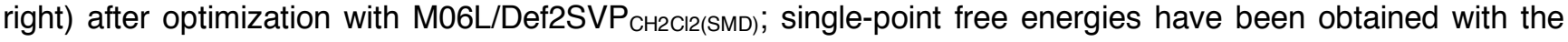
SMD model in $\mathrm{CH}_{2} \mathrm{Cl}_{2}$ and the Def2-TZVPP (MN15, M06L, $\omega$ B97XD and $\omega$ B97X) or Def2-QZVPP basis set $(\omega \mathrm{B} 97 \mathrm{MV})$. 


\begin{tabular}{|c|c|c|c|c|c|}
\hline$\Delta \mathbf{G}$ values & MN15 & M06L & wB97MV & wB97XD & wB97X \\
\hline imid_1a_gs & 0.0 & 0.0 & 0.0 & 0.0 & 0.0 \\
\hline imid_1a_ts4.1 & 10.3 & 6.6 & 16.8 & 9.8 & 37.7 \\
\hline imid_1a_ts3.2 & 12.3 & 6.3 & 18.1 & 9.5 & 35.7 \\
\hline imid_1a_ts4.2 & 15.9 & 11.3 & 21.8 & 15.0 & 43.7 \\
\hline imid_1a_ts1.1 & 16.9 & 11.5 & 19.3 & 13.2 & 35.9 \\
\hline imid_1a_ts2.2 & 17.1 & 12.0 & 22.2 & 14.5 & 39.1 \\
\hline imid_1a_ts1.2 & 18.8 & 14.4 & 24.5 & 16.4 & 40.9 \\
\hline imid_1a_ts2.1 & 20.4 & 14.7 & 27.6 & 18.1 & 41.4 \\
\hline imid_1a_ts3.1 & 20.8 & 14.6 & 25.6 & 19.7 & 46.1 \\
\hline imid_1a_gs & 0.0 & 0.0 & 0.0 & 0.0 & 0.0 \\
\hline imid_1a_tsA3 & 12.4 & 15.2 & 17.2 & 14.7 & 32.2 \\
\hline imid_1a_tsA2 & 14.0 & 16.8 & 23.3 & 18.0 & 35.9 \\
\hline imid_1a_tsA1 & 16.4 & 19.9 & 22.3 & 18.8 & 38.8 \\
\hline imid_1a_tsA4 & 16.5 & 19.5 & 24.1 & 19.9 & 40.1 \\
\hline imid_1a_tsB3 & 19.2 & 19.3 & 22.5 & 22.0 & 33.4 \\
\hline imid_1a_tsB1 & 20.0 & 18.8 & 23.1 & 22.1 & 31.4 \\
\hline imid_1a_tsB2 & 23.2 & 21.6 & 27.1 & 25.9 & 37.1 \\
\hline imid_1a_tsB4 & 25.5 & 26.5 & 29.9 & 29.5 & 51.4 \\
\hline
\end{tabular}

Table S5. Gibbs free energy values ( $\Delta \mathrm{G}$ relative to $\mathrm{Cu}-\mathrm{H}$ imid_1a_gs) for reduction of allyl phosphate (imid_1a_ts1.1 - imid_1a_ts4.2; left) and $\mathrm{Cu}-\mathrm{H}$ addition to allenyl-B(pin) 1a (imid_1a_tsA1 - imid_1a_tsB4;

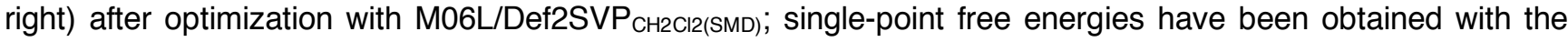
SMD model in $\mathrm{CH}_{2} \mathrm{Cl}_{2}$ and the Def2-TZVPP (MN15, M06L, $\omega$ B97XD and $\omega \mathrm{B} 97 \mathrm{X}$ ) or Def2-QZVPP basis set $(\omega \mathrm{B} 97 \mathrm{MV})$. 

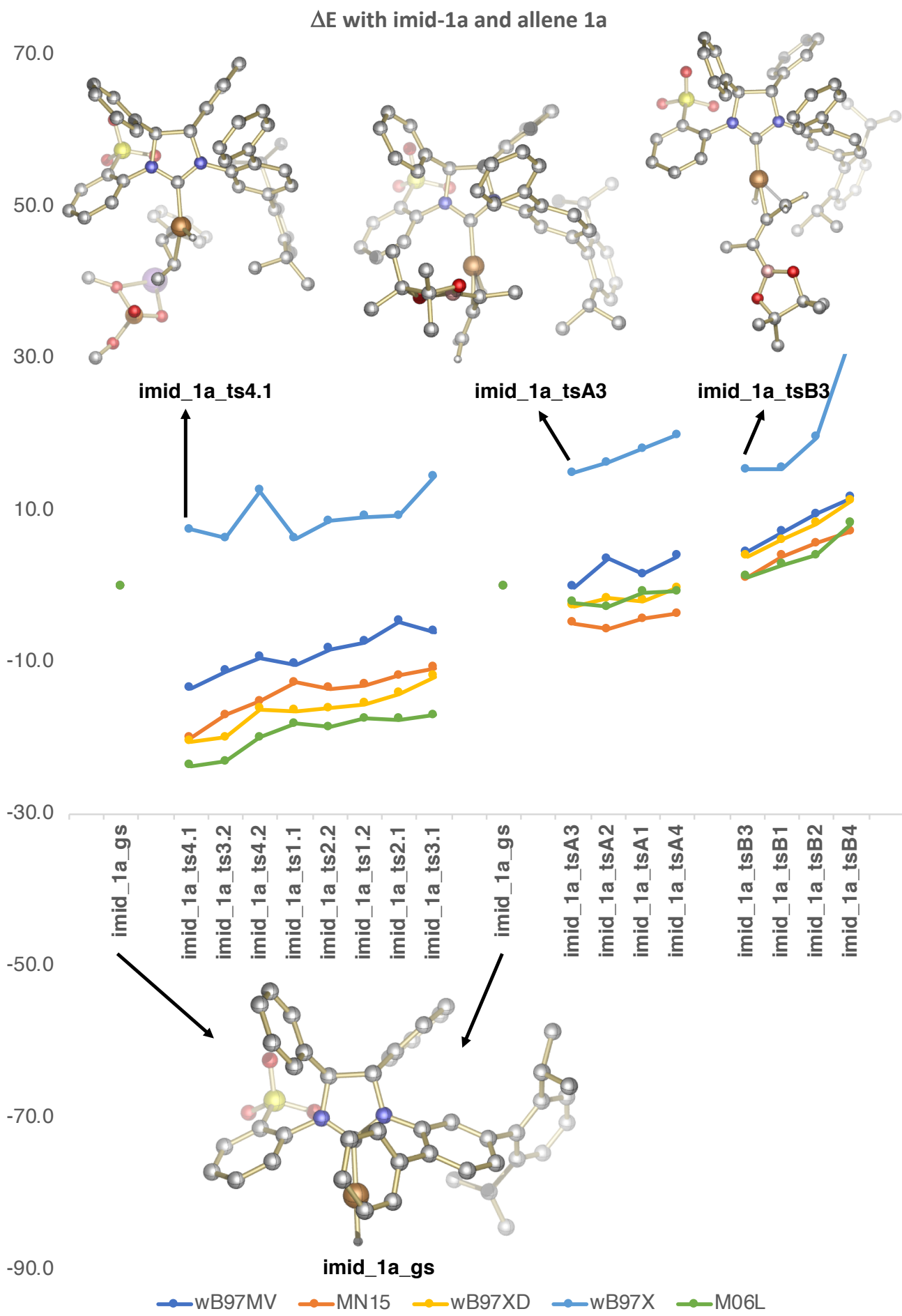

Graph S2-4. Electronic energy values ( $\triangle \mathrm{E}$ relative to $\mathrm{Cu}-\mathrm{H}$ imid_1a_gs) for reduction of allyl phosphate (imid_1a_ts1.1 - imid_1a_ts4.2; left) and $\mathrm{Cu}-\mathrm{H}$ addition to allenyl-B(pin) 1a (imid_1a_tsA1 - imid_1a_tsB4;

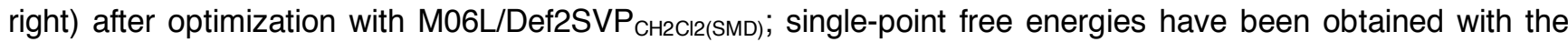
SMD model in $\mathrm{CH}_{2} \mathrm{Cl}_{2}$ and the Def2-TZVPP (MN15, M06L, $\omega \mathrm{B} 97 \mathrm{XD}$ and $\left.\omega \mathrm{B} 97 \mathrm{X}\right)$ or Def2-QZVPP basis set $(\omega \mathrm{B} 97 \mathrm{MV})$. 


\begin{tabular}{|c|c|c|c|c|c|}
\hline$\Delta E$ values & MN15 & M06L & wB97MV & wB97XD & wB97X \\
\hline imid_1a_gs & 0.0 & 0.0 & 0.0 & 0.0 & 0.0 \\
\hline imid_1a_ts4.1 & -19.9 & -23.7 & -13.5 & -20.5 & 7.4 \\
\hline imid_1a_ts3.2 & -17.0 & -23.0 & -11.2 & -19.9 & 6.4 \\
\hline imid_1a_ts4.2 & -15.2 & -19.9 & -9.4 & -16.2 & 12.6 \\
\hline imid_1a_ts1.1 & -12.7 & -18.1 & -10.3 & -16.4 & 6.3 \\
\hline imid_1a_ts2.2 & -13.4 & -18.5 & -8.3 & -16.1 & 8.6 \\
\hline imid_1a_ts1.2 & -13.0 & -17.4 & -7.3 & -15.4 & 9.1 \\
\hline imid_1a_ts2.1 & -11.8 & -17.5 & -4.6 & -14.1 & 9.2 \\
\hline imid_1a_ts3.1 & -10.8 & -17.0 & -6.0 & -11.9 & 14.4 \\
\hline imid_1a_gs & 0.0 & 0.0 & 0.0 & 0.0 & 0.0 \\
\hline imid_1a_tsA3 & -4.9 & -2.1 & -0.1 & -2.6 & 14.9 \\
\hline imid_1a_tsA2 & -5.6 & -2.8 & 3.7 & -1.6 & 16.3 \\
\hline imid_1a_tsA1 & -4.3 & -0.8 & 1.6 & -1.9 & 18.1 \\
\hline imid_1a_tsA4 & -3.7 & -0.7 & 3.9 & -0.3 & 19.9 \\
\hline imid_1a_tsB3 & 1.1 & 1.3 & 4.5 & 4.0 & 15.3 \\
\hline imid_1a_tsB1 & 4.0 & 2.9 & 7.1 & 6.1 & 15.4 \\
\hline imid_1a_tsB2 & 5.7 & 4.1 & 9.5 & 8.3 & 19.5 \\
\hline imid_1a_tsB4 & 7.3 & 8.3 & 11.6 & 11.3 & 33.2 \\
\hline
\end{tabular}

Table S6. Electronic energy values ( $\triangle \mathrm{E}$ relative to $\mathrm{Cu}-\mathrm{H}$ imid_1a_gs) for reduction of allyl phosphate (imid_1a_ts1.1 - imid_1a_ts4.2; left) and $\mathrm{Cu}-\mathrm{H}$ addition to allenyl-B(pin) 1a (imid_1a_tsA1 - imid_1a_tsB4;

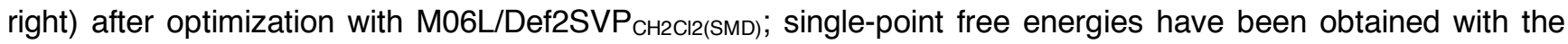
SMD model in $\mathrm{CH}_{2} \mathrm{Cl}_{2}$ and the Def2-TZVPP (MN15, M06L, $\omega \mathrm{B} 97 \mathrm{XD}$ and $\omega \mathrm{B} 97 \mathrm{X}$ ) or Def2-QZVPP basis set $(\omega \mathrm{B} 97 \mathrm{MV})$. 
$\Delta \mathrm{G}$ with imid-1a and allene $1 \mathrm{~b}$
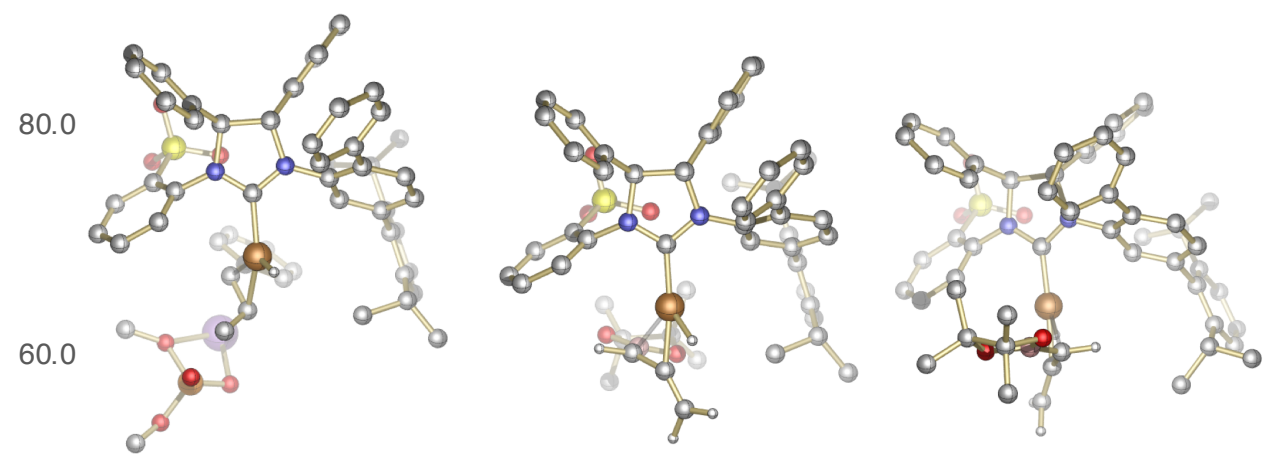

40.0

$$
\text { imid_1a_ts4.1 }
$$
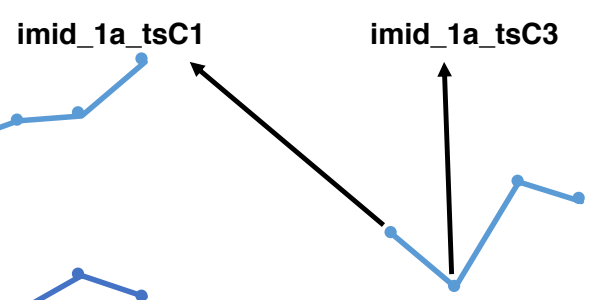

20.0
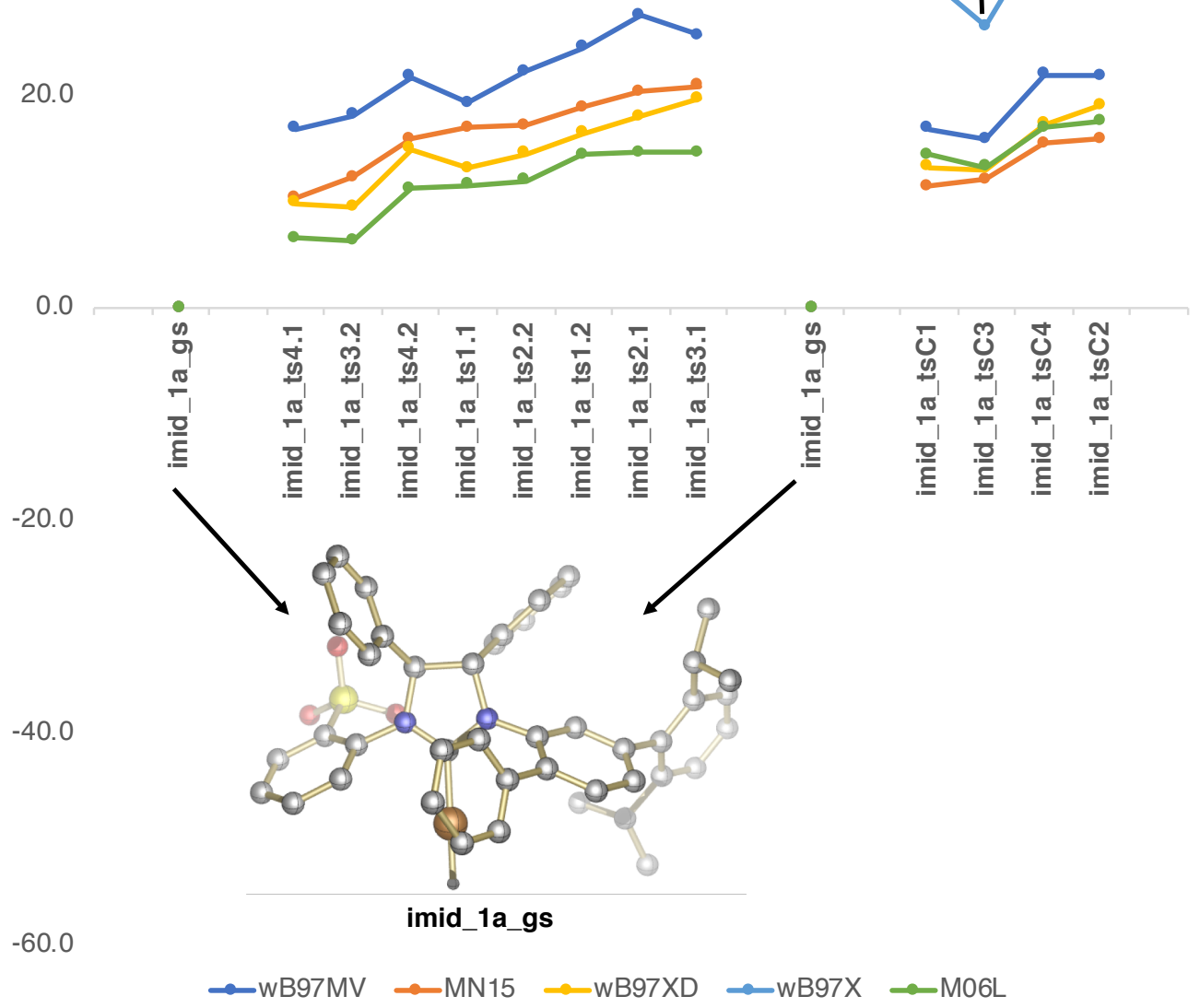

Graph S2-5. Gibbs free energy values ( $\Delta \mathrm{G}$ relative to $\mathrm{Cu}-\mathrm{H}$ imid_1a_gs) for reduction of allyl phosphate (imid_1a_ts1.1 - imid_1a_ts4.2; left) and $\mathrm{Cu}-\mathrm{H}$ addition to allenyl-B(pin) 1b (imid_1a_tsC1 - imid_1a_tsC4;

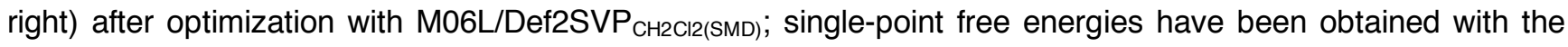
SMD model in $\mathrm{CH}_{2} \mathrm{Cl}_{2}$ and the Def2-TZVPP (MN15, M06L, $\omega \mathrm{B} 97 \mathrm{XD}$ and $\omega \mathrm{B} 97 \mathrm{X}$ ) or Def2-QZVPP basis set $(\omega \mathrm{B} 97 \mathrm{MV})$. 


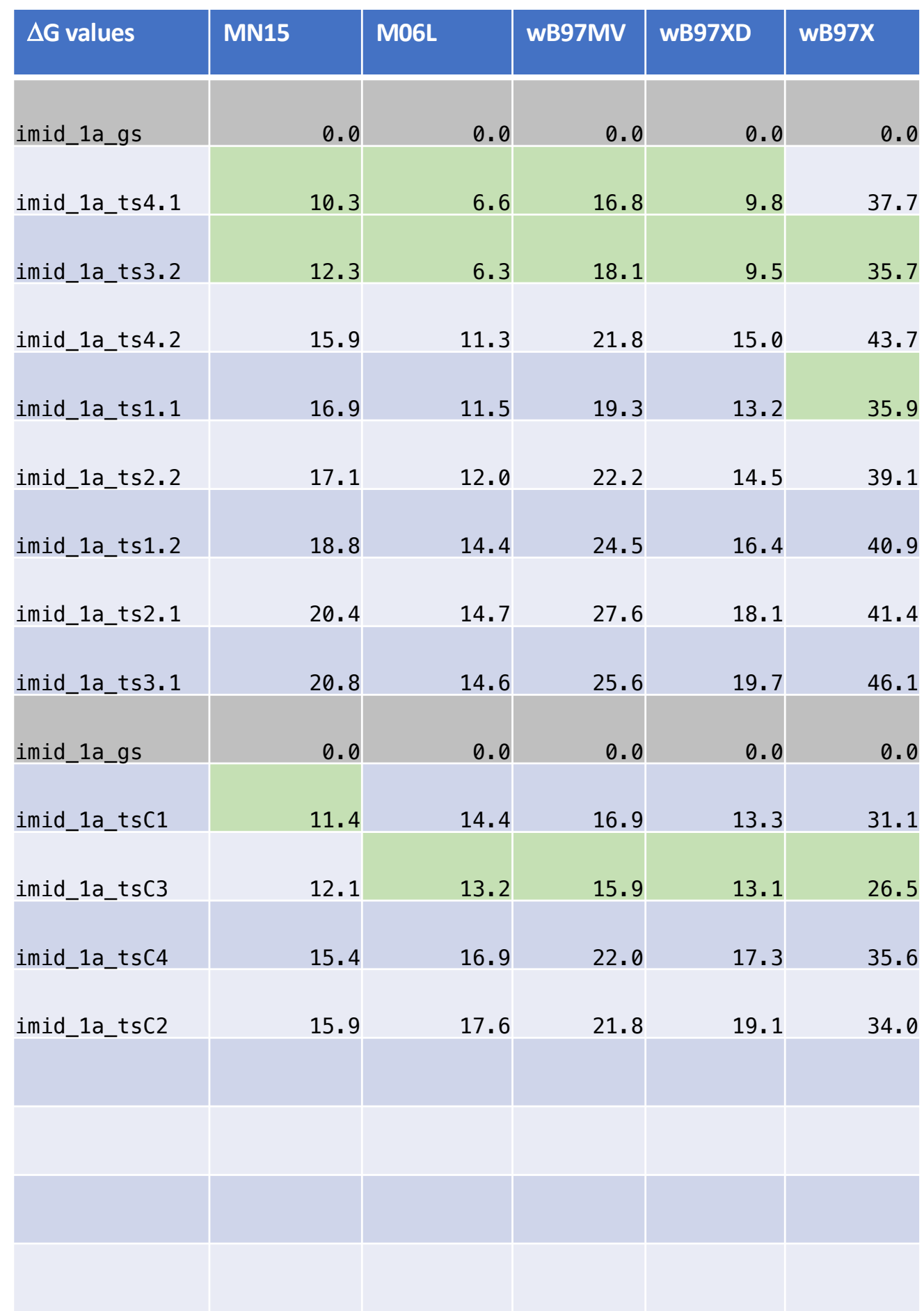

Table S7. Gibbs free energy values ( $\Delta \mathrm{G}$ relative to $\mathrm{Cu}-\mathrm{H}$ imid_1a_gs) for reduction of allyl phosphate (imid_1a_ts1.1 - imid_1a_ts4.2; left) and $\mathrm{Cu}-\mathrm{H}$ addition to allenyl-B(pin) 1b (imid_1a_tsC1 - imid_1a_tsC4; right) after optimization with M06L/Def2SVP(SMD); single-point free energies have been obtained with the SMD model in $\mathrm{CH}_{2} \mathrm{Cl}_{2}$ and the Def2-TZVPP (MN15, M06L, $\omega$ B97XD and $\omega$ B97X) or Def2-QZVPP basis set ( $\omega$ B97MV). 
$\Delta \mathrm{E}$ with imid-1a and allene $\mathbf{1 b}$
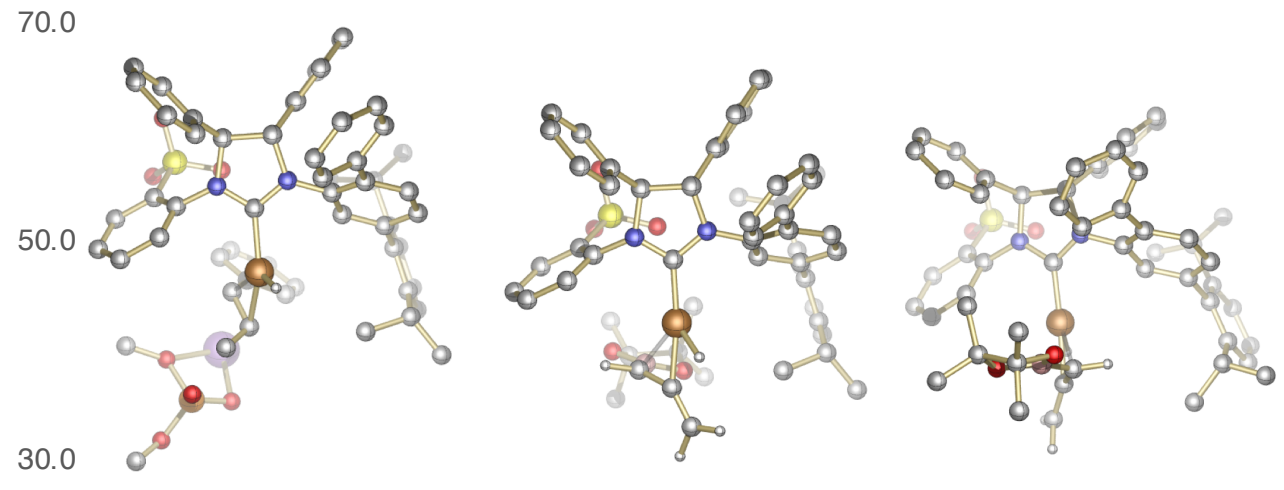

10.0

imid_1a_ts4.1

imid_1a_tsC1

imid_1a_tsC3
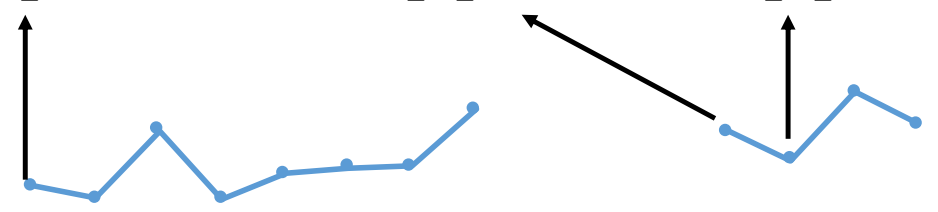

-

-
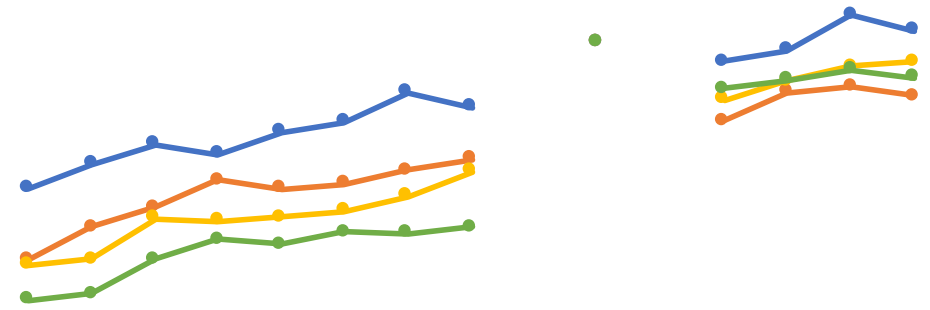

$-10.0$

\section{$-30.0$}

$-50.0$

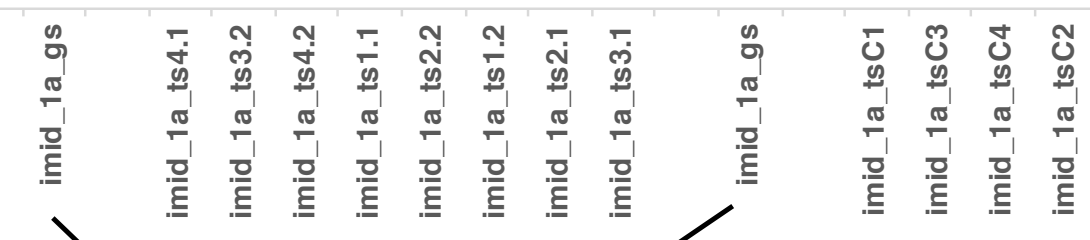

$-70.0$

$-90.0$

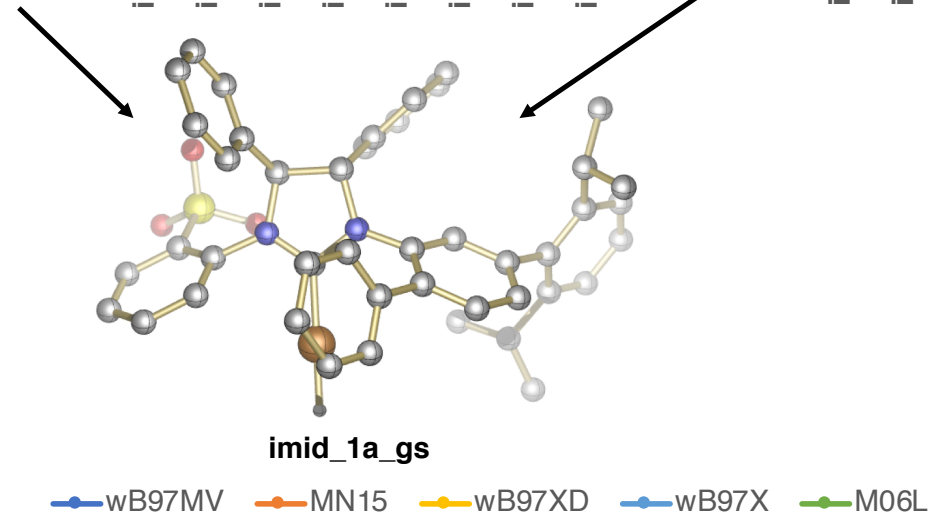

Graph S2-6. Electronic energy values ( $\Delta \mathrm{E}$ relative to $\mathrm{Cu}-\mathrm{H}$ imid_1a_gs) for reduction of allyl phosphate (imid_1a_ts1.1 - imid_1a_ts4.2; left) and $\mathrm{Cu}-\mathrm{H}$ addition to allenyl-B(pin) 1b (imid_1a_tsC1 - imid_1a_tsC4;

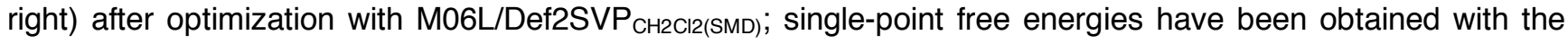
SMD model in $\mathrm{CH}_{2} \mathrm{Cl}_{2}$ and the Def2-TZVPP (MN15, M06L, $\omega \mathrm{B} 97 \mathrm{XD}$ and $\omega \mathrm{B} 97 \mathrm{X}$ ) or Def2-QZVPP basis set $(\omega \mathrm{B} 97 \mathrm{MV})$. 


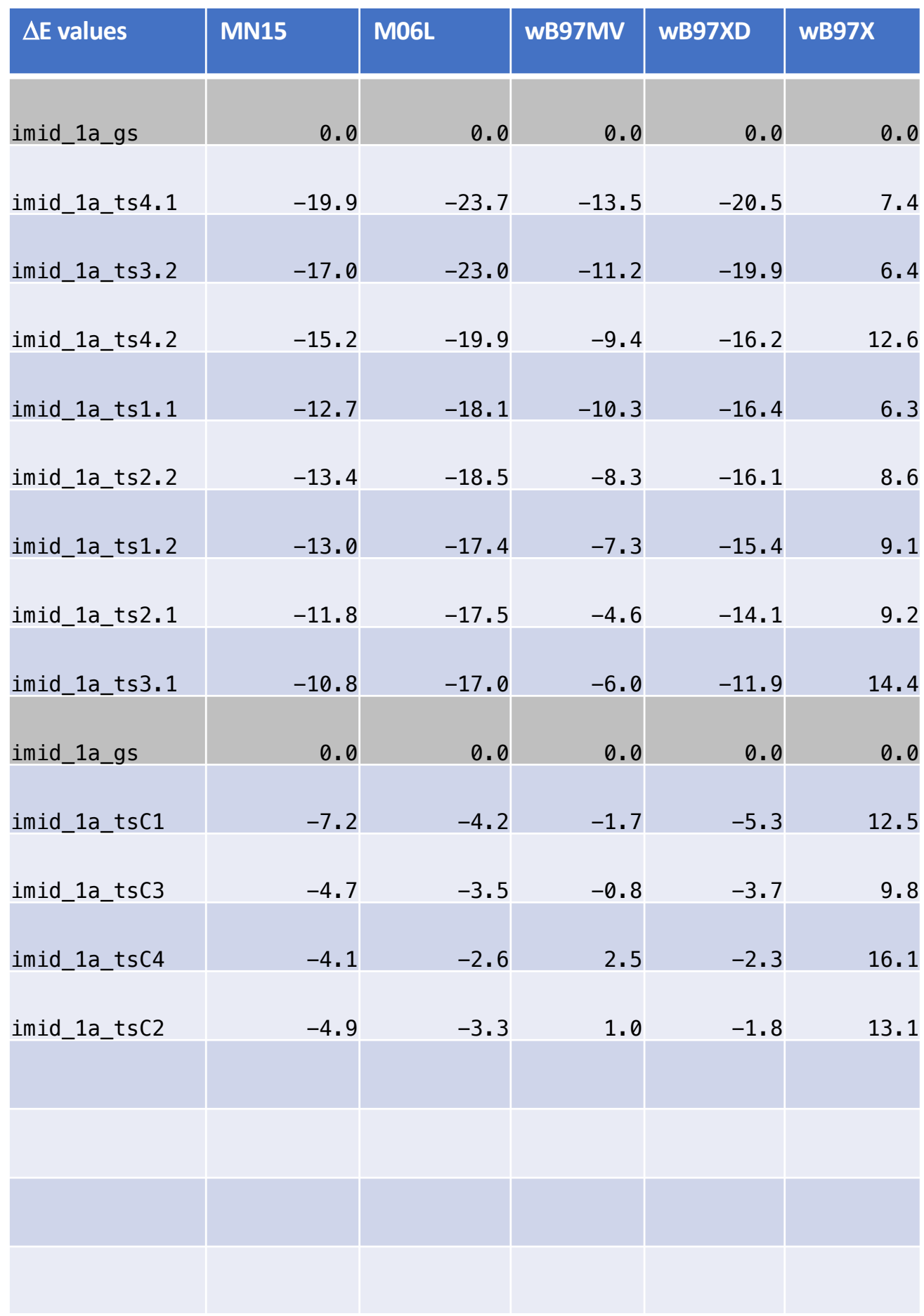

Table S8. Electronic energy values ( $\triangle \mathrm{E}$ relative to $\mathrm{Cu}-\mathrm{H}$ imid_1a_gs) for reduction of allyl phosphate (imid_1a_ts1.1 - imid_1a_ts4.2; left) and $\mathrm{Cu}-\mathrm{H}$ addition to allenyl-B(pin) 1b (imid_1a_tsC1 - imid_1a_tsC4;

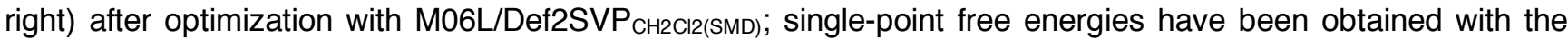
SMD model in $\mathrm{CH}_{2} \mathrm{Cl}_{2}$ and the Def2-TZVPP (MN15, M06L, $\omega$ B97XD and $\omega \mathrm{B} 97 \mathrm{X}$ ) or Def2-QZVPP basis set $(\omega \mathrm{B} 97 \mathrm{MV})$. 


\section{Coordinates after optimization with M06L/DF-Def2SVP CH2Cl2(SMD) $_{1}$}

allene_1b / electronic energy: -526.910271406 a.u. / lowest freq: $38.73 \mathrm{~cm}-1$

C $\quad-\mathbf{2 . 2 9 8 3 5 8} \quad-1.034222 \quad-0.253270$

C $\quad-3.346351 \quad-0.271875 \quad-0.033940$

B $\quad-0.835948 \quad-0.535445 \quad-0.134963$

$\begin{array}{llll}0 & -0.484673 & 0.733033 & 0.240333\end{array}$

$\begin{array}{llll}0 & 0.237188 & -1.343024 & -0.398981\end{array}$

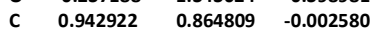

\begin{tabular}{llll} 
C & 1.424516 & -0.624752 & 0.038455 \\
\hline
\end{tabular}

\begin{tabular}{llll} 
C & 1.099154 & 1.497267 & -1.374711 \\
\hline & 0.565430 & 2.457168 & -1398536
\end{tabular}

\begin{tabular}{llll} 
H & 0.565430 & 2.457168 & -1.398536 \\
H & 2.153267 & 1.692581 & -1.615172 \\
\hline
\end{tabular}

H $\quad 0.678676 \quad 0.860493 \quad-2.165983$

$\begin{array}{llll}\text { C } & 1.542141 & 1.750878 & 1.065467\end{array}$

\begin{tabular}{llll} 
C & 1.542141 & 1.750878 & 1.065467 \\
H & 2.636282 & 1.794748 & 0.966396 \\
\hline
\end{tabular}

\begin{tabular}{llll} 
H & 2.636282 & 1.794748 & 0.966396 \\
H & 1.158399 & 2.775744 & 0.967486 \\
\hline
\end{tabular}

$\begin{array}{llll}\text { H } & 1.301598 & 1.399544 & 2.076371\end{array}$

$\begin{array}{llll}\text { C } & 1.734003 & -1.106204 & 1.445236\end{array}$

$\begin{array}{llll}\text { H } & 2.659147 & -0.658422 & 1.833405\end{array}$

\begin{tabular}{llll}
$H$ & 0.918830 & -0.870154 & 2.143804 \\
\hline & 1.865328 & -2.196883 & 1.439255
\end{tabular}

C $\quad 1.865328-2.196883-1.439255$

\begin{tabular}{llll} 
C & 2.565343 & -0.945970 & -0.899618 \\
\hline & 2.304651 & -0.756600 & -1.948133
\end{tabular}

$\begin{array}{llll}\mathrm{H} & \mathbf{2 . 3 0 4 6 5 1} & -0.756600 & -1.948133 \\ \mathrm{H} & \mathbf{3 . 4 5 3 4 9 3} & -0.347312 & -0.651235\end{array}$

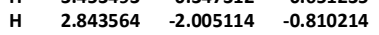

$\begin{array}{llll}H & -2.478571 & -2.083005 & -0.528891\end{array}$

$\begin{array}{llll}\text { C } & -4.372590 & 0.504520 & 0.191033\end{array}$

$\begin{array}{llll}\text { H } & -4.806622 & 0.603134 & 1.191895\end{array}$

$\mathbf{H}$
$\mathbf{3 0}$

allene_1a / electronic energy: - 566.192810303 a.u. / lowest freq: $27.97 \mathrm{~cm}-1$

$\begin{array}{llll}\text { C } & \mathbf{2} .216516 & \mathbf{0 . 5 2 0 2 5 2} & -0.058690\end{array}$

$\begin{array}{llll}\text { C } \quad 3.057978 & -0.485442 & 0.079778\end{array}$

$\begin{array}{llll}\text { B } & 0.686661 & 0.229747 & -0.025494\end{array}$

$\begin{array}{llll}0 & 0.127891 & -1.002173 & 0.182915\end{array}$

$\begin{array}{llll}0 & -0.237941 & 1.223666 & -0.205376\end{array}$

$\begin{array}{llll}\text { C } & -1.292253 & -0.875021 & -0.102010\end{array}$

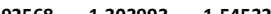

C $-1.492568-1.303993-1.545329$

$\begin{array}{llll}\mathrm{H} & -1.115459 & -2.327061 & -1.679496 \\ \mathrm{H} & -2.554318 & -1.296915 & -1.82789\end{array}$

$\begin{array}{llll}\mathrm{H} & \mathbf{- 2 . 5 5 4 3 1 8} & -1.296915 & -1.827894 \\ \mathrm{H} & -0.947571 & -0.651893 & -2.242597\end{array}$

$\begin{array}{llll}\text { H } & -0.947571 & -0.651893 & -2.242597\end{array}$

$\begin{array}{llll}\text { C } & -2.062724 & -1.776962 & 0.834925\end{array}$

$\begin{array}{llll}\text { H } & -3.145808 & -1.636322 & 0.707910\end{array}$

$\begin{array}{llll}\text { H } & -1.837074 & -2.830298 & 0.618751\end{array}$

$\begin{array}{llll}\text { H } & -1.812092 & -1.590810 & 1.886470\end{array}$

$\begin{array}{llll}\text { C } & -1.822754 & 1.006953 & 1.566046\end{array}$

$\begin{array}{llll}\text { H } & -2.819890 & 0.667400 & 1.878380\end{array}$

$\begin{array}{lllll}\text { H } & -1.080749 & 0.562447 & 2.244350\end{array}$

$\begin{array}{lllll}\text { H } & -1.783762 & 2.097345 & 1.694217\end{array}$

$\begin{array}{lllll}\text { C } & -2.578598 & 1.264704 & -0.795822\end{array}$

\begin{tabular}{lllll} 
H & -2.309885 & 1.163383 & -1.854461 \\
\hline & -3.557847 & 0.789119 & -0.61556
\end{tabular}

$\begin{array}{llll}\text { H } & -3.557847 & 0.789119 & -0.641556\end{array}$

$\begin{array}{llll}\text { H } & -2.692369 & 2.336107 & -0.580429\end{array}$

C $2.681887 \quad 1.940343 \quad-0.244210$

$\begin{array}{llll}\text { C } & 2.681887 & 1.940343 & -0.244210 \\ \text { C } & 3.875725 & -1.496258 & 0.219927\end{array}$

$\begin{array}{llll}\text { C } & 3.875725 & -1.496258 & 0.219927 \\ \text { H } & 4.227446 & -1.820056 & 1.206371\end{array}$

$\begin{array}{llll}\mathrm{H} & 4.242873 & -2.064009 & -0.642887\end{array}$

$\begin{array}{llll}\text { H } & 3.775739 & 2.030782 & -0.251924\end{array}$

$\begin{array}{llll}\text { H } & 2.290699 & 2.588762 & 0.554360\end{array}$

14

Na phos / electronic energy: -884.031519815 a.u. / lowest freq: $56.56 \mathrm{~cm}-1$

$\begin{array}{llll}\mathrm{Na} & -2.825782 & -0.000019 & -0.000016\end{array}$

$\begin{array}{llll}\text { H } & 2.355600 & -2.432107 & -0.725808\end{array}$

\begin{tabular}{llll} 
H & 1.175075 & -2.503995 & 0.612062 \\
\hline
\end{tabular}

$\begin{array}{llll}\text { C } & 1.755163 & -1.826676 & -0.034816\end{array}$

$\begin{array}{llll}0 & 0.913823 & -0.989416 & -0.802527\end{array}$

$\begin{array}{llll}H & 2.441251 & -1.246222 & 0.604429\end{array}$

\begin{tabular}{llll}
\hline & -0.924121 & -0.743537 & 1.044511
\end{tabular}

$\begin{array}{llll}P & -0.117106 & -0.000009 & 0.000012\end{array}$

\begin{tabular}{llll}
\hline & 0.913848 & 0.989385 & 0.802535
\end{tabular}

$\begin{array}{llll}0 & -0.924122 & 0.743522 & -1.044485\end{array}$

$\begin{array}{llll}\text { H } & 2.440622 & 1.246372 & -0.605090\end{array}$

$\begin{array}{llll}\text { C } & 1.755060 & 1.826748 & 0.034790\end{array}$

$\begin{array}{lllll}\text { H } & 2.356049 & 2.431678 & 0.725744\end{array}$

27

$\mathrm{Na}$ (phos)2 / electronic energy: -1605.91139889 a.u. / lowest freq: $32.92 \mathrm{~cm}-1$

$\begin{array}{llll}\text { H } & -4.058228 & -1.910718 & -1.730962\end{array}$

$\begin{array}{llll}\text { H } & -5.235484 & -2.498104 & -0.525187\end{array}$

$\begin{array}{llll}\text { C } & -4.641417 & -1.629334 & -0.839019\end{array}$

$\begin{array}{llll}\text { O } & -1.985758 & -0.162090 & -1.281734\end{array}$

$\begin{array}{llll}\text { H } & -5.336974 & -0.822515 & -1.127936\end{array}$

$\begin{array}{llll}O & -3.811095 & -1.252553 & 0.23642\end{array}$

$\begin{array}{llll}P & -2.768809 & 0.000034 & 0.000062\end{array}$

$\begin{array}{llll}\mathrm{O} & -3.811160 & 1.252552 & -0.236360\end{array}$

$\begin{array}{llll}0 & -1.985659 & 0.162228 & 1.281783\end{array}$

$\begin{array}{lllll}\text { H } & -5.336596 & 0.822191 & 1.128390\end{array}$

$\begin{array}{llll}\text { C } & -4.641566 & 1.629307 & 0.839039\end{array}$ 


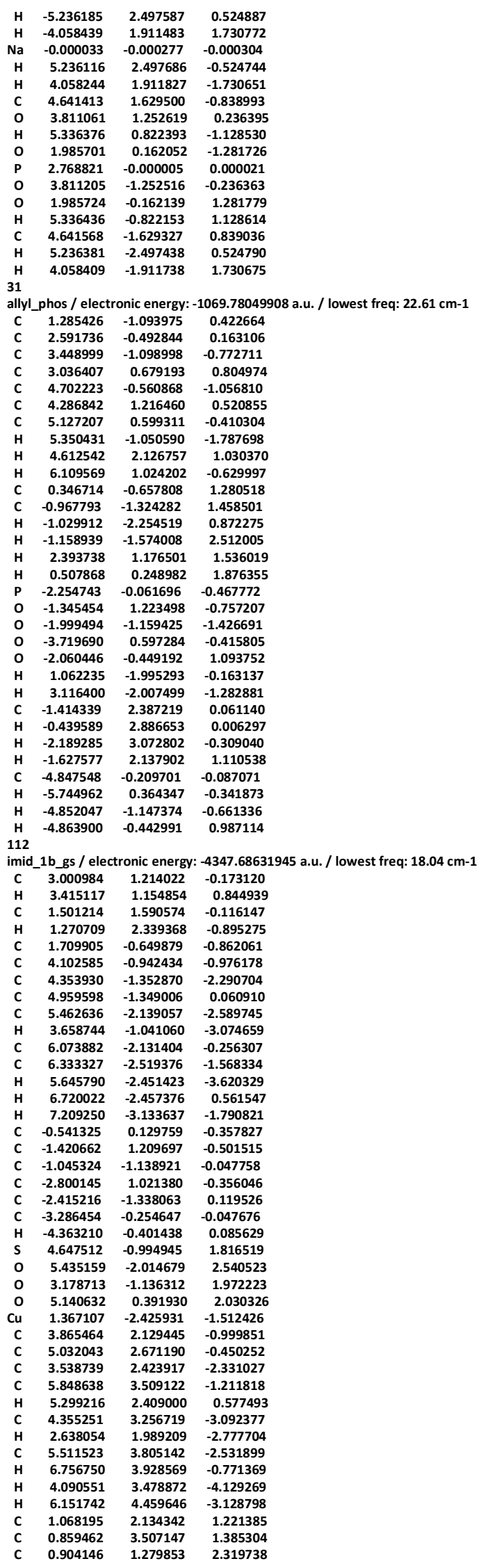




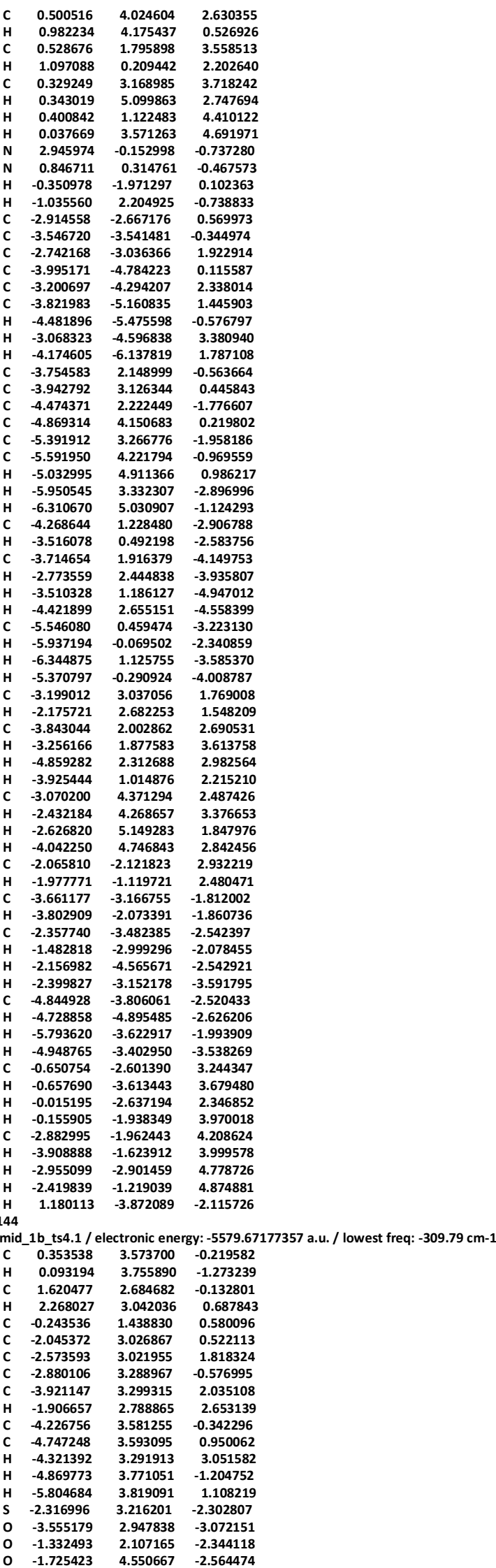




\begin{tabular}{|c|c|c|c|}
\hline & .330041 & 0.053030 & \\
\hline & 0.441 & 4.890347 & 0.504512 \\
\hline & 0.160508 & 6.079058 & -0.177027 \\
\hline & 0.778846 & 946387 & 422 \\
\hline & 0.229283 & 305747 & \\
\hline & -0.128669 & 6.028290 & -1.230477 \\
\hline & 0.842647 & 5.169882 & 2.52640 \\
\hline & 0.987762 & & \\
\hline & 0.570850 & 7.353788 & .836242 \\
\hline & 0.010595 & 228427 & -0.057750 \\
\hline & 1.105085 & 909 & 3.586773 \\
\hline & 0.622482 & & \\
\hline & -0.676285 & 2.680005 & \\
\hline & 1.055571 & 1006 & \\
\hline & -2.878373 & 5451 & \\
\hline & -2.660960 & 05 & \\
\hline & -3.1 & 56 & \\
\hline & $-2.0 €$ & 88 & \\
\hline & -3.0 & -0.9 & \\
\hline & -1.9 & 25 & \\
\hline & -2.5 & -2.2 & -3.7 \\
\hline & -3.462901 & -0.3 & \\
\hline & -1.5 & & \\
\hline & -2.4 & 05 & \\
\hline & -2.8 & -1.2 & \\
\hline & -3.4 & & \\
\hline t & & & \\
\hline 4 & -3.7 & & \\
\hline & -1.6 & -2.8 & \\
\hline H & & & \\
\hline & -5.9 & -20 & \\
\hline o & -6.0 & & \\
\hline 0 & -5.2 & 37 & \\
\hline o & -7.4 & -2 & \\
\hline U & -5.3 & & \\
\hline H & -3.4 & & \\
\hline H & -3.5 & & \\
\hline$=$ & -6.6 & & \\
\hline H & -6.3 & & 22 \\
\hline H & -7.7 & & \\
\hline H & -6.2 & 383 & \\
\hline & -8.2 & 3 & \\
\hline H & -9.2 & & \\
\hline H & -8.43 & -2.6 & -0 \\
\hline & -7.9 & & \\
\hline$C$ & & & \\
\hline c & & & \\
\hline & & & \\
\hline c & & כa & \\
\hline c & & & \\
\hline c & 3.3 & 15 & \\
\hline H & & & \\
\hline H & & & \\
\hline H & 0.206771 & 9498 & \\
\hline c & 5.3 & & \\
\hline C & 6.4 & & \\
\hline C & & -0.5 & \\
\hline C & & & \\
\hline C & & & \\
\hline C & & & \\
\hline H & & & \\
\hline$n$ & & & \\
\hline H & & & \\
\hline C & & & \\
\hline c & 81 & & \\
\hline c & & 22 & \\
\hline c & & & \\
\hline C & & & \\
\hline$c$ & & 04 & \\
\hline H & -0.6 & & \\
\hline H & & & \\
\hline H & & & \\
\hline C & & -3 & \\
\hline H & & & \\
\hline C & & & \\
\hline H & & & \\
\hline H & & & \\
\hline H & & & \\
\hline C & & & \\
\hline H & & & \\
\hline 列 & & & \\
\hline H & & & \\
\hline C & 0.02 & & \\
\hline H & & & \\
\hline C & & & \\
\hline H & & & \\
\hline & & & \\
\hline H & & & \\
\hline C & & & \\
\hline H & -1.64 & 0.1 & 3.151 \\
\hline H & & & \\
\hline & 7072070-1 & 308522 & 27020 \\
\hline
\end{tabular}




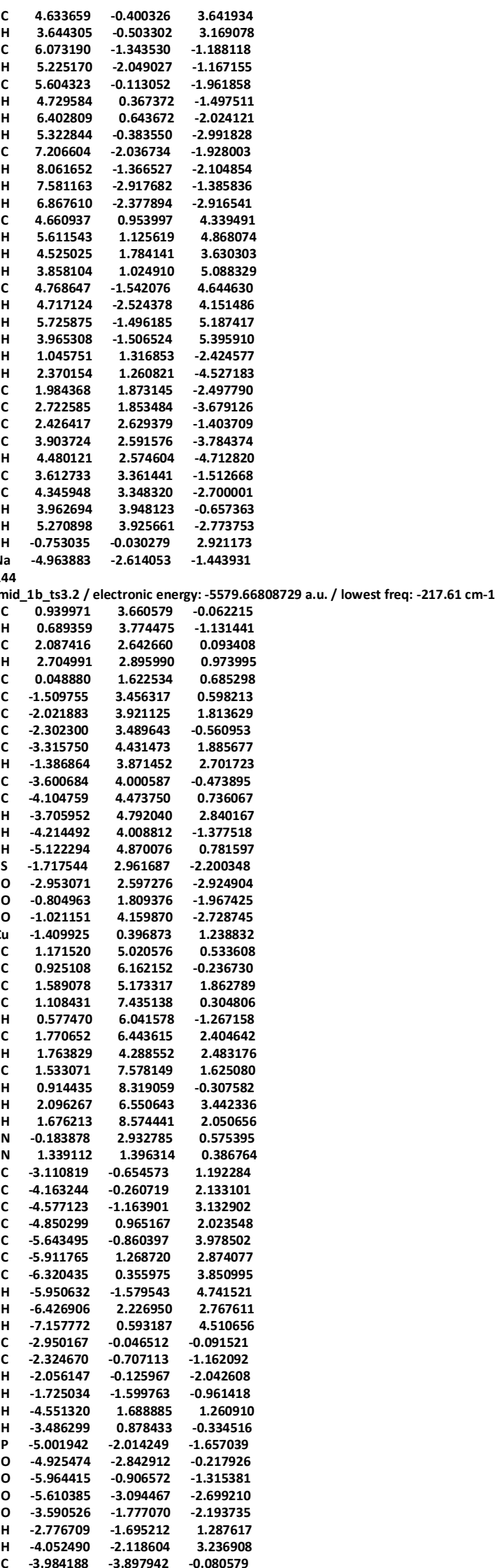




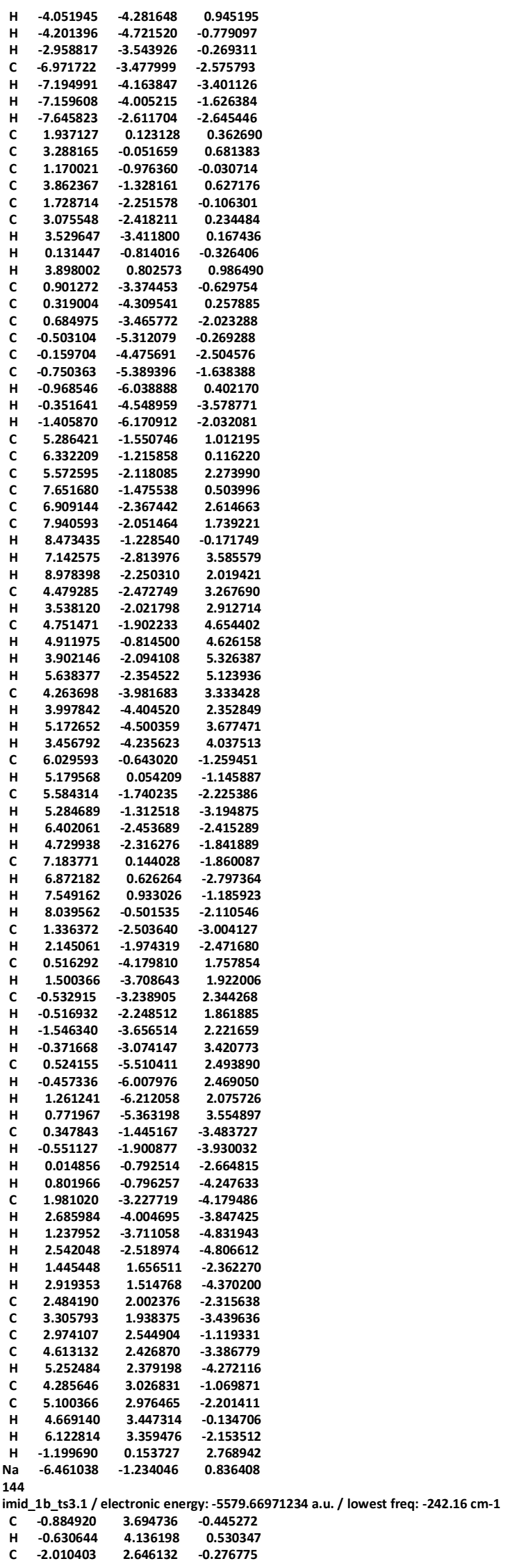




\begin{tabular}{|c|c|c|c|}
\hline & 13 & 04 & \\
\hline & -0.001715 & 1.541616 & -0.834754 \\
\hline & .552248 & 58428 & -1.141287 \\
\hline & 2.080377 & 171610 & -2.423567 \\
\hline & 2.326074 & 3.972787 & -0.141909 \\
\hline & 3.367314 & 3.608931 & -2.727357 \\
\hline & .462258 & 677295 & -3.177726 \\
\hline & 3.607196 & 4.424350 & -0.467867 \\
\hline C & 4.126513 & 4.251604 & 9150 \\
\hline H & 3.770812 & & -3.730900 \\
\hline $\mathbf{H}$ & 4.209717 & 7000 & 0.32240 \\
\hline H & 5.13 & 797 & 9060 \\
\hline$s$ & 1.810173 & 4.077828 & \\
\hline 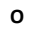 & 3.078206 & & .340782 \\
\hline U & & & \\
\hline 0 & 0.9 & 186 & 1.682492 \\
\hline $\mathrm{Cu}$ & & & \\
\hline C & $-1.1 \epsilon$ & & \\
\hline c & -0.9 & & \\
\hline C & -1.5 & & \\
\hline c & -1.21 & 62 & \\
\hline H & -0.6 & & \\
\hline c & -1.7 & & \\
\hline H & -1.68 & & \\
\hline C & -1.6 & & \\
\hline & -1.0 & & \\
\hline H & -2.1 & & \\
\hline H & -1.8 & 7.6 & \\
\hline $\mathbf{N}$ & & & \\
\hline iv & -1.2 & & \\
\hline C & 3.0 & -0.5 & \\
\hline C & & & \\
\hline C & 3.4 & -2.7 & \\
\hline c & 2.8 & -3.3 & \\
\hline c & 6828 & & \\
\hline c & & -4.6 & \\
\hline c & & 32 & \\
\hline H & 3.97 & & \\
\hline $\mathrm{H}$ & & -5 & \\
\hline H & 3.6 & -6.1 & \\
\hline C & 2.83 & -0.3 & \\
\hline C & & & \\
\hline H & 3.687173 & 1.553219 & -0.560635 \\
\hline H & 2.9 & & \\
\hline H & 219 & 31 & 187 \\
\hline H & 2.436423 & -0.9 & 5971 \\
\hline p & 5.9 & & \\
\hline 0 & & & \\
\hline 0 & 6.346966 & -0.8 & -0 \\
\hline 0 & & & \\
\hline 0 & & & \\
\hline H & & 16 & \\
\hline H & & & \\
\hline C & 4.72 & 38 & \\
\hline $\mathrm{H}$ & & & \\
\hline H & & & \\
\hline H & 4.1 & & \\
\hline C & & 72 & \\
\hline H & & & \\
\hline 1 & & & \\
\hline H & & & \\
\hline c & - & & \\
\hline C & -3.27 & & \\
\hline C & -1.12 & & \\
\hline C & -3.87 & & \\
\hline$c$ & & & \\
\hline c & & & \\
\hline H & 91 & & \\
\hline H & & & \\
\hline H & & & \\
\hline c & & & \\
\hline$c$ & & & \\
\hline & & & \\
\hline & & & \\
\hline c & & -4.1 & \\
\hline c & & & \\
\hline H & & & \\
\hline H & 169 & -4.0 & \\
\hline H & & & \\
\hline 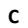 & & & \\
\hline C & & & \\
\hline C & -5.7 & & \\
\hline C & & & \\
\hline 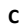 & & & \\
\hline C & -8.063967 & -1.904343 & -0.780910 \\
\hline H & & & \\
\hline & & & \\
\hline H & & 19 & 079 \\
\hline c & & & \\
\hline & & & \\
\hline C & -4.92 & -1.932127 & -3.838049 \\
\hline H & חג מדר & 352588 & -3.69201 \\
\hline
\end{tabular}




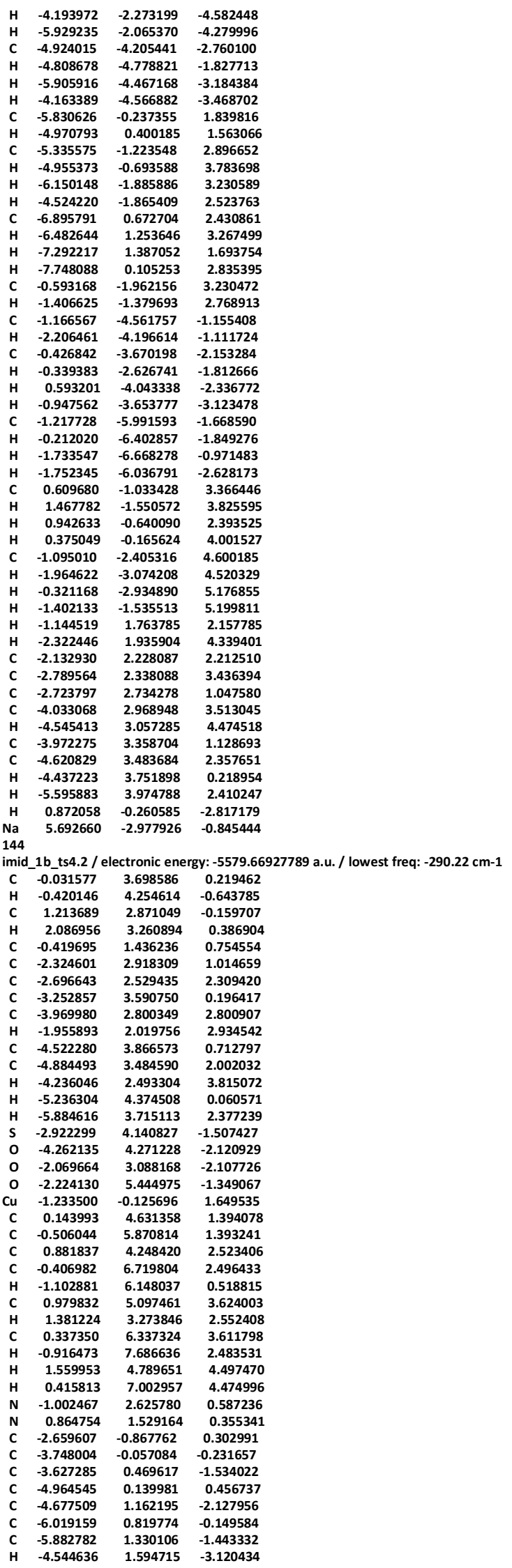




\begin{tabular}{|c|c|c|c|}
\hline & -6.954913 & 0.960029 & 0.397536 \\
\hline & -6.705575 & 1.877211 & -1.908873 \\
\hline & -2.682776 & -1.563472 & 1.531929 \\
\hline & -1.750853 & -2.592563 & 1.804066 \\
\hline & -0.879573 & -2.714987 & 1.154268 \\
\hline & -1.638667 & -2.956796 & 2.824050 \\
\hline & -5.091672 & -0.255361 & 1.468042 \\
\hline & -3.493568 & -1.402358 & 2.250420 \\
\hline & -3.512732 & -4.314678 & 0.086960 \\
\hline & -4.928446 & -3.599753 & 0.580866 \\
\hline & -3.293889 & -3.639928 & -1.243019 \\
\hline & -3.876408 & -5.887101 & -0.032780 \\
\hline & -2.500304 & -4.291851 & 1.236055 \\
\hline & -1.950289 & -1.234579 & -0.450947 \\
\hline & -2.684506 & 0.341292 & -2.073128 \\
\hline & -5.503944 & -3.954370 & 1.831280 \\
\hline & -6.214974 & -3.168391 & 2.113444 \\
\hline & -6.042040 & -4.911916 & 1.761145 \\
\hline & -4.735345 & -4.037439 & 2.613735 \\
\hline & -4.712253 & -6.321064 & -1.096854 \\
\hline & -4.910437 & -7.387730 & -0.941417 \\
\hline & -5.675956 & -5.787148 & -1.104692 \\
\hline & -4.223370 & -6.189818 & -2.073316 \\
\hline & 1.755399 & 0.445350 & 0.219743 \\
\hline & 1.271389 & -0.850663 & 0.017268 \\
\hline & 3.136813 & 0.664388 & 0.235903 \\
\hline & 2.137812 & -1.929195 & -0.171365 \\
\hline & 4.023837 & -0.402700 & 0.054109 \\
\hline & 3.517969 & -1.689657 & -0.160190 \\
\hline & 4.212744 & -2.520030 & -0.319779 \\
\hline & 3.535758 & 1.669127 & 0.394487 \\
\hline & 0.195533 & -1.023125 & -0.044845 \\
\hline & 5.495530 & -0.177268 & 0.142891 \\
\hline & 6.217661 & 0.285486 & -0.981549 \\
\hline & 6.153995 & -0.434630 & 1.366079 \\
\hline & 7.598946 & 0.477516 & -0.859008 \\
\hline & 7.536187 & -0.219683 & 1.445584 \\
\hline & 8.255600 & 0.230245 & 0.343950 \\
\hline & 8.173899 & 0.822743 & -1.722507 \\
\hline & 8.054624 & -0.406773 & 2.391017 \\
\hline & 9.334296 & 0.390172 & 0.421007 \\
\hline & 1.561619 & -3.286890 & -0.391078 \\
\hline & 1.731838 & -4.290181 & 0.595395 \\
\hline & 0.803098 & -3.546689 & -1.562265 \\
\hline & 1.113905 & -5.532191 & 0.402232 \\
\hline & 0.205003 & -4.804641 & -1.705972 \\
\hline & 0.351037 & -5.786995 & -0.731925 \\
\hline & 1.221024 & -6.311845 & 1.159702 \\
\hline & -0.390818 & -5.021866 & -2.594812 \\
\hline & -0.137791 & -6.757020 & -0.856193 \\
\hline & 0.699289 & -2.518946 & -2.681260 \\
\hline & 0.522390 & -1.534125 & -2.218110 \\
\hline & -0.450981 & -2.761413 & -3.645550 \\
\hline & -1.411450 & -2.885626 & -3.124640 \\
\hline & -0.551549 & -1.911160 & -4.336170 \\
\hline & -0.292614 & -3.655976 & -4.267628 \\
\hline & 2.022903 & -2.419361 & -3.436670 \\
\hline & 2.857013 & -2.145563 & -2.774708 \\
\hline & 2.280549 & -3.379043 & -3.912436 \\
\hline & 1.972977 & -1.659551 & -4.231269 \\
\hline & 2.496826 & -4.014775 & 1.881582 \\
\hline & 3.343170 & -3.355341 & 1.630792 \\
\hline & 3.084382 & -5.260324 & 2.526644 \\
\hline & 3.731627 & -4.985248 & 3.371888 \\
\hline & 2.309134 & -5.927889 & 2.932352 \\
\hline & 3.693067 & -5.847437 & 1.823073 \\
\hline & 1.623268 & -3.257078 & 2.878105 \\
\hline & 2.191366 & -2.992238 & 3.783357 \\
\hline & 1.222602 & -2.320879 & 2.458521 \\
\hline & 0.765708 & -3.872071 & 3.195150 \\
\hline & 5.412571 & -0.917937 & 2.600537 \\
\hline & 4.354215 & -1.064868 & 2.330316 \\
\hline & 5.536809 & 0.496243 & -2.322459 \\
\hline & 4.460634 & 0.653367 & -2.132693 \\
\hline & 6.048371 & 1.716185 & -3.074370 \\
\hline & 5.977992 & 2.634147 & -2.471867 \\
\hline & 7.098320 & 1.604179 & -3.384799 \\
\hline & 5.465603 & 1.875763 & -3.993067 \\
\hline & 5.663144 & -0.761789 & -3.178272 \\
\hline & 6.716262 & -0.964393 & -3.430948 \\
\hline & 5.275788 & -1.651220 & -2.659317 \\
\hline & 5.108476 & -0.658193 & -4.123523 \\
\hline & 5.450877 & 0.125745 & 3.711284 \\
\hline & 6.480020 & 0.317725 & 4.053269 \\
\hline & 5.029588 & 1.087158 & 3.381184 \\
\hline & 4.872357 & -0.206583 & 4.586227 \\
\hline & 5.943635 & -2.261827 & 3.086355 \\
\hline & 5.908646 & -3.028724 & 2.297618 \\
\hline & 6.989162 & -2.190824 & 3.425099 \\
\hline & 5.354362 & -2.632396 & 3.938660 \\
\hline & 0.07786 & 1.32036 & -2.117762 \\
\hline & 0.655955 & 1.264002 & 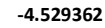 \\
\hline
\end{tabular}




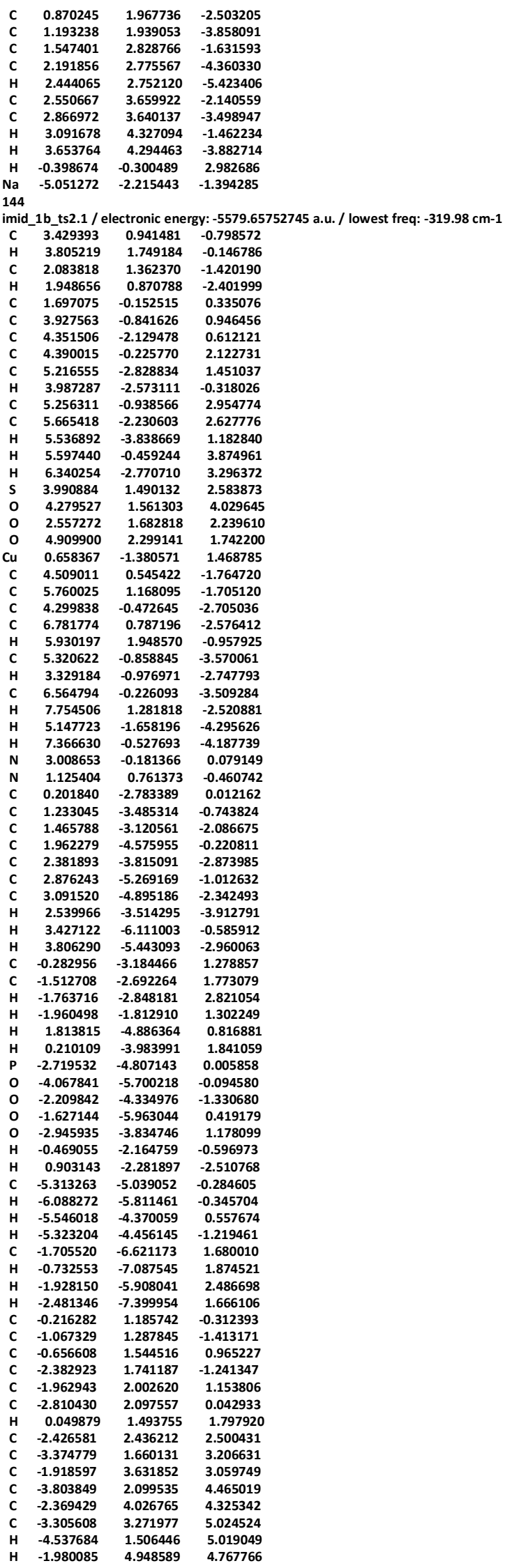




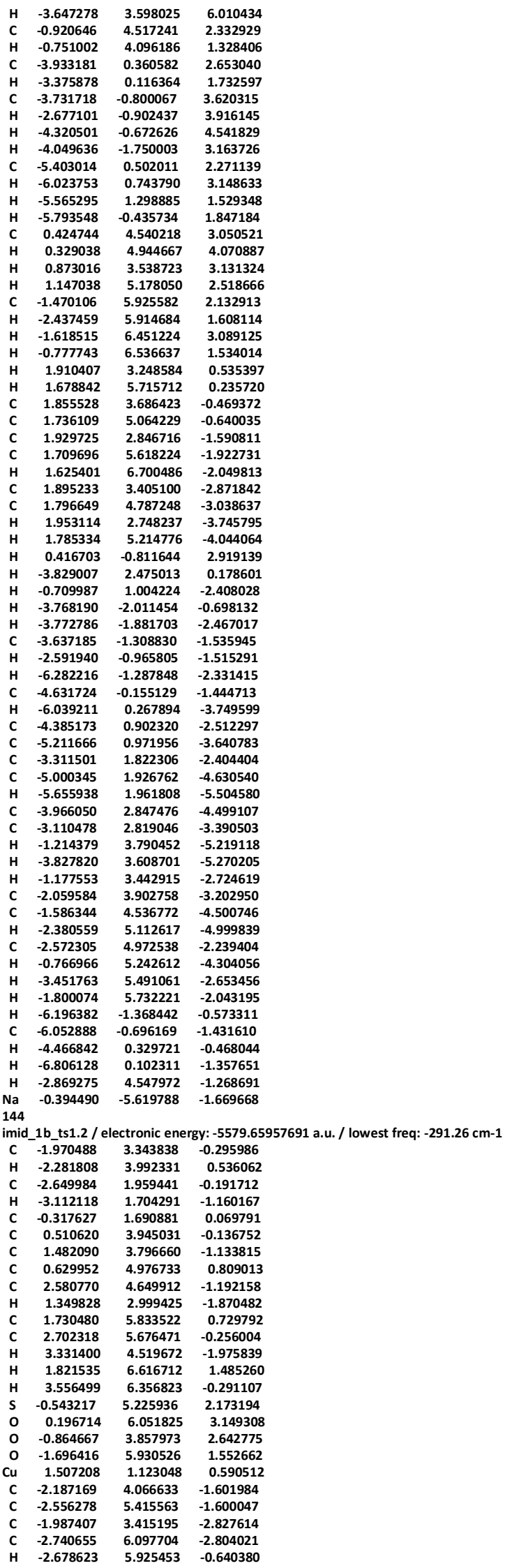




\begin{tabular}{|c|c|c|c|}
\hline & 168388 & 096851 & \\
\hline & 1.683220 & 62433 & 13470 \\
\hline & .549182 & 5.441041 & .018727 \\
\hline & 3.032110 & 150924 & 7800 \\
\hline & 2.011789 & & 77880 \\
\hline & -2.693589 & - 975847 & 4.960786 \\
\hline & & 2341 & 5616 \\
\hline & -1.505261 & & 5446 \\
\hline & & & \\
\hline & 3.893125 & 152 & \\
\hline & 931 & & \\
\hline & 3.532557 & & 2378 \\
\hline & 377 & & 7889 \\
\hline & 4.130097 & & 3801 \\
\hline & 5.100728 & & 2690 \\
\hline & & & \\
\hline & & & \\
\hline & 960 & & 754 \\
\hline & & & \\
\hline$c$ & & & \\
\hline & & & \\
\hline & & & \\
\hline & & & \\
\hline$n$ & & & \\
\hline & & & \\
\hline U & & & \\
\hline U & & & \\
\hline & & & \\
\hline U & & & \\
\hline 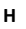 & & & \\
\hline & & & \\
\hline & & & \\
\hline H & & & \\
\hline & & & \\
\hline & & & \\
\hline$c$ & & & \\
\hline H & & & \\
\hline & & & \\
\hline H & 5.7 & & \\
\hline c & 30 & & \\
\hline$C$ & -0.63 & 2 & \\
\hline$c$ & -2.8 & & \\
\hline$c$ & -0.7 & & \\
\hline C & -3.07 & 0 & \\
\hline$c$ & -2.0 & 5 & \\
\hline H & -3.7 & 57 & \\
\hline$C$ & -4.3 & 30 & \\
\hline$c$ & & & \\
\hline & -4.69 & & \\
\hline$c$ & -6.53 & & \\
\hline$c$ & -5.9 & 3 & \\
\hline$c$ & -6.8 & & \\
\hline H & -7.2 & & \\
\hline 4 & -6.209441 & -3.4 & \\
\hline H & -7.8 & & \\
\hline C & -3.73 & & \\
\hline$H$ & -2.73 & -2.2 & \\
\hline$c$ & & & \\
\hline $\mathbf{H}$ & -3.8 & & \\
\hline C & -5.3 & 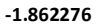 & \\
\hline$H$ & & & \\
\hline H & -6.4 & & \\
\hline H & -5.0 & 55 & \\
\hline c & & & \\
\hline $\mathrm{H}$ & -6.7 & & \\
\hline H & -5.4 & & \\
\hline H & -5.2 & & \\
\hline$c$ & & & \\
\hline H & 77 & & \\
\hline H & -4.2 & & \\
\hline 4 & & & \\
\hline$c$ & & & \\
\hline$\pi$ & -3.2 & & \\
\hline & & & \\
\hline & & & \\
\hline H & & & \\
\hline H & & & \\
\hline & & & \\
\hline & & & \\
\hline C & & & \\
\hline & & & \\
\hline & & & \\
\hline C & & & \\
\hline & & & \\
\hline & & & \\
\hline H & & & \\
\hline & & & \\
\hline & & & \\
\hline & & & \\
\hline & & & \\
\hline & & & \\
\hline & 544 & -2.841899 & 4.12206 \\
\hline
\end{tabular}




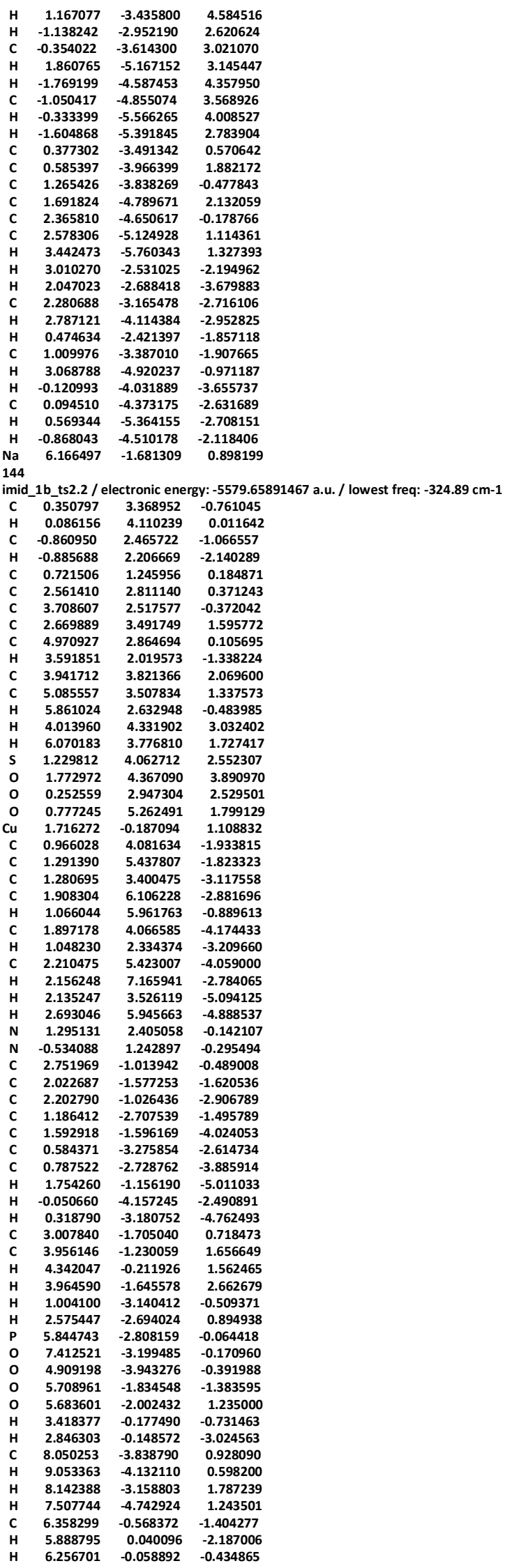




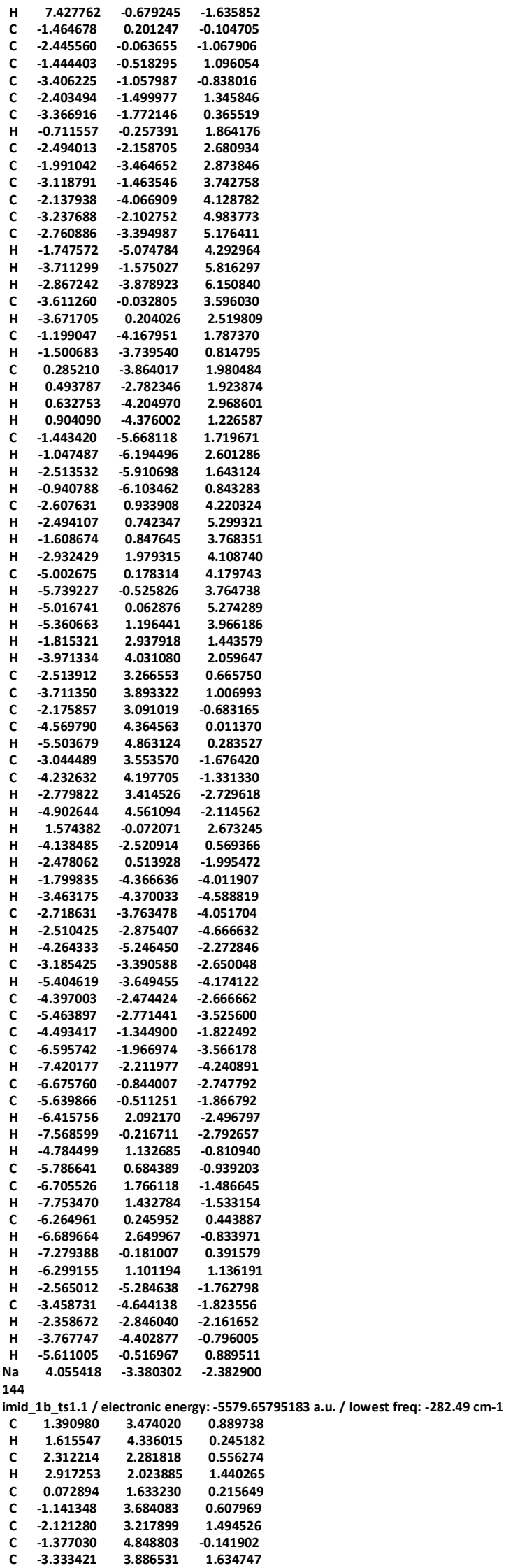




\begin{tabular}{|c|c|c|c|}
\hline & -1.907027 & 321052 & \\
\hline & -2.596786 & 5512639 & 20152 \\
\hline & -3.571272 & 5.042749 & .8920 \\
\hline & -4.085264 & 507857 & 331972 \\
\hline & 2924 & 3614 & 1146 \\
\hline & -4.517229 & 5.579856 & 0.993986 \\
\hline & -0.197155 & .527499 & 1.345271 \\
\hline & 1.018626 & 392789 & -2.216577 \\
\hline & 0.377377 & 4.340435 & -2.017823 \\
\hline & 0.786023 & 281952 & 335 \\
\hline & -1.543981 & & \\
\hline & 1.370706 & & 2.332987 \\
\hline & & & \\
\hline & & 304 & \\
\hline & & 5220 & 2903 \\
\hline & & & \\
\hline & & & \\
\hline & & & 873 \\
\hline & & & \\
\hline & & & \\
\hline & & & .424 \\
\hline & & & \\
\hline & & & \\
\hline & & & \\
\hline & -3.18 & -0.3 & \\
\hline & -4.3 & & \\
\hline & & 05 & \\
\hline & -5.2 & & \\
\hline & -5.6 & 9 & \\
\hline & & & \\
\hline c & & & \\
\hline & -5.8 & & \\
\hline & & & \\
\hline H & & & \\
\hline & -3.0 & 32 & \\
\hline & -2 & 8 & \\
\hline 1 & & & \\
\hline 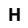 & & -0.7 & \\
\hline 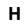 & -5.0 & & \\
\hline$t$ & -3.6 & & \\
\hline$r$ & -4.8 & 71 & 30 \\
\hline 0 & -5.5 & -1 & \\
\hline 0 & & & \\
\hline 0 & -5.6 & -3. & \\
\hline U & -3. & & \\
\hline$n$ & & & \\
\hline 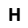 & & 97 & \\
\hline & & 0 & \\
\hline H & -6 & & \\
\hline H & -6.9 & & \\
\hline H & -5.39 & 67 & \\
\hline$=$ & -5.0 & 2 & \\
\hline H & -5.7 & & \\
\hline 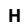 & -4.5 & & \\
\hline 1 & -4.2 & & \\
\hline$c$ & & & \\
\hline C & & -0.4 & \\
\hline & & & \\
\hline C & & & \\
\hline C & & & \\
\hline 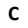 & & & \\
\hline H & -0.1 & 20 & \\
\hline$c$ & 857 & 13 & \\
\hline c & & & \\
\hline c & -0.07 & & \\
\hline$c$ & & & \\
\hline$c_{1}+2$ & & & \\
\hline c & & & \\
\hline H & -1.8 & 87 & \\
\hline H & & -4 & \\
\hline 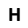 & & & \\
\hline 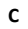 & & & \\
\hline H & & -2 & \\
\hline c & & & \\
\hline H & & & \\
\hline C & -1.0 & & \\
\hline H & & & \\
\hline H & & & \\
\hline H & & & \\
\hline C & & & \\
\hline H & & & \\
\hline H & & & \\
\hline H & 383 & 283 & \\
\hline C & & & \\
\hline H & & & \\
\hline H & & -0 & \\
\hline & & & \\
\hline C & & & \\
\hline H & & & \\
\hline$n$ & & $-3.3+8$ & re \\
\hline & & & \\
\hline & 00300 & 2.014270 & 213861 \\
\hline
\end{tabular}




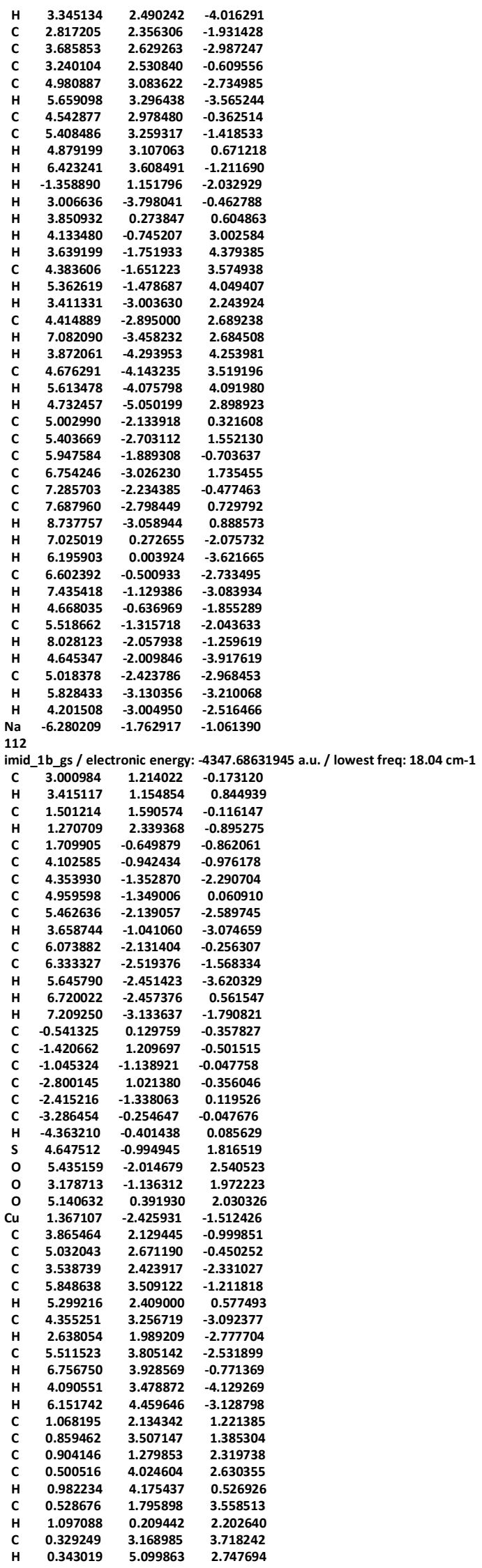




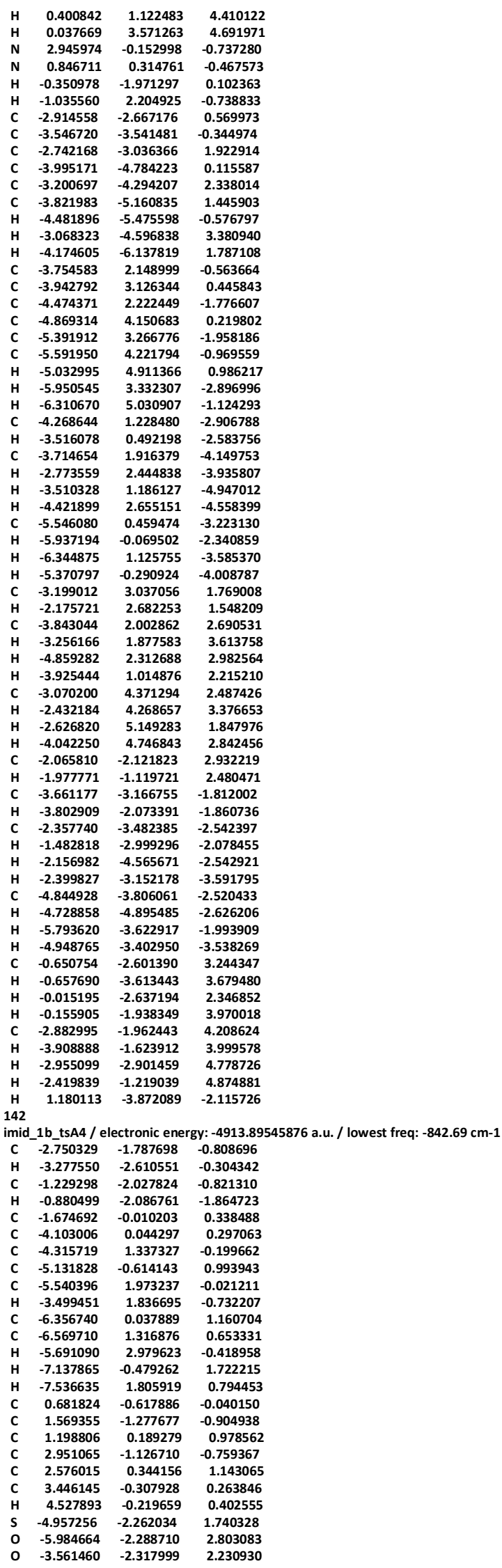




\begin{tabular}{|c|c|c|c|}
\hline & & & \\
\hline & -1.462730 & 1.578107 & .422779 \\
\hline & -3.390571 & -1.531243 & .152331 \\
\hline & -4.704937 & 1.959809 & 4217 \\
\hline & -2.738458 & -0.792591 & -3.149002 \\
\hline & -5.350540 & -1.665686 & \\
\hline & -5.213666 & -2.516797 & -1.580271 \\
\hline & -3.382976 & -0.501660 & -4.350317 \\
\hline & -1.71 & & \\
\hline & -4.691378 & 3588 & -4.566789 \\
\hline & 5432 & -2.006245 & -3.737805 \\
\hline & -2.862062 & 0.071263 & 2024 \\
\hline & -5.1 & & \\
\hline & -0.779292 & -3.277583 & -0.099637 \\
\hline & & & \\
\hline & & & \\
\hline & & & \\
\hline & -0.76 & & \\
\hline & & & \\
\hline & -0.6 & & \\
\hline & & -5.6 & .096 \\
\hline H & -0.0 & & \\
\hline & & & \\
\hline & & & 814 \\
\hline $\mathbf{N}$ & & & \\
\hline $\mathbf{N}$ & & & \\
\hline & & & \\
\hline H & & & \\
\hline C & & & \\
\hline & & & \\
\hline & & & \\
\hline & & & \\
\hline & & & \\
\hline & & & \\
\hline H & & & \\
\hline H & & & \\
\hline & & & \\
\hline C & & -1. & \\
\hline & 213 & -3.2 & 304 \\
\hline C & & & \\
\hline c & & & \\
\hline C & 496 & 60 & \\
\hline c & & & \\
\hline H & & & \\
\hline H & & -1. & \\
\hline H & & & \\
\hline C & & & \\
\hline H & & & \\
\hline c & & & \\
\hline H & & 644 & \\
\hline H & & & \\
\hline H & & & \\
\hline c & & & \\
\hline H & & & \\
\hline H & & & \\
\hline H & & & \\
\hline C & & & \\
\hline H & & & \\
\hline c & & & \\
\hline H & & & \\
\hline H & & & \\
\hline H & & & \\
\hline C & & & \\
\hline H & & & \\
\hline H & & & \\
\hline $\mathbf{H}$ & & & \\
\hline c & & & \\
\hline H & & & \\
\hline c & & & 743 \\
\hline H & & & \\
\hline c & & & 21 \\
\hline H & & & \\
\hline H & & & \\
\hline H & & & \\
\hline c & & & \\
\hline$H$ & & & \\
\hline H & & & \\
\hline H & & & \\
\hline C & & & \\
\hline & & & \\
\hline H & & & \\
\hline H & & & \\
\hline c & & & \\
\hline H & & & \\
\hline H & 17 & -1.4 & 648280 \\
\hline H & & & \\
\hline C & & & \\
\hline c & & & \\
\hline B & -1.0 & & 464 \\
\hline 0 & & & \\
\hline 0 & & & \\
\hline c & 0.342952 & 3.463210 & -2.031 \\
\hline
\end{tabular}




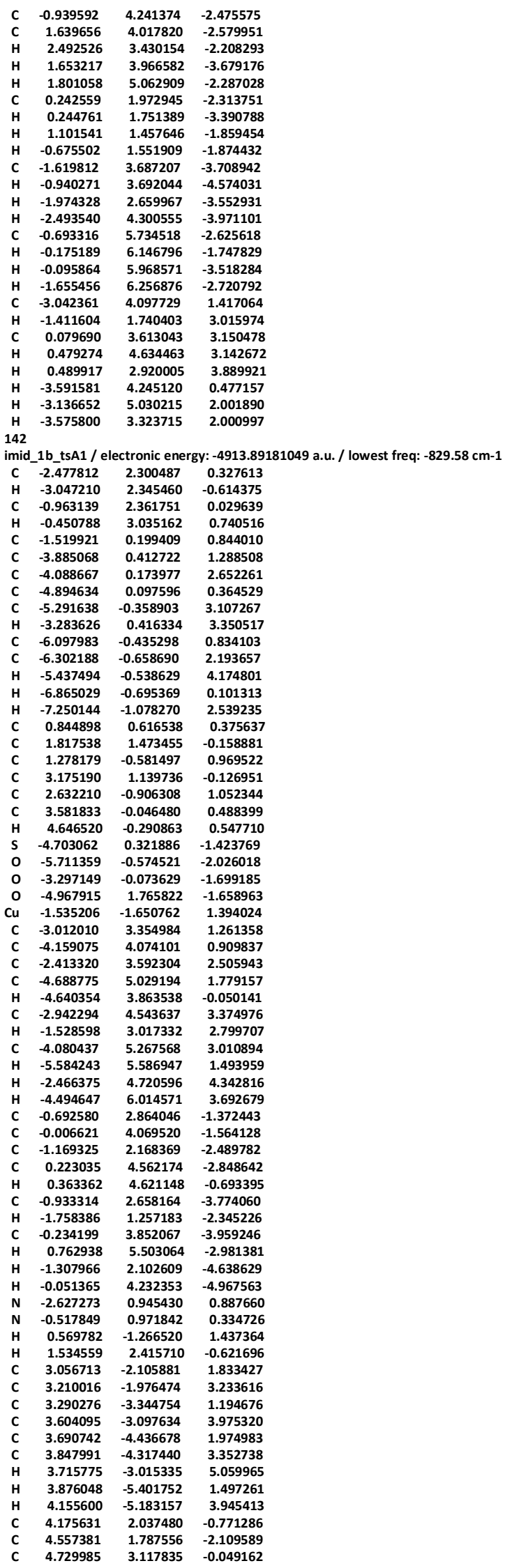




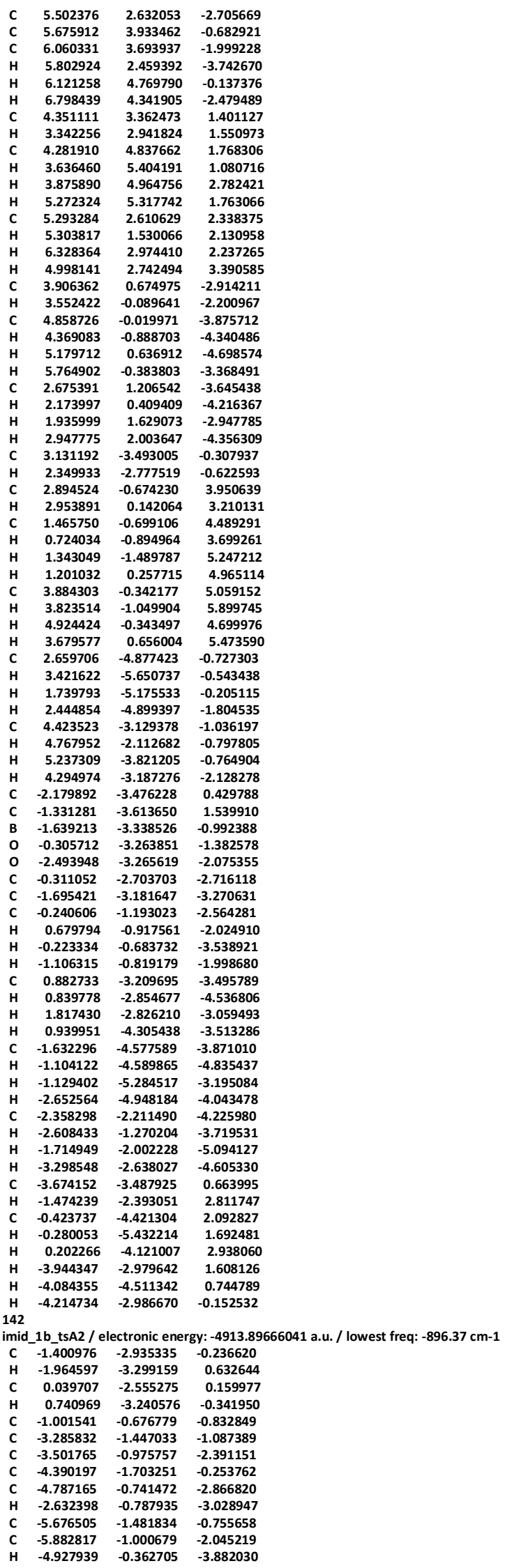




\begin{tabular}{|c|c|c|c|}
\hline & -6.521756 & & \\
\hline & -6.899496 & -0.823451 & -2.404350 \\
\hline & 1.381846 & -0.490226 & -0.293810 \\
\hline & .593352 & -1.188603 & 198634 \\
\hline & 3054 & 7994 & 3286 \\
\hline & 3.801602 & -0.502938 & -0.042839 \\
\hline & 2.586409 & 1.607075 & -0.065199 \\
\hline & 3.788608 & & \\
\hline$n$ & .728847 & 1.437418 & 162626 \\
\hline s & -4.271245 & -2.313248 & 1.453535 \\
\hline 0 & -5.533478 & & \\
\hline 0 & & & 2.025666 \\
\hline 0 & -4.171538 & -3.791018 & \\
\hline & -1.380113 & 3221 & 3980 \\
\hline C & -1.5 & & \\
\hline C & -2.558438 & & \\
\hline C & & & \\
\hline 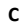 & -2.7 & -5.7 & \\
\hline H & -3.2 & & \\
\hline C & -0.8 & & \\
\hline H & 0.133966 & & \\
\hline C & -1.86 & -5.7 & \\
\hline H & & & \\
\hline & & & \\
\hline H & & & \\
\hline & & & \\
\hline & & & \\
\hline & & & \\
\hline C & & & \\
\hline H & & & \\
\hline$c$ & & & \\
\hline H & & & \\
\hline C & & & 974 \\
\hline H & & & \\
\hline H & & & \\
\hline $\mathrm{H}$ & & & \\
\hline $\mathbf{N}$ & & & \\
\hline $\mathbf{N}$ & & & 2882 \\
\hline H & & & \\
\hline H & & & \\
\hline C & & & 9877 \\
\hline c & & & \\
\hline c & & & 444 \\
\hline C & & & \\
\hline c & & & \\
\hline c & 39 & & 1945 \\
\hline H & & & \\
\hline H & & & \\
\hline H & & & \\
\hline C & & & \\
\hline C & 5.417163 & -1.9 & \\
\hline C & & & \\
\hline$c$ & & & \\
\hline C & & & \\
\hline C & & & \\
\hline H & & & \\
\hline H & 7.867542 & -2. & \\
\hline H & & & \\
\hline c & 16 & & \\
\hline H & & & 045 \\
\hline C & & & \\
\hline H & & & \\
\hline H & & & -4 \\
\hline H & & & \\
\hline$c$ & & & \\
\hline H & & & \\
\hline H & & & \\
\hline H & & & \\
\hline c & & & \\
\hline$H$ & & & \\
\hline c & & & \\
\hline H & & & \\
\hline$H$ & & & \\
\hline H & & & \\
\hline c & & & \\
\hline H & & & \\
\hline H & & & \\
\hline 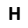 & & & \\
\hline C & & & \\
\hline H & & & \\
\hline c & & & \\
\hline H & & & \\
\hline C & 2.458 & & \\
\hline 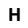 & & & \\
\hline H & & & \\
\hline H & & & \\
\hline C & & & \\
\hline H & & & \\
\hline & & & \\
\hline H & & & -3.5 \\
\hline & & & \\
\hline & 068991 & .707084 & 891 \\
\hline
\end{tabular}




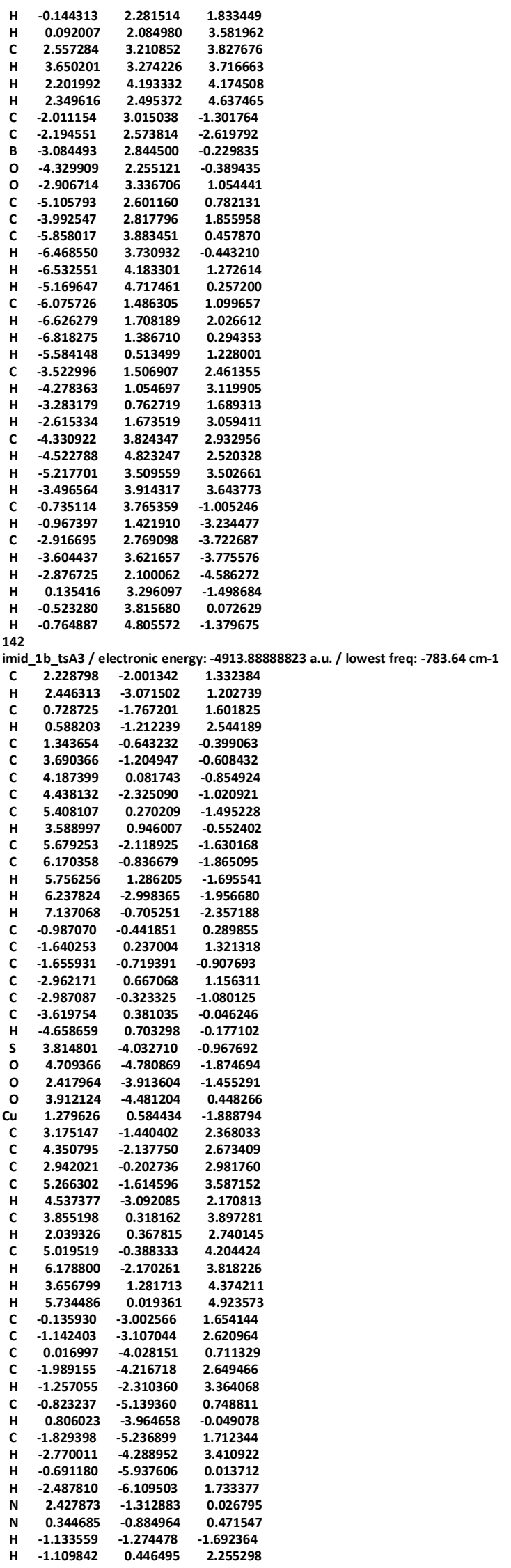




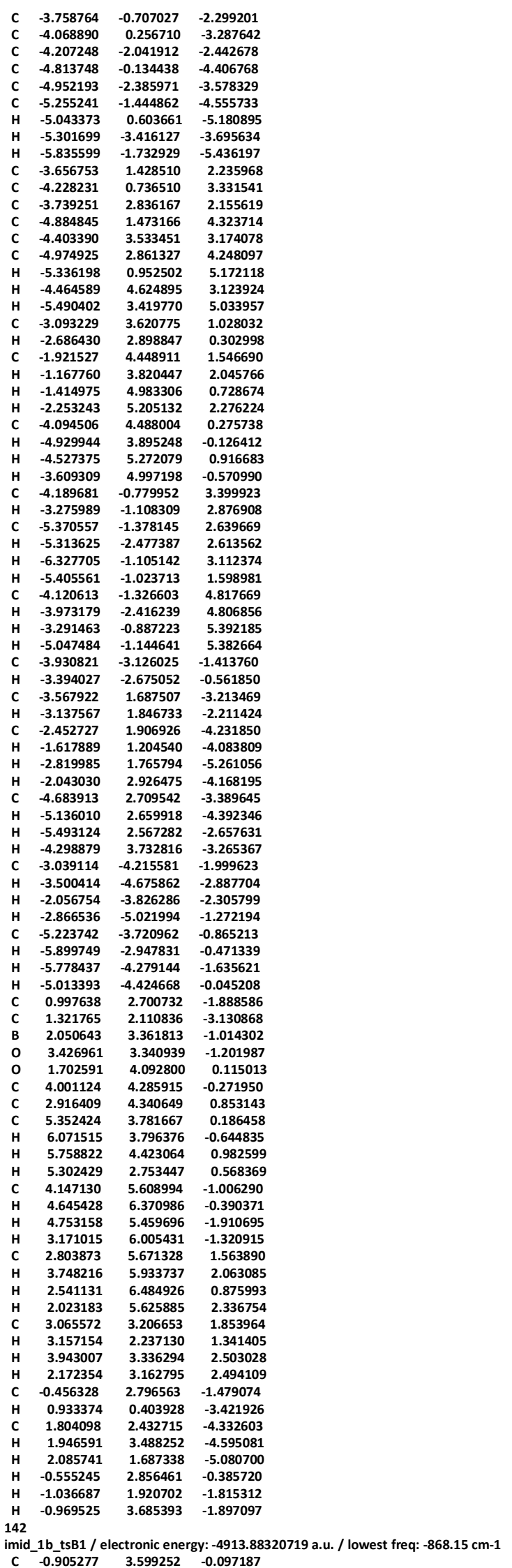




\begin{tabular}{|c|c|c|c|}
\hline & -0.807186 & .854170 & \\
\hline & 0288 & 24324 & -0.278544 \\
\hline & -2.529725 & 2.680275 & -1.237174 \\
\hline & 0.122953 & 528564 & -0.567377 \\
\hline & 1.626636 & 382606 & 124400 \\
\hline & 2.334144 & .564948 & -1.616152 \\
\hline & 56196 & 3.617479 & 1432 \\
\hline & 3.658823 & 3.995936 & -1.596272 \\
\hline & 1.826807 & .350855 & -2.560539 \\
\hline & 3.585644 & 16071 & 0.815876 \\
\hline & 4.284693 & 38061 & 4558 \\
\hline & 4.201232 & 4533 & \\
\hline & 1933 & 4125 & 1855 \\
\hline & 5.326009 & 568180 & -0.345237 \\
\hline & -1.737617 & 0.000739 & -0.295252 \\
\hline$c$ & -3.014428 & -0.277936 & -0.793018 \\
\hline & & & \\
\hline C & -3.5 & 548 & \\
\hline & & 2256 & \\
\hline$c$ & & 32 & \\
\hline & -3.1 & -3.5 & -0 . \\
\hline & & & \\
\hline 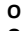 & 556 & & 134 \\
\hline & & & \\
\hline 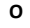 & & & \\
\hline $\mathrm{Cu}$ & 1.6 & & \\
\hline & -1.1 & & \\
\hline & -1.1 & & \\
\hline c & -1.2 & & \\
\hline & -1.3 & & \\
\hline & & & \\
\hline c & & & \\
\hline H & -1.1 & & \\
\hline & & & \\
\hline H & & & \\
\hline- & & & \\
\hline & & & \\
\hline & -3.0 & & \\
\hline & & & \\
\hline c & & & \\
\hline C & -5.2 & & \\
\hline & & & \\
\hline$c$ & -3.5 & & \\
\hline - & -1.5 & & \\
\hline c & & & \\
\hline H & -6 & & \\
\hline H & & & \\
\hline $\mathrm{H}$ & $-5.6 c$ & 4067 & \\
\hline $\mathbf{N}$ & & 11 & \\
\hline $\mathbf{N}$ & -1 & & \\
\hline H & -0.01 & 53 & \\
\hline H & & & \\
\hline c & -0.7 & & \\
\hline c & & & \\
\hline & & & \\
\hline & 808 & & \\
\hline C & -0.3 & -4.7 & \\
\hline$c$ & & & \\
\hline & & & \\
\hline H & & & \\
\hline H & & & \\
\hline$c$ & & & \\
\hline$c$ & & & \\
\hline$c$ & & & \\
\hline & & & \\
\hline & & & \\
\hline$c$ & & & \\
\hline & & & \\
\hline H & & & \\
\hline H & & & \\
\hline$c$ & & & \\
\hline H & & & \\
\hline$c$ & & & \\
\hline-1 & & & \\
\hline-1 & & & \\
\hline H & & & \\
\hline C & & & \\
\hline-1 & & & \\
\hline $\mathrm{H}$ & & & \\
\hline H & & & \\
\hline c & & & \\
\hline H & & & \\
\hline C & & 82 & \\
\hline H & & & \\
\hline & & & \\
\hline 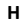 & & & \\
\hline 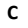 & $\ldots$ & & 127 \\
\hline H & & & \\
\hline & & & \\
\hline H & & & \\
\hline$c$ & & & \\
\hline 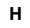 & 2802361 & 872 & ר? \\
\hline
\end{tabular}




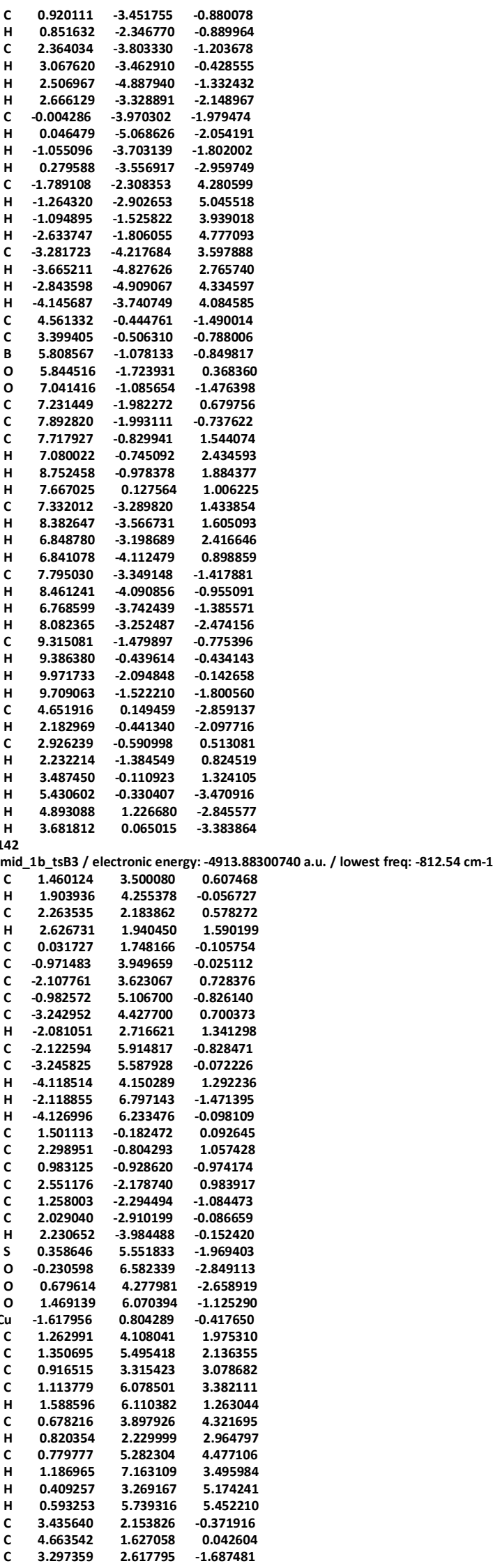




\begin{tabular}{|c|c|c|c|}
\hline & & & \\
\hline & 4.773930 & 1.268056 & 1.071225 \\
\hline & 4.377124 & 2.555195 & -2.566381 \\
\hline & 2.346834 & 3.054139 & -2.019877 \\
\hline & 5.602294 & 2.032376 & -2.146067 \\
\hline & 6.703534 & 1.168826 & -0.499426 \\
\hline & 4.262080 & 2.925152 & -3.588531 \\
\hline & 6.447377 & 1.990287 & -2.838012 \\
\hline & 0.146433 & 3.078098 & 0.046315 \\
\hline & 1.229114 & 1.196850 & 0.185013 \\
\hline & 0.392730 & -0.418215 & -1.741335 \\
\hline & 2.702868 & -0.225221 & 1.892195 \\
\hline & 0.810858 & -3.073154 & -2.277553 \\
\hline & -0.552273 & -3.422747 & -2.441459 \\
\hline & 1.774819 & -3.455237 & -3.244779 \\
\hline & -0.924814 & -4.154911 & -3.575693 \\
\hline & 1.350720 & -4.184986 & -4.362668 \\
\hline & 0.014839 & -4.533861 & -4.528500 \\
\hline & -1.97 & -4.434421 & -3.718747 \\
\hline & 2.077334 & -4.483630 & -5.121486 \\
\hline & -0.296648 & -5.103651 & -5.408014 \\
\hline & 3.330736 & -2.857958 & 2.058762 \\
\hline & 4.731448 & -3.001767 & 1.936746 \\
\hline & 2.652445 & -3.357703 & 3.192885 \\
\hline & 5.433211 & -3.647507 & 2.962118 \\
\hline & 3.394384 & -3.993880 & 4.196544 \\
\hline & 4.773533 & -4.138771 & 486 \\
\hline & 6.516294 & -3.773076 & 2.876516 \\
\hline & 2.878399 & -4.38 & 338 \\
\hline & 5.338167 & -4.639295 & 585 \\
\hline & 1.146453 & -3.240328 & 3.349246 \\
\hline & 0.752509 & -2.713095 & 2.465483 \\
\hline & 0.767844 & -2.411939 & 4.571236 \\
\hline & 1.206287 & -1.403413 & 4.532725 \\
\hline & -0.323738 & -2.293994 & 4.643607 \\
\hline & 1.107194 & -2.883282 & 5.506960 \\
\hline & 0.485269 & -4.613748 & 3.384048 \\
\hline & 0.745258 & -5.214948 & 2.499735 \\
\hline & 0.788450 & -5.189660 & 4.272743 \\
\hline & -0.611154 & -4.523562 & 3.411664 \\
\hline & 5.473105 & -2.5 & 0.698 \\
\hline & 4.815949 & -1.830694 & 0.153951 \\
\hline & 5.748504 & -3.709971 & -0.232514 \\
\hline & 6.224460 & -3.37 & -1.16 \\
\hline & 6.426413 & -4.438857 & 0.240050 \\
\hline & 4.826982 & -4.249483 & -0.499320 \\
\hline & 6.762469 & -1.788955 & 1.021766 \\
\hline & 7.228708 & -1.403563 & 0.103428 \\
\hline & 6.592006 & -0.935070 & 1.694137 \\
\hline & 7.507034 & -2.441674 & 1.502634 \\
\hline & 3.233553 & -3.042692 & -3.11 \\
\hline & 3.496025 & -3.105813 & -2.045096 \\
\hline & -1.588238 & -3.054535 & -1.392288 \\
\hline & -1.385581 & -2.009775 & -1.09 \\
\hline & -3.023458 & -3.095891 & -1.890983 \\
\hline & -3.175522 & -2.469314 & -2.783123 \\
\hline & -3.349211 & -4.119334 & -2.136486 \\
\hline & -3.699929 & -2.72 & -1.10 \\
\hline & -1.450591 & -3.925924 & -0.145020 \\
\hline & -1.625130 & -4.987615 & -0.383 \\
\hline & -0.454071 & -3.8 & 25 \\
\hline & -2.189883 & -3.634425 & 0.618246 \\
\hline & 3.441372 & -1.587234 & -3.526298 \\
\hline & 3.208142 & -1.435616 & -4.592279 \\
\hline & 2.808332 & -0.895609 & -2.951131 \\
\hline & 4.488019 & -1.282732 & -3.369033 \\
\hline & 4.198760 & -3.951359 & -3.858420 \\
\hline & 4.066329 & -5.010535 & -3.590783 \\
\hline & 4.094268 & -3.869502 & -4.951076 \\
\hline & 5.238206 & -3.679989 & -3.624544 \\
\hline & -4.614512 & 97 & 664 \\
\hline & -3.337300 & -0.126826 & -0.234975 \\
\hline & -5.686674 & -0.880259 & -0.048323 \\
\hline & -5.463625 & -1.82 & 0.932301 \\
\hline & -7.004657 & -0.871332 & -0.465387 \\
\hline & -6.635674 & -2.673799 & 0.984899 \\
\hline & -7.751020 & & \\
\hline & -6.373801 & -3.863324 & 111 \\
\hline & -5.452127 & -4.372703 & 0.390566 \\
\hline & -7.191551 & -4.597247 & \\
\hline & -6.240079 & -3.55 & -0.971907 \\
\hline & -6.847793 & -3.135741 & 2.409923 \\
\hline & -7.787025 & -3.700063 & 2.505194 \\
\hline & -6.029463 & -3.801060 & 770 \\
\hline & -6.877111 & -2.296692 & 3.116357 \\
\hline & -8.349330 & -0.834450 & 1.506590 \\
\hline & -8.993389 & -1.397452 & 2.196538 \\
\hline & -7.568407 & -0.333868 & 2.096478 \\
\hline & -8.963236 & -0.054173 & 1.035809 \\
\hline & -8.843949 & -2.423550 & -0.348674 \\
\hline & -8.451571 & -2.946038 & -1.2299 \\
\hline & -9.371255 & -3.155413 & 0.280473 \\
\hline
\end{tabular}




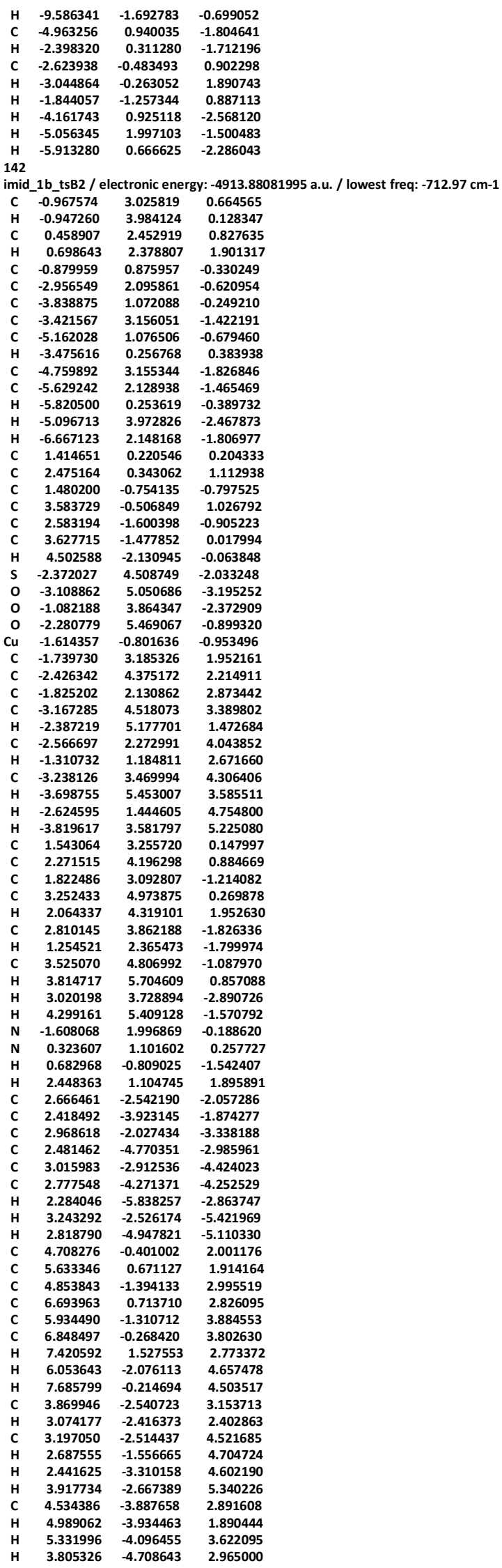




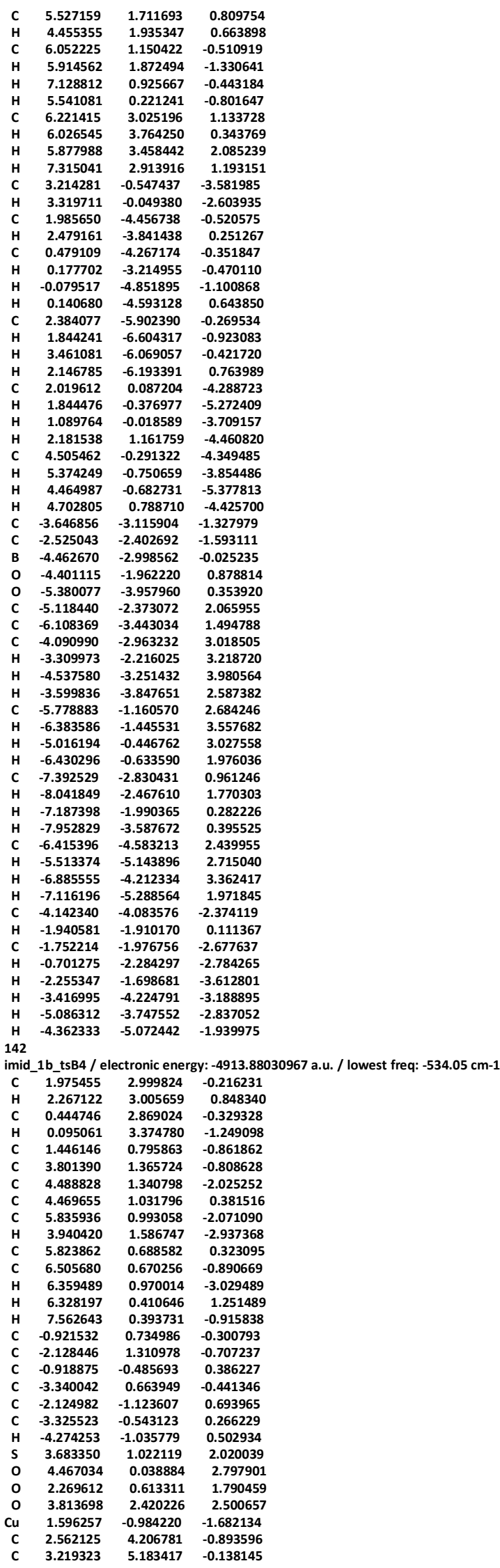




\begin{tabular}{|c|c|c|c|}
\hline & 2.462184 & 4.375794 & -2.281705 \\
\hline & 3.760686 & 6.312641 & -0.754434 \\
\hline & 3.309850 & 5.049987 & 0.943661 \\
\hline & 3.006465 & 5.499745 & -2.898681 \\
\hline & 1.959975 & 3.611912 & -2.884135 \\
\hline & 3.656043 & 6.472931 & -2.135293 \\
\hline & 4.271373 & 7.067503 & -0.151387 \\
\hline & 2.926177 & 5.617659 & -3.982312 \\
\hline & 4.083892 & 7.354133 & -2.619833 \\
\hline & -0.297774 & 3.432512 & 0.850513 \\
\hline & -1.054006 & 4.600128 & 0.709413 \\
\hline & -0.208830 & 2.818039 & 2.108117 \\
\hline & -1.710732 & 5.155545 & 1.808242 \\
\hline & -1.122851 & 5.079930 & -0.272269 \\
\hline & -0.881973 & 3.364104 & 3.199455 \\
\hline & 0.410015 & 1.920273 & 2.221450 \\
\hline & -1.631834 & 4.534161 & 3.053895 \\
\hline & -2.292819 & 6.072693 & 1.687073 \\
\hline & -0.811725 & 2.879628 & 4.177075 \\
\hline & -2.153502 & 4.961879 & 3.914224 \\
\hline & 2.421407 & 1.720301 & -0.808500 \\
\hline & 0.296870 & 1.407667 & -0.511015 \\
\hline & 0.035381 & -0.900353 & 0.727379 \\
\hline & -2.125563 & 2.262970 & -1.245881 \\
\hline & -2.131541 & -2.341174 & 1.554421 \\
\hline & -2.441831 & -3.611627 & 1.008953 \\
\hline & -1.834753 & -2.204506 & 2.929555 \\
\hline & -2.387667 & -4.732795 & 1.843973 \\
\hline & -1.778592 & -3.358202 & 3.724725 \\
\hline & -2.041786 & -4.612777 & 3.188571 \\
\hline & -2.611147 & -5.721588 & 1.435725 \\
\hline & -1.533519 & -3.264511 & 4.786974 \\
\hline & -1.991256 & -5.502529 & 3.821987 \\
\hline & -4.628362 & 1.209613 & -0.954913 \\
\hline & -5.290447 & 2.258447 & -0.271651 \\
\hline & -5.176936 & 0.656450 & -2.132988 \\
\hline & -6.505445 & 2.727194 & -0.784144 \\
\hline & -6.395775 & 1.158544 & -2.609895 \\
\hline & -7.057177 & 2.182198 & -1.942099 \\
\hline & -7.034560 & 3.533931 & -0.271484 \\
\hline & -6.827078 & 0.742503 & -3.525656 \\
\hline & -8.006986 & 2.563962 & -2.326011 \\
\hline & -4.474109 & -0.436816 & -2.920778 \\
\hline & -3.559232 & -0.720038 & -2.375653 \\
\hline & -4.037825 & 0.073286 & -4.290079 \\
\hline & -3.361869 & 0.937578 & -4.203908 \\
\hline & -3.505284 & -0.707082 & -4.853719 \\
\hline & -4.898501 & 0.386629 & -4.901736 \\
\hline & -5.329180 & -1.692442 & -3.043989 \\
\hline & -5.635238 & -2.081792 & -2.060992 \\
\hline & -6.247890 & -1.509814 & -3.623410 \\
\hline & -4.776726 & -2.492681 & -3.559823 \\
\hline & -4.722039 & 2.823858 & 1.019477 \\
\hline & -3.620845 & 2.814039 & 0.925827 \\
\hline & -5.077919 & 1.930228 & 2.206150 \\
\hline & -4.609423 & 2.296696 & 3.132816 \\
\hline & -6.167153 & 1.908207 & 2.371005 \\
\hline & -4.746813 & 0.892060 & 2.058627 \\
\hline & -5.142001 & 4.259167 & 1.294930 \\
\hline & -4.620698 & 4.648219 & 2.181271 \\
\hline & -4.913233 & 4.929847 & 0.452985 \\
\hline & -6.219275 & 4.344095 & 1.505424 \\
\hline & -1.616303 & -0.852532 & 3.589354 \\
\hline & -1.845080 & -0.069012 & 2.848416 \\
\hline & -2.769496 & -3.763909 & -0.465684 \\
\hline & -3.332061 & -2.865579 & -0.772018 \\
\hline & -1.488009 & -3.791436 & -1.292696 \\
\hline & -0.846832 & -2.916973 & -1.101289 \\
\hline & -0.892910 & -4.691026 & -1.063991 \\
\hline & -1.708830 & -3.812257 & -2.371974 \\
\hline & -3.639732 & -4.969752 & -0.782320 \\
\hline & -3.107205 & -5.920262 & -0.625235 \\
\hline & -4.555326 & -4.997791 & -0.172639 \\
\hline & -3.946624 & -4.956510 & -1.838153 \\
\hline & -0.166685 & -0.661256 & 4.019545 \\
\hline & 0.152323 & -1.448546 & 4.722078 \\
\hline & 0.526457 & -0.675517 & 3.166299 \\
\hline & -0.029278 & 0.304170 & 4.530588 \\
\hline & -2.573090 & -0.646433 & 4.759362 \\
\hline & -3.622179 & -0.798726 & 4.463466 \\
\hline & -2.363343 & -1.333482 & 5.594043 \\
\hline & -2.487824 & 0.376232 & 5.157127 \\
\hline & 1.393657 & -3.676287 & -2.884900 \\
\hline & 1.160184 & -2.347867 & -3.109522 \\
\hline & 1.908498 & -3.948133 & -1.486790 \\
\hline & 1.889988 & -2.899768 & -0.557463 \\
\hline & 2.405485 & -5.103392 & -0.929343 \\
\hline & 2.673854 & -3.312826 & 0.595421 \\
\hline & 2.572124 & -4.873781 & 0.493913 \\
\hline & 4.077648 & -2.778083 & 0.375040 \\
\hline & 4.023614 & -1.686335 & 0.25527 \\
\hline & 4.740082 & -2.987070 & 1.226 \\
\hline
\end{tabular}




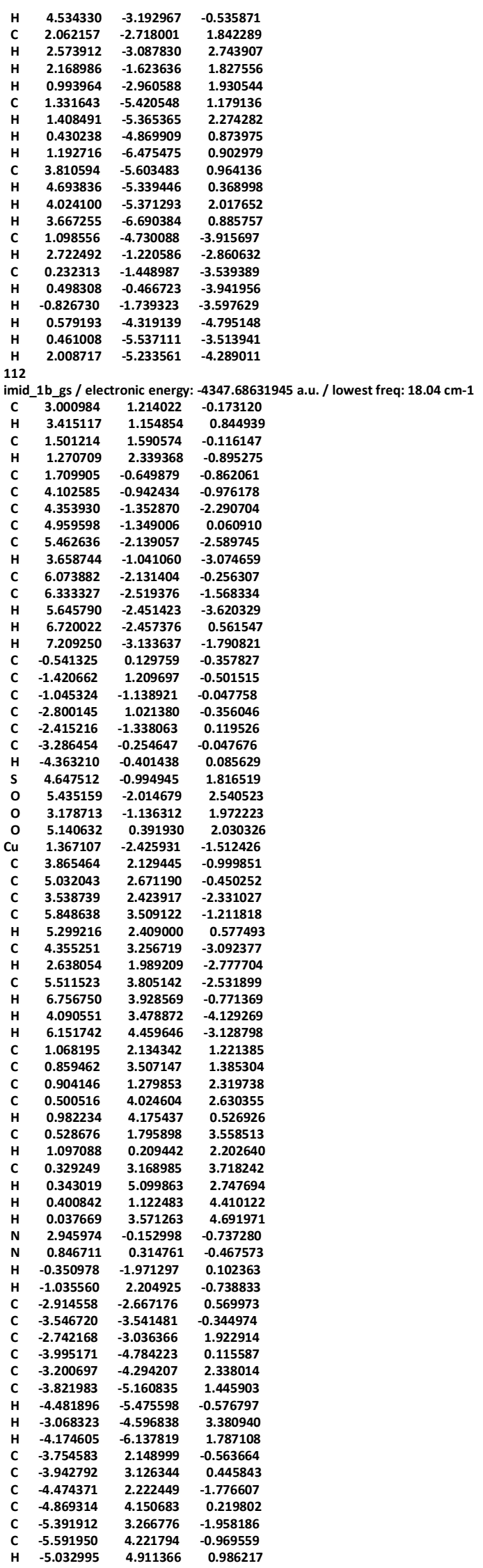




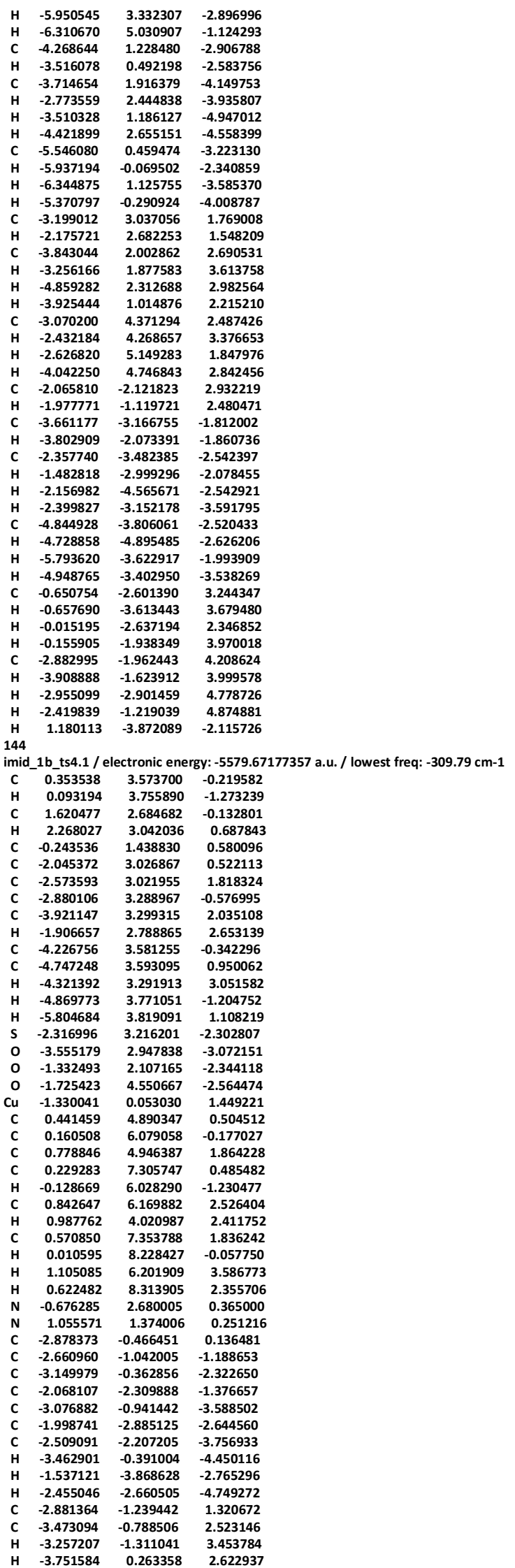




\begin{tabular}{|c|c|c|c|}
\hline & -1.661077 & -2.857137 & \\
\hline & -2.555923 & -2.282600 & 006 \\
\hline & -5.909033 & -2.085876 & 1.345076 \\
\hline & -6.046777 & 1.045407 & 06252 \\
\hline & -5.236310 & & \\
\hline & -7.436979 & -2.362264 & 798682 \\
\hline & -5.325395 & -1.357817 & 0726 \\
\hline & -3.438114 & 79051 & 149553 \\
\hline & -3.587040 & 0.632606 & -2.210656 \\
\hline & -6.609616 & 0.246558 & $0.24872 \mathrm{~s}$ \\
\hline & -6.346249 & 0.859591 & -0.622022 \\
\hline & -7.706522 & & 0.325127 \\
\hline & -6.216259 & 383 & \\
\hline & -8.290106 & & \\
\hline & -9.263639 & 523 & 5575 \\
\hline & -8.434452 & & 8796 \\
\hline & -7.9 & & \\
\hline & & & \\
\hline & & & \\
\hline & & & \\
\hline & & & \\
\hline & & & \\
\hline & & & \\
\hline & & & \\
\hline & & & \\
\hline & & & \\
\hline & & & \\
\hline & & & \\
\hline & & & \\
\hline & & & \\
\hline & & & \\
\hline & & & \\
\hline & & & \\
\hline & & & \\
\hline & & & \\
\hline & & & \\
\hline & & & \\
\hline & & & \\
\hline & & & \\
\hline & & & \\
\hline & & & \\
\hline & -0.6 & & \\
\hline & & & \\
\hline & & & \\
\hline & & & \\
\hline & & & \\
\hline & & & \\
\hline & & & \\
\hline & 48 & & \\
\hline$H$ & & & \\
\hline & 3.87 & 339 & \\
\hline & & & \\
\hline & & & \\
\hline & & & \\
\hline & & & \\
\hline & & & \\
\hline & & & \\
\hline & & & \\
\hline & & & \\
\hline & & & 32 \\
\hline & & & \\
\hline & -1. & & \\
\hline & & & \\
\hline & & & \\
\hline & & & \\
\hline & & & \\
\hline & & & \\
\hline & & & \\
\hline & & & \\
\hline & & & \\
\hline & & & \\
\hline & & & \\
\hline & & & \\
\hline & & & \\
\hline & & & \\
\hline & & & \\
\hline & & & \\
\hline & & & \\
\hline & & & \\
\hline & & & \\
\hline & & & \\
\hline & & & \\
\hline & & & \\
\hline & & & \\
\hline & & & \\
\hline & & & 183 \\
\hline & & & \\
\hline & & & \\
\hline & & & \\
\hline & & & \\
\hline & & & \\
\hline & 3612733 & 361441 & 1512 \\
\hline
\end{tabular}




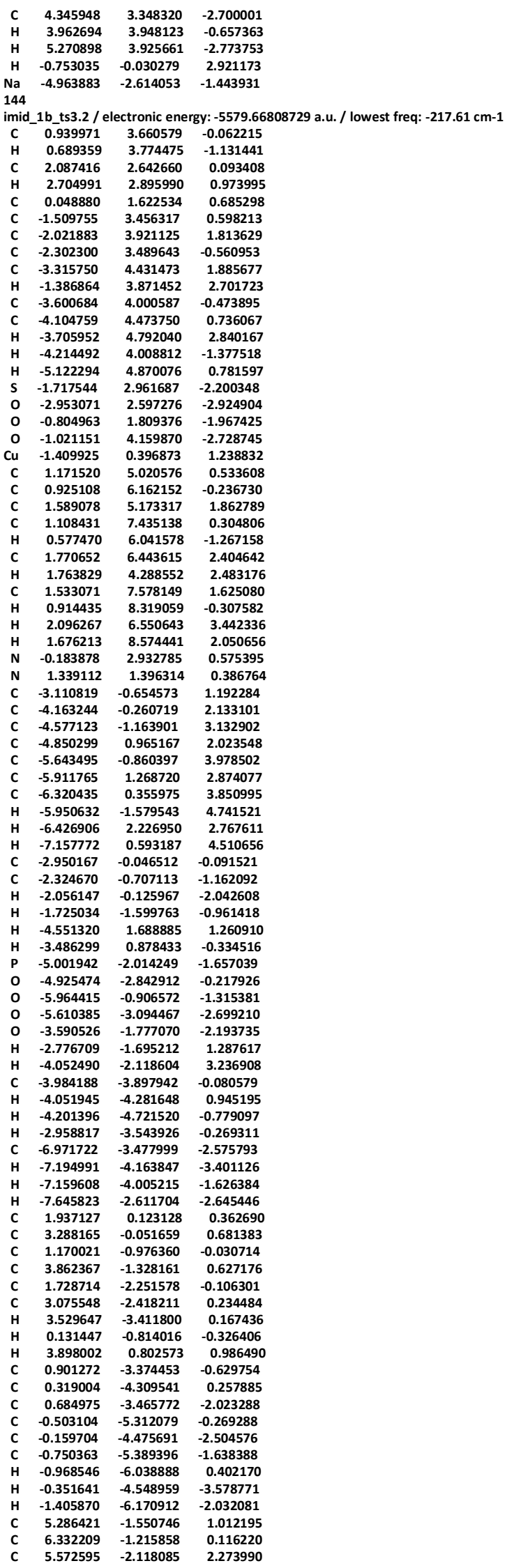




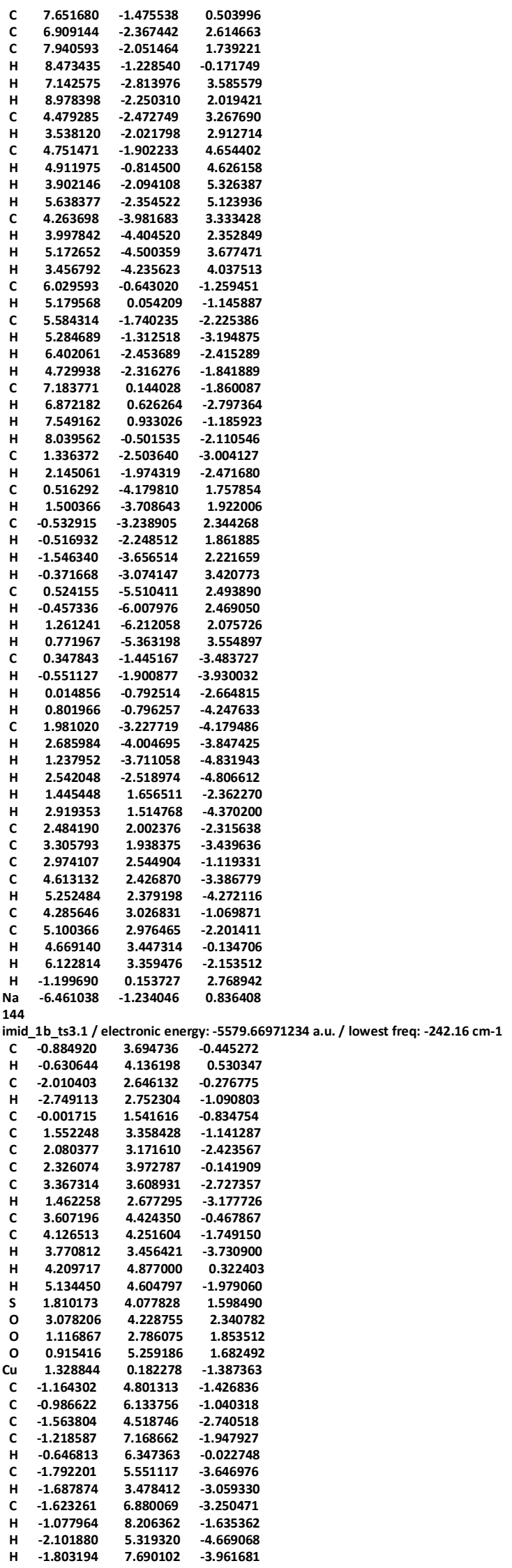




\begin{tabular}{|c|c|c|c|}
\hline & 0.252276 & 848231 & \\
\hline & 93 & 370637 & -0.459058 \\
\hline & 3.023619 & -0.913467 & 1381334 \\
\hline & 3.064243 & -2.348414 & 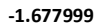 \\
\hline & 3.462203 & & \\
\hline & 2.846716 & -3.338026 & -0.697483 \\
\hline & 3.656828 & -4.117847 & 3621 \\
\hline & & & \\
\hline & 3.467622 & -5.085532 & -2.261486 \\
\hline & & & 738 \\
\hline & & & \\
\hline & & & \\
\hline & 2.83 & & \\
\hline & 463 & 532 & \\
\hline & & & \\
\hline & & & \\
\hline & & & \\
\hline & & & \\
\hline & 5.97 & & \\
\hline & & & \\
\hline & & & \\
\hline & & & \\
\hline & & & \\
\hline & & & \\
\hline & & & \\
\hline & & & \\
\hline & & & \\
\hline & & & \\
\hline & & & \\
\hline & & & \\
\hline & & & \\
\hline & & & \\
\hline & & & \\
\hline & 7 & & \\
\hline & -3.2 & & \\
\hline C & -1.1 & & \\
\hline & -3.8 & & \\
\hline & -1.7 & & \\
\hline C & -3.08 & & \\
\hline$H$ & 91 & & \\
\hline & -0.0 & -0.8 & \\
\hline & -3.8 & & \\
\hline & -0.8 & & \\
\hline & -0.5 & & \\
\hline & -0.2 & & \\
\hline & & & \\
\hline & & & \\
\hline & & & \\
\hline H & & & \\
\hline & & & \\
\hline & 1.47 & & \\
\hline & : & & \\
\hline & -6.2 & & \\
\hline & & & \\
\hline & -7.6 & & \\
\hline & -7.1 & & \\
\hline & -8.0 & & \\
\hline & & & \\
\hline & & & \\
\hline$H_{2}$ & -9.1 & & \\
\hline & & & \\
\hline & -3.7 & & \\
\hline & -4.9 & & \\
\hline & & & \\
\hline & & & \\
\hline & & & \\
\hline & & & \\
\hline & & & \\
\hline & & & \\
\hline & & & \\
\hline & & & \\
\hline & & & \\
\hline & & & \\
\hline & & & \\
\hline & & & \\
\hline & & & \\
\hline & & & \\
\hline & & & \\
\hline & & & \\
\hline & & & \\
\hline & & & \\
\hline & & & \\
\hline & & & \\
\hline & & & \\
\hline & & & \\
\hline & & & \\
\hline & 01 & 38 & 77 \\
\hline & & & \\
\hline & & & \\
\hline & & & \\
\hline & & & \\
\hline & 175 & 791 & -262817 \\
\hline
\end{tabular}




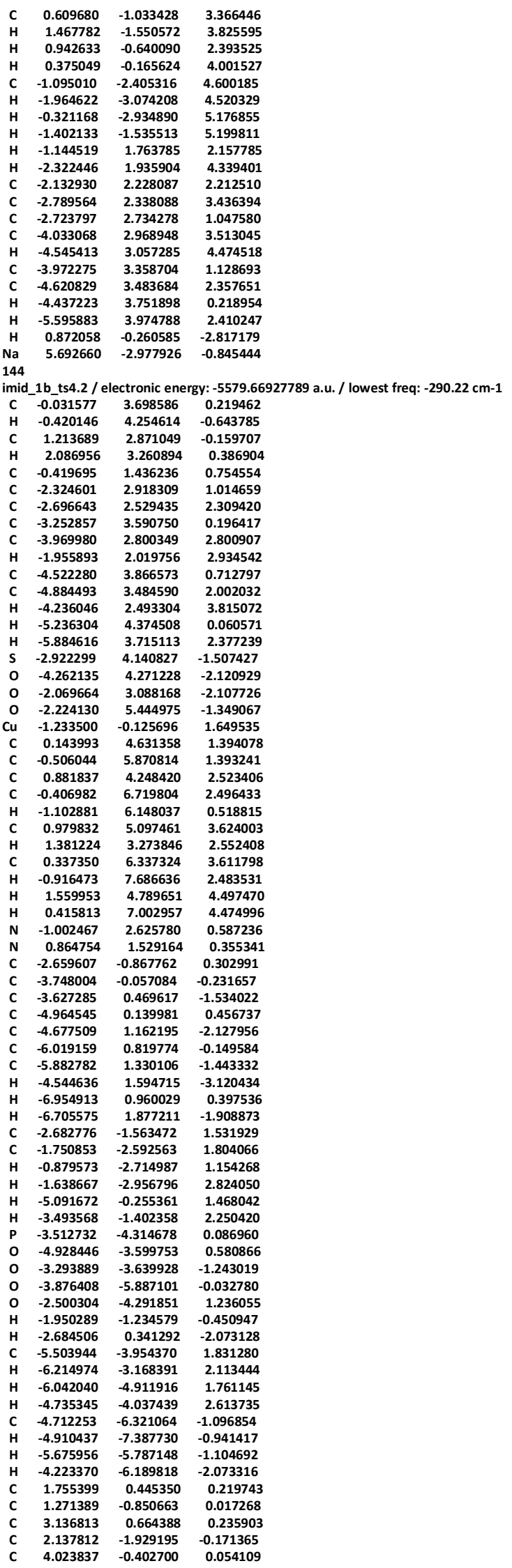




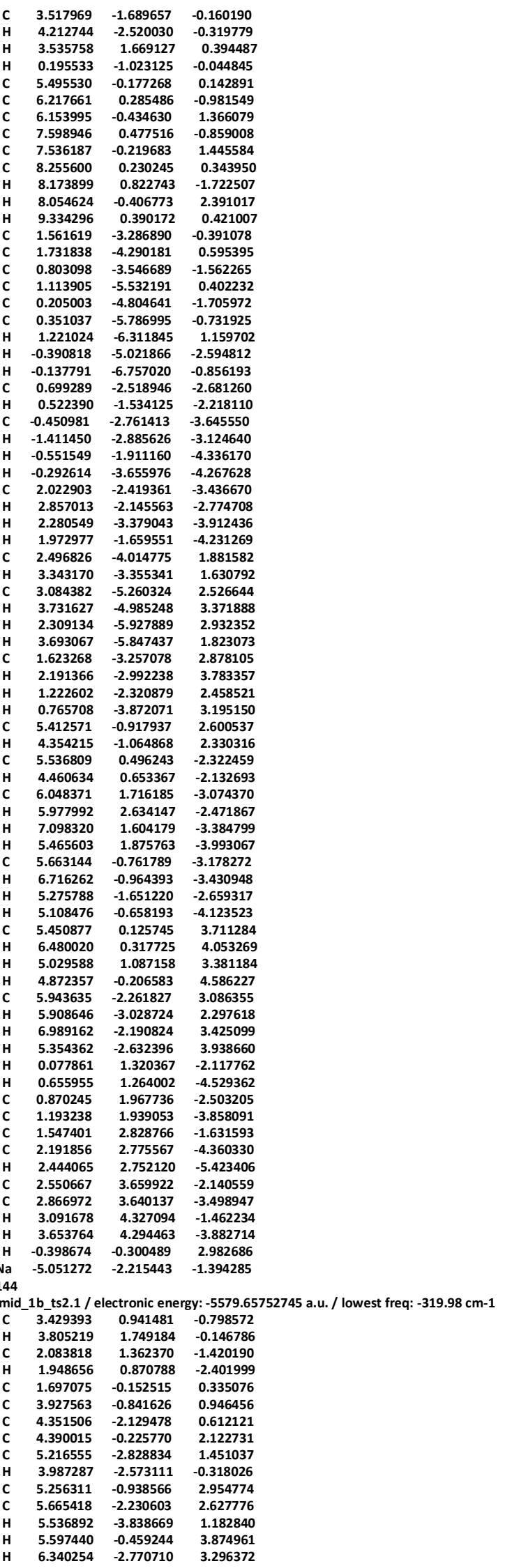




\begin{tabular}{|c|c|c|c|}
\hline & 990884 & 132 & $3838 / 3$ \\
\hline & 9527 & 1303 & 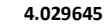 \\
\hline & 557272 & 682818 & 23961 \\
\hline & 09900 & 99141 & 742200 \\
\hline & 367 & & \\
\hline & 4.509011 & 0.545422 & -1.764720 \\
\hline & 5.760025 & 1.168095 & .705120 \\
\hline & 4.299838 & 0.472645 & \\
\hline & 6.781774 & & -2.576412 \\
\hline & 5.930197 & 3570 & \\
\hline & 5.320622 & -0.85 & \\
\hline & 3.329184 & -0.976971 & -2.747793 \\
\hline & 6.56 & 5093 & -3.5 \\
\hline & & & -2 \\
\hline & 5.147723 & 196 & \\
\hline & & & \\
\hline & & & \\
\hline & & 373 & \\
\hline & & & \\
\hline & & -3.4 & \\
\hline & & -3.1 & \\
\hline & 1.962 & -4.5 & \\
\hline & & -3.8 & \\
\hline & & -5.2 & \\
\hline & 3.09 & & \\
\hline & & & \\
\hline & & & \\
\hline & 3.80 & 993 & \\
\hline & -0.28 & 66 & \\
\hline & -1.51 & 4 & \\
\hline & -1.7 & & \\
\hline & -1.9 & & \\
\hline - & & -4.8 & \\
\hline H & & 91 & \\
\hline & -2.7 & -4.80 & \\
\hline 0 & -4.0 & -5.7 & \\
\hline 0 & & & \\
\hline 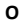 & -1.6 & -5.9 & \\
\hline 0 & -2.9 & -3.8 & \\
\hline H & -0.469055 & -2.1 & \\
\hline n & & -2.2 & \\
\hline & -5.3 & & \\
\hline H & -6.08 & -5.8 & \\
\hline H & & & \\
\hline & -5.3 & & \\
\hline & -1.7 & -6.6 & \\
\hline H & -0.7 & & \\
\hline & -1.9 & & \\
\hline H & -2.4 & -7.3 & \\
\hline$c$ & -0.2 & & \\
\hline$c$ & -1.0 & & \\
\hline & -0.6 & & \\
\hline$c$ & -2.3 & & \\
\hline$c$ & & & \\
\hline & -2.8 & & \\
\hline H & & 755 & 92 \\
\hline$c$ & -2.42 & & \\
\hline$c$ & & & \\
\hline & 7 & & \\
\hline$c$ & -3 & & \\
\hline$c$ & & & \\
\hline & . & & \\
\hline H & & & \\
\hline H & & & \\
\hline$H$ & & & \\
\hline 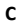 & & & \\
\hline 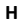 & & & \\
\hline$c$ & & & \\
\hline 11 & & & \\
\hline 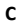 & -3.7 & & \\
\hline 4 & & & \\
\hline $\mathrm{H}$ & & & \\
\hline H & -4.0 & 3 & \\
\hline C & & & \\
\hline H & -6 & & \\
\hline H & & & \\
\hline H & & & \\
\hline & & & \\
\hline H & & & \\
\hline$\cdots$ & & & \\
\hline H & & & \\
\hline C & & & \\
\hline H & & & \\
\hline & & & \\
\hline & & & \\
\hline H & & & \\
\hline H & & & \\
\hline & & & \\
\hline c & & & \\
\hline 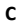 & & & -1.3 \\
\hline & & & \\
\hline & 01 & 6.700486 & 2040 \\
\hline
\end{tabular}




\begin{tabular}{rrrr} 
C & 1.895233 & 3.405100 & -2.871842 \\
C & 1.796649 & 4.787248 & -3.038637 \\
H & 1.953114 & 2.748237 & -3.745795 \\
H & 1.785334 & 5.214776 & -4.044064 \\
H & 0.416703 & -0.811644 & 2.919139 \\
H & -3.829007 & 2.475013 & 0.178601 \\
H & -0.709987 & 1.004224 & -2.408028 \\
H & -3.768190 & -2.011454 & -0.698132 \\
H & -3.772786 & -1.881703 & -2.467017 \\
C & -3.637185 & -1.308830 & -1.535945 \\
H & -2.591940 & -0.965805 & -1.515291 \\
H & -6.282216 & -1.287848 & -2.331415 \\
C & -4.631724 & -0.155129 & -1.444713 \\
H & -6.039211 & 0.267894 & -3.749599 \\
C & -4.385173 & 0.902320 & -2.512297 \\
C & -5.211666 & 0.971956 & -3.640783 \\
C & -3.311501 & 1.822306 & -2.404404 \\
C & -5.000345 & 1.926762 & -4.630540 \\
H & -5.655938 & 1.961808 & -5.504580 \\
C & -3.966050 & 2.847476 & -4.499107 \\
C & -3.110478 & 2.819046 & -3.390503 \\
H & -1.214379 & 3.790452 & -5.219118 \\
H & -3.827820 & 3.608701 & -5.270205 \\
H & -1.177553 & 3.442915 & -2.724619 \\
C & -2.059584 & 3.902758 & -3.202950 \\
C & -1.586344 & 4.536772 & -4.500746 \\
H & -2.380559 & 5.112617 & -4.999839 \\
C & -2.572305 & 4.972538 & -2.239404 \\
H & -0.766966 & 5.242612 & -4.304056 \\
H & -3.451763 & 5.491061 & -2.653456 \\
H & -1.800074 & 5.732221 & -2.043195 \\
H & -6.196382 & -1.368442 & -0.573311 \\
C & -6.052888 & -0.696169 & -1.431610 \\
H & -4.466842 & 0.329721 & -0.468044 \\
H & -6.806128 & 0.102311 & -1.357651 \\
H & -2.869275 & 4.547972 & -1.268691 \\
Na & -0.394490 & -5.619788 & -1.669668 \\
\hline 44 & & & \\
\hline & 1 & &
\end{tabular}

$\begin{array}{llll}\mathrm{Na} & -0.394490 & -5.619788 & -1.268691 \\ 144 & & & \end{array}$

imid_1b_ts1.2 / electronic energy: -5579.65957691 a.u. / lowest freq: $-291.26 \mathrm{~cm}-1$

$\begin{array}{lll}\text { C }-1.970488 & 3.343838 & -0.295986\end{array}$

$\begin{array}{llll}\text { H } & -2.281808 & 3.992331 & 0.53606\end{array}$

$\begin{array}{lllll}\text { C } & -2.649984 & 1.959441 & -0.191712\end{array}$

$\begin{array}{llll}H & -3.112118 & 1.704291 & -1.160167\end{array}$

$\begin{array}{llll}\text { C } & -0.317627 & 1.690881 & 0.069791\end{array}$

C $\quad 0.510620 \quad 3.945031 \quad-0.136752$

C $\quad 1.482090 \quad 3.796660 \quad-1.133815$

$\begin{array}{llll}\text { C } & 0.629952 & 4.976733 & 0.809013\end{array}$

$\begin{array}{llll}\text { C } & 2.580770 & 4.649912 & -1.192158\end{array}$

$\begin{array}{llll}\text { H } & 1.349828 & 2.999425 & -1.870482\end{array}$

$\begin{array}{llll}\text { C } & 1.730480 & 5.833522 & 0.729792\end{array}$

$\begin{array}{llll}\text { C } & 2.702318 & 5.676471 & -0.256004\end{array}$

$\begin{array}{llll}\text { H } & 3.331400 & 4.519672 & -1.975839\end{array}$

$\begin{array}{llll}H & 1.821535 & 6.616712 & 1.485260\end{array}$

$\begin{array}{llll}H & 3.556499 & 6.356823 & -0.291107\end{array}$

$\begin{array}{llll}\text { S } & -0.543217 & 5.225936 & 2.173194\end{array}$

$\begin{array}{llll}0 & 0.196714 & 6.051825 & 3.149308\end{array}$

$\begin{array}{llll}0 & -0.864667 & 3.857973 & 2.642775\end{array}$

\begin{tabular}{llll}
\hline & -1.696416 & 5.930526 & 1.552662
\end{tabular}

$\begin{array}{cccc}\mathrm{Cu} & 1.507208 & 1.123048 & 0.590512 \\ \mathrm{C} & -2.187169 & 4.066633 & -1.601984\end{array}$

C $\quad-2.556278 \quad 5.415563 \quad-1.600047$

$\begin{array}{llll}\text { C } & -1.987407 & 3.415195 & -2.827614\end{array}$

$\begin{array}{llll}C & -2.740655 & 6.097704 & -2.827614\end{array}$

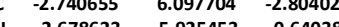

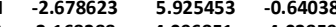

$\begin{array}{llll}\text { C } & -2.168388 & 4.096851 & -4.028592\end{array}$

$\begin{array}{llll}\text { H } & -1.683220 & 2.362433 & -2.843470\end{array}$

$\begin{array}{llll}\text { C } & -2.549182 & 5.441041 & -4.018727\end{array}$

$\begin{array}{llll}\text { H } & -3.032110 & 7.150924 & -2.791002\end{array}$

$\begin{array}{rrrr}H & -2.011789 & 3.578380 & -4.977880\end{array}$

$\begin{array}{llll}H & -2.693589 & 5.975847 & -4.960786\end{array}$

$\begin{array}{llll}\mathrm{N} & -0.544061 & 2.992341 & -0.106616 \\ \mathrm{~N} & -1.505261 & 1.045215 & 0.03546\end{array}$

$\begin{array}{llll}N & -1.505261 & 1.045215 & 0.035446\end{array}$

$\begin{array}{llll}\text { C } & 3.392035 & 0.454797 & 0.671983\end{array}$

$\begin{array}{llll}\text { C } & 3.893125 & -0.282052 & 1.836355\end{array}$

$\begin{array}{llll}\text { C } & 4.862931 & 0.324726 & 2.660436\end{array}$

$\begin{array}{lllll}C & 3.532557 & -1.616533 & 2.112378\end{array}$

$\begin{array}{llll}\text { C } & 5.460377 & -0.373922 & 3.707889\end{array}$

\begin{tabular}{llll}
\hline & 4.130097 & -2.312262 & 3.163801
\end{tabular}

$\begin{array}{llll}\text { C } & 5.100728 & -1.700745 & 3.962690\end{array}$

$\begin{array}{llll}\text { H } & 6.214109 & 0.118826 & 4.326509\end{array}$

$\begin{array}{llll}\text { H } & 3.836112 & -3.347601 & 3.355562\end{array}$

$\begin{array}{llll}H & 5.569960 & -2.252755 & 4.779754\end{array}$

$\begin{array}{llll}\text { C } & 2.763750 & -0.163233 & -0.450872\end{array}$

$\begin{array}{llll}\text { C } & 2.833520 & 0.403493 & -1.740331\end{array}$

$\begin{array}{llll}H & 2.162341 & 0.036536 & -2.518122\end{array}$

$\begin{array}{llll}\text { H } & 3.107582 & 1.456958 & -1.830668\end{array}$

\begin{tabular}{llll}
$H$ & 2.787131 & -2.125825 & 1.492962 \\
\hline
\end{tabular}

$\begin{array}{llll}\text { H } & 2.402060 & -1.195297 & -0.366287\end{array}$

$\begin{array}{llll}\text { P } & 5.507201 & -0.888475 & -1.905955\end{array}$

$\begin{array}{lllll}\mathrm{O} & \mathbf{6 . 2 2 8 8 3 3} & 0.108127 & -0.821462\end{array}$

$\begin{array}{llll}0 & 5.236483 & -2.127252 & -1.093583 \\ 0 & 6.705389 & -1.057144 & -2.981261\end{array}$ 


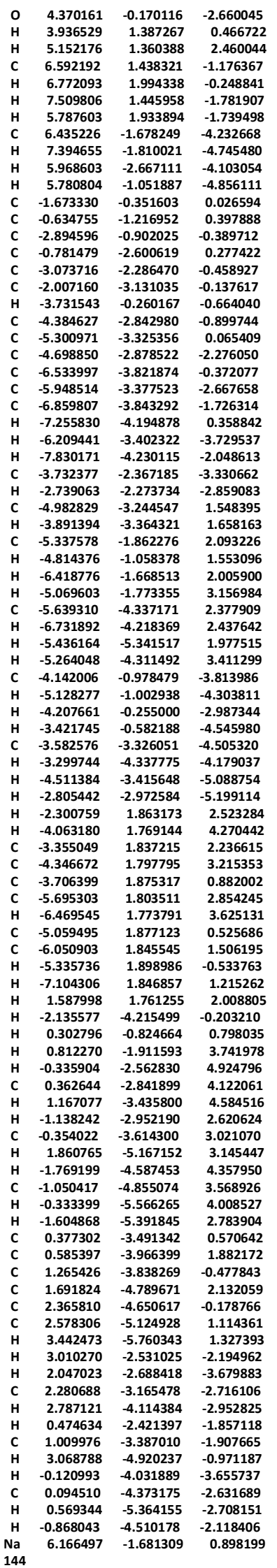




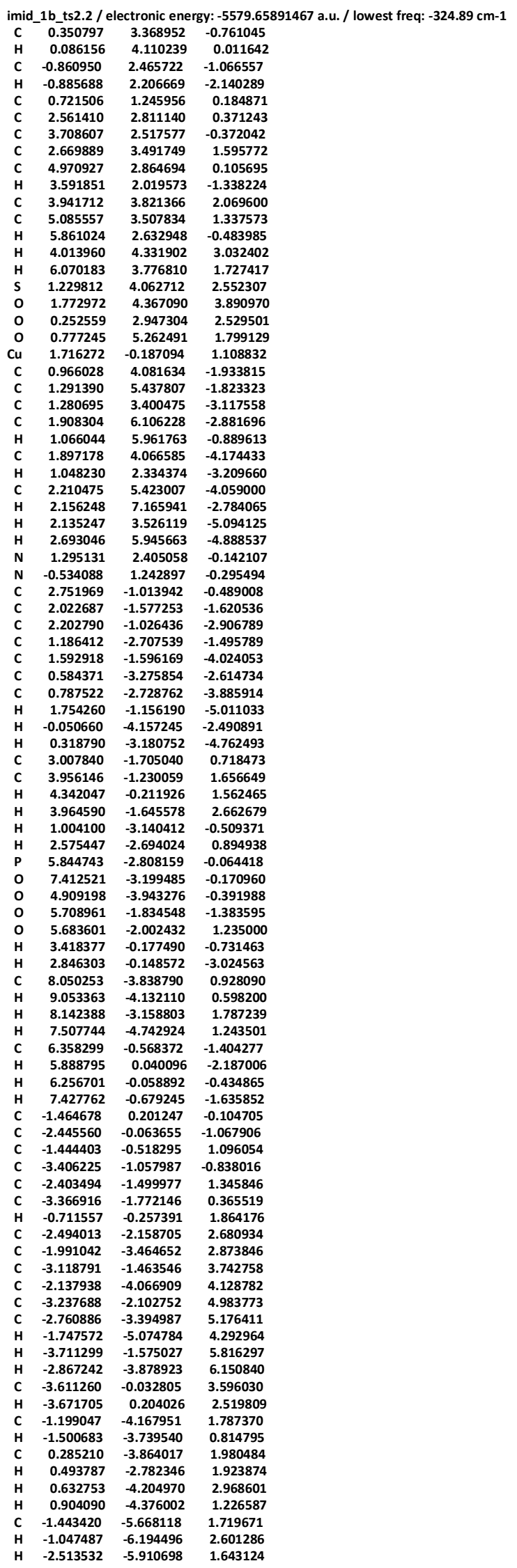




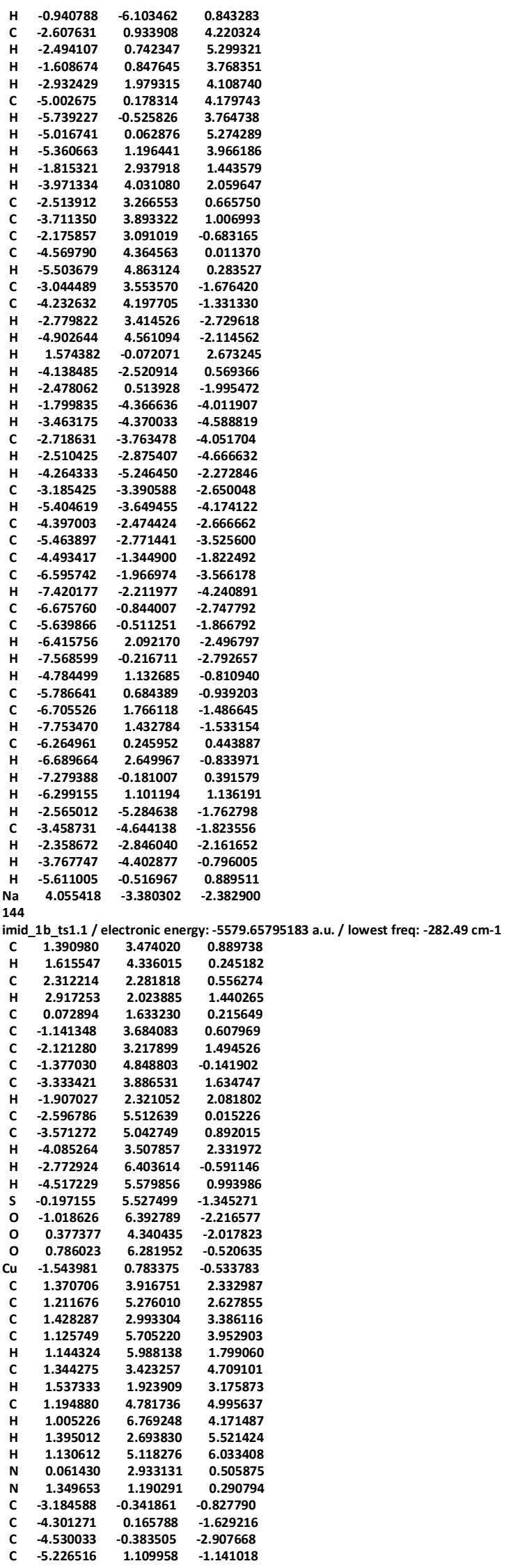




\begin{tabular}{|c|c|c|c|}
\hline & & & \\
\hline & -6.337273 & 1.478718 & -1.898161 \\
\hline & 5.556660 & 915473 & \\
\hline & 5.800147 & -0.461228 & .646481 \\
\hline & -7.042557 & 2.210718 & -1.497649 \\
\hline & -7.431387 & 292 & \\
\hline & -3.034218 & 0.123532 & 0.573829 \\
\hline & -2.347559 & & 100658 \\
\hline & -1.747759 & & \\
\hline & -2.012888 & -0.7 & 2.389008 \\
\hline & -5.083892 & & -0.152737 \\
\hline & -3.6 & & 3622 \\
\hline & -4.848502 & & \\
\hline & -5.936462 & -1.4 & \\
\hline & -4.7 & -3.0 & \\
\hline U & -5. & & \\
\hline & -3.6 & & \\
\hline $\mathrm{H}$ & -2.731396 & -1 & \\
\hline 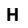 & -3.8 & & \\
\hline 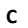 & -6.2 & & \\
\hline H & -6.780761 & & 5034 \\
\hline H & -6.9 & & \\
\hline H & & & \\
\hline$c$ & & & \\
\hline H & -5.7 & & \\
\hline H & & & \\
\hline & & & \\
\hline c & & & \\
\hline C & & & \\
\hline & & & \\
\hline & & & \\
\hline & & & \\
\hline$c$ & & & \\
\hline H & -0.1 & & \\
\hline C & & & \\
\hline & & & \\
\hline & -0.0 & & \\
\hline & -1.3 & & \\
\hline & -1.1 & & \\
\hline c & -1.7 & & -1 \\
\hline & -1.8 & & \\
\hline H & -1.423254 & & \\
\hline & & & \\
\hline & & & \\
\hline H & 37 & & -2 \\
\hline c & & & \\
\hline H & & & \\
\hline c & -1.0 & & \\
\hline H & -1.8 & & \\
\hline H & -1.398481 & & \\
\hline H & -0 & & \\
\hline c & & & 921 \\
\hline H & & & \\
\hline H & & & \\
\hline H & 383 & 283 & 7777 \\
\hline C & -0.314 & -1.5 & \\
\hline H & & & \\
\hline H & -0.6 & & \\
\hline H & & & \\
\hline C & & & \\
\hline H & & & \\
\hline H & & & \\
\hline H & & & \\
\hline H & & & \\
\hline H & & & 291 \\
\hline$c$ & & & \\
\hline & & & \\
\hline & & & \\
\hline & & & \\
\hline$y$ & & & \\
\hline & & & \\
\hline$c$ & & & \\
\hline H & & & \\
\hline H & & & \\
\hline H & -1.3 & & \\
\hline H & & & \\
\hline & & & \\
\hline $\boldsymbol{H}$ & & & \\
\hline 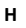 & & & \\
\hline & & & \\
\hline $\boldsymbol{H}$ & & & \\
\hline 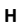 & & & \\
\hline & & & \\
\hline & & & \\
\hline H & 61 & 53 & 981 \\
\hline c & & & \\
\hline & & & \\
\hline & & & \\
\hline 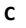 & & 18 & 608 \\
\hline & & & \\
\hline & & & \\
\hline & 754246 & -3.026230 & 1.735 \\
\hline
\end{tabular}




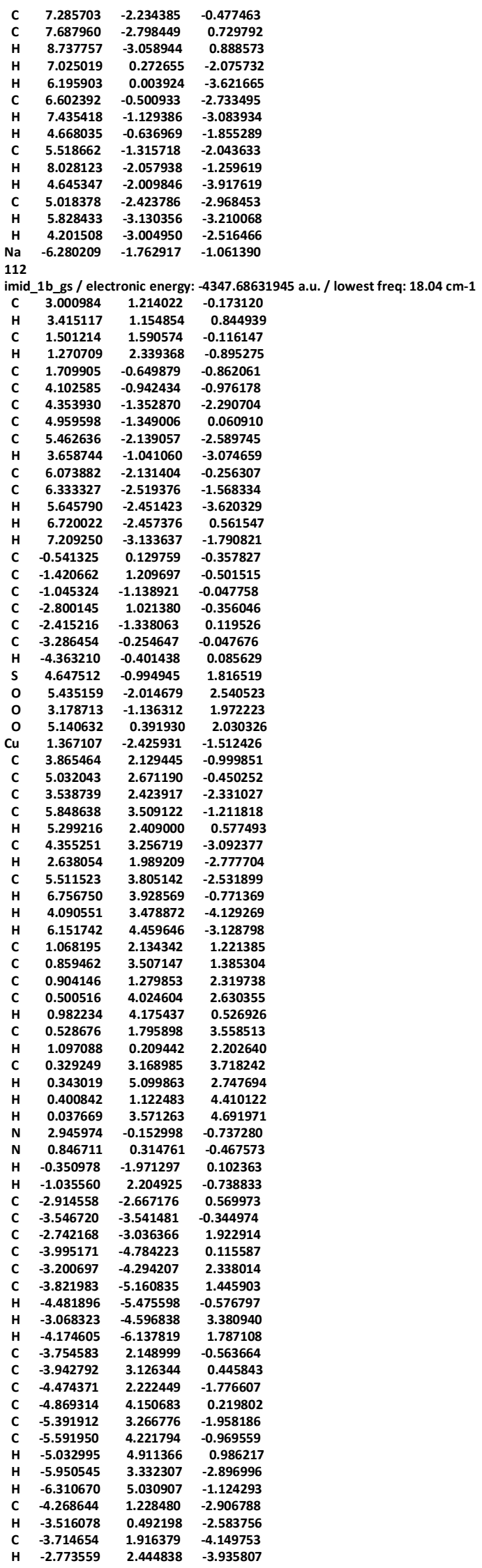




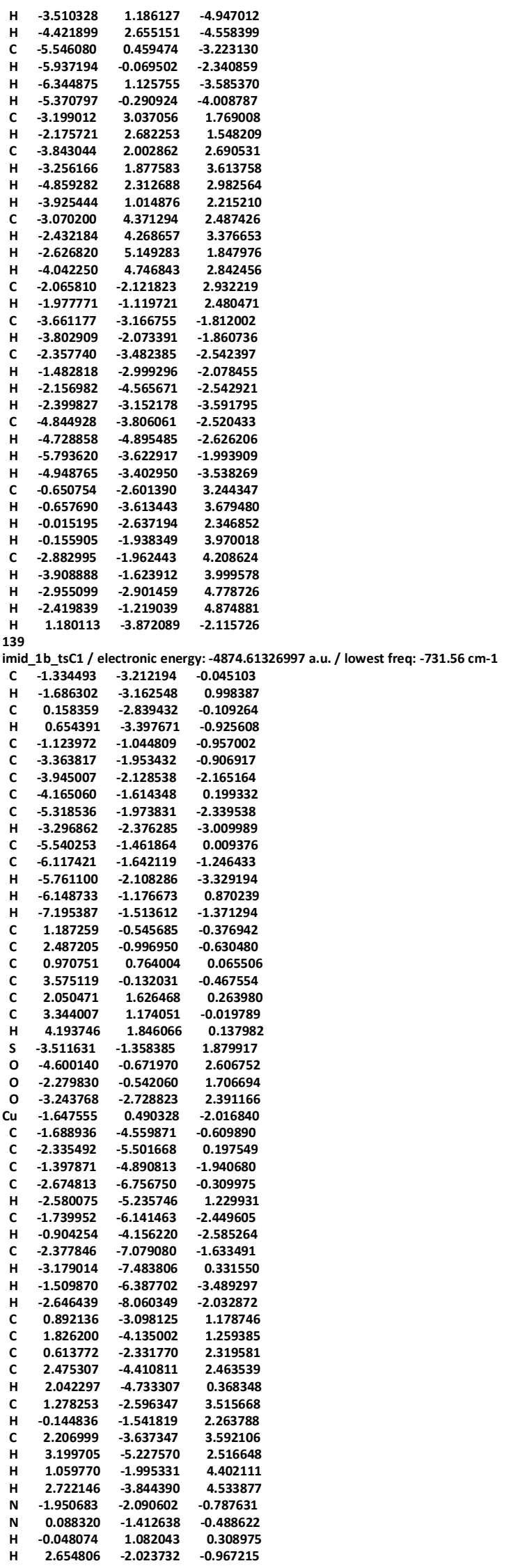




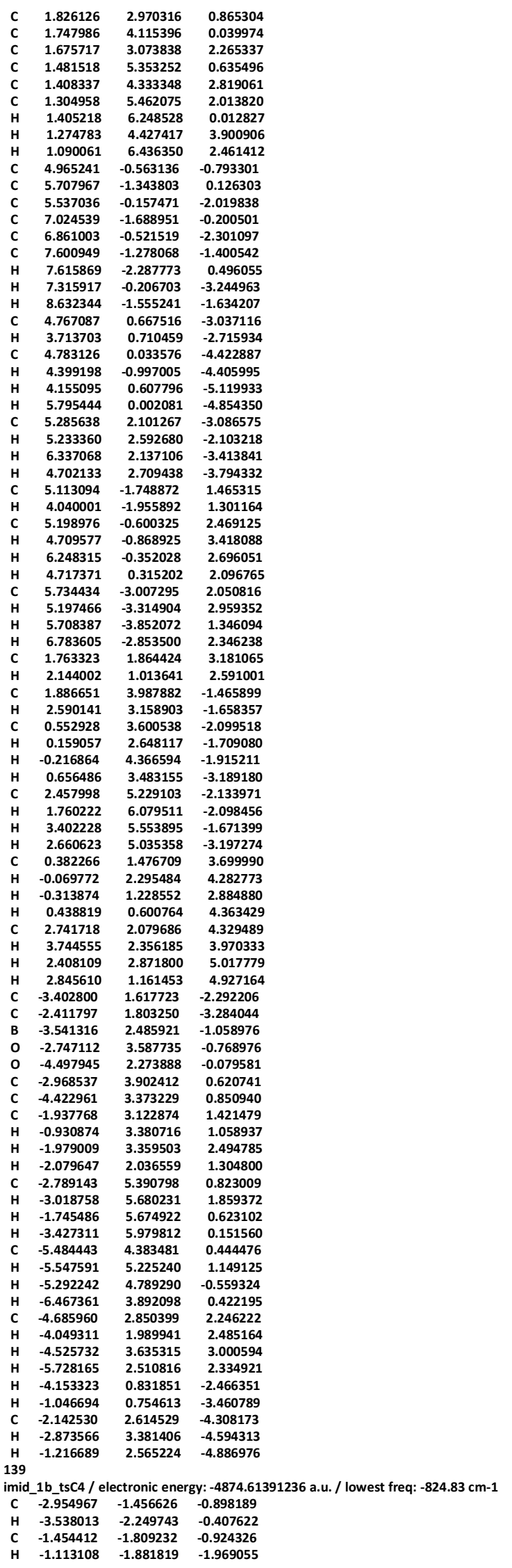




\begin{tabular}{|c|c|c|c|}
\hline & & & \\
\hline & & 444277 & \\
\hline & .263901 & .774230 & 13440 \\
\hline & .210104 & .146135 & 652 \\
\hline & 5426 & & \\
\hline & -3.430874 & 217326 & -0.687581 \\
\hline & & & 1.266390 \\
\hline & -6.4 & & \\
\hline & -5.471521 & & -0.2010665 \\
\hline & -7.159182 & 144432 & \\
\hline & -7.367726 & & \\
\hline & & & \\
\hline & 1.406067 & & \\
\hline & 087 & & 7232 \\
\hline & & & 3577 \\
\hline & & & 5502 \\
\hline & & & \\
\hline & & & \\
\hline & 03 & 1 & \\
\hline & & & \\
\hline & -3.7 & & \\
\hline & -5.5 & & \\
\hline & & & \\
\hline & -3.5 & & \\
\hline c & & 43 & \\
\hline$c$ & -2.8 & 7 & \\
\hline$c$ & & & \\
\hline n & & & \\
\hline & -3.5 & 4 & \\
\hline $\mathbf{H}$ & & & \\
\hline$c$ & & & \\
\hline & & & \\
\hline $\mathbf{H}$ & -2.9 & & \\
\hline H & & & \\
\hline c & -1.1 & -3.0 & \\
\hline$c$ & -0.9 & & \\
\hline$c$ & & & \\
\hline & & & \\
\hline & -1.1 & & \\
\hline$c$ & & & \\
\hline H & -1.02 & & \\
\hline & -0.5 & & \\
\hline H & -0.6 & & \\
\hline H & & & \\
\hline H & & & \\
\hline $\mathrm{v}$ & & & \\
\hline N & & & \\
\hline & & & \\
\hline H & & & \\
\hline$c$ & & & \\
\hline$c$ & & & \\
\hline$c$ & & & \\
\hline C & & & \\
\hline C & & & \\
\hline$c$ & & & \\
\hline H & & & \\
\hline H & & & \\
\hline H & & & \\
\hline C & & & \\
\hline C & & & \\
\hline C & & & \\
\hline$c$ & & & \\
\hline$c$ & & & \\
\hline$c$ & & & \\
\hline & & & \\
\hline H & & & \\
\hline H & & & \\
\hline$c$ & & & \\
\hline n & & & \\
\hline 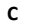 & & & \\
\hline 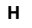 & & & \\
\hline & & & \\
\hline H & & & \\
\hline$c$ & & & \\
\hline H & & & \\
\hline H & & & \\
\hline H & & & \\
\hline c & & & \\
\hline H & & & \\
\hline 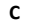 & & & \\
\hline & & & \\
\hline & & & \\
\hline H & & & \\
\hline & & & \\
\hline & & & \\
\hline & & & \\
\hline H & 12 & 56 & 166 \\
\hline & & & \\
\hline & & & \\
\hline$c$ & & & ובכס \\
\hline & & & \\
\hline & 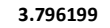 & 15 & 0567 \\
\hline
\end{tabular}




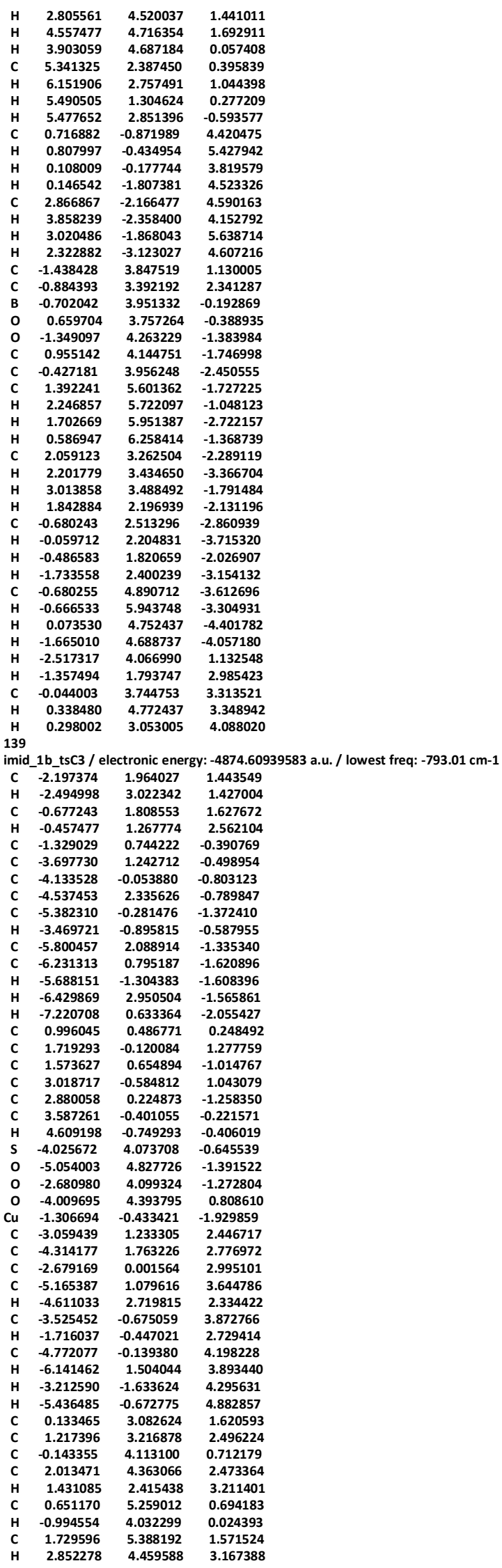




\begin{tabular}{|c|c|c|c|}
\hline & 0.421473 & 6.061073 & -0.012182 \\
\hline & 2.347979 & 6.289333 & 1.553294 \\
\hline & -2.410838 & 1.387728 & 0.081568 \\
\hline & -0.318549 & 0.944598 & 0.475913 \\
\hline & 0.999149 & 1.154869 & -1.800593 \\
\hline & 1.262513 & -0.254965 & 2.262719 \\
\hline & 3.529911 & 0.489503 & -2.574582 \\
\hline & 3.171055 & -0.268627 & -3.715844 \\
\hline & 4.493235 & 1.522340 & -2.668063 \\
\hline & 3.798719 & 0.018165 & -4.934030 \\
\hline & 5.089995 & 1.774986 & -3.910030 \\
\hline & 4.749037 & 1.030265 & -5.033577 \\
\hline & 3.539835 & -0.557666 & -5.825002 \\
\hline & 5.829346 & 2.574718 & -4.000139 \\
\hline & 5.224641 & 1.240632 & -5.995201 \\
\hline & 3.772300 & -1.300128 & 2.112827 \\
\hline & 4.480193 & -0.564997 & 3.092213 \\
\hline & 3.771868 & -2.712455 & 2.134137 \\
\hline & 5.188059 & -1.263615 & 4.077018 \\
\hline & 4.490024 & -3.370631 & 3.141803 \\
\hline & 5.194473 & -2.656090 & 4.104637 \\
\hline & 5.747931 & -0.708538 & 4.834530 \\
\hline & 4.492314 & -4.464623 & 3.171165 \\
\hline & 5.751270 & -3.185369 & 4.882450 \\
\hline & 3.005748 & -3.539879 & 1.116432 \\
\hline & 2.539499 & -2.850706 & 0.393324 \\
\hline & 1.875183 & -4.323126 & 1.774747 \\
\hline & 1.171666 & -3.657330 & 2.297066 \\
\hline & 1.297696 & -4.882898 & 1.024971 \\
\hline & 2.255984 & -5.048447 & 2.511571 \\
\hline & 3.931833 & -4.461137 & 0.331039 \\
\hline & 4.744124 & -3.905906 & -0.161949 \\
\hline & 4.400696 & -5.218165 & 0.979211 \\
\hline & 3.378614 & -5.003072 & -0.450603 \\
\hline & 4.531348 & 0.951575 & 3.047516 \\
\hline & 3.652877 & 1.296145 & 2.476446 \\
\hline & 5.766449 & 1.424794 & 2.285467 \\
\hline & 5.757963 & 2.518826 & 2.158632 \\
\hline & 6.691476 & 1.157911 & 2.821515 \\
\hline & 5.828670 & 0.973057 & 1.283711 \\
\hline & 4.460563 & 1.596413 & 4.424198 \\
\hline & 4.388899 & 2.690282 & 4.339189 \\
\hline & 3.588631 & 1.250199 & 4.999058 \\
\hline & 5.356637 & 1.388863 & 5.028640 \\
\hline & 4.827169 & 2.401302 & -1.474627 \\
\hline & 4.687898 & 1.795582 & -0.565359 \\
\hline & 2.171751 & -1.408709 & -3.610572 \\
\hline & 1.349822 & -1.063964 & -2.954947 \\
\hline & 1.542484 & -1.806471 & -4.935180 \\
\hline & 1.061758 & -0.956132 & -5.441456 \\
\hline & 2.276431 & -2.242110 & -5.630940 \\
\hline & 0.769498 & -2.571298 & -4.773838 \\
\hline & 2.812419 & -2.625219 & -2.944661 \\
\hline & 3.643984 & -3.014086 & -3.554236 \\
\hline & 3.216896 & -2.390961 & -1.949656 \\
\hline & 2.084101 & -3.441995 & -2.822848 \\
\hline & 3.847433 & 3.568017 & -1.376773 \\
\hline & 3.908538 & 4.217139 & -2.264949 \\
\hline & 2.805101 & 3.224936 & -1.291663 \\
\hline & 4.065258 & 4.190238 & -0.495165 \\
\hline & 6.265692 & 2.895553 & -1.462231 \\
\hline & 6.988210 & 2.070868 & -1.557323 \\
\hline & 6.472011 & 3.612521 & -2.271535 \\
\hline & 6.484435 & 3.418279 & -0.519736 \\
\hline & -1.053895 & -2.530566 & -2.023780 \\
\hline & -1.568019 & -1.904539 & -3.180901 \\
\hline & -1.886920 & -3.299211 & -1.013230 \\
\hline & -3.268486 & -3.426643 & -1.028761 \\
\hline & -1.323025 & -4.003877 & 0.042323 \\
\hline & -3.657446 & -4.080284 & 0.200685 \\
\hline & -2.353140 & -4.852405 & 0.591219 \\
\hline & -4.003408 & -3.000652 & 1.211546 \\
\hline & -4.821429 & -2.370826 & 0.834272 \\
\hline & -4.331928 & -3.428239 & 2.169530 \\
\hline & -3.140071 & -2.347180 & 1.404235 \\
\hline & -4.857888 & -4.959963 & -0.069865 \\
\hline & -5.124352 & -5.548268 & 0.820529 \\
\hline & -5.729861 & -4.343647 & -0.331394 \\
\hline & -4.681711 & -5.653582 & -0.901486 \\
\hline & -2.245038 & -6.201960 & -0.101798 \\
\hline & -2.954005 & -6.934458 & 0.309511 \\
\hline & -2.428852 & -6.116878 & -1.182481 \\
\hline & -1.231569 & -6.605681 & 0.033122 \\
\hline & -2.133485 & -5.005854 & 2.081193 \\
\hline & -2.016683 & -4.036264 & 2.582642 \\
\hline & -2.976021 & -5.535883 & 2.549409 \\
\hline & -1.225462 & -5.592904 & 2.278915 \\
\hline & 0.041662 & -2.613495 & -1.938794 \\
\hline & -1.319148 & -0.156540 & -3.483353 \\
\hline & -2.256939 & -2.194748 & -4.285803 \\
\hline & -2.449897 & -3.244537 & -4.53976 \\
\hline & -2.653039 & -1.432888 & -4.961065 \\
\hline
\end{tabular}


139

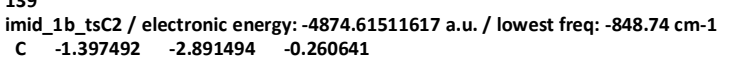

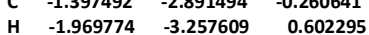

\begin{tabular}{lrrr} 
C & -1.06979802 & -2.514253 & 0.149542 \\
\hline
\end{tabular}

$\begin{array}{llll}\text { H } & 0.744825 & -3.210041 & -0.332128\end{array}$

$\begin{array}{llll}\text { C } & -0.987209 & -0.635784 & -0.852071\end{array}$

C $\quad-\mathbf{3 . 2 7 1 4 9 5} \quad-1.396453 \quad-1.127234$

C $\quad-3.467998 \quad-0.929815 \quad-2.435572$

$\begin{array}{llll}\text { C } & -4.388179 & -1.652447 & -0.310760\end{array}$

$\begin{array}{llll}\text { C } & -4.745721 & -0.694876 & -2.930882\end{array}$

\begin{tabular}{llll} 
H & -2.589821 & -0.747623 & -3.061224 \\
\hline
\end{tabular}

$\begin{array}{llll}\text { C } & -5.666875 & -1.432110 & -0.832647\end{array}$

$\begin{array}{llll}\text { C } & -5.853824 & -0.951265 & -2.125075\end{array}$

\begin{tabular}{llll} 
H & -4.870756 & -0.320410 & -3.949798 \\
\hline
\end{tabular}

\begin{tabular}{cccc}
$H$ & -6.522061 & -1.615653 & -0.178269 \\
\hline
\end{tabular}

$\begin{array}{llll}\text { H } & -6.864982 & -0.773631 & -2.499317\end{array}$

$\begin{array}{llll}\text { C } & 1.396701 & -0.457700 & -0.311313\end{array}$

$\begin{array}{llll}\text { C } & 2.604827 & -1.153882 & -0.167256 \\ \text { C } & 1.409089 & 0.941267 & -0.279816\end{array}$

$\begin{array}{llll}\text { C } \quad 3.811380 & -0.465093 & -0.000926\end{array}$

C $\quad$ C $2.600174-0.4651799-0.000926$

$\begin{array}{lrrr}\text { C } & 2.600174 & 1.641799 & -0.092999 \\ \text { C } & 3.799906 & 0.934592 & 0.035639\end{array}$

$\begin{array}{cccc}\text { C } & 3.799906 & 0.934592 & 0.035639 \\ \text { H } & 4.737250 & 1.478586 & 0.189991\end{array}$

$\begin{array}{lllll}\text { S } & -4.294999 & -2.263512 & 1.397126\end{array}$

$\begin{array}{llll}0 & -5.571547 & -1.832979 & 2.013160\end{array}$

$\begin{array}{llll}0 & -3.090662 & -1.637785 & 1.990278\end{array}$

$\begin{array}{llll}0 & -4.182840 & -3.740647 & 1.256201\end{array}$

$\begin{array}{llll}\mathrm{Cu} & -1.349093 & 1.052138 & -1.722416\end{array}$

$\begin{array}{llll}\text { C } & -1.513254 & -3.873792 & -1.402250\end{array}$

$\begin{array}{llll}\text { C } & -2.563997 & -4.798622 & -1.405043\end{array}$

$\begin{array}{llll}\text { C } & -0.641821 & -3.828883 & -2.499838\end{array}$

\begin{tabular}{llll} 
C & -2.729303 & -5.676221 & -2.477423 \\
\hline & -3.255533 & -4.806780 & -0.556059
\end{tabular}

$\begin{array}{llll}\text { H } & -\mathbf{- 3 . 2 5 5 5 3 3} & -4.806780 & -0.556059\end{array}$

$\begin{array}{llll}\text { C } & -0.806958 & -4.707201 & -3.569332\end{array}$

\begin{tabular}{cccc} 
H & 0.171961 & -3.096265 & -2.526355 \\
\hline
\end{tabular}

\begin{tabular}{llll} 
C & -1.851173 & -5.634499 & -3.559907 \\
\hline
\end{tabular}

\begin{tabular}{llll} 
H & -3.551532 & -6.396447 & -2.466934 \\
\hline
\end{tabular}

\begin{tabular}{llll} 
H & -0.118990 & -4.665106 & -4.417565 \\
\hline
\end{tabular}

\begin{tabular}{lrrr} 
H & -1.979875 & -6.322631 & -4.399265 \\
\hline & 0.301463 & -2.516847 & 1.638394
\end{tabular}

$\begin{array}{llll}\text { C } & 0.301463 & -2.516847 & 1.638394 \\ \text { C } & 0.827416 & -3.663446 & 2.243958\end{array}$

\begin{tabular}{llll} 
C & 0.016138 & -1.399455 & 2.431964 \\
\hline
\end{tabular}

$\begin{array}{llll}\text { C } & 1.050797 & -3.700936 & 3.620004\end{array}$

\begin{tabular}{lllll} 
H & 1.062298 & -4.537317 & 1.627869 \\
\hline
\end{tabular}

\begin{tabular}{lllll} 
C & 0.249914 & -1.432151 & 3.805322 \\
\hline
\end{tabular}

\begin{tabular}{lllll} 
H & -0.402179 & -0.498446 & 1.974434 \\
\hline
\end{tabular}

$\begin{array}{llll}\text { C } & 0.765749 & -2.582805 & 4.403915\end{array}$

$\begin{array}{llll}\text { H } & 1.463197 & -4.603135 & 4.079229\end{array}$

$\begin{array}{llll}\text { H } & 0.021017 & -0.553636 & 4.414437\end{array}$

$\begin{array}{llll}\text { H } & 0.949018 & -2.606227 & \mathbf{5 . 4 8 1 2 5 2}\end{array}$

$\begin{array}{cccc}\mathrm{N} & -1.935480 & -1.572139 & -0.679995 \\ \mathrm{~N} & 0.187670 & -1.165363 & -0.428933\end{array}$

$\begin{array}{llll}\mathrm{H} & 0.471461 & 1.499396 & -0.336614\end{array}$

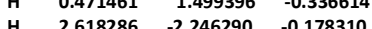

\begin{tabular}{llll}
$H$ & 0.471461 & 1.499396 & -0.336614 \\
\hline$C$ & 2.618286 & -2.246290 & -0.178310 \\
\hline
\end{tabular}

$\begin{array}{lllr}\text { C } & 2.552494 & 3.123457 & 0.046331 \\ \text { C } & 2.926930 & 3.953049 & -1.032268\end{array}$

$\begin{array}{llll}\text { C } & 2.098278 & 3.681595 & 1.264350\end{array}$

$\begin{array}{llll}\text { C } & 2.851749 & 5.342478 & -0.871459\end{array}$

$\begin{array}{llll}\text { C } & 2.029577 & 5.075541 & 1.377517 \\ \text { C } & 2.405582 & 5.901854 & 0.321853\end{array}$

\begin{tabular}{lllr} 
H & 3.139191 & 5.995800 & -1.700993 \\
\hline
\end{tabular}

$\begin{array}{llll}\mathrm{H} & \mathbf{1 . 6 7 2 1 0 2} & 5.522207 & 2.309863\end{array}$

\begin{tabular}{llll}
$\mathrm{H}$ & 1.672102 & 5.522207 & 2.309863 \\
$\mathrm{H}$ & $\mathbf{2 . 3 4 5 8 9 1}$ & 6.988189 & 0.429113 \\
\hline
\end{tabular}

$\begin{array}{llll}\text { C } & 5.095266 & -1.211394 & 0.142197\end{array}$

$\begin{array}{llll}\text { C } & 5.398836 & -1.868805 & 1.360042\end{array}$

$\begin{array}{llll}\text { C } & 6.001394 & -1.251590 & -0.944766\end{array}$

$\begin{array}{rrrr}\text { C } & 6.615340 & -2.555367 & 1.463779 \\ \text { C } & 7.204594 & -1.952099 & -0.792883\end{array}$

$\begin{array}{llll}\text { C } & 7.510640 & -2.599454 & 0.399286\end{array}$

$\begin{array}{llll}\mathrm{H} & 6.871815 & -3.564988 & 2.395053\end{array}$

\begin{tabular}{rrrr}
$\mathrm{H}$ & 6.871815 & -3.064988 & 2.395053 \\
$\mathrm{H}$ & $\mathbf{7 . 9 1 2 0 2 1}$ & -1.997397 & -1.624611 \\
\hline
\end{tabular}

$\begin{array}{llll}\text { H } & \mathbf{8 . 4 5 4 2 6 6} & -\mathbf{3 . 1 4 2 0 0 5} & \mathbf{0 . 5 0 1 3 2 6}\end{array}$

$\begin{array}{llll}\text { C } & 5.655462 & -0.616175 & -2.281442\end{array}$

$\begin{array}{llll}\text { H } & 5.023382 & 0.263972 & -2.077692\end{array}$

$\begin{array}{llll}\text { C } & 4.822577 & -1.578848 & -3.125000\end{array}$

\begin{tabular}{llll} 
H & 3.906679 & -1.895494 & -2.604310 \\
\hline & 4.518279 & -1.114496 & -4.075131
\end{tabular}

$\begin{array}{lll}\mathrm{H} & 4.518279 & -1.1144 \\ \mathrm{H} & 5.394153 & -2.4887\end{array}$

\begin{tabular}{ccccc}
$H$ & 5.5184153 & -2.488793 & -3.367883 \\
\hline & 5.3945 & -0.125064 & -3.060717
\end{tabular}

$\begin{array}{llll}\text { C } & 6.866241 & -0.125064 & -3.060717\end{array}$

$\begin{array}{rrrr}\text { H } & 7.507049 & 0.536897 & -2.459187 \\ \text { H } & 7.494151 & -0.951537 & -3.426992\end{array}$

$\begin{array}{llll}\text { H } & 6.547038 & 0.441989 & -3.947212\end{array}$

\begin{tabular}{llll} 
C & 4.463084 & -1.778131 & 2.555860 \\
\hline
\end{tabular}

\begin{tabular}{lllll} 
H & 3.428297 & -1.816578 & 2.171762 \\
\hline
\end{tabular}

\begin{tabular}{llll} 
C & 4.625192 & -0.437571 & 3.270662 \\
\hline & 3.89492 & -0.336712 & 4.088660
\end{tabular}

\begin{tabular}{llll}
$\mathrm{H}$ & $\mathbf{3} .894992$ & -0.336712 & 4.088660 \\
\hline & 5.631503 & -0.342599 & 3.709303
\end{tabular}

$\begin{array}{llll}\text { H } & 5.631503 & -0.342599 & 3.709303\end{array}$

$\begin{array}{cccc}\text { H } & 4.480560 & 0.417043 & 2.593612 \\ \text { C } & 4.618885 & -2.924013 & 3.543374\end{array}$

$\begin{array}{llll}\text { H } & 3.852745 & -2.859398 & 4.328910\end{array}$

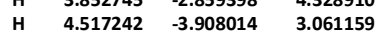




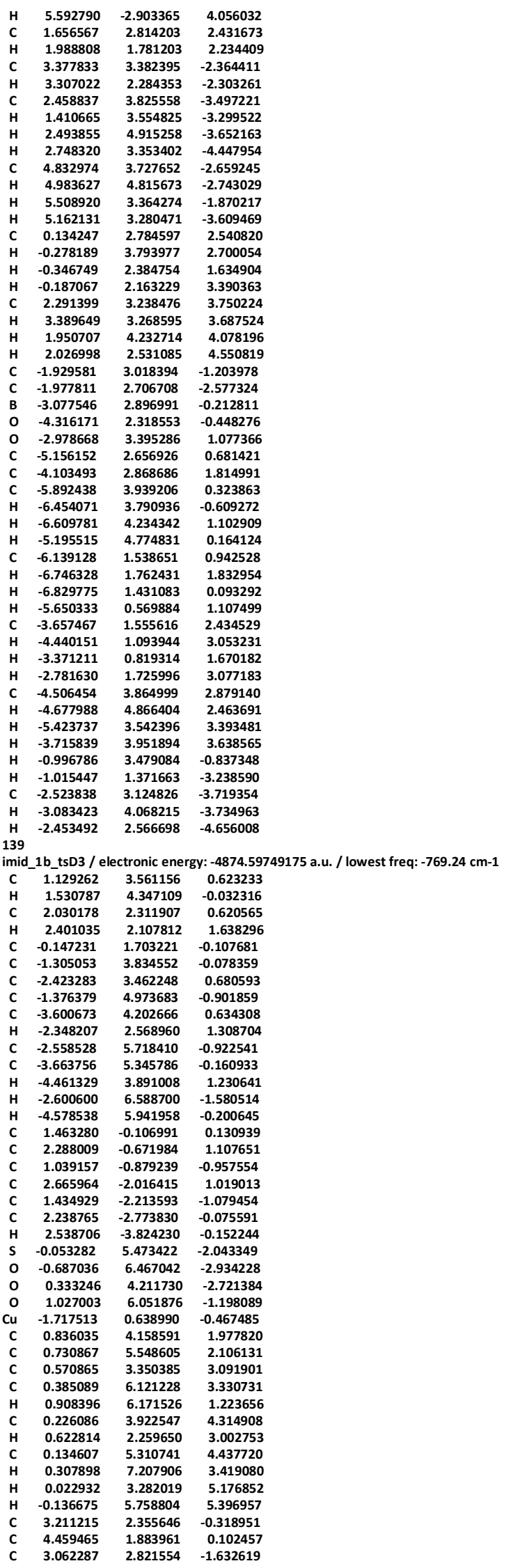




\begin{tabular}{|c|c|c|c|}
\hline & & & \\
\hline & 4.578294 & 1.523014 & 1.129646 \\
\hline & 4.152213 & 2.818849 & -2.501455 \\
\hline & 2.093519 & 3.207245 & -1.975188 \\
\hline & 5.397075 & 2.351334 & -2.074265 \\
\hline & 6.522637 & 1.524528 & -0.424856 \\
\hline & 4.027989 & 3.190096 & -3.522077 \\
\hline & 6.249232 & 2.355189 & -2.758806 \\
\hline & -0.133063 & 3.039633 & 0.024685 \\
\hline & 1.076696 & 1.244236 & 0.228348 \\
\hline & 0.421225 & -0.413675 & -1.731348 \\
\hline & 2.615984 & -0.073329 & 1.961670 \\
\hline & 1.066181 & -3.003825 & -2.290786 \\
\hline & -0.262507 & -3.460155 & -2.473038 \\
\hline & 2.061712 & -3.271070 & -3.263293 \\
\hline & -0.568782 & -4.184691 & -3.631726 \\
\hline & 1.704472 & -3.997310 & -4.406553 \\
\hline & 0.402946 & -4.450764 & -4.591294 \\
\hline & -1.586848 & -4.54 & -3.79 \\
\hline & 2.456424 & -4.206708 & -5.170799 \\
\hline & 0.142987 & -5.014636 & -5.491071 \\
\hline & 3.477667 & -2.63 & 2.103508 \\
\hline & 4.888736 & -2.642975 & 2.020696 \\
\hline & 2.819530 & -3.223555 & 3.208753 \\
\hline & 5.620921 & -3.235123 & 3.056904 \\
\hline & 3.591828 & -3.799827 & 4.225762 \\
\hline & 4.980946 & -3.80 & 440 \\
\hline & 6.713001 & -3.252916 & 3.003097 \\
\hline & 3.091976 & -4.252745 & 5.087601 \\
\hline & 5.569728 & -4.26 & 4.9539966 \\
\hline & 1.305486 & -3.258222 & 3.321489 \\
\hline & 0.884530 & -2.770713 & 2.427117 \\
\hline & 0.813545 & -2.474257 & 4.532204 \\
\hline & 1.150944 & -1.427168 & 4.504598 \\
\hline & -0.285867 & -2.465616 & 4.575976 \\
\hline & 1.174043 & -2.911098 & 5.476791 \\
\hline & 0.785345 & -4.691435 & 3.338982 \\
\hline & 1.123520 & -5.258976 & 2.458824 \\
\hline & 1.126163 & -5.238316 & 4.232241 \\
\hline & -0.314800 & -4.712982 & 3.344166 \\
\hline & 5.611741 & -2.07 & 0.8 \\
\hline & 4.909825 & -1.41 & 0.276350 \\
\hline & 5.990412 & -3.200578 & -0.153029 \\
\hline & 6.447137 & -2.798446 & -1.0 \\
\hline & 6.718544 & -3.889246 & 0.304909 \\
\hline & 5.117190 & -3.801459 & -0.449133 \\
\hline & 6.833518 & -1.248120 & 1.178725 \\
\hline & 7.283481 & -0.800339 & 0.280778 \\
\hline & 6.585603 & -0.430403 & 1.872100 \\
\hline & 7.619788 & -1.854697 & 1.653489 \\
\hline & 3.477592 & -2.736890 & $-3.1 \mathrm{C}$ \\
\hline & 3.731827 & -2.786981 & -2.039153 \\
\hline & -1.324987 & -3.210438 & -1.415027 \\
\hline & -1.212937 & -2.158794 & -1.09 \\
\hline & -2.752412 & -3.365940 & -1.912882 \\
\hline & -2.962710 & -2.736202 & -2.790208 \\
\hline & -2.988197 & -4.408429 & -2.179853 \\
\hline & -3.457378 & -3.07 & -1.1 \\
\hline & -1.107831 & -4.095991 & -0.189669 \\
\hline & -1.202659 & -5.161750 & -0.453 \\
\hline & -0.115351 & -3.95 & 279 \\
\hline & -1.859460 & -3.881761 & 0.586519 \\
\hline & 3.561339 & -1.265431 & -3.509746 \\
\hline & 3.330542 & -1.127224 & -4.578130 \\
\hline & 2.860772 & -0.637477 & -2.939812 \\
\hline & 4.573777 & -0.869098 & -3.335102 \\
\hline & 4.526292 & -3.552101 & -3.850502 \\
\hline & 4.476778 & -4.622308 & -3.5 \\
\hline & 4.433217 & -3.463110 & -4.943656 \\
\hline & 5.535891 & -3.200211 & \\
\hline & -4.653560 & -0.3 & \\
\hline & -3.385215 & -0.379846 & -0.332455 \\
\hline & -5.771582 & -1.185925 & -0.205959 \\
\hline & -5.61 & -2.076 & דרברת \\
\hline & -7.061636 & -1.188205 & -0.700589 \\
\hline & -6.801907 & -2.904878 & 0.873161 \\
\hline & -7.869819 & & \\
\hline & -6.503388 & -4.148709 & 746 \\
\hline & -5.608646 & -4.646929 & 0.450205 \\
\hline & -7.331144 & -4.871471 & 0.079839 \\
\hline & -6.303439 & -3.899118 & -1.001414 \\
\hline & -7.100953 & -3.277029 & 2.308567 \\
\hline & -8.046884 & -3.833300 & 2.382739 \\
\hline & -6.305535 & -3.922134 & גדת דיר \\
\hline & -7.168935 & -2.394874 & 2.957395 \\
\hline & -8.515713 & -1.020196 & 1.186030 \\
\hline & -9.200234 & -1.536710 & 1.873367 \\
\hline & -7.762503 & -0.490117 & 1.786187 \\
\hline & -9.096672 & -0.265781 & 0.637768 \\
\hline & -8.926158 & -2.710862 & \\
\hline & -8.491451 & -3.292 & -1.421890 \\
\hline & -9.501834 & -3.395091 & 0.041277 \\
\hline
\end{tabular}




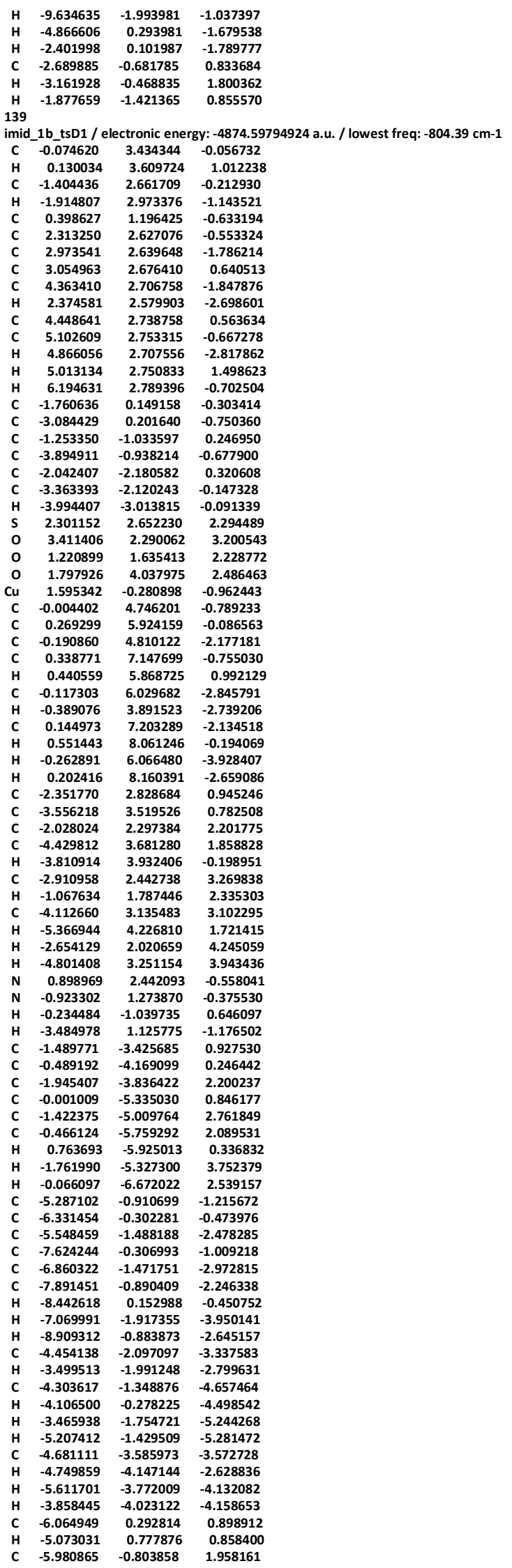




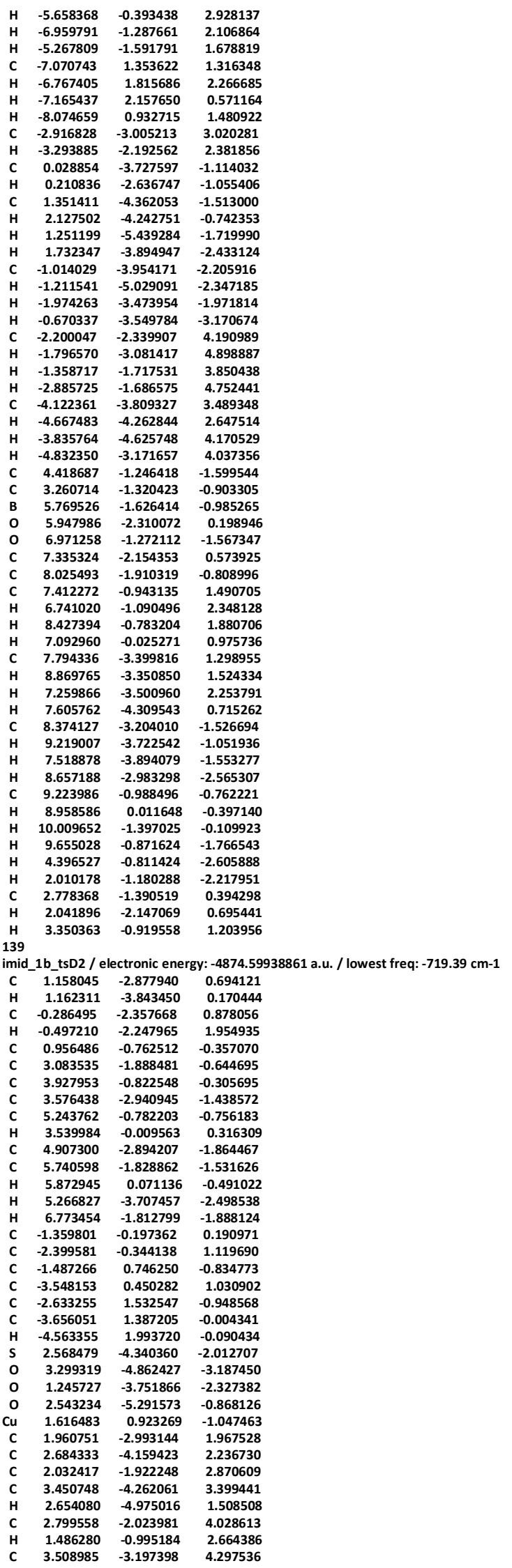




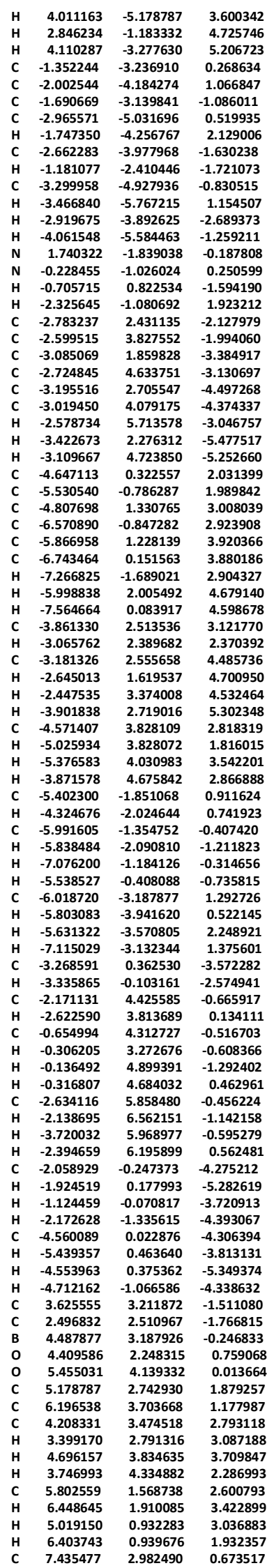




$\begin{array}{cccc}\text { H } & \mathbf{8 . 0 9 3 4 7 2} & 2.670633 & 1.496693 \\ \text { H } & 7.173296 & 2.090992 & 0.085936 \\ \text { H } & 8.010818 & 3.653431 & 0.020629 \\ \text { C } & 6.584688 & 4.915032 & 1.996907 \\ \text { H } & 5.719023 & 5.544468 & 2.237936 \\ \text { H } & 7.065038 & 4.613975 & 2.939330 \\ \text { H } & 7.302773 & 5.535930 & 1.443079 \\ \text { H } & 3.932362 & 3.887200 & -2.324752 \\ \text { H } & 1.886306 & 2.086734 & -0.023144 \\ \text { C } & 1.714373 & 2.042429 & -2.818194 \\ \text { H } & 0.645625 & 2.291477 & -2.883670 \\ \text { H } & 2.196326 & 1.774007 & -3.766726\end{array}$

imid_1b_tsD4 / electronic energy: - -4874.59953989 a.u. / lowest freq: $-414.57 \mathrm{~cm}-1$

c $2.129798 \quad 2.8301710 .031240$

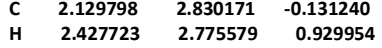

$\begin{array}{lllr}\text { C } & 0.593765 & 2.775487 & -0.240707\end{array}$

$\begin{array}{llll}\text { H } & 0.263459 & 3.347560 & -1.128185\end{array}$

$\begin{array}{llll}\text { C } & 1.495938 & 0.689573 & -0.889827\end{array}$

$\begin{array}{llll}\text { C } & 3.876525 & 1.145355 & -0.809721\end{array}$

$\begin{array}{llll}\text { C } & 4.557358 & 1.140349 & -2.030498\end{array}$

$\begin{array}{llll}\text { C } & 4.534442 & 0.731696 & 0.361247\end{array}$

$\begin{array}{llll}\text { C } & 5.886998 & 0.733508 & -2.098518\end{array}$

$\begin{array}{lllll}\text { H } & 4.018337 & 1.450773 & -2.928173\end{array}$

$\begin{array}{llll}\text { C } & 5.871776 & 0.331925 & 0.281169\end{array}$

$\begin{array}{llll}\text { C } & 6.546832 & 0.333067 & -0.936582\end{array}$

$\begin{array}{llll}\text { H } & 6.405050 & 0.727093 & -3.060167\end{array}$

$\begin{array}{llll}\text { H } & 6.366420 & -0.006744 & 1.194421\end{array}$

\begin{tabular}{llll}
$H$ & 7.590457 & 0.011677 & -0.979562 \\
\hline
\end{tabular}

$\begin{array}{llll}\text { C } & -0.871026 & 0.710881 & -0.316774\end{array}$

$\begin{array}{llll}\text { C } & -2.051017 & 1.364661 & -0.683315\end{array}$

$\begin{array}{llll}\text { C } & -0.924443 & -0.537507 & \mathbf{0 . 3 1 5 3 8 7}\end{array}$

$\begin{array}{llll}\text { C } & -3.291852 & 0.770176 & -0.430004\end{array}$

$\begin{array}{llll}\text { C } & -2.158627 & -1.127026 & 0.608204\end{array}$

\begin{tabular}{lllll} 
C & -3.331984 & -0.466314 & 0.224100 \\
\hline
\end{tabular}

\begin{tabular}{llll} 
H & -4.302034 & -0.920307 & 0.451296 \\
\hline & 3.752624 & 0.683596 & 2.000732
\end{tabular}

2.735758

\begin{tabular}{llll}
0 & 4.502566 & -0.357114 & 2.735758 \\
\hline & 2.325652 & 0.333417 & 1757366
\end{tabular}

1.757366

$\begin{array}{llll}\mathrm{Cu} & 1.568365 & -1.031435 & -1.849557\end{array}$

$\begin{array}{llll}\text { C } & 2.766241 & 4.038248 & -0.759203\end{array}$

$\begin{array}{rrrr}\text { C } & 3.461562 & 4.956870 & 0.033883 \\ \text { C } & 2.671363 & 4.266462 & -2.139057\end{array}$

$\begin{array}{llll}\text { C } & 4.043477 & 6.089399 & -0.537896\end{array}$

$\begin{array}{lllll}\text { H } & 3.549189 & 4.774358 & 1.108944\end{array}$

\begin{tabular}{llll} 
C & 3.256201 & 5.393329 & -2.711694 \\
\hline
\end{tabular}

\begin{tabular}{llll} 
H & $\mathbf{2 . 1 3 9 2 9 2}$ & $\mathbf{3 . 5 4 6 1 5 5}$ & -2.769156 \\
\hline
\end{tabular}

$\begin{array}{llll}\text { C } & 3.942301 & 6.309774 & -1.910795\end{array}$

$\begin{array}{llll}\text { H } & 4.583167 & 6.799713 & 0.093411\end{array}$

$\begin{array}{llll}\text { H } & 3.179105 & 5.558512 & -3.789334\end{array}$

$\begin{array}{llll}\text { H } & 4.401369 & 7.193834 & -2.360356\end{array}$

$\begin{array}{llll}\text { C } & -0.114854 & 3.305508 & 0.974958\end{array}$

$\begin{array}{llll}\text { C } & -0.815195 & 4.513818 & 0.905980\end{array}$

$\begin{array}{llll}\text { C } & -0.042760 & 2.620886 & 2.196907\end{array}$

$\begin{array}{llll}\text { C } & -1.432083 & 5.040917 & 2.041332\end{array}$

$\begin{array}{llll}\text { H } & -0.871331 & 5.048031 & -0.048005\end{array}$

$\begin{array}{llll}\text { C } & -0.675646 & 3.140414 & 3.324740\end{array}$

$\begin{array}{lllll}\text { H } & 0.534399 & 1.690531 & 2.255028\end{array}$

$\begin{array}{llll}\text { C } & -1.368748 & 4.351561 & 3.251609\end{array}$

\begin{tabular}{llll} 
H & -1.969495 & 5.990482 & 1.976963 \\
\hline & -0.616257 & 2.602680 & 4.274856
\end{tabular}

H $-1.858094 \quad 4.758173 \quad 4.140693$

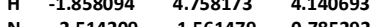

$\begin{array}{llll}N & 2.514209 & 1.561479 & -0.785292\end{array}$

\begin{tabular}{llll}
$\mathrm{N}$ & 0.377096 & 1.334737 & -0.503007 \\
\hline & 0.010186 & -1.015644 & 0.625671
\end{tabular}

$\begin{array}{llll}\mathrm{H} & 0.010186 & -1.015644 & 0.625671\end{array}$

$\begin{array}{llll}\text { H } & -2.003472 & 2.338510 & -1.179025\end{array}$

$\begin{array}{llll}\text { C } & -2.216259 & -2.386975 & 1.402956\end{array}$

$\begin{array}{llll}\text { C } & -2.605161 & -3.607336 & 0.796230\end{array}$

\begin{tabular}{llll} 
C & -1.882607 & -2.343448 & 2.775652 \\
\hline
\end{tabular}

$\begin{array}{llll}\text { C } & -2.589573 & -4.775186 & 1.566183\end{array}$

$\begin{array}{llll}\text { C } & -1.868594 & -3.541618 & 3.504213\end{array}$

\begin{tabular}{lllll} 
C & -2.207270 & -4.748991 & 2.906022 \\
\hline
\end{tabular}

$\begin{array}{llll}\text { H } & -2.872268 & -5.727159 & 1.110149\end{array}$

$\begin{array}{llll}H & -1.595659 & -3.520242 & 4.563680\end{array}$

$\begin{array}{llll}\text { H } & -2.188285 & -5.674925 & 3.487261\end{array}$

$\begin{array}{llll}\text { C } & -4.554990 & 1.406261 & -0.901671\end{array}$

$\begin{array}{llll}\text { C } & -5.161234 & 2.445980 & -0.155018\end{array}$

$\begin{array}{llll}\text { C } & -5.135710 & 0.949755 & -2.105510 \\ \text { C } & -6.352947 & 3.003840 & -0.632464\end{array}$

$\begin{array}{llll}\text { C } & -6.352947 & 3.003840 & -0.632464 \\ \text { C } & -6.328154 & 1.540268 & -2.546270\end{array}$

$\begin{array}{llll}C & -6.328154 & 1.540268 & -2.546270\end{array}$

$\begin{array}{llll}\text { C } & -6.934627 & 2.555784 & -1.817050\end{array}$

$\begin{array}{llll}\text { H } & -6.839641 & 3.804625 & -0.070635\end{array}$

$\begin{array}{llll}\text { H } & -6.782239 & 1.198462 & -3.481491\end{array}$

$\begin{array}{lllll}\text { H } & -7.864844 & 3.006313 & -2.173458\end{array}$

$\begin{array}{llll}\text { C } & -4.497008 & -0.135795 & -2.955910\end{array}$

$\begin{array}{llll}\text { H } & -3.605439 & -0.508759 & -2.426329\end{array}$

$\begin{array}{llll}\text { C } & -4.023269 & 0.424538 & -4.292712\end{array}$

\begin{tabular}{llll} 
H & -3.289451 & 1.233759 & -4.158254 \\
\hline & -3.54658 & -0.35586 & -4.90438
\end{tabular}

$\begin{array}{cccc}\text { H } & -3.546458 & -0.355861 & -4.904318\end{array}$

$\begin{array}{rrrr}\text { H } & -4.859853 & 0.833067 & -4.881160\end{array}$

$\begin{array}{llll}\text { C } & -5.430141 & -1.324134 & -3.155952\end{array}$ 


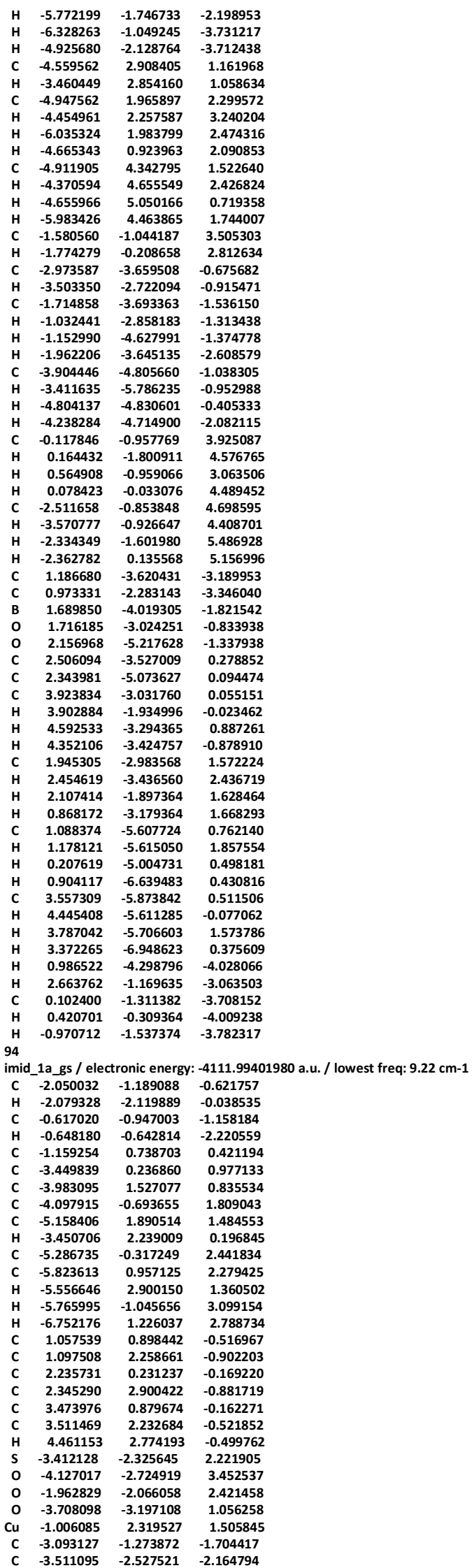




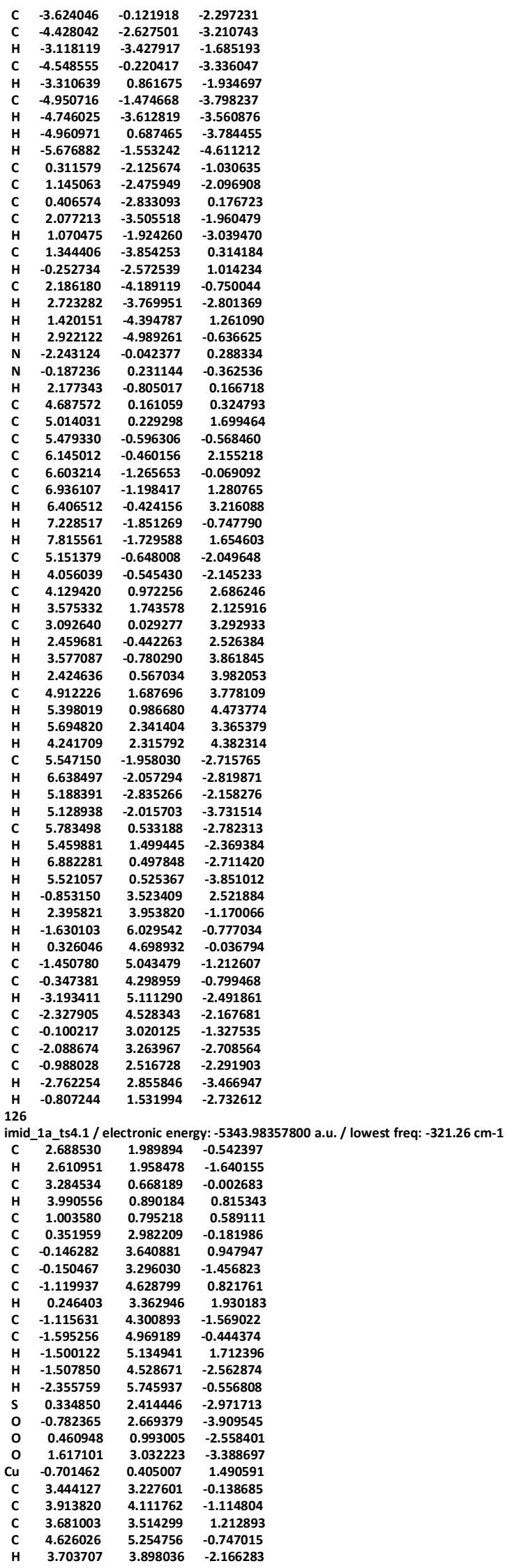




\begin{tabular}{|c|c|c|c|}
\hline & & & \\
\hline & 3.304404 & 2.834282 & 1.984409 \\
\hline & 4.866317 & 5.527774 & 0.598889 \\
\hline & 4.992414 & 5.937037 & -1.518022 \\
\hline & 4.568888 & 4.868101 & 2.637521 \\
\hline & 5.424296 & 6.422463 & 0.886040 \\
\hline & 1.316089 & 1.959192 & 0.019200 \\
\hline & 2.085089 & 0.002876 & 0.580605 \\
\hline & -2.311708 & 0.559655 & 0.149679 \\
\hline & -2.542385 & -0.276364 & -1.025198 \\
\hline & -2.557774 & 0.329392 & -2.297699 \\
\hline & -2.877424 & -1.645736 & -0.938210 \\
\hline & -2.927673 & -0.389217 & -3.432143 \\
\hline & -3.262538 & -2.357465 & -2.073992 \\
\hline & -3.298843 & -1.732421 & -3.325267 \\
\hline & -2.925491 & 0.109258 & -4.404710 \\
\hline & -3.537459 & -3.410538 & -1.979187 \\
\hline & -3.600831 & -2.294755 & -4.211812 \\
\hline & -2.716737 & 0.19 & 1.454868 \\
\hline & -2.903192 & 1.150245 & 2.484159 \\
\hline & -3.004504 & 0.811321 & 3.513814 \\
\hline & -2.511169 & 2.161661 & 2.353360 \\
\hline & -2.859186 & -2.155687 & 0.029903 \\
\hline & -3.057146 & -0.825311 & 1.655830 \\
\hline & -5.671686 & 22 & 1.309277 \\
\hline & -5.189317 & 336 & -0.138303 \\
\hline & -5.848935 & -0.1 & 0.950335 \\
\hline & -7.098160 & 2.012596 & 1.584045 \\
\hline & -4.732336 & 1.770712 & 2.433150 \\
\hline & -2.221376 & 1.634273 & -0.064067 \\
\hline & -2.277787 & 1.380608 & -2.396705 \\
\hline & -4.892240 & 3.325388 & -0.257196 \\
\hline & -4.348279 & 3.473455 & -1.198284 \\
\hline & -5.814309 & 3.926452 & -0.287765 \\
\hline & -4.265923 & 3.672167 & 0.579043 \\
\hline & -7.272418 & 3.004467 & 2.588216 \\
\hline & -8.304014 & 3.365960 & 2.505173 \\
\hline & -7.123217 & 2.589517 & 3.594830 \\
\hline & -6.589142 & 3.855514 & 2.454910 \\
\hline & 2.030695 & -1.366084 & 0.942481 \\
\hline & 3.003734 & -1.9 & 1.772330 \\
\hline & 0.994522 & -2.1 & 0.399942 \\
\hline & 2.920177 & -3.351608 & 1.960235 \\
\hline & 0.893434 & -3.5 & 866 \\
\hline & 1.894355 & -4.11 & 1.411984 \\
\hline & 0.268181 & -1.641429 & -0.254732 \\
\hline & -0.211790 & -4.309607 & 0.041771 \\
\hline & -1.226161 & -4.84 & 0.878826 \\
\hline & -0.233116 & -4.547072 & -1.351410 \\
\hline & -2.240728 & -5.610799 & 0.298968 \\
\hline & -1.269592 & -5.32 & -1.88 \\
\hline & -2.261597 & -5.857307 & -1.072513 \\
\hline & -3.030594 & -6.027540 & 0.928136 \\
\hline & -1.295762 & -5.512878 & -2.963774 \\
\hline & -3.060552 & -6.464691 & -1.506399 \\
\hline & 0.815434 & -3.981058 & -2.293514 \\
\hline & 1.628445 & -3.553052 & -1.685783 \\
\hline & -1.258947 & -4.51 & 2.3 \\
\hline & -0.218040 & -4.51 & 2.726105 \\
\hline & -1.810606 & -3.111438 & 2.587876 \\
\hline & -1.233126 & -2.3 & 05 \\
\hline & -2.857859 & -3.044320 & 2.249613 \\
\hline & -1.791831 & -2.838827 & 3.654284 \\
\hline & -2.023506 & -5.529835 & 3.202094 \\
\hline & -3.105799 & -5.505668 & 3.003144 \\
\hline & -1.677433 & -6.559500 & 3.029641 \\
\hline & -1.895525 & -5.313691 & 4.272321 \\
\hline & 0.224780 & -2.85 & -3.132390 \\
\hline & -0.591508 & -3.219602 & -3.774791 \\
\hline & -0.187056 & -2.043091 & -2.508935 \\
\hline & 0726 & -2.4 & -3.7 \\
\hline & 1.439444 & -5.052659 & -3.179668 \\
\hline & 1.865446 & -5.877405 & -2.589603 \\
\hline & 0.712023 & -5.48 & -3.881335 \\
\hline & 2.252648 & -4.628402 & -3.787128 \\
\hline & 2.302850 & -0.264180 & -2.374775 \\
\hline & 3.484288 & -1.694056 & -4.038492 \\
\hline & 3.333618 & -0.590945 & -2.192709 \\
\hline & 3.999220 & -1.384080 & -3.125569 \\
\hline & & & \\
\hline & 5.322426 & -1.774641 & -2.905903 \\
\hline & 5.839030 & -2.397382 & -3.640638 \\
\hline & 5.321901 & -0.561105 & \\
\hline & 5.985206 & -1.357757 & -1.752413 \\
\hline & 5.840559 & -0.226045 & 0.085383 \\
\hline & 7.023947 & -1.649719 & -1.578870 \\
\hline & -0.291500 & 0.346015 & 3.022782 \\
\hline & 7.383625 & -1.368770 & 3.238323 \\
\hline & 5.624991 & -2.601268 & 2.000856 \\
\hline & 6.361116 & -0.983533 & 3.223188 \\
\hline & 5.370989 & -1.680728 & 2.534185 \\
\hline & 6.827599 & 0.754878 & 4.42184 \\
\hline
\end{tabular}




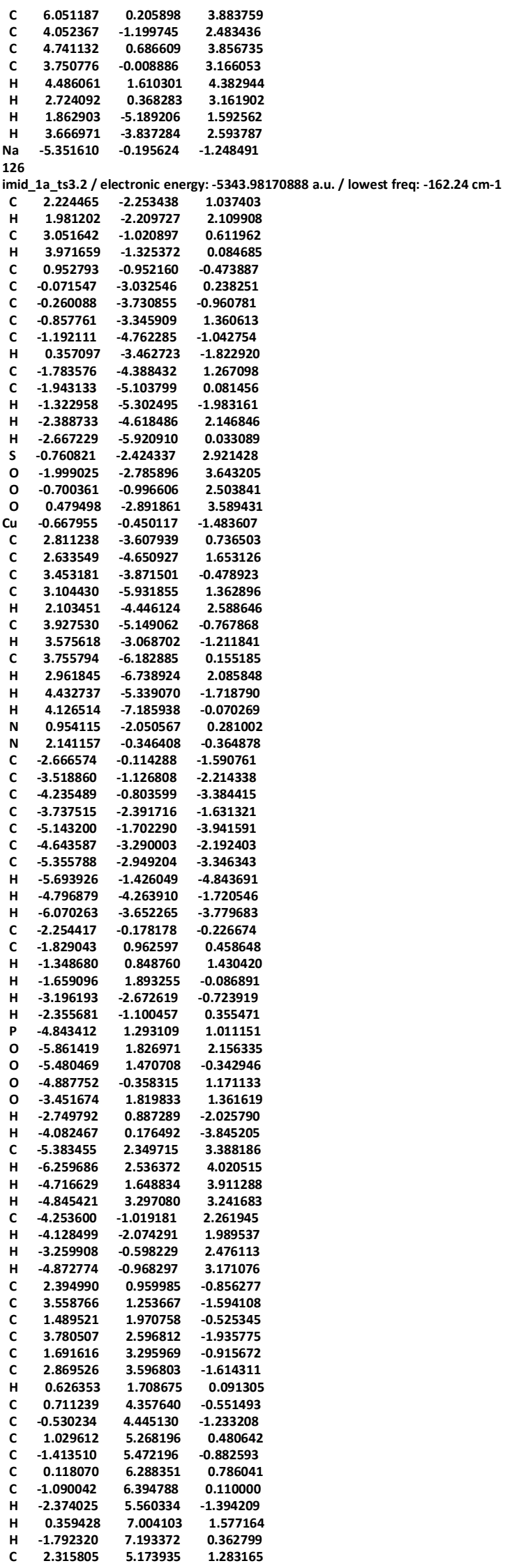




\begin{tabular}{rrrr} 
H & 2.810160 & 4.221914 & 1.027789 \\
C & -0.883440 & 3.478597 & -2.354365 \\
H & -0.553794 & 2.467997 & -2.039221 \\
C & -2.375042 & 3.395261 & -2.640304 \\
H & -2.968796 & 3.179243 & -1.738508 \\
H & -2.765434 & 4.328481 & -3.073665 \\
H & -2.578110 & 2.605573 & -3.379028 \\
C & -0.124564 & 3.818223 & -3.634953 \\
H & -0.421960 & 4.808692 & -4.013647 \\
H & 0.963998 & 3.837042 & -3.486339 \\
H & -0.336598 & 3.082923 & -4.425726 \\
C & 2.045009 & 5.146873 & 2.783120 \\
H & 1.599694 & 6.088319 & 3.139585 \\
H & 1.360083 & 4.332058 & 3.060200 \\
H & 2.979314 & 5.003060 & 3.345455 \\
C & 3.276826 & 6.302174 & 0.923919 \\
H & 3.515997 & 6.314754 & -0.149422 \\
H & 2.851054 & 7.286577 & 1.175324 \\
H & 4.224578 & 6.205512 & 1.474531 \\
H & 1.445402 & -0.101220 & 2.638800 \\
H & 2.035552 & 1.563501 & 4.380102 \\
C & 2.456624 & 0.324506 & 2.668333 \\
C & 2.786945 & 1.260489 & 3.646458 \\
C & 3.415895 & -0.073009 & 1.725808 \\
C & 4.070624 & 1.810022 & 3.693737 \\
H & 4.324974 & 2.541776 & 4.464702 \\
C & 4.698525 & 0.481150 & 1.778071 \\
C & 5.027190 & 1.418699 & 2.757959 \\
H & 5.445621 & 0.170354 & 1.040730 \\
H & 6.034369 & 1.841366 & 2.791483 \\
H & -0.405909 & -0.628117 & -3.015803 \\
H & 7.861428 & -0.459151 & -2.101753 \\
H & 6.253858 & 1.256279 & -1.307216 \\
C & 6.792219 & -0.592518 & -2.283864 \\
C & 5.890061 & 0.372055 & -1.838786 \\
H & 7.039651 & -2.479732 & -3.310174 \\
C & 6.332802 & -1.724401 & -2.958564 \\
C & 4.510025 & 0.214867 & -2.045000 \\
C & 4.965427 & -1.881542 & -3.187951 \\
C & 4.060421 & -0.925280 & -2.730516 \\
H & 4.597334 & -2.758968 & -3.726415 \\
H & 2.990879 & -1.051009 & -2.922262 \\
H & 3.066403 & 4.627118 & -1.922659 \\
H & 4.677410 & 2.848569 & -2.507853 \\
Na & -6.014720 & -0.625845 & -0.920009 \\
126 & & & \\
\hline & & &
\end{tabular}

imid_1a_ts4.2 / electronic energy: -5343.97866115 a.u. / lowest freq: $-337.28 \mathrm{~cm}-1$

C 3.429717 - 1.206003

H $3.398150-1.257007-1.180382$

$\begin{array}{rrrr}\text { H } & 3.398150 & -1.257007 & 1.180382 \\ \text { C } & 3.441286 & 0.263131 & -0.387994\end{array}$

$\begin{array}{llll}\text { H } & 4.042614 & 0.352107 & -1.309926\end{array}$

C $\quad \begin{array}{lll}1.325376 & -0.672297 & -0.819962\end{array}$

$\begin{array}{llll}\text { C } & 1.593129 & -2.962438 & -0.145272 \\ \text { C } & 1.428888 & -3.874221 & -1.192050\end{array}$

C $\quad 1.428888 \quad-3.874221-1.192050$

$\begin{array}{llll}\text { C } & 1.189047 & -3.303729 & 1.158892\end{array}$

-0.951519
-4865

$\begin{array}{lllr}\text { H } & 1.736271 & -3.575460 & -2.197347 \\ \text { C } & 0.661153 & -4.576684 & 1.387318\end{array}$

$\begin{array}{llll}\text { C } & 0.513802 & -5.490183 & 0.344906\end{array}$

$\begin{array}{llll}\text { H } & 0.763591 & -5.840870 & -1.776118\end{array}$

$\begin{array}{llll}\text { H } & 0.341131 & -4.827599 & \mathbf{2 . 4 0 1 2 4 0}\end{array}$

$\begin{array}{llll}H & 0.096389 & -6.480040 & 0.545511\end{array}$

$\begin{array}{lllll}\mathrm{S} & \mathbf{1 . 2 8 2 4 7 1} & -2.155838 & 2.566366\end{array}$

$\begin{array}{lllll}0 & 0.335537 & -2.700433 & 3.558857\end{array}$

$\begin{array}{llll}0 & 0.885062 & -0.837161 & 1.998620\end{array}$

$\begin{array}{rrrr}\mathrm{O} & 2.699855 & -2.200632 & 3.008012 \\ \mathrm{Cu} & -0.399818 & -1.076314 & -1.666207\end{array}$

$\begin{array}{llll}\text { C } & 4.577597 & -2.040348 & -0.417264\end{array}$

$\begin{array}{llll}\text { C } & 5.396212 & -2.714431 & 0.494306\end{array}$

$\begin{array}{llll}\text { C } & 4.831726 & -2.172929 & -1.789706\end{array}$

$\begin{array}{llll}\text { C } & 6.461640 & -3.496346 & 0.044891\end{array}$

$\begin{array}{lllll}\text { H } & 5.184368 & -2.627118 & 1.564006\end{array}$

$\begin{array}{llll}\text { C } & 5.892030 & -2.955997 & -2.239162\end{array}$

\begin{tabular}{llll} 
H & 4.183581 & -1.663159 & -2.511084 \\
\hline
\end{tabular}

$\begin{array}{llll}\text { C } & 6.712166 & -3.617165 & -1.321194\end{array}$

$\begin{array}{llll}\text { H } & \mathbf{7 . 0 9 5 8 7 7} & -4.016645 & \mathbf{0 . 7 6 6 8 7 4}\end{array}$

$\begin{array}{llll}H & 6.081064 & -3.053685 & -3.311148\end{array}$

$\begin{array}{llll}H & 7.544652 & -4.230978 & -1.674021\end{array}$

$\begin{array}{llll}N & 2.126072 & -1.674820 & -0.443123\end{array}$

$\begin{array}{llll}\text { N } & 2.009884 & 0.478738 & -0.749017\end{array}$

$\begin{array}{llll}\text { C } & -2.079642 & -0.918643 & -0.420408\end{array}$

$\begin{array}{llll}\text { C } & -2.265463 & -1.520529 & 0.895413\end{array}$

$\begin{array}{llll}\text { C } & -2.354260 & -0.674529 & 2.020310\end{array}$

$\begin{array}{llll}\text { C } & -2.501570 & -2.897921 & 1.085854\end{array}$

$\begin{array}{llll}\text { C } & -2.719260 & -1.171905 & 3.268757\end{array}$

$\begin{array}{llll}\text { C } & -2.858838 & -3.393775 & 2.338289\end{array}$

$\begin{array}{llll}\text { C } & -2.986055 & -2.533797 & 3.432336\end{array}$

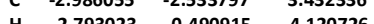

H $\quad 3.042536 \quad-4.464288 \quad 2.460561$

$\begin{array}{llll}\text { H } & -3.273371 & -2.925662 & 4.410330\end{array}$

$\begin{array}{llll}\text { C } & -2.357956 & -1.567005 & -1.644534\end{array}$

$\begin{array}{llll}\text { C } & -2.628179 & -0.841732 & -2.835754\end{array}$ 


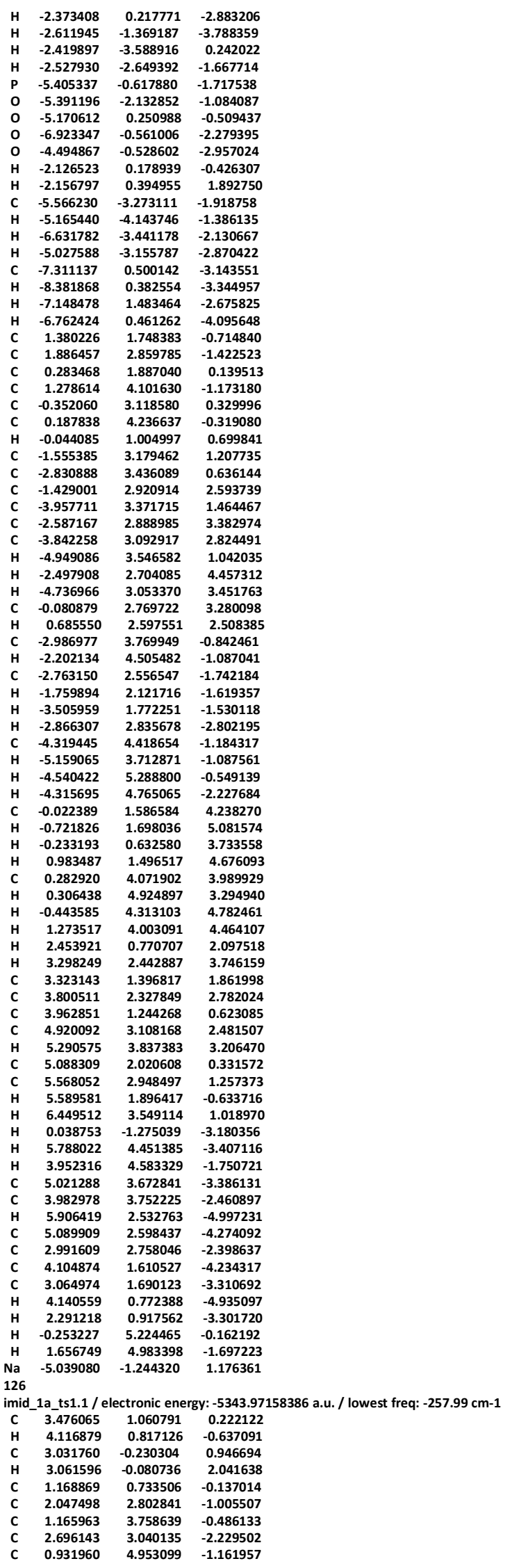




\begin{tabular}{|c|c|c|c|}
\hline & 0.660180 & 3.543359 & \\
\hline & 092 & 50543 & -2.887042 \\
\hline & 595950 & 5.205107 & -23616 \\
\hline & 5889 & & \\
\hline & 7734 & & \\
\hline & .425689 & 6.140361 & -2.9001 \\
\hline & 3.733752 & 1.804892 & -3.068741 \\
\hline & .783965 & & \\
\hline & .008566 & .523421 & -2.869456 \\
\hline & 5.047380 & 357659 & \\
\hline & -0.639155 & & \\
\hline & & & \\
\hline & & & \\
\hline & & & \\
\hline & 6.230215 & & 87294 \\
\hline & & & \\
\hline & & & \\
\hline & & & \\
\hline & 5.58 & & \\
\hline & & & \\
\hline & & & \\
\hline & & & \\
\hline & & & \\
\hline 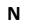 & & & \\
\hline & -2.60 & & \\
\hline C & $-3.0 \mathrm{~s}$ & & \\
\hline & -3.7 & & \\
\hline & -3.0 & & \\
\hline & -4.3 & & \\
\hline & -3.6 & & \\
\hline 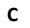 & -4.2 & & \\
\hline & -4.8 & & \\
\hline $\mathbf{H}$ & -3.5 & & \\
\hline H & -4.7 & & \\
\hline$c$ & -2.2 & & \\
\hline$c$ & -2.2 & 7 & \\
\hline H & -2.1 & & \\
\hline H & -1.8 & & \\
\hline-1 & -2.5 & & \\
\hline H & -2.1 & & \\
\hline P & -5.22 & & \\
\hline 0 & -5.1 & & \\
\hline 0 & -5.6 & & \\
\hline 0 & -6.36 & 64 & \\
\hline 0 & -3.9 & & \\
\hline H & -2.9 & & \\
\hline H & -3.7 & & \\
\hline$c$ & -4.7 & & \\
\hline H & -4.4 & & \\
\hline H & -5.5 & & \\
\hline H & -3.8 & & \\
\hline 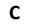 & -7.7 & & \\
\hline H & -8.3 & & \\
\hline H & -7.8 & & \\
\hline 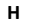 & -8.0 & & \\
\hline c & 0.796871 & & \\
\hline$c$ & & -1 & \\
\hline$c$ & & & \\
\hline$c$ & -0.1 & & \\
\hline c & -0.4 & & \\
\hline C & & & \\
\hline H & & & \\
\hline 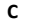 & -0.89 & 8 & \\
\hline c & & & \\
\hline$c$ & & & \\
\hline C & -2.7 & & \\
\hline C & -0.4 & & \\
\hline c & & & \\
\hline H & -3.7 & & \\
\hline H & & & \\
\hline 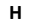 & & & \\
\hline C & & & \\
\hline H & & & \\
\hline 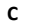 & & & \\
\hline H & & & \\
\hline 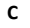 & & & \\
\hline 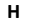 & & & \\
\hline H & & & \\
\hline H & & & \\
\hline 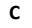 & & & \\
\hline & & & \\
\hline H & & & \\
\hline H & & & \\
\hline & & & \\
\hline & & & \\
\hline H & & & \\
\hline H & 3.450578 & 81 & 97 \\
\hline C & & & \\
\hline & & & \\
\hline H & 14 & -7.4 & -0.700406 \\
\hline & & & \\
\hline & 3.839729 & -1.104292 & -1527 \\
\hline
\end{tabular}




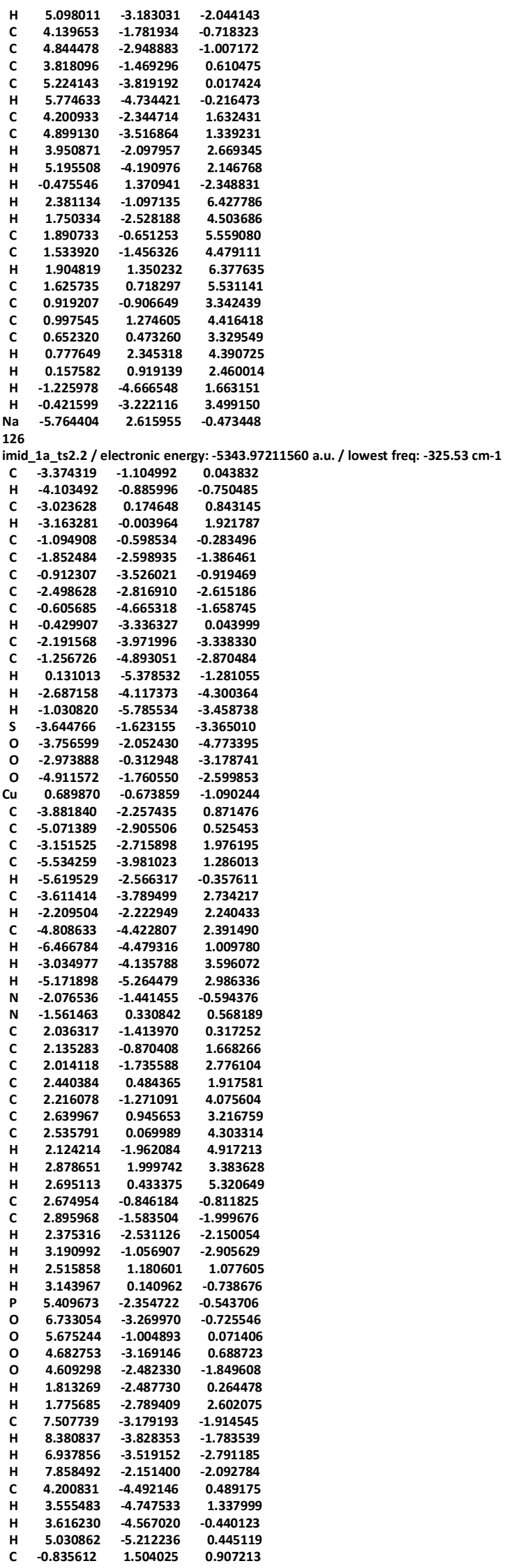




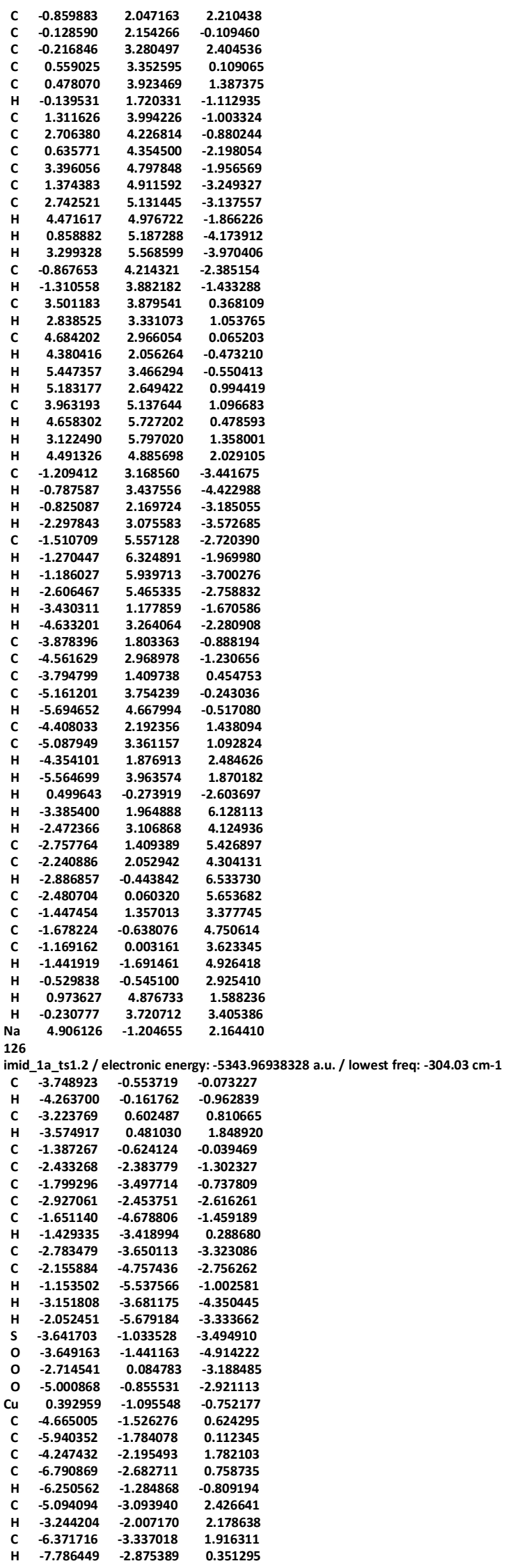




\begin{tabular}{|c|c|c|c|}
\hline & -4.758022 & 88 & \\
\hline & -7.037996 & -4.041097 & 2.421005 \\
\hline & -2.490675 & 1.204496 & .514675 \\
\hline & -1.742011 & 381285 & 0.77623 \\
\hline & 2.274731 & -1.730695 & .969136 \\
\hline & 3.175084 & -0.973149 & 500 \\
\hline & 3.954989 & -1.653066 & 1215 \\
\hline & 3.358513 & 0.415982 & -1.708260 \\
\hline 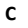 & 4.900659 & -0.974815 & -3.570610 \\
\hline & 4.305138 & 091969 & -2.475944 \\
\hline & 5.087603 & & -3.405063 \\
\hline & 8848 & & 2605 \\
\hline n & 4.428375 & 328 & 17153 \\
\hline & 5.829017 & 931514 & -4.004852 \\
\hline$c$ & 706 & & 001 \\
\hline C & 78 & & \\
\hline & & & \\
\hline & & & \\
\hline H & & & \\
\hline & & & \\
\hline & 4.503151 & & \\
\hline 0 & & & \\
\hline 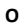 & & & \\
\hline & & & \\
\hline 0 & & & \\
\hline $\mathbf{H}$ & & & \\
\hline $\boldsymbol{H}$ & & & \\
\hline C & & -4.6 & \\
\hline $\mathrm{H}$ & & & \\
\hline $\mathbf{H}$ & & & \\
\hline H & & & \\
\hline C & & -3.8 & \\
\hline $\mathbf{H}$ & & & \\
\hline H & & & \\
\hline H & & -2 & \\
\hline c & 63 & & \\
\hline C & -0.9 & & \\
\hline C & & & \\
\hline c & 33 & & \\
\hline c & 55 & & 6804 \\
\hline$c$ & & & \\
\hline H & & & 312 \\
\hline C & & & \\
\hline c & & & \\
\hline c & 20 & & 48 \\
\hline c & & & \\
\hline 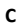 & & & \\
\hline c & & & \\
\hline H & & & \\
\hline 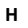 & 638 & 5.108262 & 5505 \\
\hline H & & & \\
\hline c & & & 045 \\
\hline H & & & \\
\hline c & & & \\
\hline H & & & \\
\hline c & & & \\
\hline$H$ & & & \\
\hline H & & & \\
\hline H & & & \\
\hline c & & & \\
\hline H & & & \\
\hline $\mathrm{H}$ & & & \\
\hline 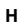 & & & \\
\hline c & -0.1 & & \\
\hline H & & & \\
\hline H & & & \\
\hline 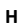 & & & \\
\hline c & -0.4 & & \\
\hline H & & & \\
\hline 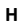 & & & \\
\hline H & & & \\
\hline H & & & \\
\hline 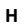 & & & \\
\hline & & & \\
\hline 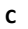 & & & \\
\hline 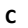 & & & \\
\hline & & & \\
\hline H & & & \\
\hline c & & & \\
\hline 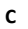 & & & \\
\hline 4 & & & \\
\hline H & & & \\
\hline $\mathrm{H}$ & & & \\
\hline & & & \\
\hline H & -2.569 & 20 & 15 \\
\hline c & & & \\
\hline & & & \\
\hline H & & & \\
\hline c & & & \\
\hline & & & \\
\hline & & & \\
\hline & -1.84125 & 195359 & 8023 \\
\hline
\end{tabular}




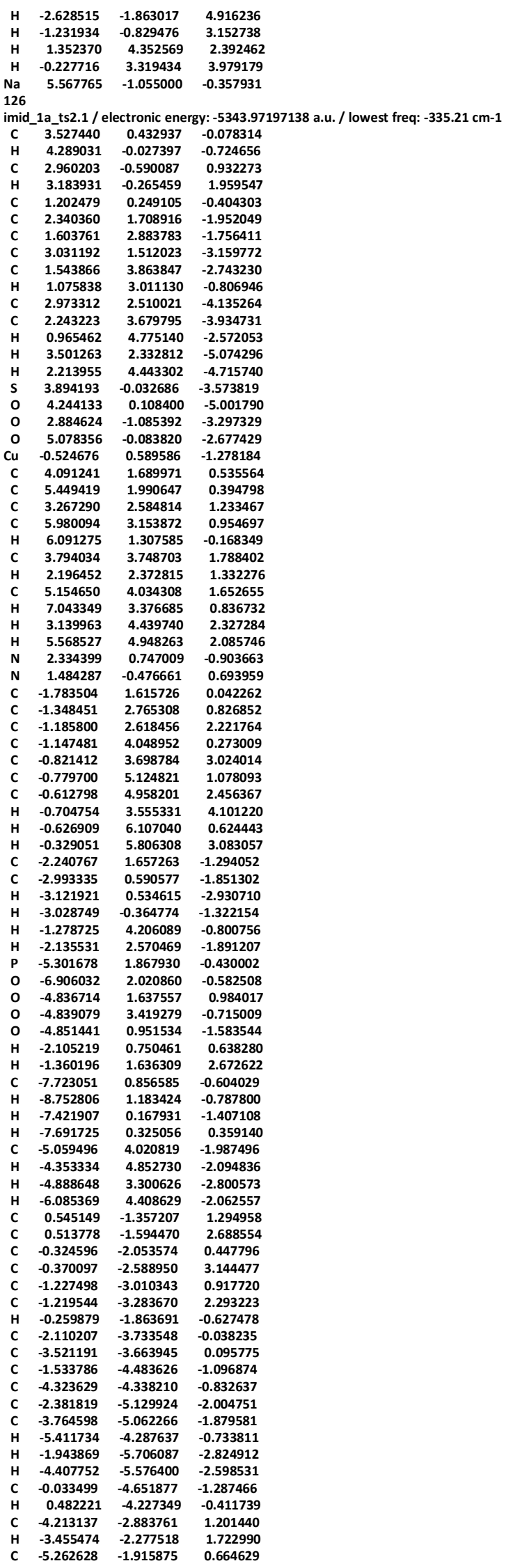




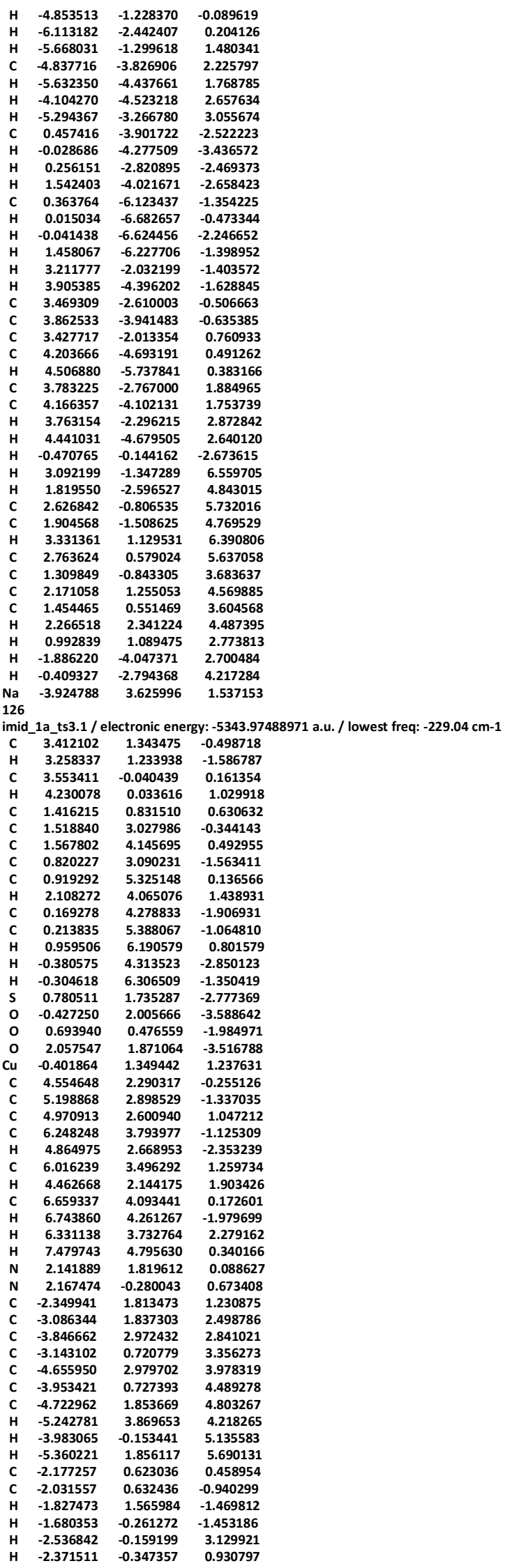




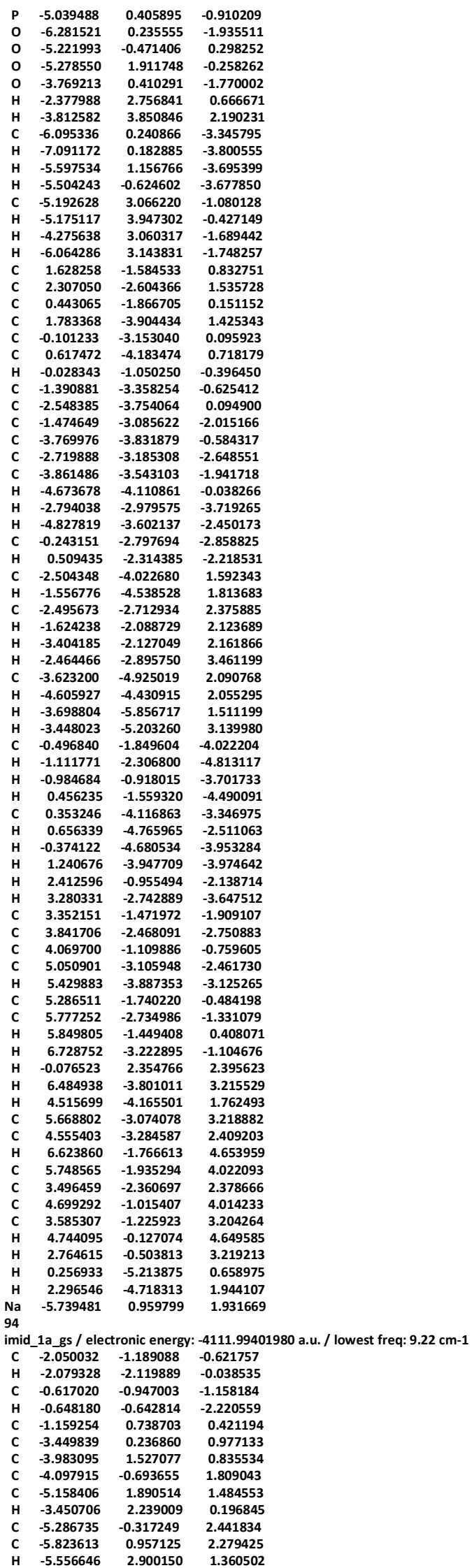




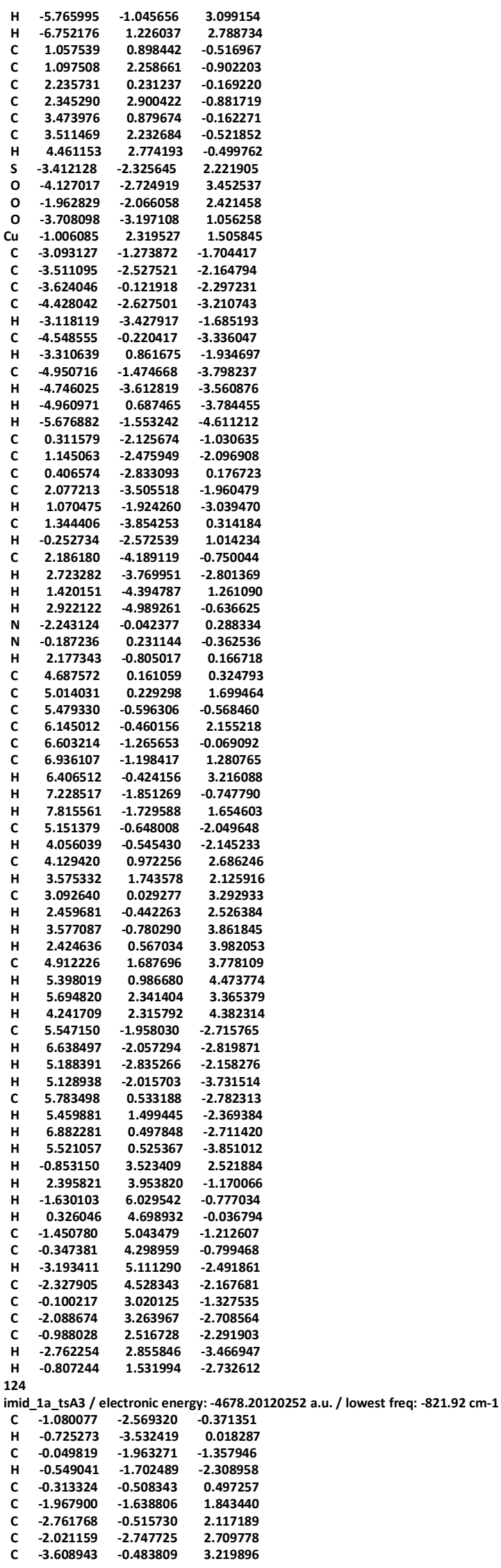




\begin{tabular}{|c|c|c|c|}
\hline &. .705063 & 345732 & \\
\hline & 6204 & 2.709274 & 3.799392 \\
\hline & -3.690191 & -1.594503 & 4.058594 \\
\hline & -4.205811 & 411360 & 41329 \\
\hline & -2.908423 & & \\
\hline & -4.357261 & -1.589032 & 923997 \\
\hline & 1.369881 & & -1.113450 \\
\hline & 1.318002 & & -2.371699 \\
\hline & 2.475639 & & -0.275526 \\
\hline & 2.440693 & & -2.768203 \\
\hline & 3.570800 & & -0.659214 \\
\hline & 907 & & 34704 \\
\hline & 4.390407 & 7851 & -2 \\
\hline & -0.914008 & & \\
\hline & -0.994331 & -4.8 & \\
\hline & 0.412526 & & \\
\hline & & & \\
\hline & -0.2 & & 758 \\
\hline & -2.446697 & -2.766217 & \\
\hline 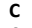 & -2.9 & & \\
\hline & -3.2 & -1.6 & \\
\hline & -4.1 & -4.2 & \\
\hline H & -2.2 & & \\
\hline$C$ & -4.5 & 6 & \\
\hline п & -2.9 & & \\
\hline & -4.9 & & \\
\hline 7 & & & \\
\hline & -5.1 & -0.9 & \\
\hline & -5.9 & & \\
\hline & & & \\
\hline & & & \\
\hline & & & \\
\hline$c$ & & & \\
\hline $\boldsymbol{y}$ & & & \\
\hline & & & \\
\hline - & & & \\
\hline$c$ & & & \\
\hline T & & & \\
\hline & & & \\
\hline H & & & \\
\hline N & 05 & & \\
\hline & & & \\
\hline & 17 & & 420 \\
\hline$C$ & & & \\
\hline$c$ & & & \\
\hline & & & \\
\hline & & & \\
\hline 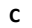 & & & \\
\hline$c$ & & & \\
\hline H & & & \\
\hline & & & \\
\hline & & & \\
\hline$C$ & & & \\
\hline H & & & \\
\hline & & & \\
\hline & & & \\
\hline$c$ & & & \\
\hline-4 & & & \\
\hline & & & \\
\hline 4 & & & \\
\hline & & & \\
\hline & & & \\
\hline $\boldsymbol{H}$ & & & \\
\hline H & & & \\
\hline C & & & \\
\hline H & & & \\
\hline H & & & \\
\hline & & & \\
\hline c & & & \\
\hline H & & & \\
\hline & & & \\
\hline & & & \\
\hline$c$ & & & \\
\hline & & & \\
\hline B & & & \\
\hline 0 & & & \\
\hline 0 & & & \\
\hline & & & \\
\hline & & & \\
\hline$c$ & & & \\
\hline & & & \\
\hline & & & \\
\hline H & & & \\
\hline & & & \\
\hline & & & \\
\hline H & & & \\
\hline & & & \\
\hline & & & \\
\hline & & & \\
\hline & & & \\
\hline & & & \\
\hline c & -4.7 & 813505 & -1963 \\
\hline
\end{tabular}




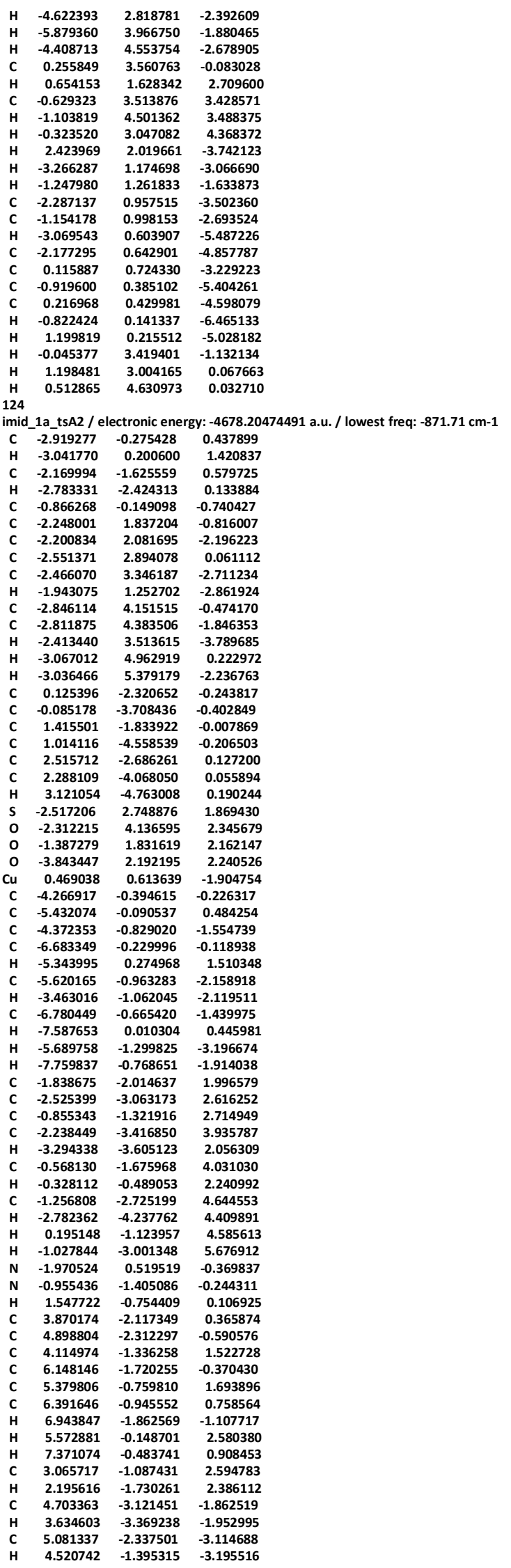




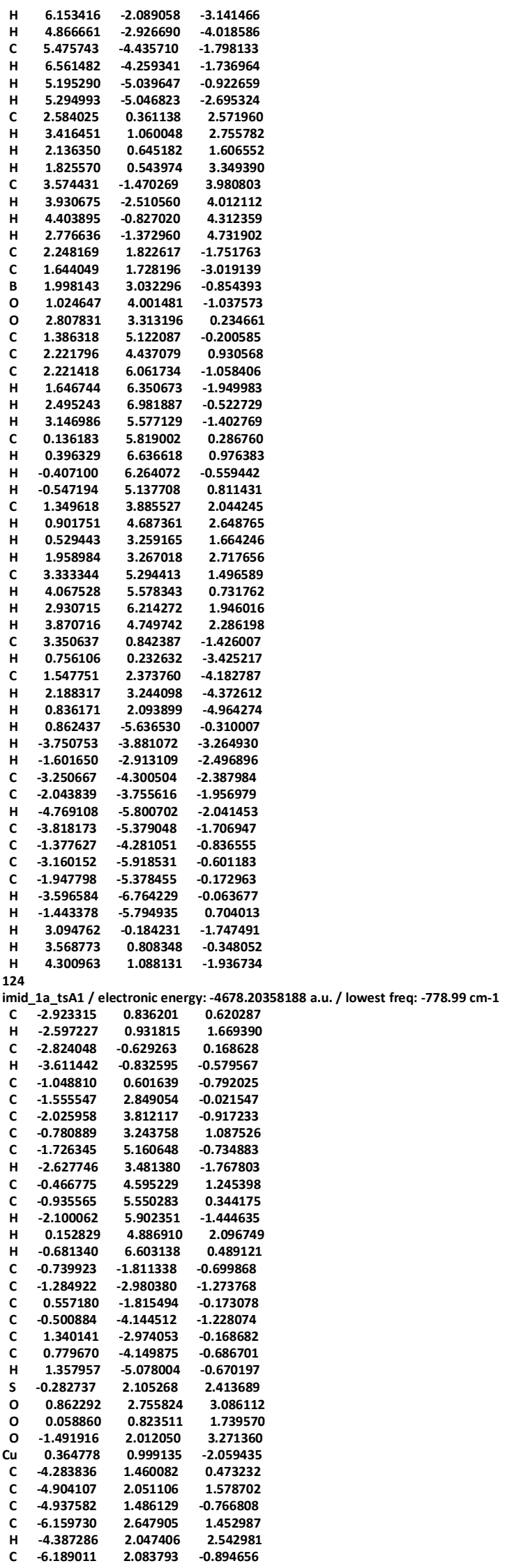




\begin{tabular}{|c|c|c|c|}
\hline & -4.451587 & 1.043861 & \\
\hline & -6.804741 & 2.664477 & 0.217200 \\
\hline & -6.633215 & 3.105638 & .3250 \\
\hline & -6.687627 & 2.099996 & -1.867158 \\
\hline & -7.786477 & 134063 & 648 \\
\hline & -2.954903 & -1.637570 & 1.275617 \\
\hline & -4.044314 & -2.513924 & 1.290074 \\
\hline & -2.003530 & -1.7 & \\
\hline 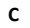 & -4.184685 & -3.457024 & 2.308982 \\
\hline & -4.787772 & -2.45 & \\
\hline$c$ & -2.143506 & -2.653283 & 3.317977 \\
\hline $\mathbf{H}$ & -1.161309 & -1.004531 & 2.303374 \\
\hline & -3.2 & -3.5 & \\
\hline H & -5.040879 & & 2.307997 \\
\hline H & 281 & & 3213 \\
\hline H & -3.3 & & \\
\hline & & & \\
\hline & -1.5 & 656 & 2672 \\
\hline $\boldsymbol{n}$ & 592 & & \\
\hline & & & \\
\hline C & 3.844463 & -3.0 & 5059 \\
\hline C & & -2.8 & \\
\hline C & & & \\
\hline$c$ & & & \\
\hline c & & -2.8 & \\
\hline H & & & \\
\hline n & & & \\
\hline H & 138 & & \\
\hline C & 60 & & \\
\hline $\mathrm{H}$ & & & \\
\hline C & 39 & $-3 . C$ & \\
\hline H & & & \\
\hline c & 3.395423 & -1.7 & \\
\hline $\mathbf{H}$ & 465 & & \\
\hline H & 213 & $-1 . c$ & \\
\hline H & 39 & -1 & \\
\hline C & & & \\
\hline $\mathrm{H}$ & 925 & -3. & \\
\hline H & 81 & -4.7 & -2 \\
\hline H & 128 & -3.8 & \\
\hline C & 1.666294 & -1.5 & \\
\hline H & 404 & -1 & \\
\hline H & 054 & -0. & \\
\hline H & 0.812970 & -1.5 & \\
\hline C & 1.68 & -4.0 & \\
\hline H & 1.65 & & \\
\hline H & 2.5 & & \\
\hline $\mathbf{H}$ & & & \\
\hline C & 91 & 87 & \\
\hline c & & & -3 \\
\hline B & 2.800611 & 2.446718 & \\
\hline 0 & & & \\
\hline 0 & & 8837 & 244 \\
\hline C & 39 & 1.588629 & \\
\hline C & 29 & & \\
\hline C & 3.432772 & 247 & 014 \\
\hline H & 3.403794 & 159 & 9074 \\
\hline H & & & \\
\hline H & & & \\
\hline C & & & \\
\hline $\mathbf{H}$ & & & \\
\hline H & & -0.0 & \\
\hline H & 6.308459 & 712 & -0.6 \\
\hline C & & & \\
\hline H & & & \\
\hline H & & & \\
\hline H & & & \\
\hline c & & & \\
\hline H & & & \\
\hline H & & & \\
\hline , & & & \\
\hline C & & & \\
\hline H & & & \\
\hline C & & & \\
\hline H & & & \\
\hline H & & & \\
\hline H & & & \\
\hline H & & & \\
\hline H & -2.3 & & \\
\hline C & -4.259196 & 22 & \\
\hline c & & & \\
\hline H & -6.09 & & \\
\hline C & -5.117055 & 29 & \\
\hline C & & & \\
\hline C & -4.71 & & \\
\hline C & -3.47 & -4.1 & \\
\hline H & -5.3 & -5.00 & \\
\hline & & & \\
\hline H & & & \\
\hline & 1.4 & 4.460 & -3.420951 \\
\hline & 0.868651 & 4.376758 & -1.75049 \\
\hline
\end{tabular}




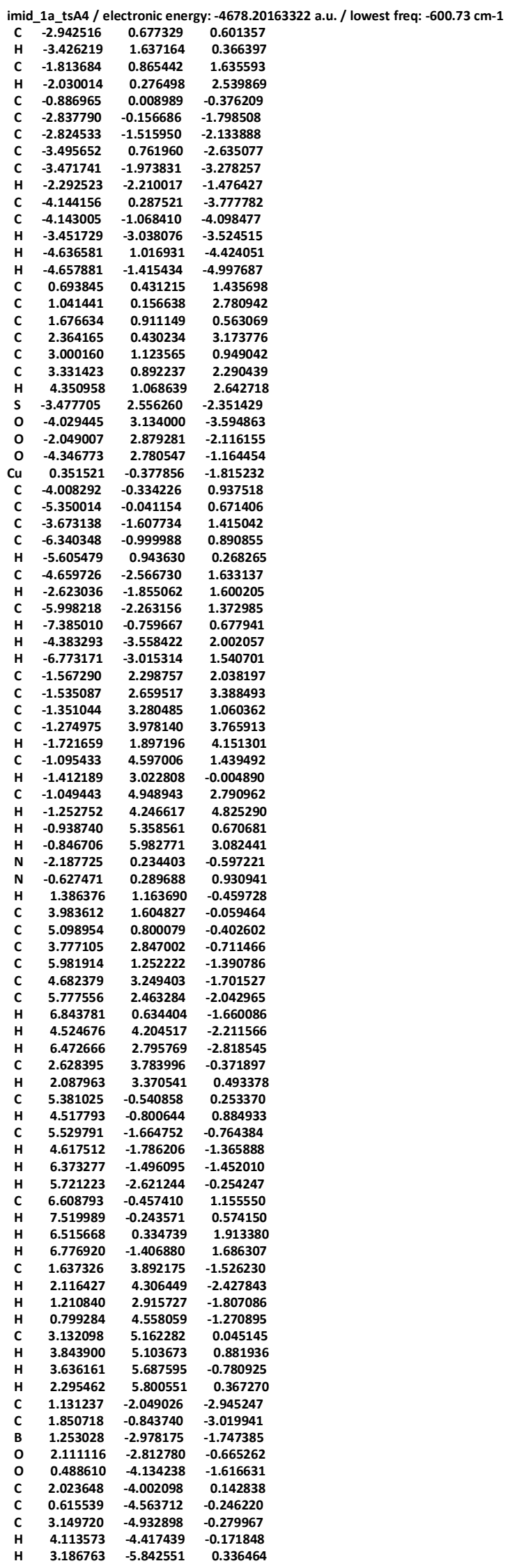




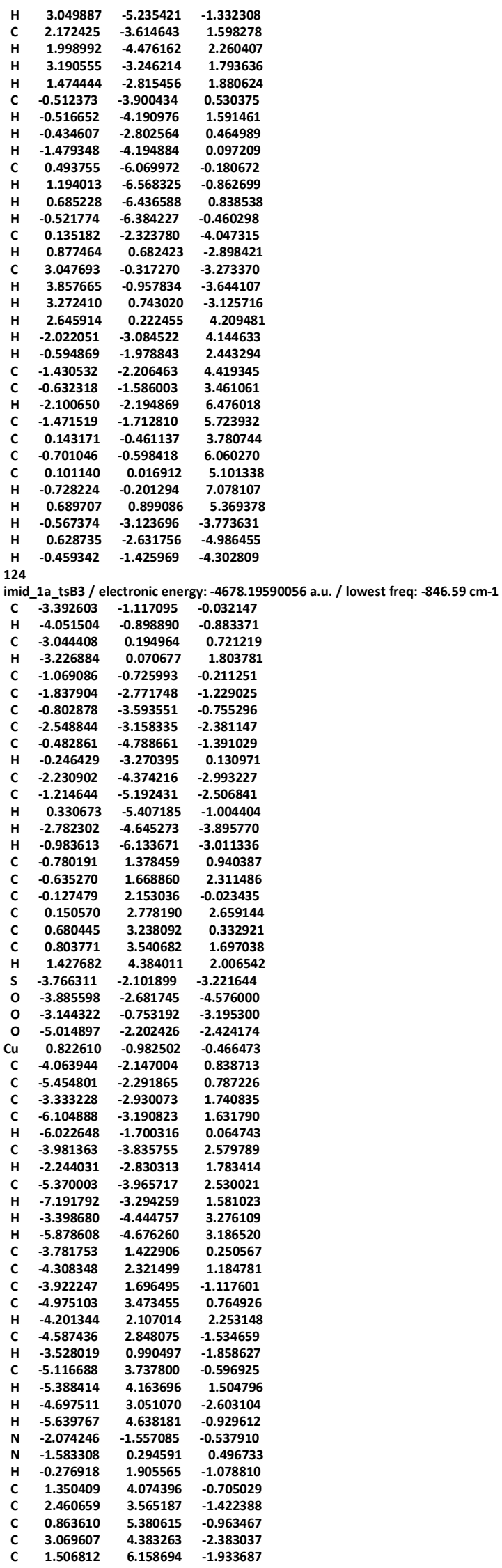




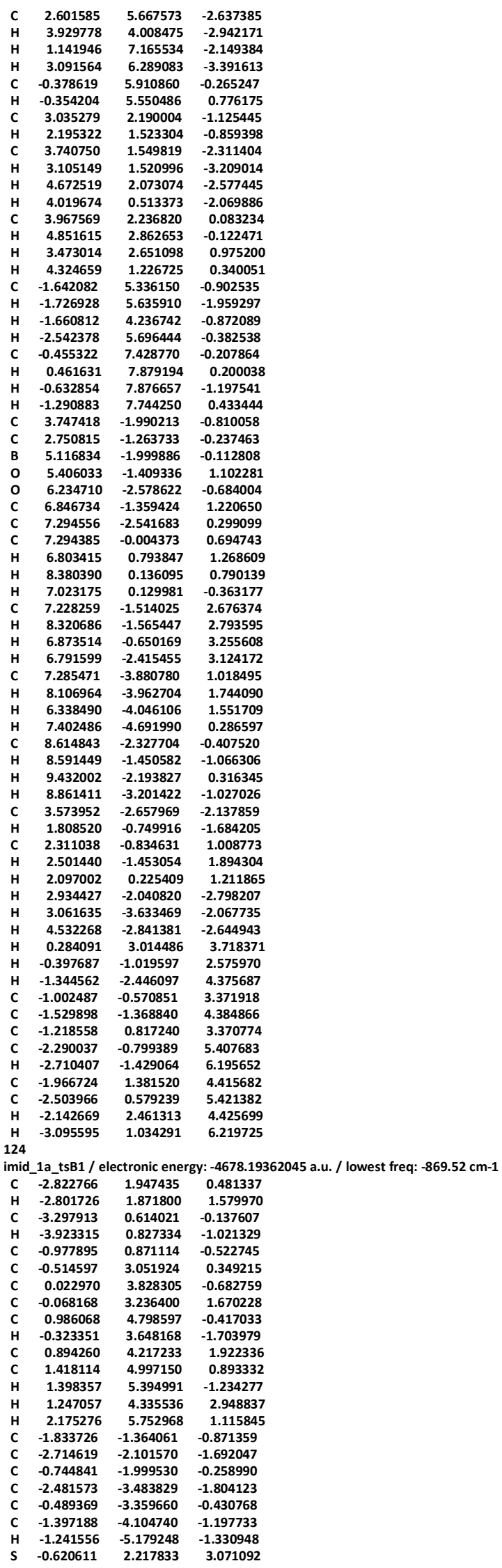




\begin{tabular}{|c|c|c|c|}
\hline & 399142 & 441581 & \\
\hline & 4150 & 9403 & 54319 \\
\hline & 1.962707 & 2.749692 & 3.4263 \\
\hline & 394014 & 625254 & -0.9037 \\
\hline & 3.649146 & & \\
\hline & -4.293210 & 899057 & 0 \\
\hline & -3.783622 & 3.520692 & 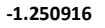 \\
\hline & -5.070940 & & \\
\hline & -4.166176 & 3019 & 126912 \\
\hline & -4.555189 & 4.62 & -1.602447 \\
\hline & -3.270547 & & -2.027606 \\
\hline & -5.204731 & 5.368209 & -0.613021 \\
\hline & -5.570806 & 5757 & 4525 \\
\hline & 824 & & \\
\hline & -5.8 & & -0.8 \\
\hline & -4.079315 & 0.268851 & \\
\hline & & 9 & \\
\hline & & 6 & \\
\hline & & 83 & \\
\hline & & & \\
\hline & -4.2 & -1.5 & \\
\hline & -2.472778 & -0.4 & \\
\hline & -5.5 & 7 & \\
\hline & & & \\
\hline & -3.7 & & \\
\hline & -6.1 & -2.5 & \\
\hline & -1.4 & & \\
\hline & -2.0 & & -0.5 \\
\hline & -0.1 & & \\
\hline & & & \\
\hline & & & \\
\hline & & & \\
\hline & & & \\
\hline & & & \\
\hline & & & \\
\hline & & & \\
\hline & & & \\
\hline & & 07 & \\
\hline c & & 5 & \\
\hline & -1.63 & -4.4 & \\
\hline & & & 87 \\
\hline & & & \\
\hline & 3.65 & -2. & \\
\hline $\mathrm{H}$ & & & \\
\hline & & & \\
\hline & & & \\
\hline C & & & \\
\hline 1 & & & \\
\hline & & 27 & \\
\hline H & & & \\
\hline$c$ & -0.914627 & -40 & \\
\hline H & & & \\
\hline & -0.71 & 36 & \\
\hline H & & & \\
\hline$c$ & & & \\
\hline$H$ & 222 & -6.9 & \\
\hline H & & 37 & \\
\hline H & & & \\
\hline & & & \\
\hline$c$ & & & \\
\hline B & & & \\
\hline 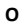 & & & \\
\hline 0 & & & \\
\hline$c$ & & & \\
\hline$r$ & & & \\
\hline$c$ & & & \\
\hline H & & & \\
\hline & & & \\
\hline H & & & \\
\hline c & & & \\
\hline H & & & \\
\hline & & & \\
\hline H & & & \\
\hline c & & & \\
\hline H & & & \\
\hline H & & & \\
\hline H & & & \\
\hline & & & \\
\hline H & & & \\
\hline 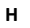 & & & \\
\hline & & & \\
\hline & & & \\
\hline H & & & \\
\hline & & & \\
\hline & & & \\
\hline H & & & \\
\hline H & & & \\
\hline & & & \\
\hline & & & \\
\hline H & & -4.6 & \\
\hline & & & \\
\hline & -4.498900 & 1.146539 & -4.531 \\
\hline
\end{tabular}




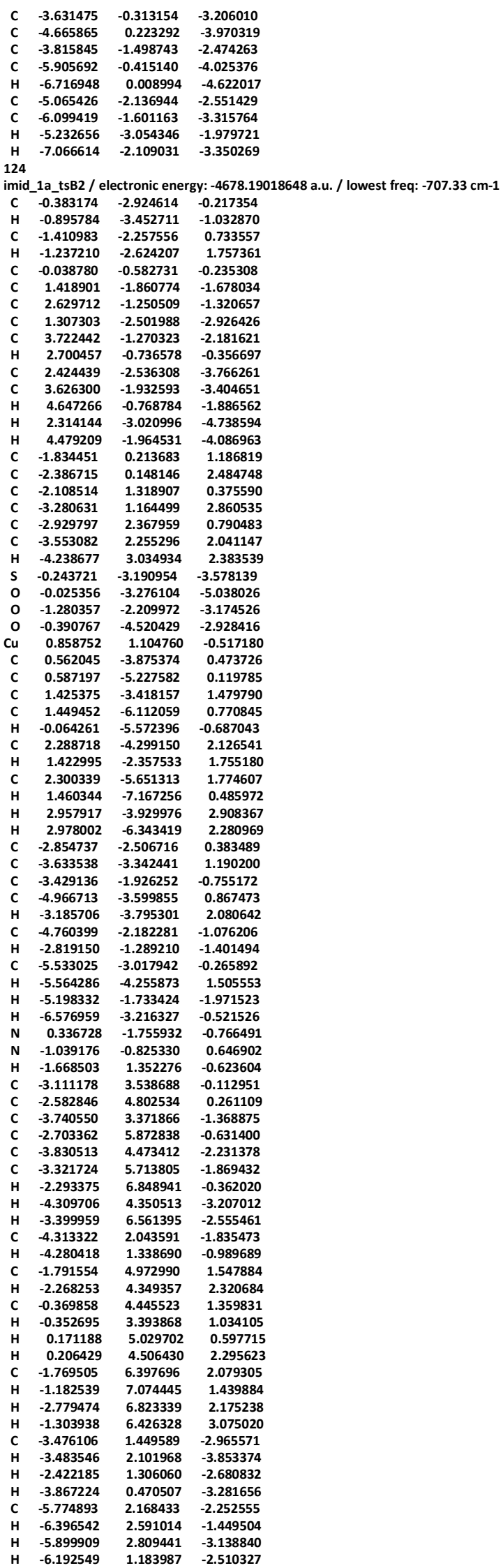




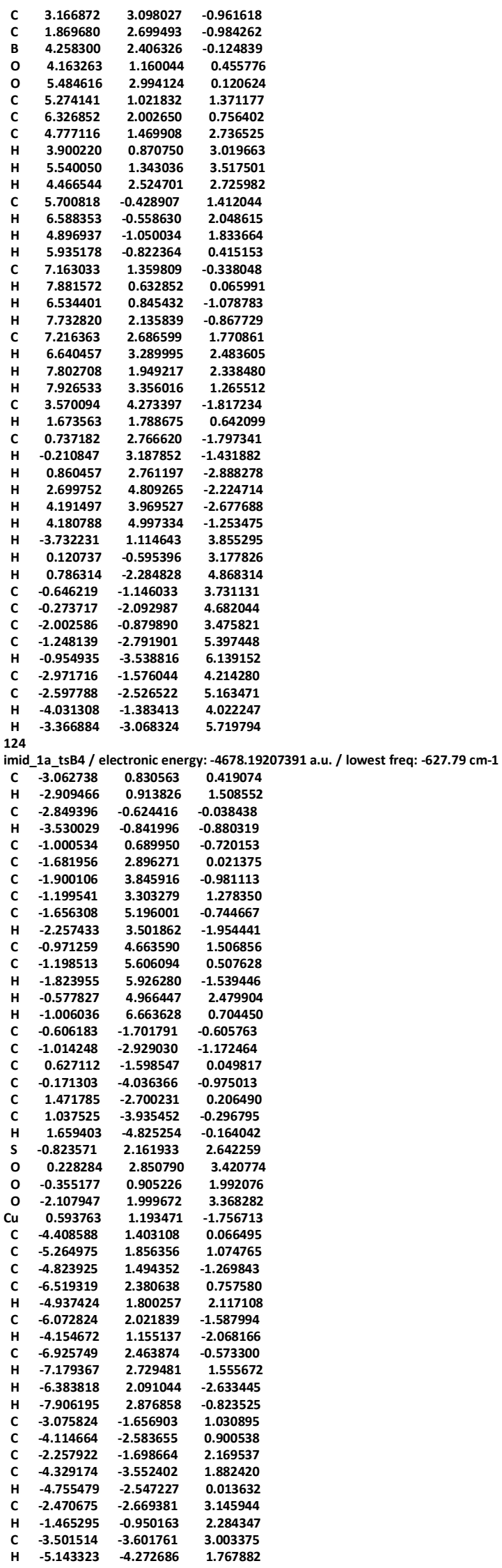




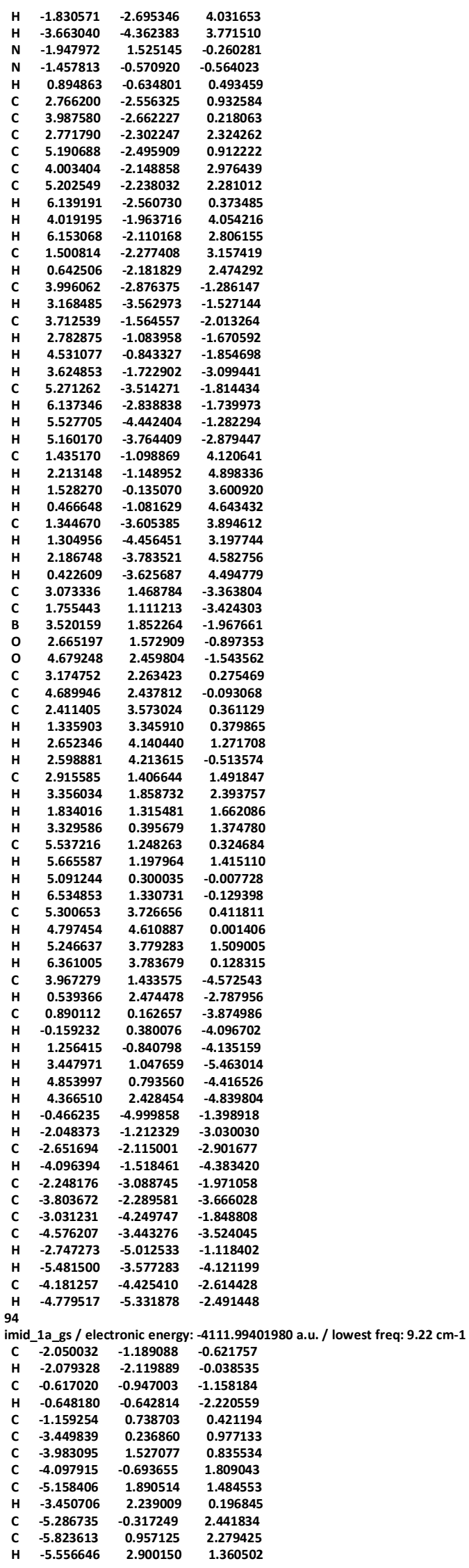




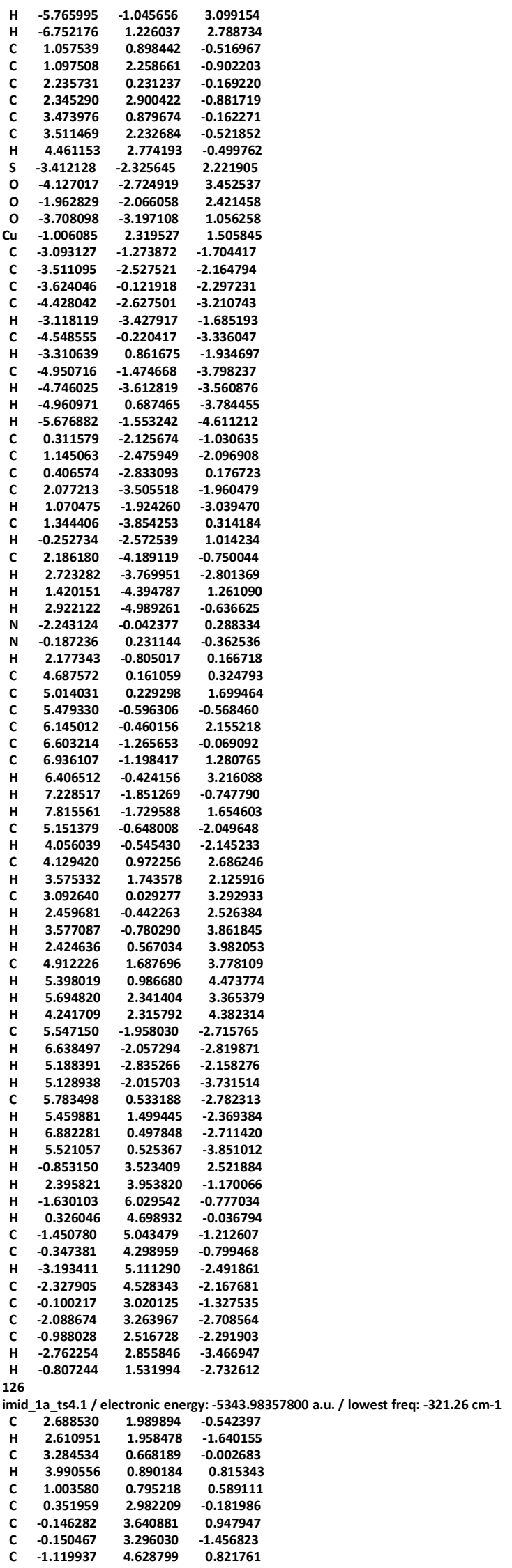




\begin{tabular}{|c|c|c|c|}
\hline & 246403 & 362946 & \\
\hline & -1.115631 & 300903 & 1.569022 \\
\hline & 595256 & 4.969189 & -0.444374 \\
\hline & 0122 & 941 & 712 \\
\hline & 850 & & 7 \\
\hline & -2.355759 & 5.745937 & -0.556808 \\
\hline & 0.354050 & 4446 & -2.971713 \\
\hline & & & \\
\hline & 0.460948 & 993005 & -2.558401 \\
\hline & 1.617101 & 032223 & \\
\hline & -0.70 & & \\
\hline & & & \\
\hline & 3.913820 & & \\
\hline & 3.681003 & & \\
\hline & 4.626026 & & -0.747015 \\
\hline & & & \\
\hline & & & \\
\hline & & & \\
\hline & & & \\
\hline & & & \\
\hline & & & \\
\hline & & & \\
\hline & & & \\
\hline & & & \\
\hline & & & \\
\hline & -2.5 & 4 & \\
\hline & & & \\
\hline & -2.8 & & \\
\hline & -2.92 & 7 & \\
\hline & -3.26 & ל & \\
\hline & -3.2 & -1.7 & \\
\hline & -2.9 & & \\
\hline & -3.5 & -3.4 & \\
\hline $\boldsymbol{\Pi}$ & & & \\
\hline & -2.7 & & \\
\hline 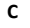 & -2.9 & & \\
\hline H & -3.0 & & \\
\hline & -2.5 & & \\
\hline H & -2.8 & -2.1 & \\
\hline H & -3.0 & & \\
\hline & -5.67 & & \\
\hline b & & & \\
\hline 0 & -5.8 & & \\
\hline U & & & \\
\hline U & & & \\
\hline+ & -2.2 & & \\
\hline H & & & \\
\hline 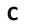 & & & \\
\hline H & -4.3 & & \\
\hline H & & & \\
\hline$n$ & -4.2 & & \\
\hline & -7.2 & & \\
\hline H & -8.3 & & \\
\hline H & & & \\
\hline & -6.58 & & \\
\hline & 695 & 84 & \\
\hline C & & & \\
\hline$c$ & & & \\
\hline$c$ & & & \\
\hline$c$ & & & \\
\hline$c$ & & & \\
\hline H & & & \\
\hline$c$ & -0.2 & & \\
\hline C & & & \\
\hline$c$ & & & \\
\hline c & & & \\
\hline C & & & \\
\hline$c$ & & & \\
\hline H & -3. & & \\
\hline H & & & \\
\hline H & & & \\
\hline$c$ & & & \\
\hline 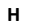 & & & \\
\hline C & & & \\
\hline $\mathrm{H}$ & & & \\
\hline C & & & \\
\hline 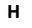 & & & \\
\hline $\mathrm{H}$ & & & \\
\hline H & & & \\
\hline C & & & \\
\hline H & & & \\
\hline H & & & \\
\hline H & & & \\
\hline C & & & \\
\hline & & & \\
\hline H & & & \\
\hline H & 0726 & 23 & \\
\hline C & & & \\
\hline & & & \\
\hline H & 3 & -5.4 & -3.88133 \\
\hline & & & \\
\hline & 50 & -0.264180 & -2.37477 \\
\hline
\end{tabular}




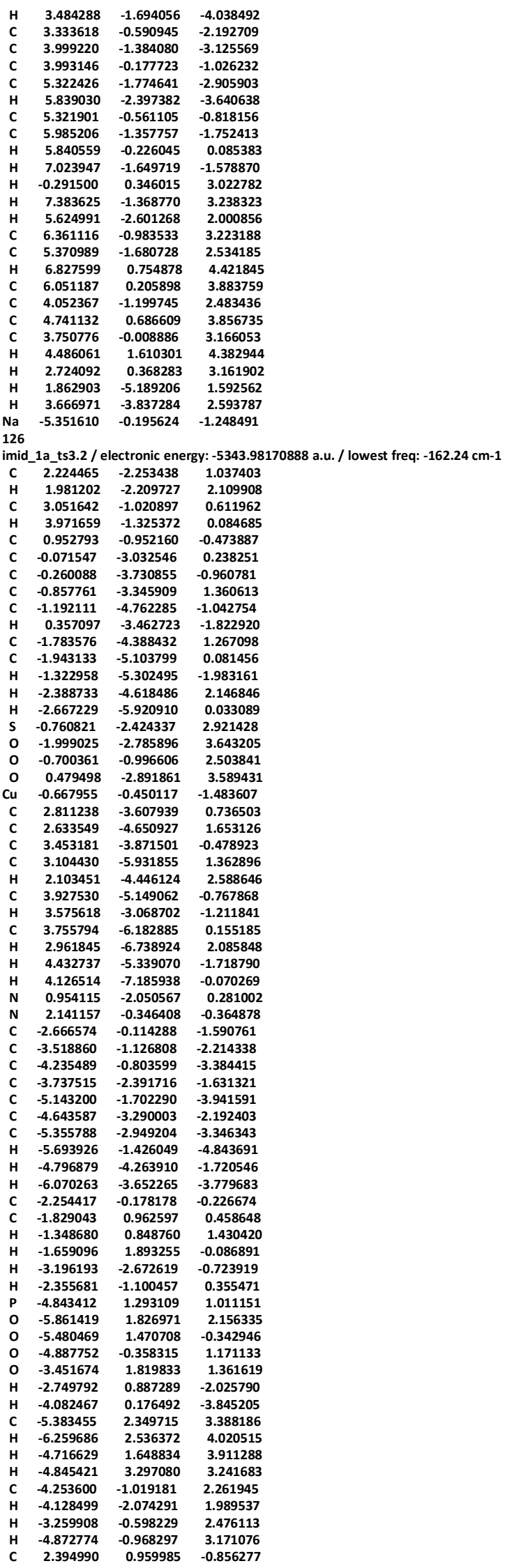




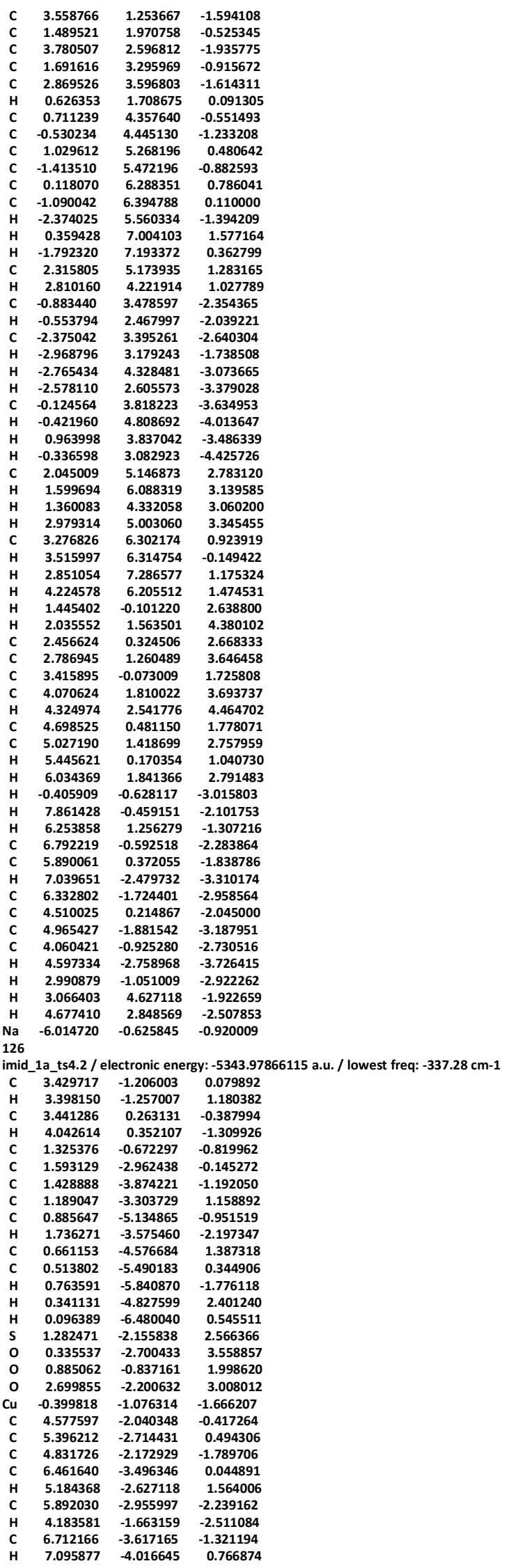




\begin{tabular}{|c|c|c|c|}
\hline & & & \\
\hline & 544652 & -4.230978 & -1.674021 \\
\hline & 126072 & .674820 & .443123 \\
\hline & 009884 & .478738 & .749017 \\
\hline & -2.079642 & -0.918643 & -0.420408 \\
\hline & -2.265463 & -1.520529 & \\
\hline & -2.354260 & -0.674529 & 2.020310 \\
\hline & -2.501570 & & \\
\hline & -2.719260 & -1.171905 & 3.268757 \\
\hline & -2.858838 & & 2.338289 \\
\hline & -2.986055 & 797 & \\
\hline & -2.793023 & & \\
\hline & -3.042536 & & \\
\hline & -3.273371 & -2.925662 & 4.410330 \\
\hline$c$ & -2.357956 & -1.5 & \\
\hline C & -2.62 & & \\
\hline n & -2.37 & & \\
\hline H & -2.611945 & & \\
\hline H & -2.4 & & \\
\hline $\mathbf{H}$ & -2.52 & & \\
\hline & -5.40 & -0.6 & \\
\hline 4 & -5.3 & & \\
\hline 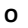 & & & \\
\hline 0 & -6.9 & & \\
\hline 0 & -4.4 & & \\
\hline H & -2.1 & & \\
\hline 11 & -2.15 & & \\
\hline c & -5.56 & & \\
\hline H & -5.16 & & \\
\hline $\mathbf{H}$ & -6.6 & & \\
\hline H & -5.02 & & \\
\hline 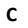 & -7.3 & & \\
\hline $\mathbf{H}$ & -8.3 & & \\
\hline H & -7.1 & & \\
\hline H & -6.7 & & \\
\hline C & 1.3 & & \\
\hline c & 1.88 & & \\
\hline C & $0.2 \varepsilon$ & & \\
\hline C & 1.2 & & \\
\hline c & -0.35 & & \\
\hline & & & \\
\hline H & -0.0 & 997 & 841 \\
\hline$C$ & -1.5 & & \\
\hline c & & & \\
\hline c & -1.4 & & \\
\hline & -3.9 & & \\
\hline C & -2.58 & & \\
\hline c & -3.8 & & \\
\hline H & -4.9 & & 035 \\
\hline H & -2.497908 & 085 & \\
\hline H & -4.7 & & \\
\hline c & -0.08 & & \\
\hline H & & & \\
\hline c & -2.9 & & \\
\hline H & -2.2 & & \\
\hline c & -2.76 & & \\
\hline H & -1.75 & & \\
\hline H & -3.5 & & \\
\hline$n$ & -2.8 & & \\
\hline c & & & \\
\hline H & -5.1 & & \\
\hline H & -4.5 & & \\
\hline$H$ & & & \\
\hline c & -0.0 & & \\
\hline H & -0.7 & & \\
\hline H & & & \\
\hline & & & \\
\hline c & & & \\
\hline H & & & \\
\hline 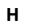 & & & \\
\hline H & & & \\
\hline & & & \\
\hline & & & \\
\hline & & & \\
\hline & & & \\
\hline & & & \\
\hline & & & \\
\hline$\Pi$ & & & \\
\hline & & & \\
\hline & & & \\
\hline & & & \\
\hline & & & \\
\hline & & & \\
\hline & & & \\
\hline H & & 29 & \\
\hline & & & \\
\hline & & & \\
\hline & & & \\
\hline C & & & -4.6 \\
\hline & & & \\
\hline & & & \\
\hline & 3.064974 & 690123 & -3.31069 \\
\hline
\end{tabular}




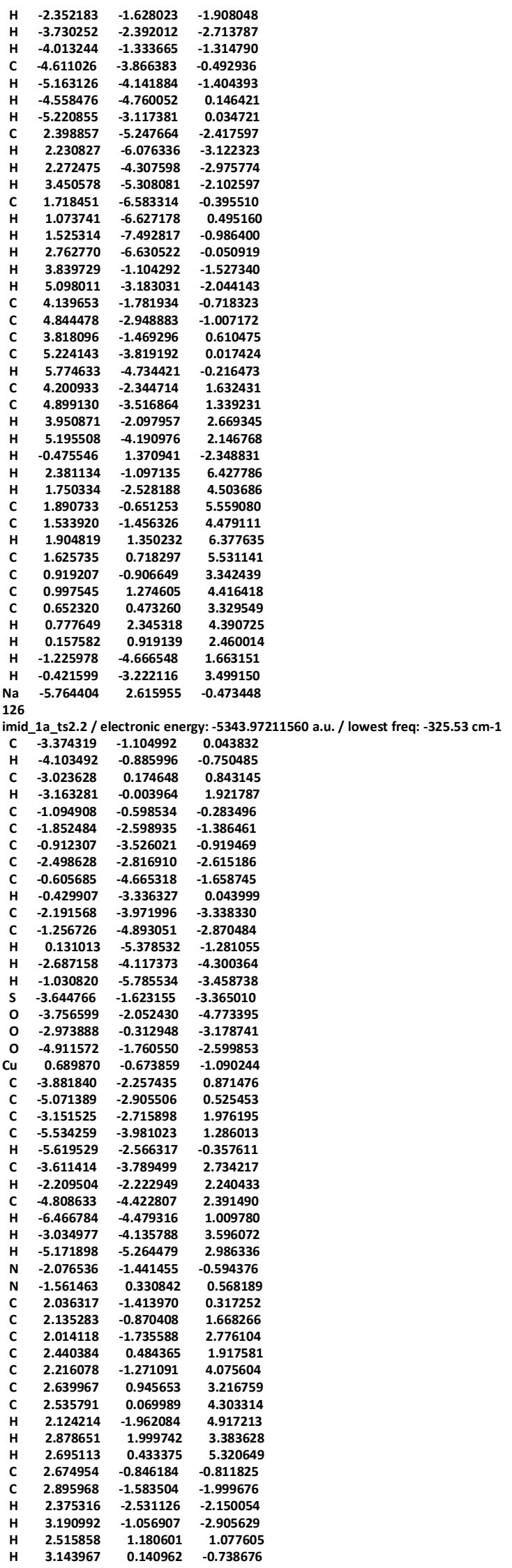




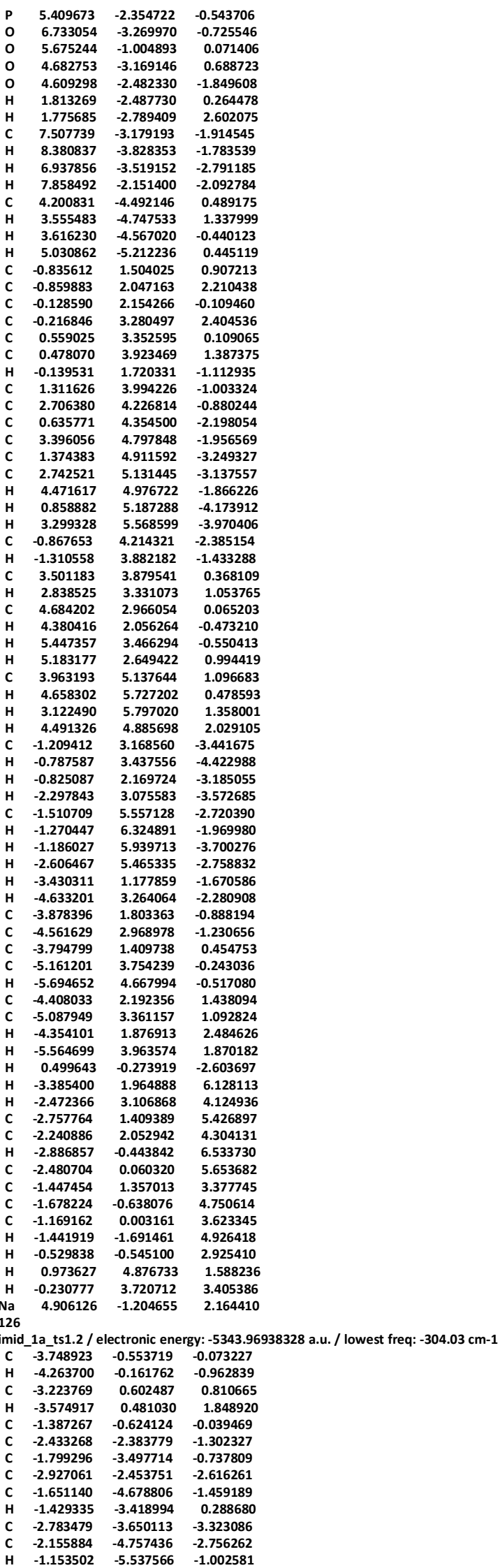




\begin{tabular}{|c|c|c|c|}
\hline & & & -4.350445 \\
\hline & -2.052451 & -5.679184 & -3.333662 \\
\hline & -3.641703 & 1.033528 & -3.494910 \\
\hline & -3.649163 & -1.441163 & 4222 \\
\hline & -2.714541 & 0.084783 & -3.188485 \\
\hline & -5.000868 & -0.855531 & -2.921113 \\
\hline & 0.392959 & -1.095548 & -0.752177 \\
\hline & -4.665005 & & \\
\hline & -5.940352 & -1.784078 & 0.112345 \\
\hline & -4.247432 & -2.195493 & 1.782103 \\
\hline & -6.790869 & 11 & 88735 \\
\hline & -6.250562 & -1.2 & 194 \\
\hline & -5.094094 & -3.09 & \\
\hline & -3.244204 & -2.0 & 78638 \\
\hline & -6.371716 & & \\
\hline & & & \\
\hline & -4.7 & & \\
\hline & -7.037996 & & \\
\hline & -2.4 & & \\
\hline & -1.7 & & \\
\hline & 2.27 & & \\
\hline & & & \\
\hline & & & \\
\hline & & & \\
\hline & & & \\
\hline & & & \\
\hline & & & \\
\hline & & & \\
\hline & & & \\
\hline & & & \\
\hline & & & \\
\hline$c$ & 1.6 & & \\
\hline H & & & \\
\hline & & & \\
\hline & & & \\
\hline H & & & \\
\hline & & & \\
\hline o & & & \\
\hline 0 & & & \\
\hline 0 & 174 & & \\
\hline 0 & & & \\
\hline H & 2.162227 & -2.7 & \\
\hline H & & & \\
\hline & & & \\
\hline H & 856 & -4.7 & 900 \\
\hline H & & & 399 \\
\hline H & 3.363347 & & \\
\hline & 6.7 & & \\
\hline H & & & \\
\hline H & 186 & -4 & \\
\hline 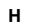 & & & \\
\hline c & 63 & & \\
\hline c & & & \\
\hline & & & \\
\hline & & & \\
\hline$c$ & & & 804 \\
\hline$c$ & & & \\
\hline & & & \\
\hline & & & \\
\hline C & & & \\
\hline & & & \\
\hline c & & & \\
\hline c & & & \\
\hline C & & & \\
\hline H & & & \\
\hline H & & & \\
\hline H & & & \\
\hline 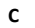 & & & \\
\hline H & & & \\
\hline c & & & \\
\hline H & & & \\
\hline 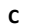 & & & \\
\hline 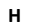 & & & \\
\hline H & & & \\
\hline H & & & \\
\hline c & & & \\
\hline & & & \\
\hline H & & & \\
\hline n & & & \\
\hline C & & & \\
\hline H & & & \\
\hline$n$ & & & \\
\hline H & & & \\
\hline 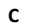 & & & \\
\hline H & -0.347792 & & -1.4 \\
\hline H & & & \\
\hline H & & & \\
\hline 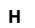 & & & \\
\hline H & -3.5 & & 8 \\
\hline c & & & \\
\hline c & & & \\
\hline & 3.567731 & 992188 & 0.336 \\
\hline
\end{tabular}




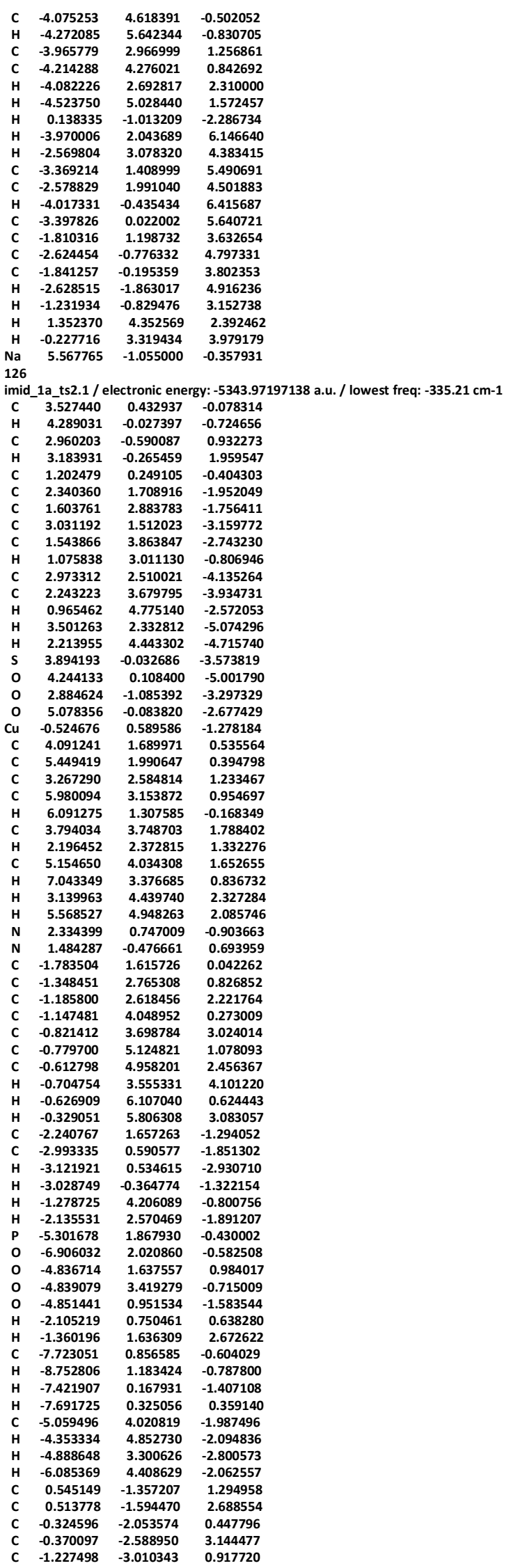




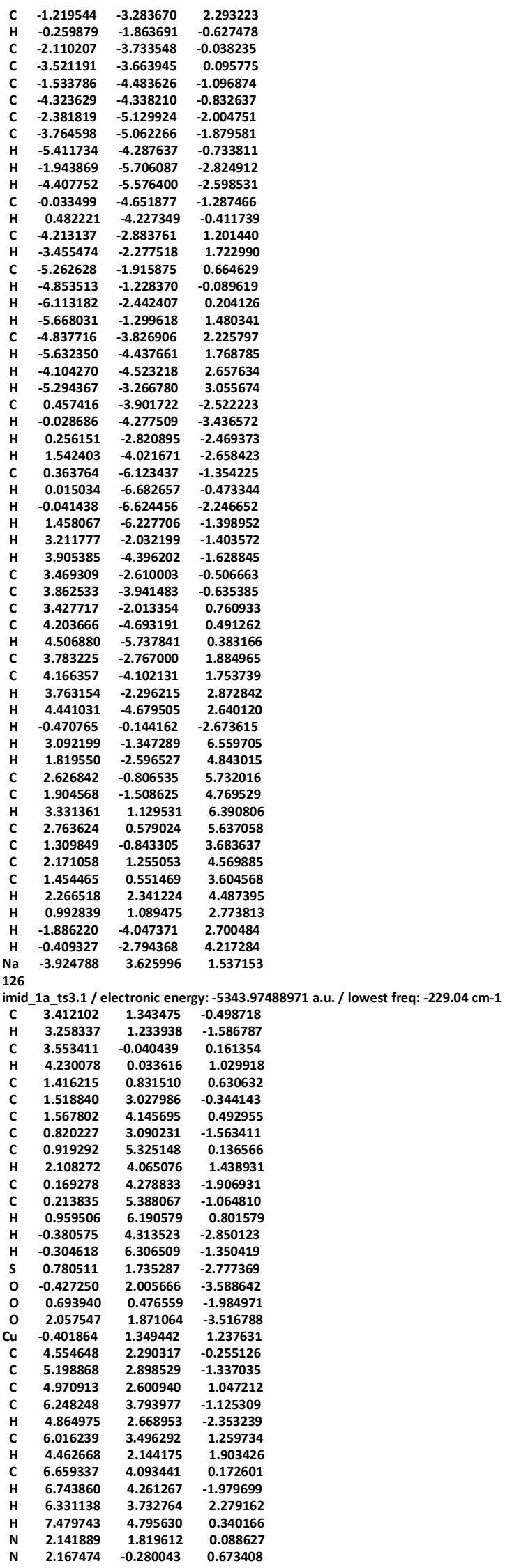




\begin{tabular}{|c|c|c|c|}
\hline & & & \\
\hline & .086344 & 1.837303 & 98786 \\
\hline & -3.846662 & 72432 & \\
\hline & -3.143102 & 20779 & 5021 \\
\hline & -4.655950 & 979702 & 978319 \\
\hline & & 727393 & \\
\hline & -4.722962 & & 03267 \\
\hline & -5.242781 & .869653 & .218265 \\
\hline & -3.983065 & -0.153441 & 5.135583 \\
\hline & -5.360221 & 1.856117 & 690131 \\
\hline & -2.177257 & .623036 & 8954 \\
\hline & -2.031557 & & \\
\hline & -1.827473 & .565984 & \\
\hline & -1.680353 & -0.261272 & \\
\hline & -2.536842 & & \\
\hline & & & \\
\hline & -5.0 & & \\
\hline 0 & -6.281521 & & \\
\hline 0 & & & \\
\hline & & & \\
\hline & -3.769213 & & \\
\hline H & & & \\
\hline $\mathbf{H}$ & & & \\
\hline & & & \\
\hline H & & & \\
\hline $\mathbf{H}$ & & & \\
\hline & 243 & & \\
\hline c & & & \\
\hline H & & & \\
\hline $\mathbf{n}$ & & & \\
\hline H & -6.0 & & \\
\hline c & & & \\
\hline & & & \\
\hline 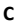 & & & \\
\hline$c$ & & -3.5 & \\
\hline c & & 40 & \\
\hline & & & \\
\hline $\mathrm{H}$ & & 0 & \\
\hline 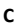 & -1.390881 & 54 & \\
\hline C & & 4 & \\
\hline C & -1.4 & 2 & \\
\hline c & -3.769976 & 79 & \\
\hline c & & 8 & \\
\hline c & -3.8 & & \\
\hline H & -4.6 & -4.1 & \\
\hline$H$ & 38 & -2 & \\
\hline H & -4.82 & -36 & \\
\hline C & -0.2 & -2.7 & \\
\hline H & & & \\
\hline C & -2.504348 & -4.02 & \\
\hline H & -1. & & \\
\hline c & -2.4 & -2.7 & \\
\hline H & -1.624238 & -2.0 & \\
\hline H & & & \\
\hline H & 466 & -2.8 & \\
\hline C & & -4.9 & \\
\hline H & & & \\
\hline H & -3.6 & & \\
\hline H & -3.4 & -5.2 & \\
\hline$c$ & & & \\
\hline H & -1.1 & & \\
\hline H & -0.9 & & \\
\hline 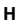 & & & \\
\hline C & & & \\
\hline H & & & \\
\hline H & -0.3 & -4.6 & \\
\hline 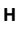 & & & \\
\hline $\mathbf{H}$ & & & \\
\hline H & & -2.7 & \\
\hline 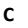 & & & \\
\hline & & & \\
\hline & & & \\
\hline & & & \\
\hline H & & & \\
\hline C & & & \\
\hline C & & & \\
\hline & & & \\
\hline H & & & \\
\hline $\mathbf{H}$ & -0.0 & & \\
\hline & & & \\
\hline 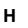 & & & \\
\hline 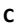 & & & \\
\hline & & & \\
\hline H & & & \\
\hline 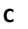 & 5.748565 & -1.935 & 93 \\
\hline c & & & \\
\hline & & & \\
\hline & & & \\
\hline H & & & 585 \\
\hline & & & \\
\hline & & & \\
\hline & 2.296546 & -4.718313 & 1.9441 \\
\hline
\end{tabular}




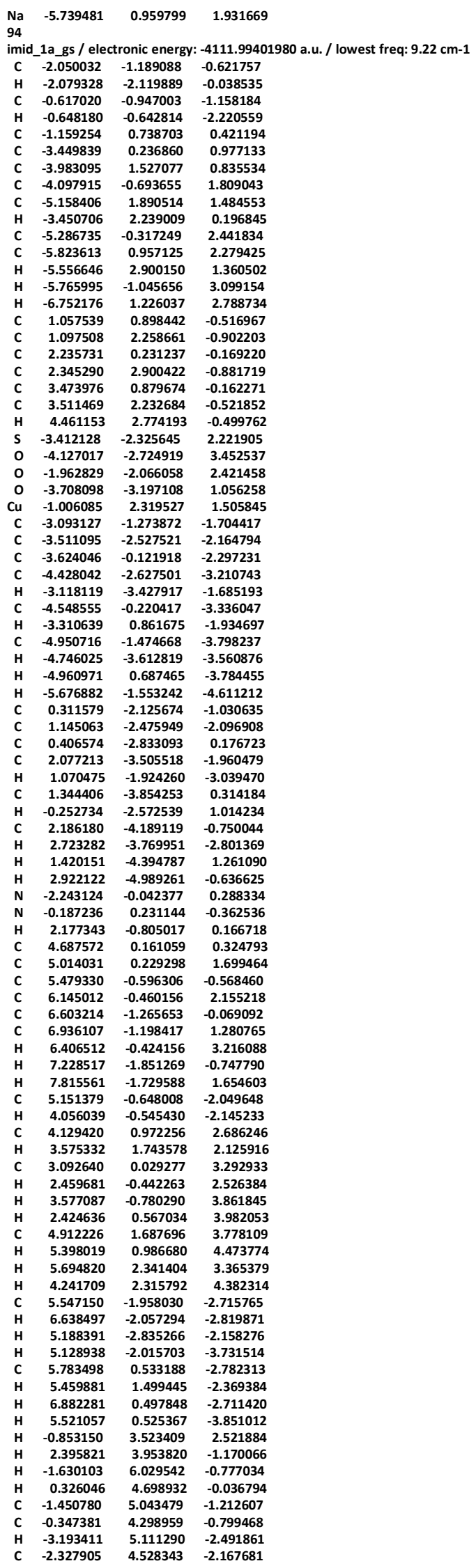




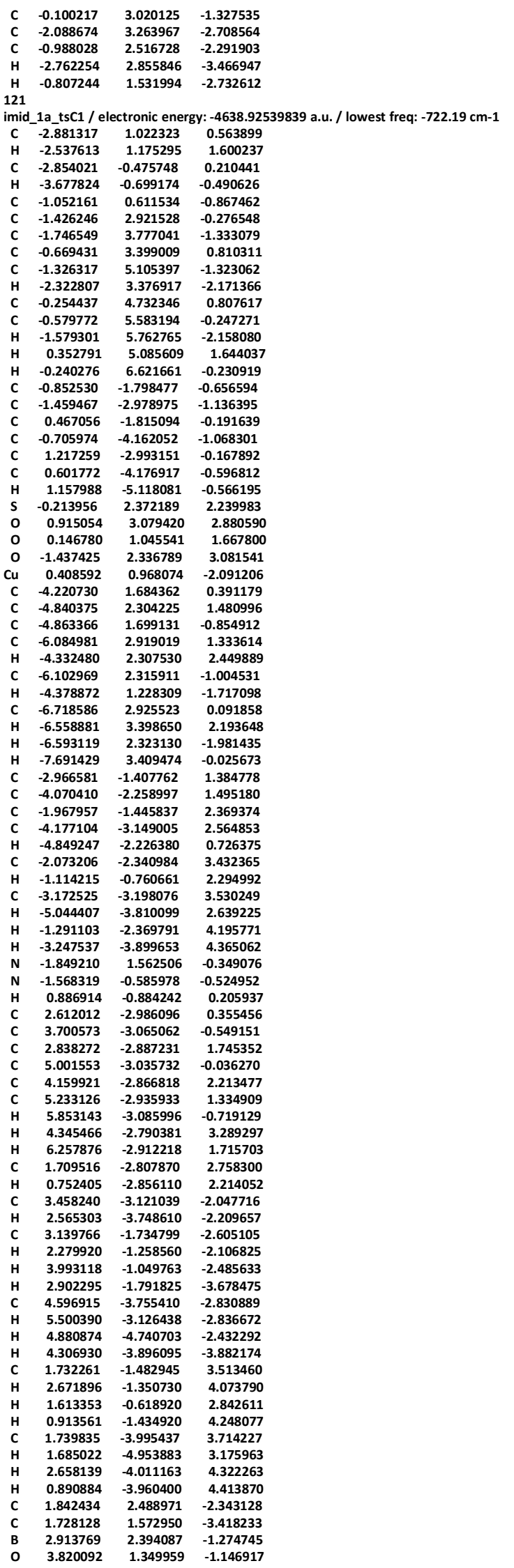




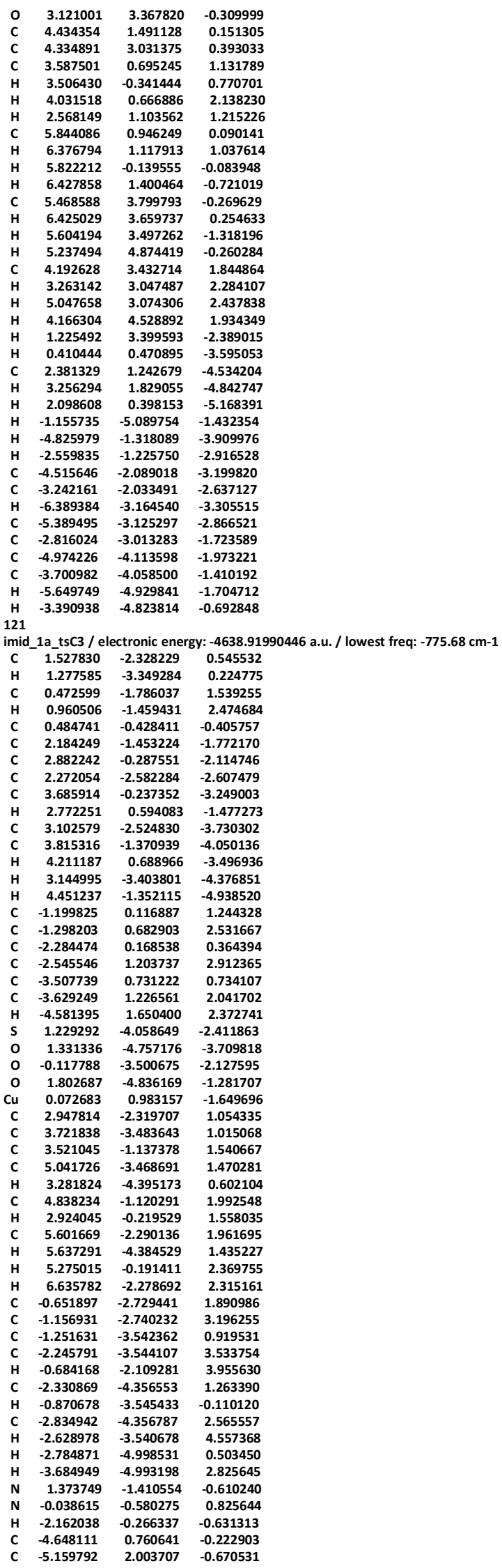




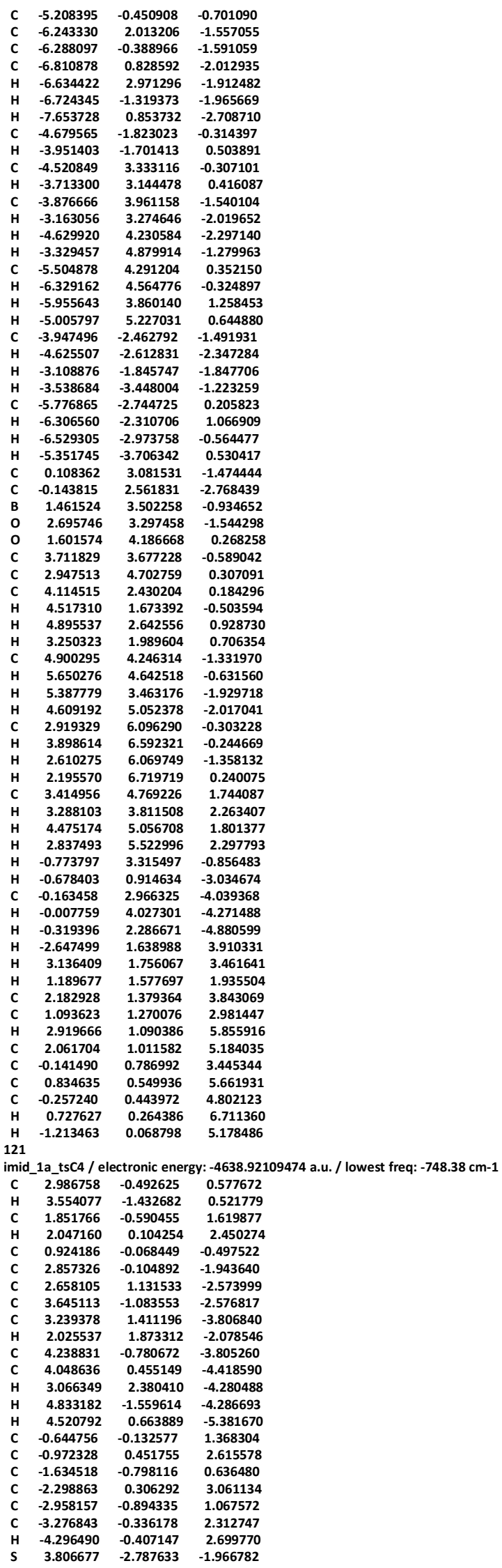




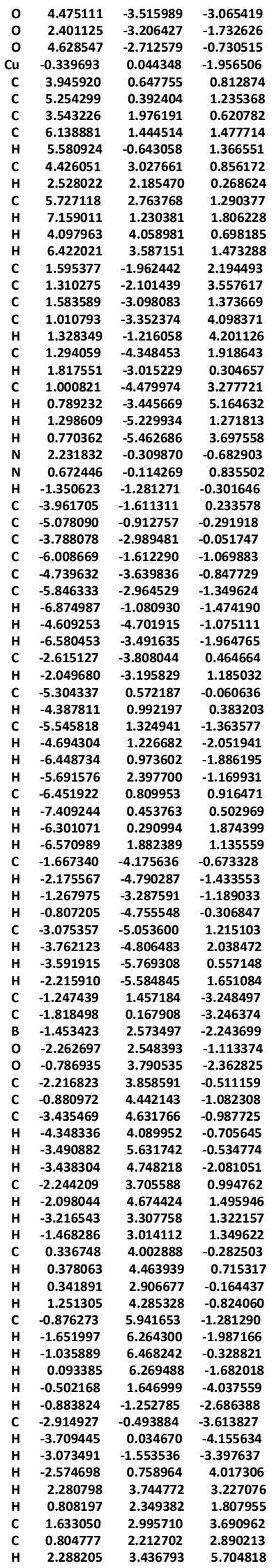




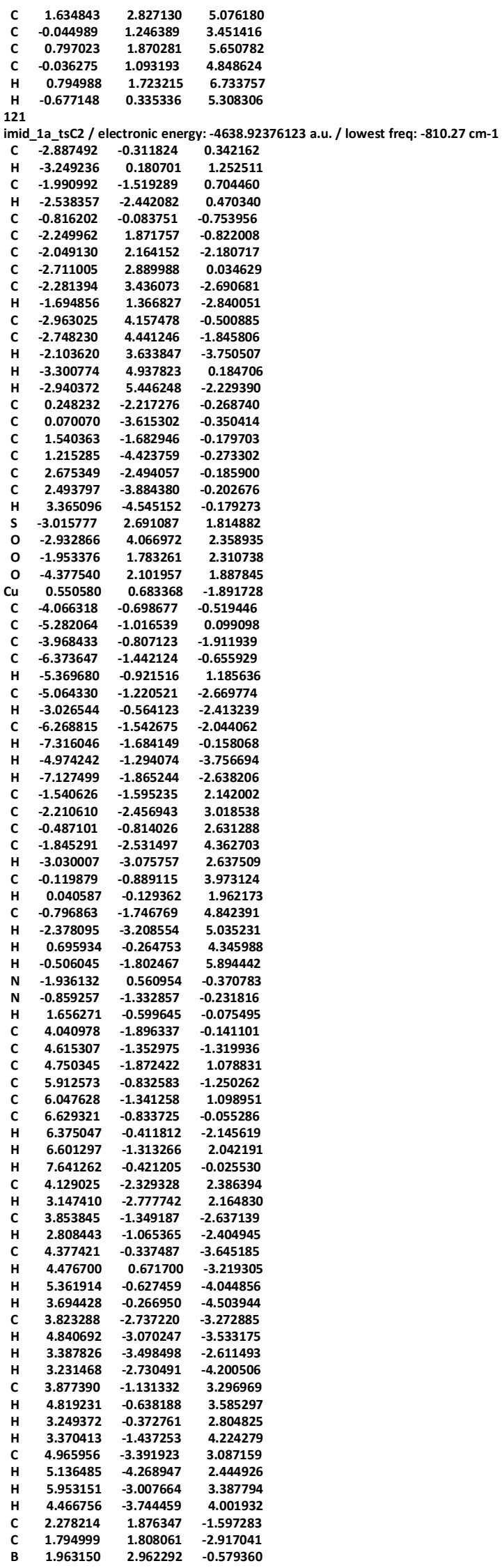




\begin{tabular}{rrrr} 
& & & \\
O & 1.029437 & 3.977758 & -0.715669 \\
O & 2.639428 & 3.039508 & 0.628237 \\
C & 1.278346 & 4.920123 & 0.354088 \\
C & 1.943577 & 4.013830 & 1.438803 \\
C & 2.232633 & 5.971665 & -0.191734 \\
H & 1.794447 & 6.435779 & -1.086522 \\
H & 2.429345 & 6.770591 & 0.537324 \\
H & 3.195959 & 5.528981 & -0.484310 \\
C & -0.022034 & 5.559528 & 0.785264 \\
H & 0.149343 & 6.248429 & 1.626267 \\
H & -0.450265 & 6.147147 & -0.039726 \\
H & -0.773339 & 4.825250 & 1.102766 \\
C & 0.917487 & 3.254583 & 2.260447 \\
H & 0.368148 & 3.903828 & 2.957412 \\
H & 0.171620 & 2.756122 & 1.626061 \\
H & 1.420713 & 2.477327 & 2.854340 \\
C & 2.942284 & 4.721030 & 2.327882 \\
H & 3.780770 & 5.139627 & 1.756179 \\
H & 2.462291 & 5.538655 & 2.885630 \\
H & 3.360937 & 4.020547 & 3.064573 \\
H & 3.037538 & 1.131353 & -1.307258 \\
H & 0.818344 & 0.429240 & -3.439504 \\
C & 1.834912 & 2.470789 & -4.073624 \\
H & 2.521571 & 3.319019 & -4.184003 \\
H & 1.204613 & 2.218822 & -4.929879 \\
H & 1.088294 & -5.508776 & -0.321861 \\
H & -3.954879 & -4.157478 & -2.641405 \\
H & -1.743524 & -3.084702 & -2.306572 \\
C & -3.322580 & -4.468581 & -1.805956 \\
C & -2.079697 & -3.867291 & -1.620140 \\
H & -4.740478 & -5.927000 & -1.071728 \\
C & -3.761157 & -5.463267 & -0.930118 \\
C & -1.249127 & -4.254531 & -0.555594 \\
C & -2.938730 & -5.866862 & 0.122311 \\
C & -1.690575 & -5.272428 & 0.303741 \\
H & -3.273125 & -6.646643 & 0.811267 \\
H & -1.055659 & -5.577430 & 1.140841 \\
& & & \\
\hline
\end{tabular}




\section{NMR Spectra}
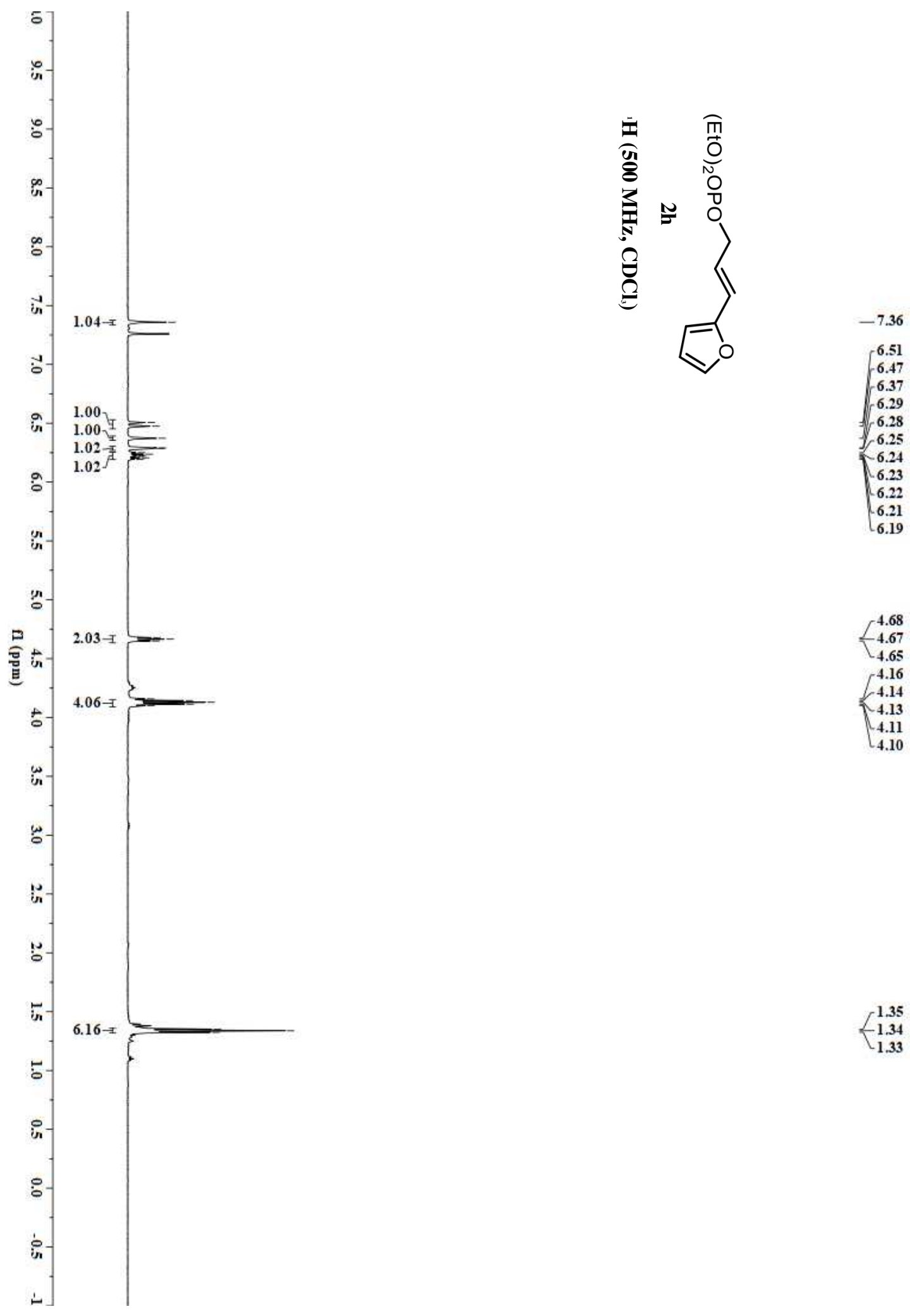

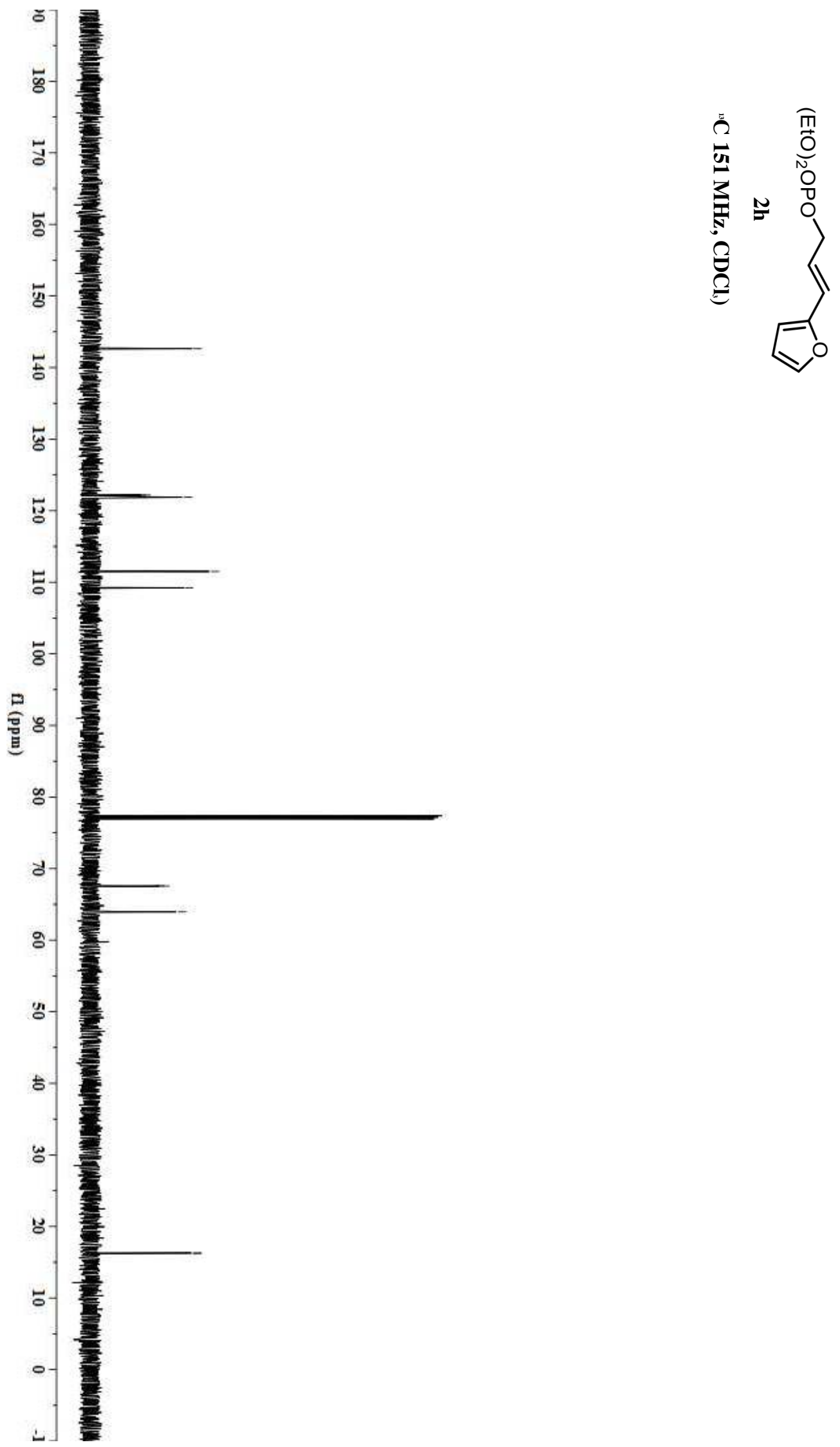$$
-142.6
$$$$
{ }_{-122.1}^{122.2}
$$$$
121.9
$$$$
-111.5
$$$$
\mathcal{L}_{67.6}^{67.6}
$$$$
-64.0
$$$$
63.9
$$ 

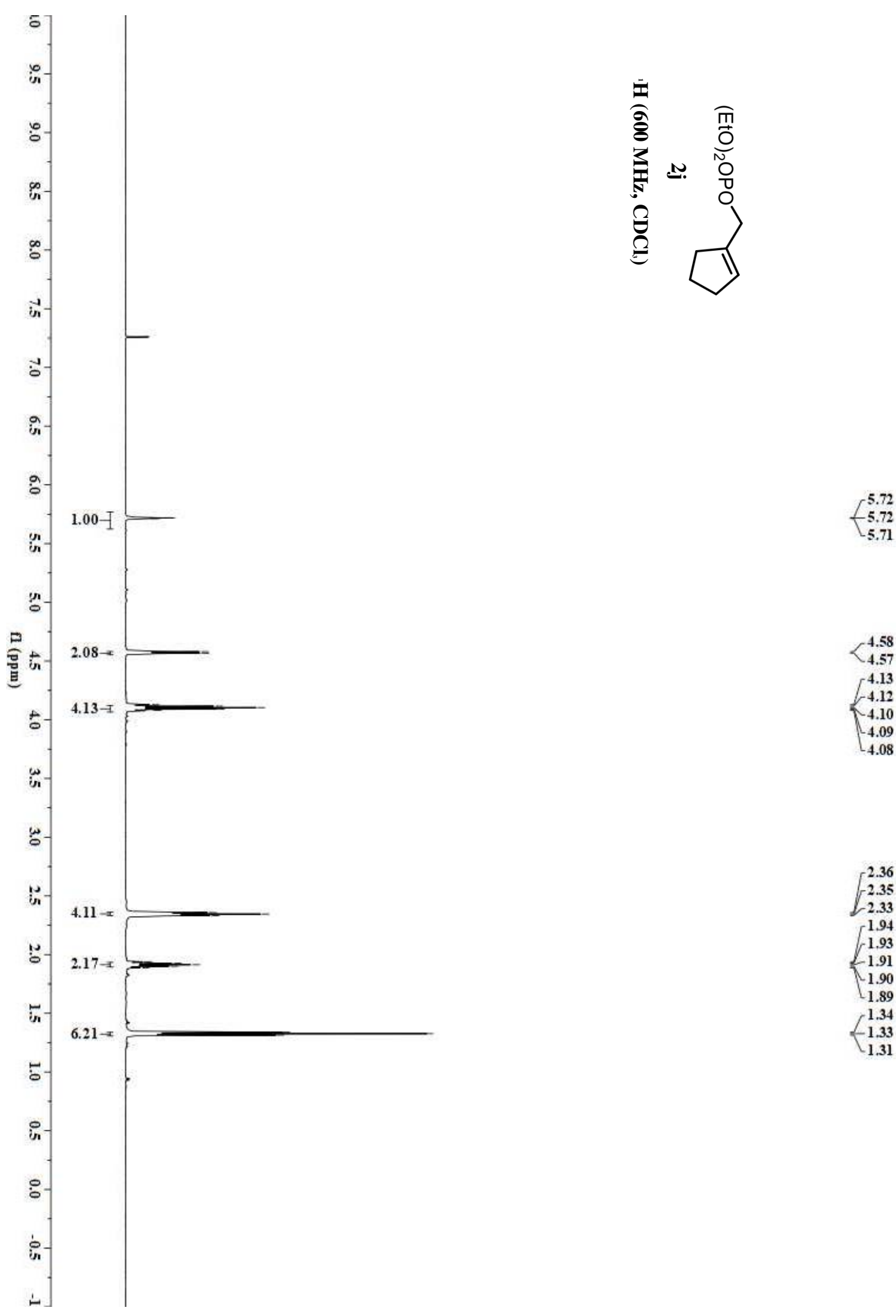

$<.58$

4.13

$-4.12$

$\Upsilon_{4.09}^{4.10}$

4.08

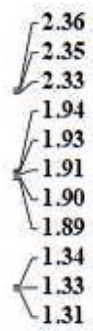



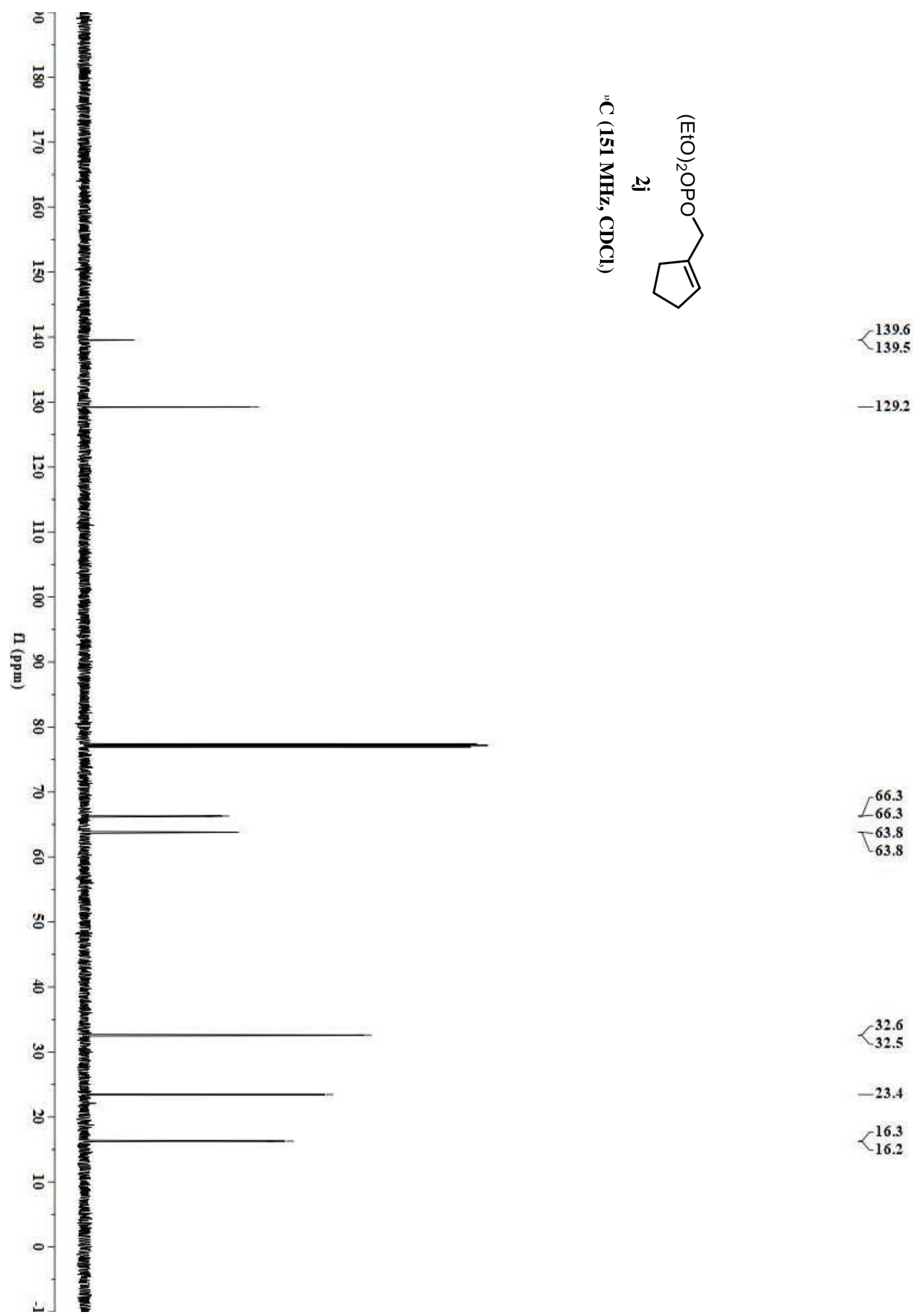

$-129.2$

66.3

$L_{66.3}$

$\leftarrow \begin{array}{r}63.8 \\ 63.8\end{array}$

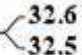

$-23.4$

$\gamma_{16.2}^{16.3}$ 


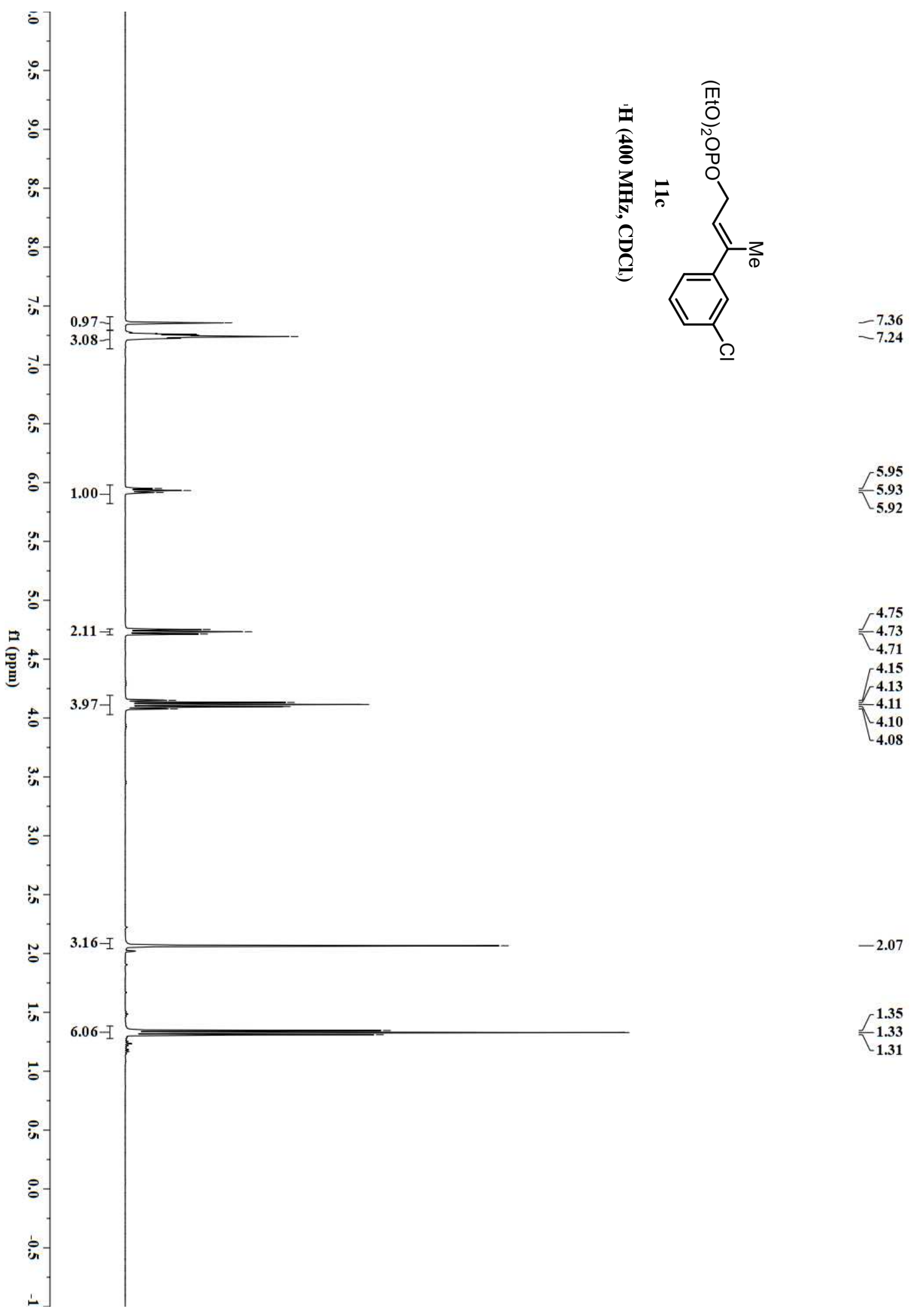


Sun, et al., Supporting Information, Page S188
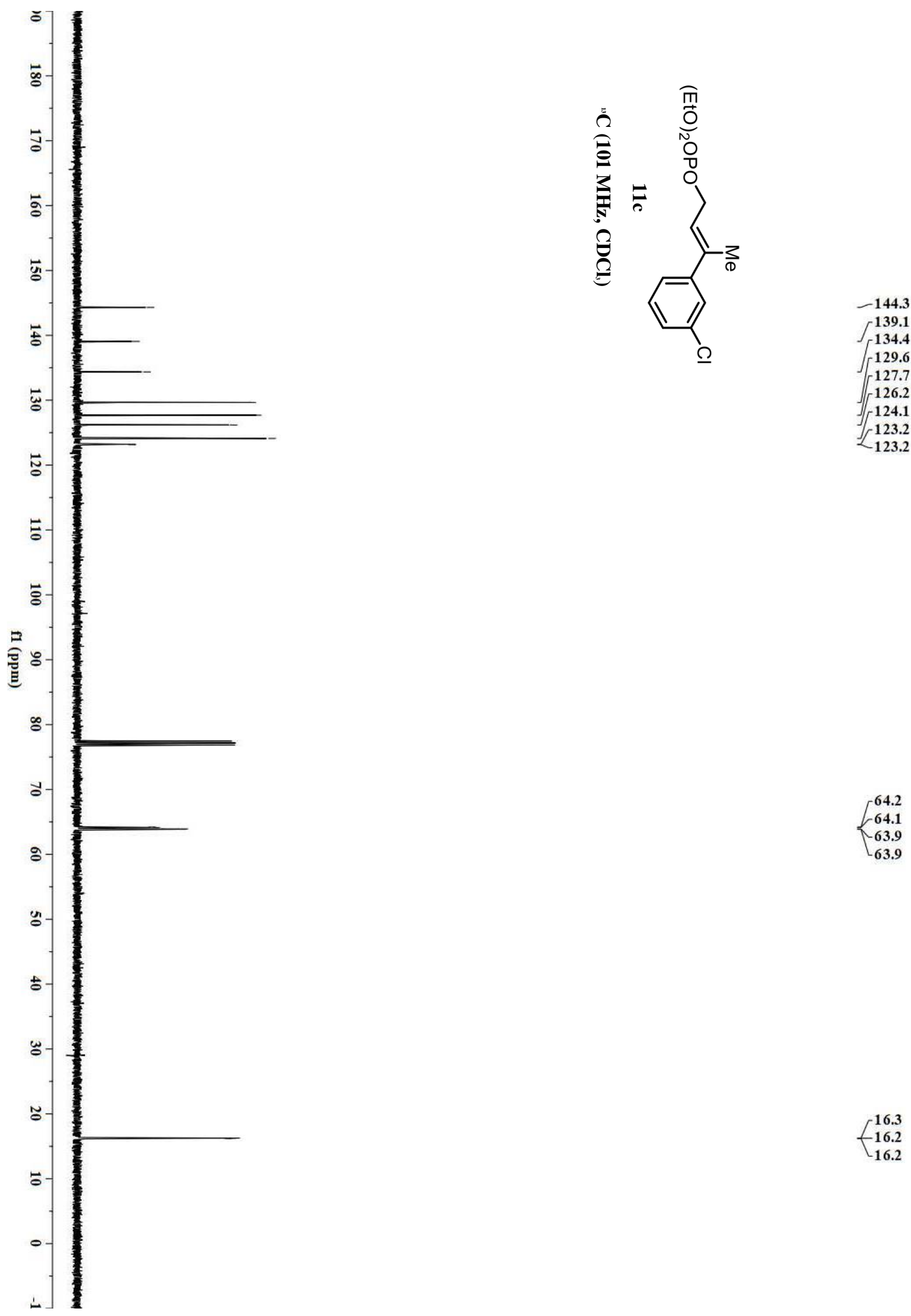

64.2

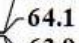

63.9

63.9

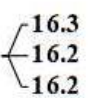




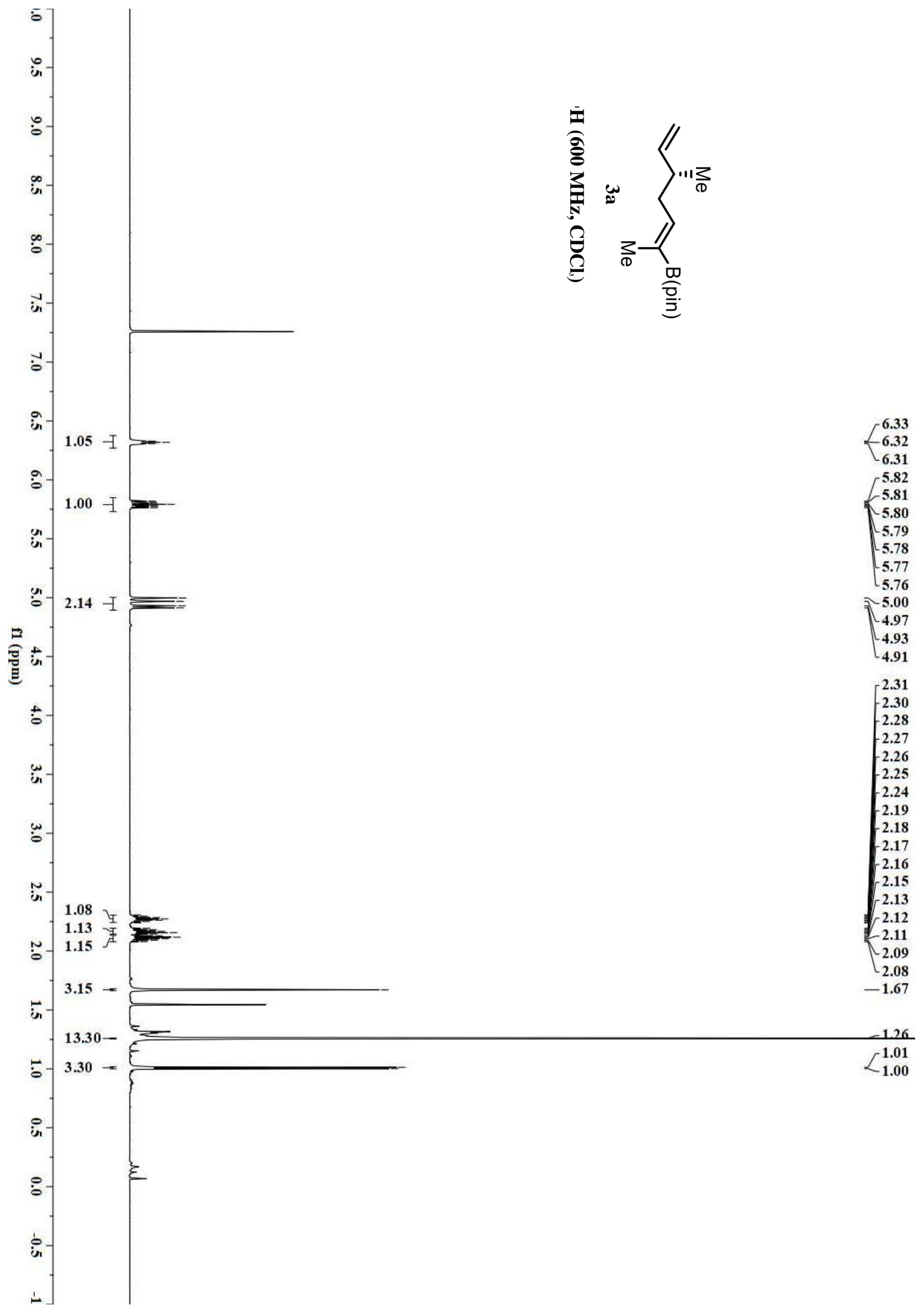




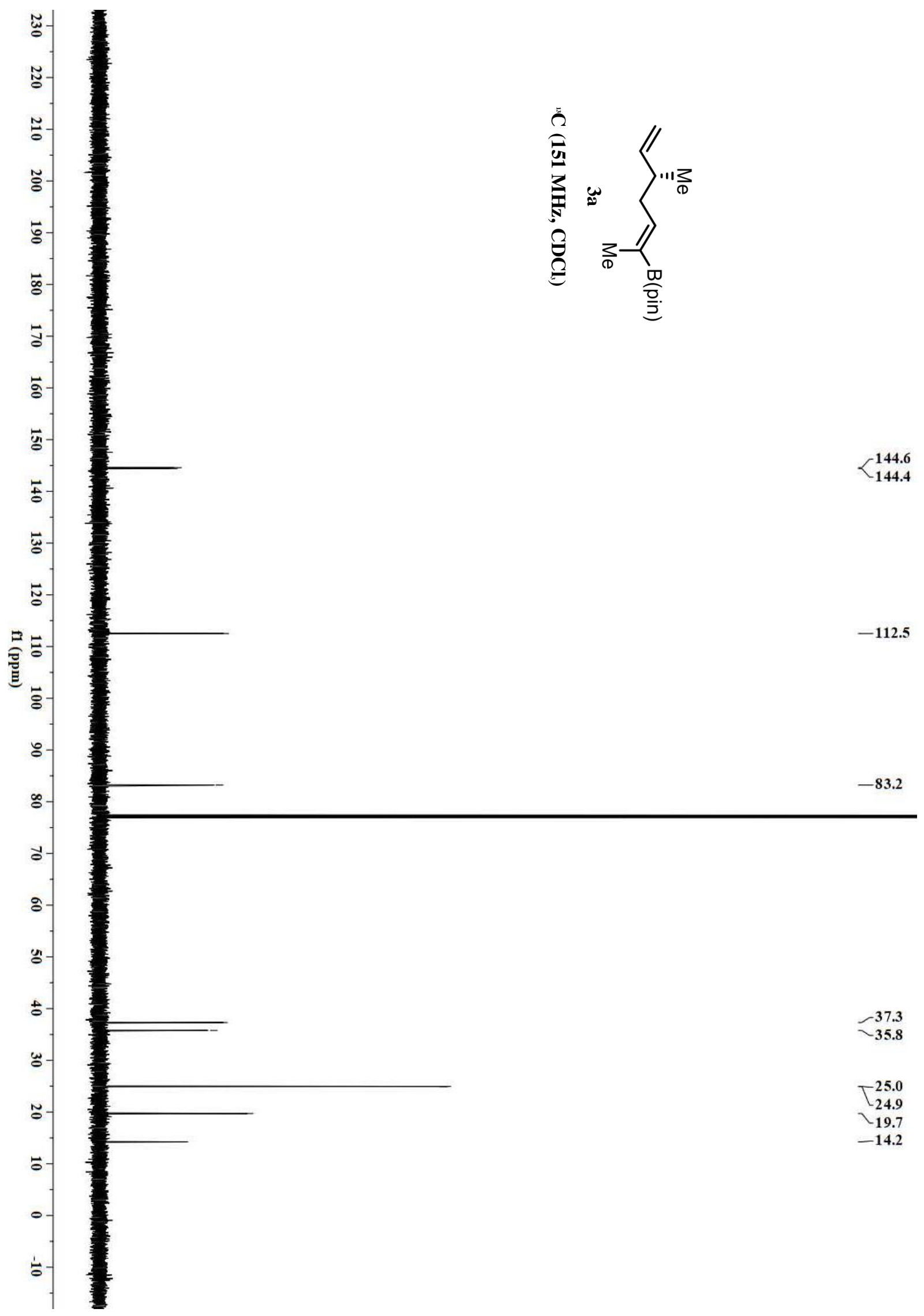




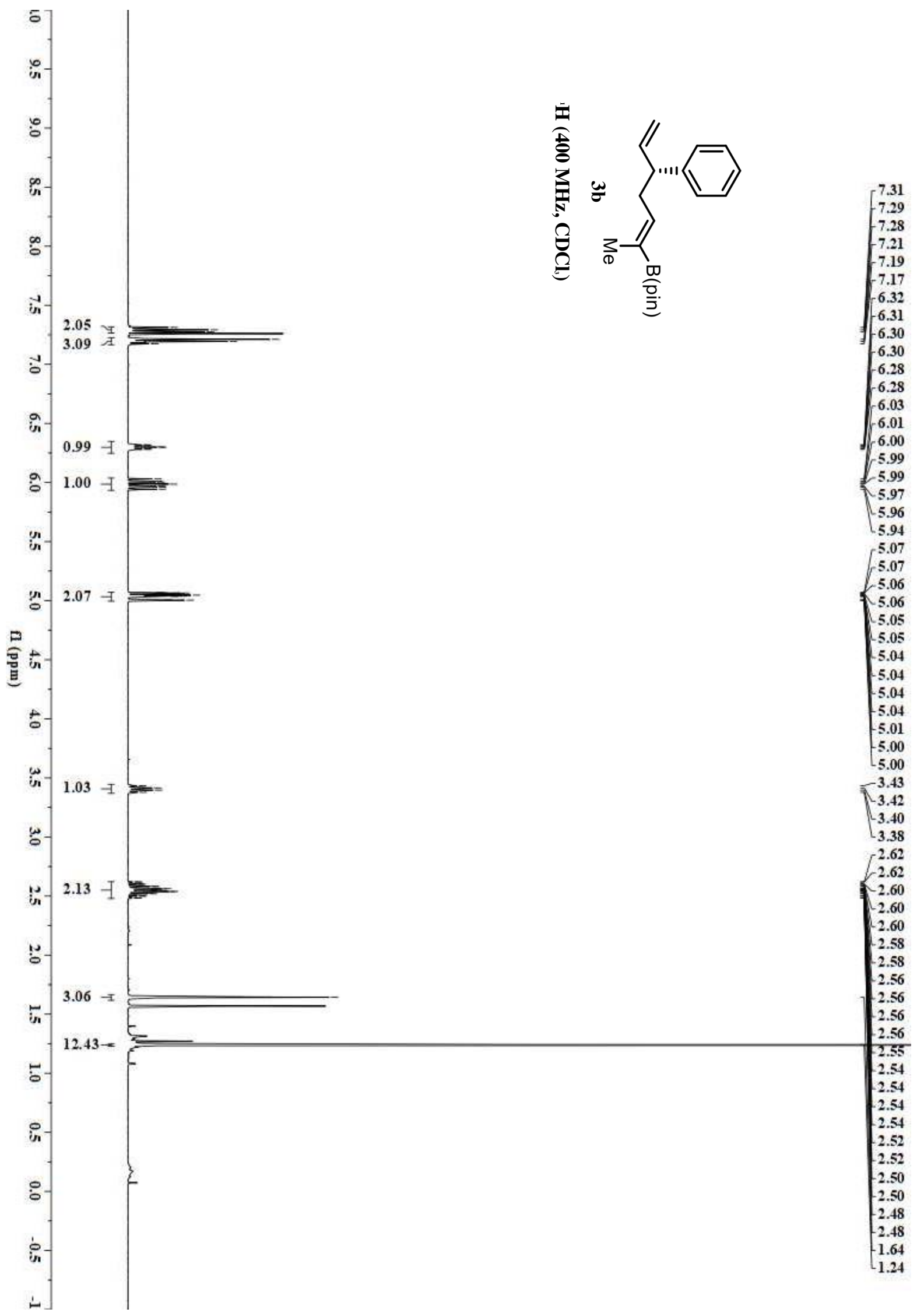




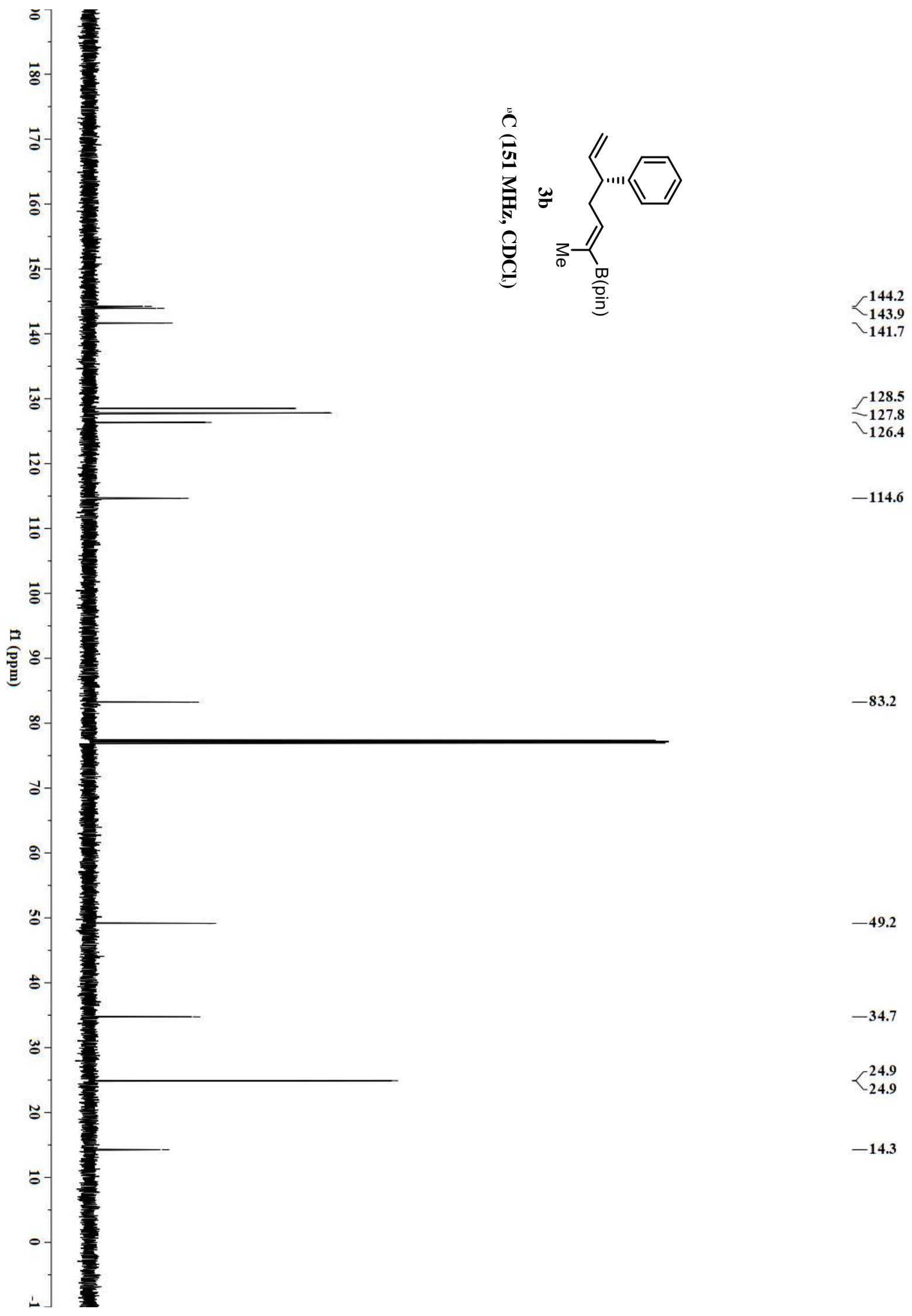




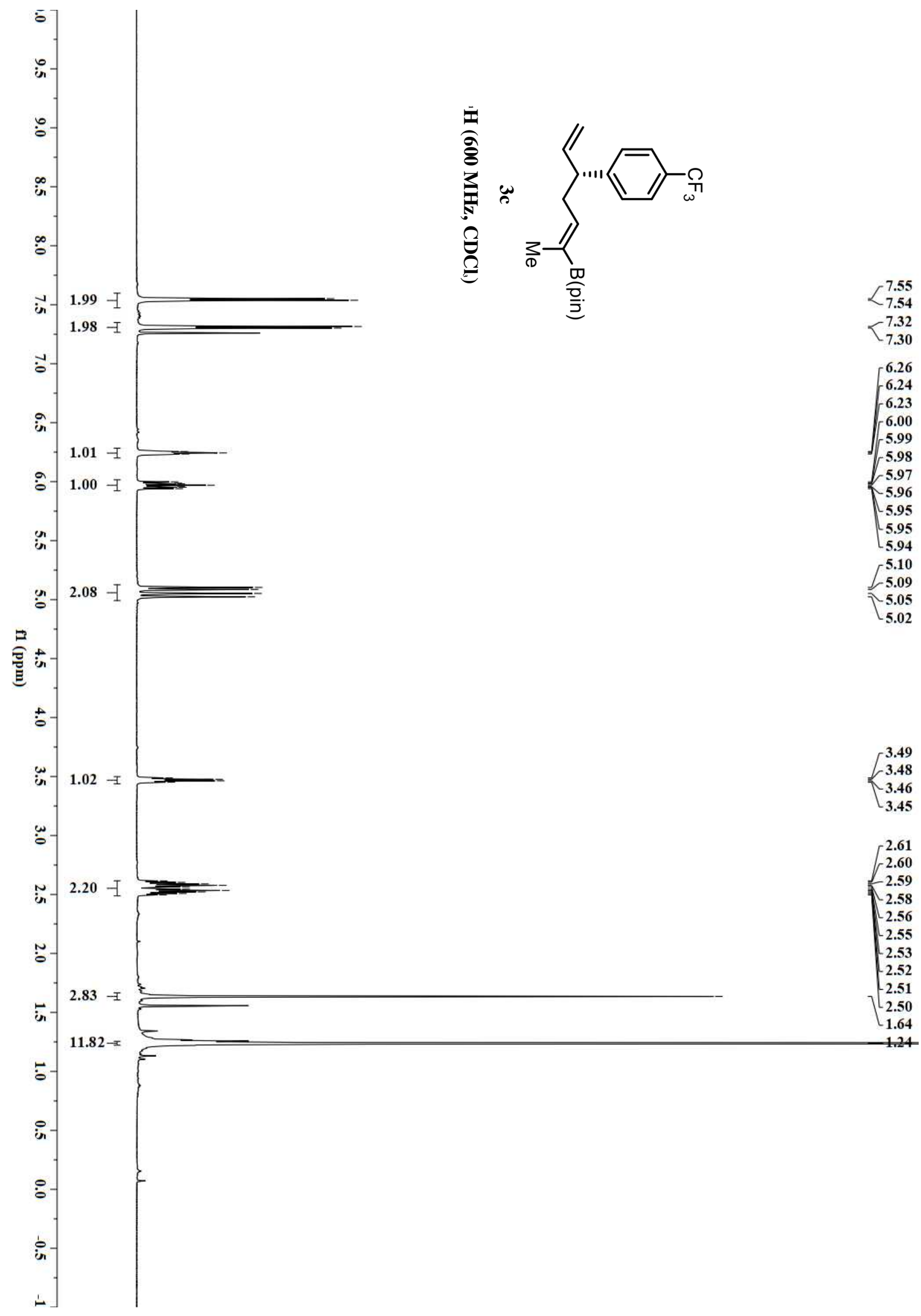




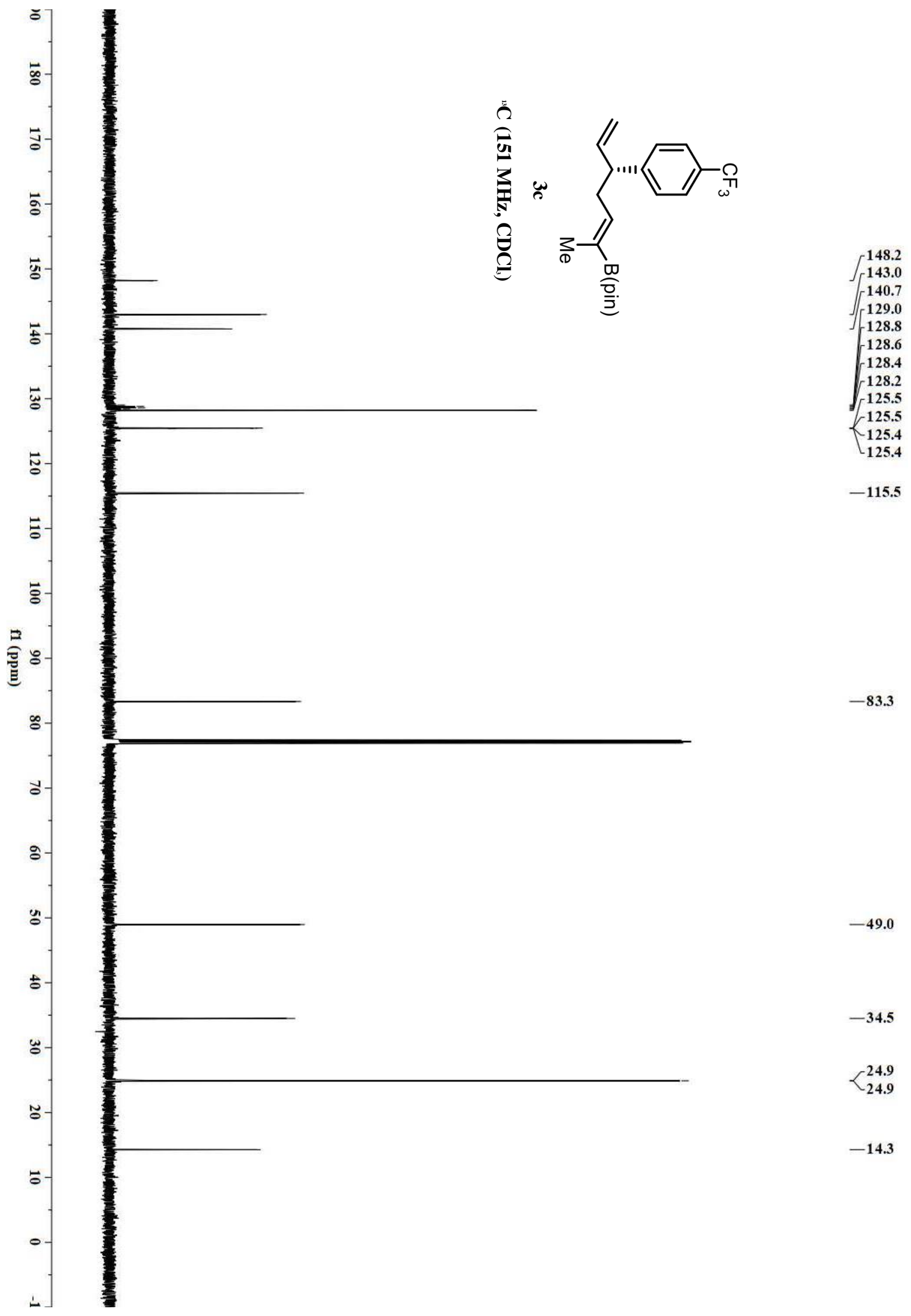




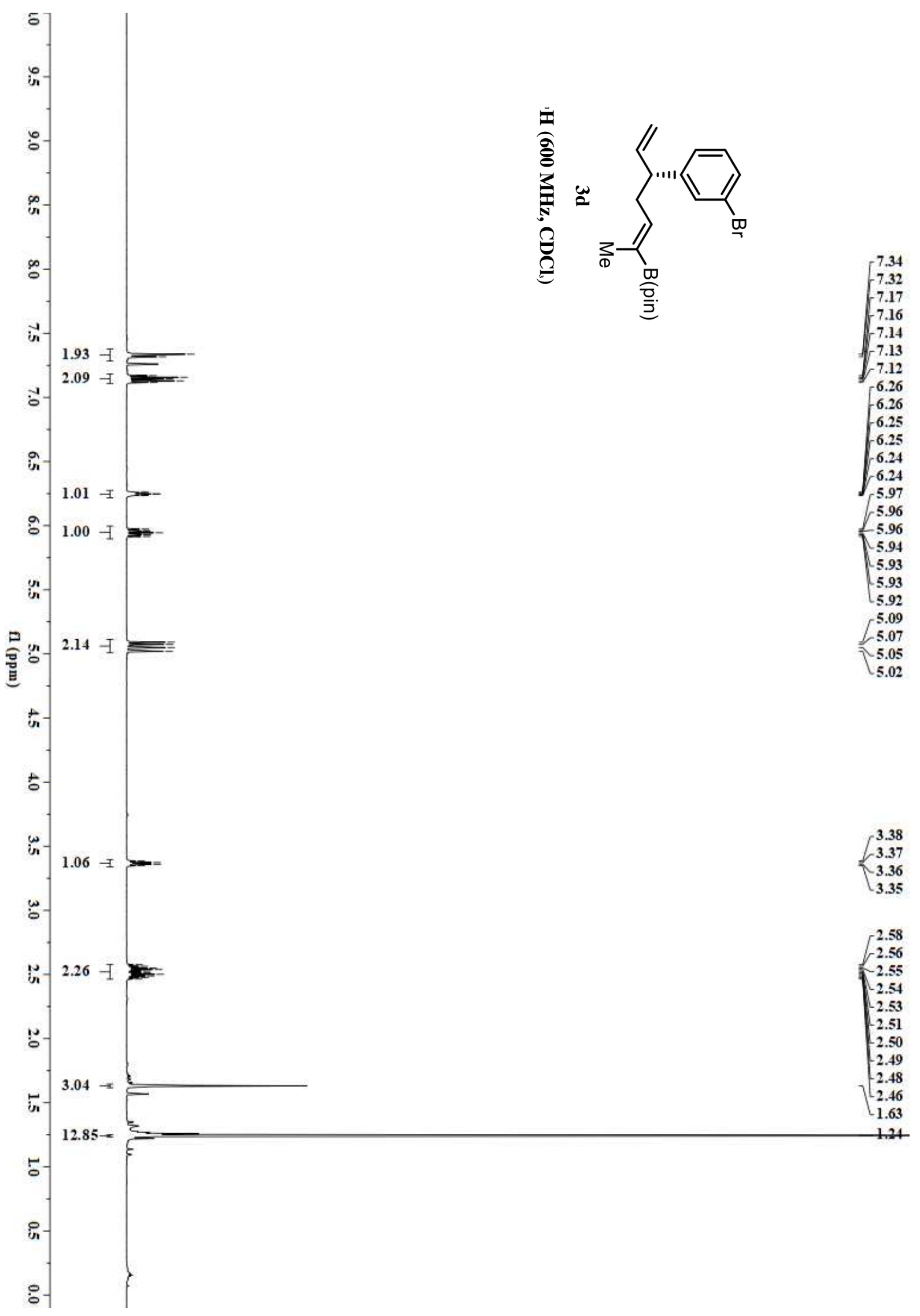




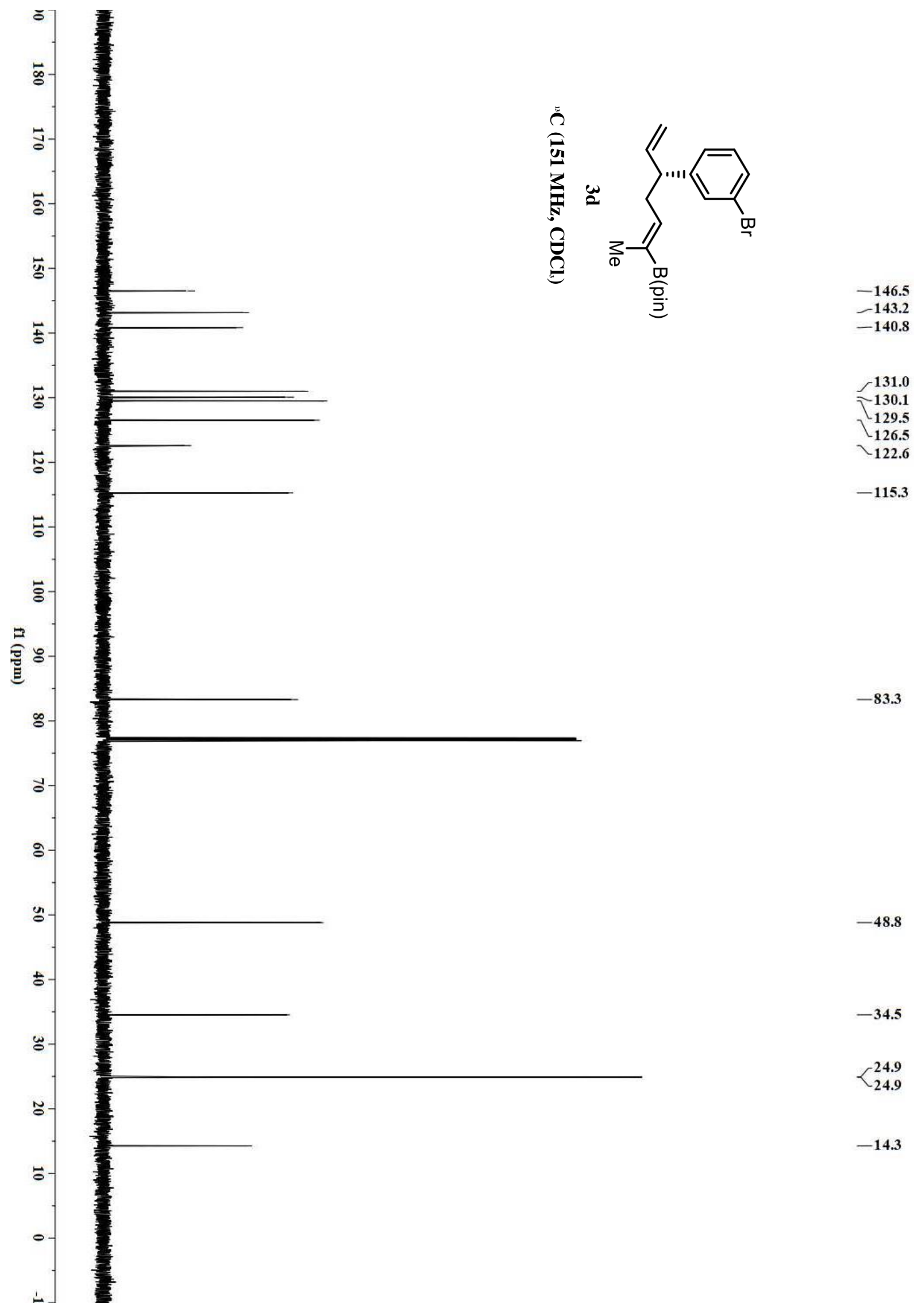




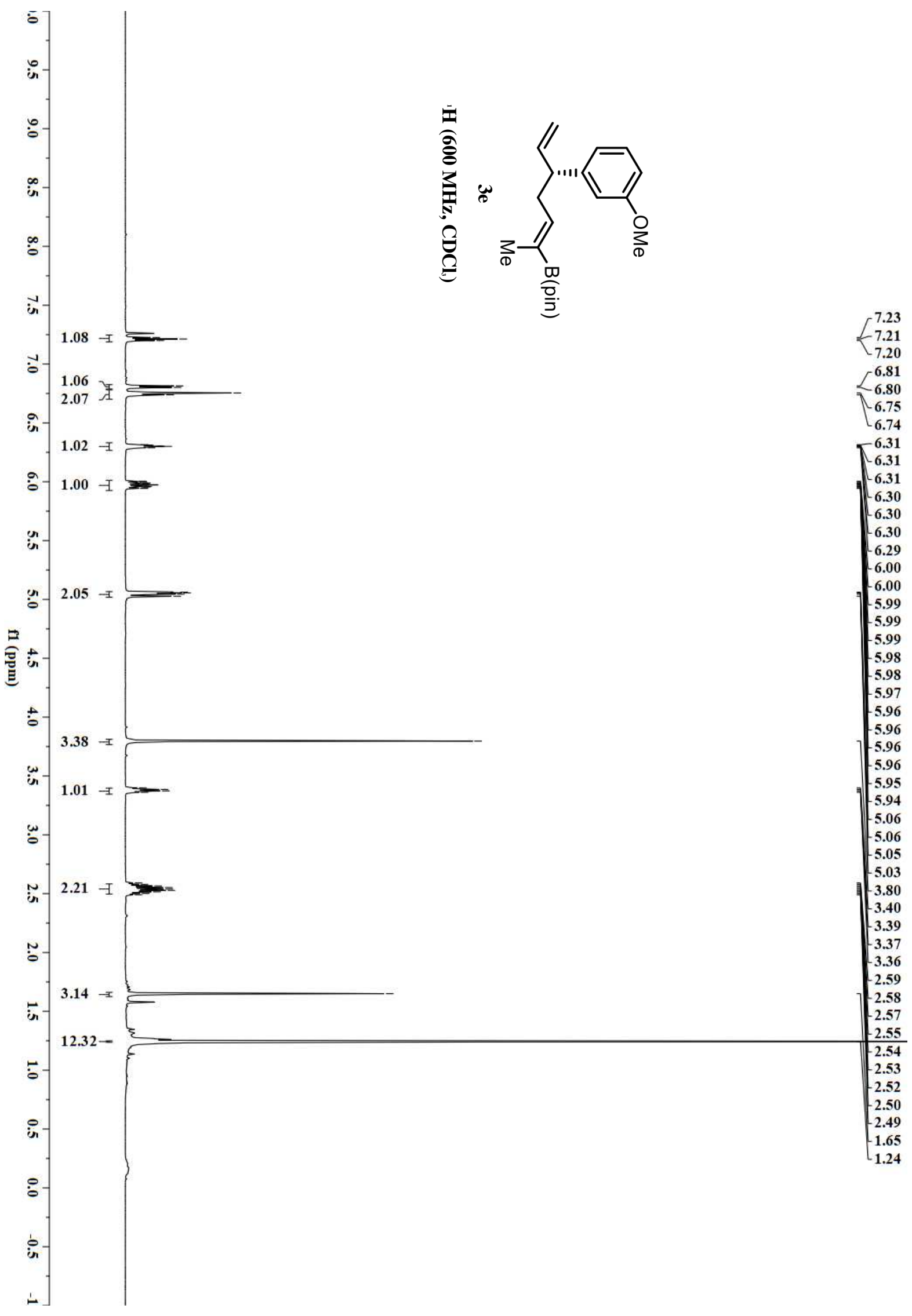




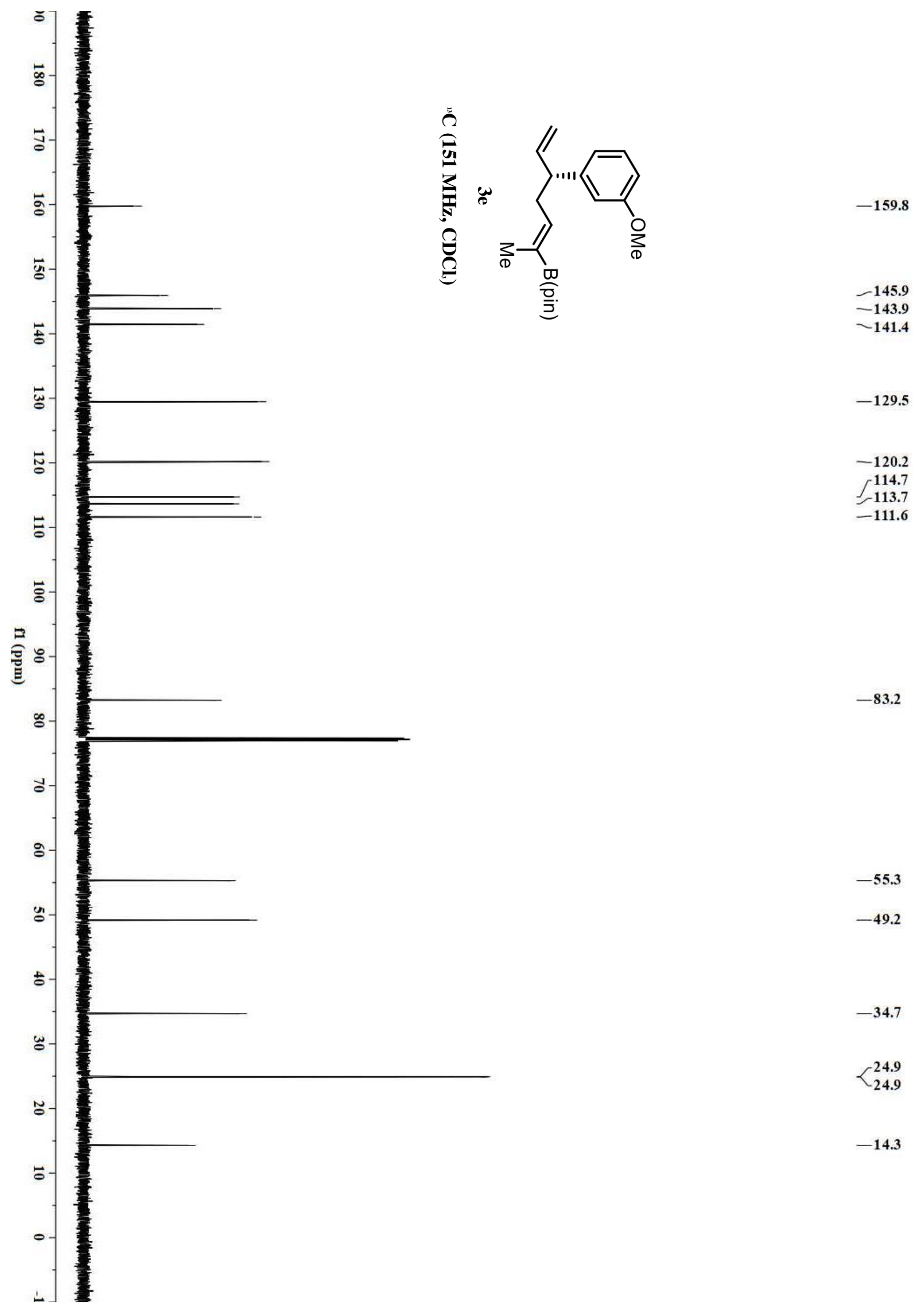




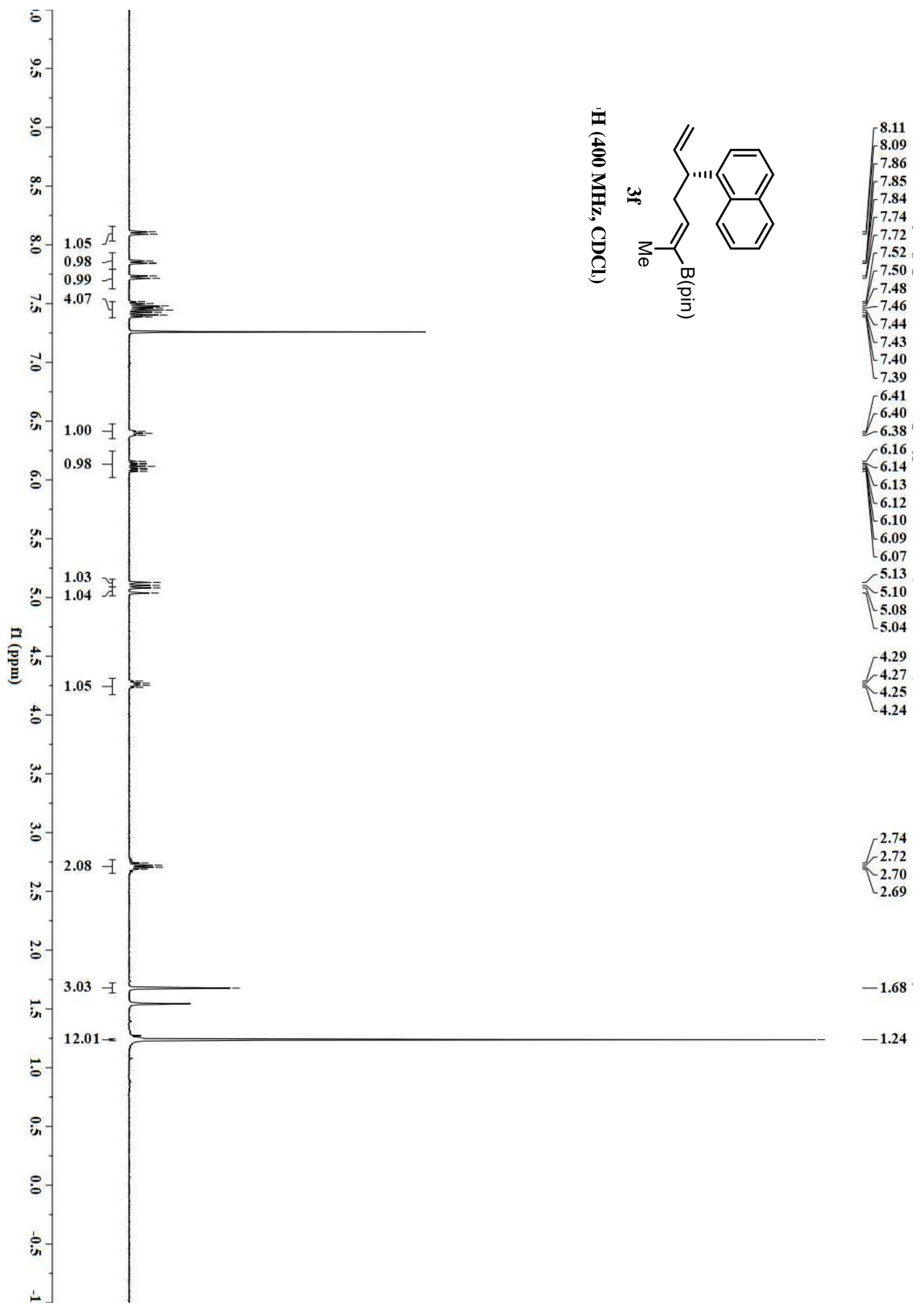




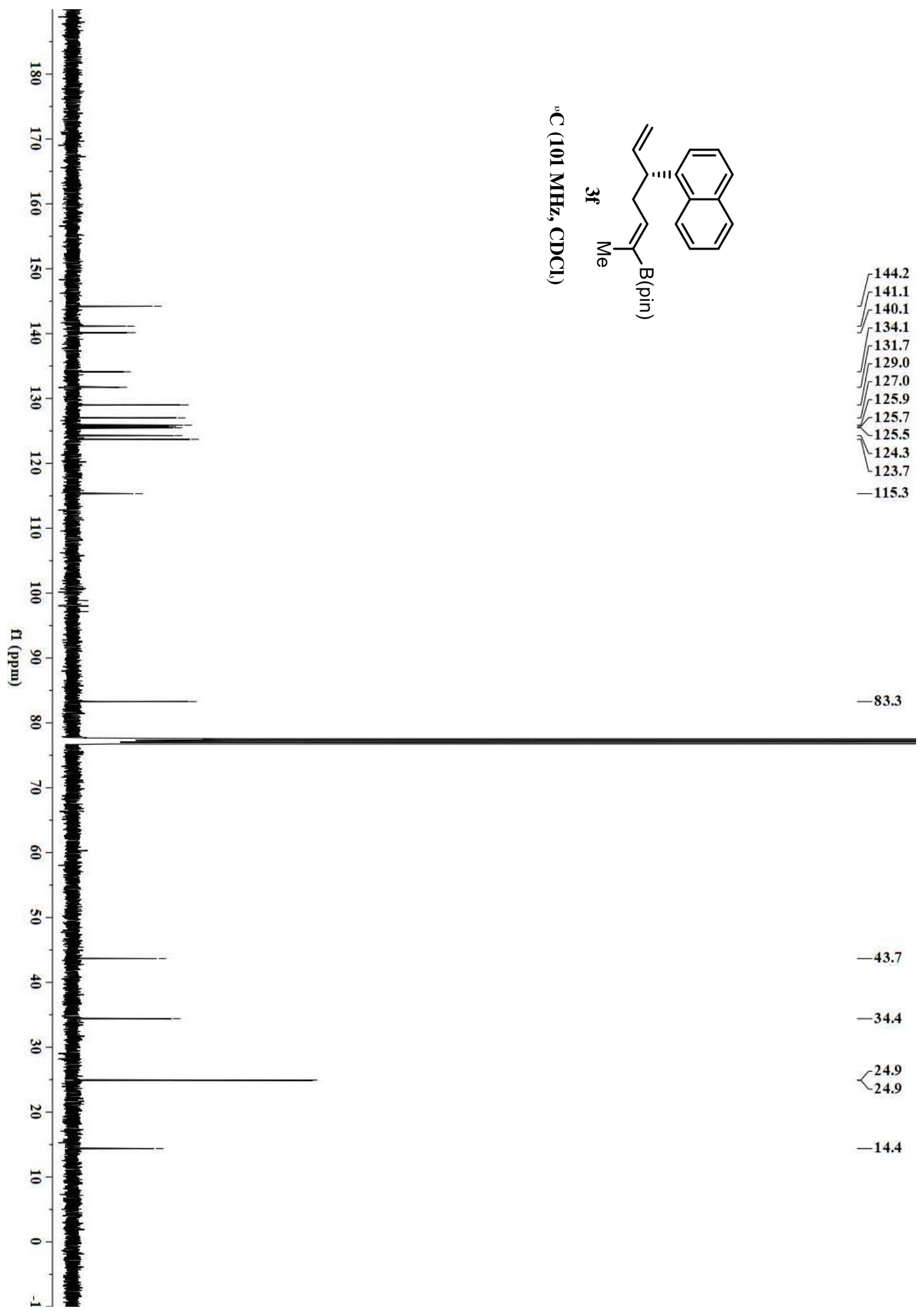




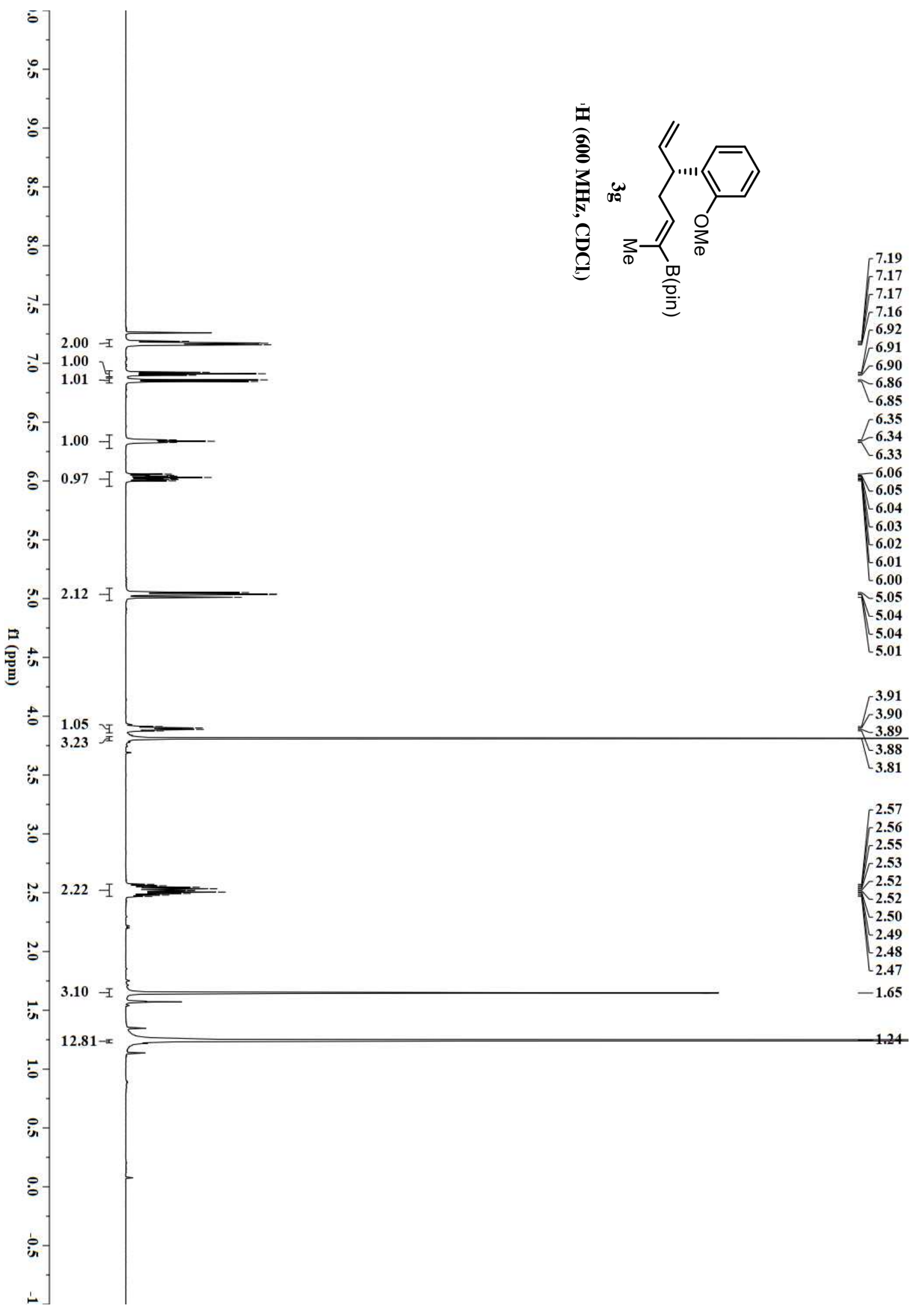


Sun, et al., Supporting Information, Page S202

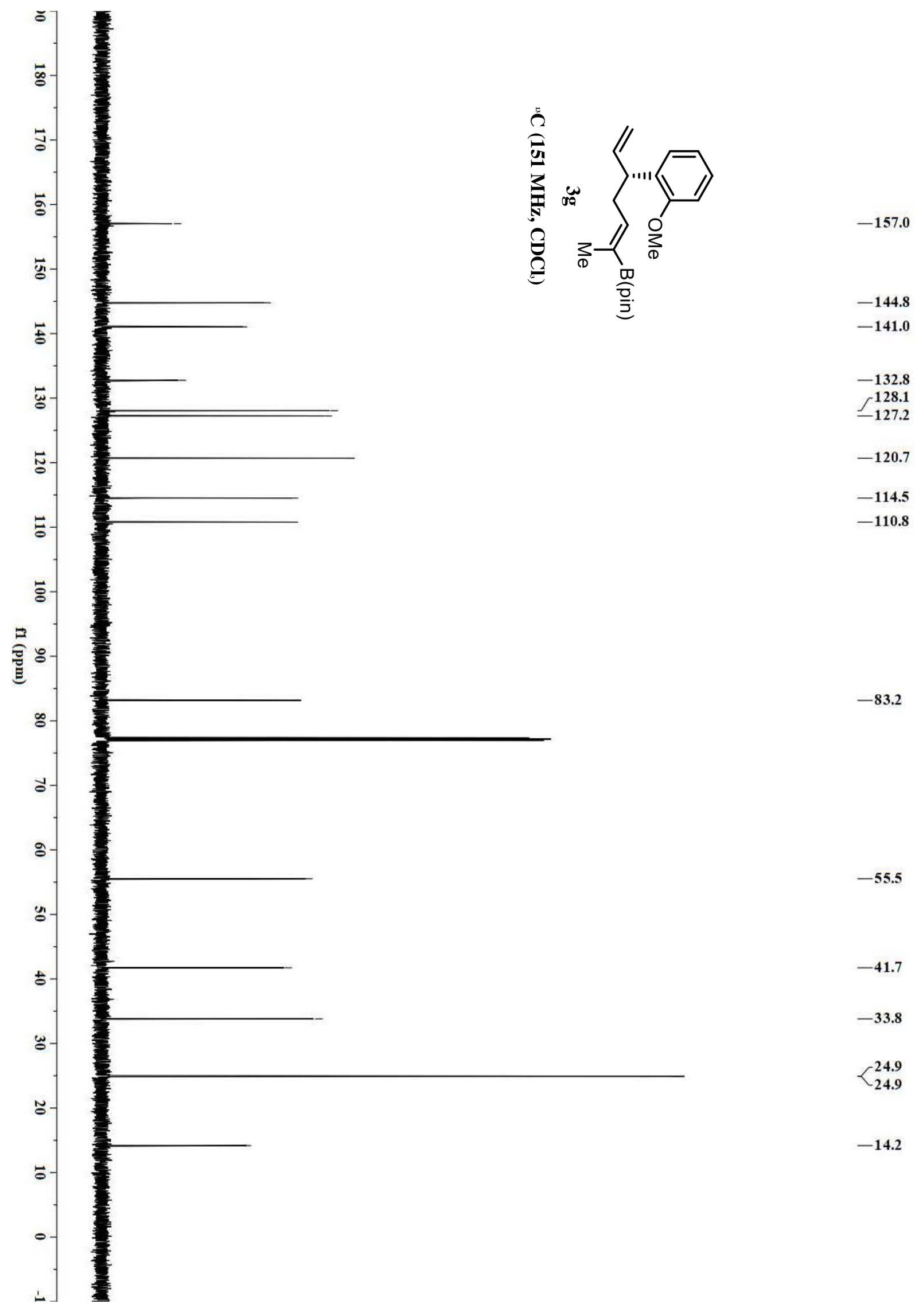




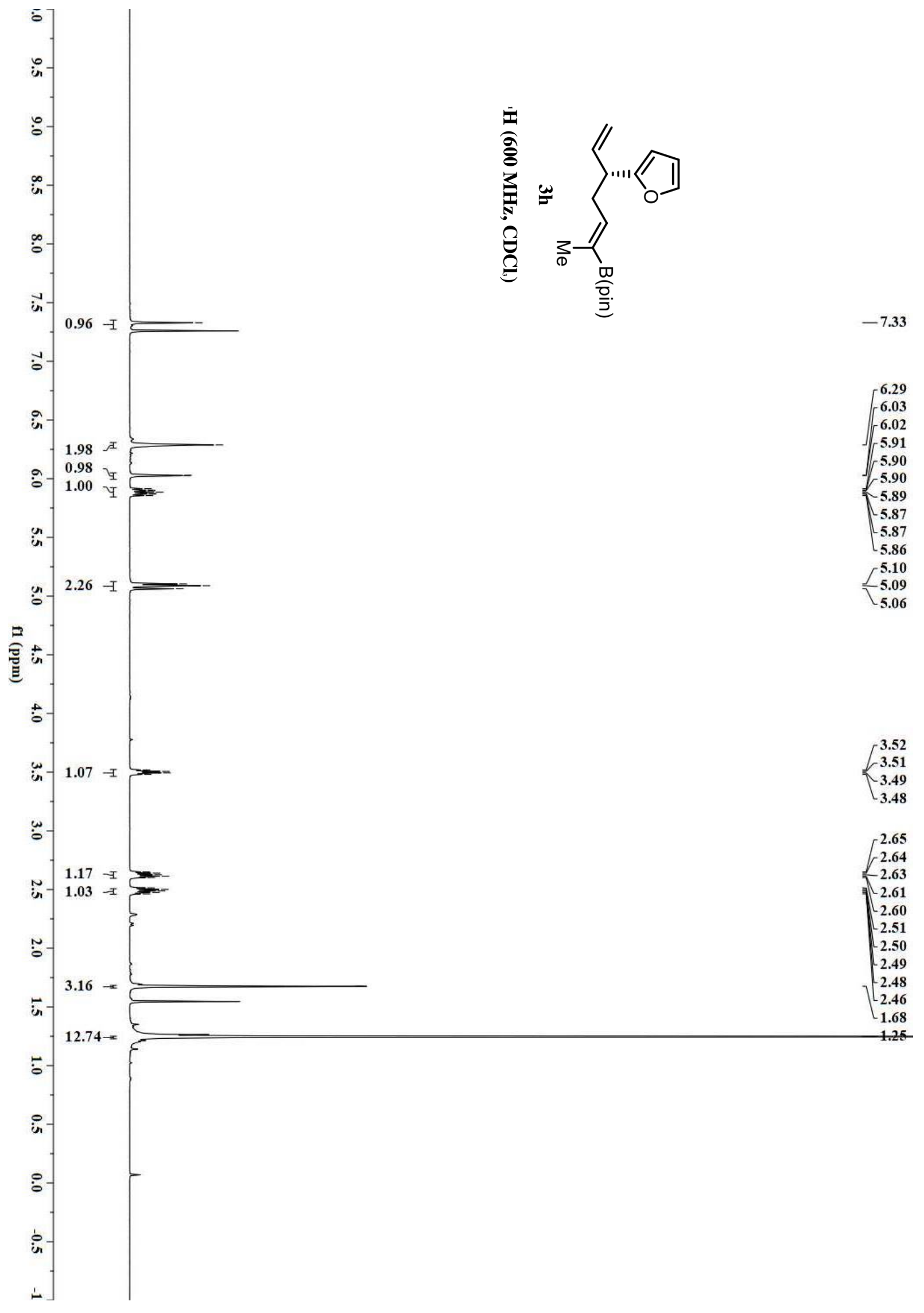




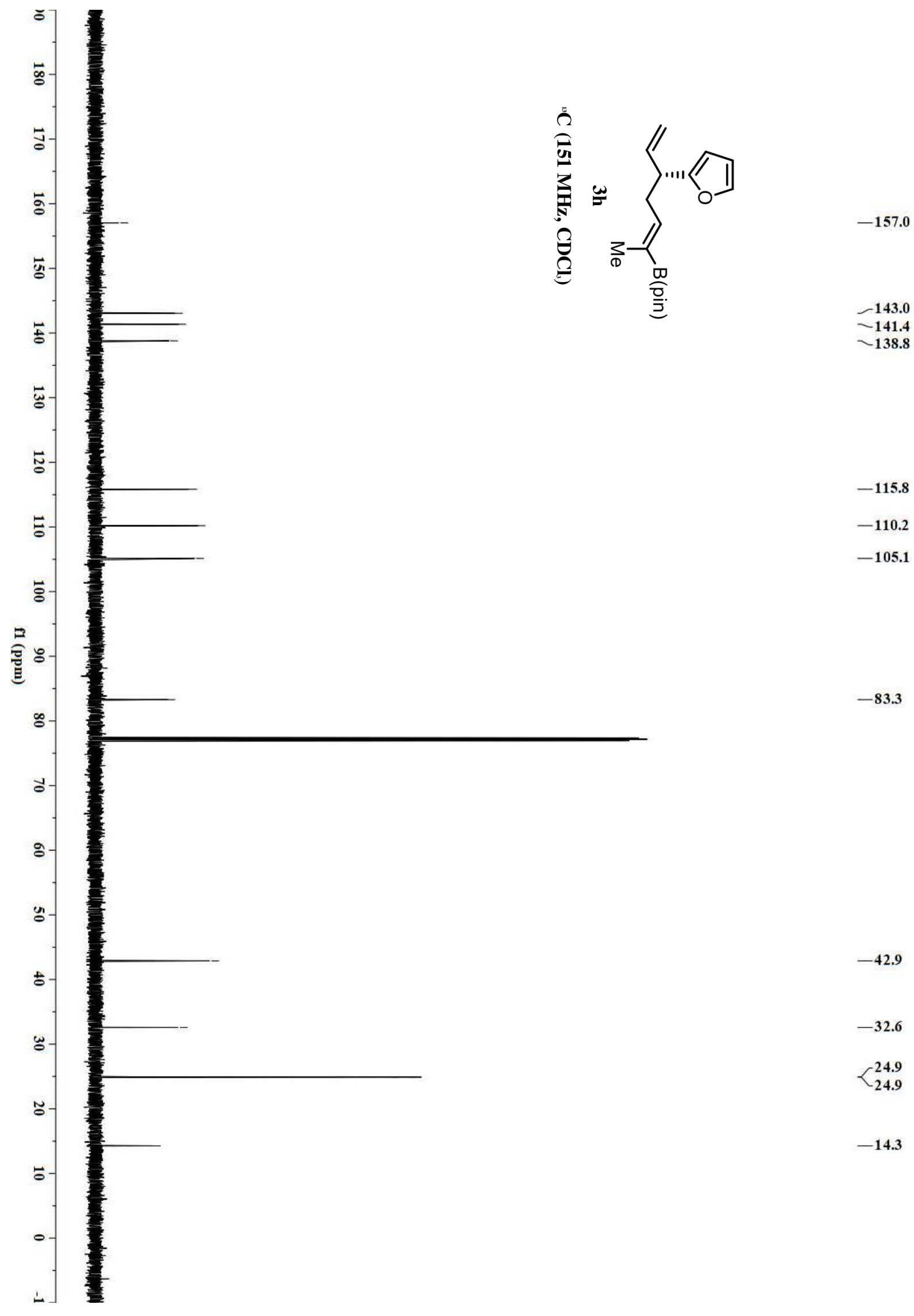




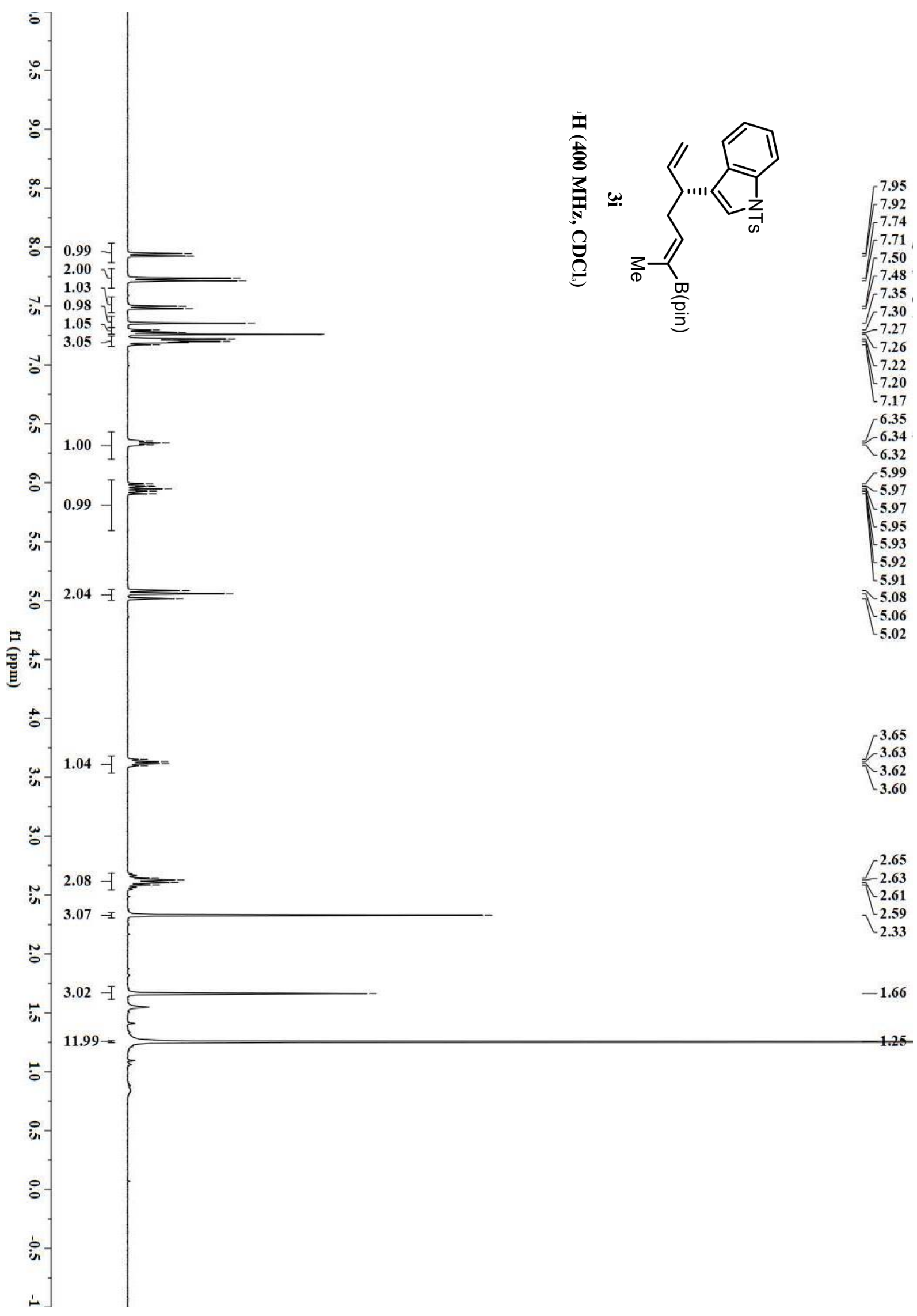




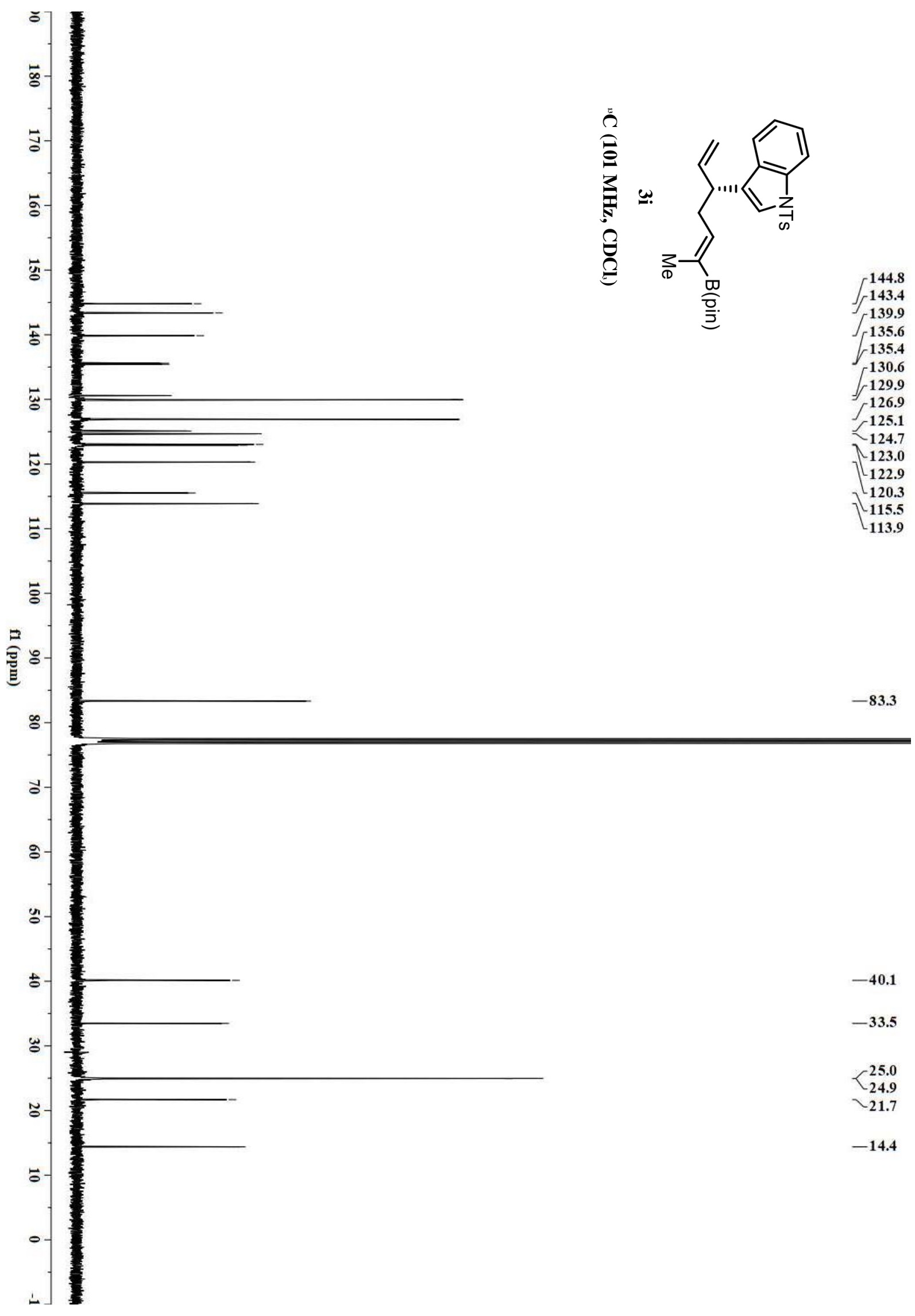




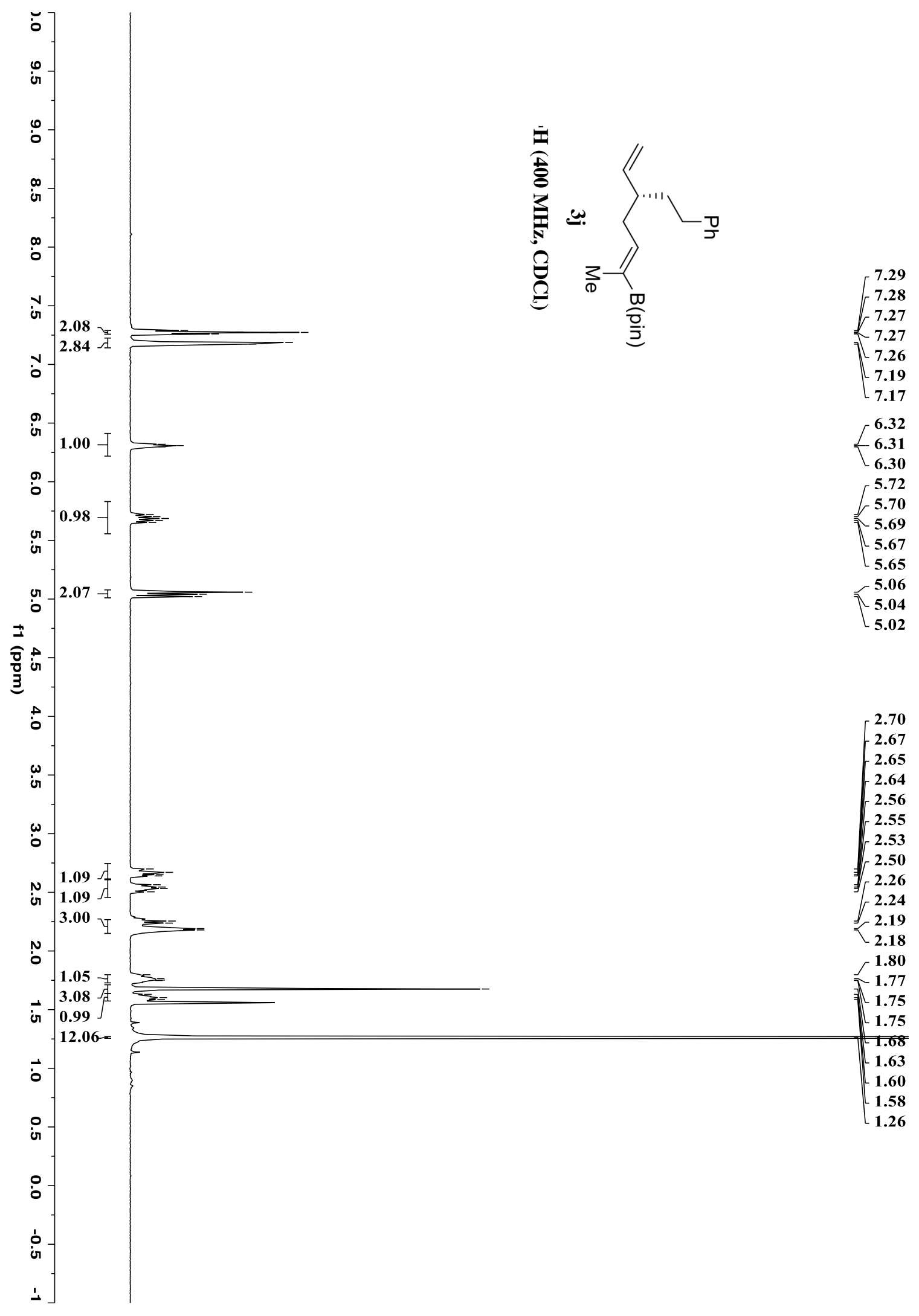




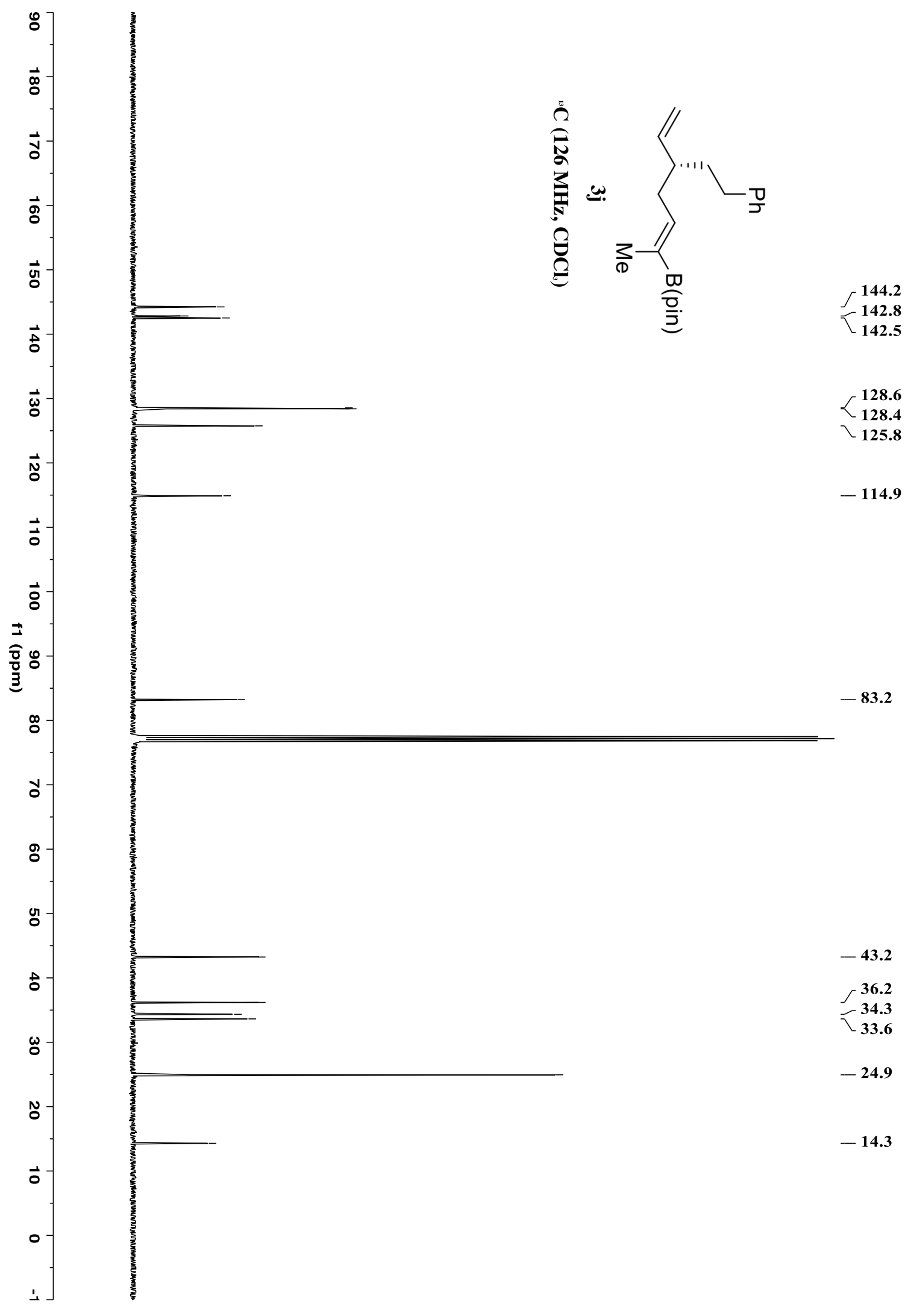


Sun, et al., Supporting Information, Page S209

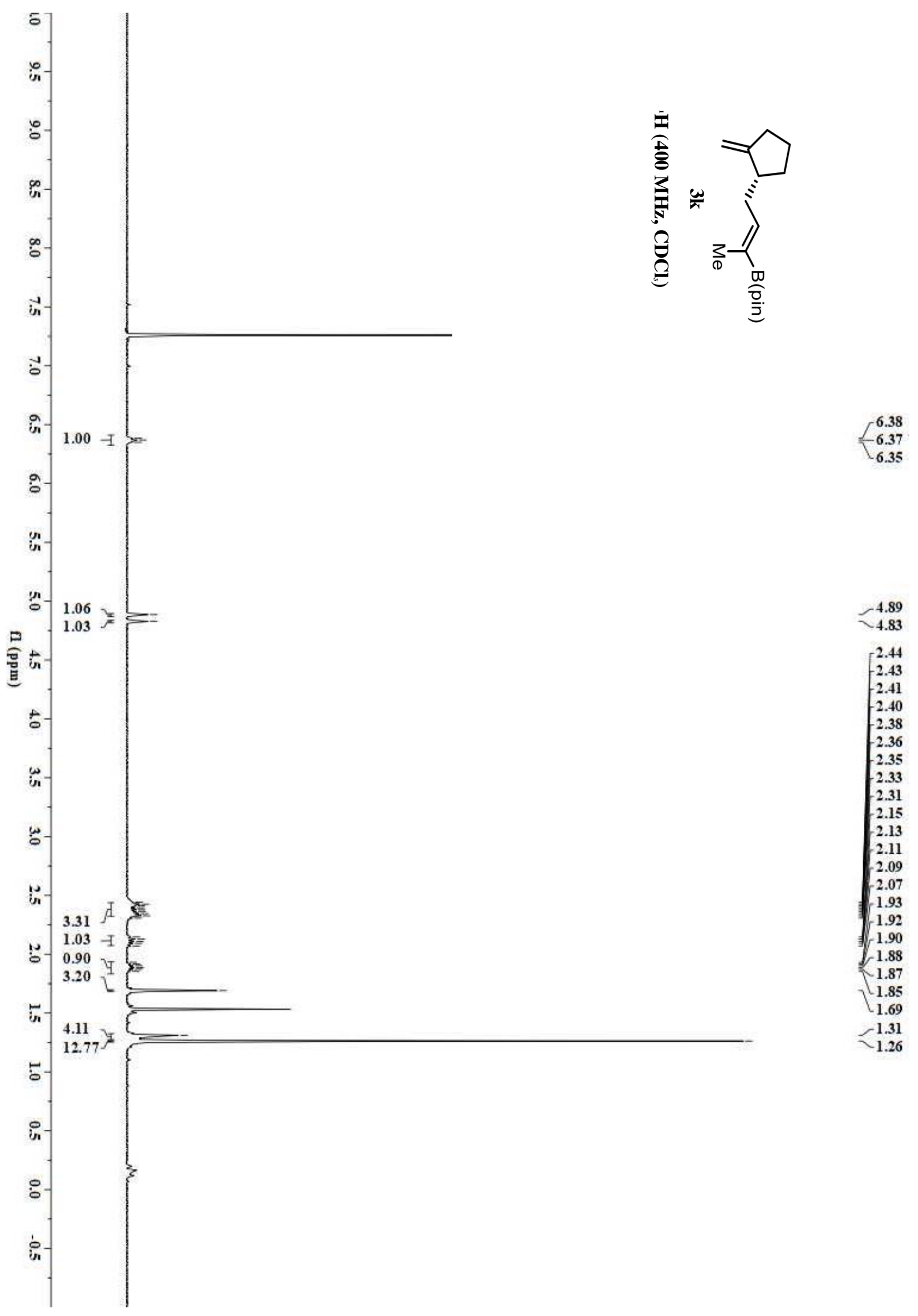



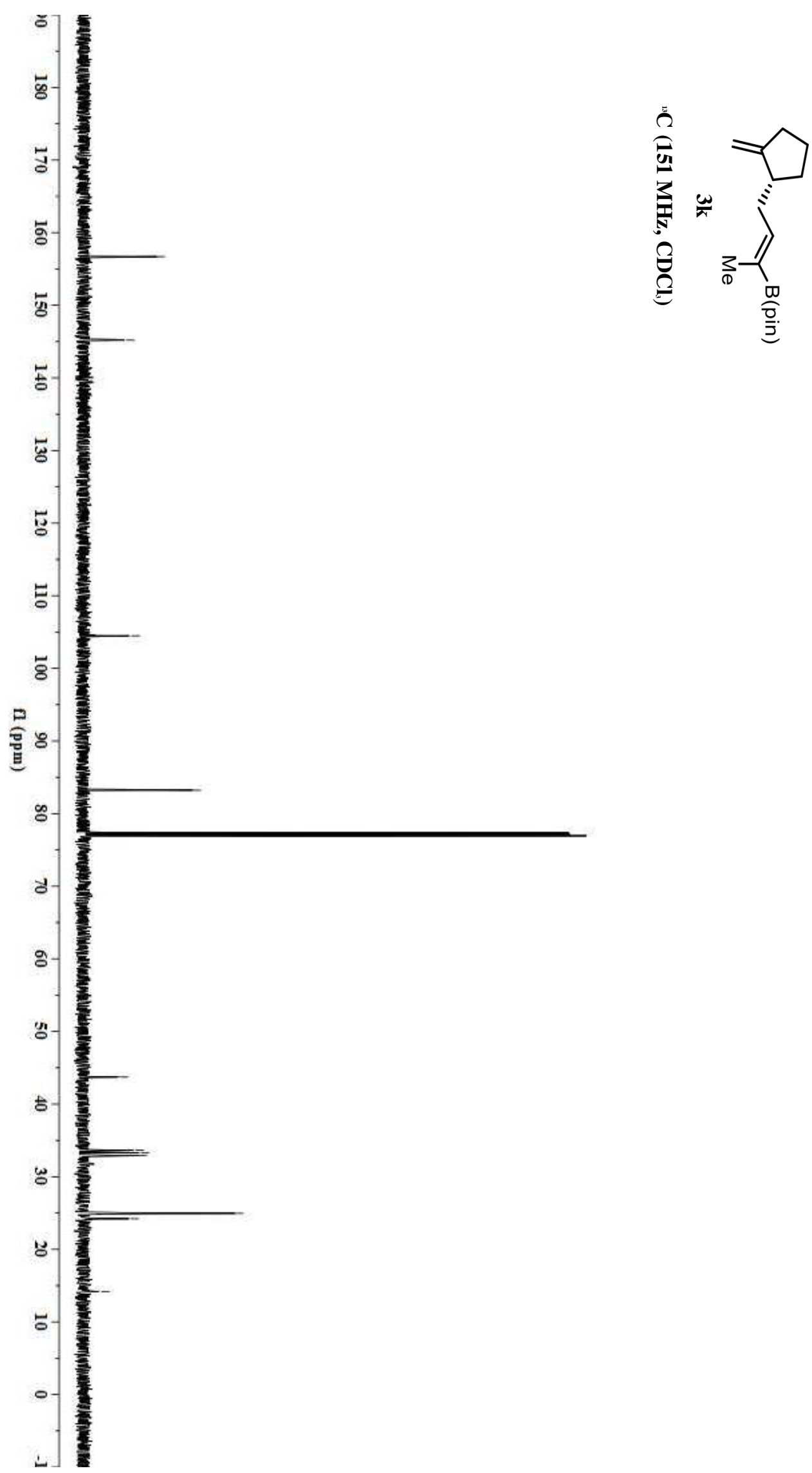


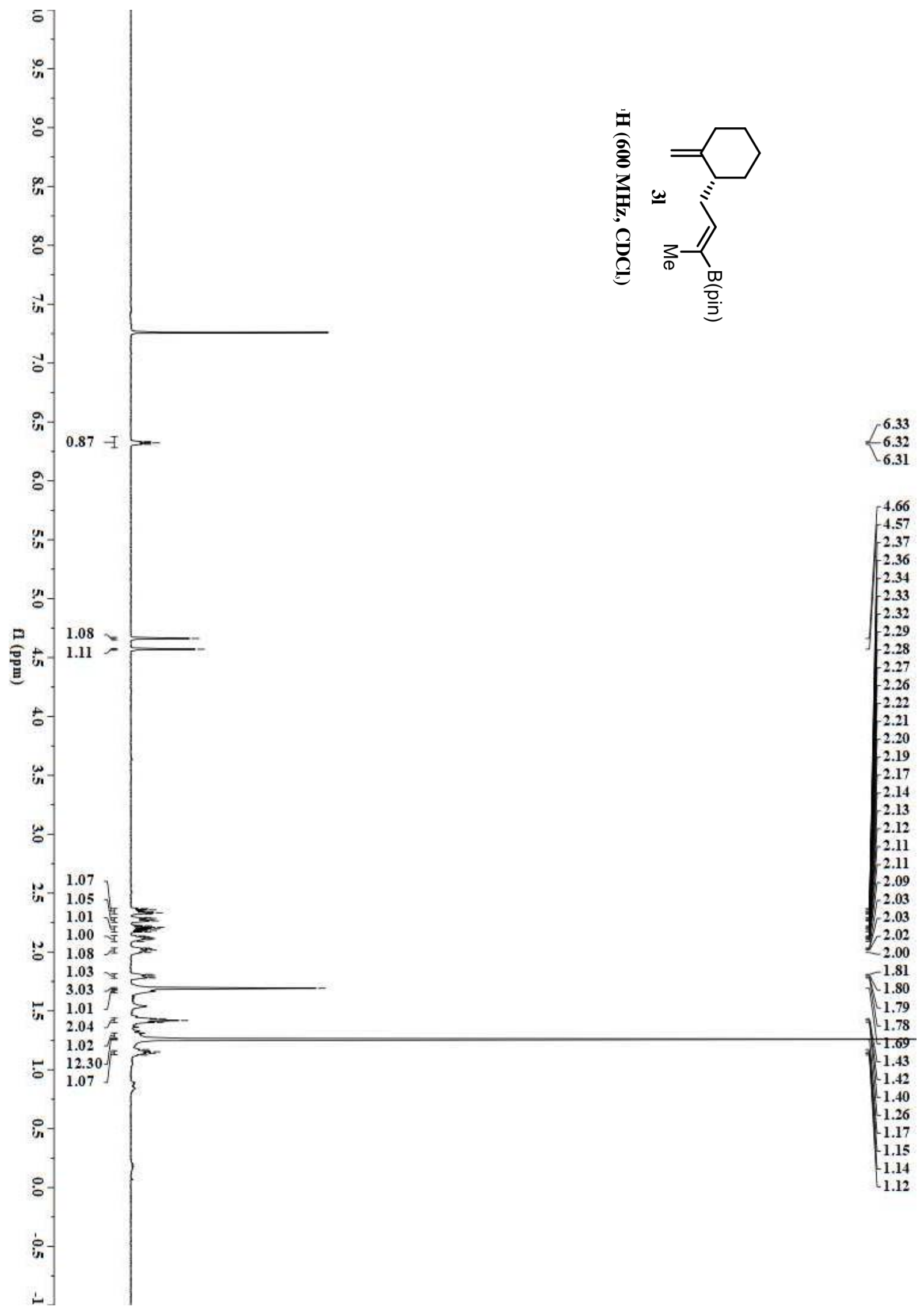


Sun, et al., Supporting Information, Page S212

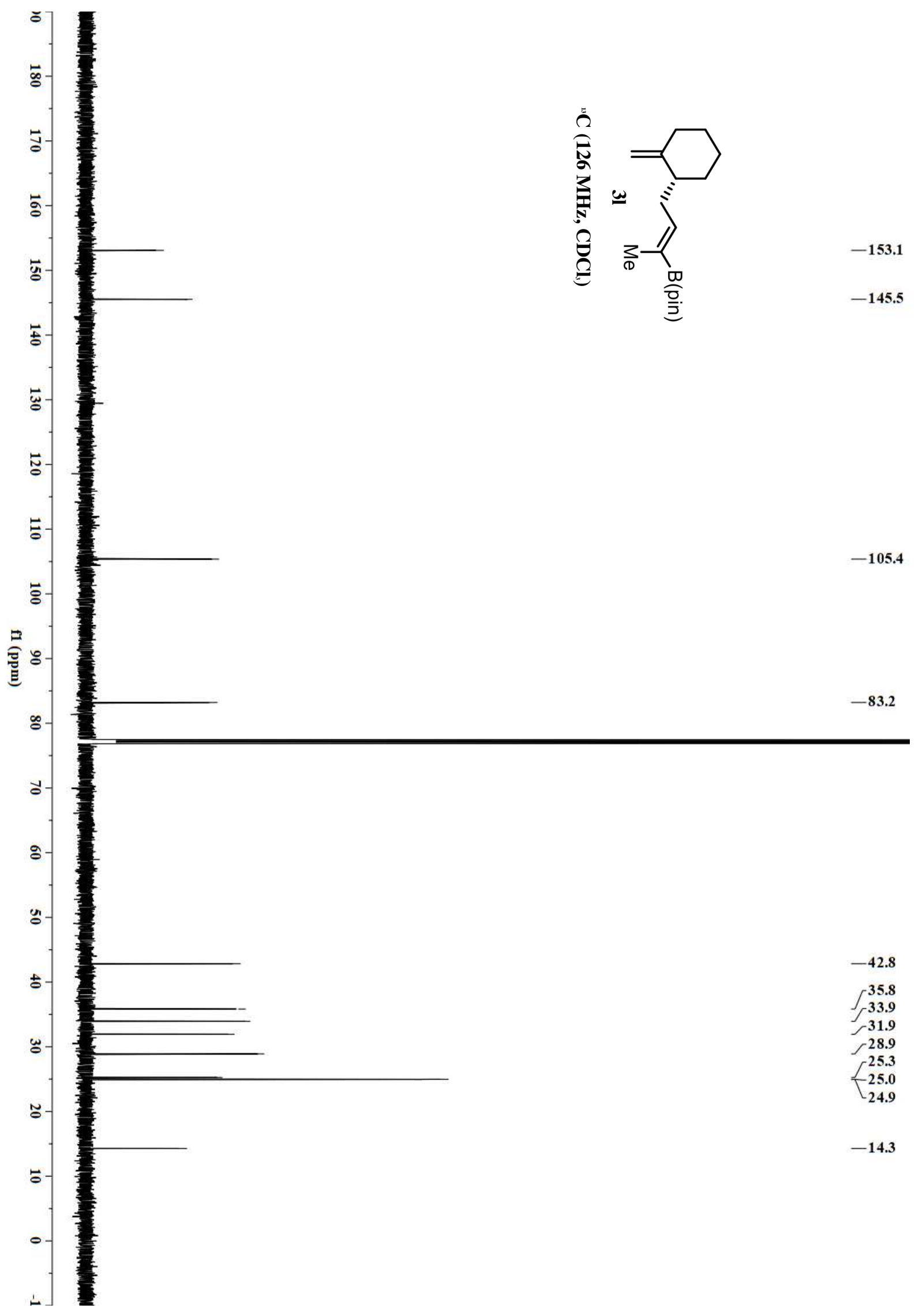




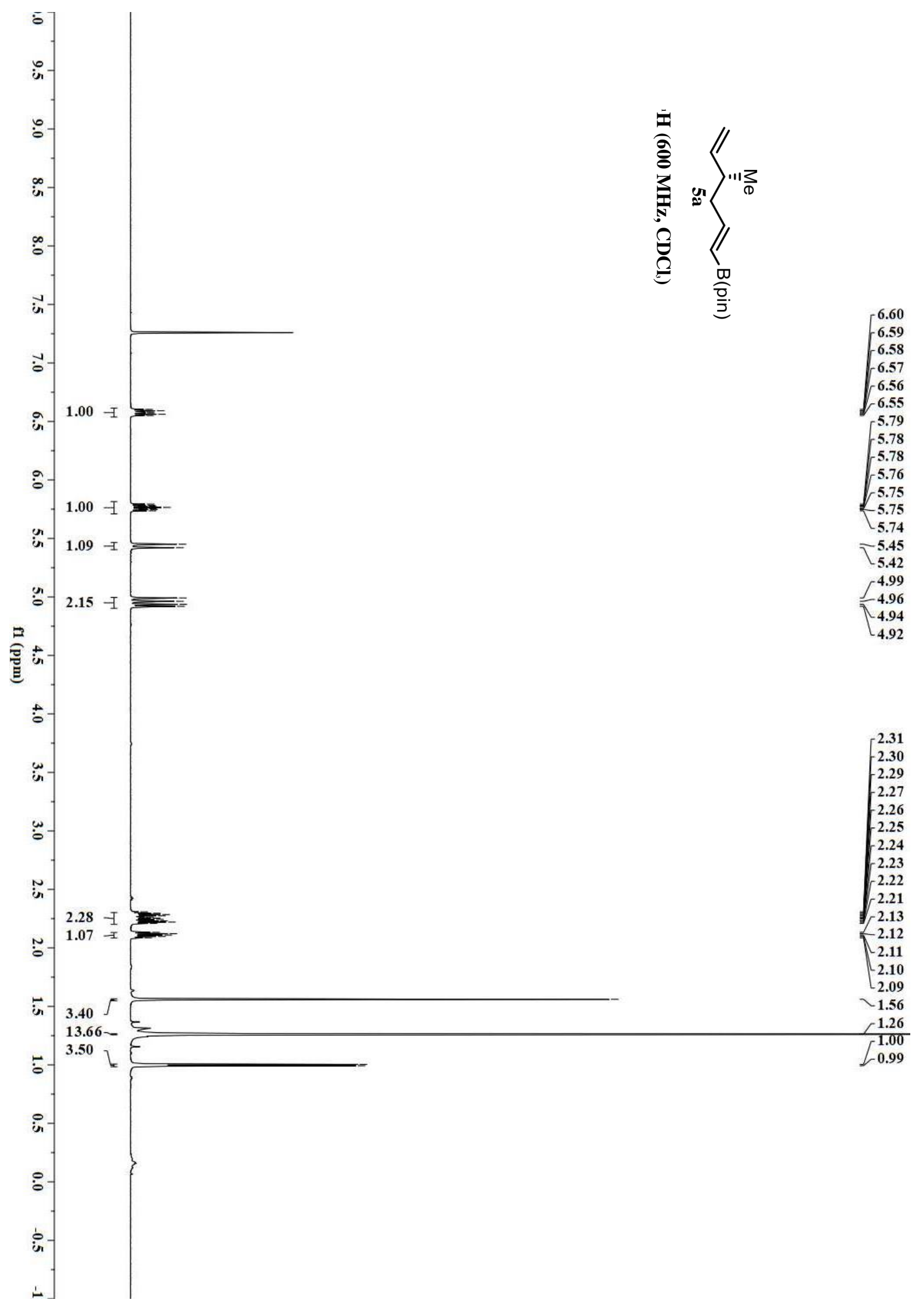




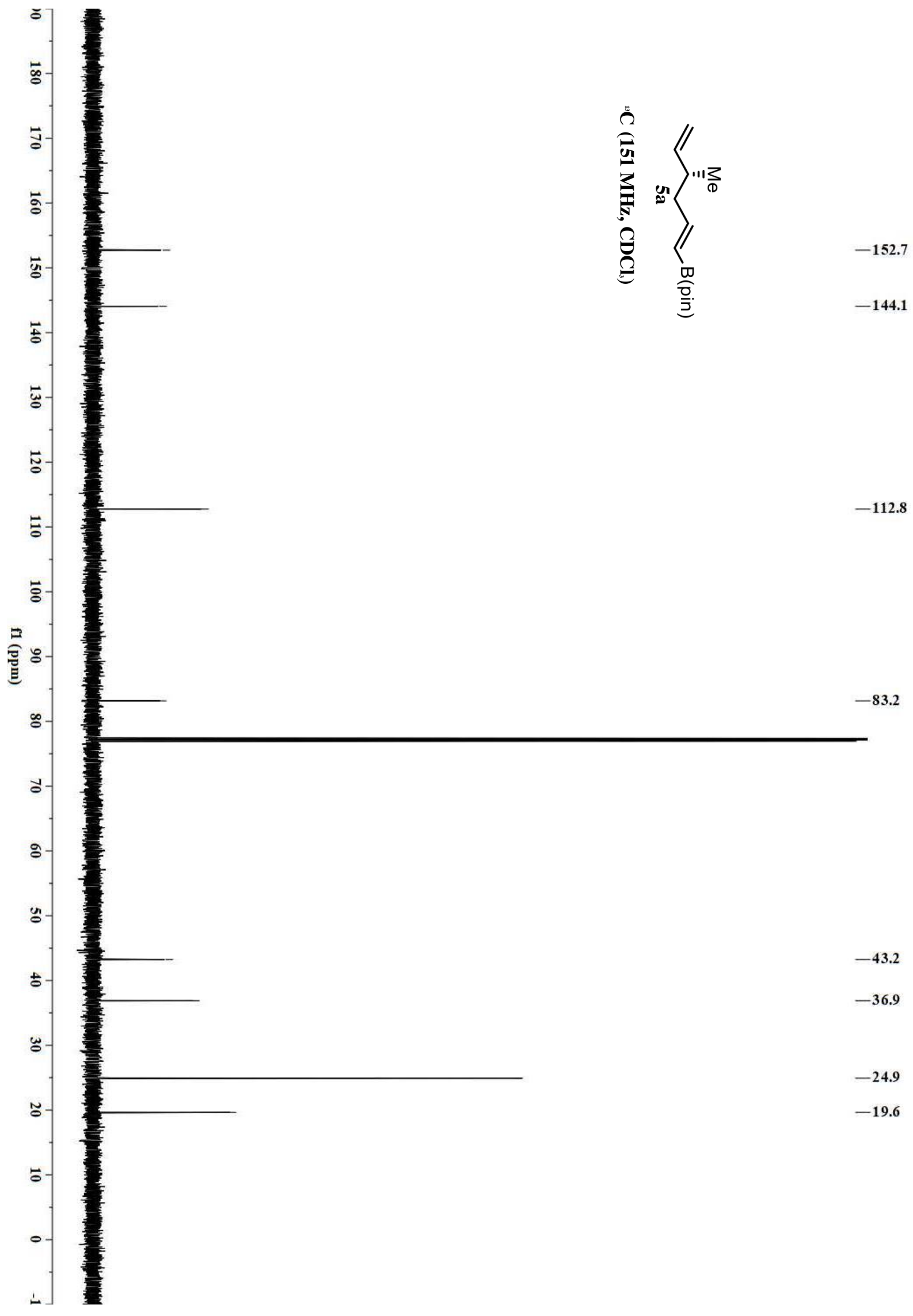




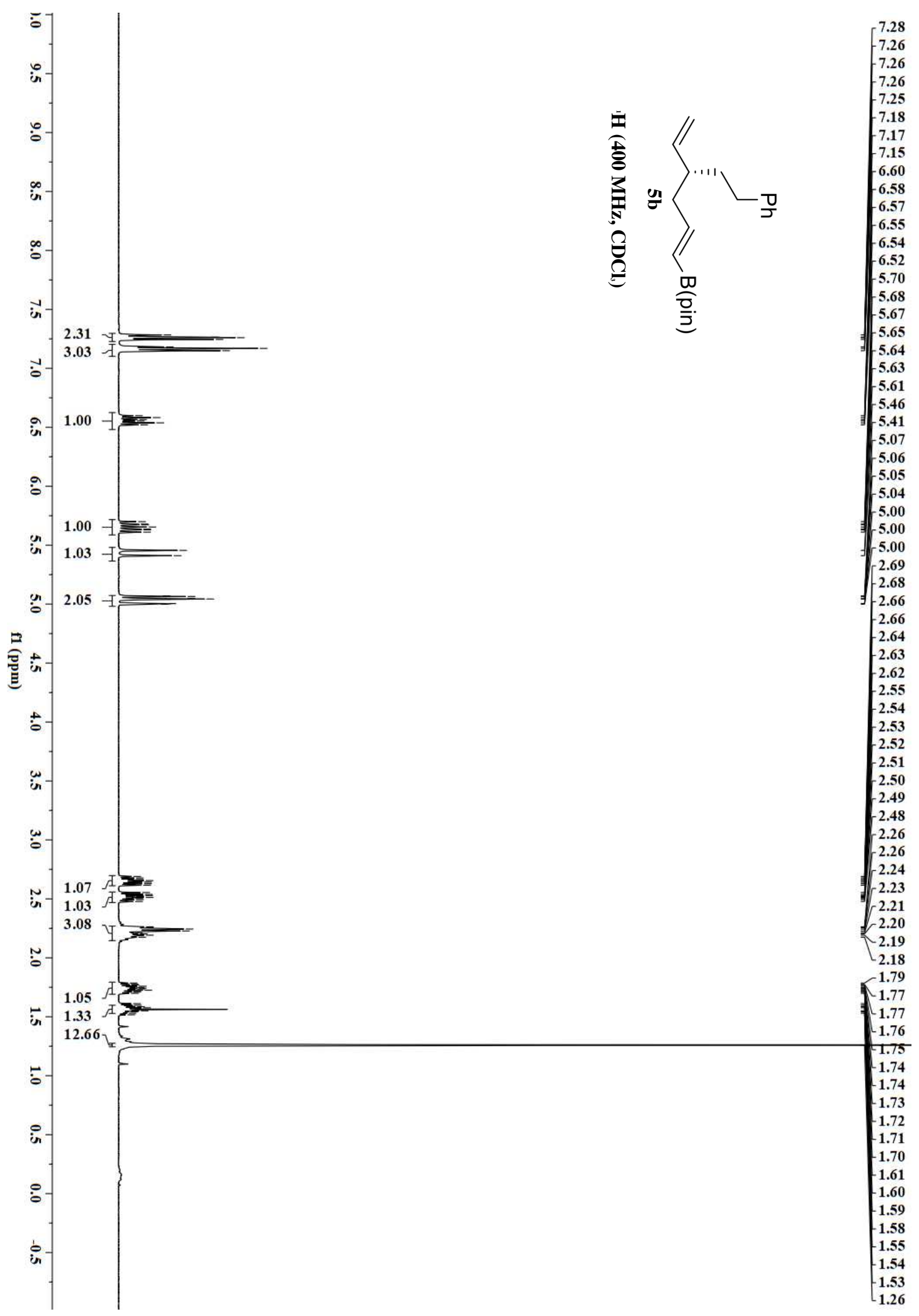




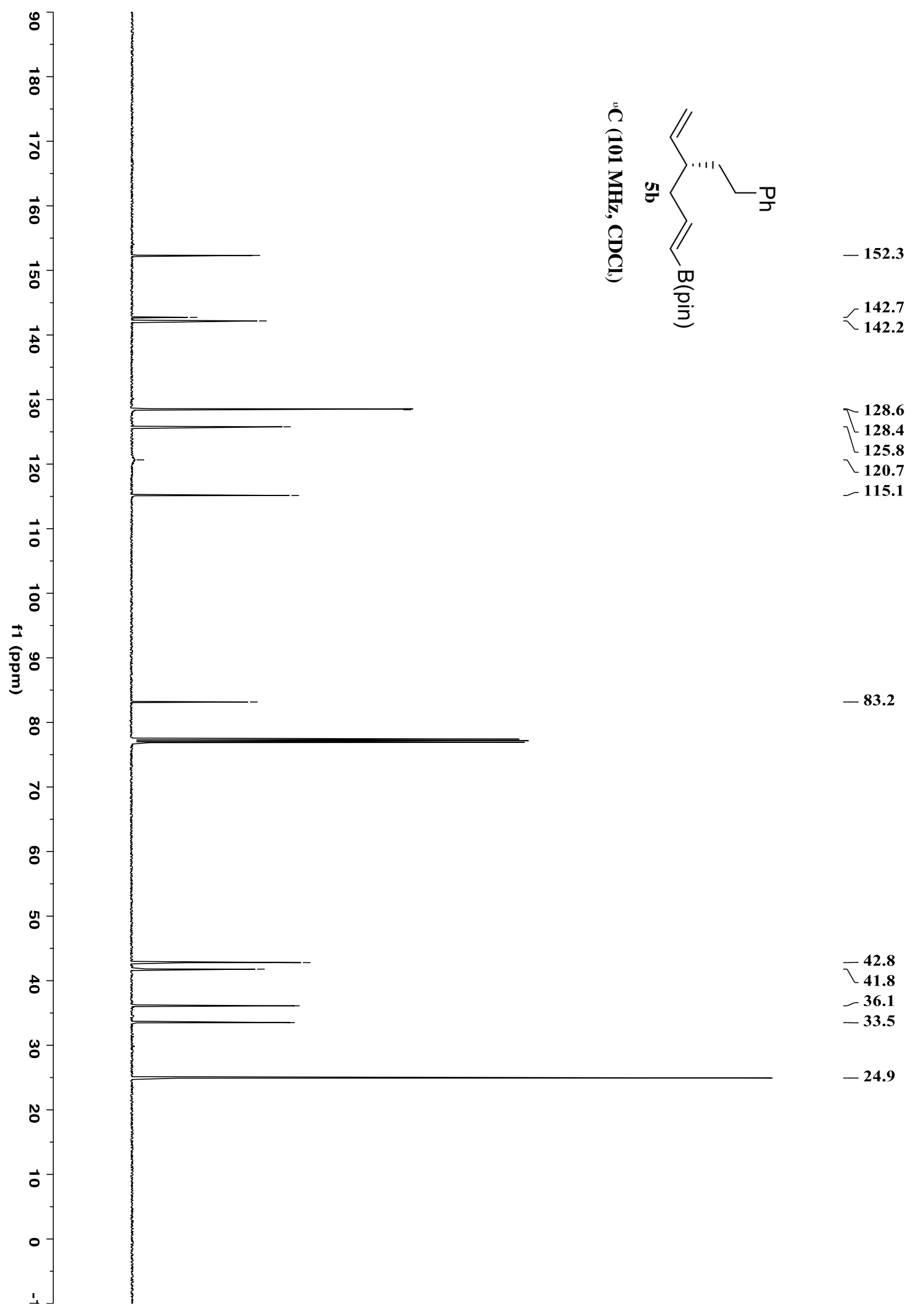




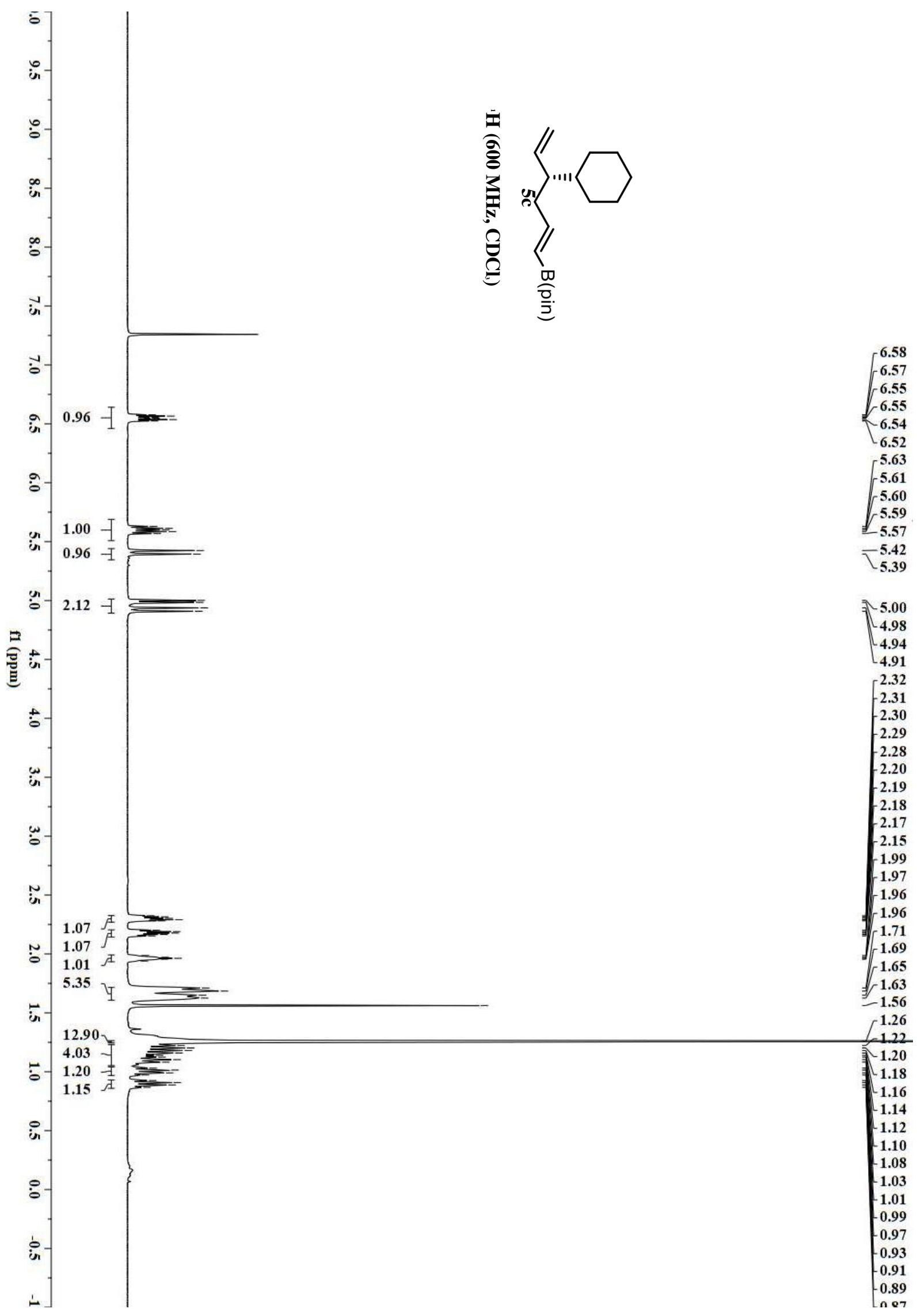


Sun, et al., Supporting Information, Page S218

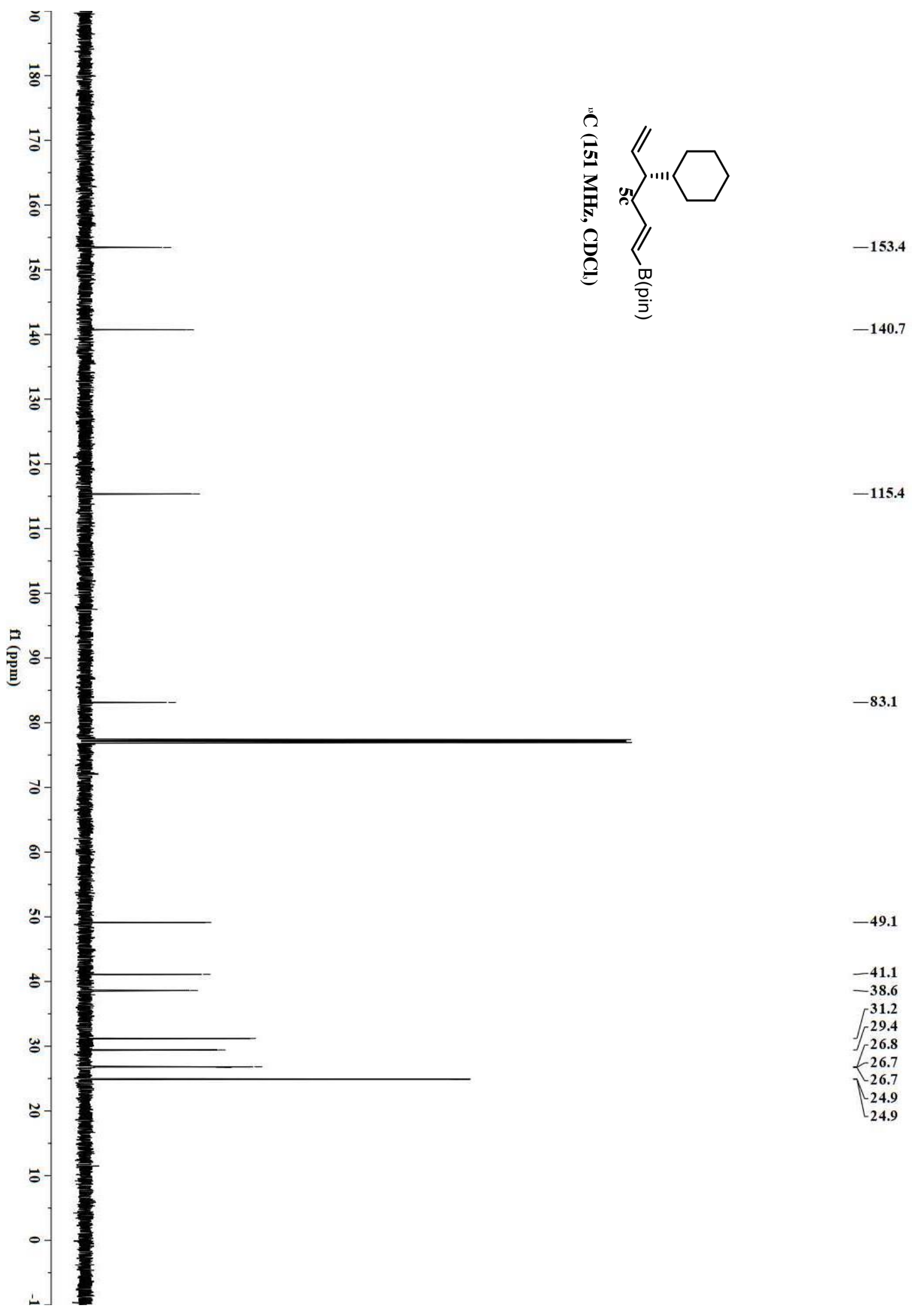




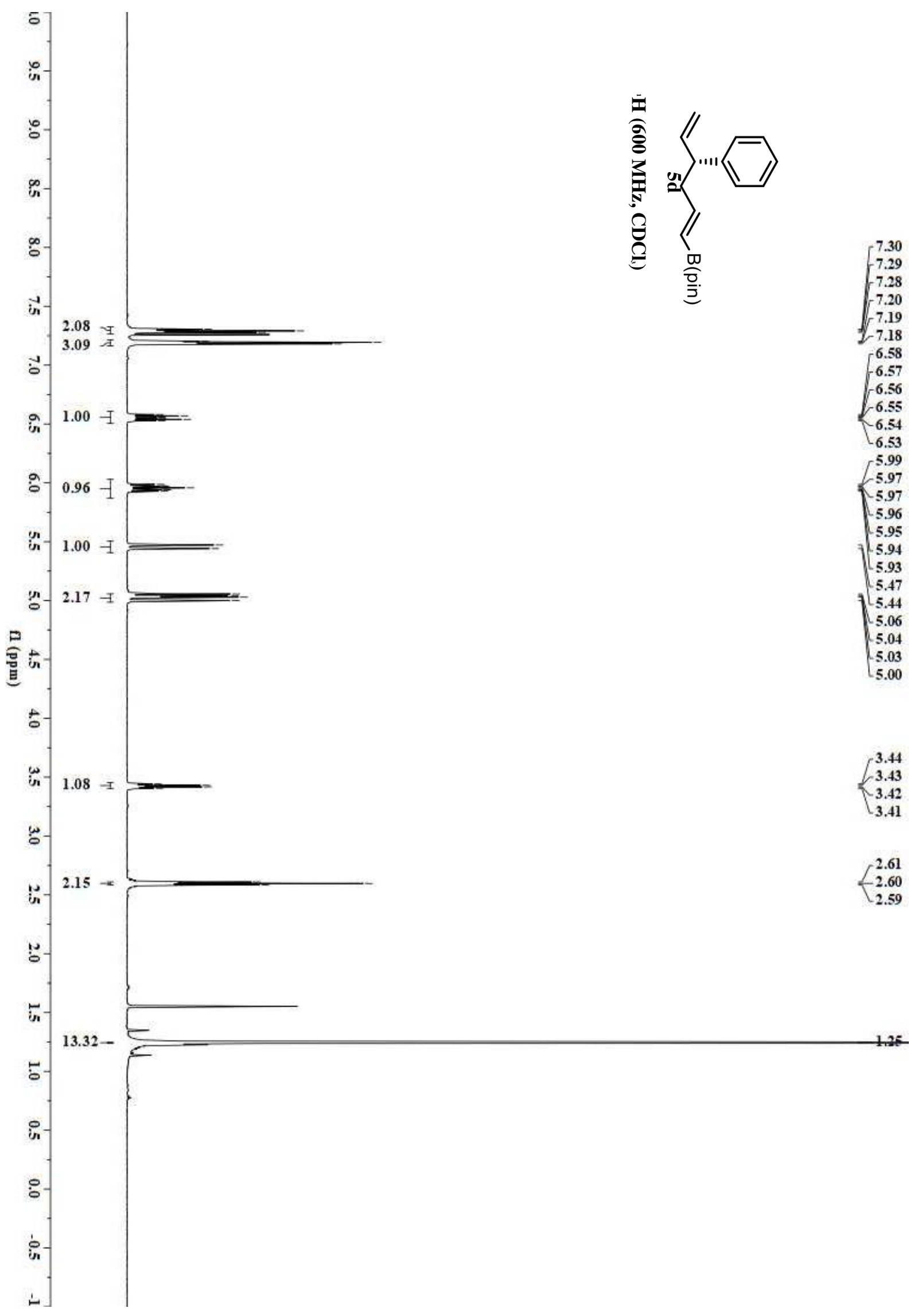



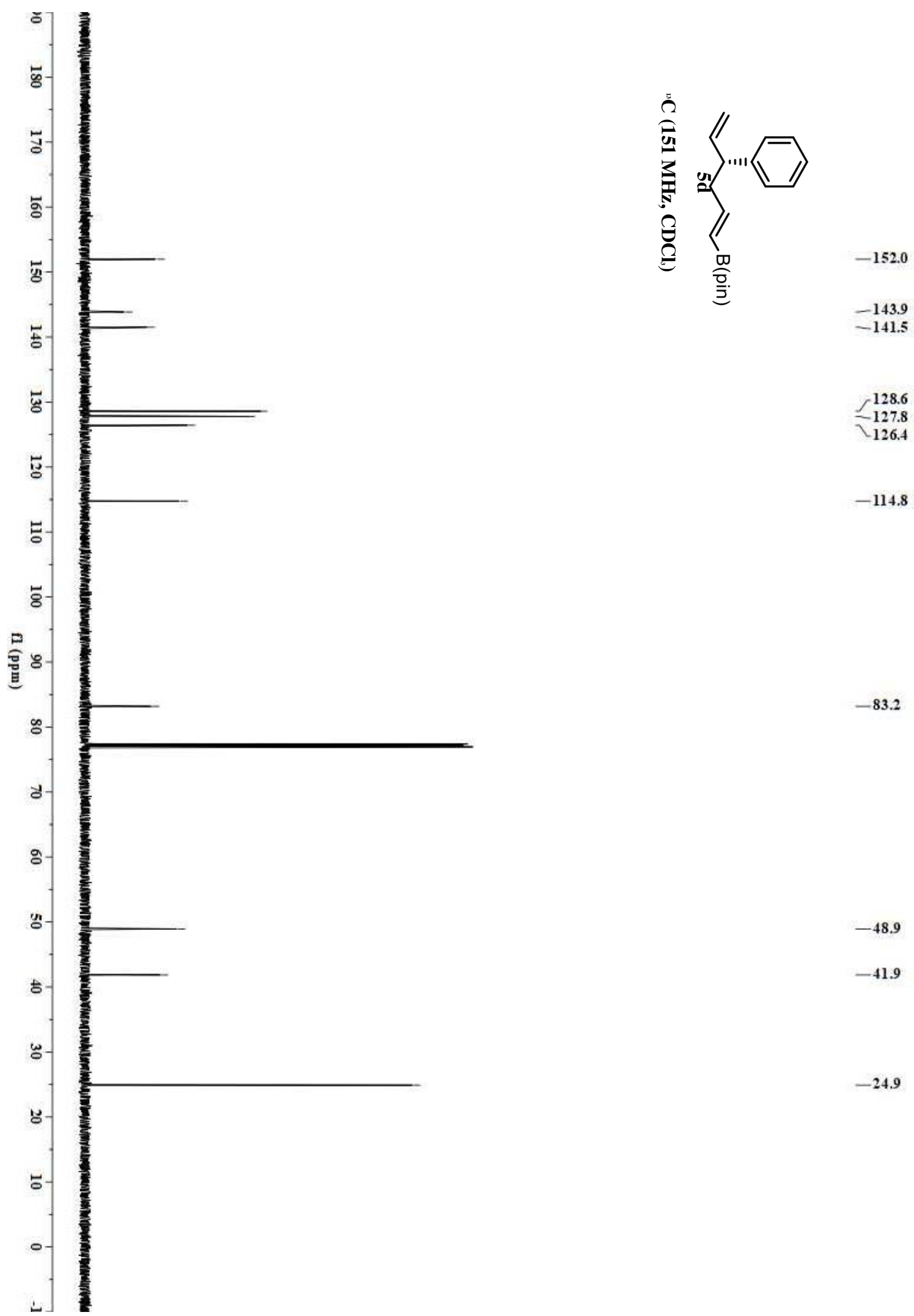

$-83.2$

$-48.9$

$-41.9$

$-24.9$ 


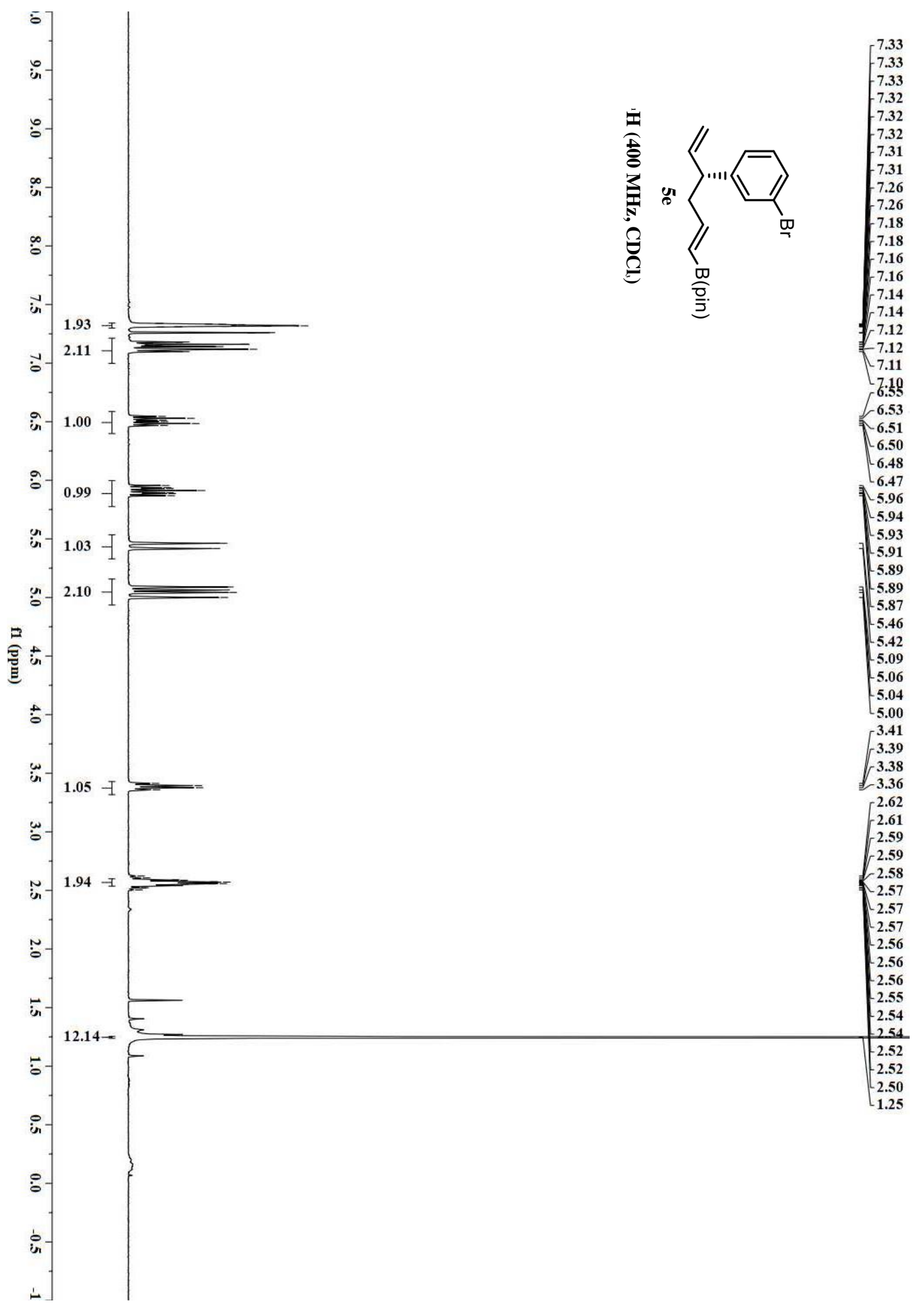



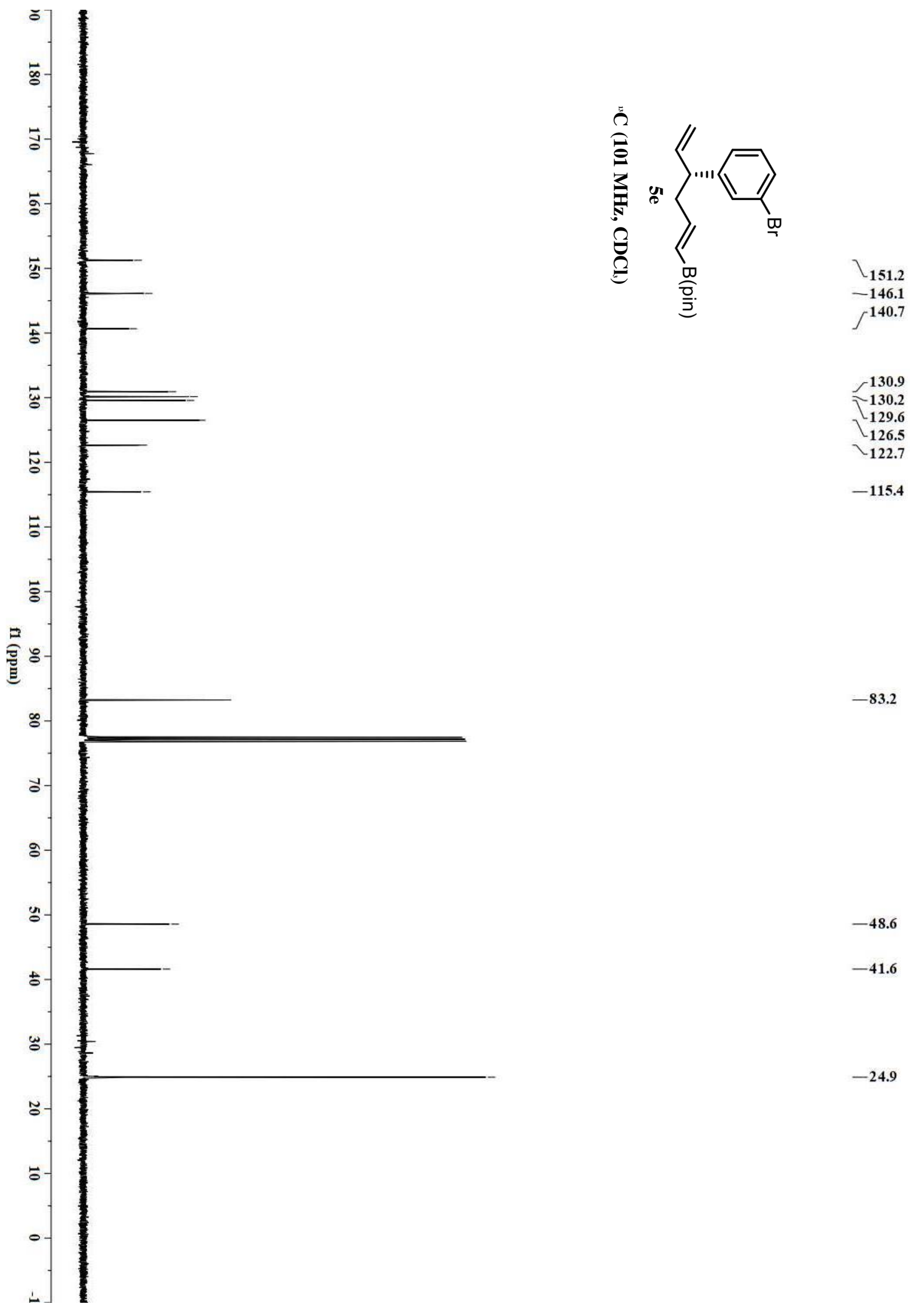

130.2

129.6

126.5

$-115.4$

$-83.2$

$-48.6$

$-41.6$

$-24.9$ 


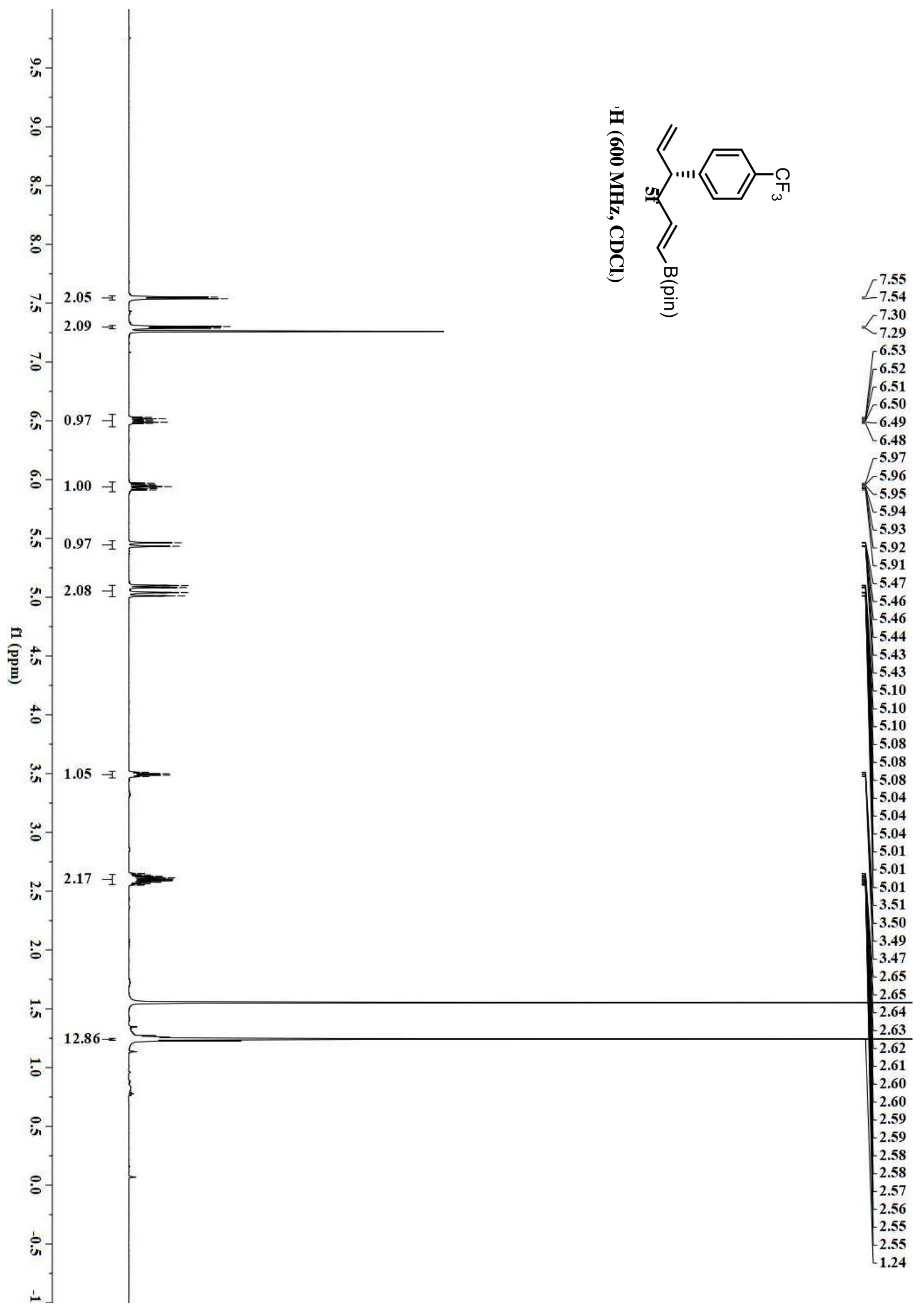




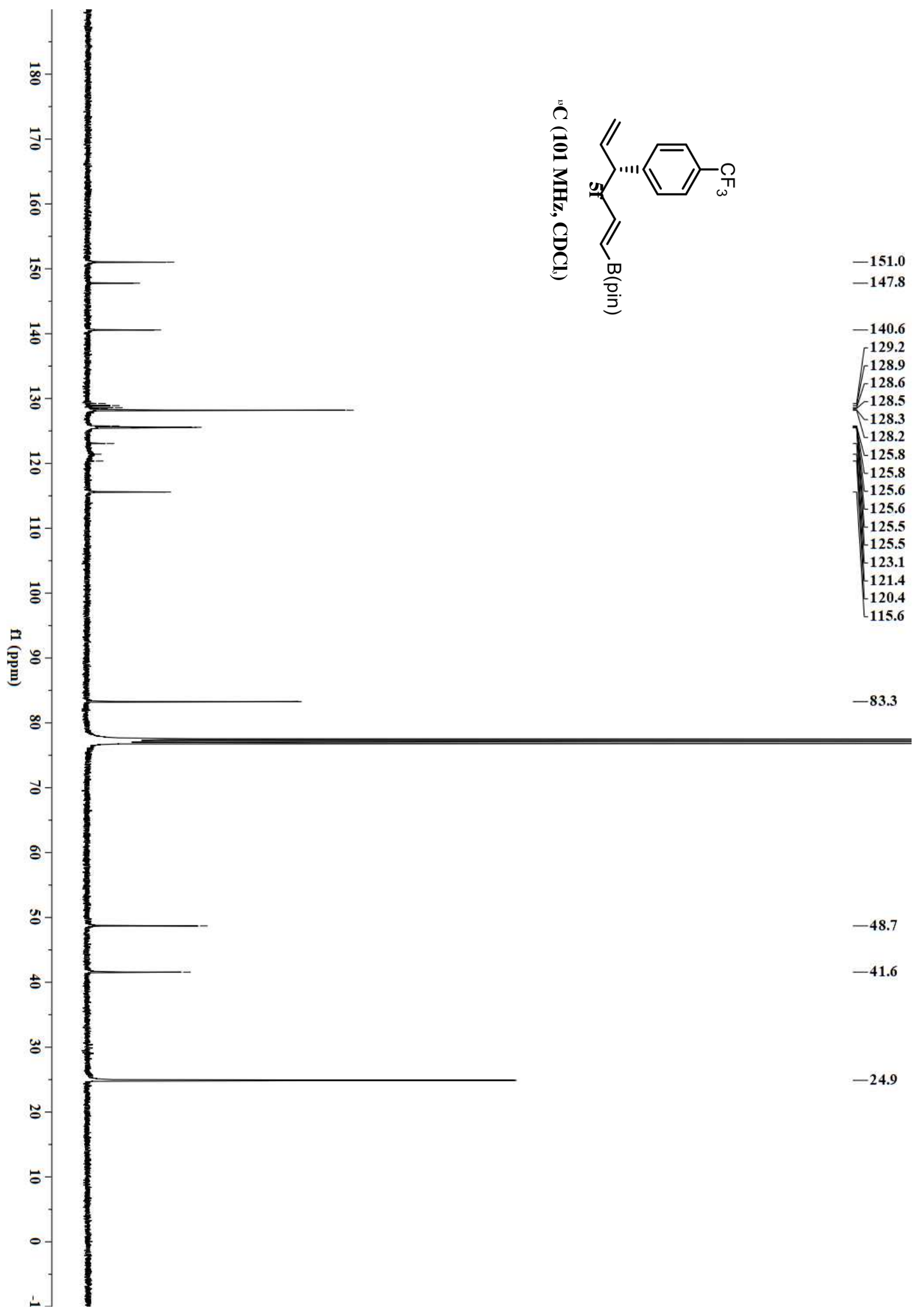




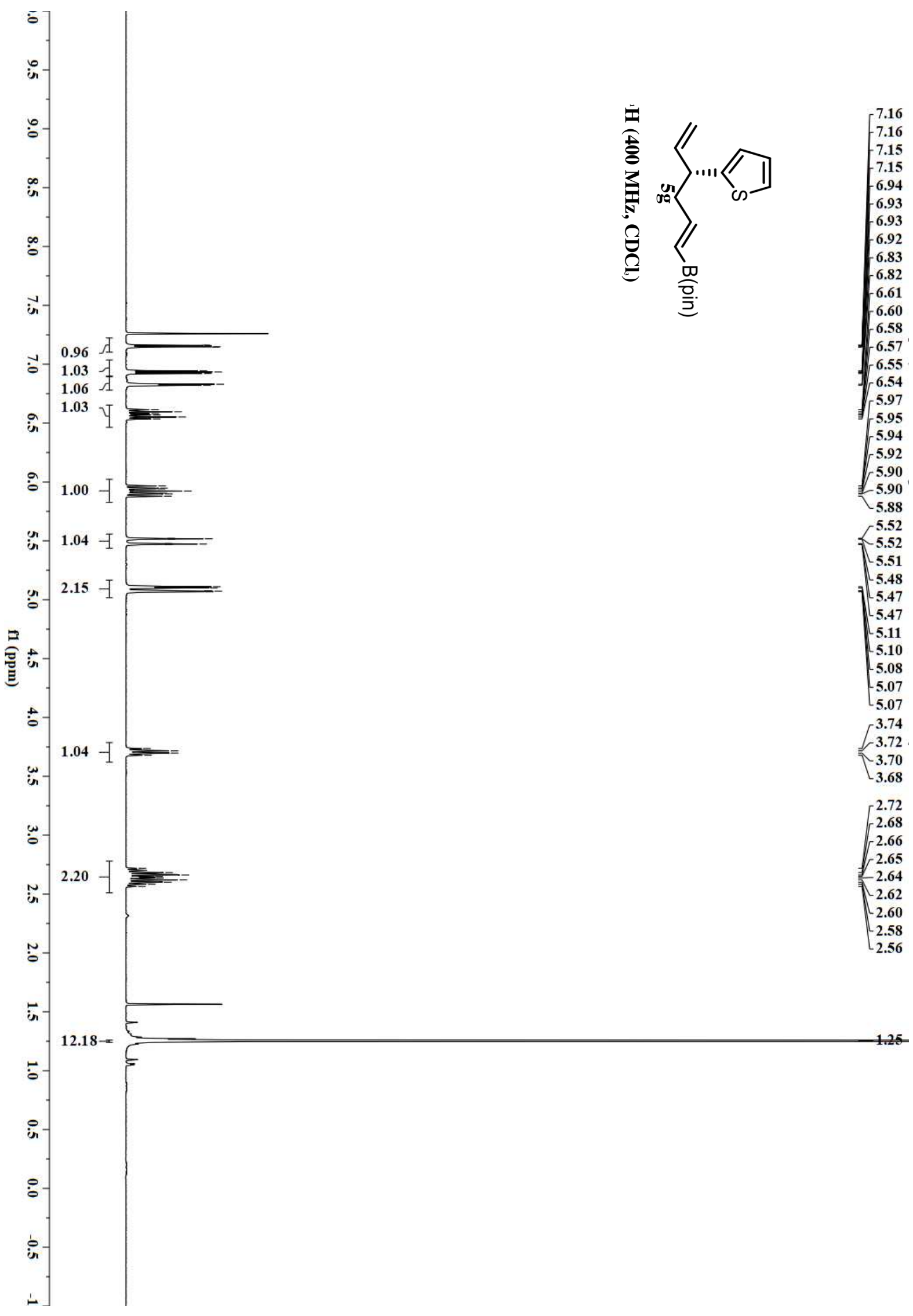



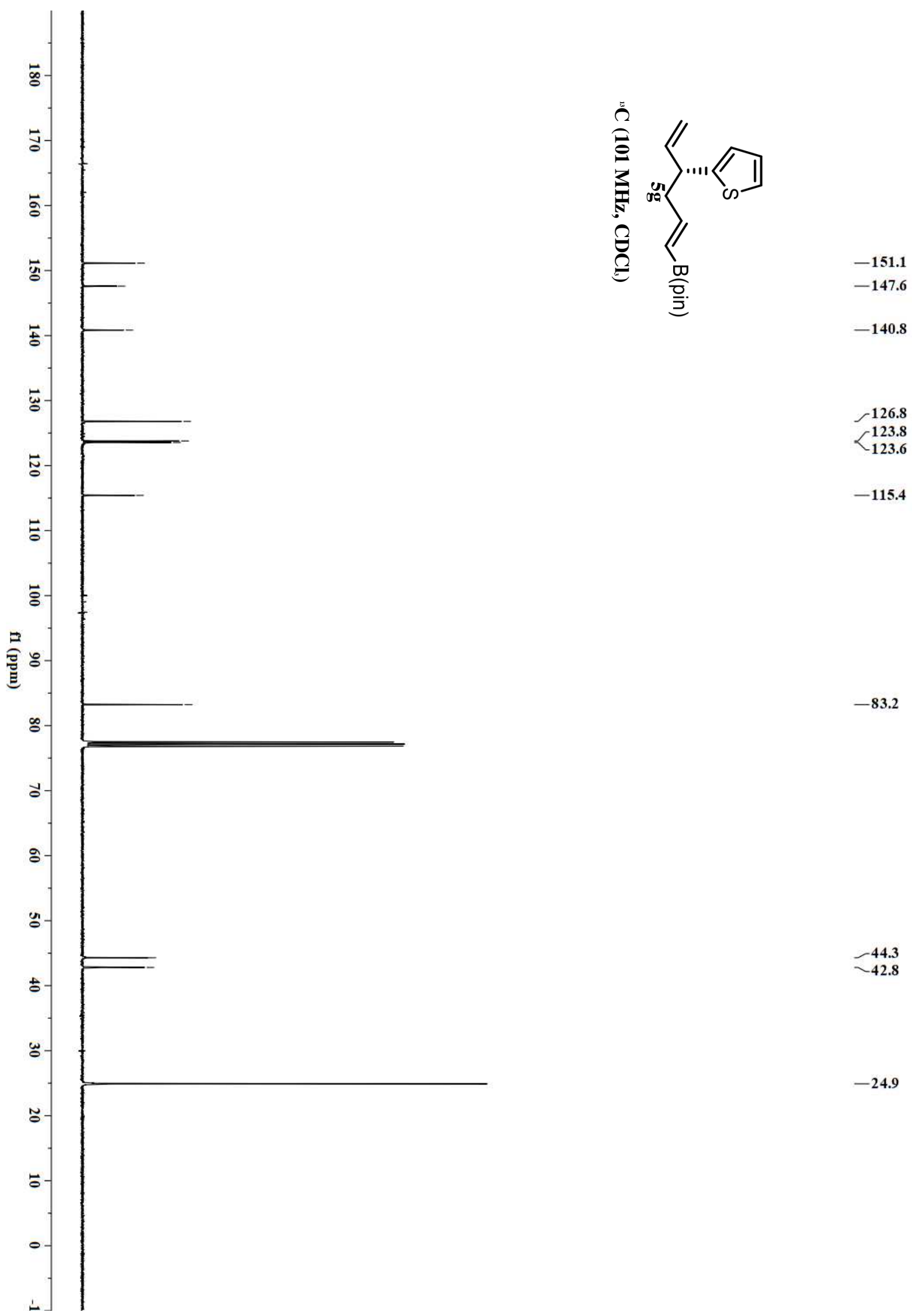

$-115.4$

$-83.2$

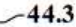

-44.3
-42.8

$-24.9$ 


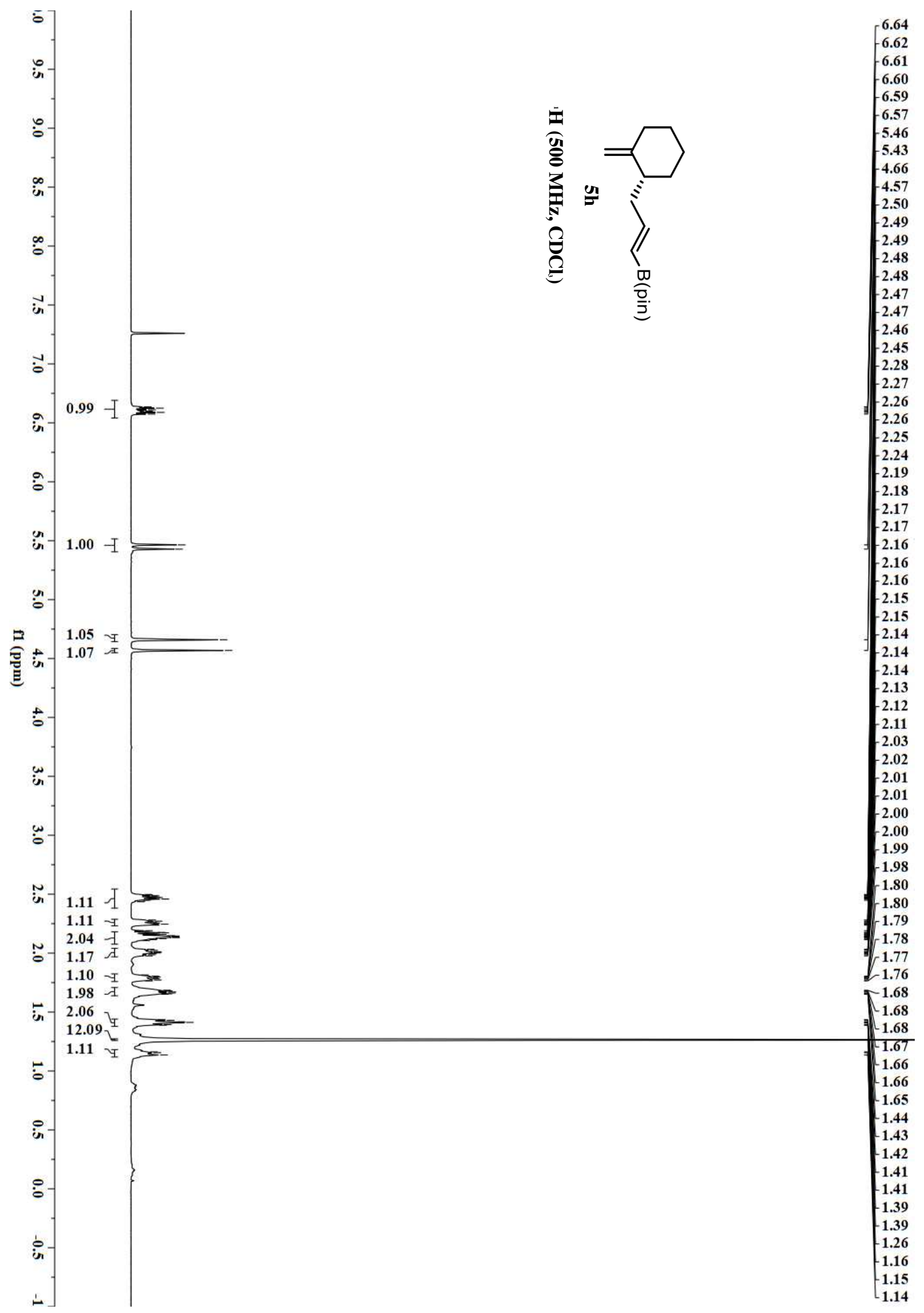




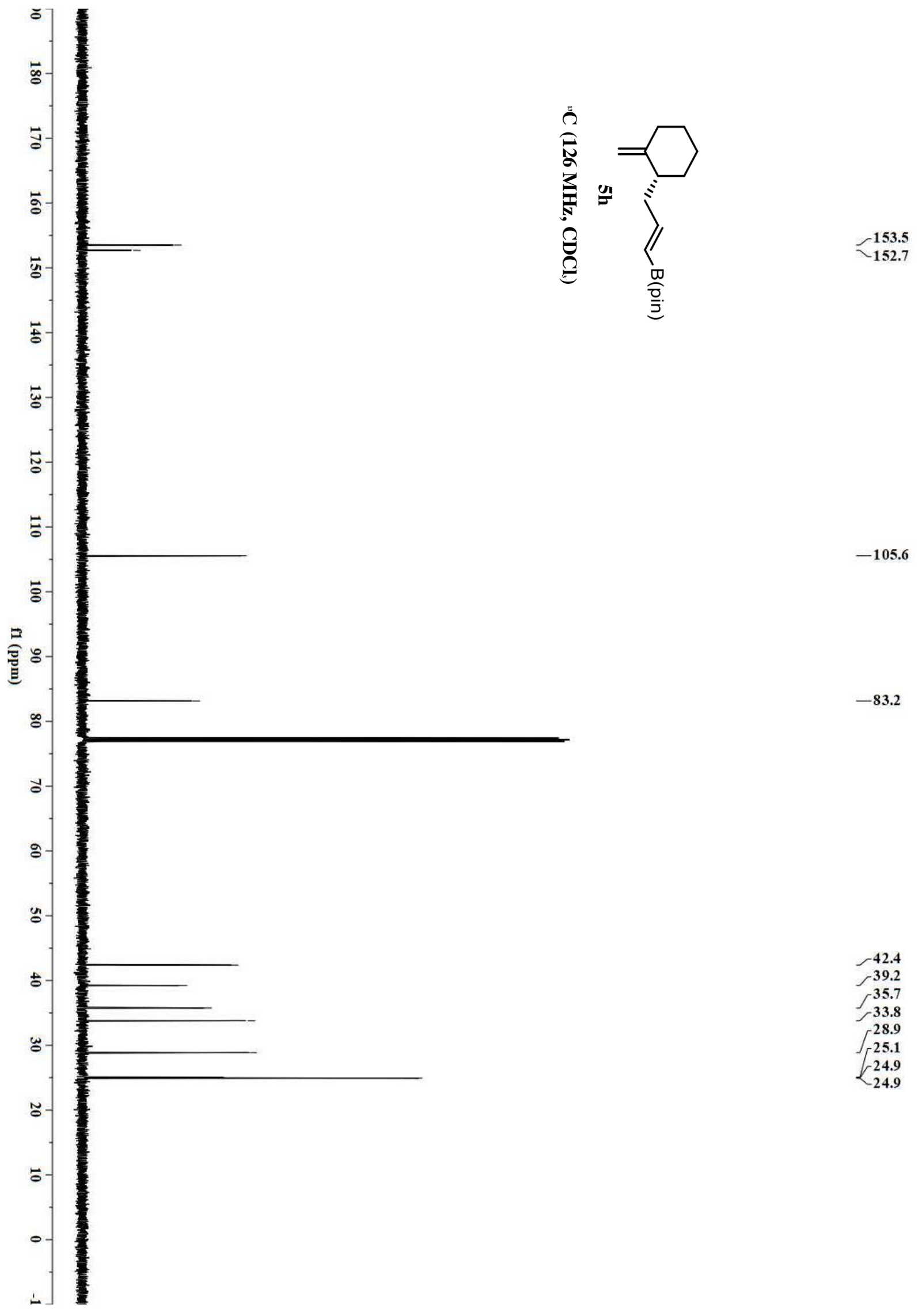




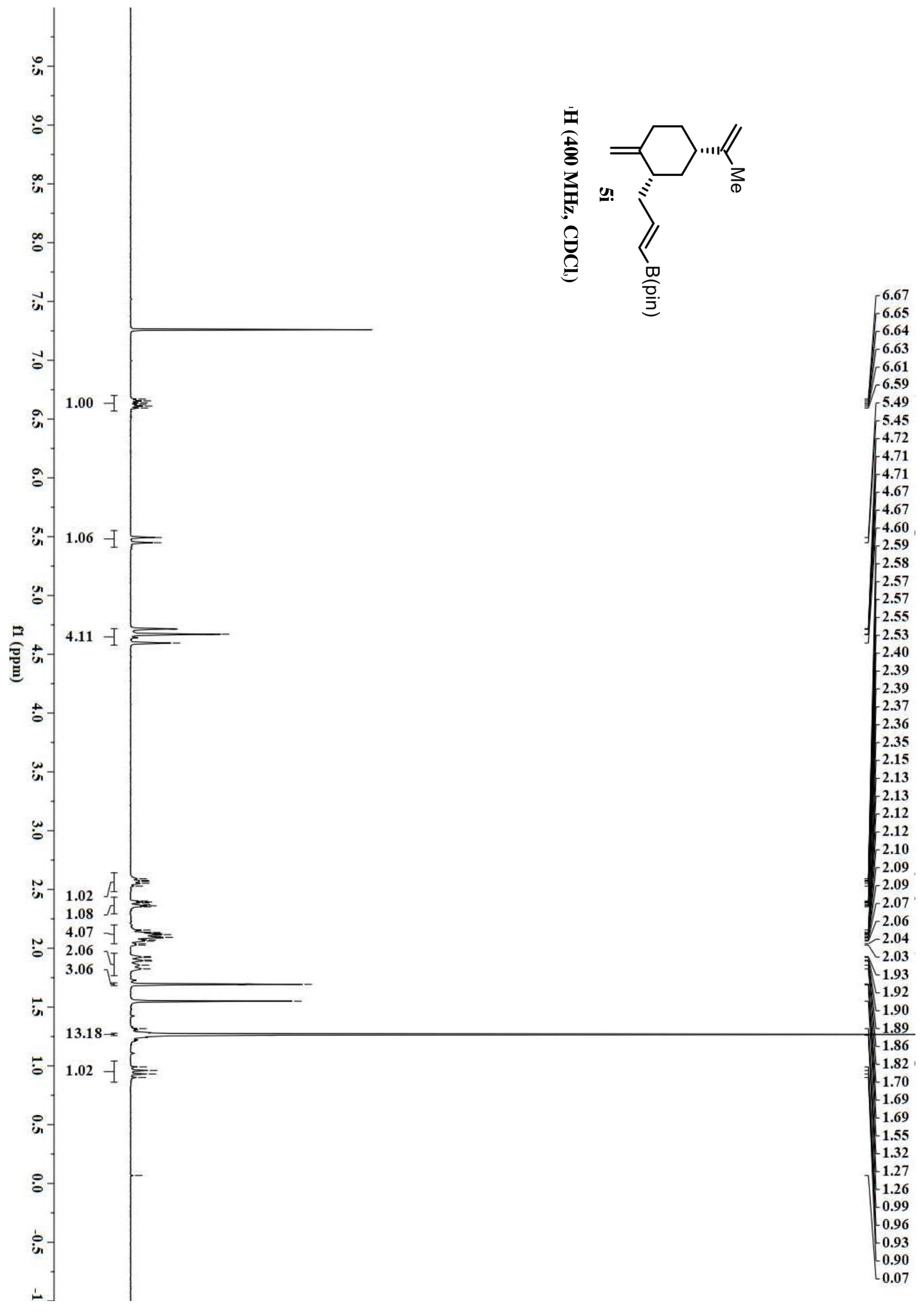




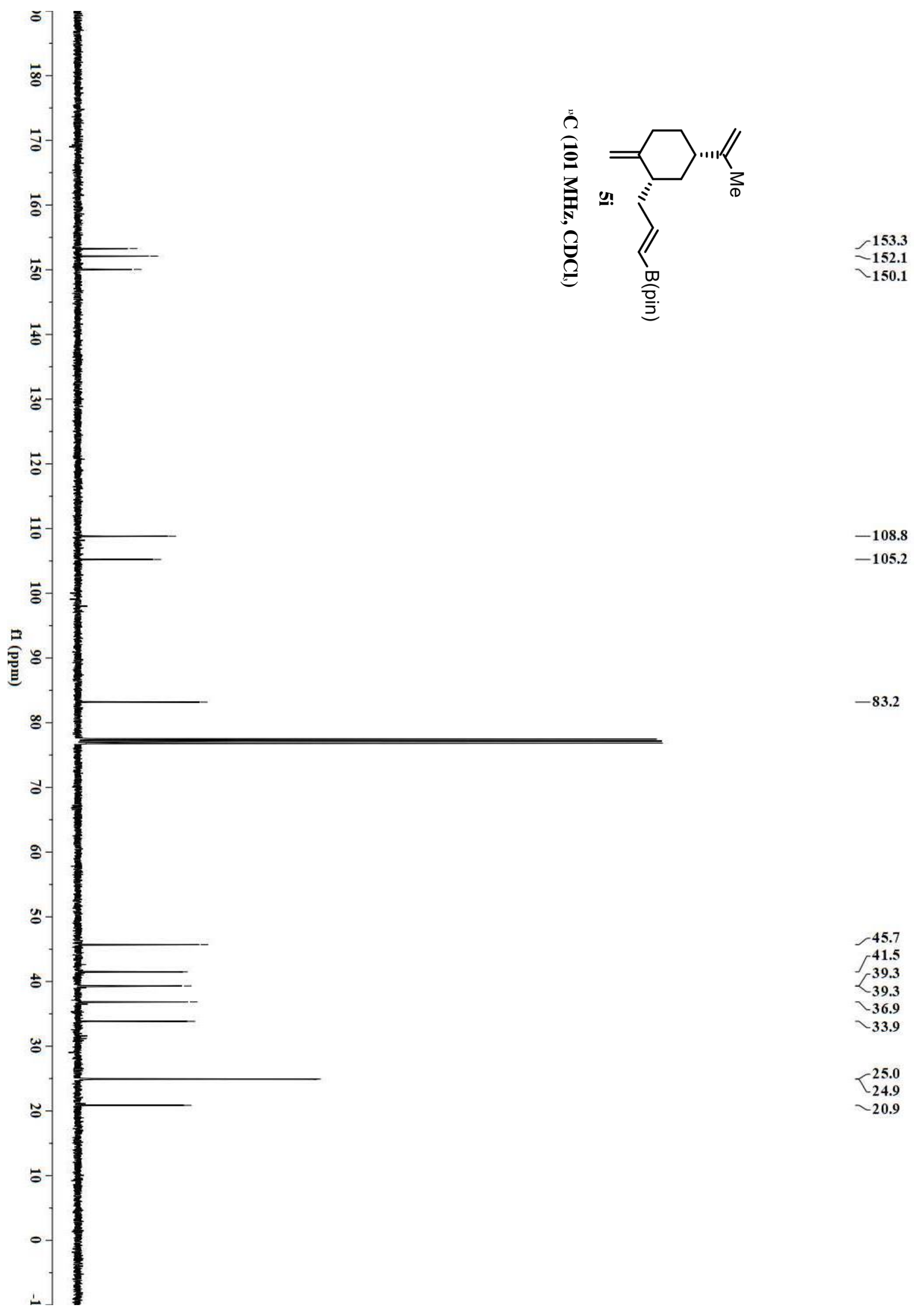




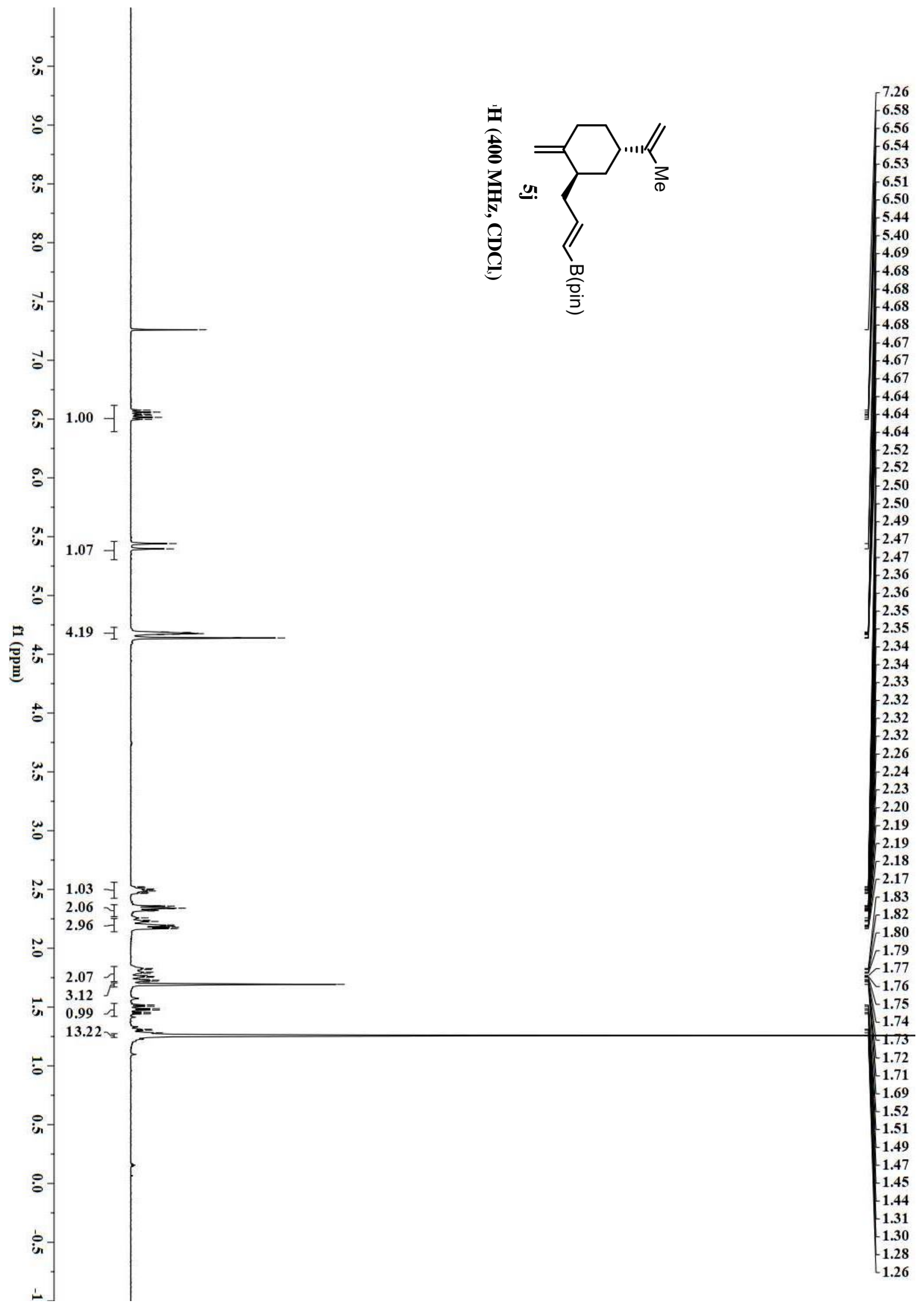



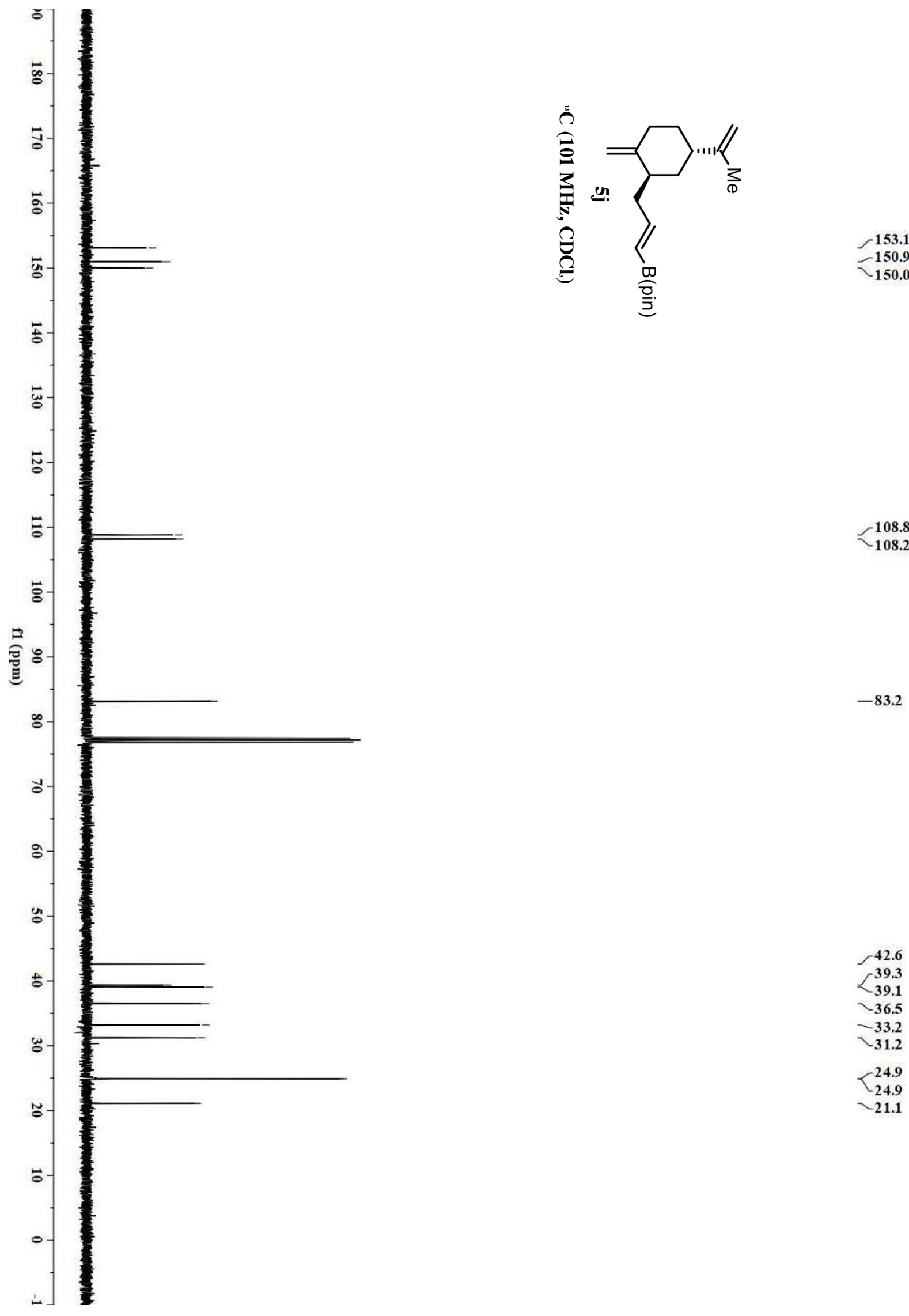

$\gamma_{150.0}$

$>36.5$

$-33.2$

$\checkmark 31.2$

$\chi_{24.9}^{24.9}$

$\sim 21.1$ 


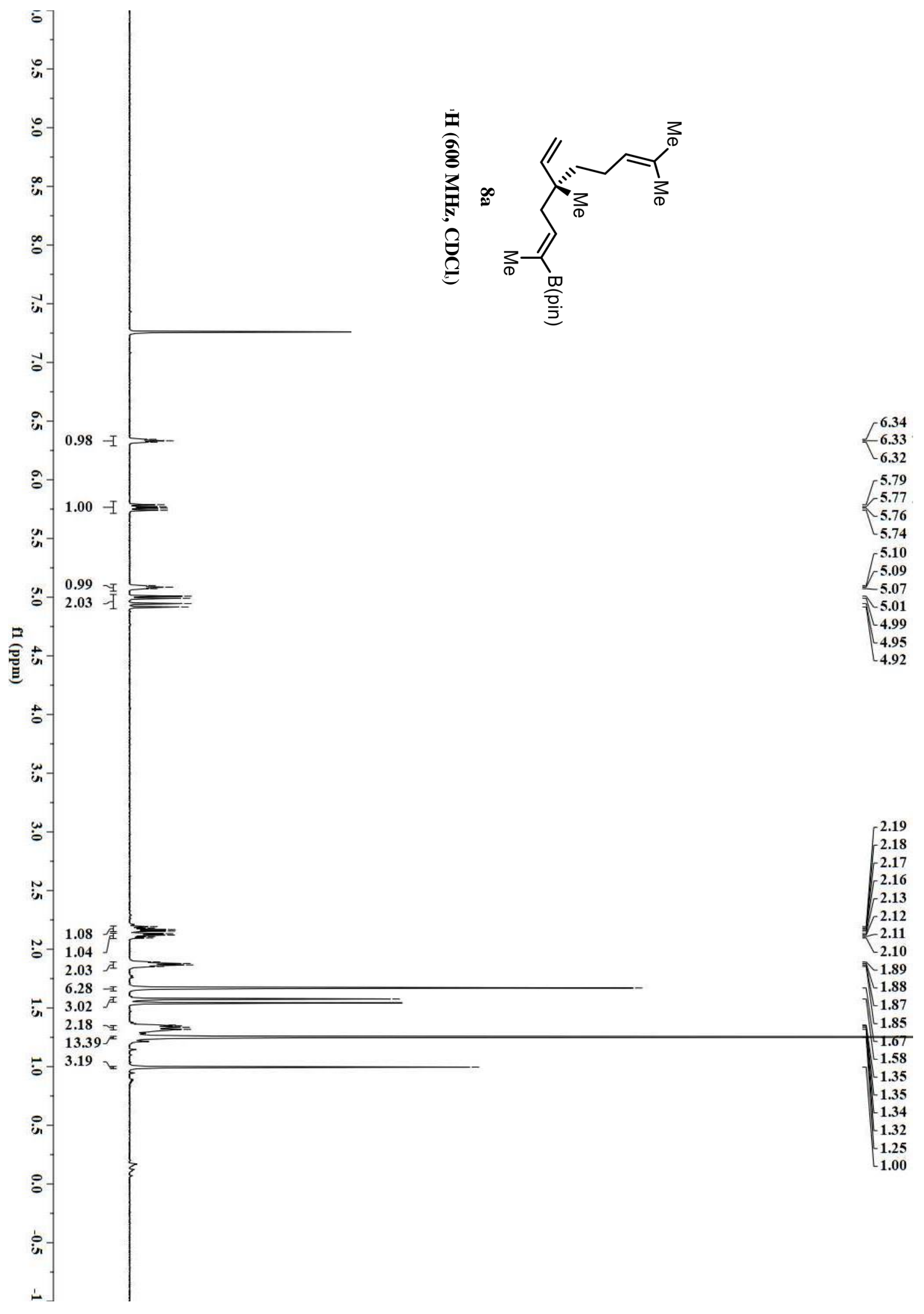




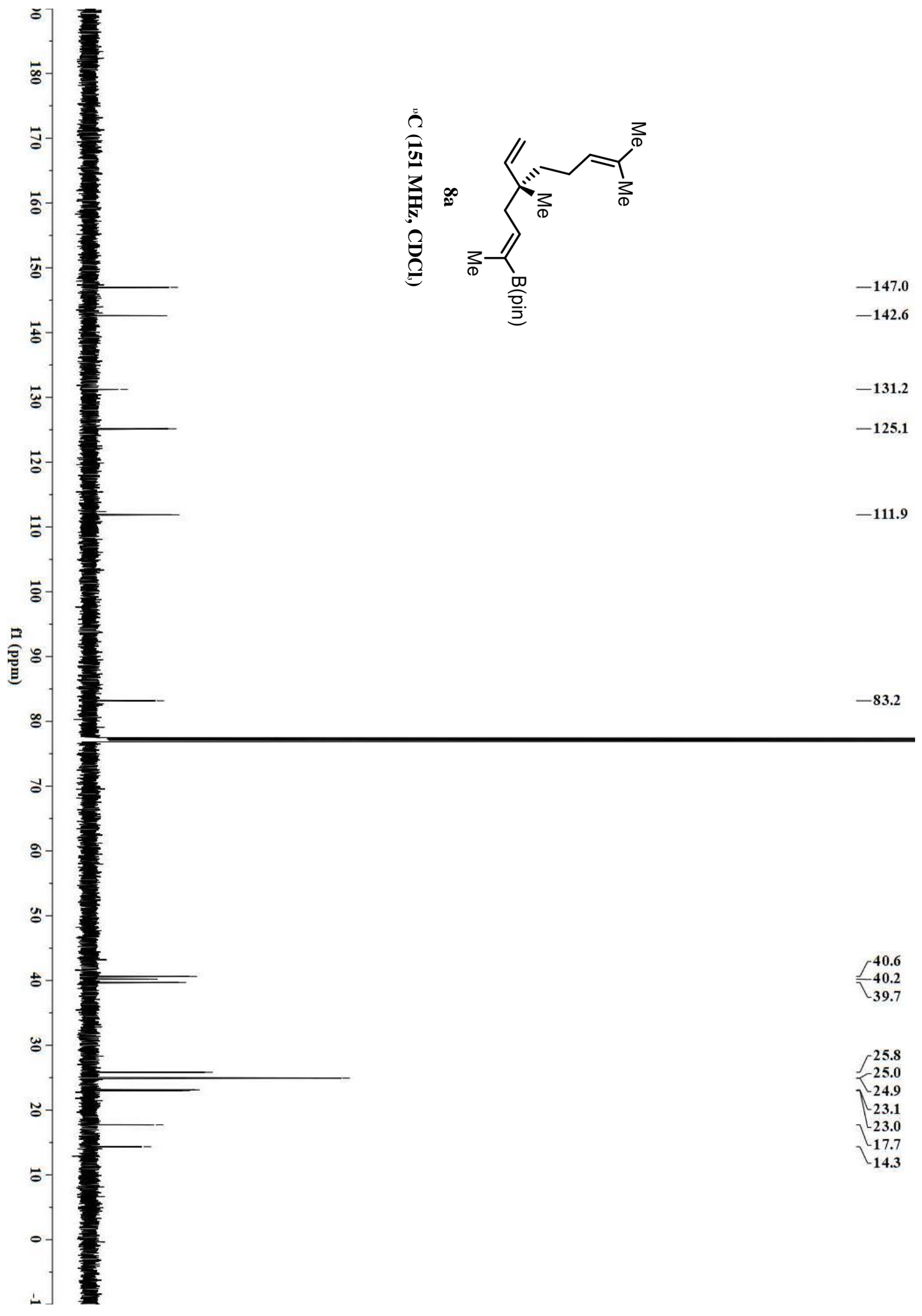




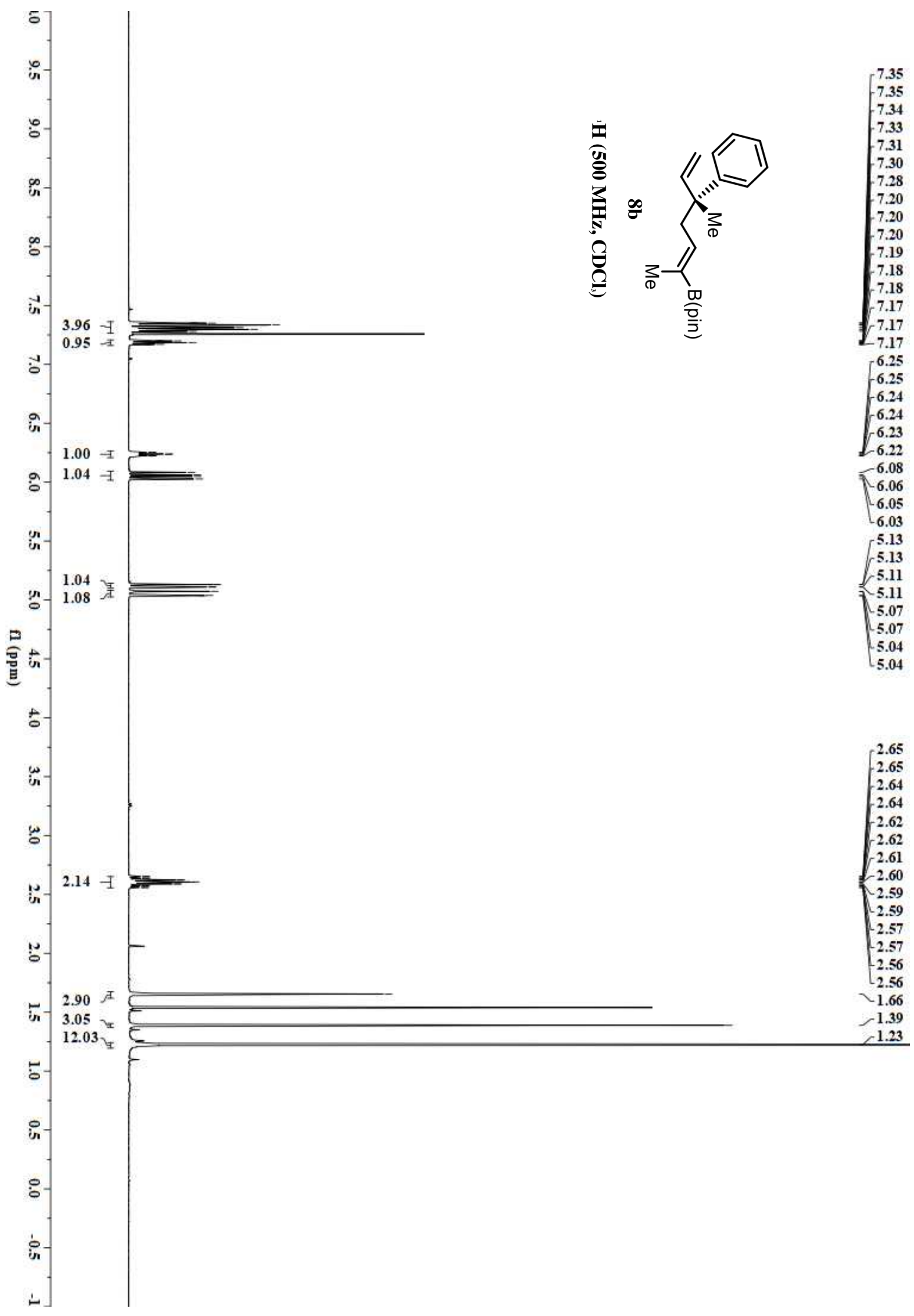




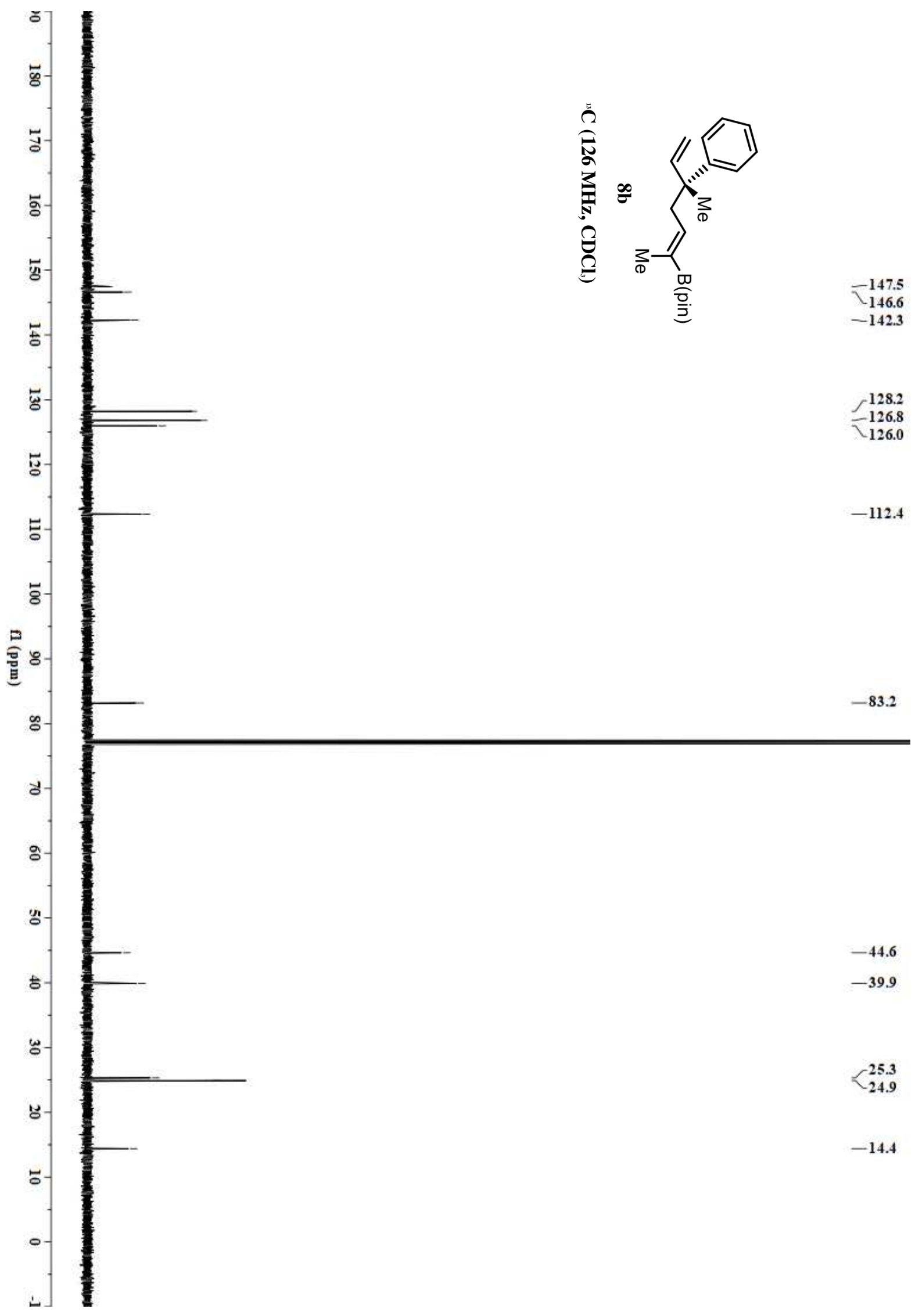




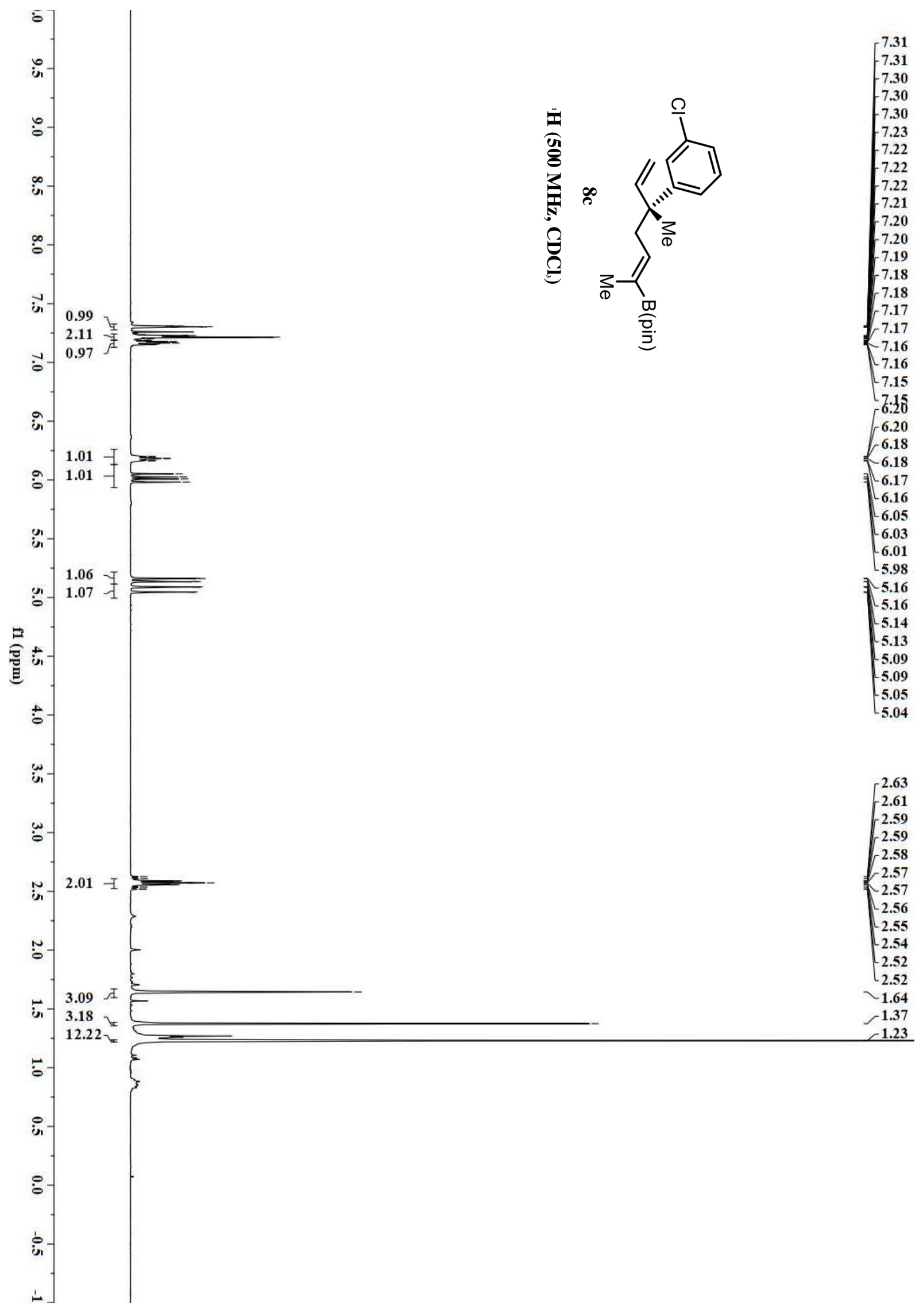




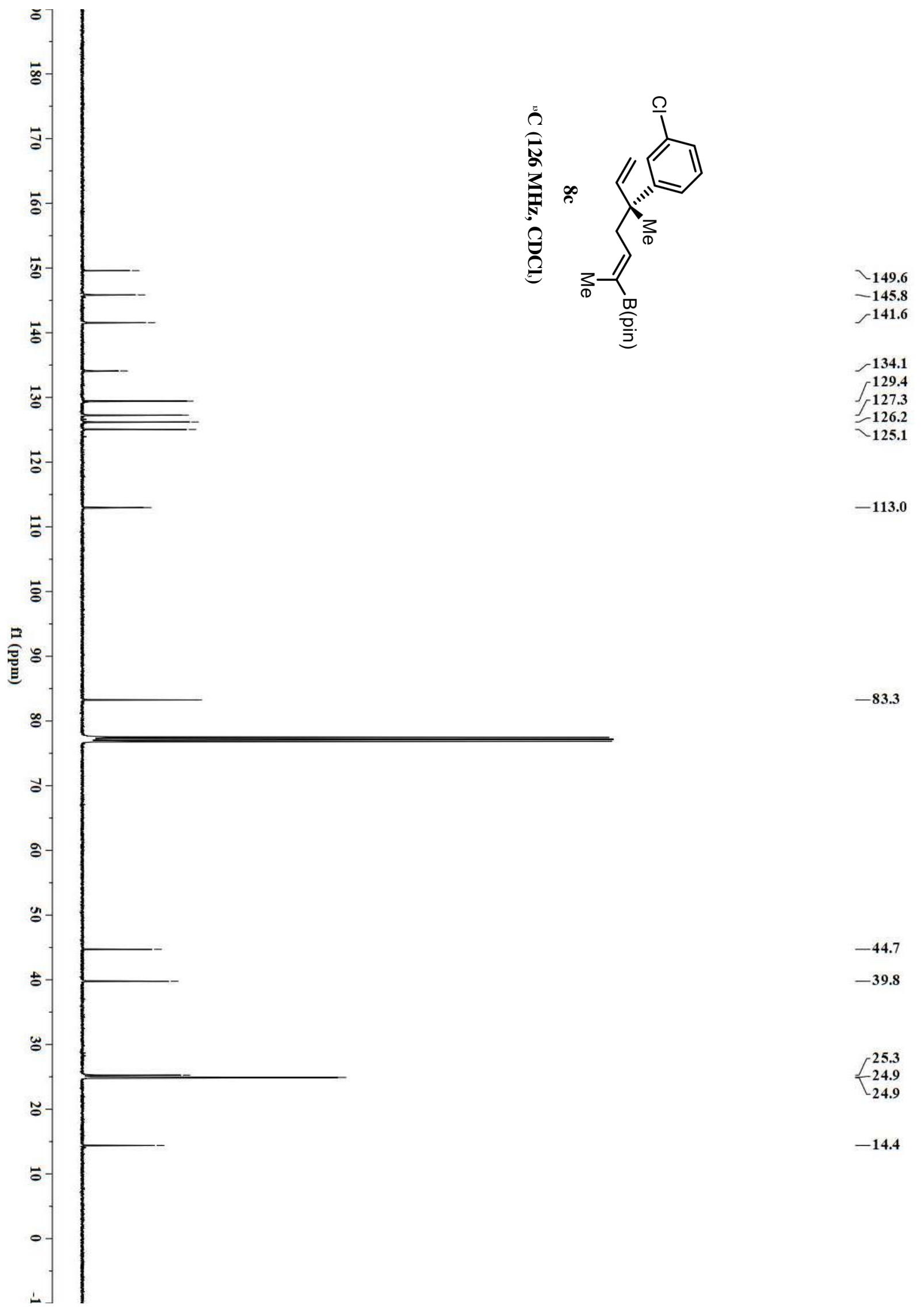




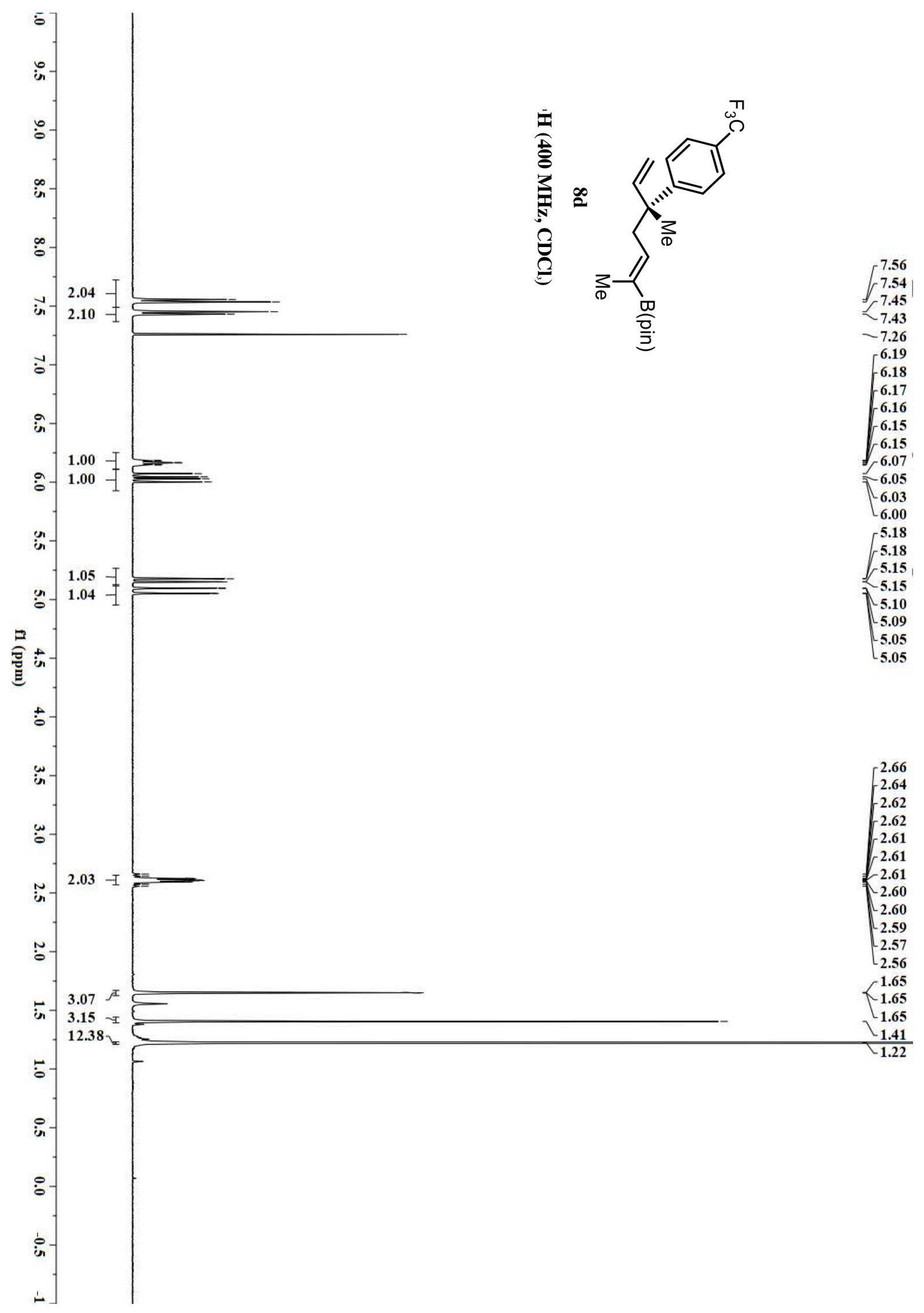




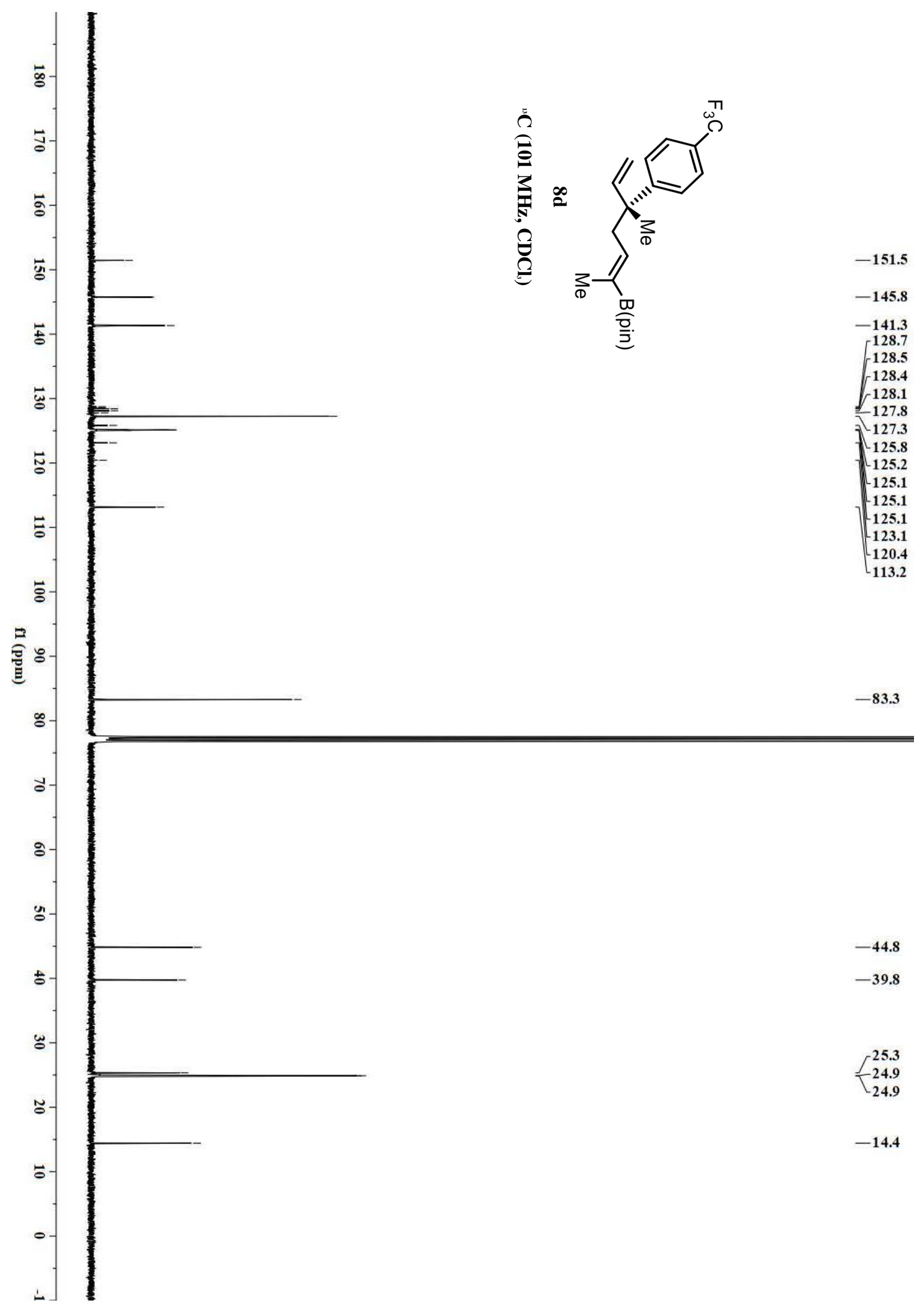




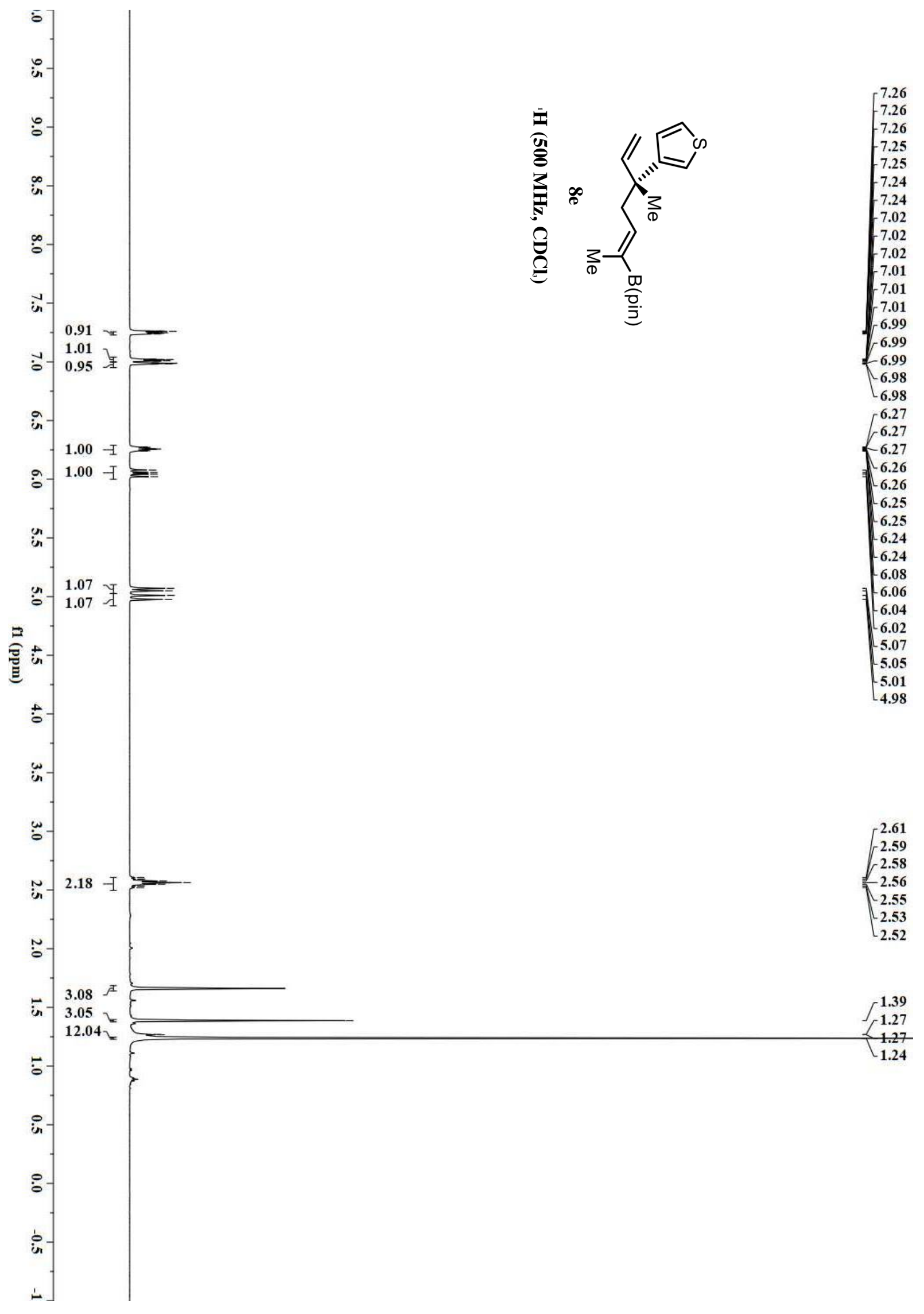




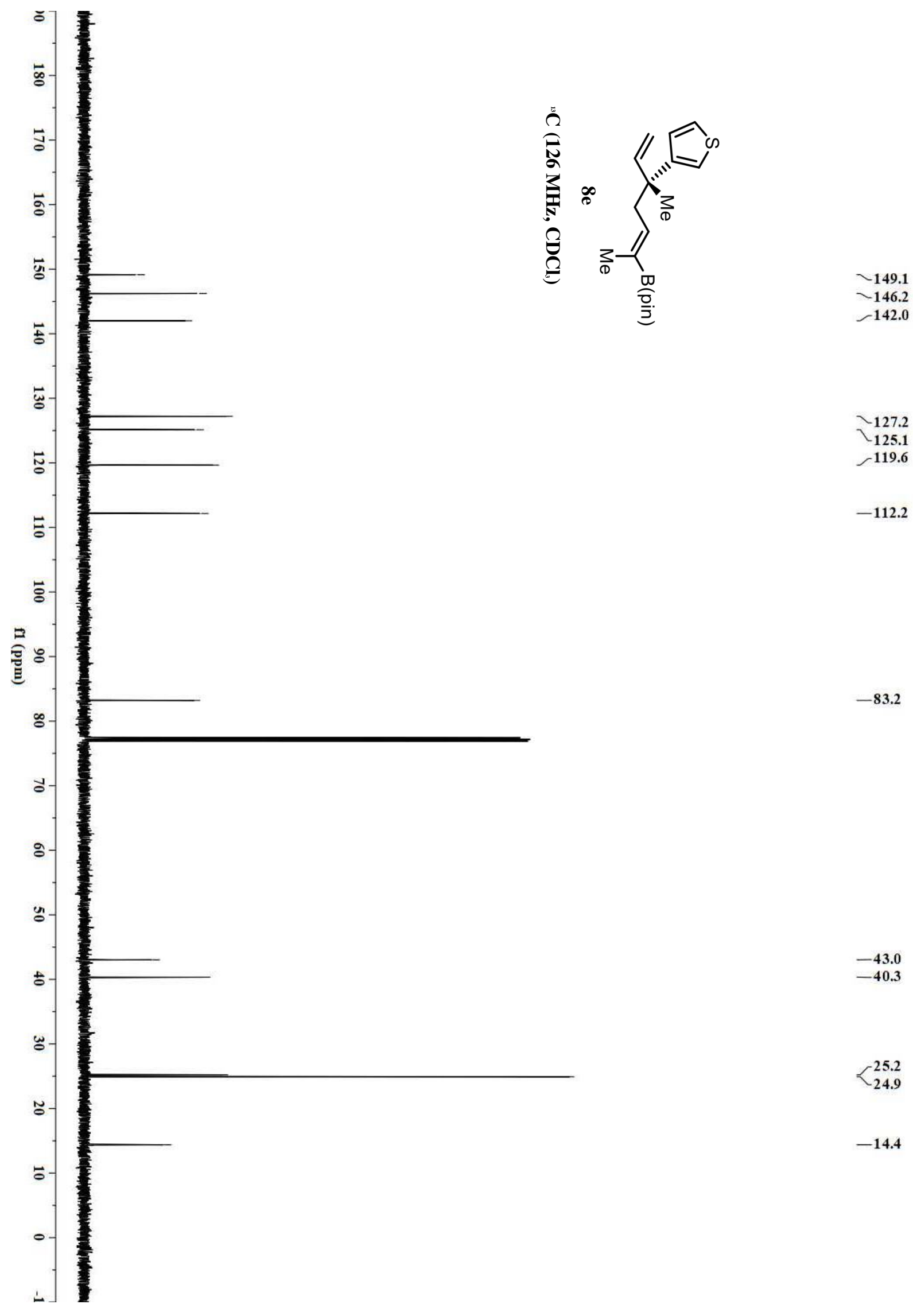




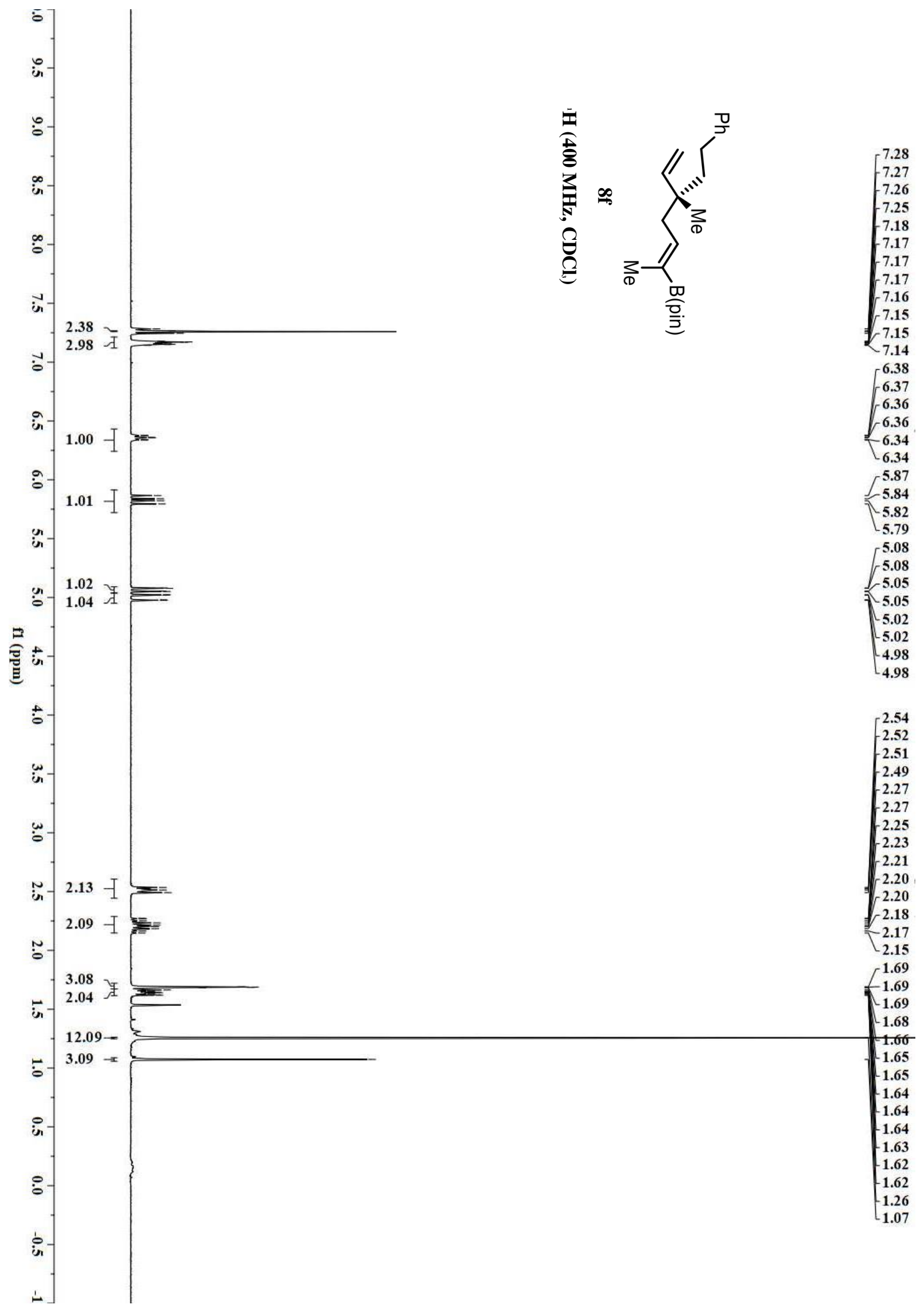




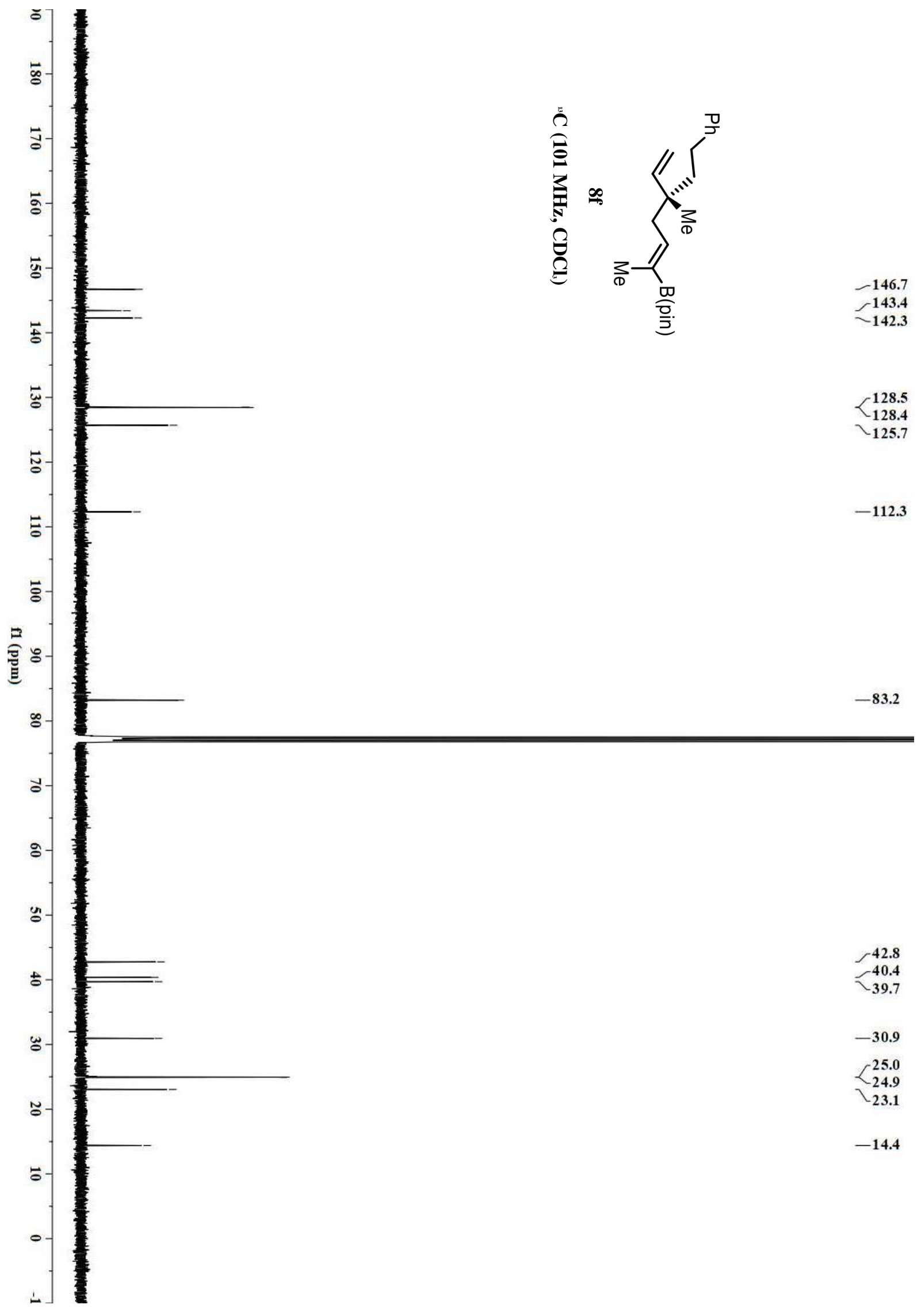




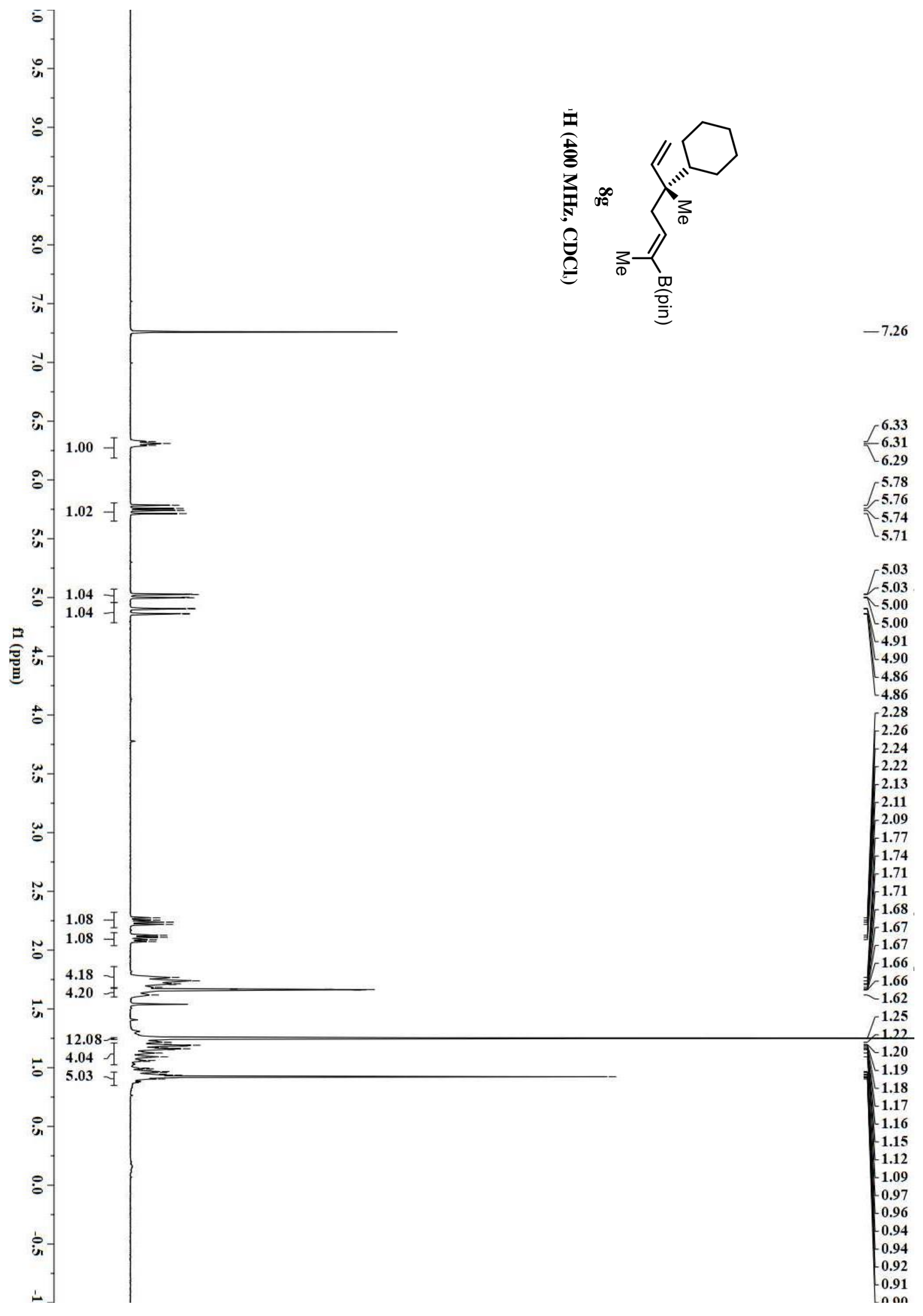




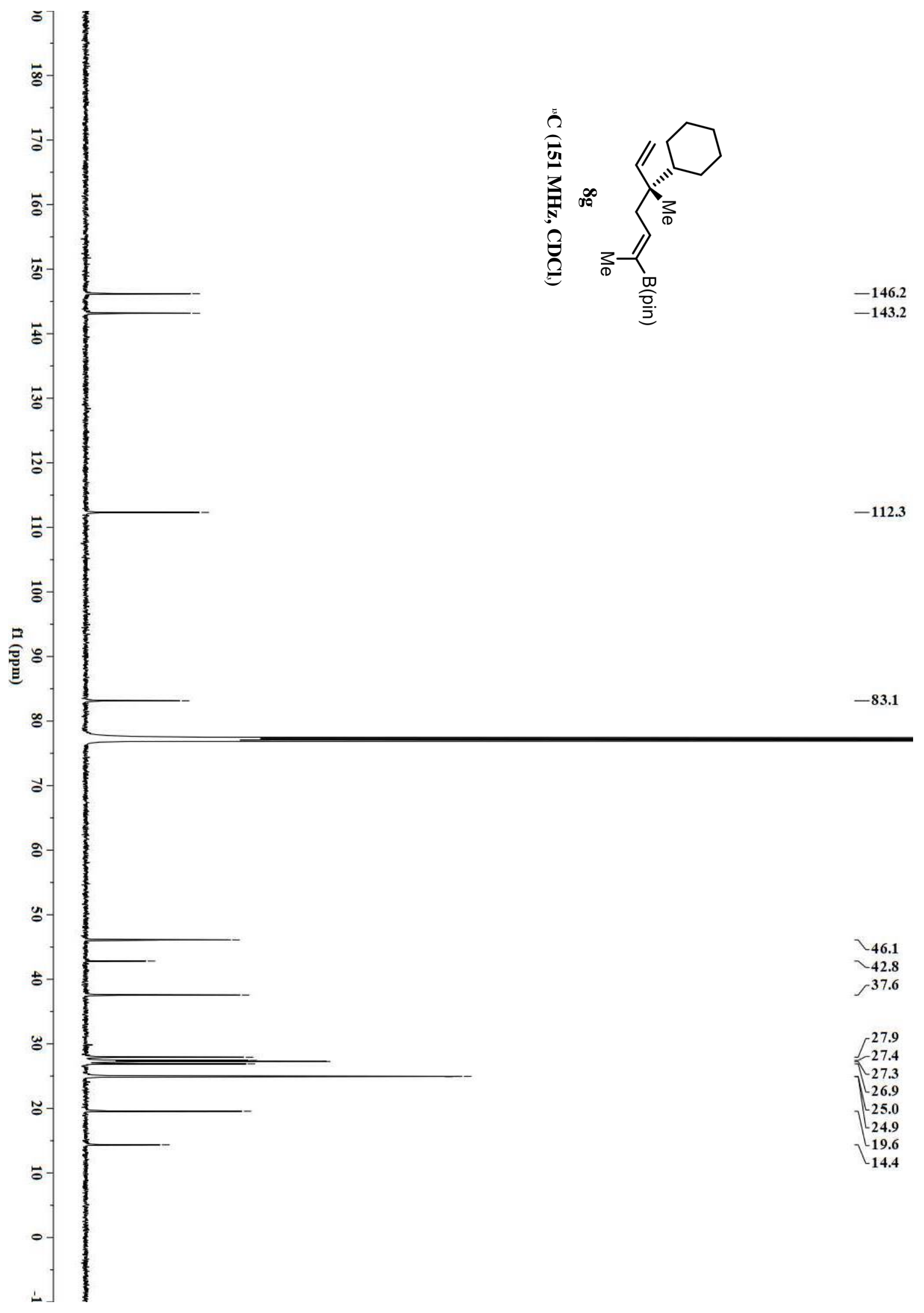




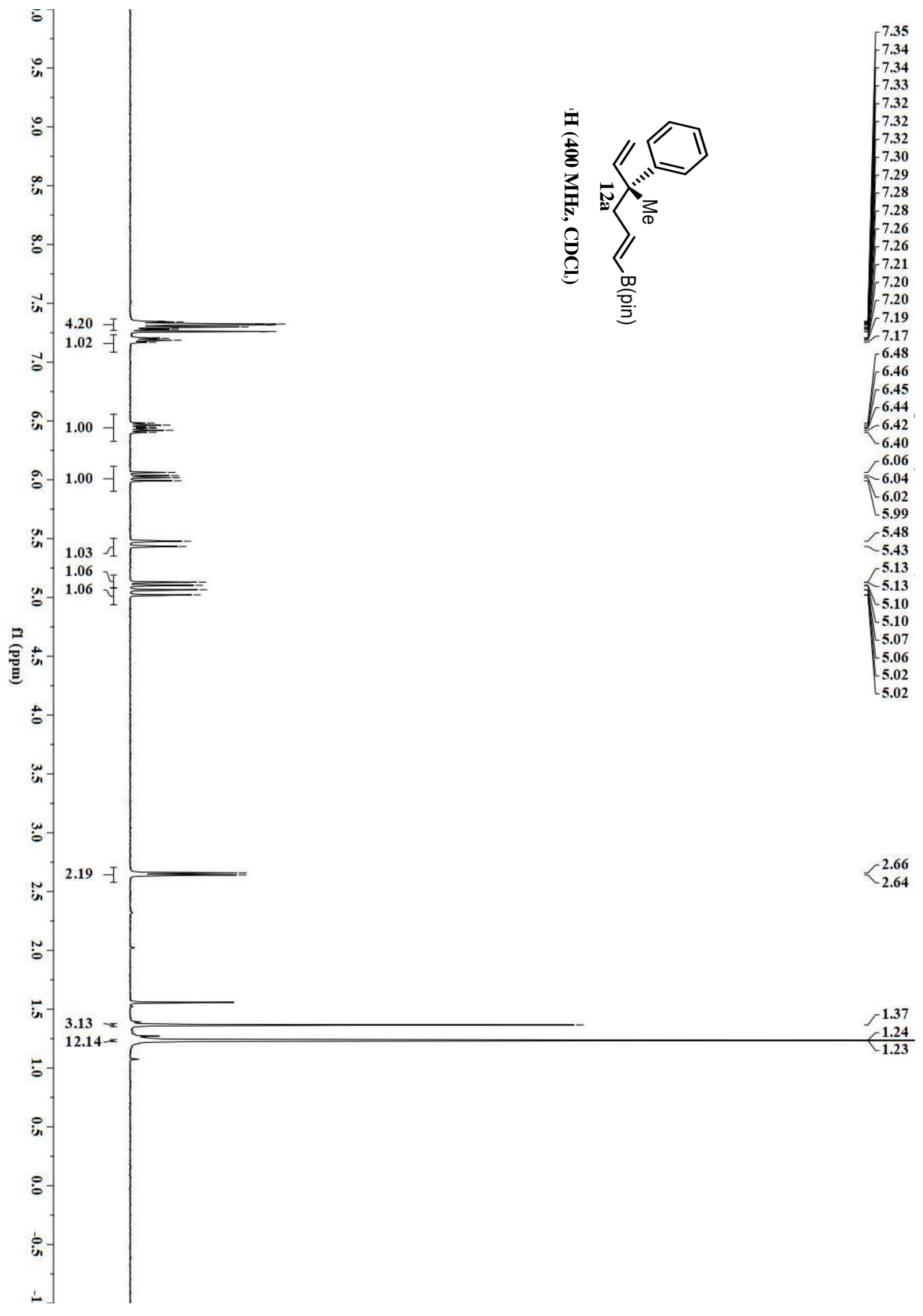




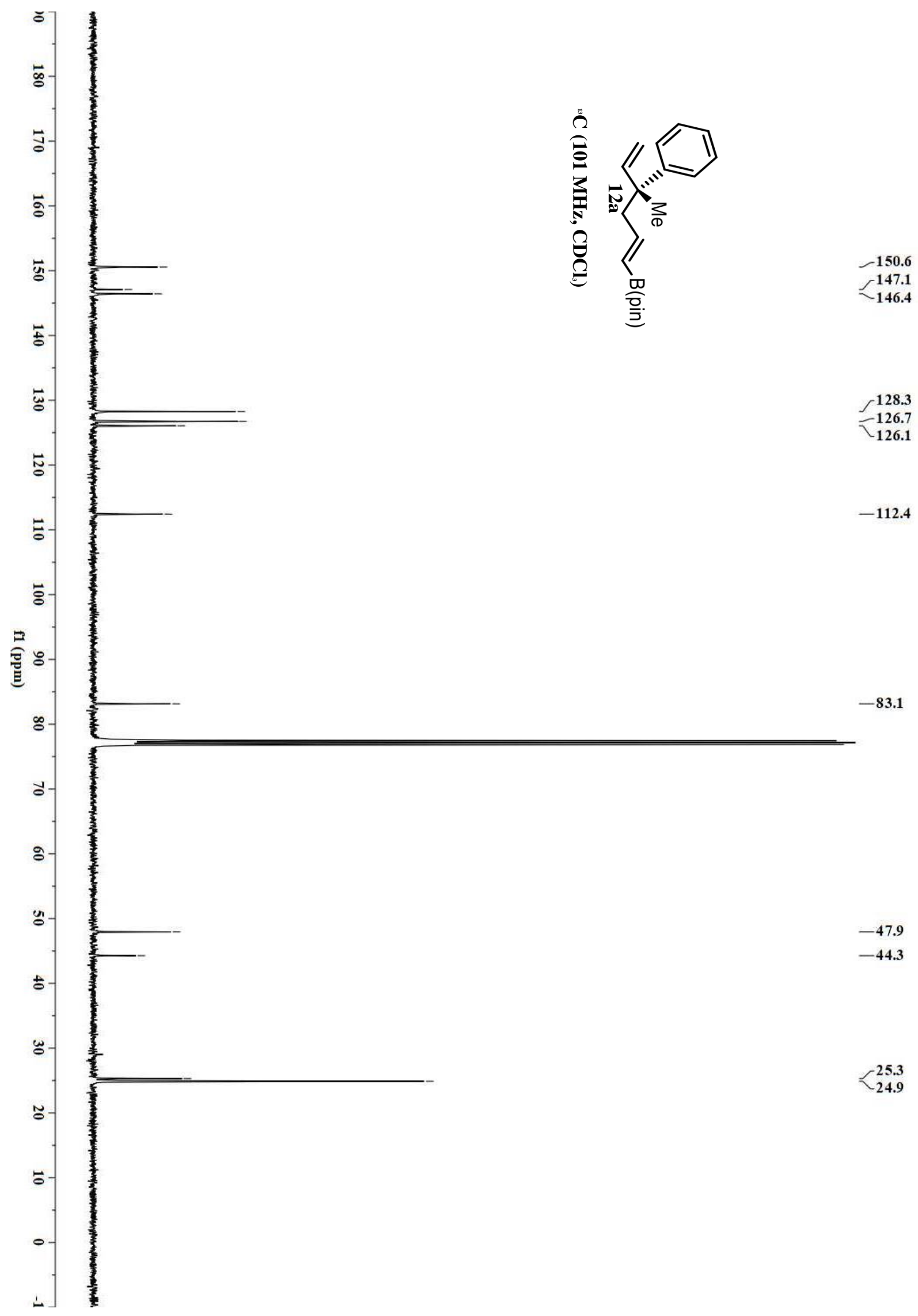




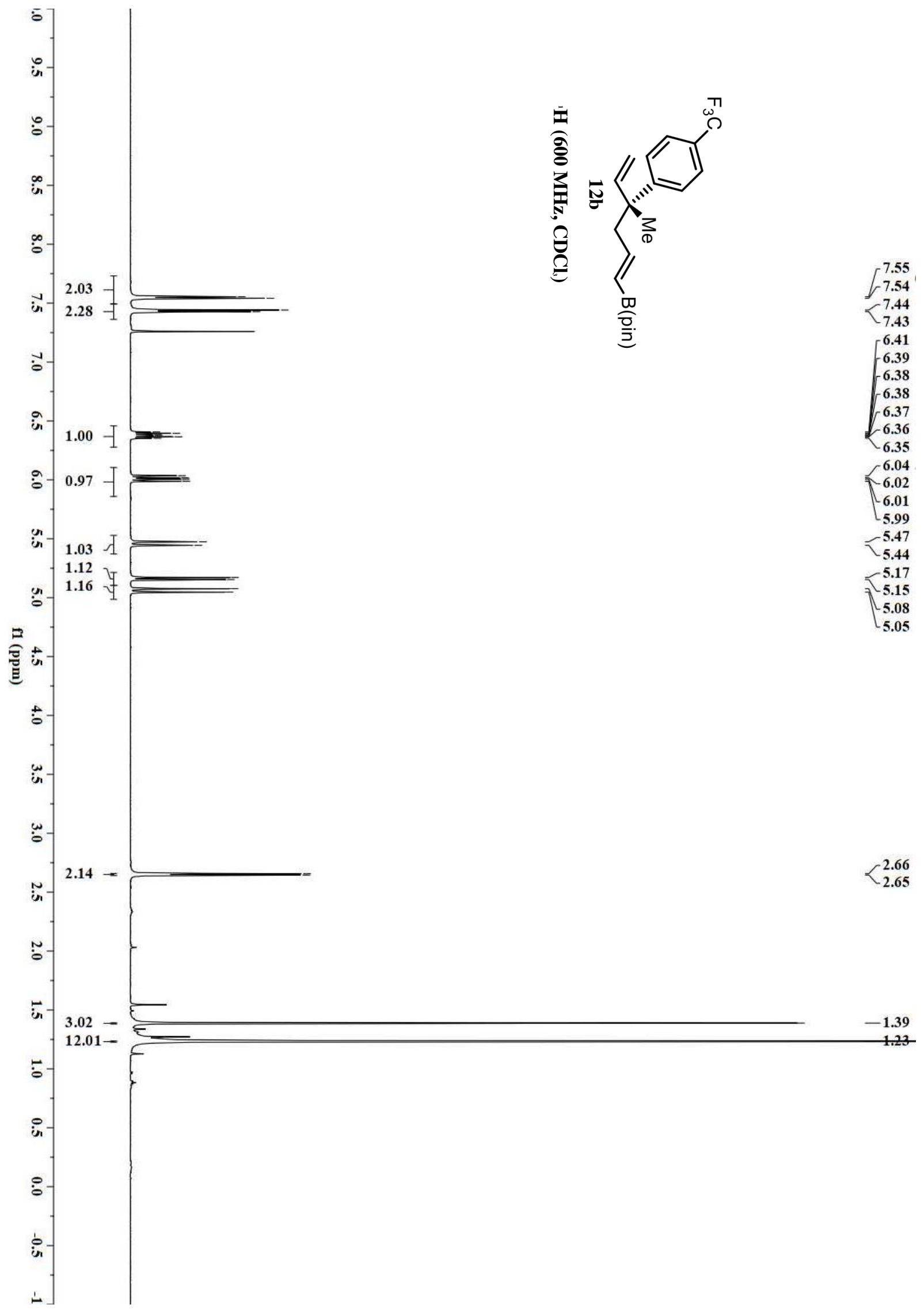




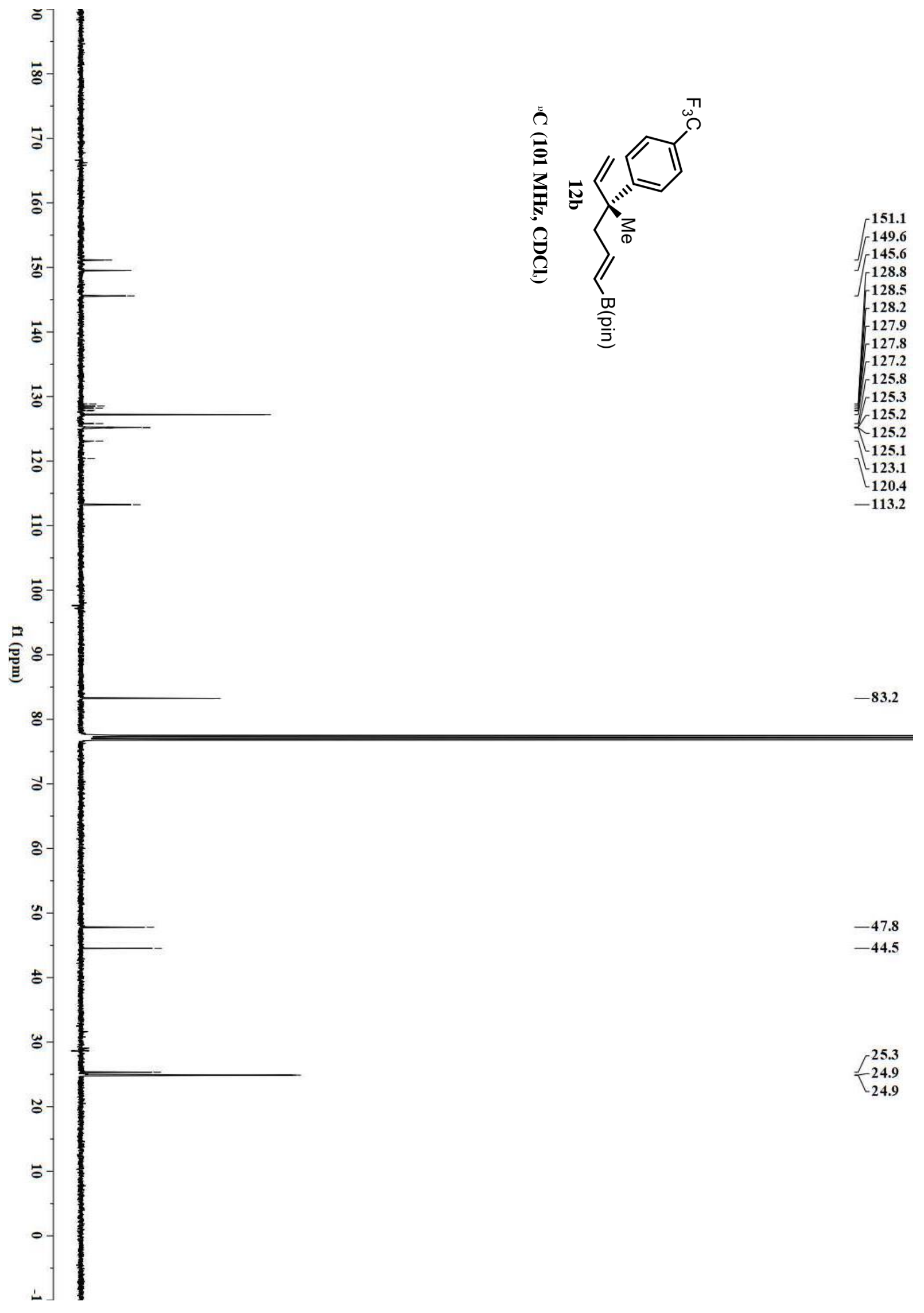




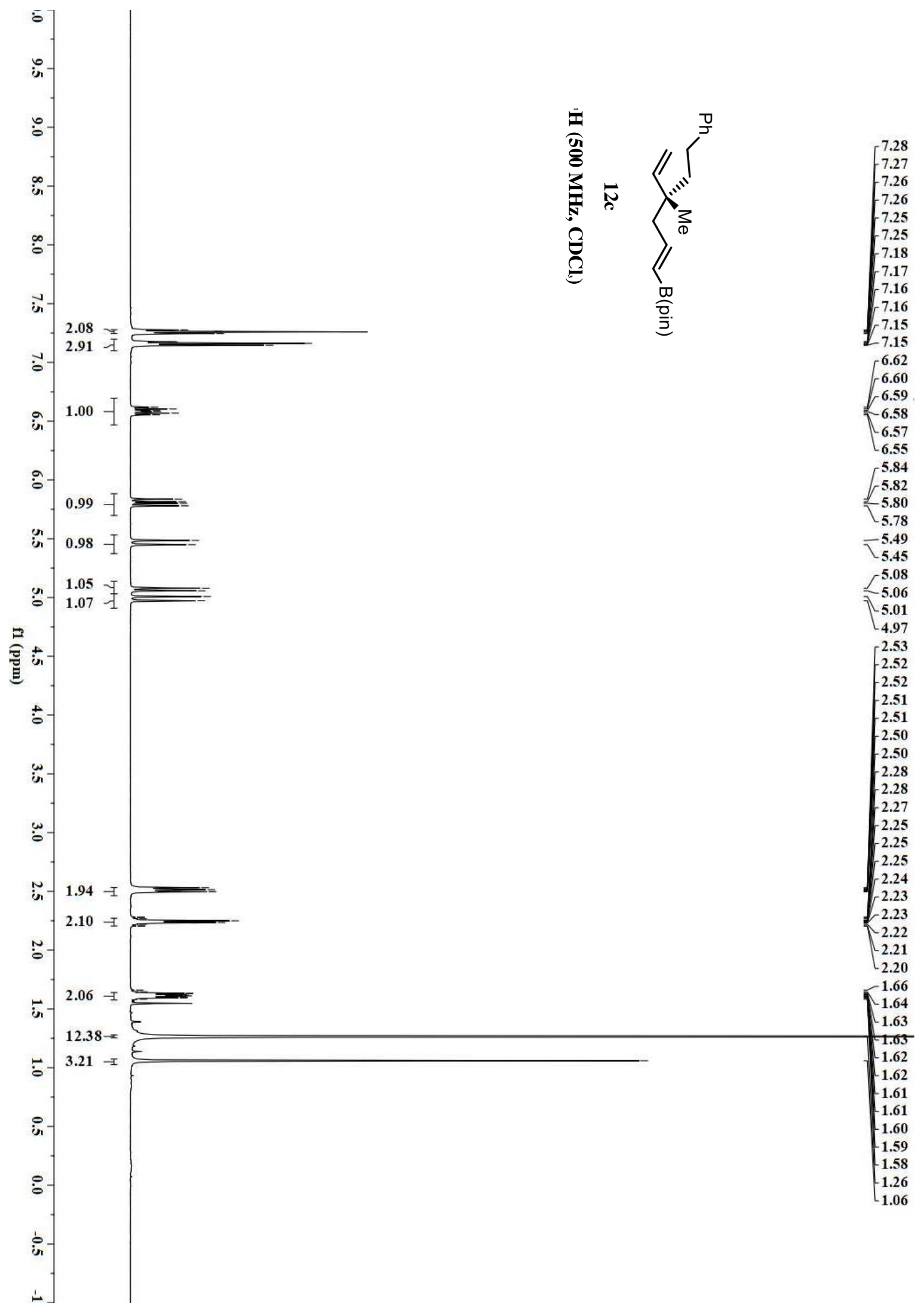


Sun, et al., Supporting Information, Page S252

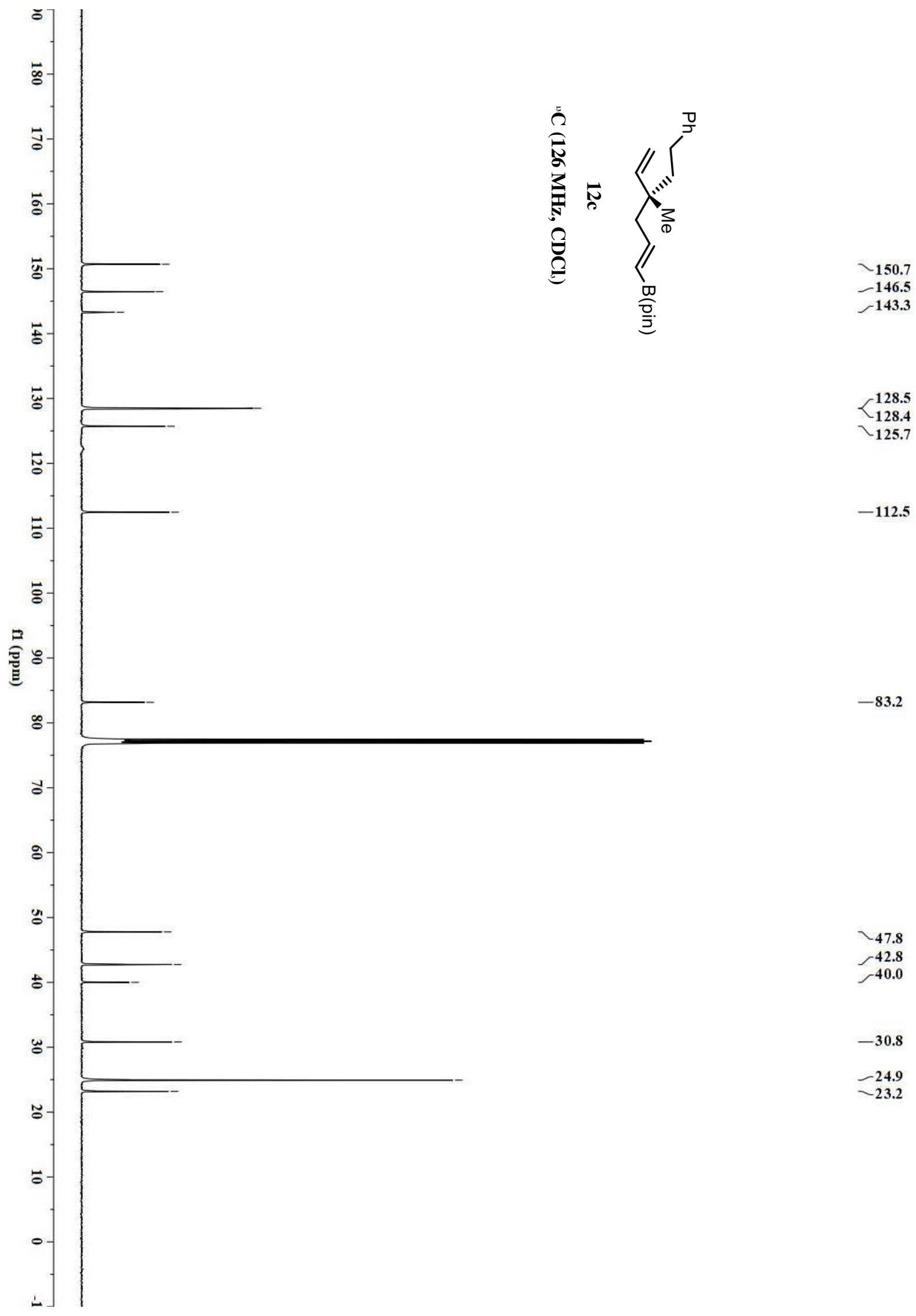




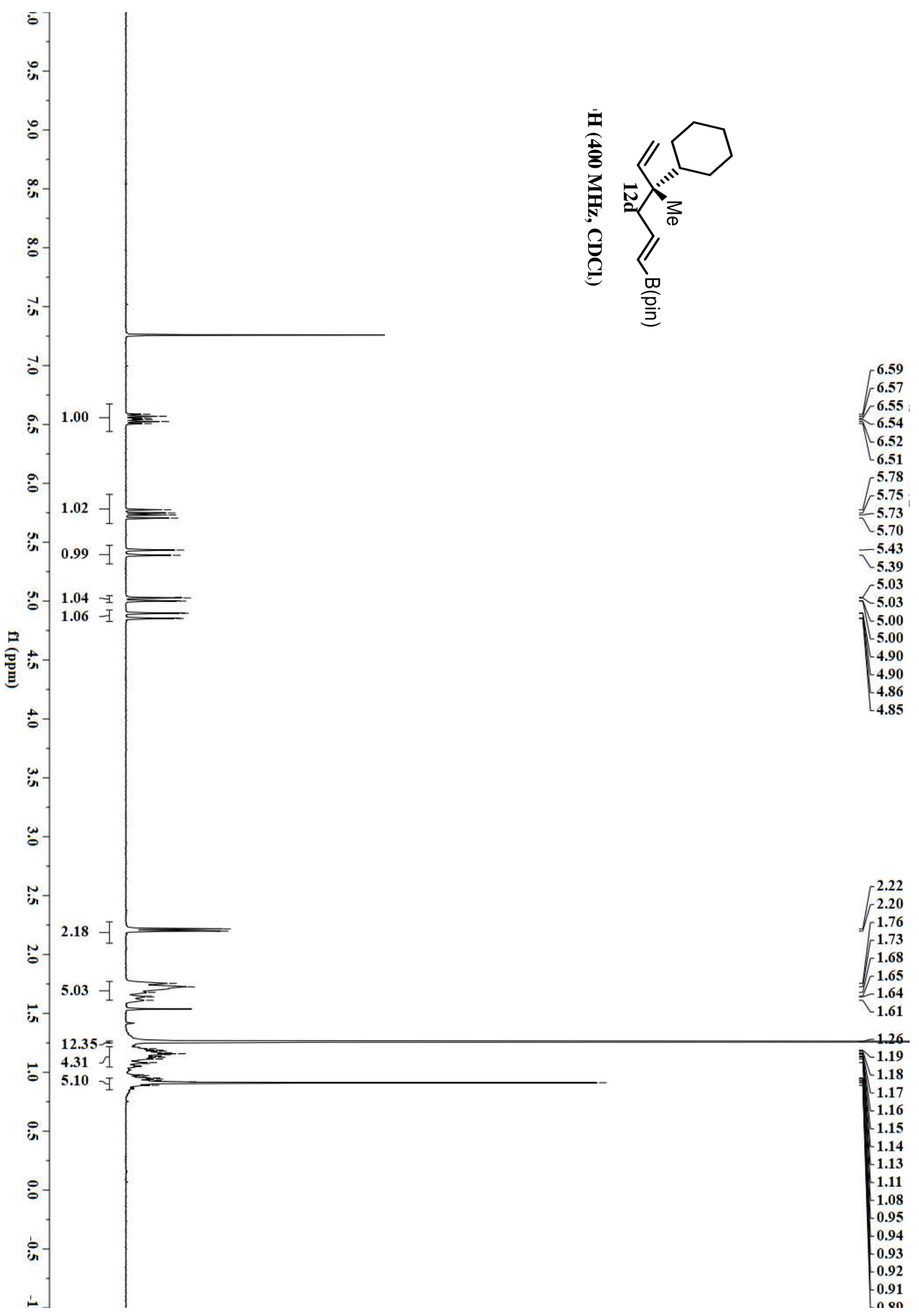




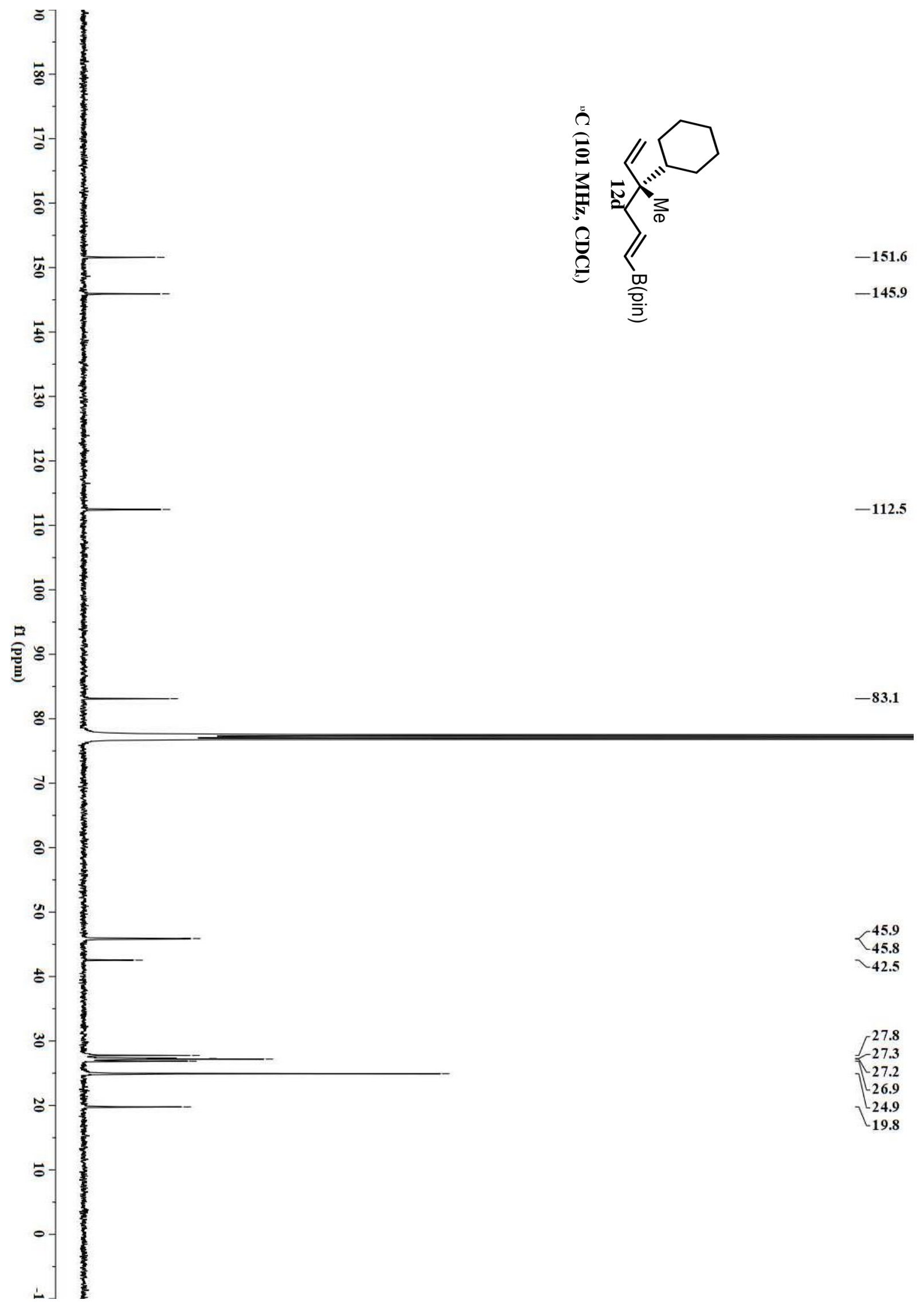




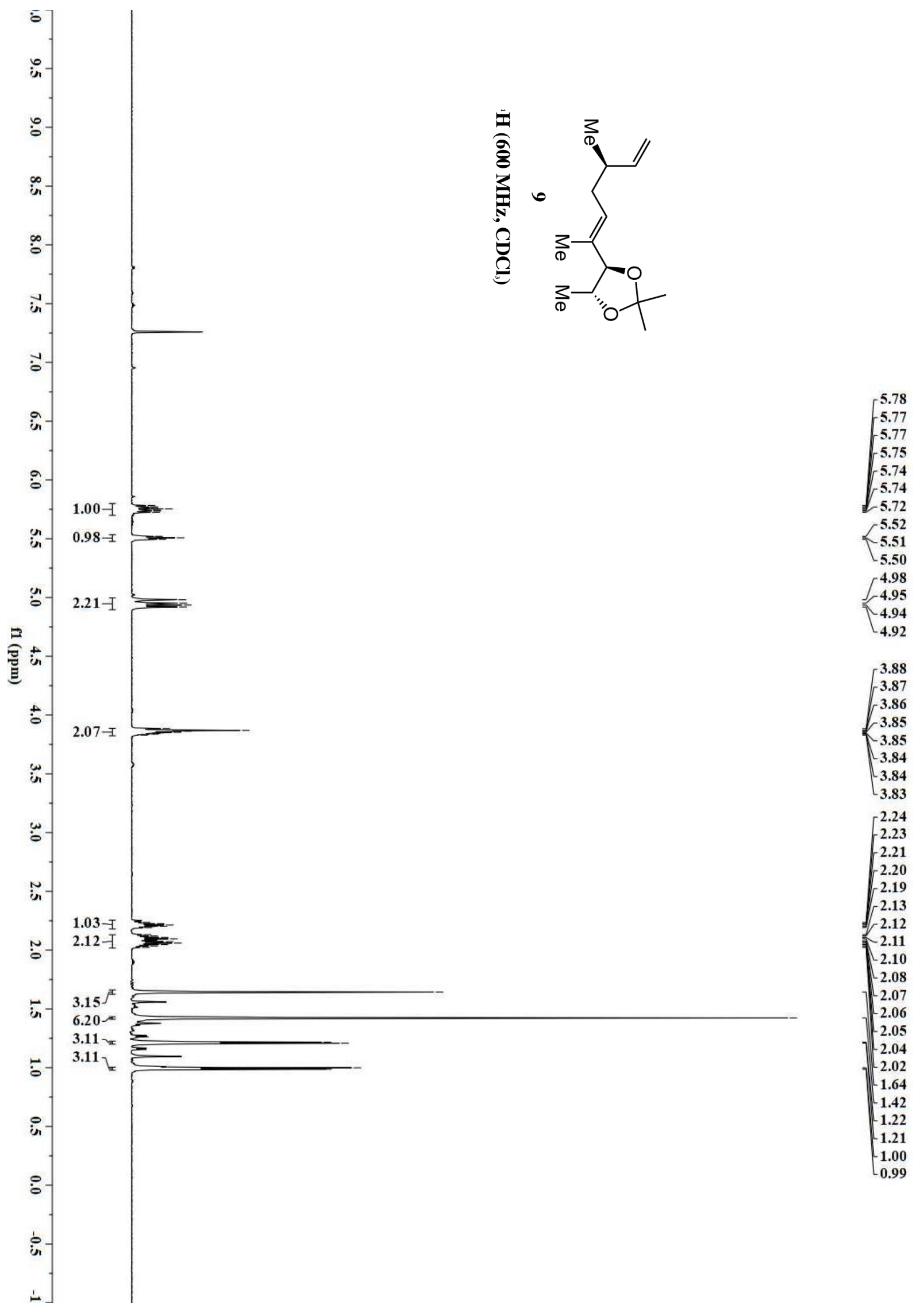


Sun, et al., Supporting Information, Page S256

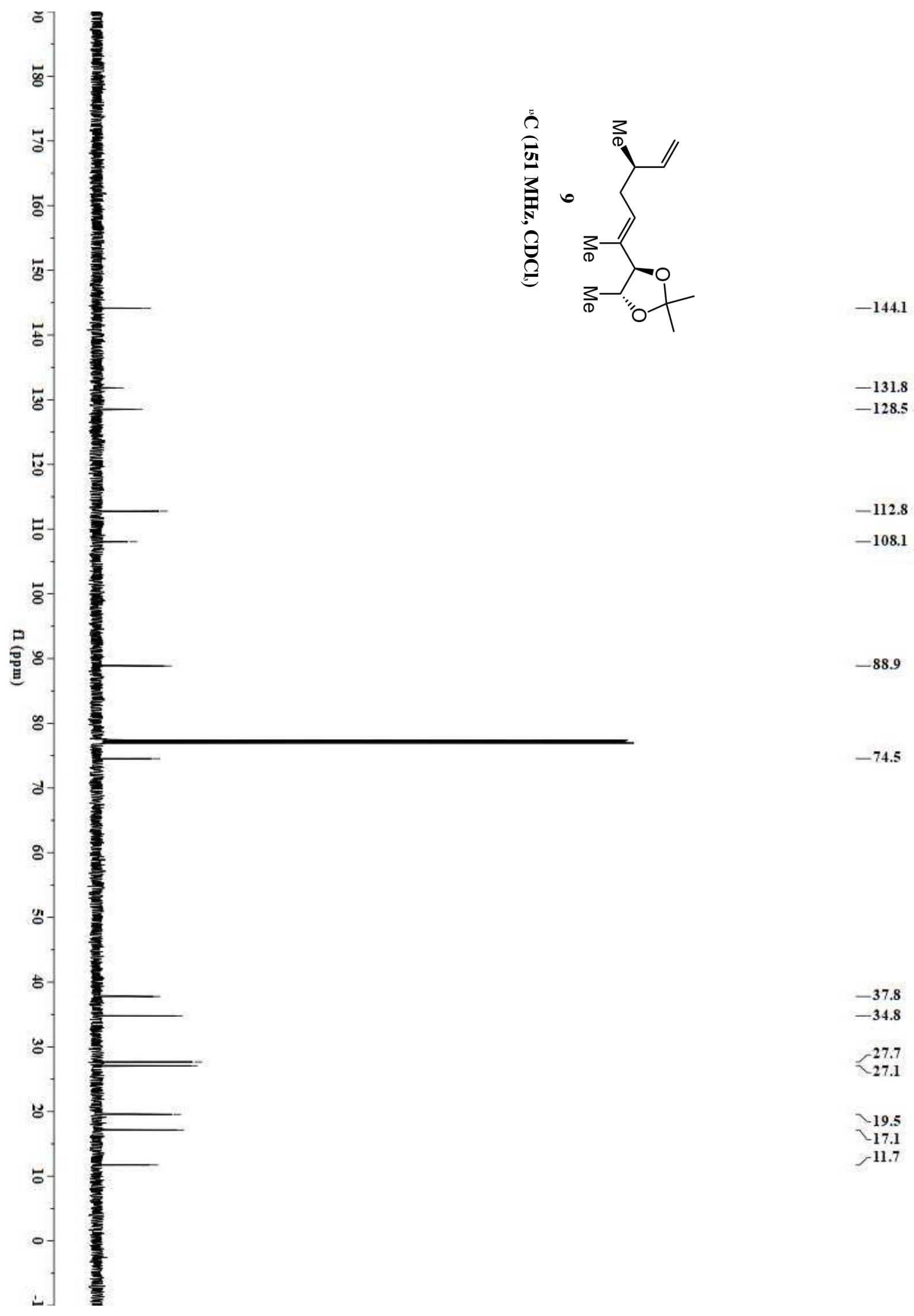




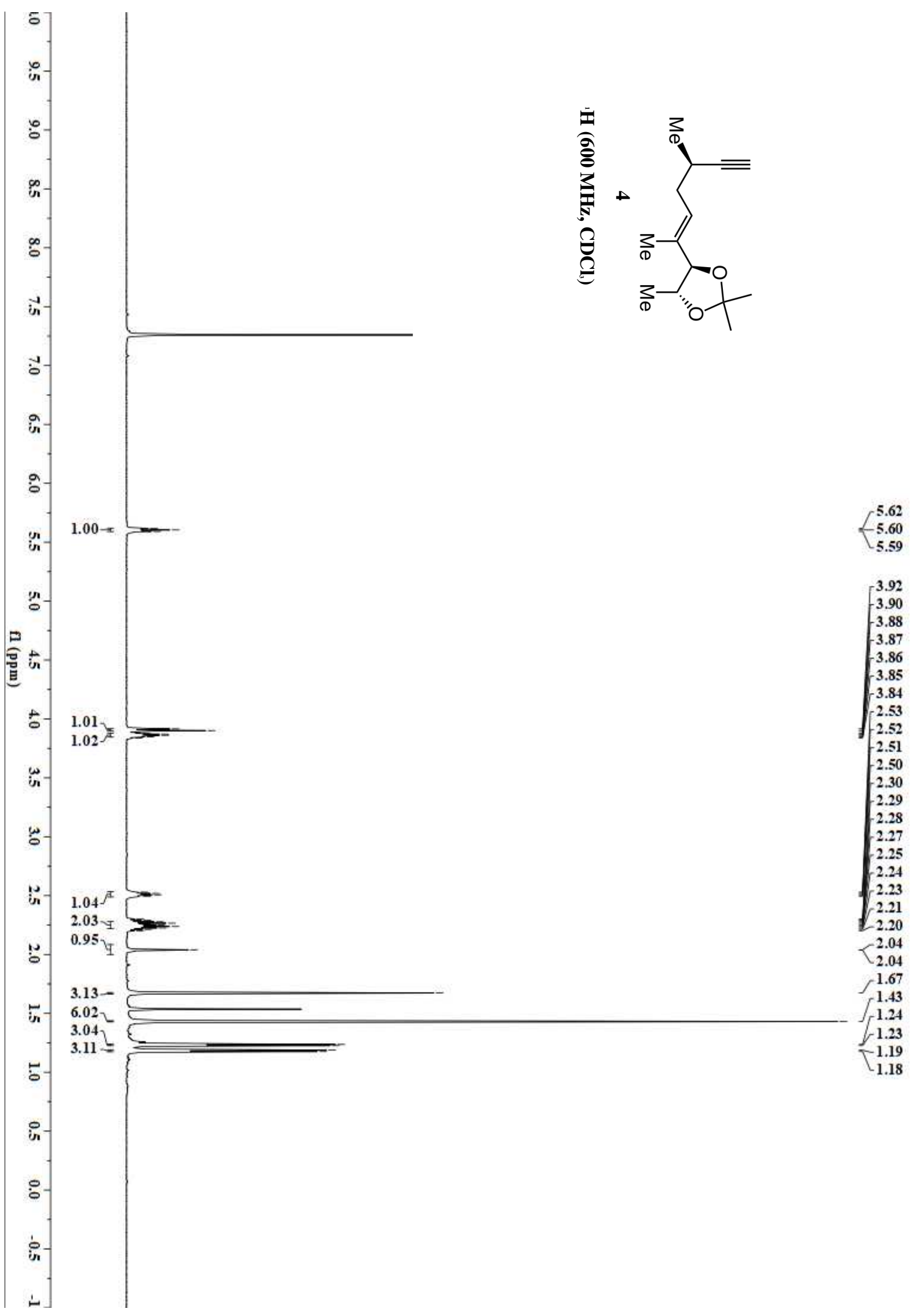




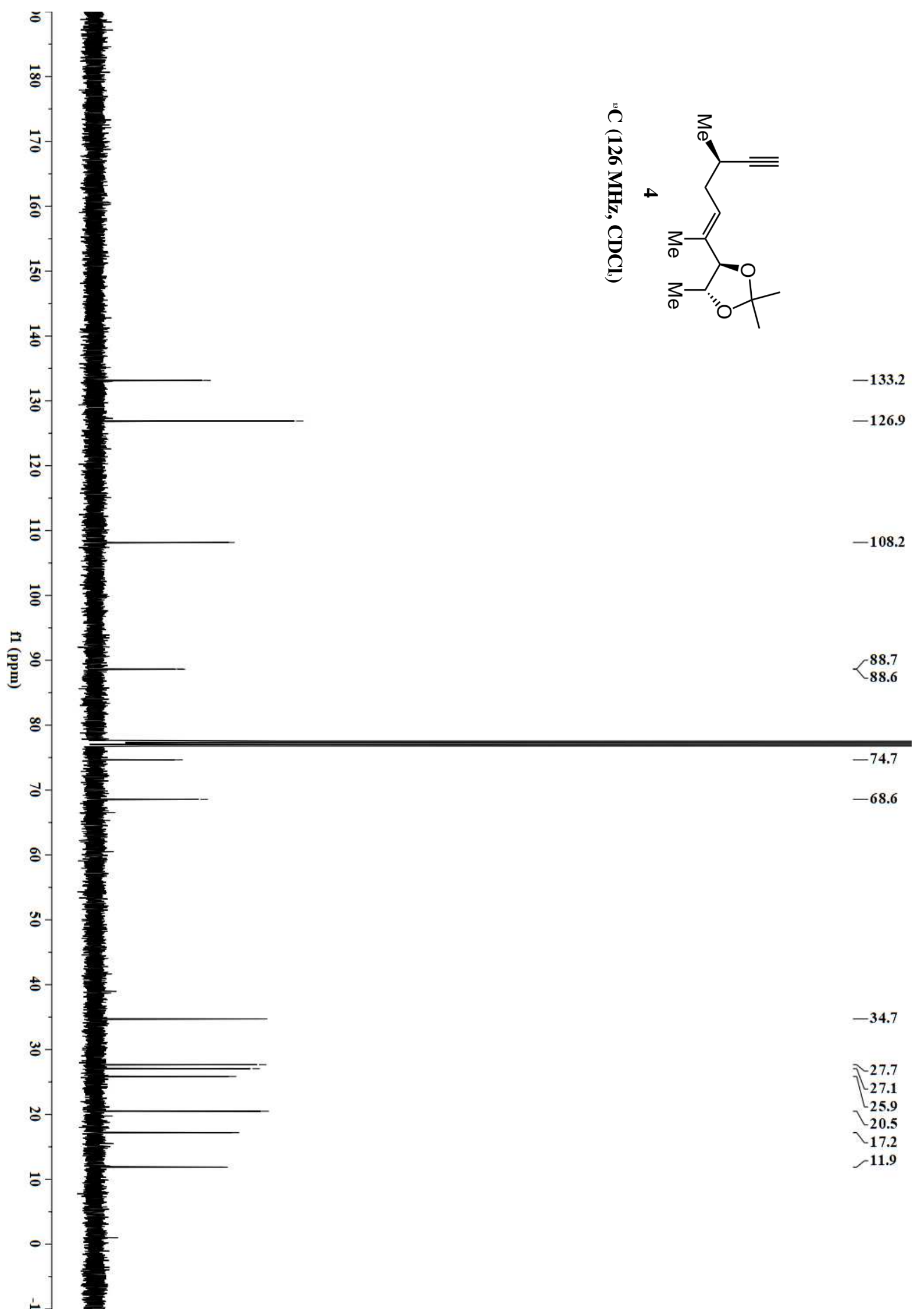




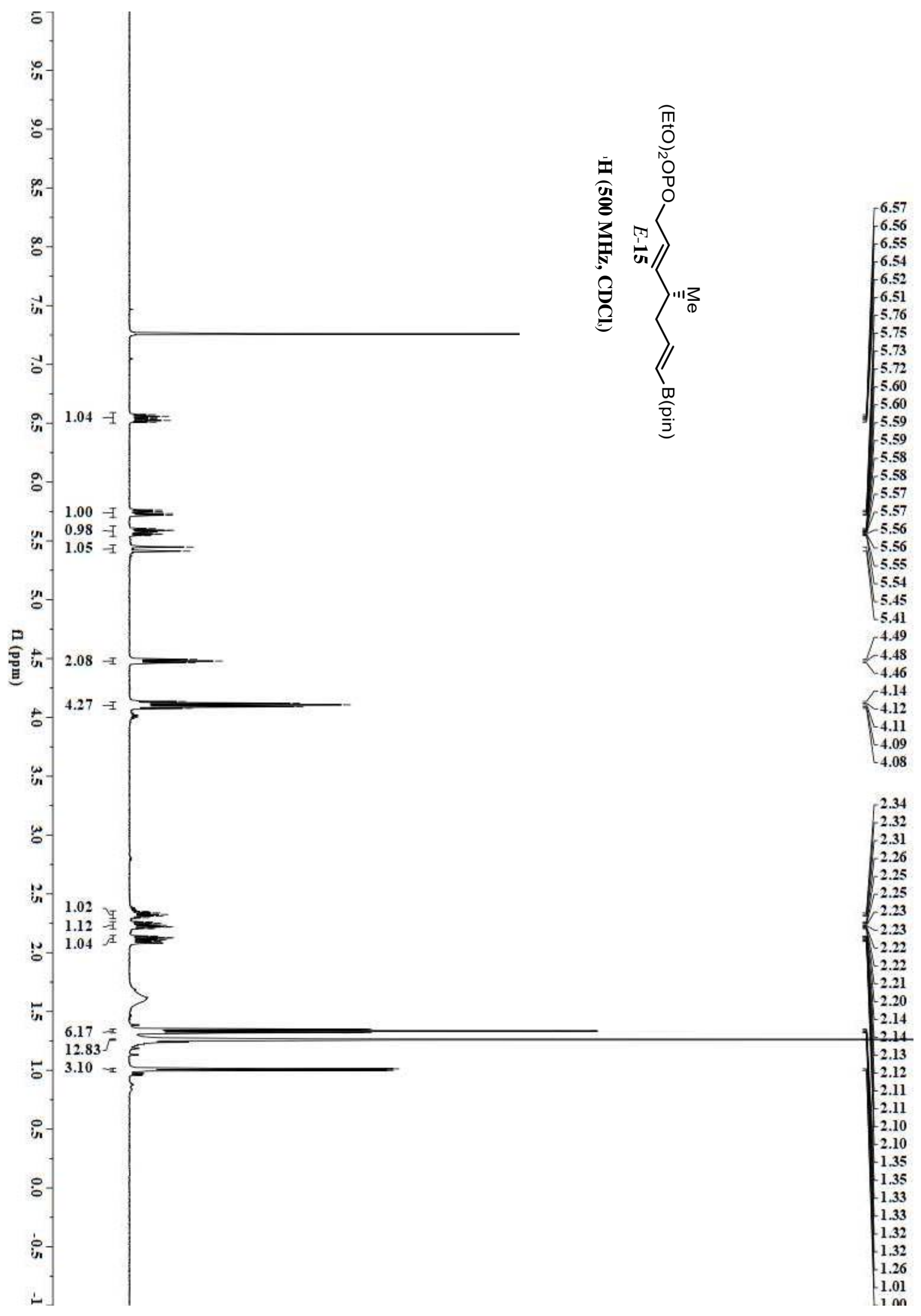




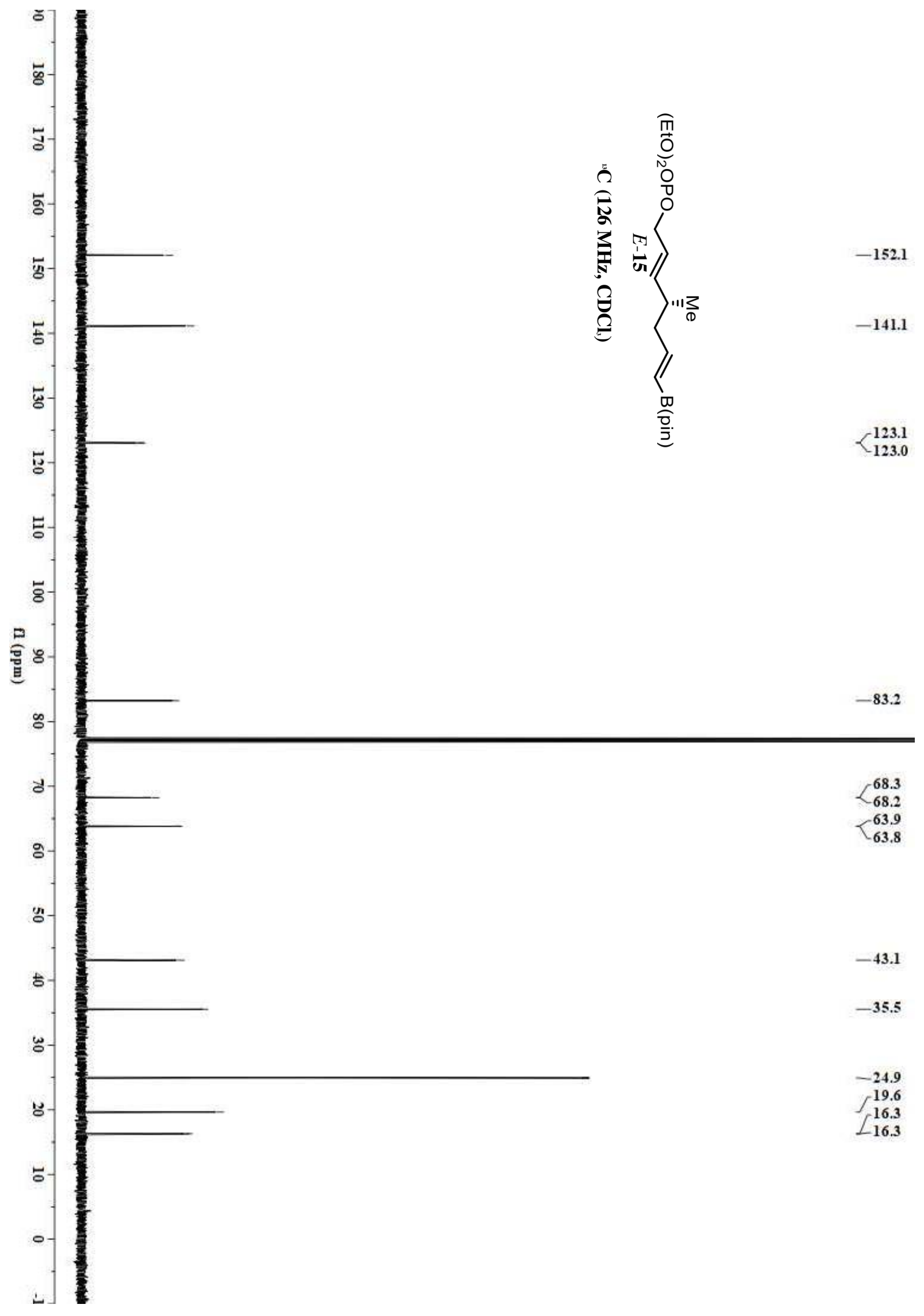




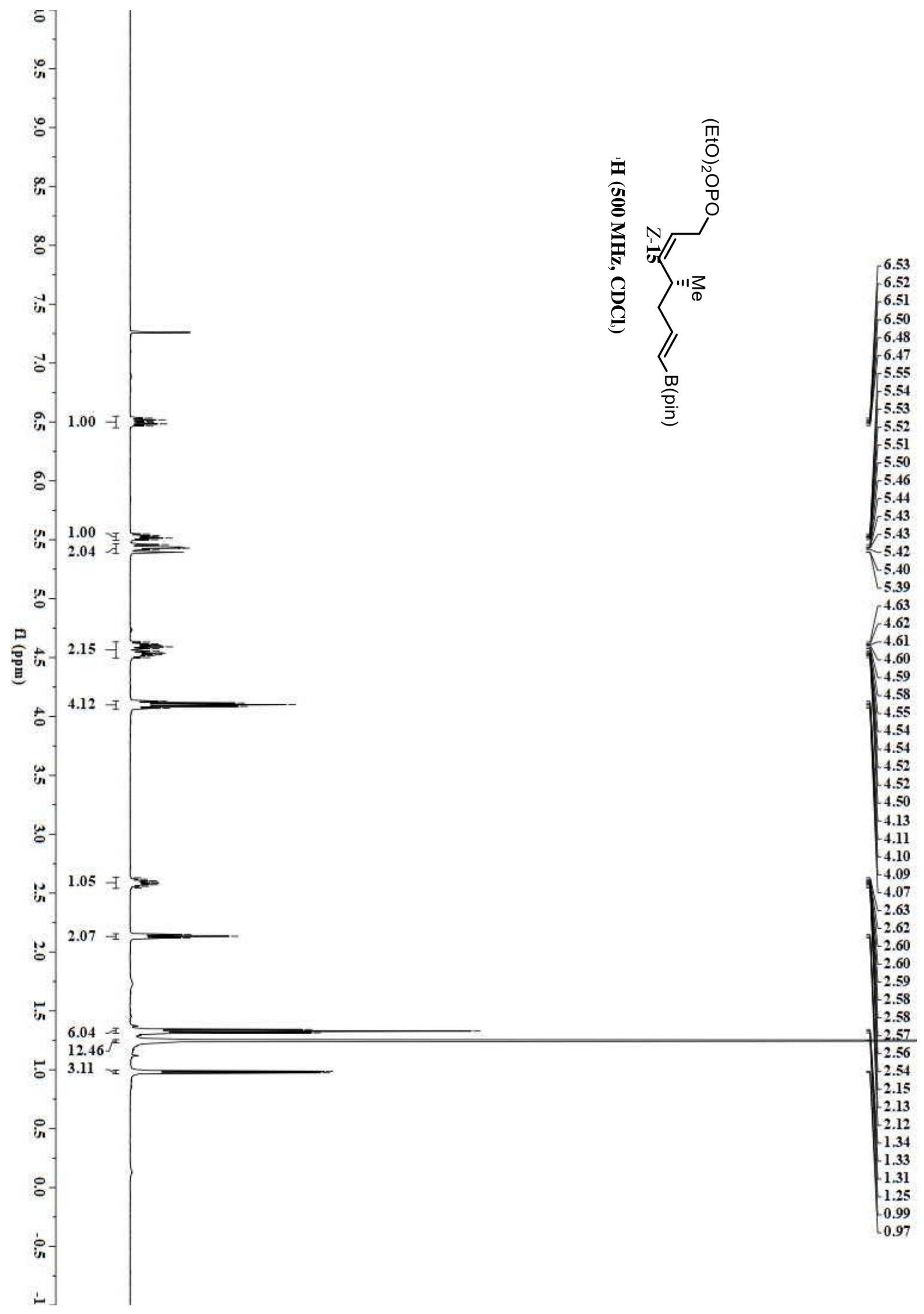


Sun, et al., Supporting Information, Page S262

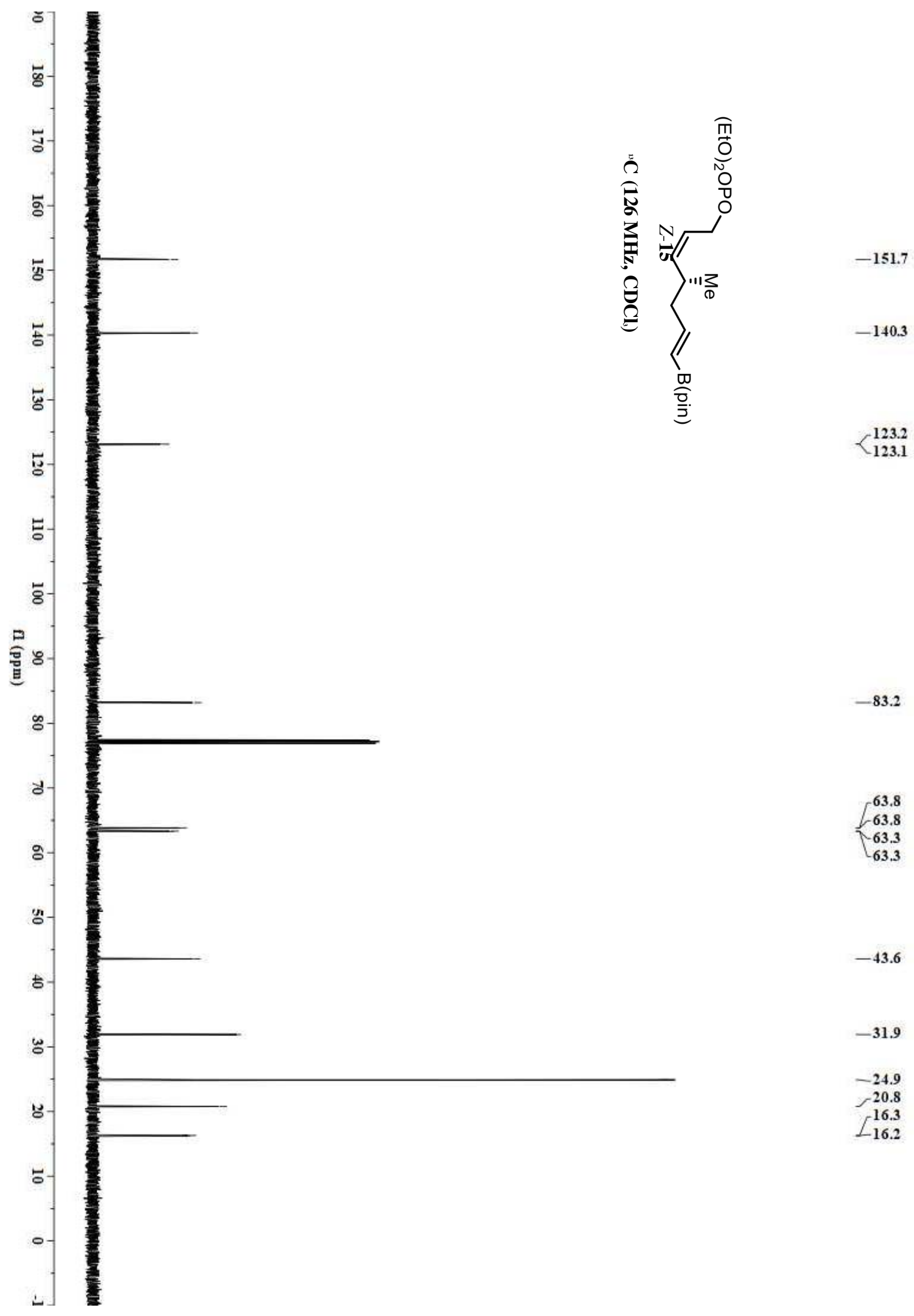




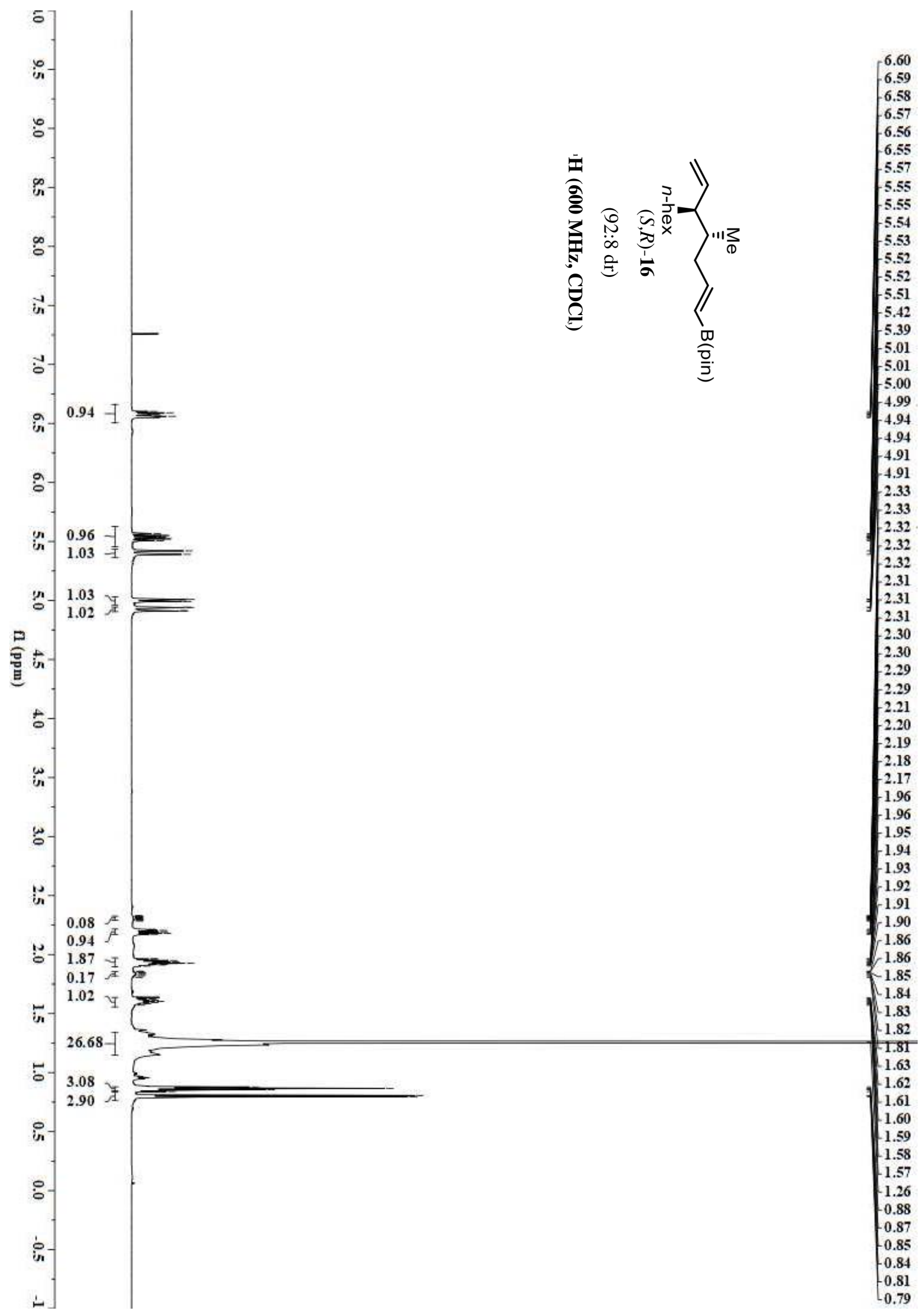




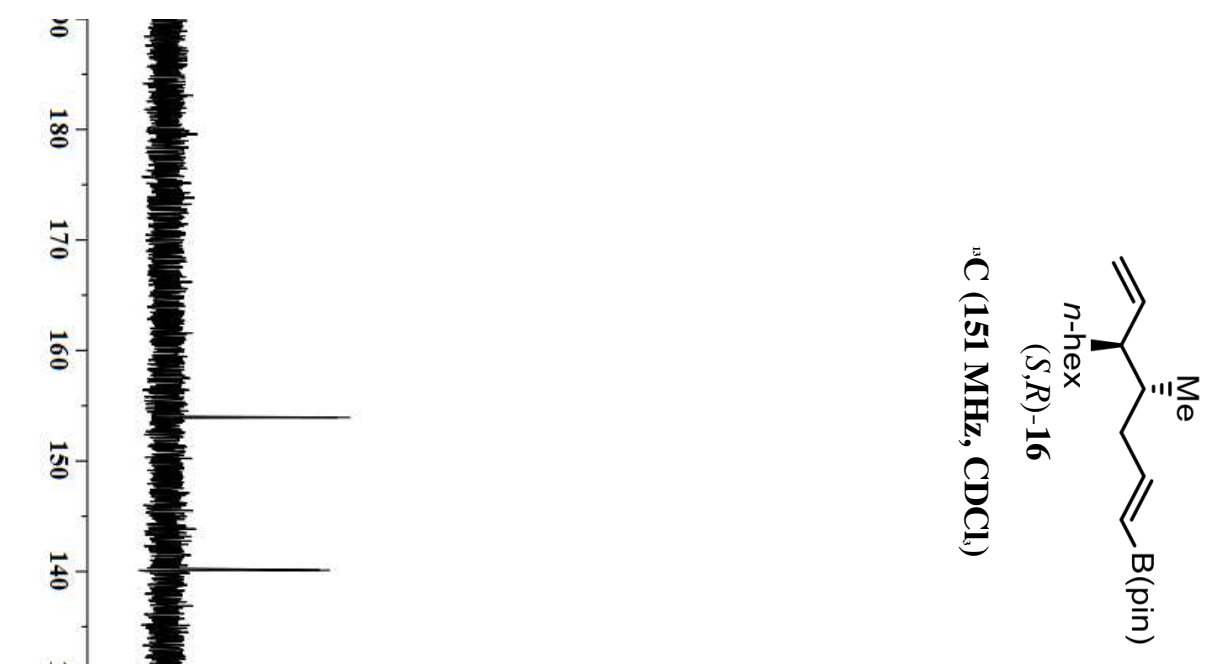




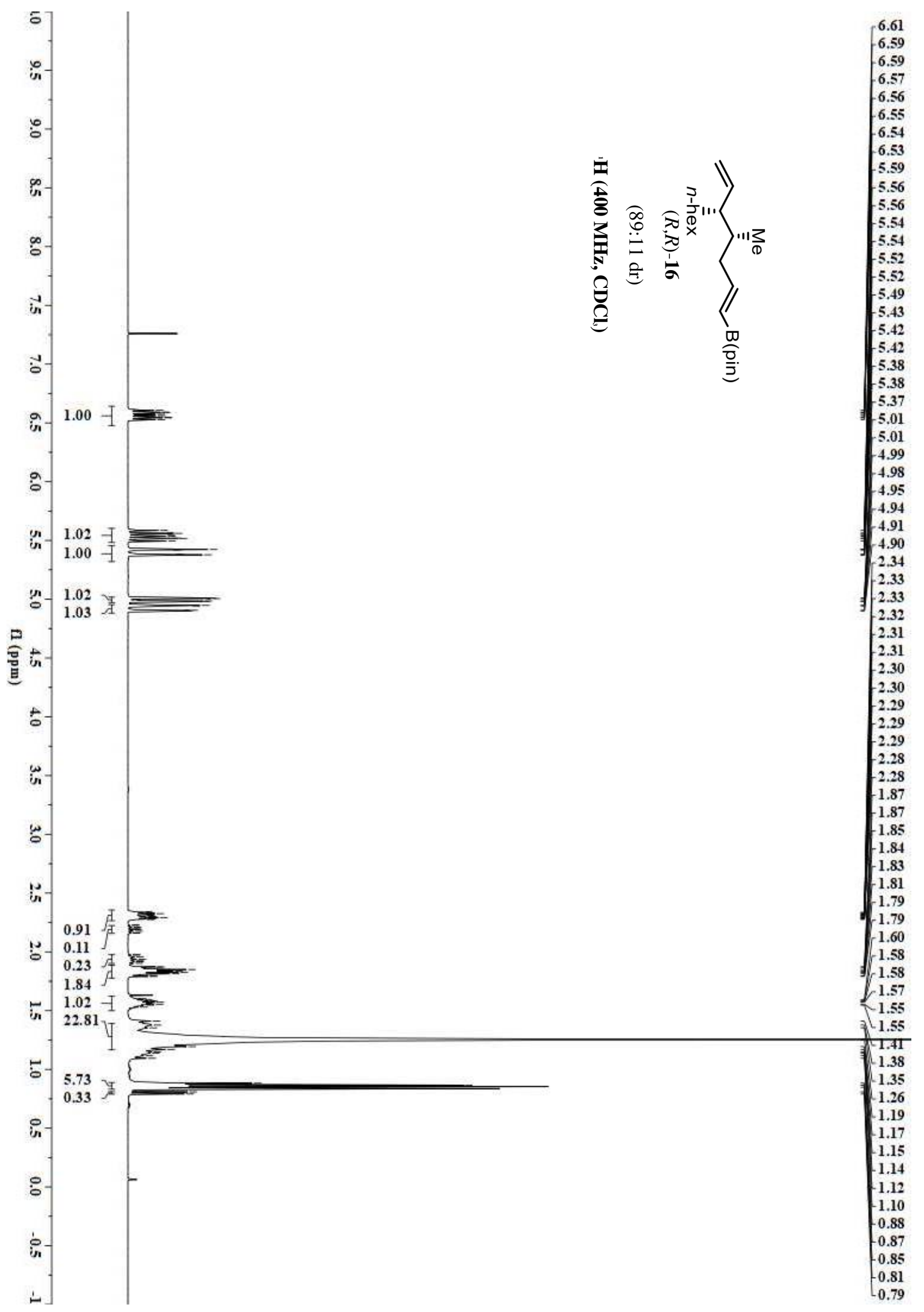



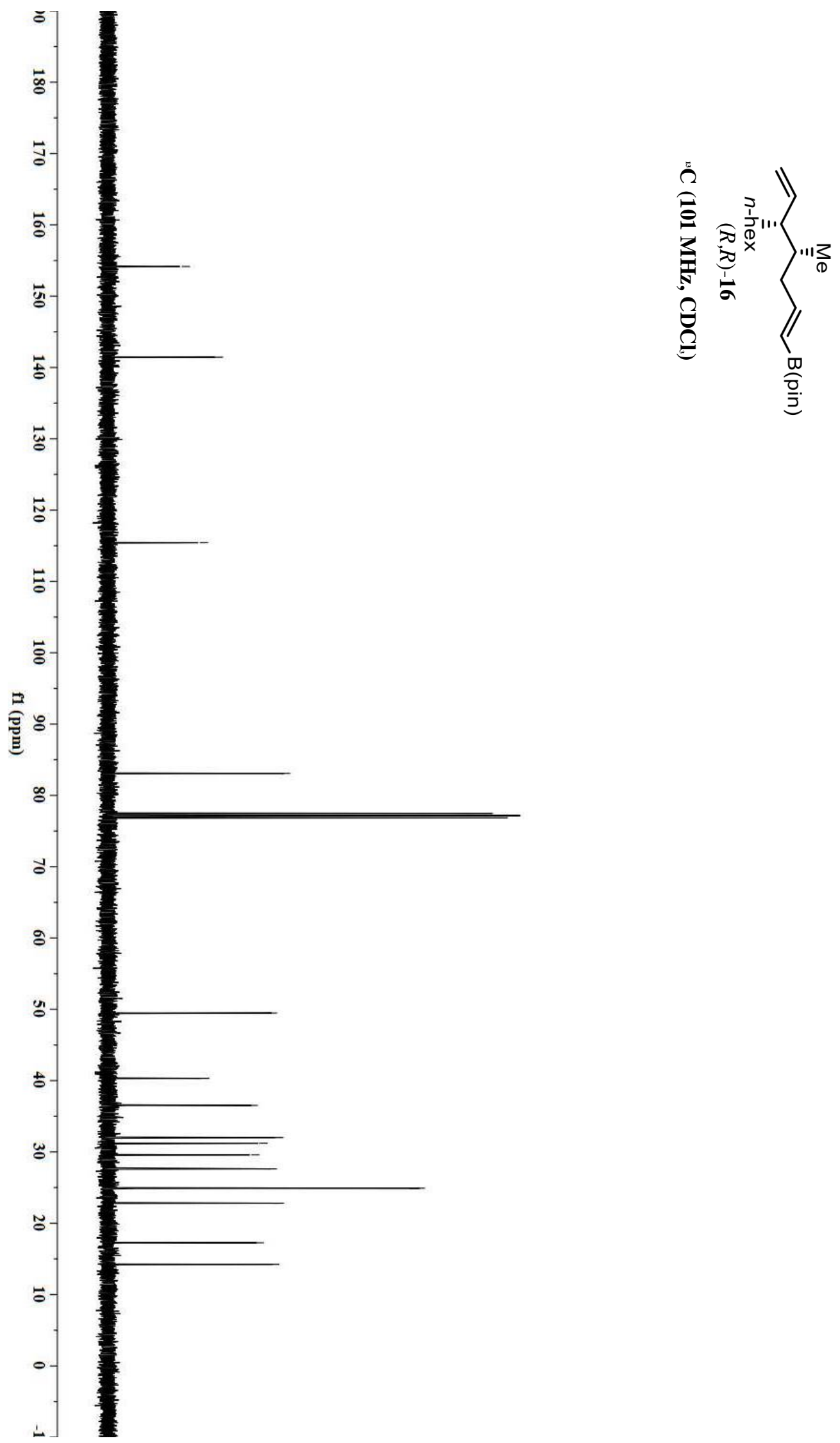

24.9

22.8

$-17.3$

$-14.2$ 

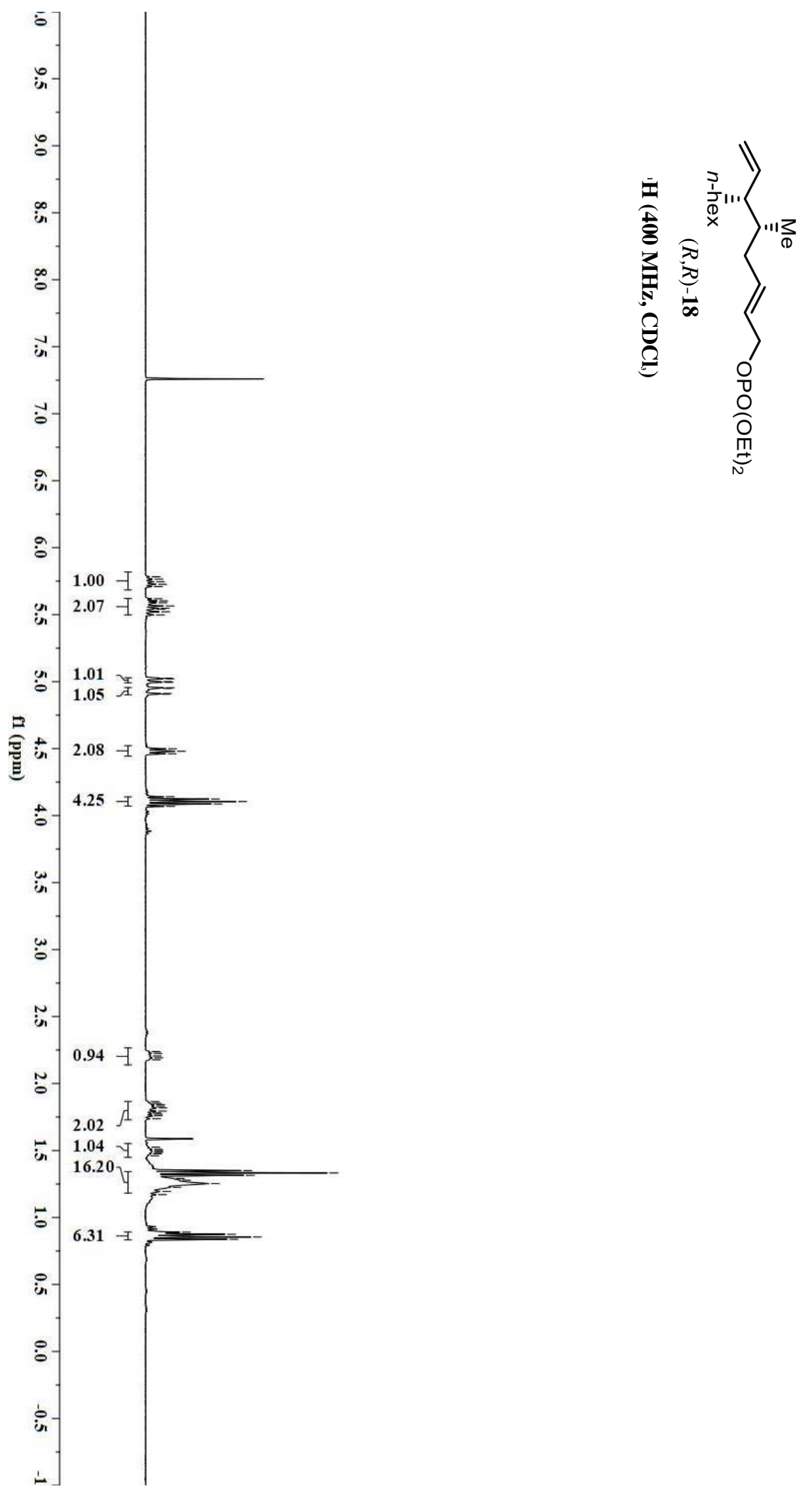


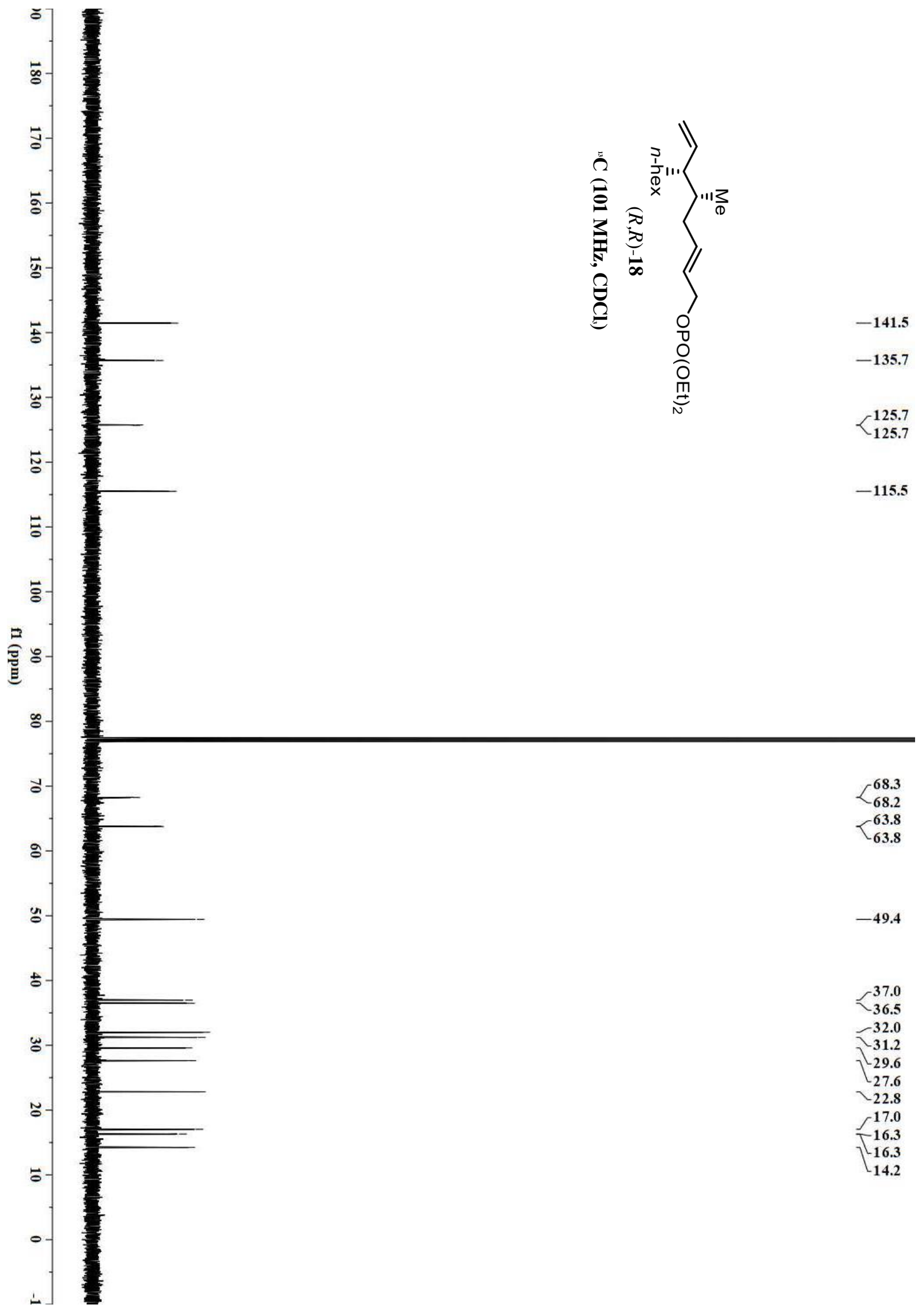


Sun, et al., Supporting Information, Page S269
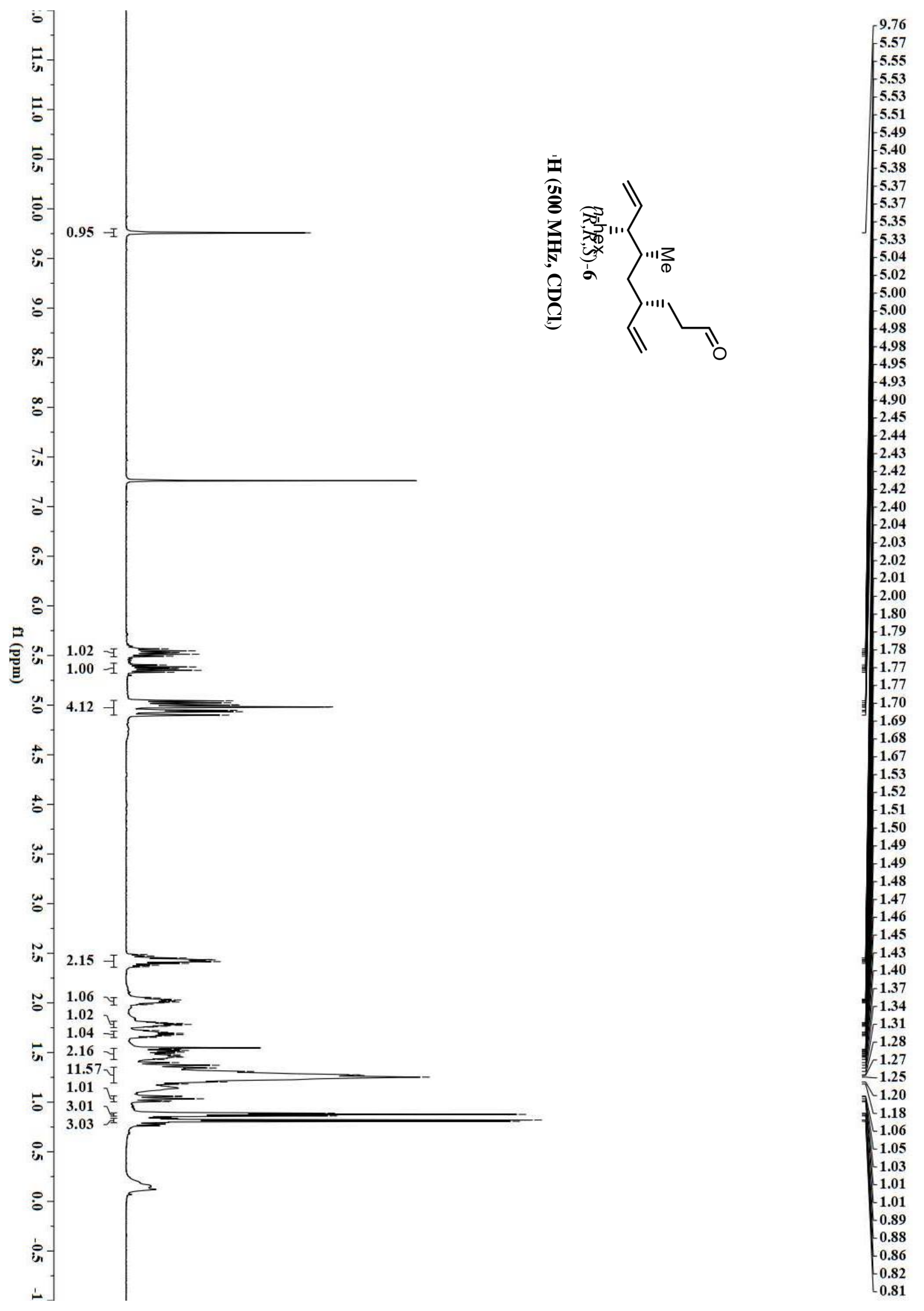


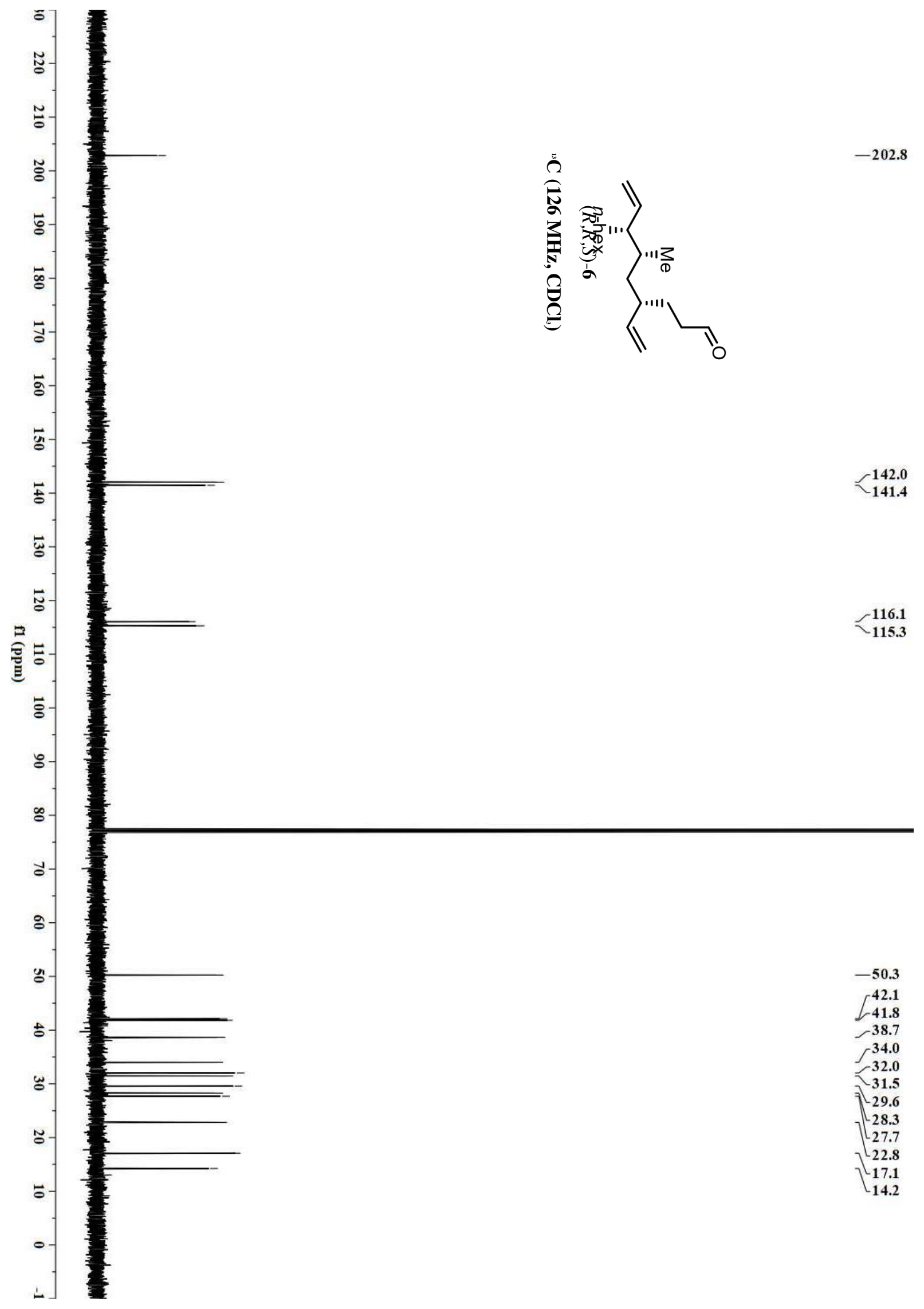



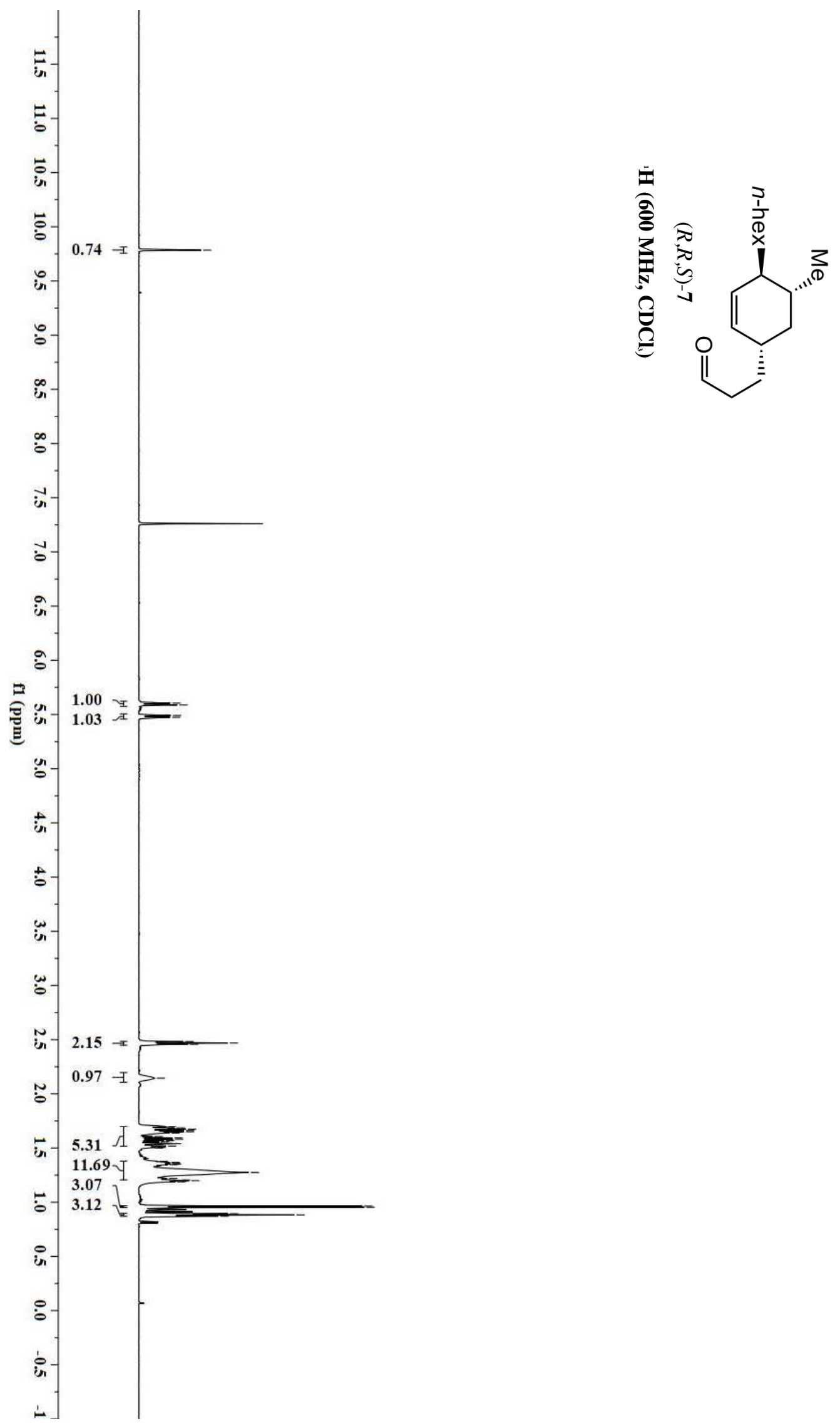


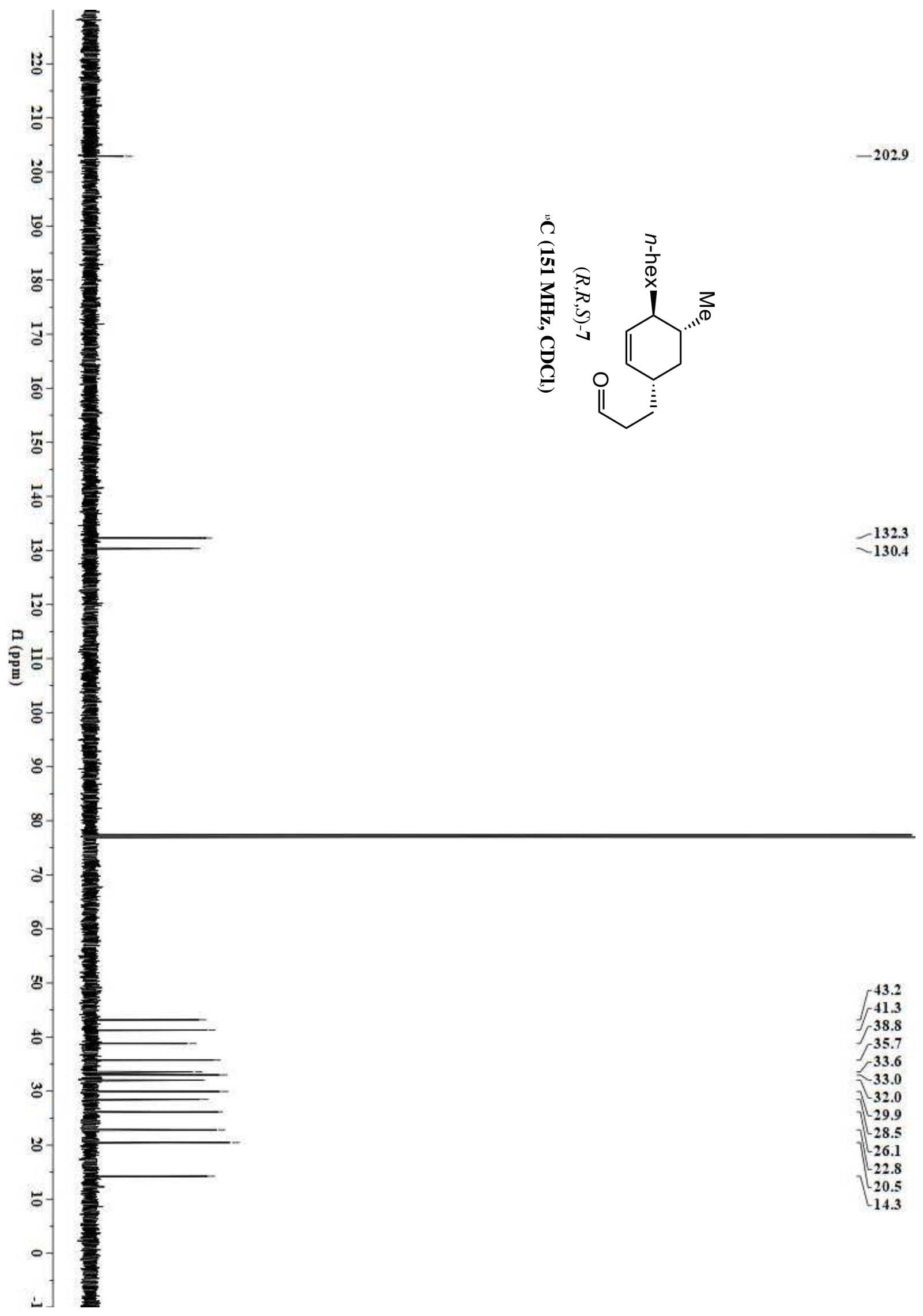



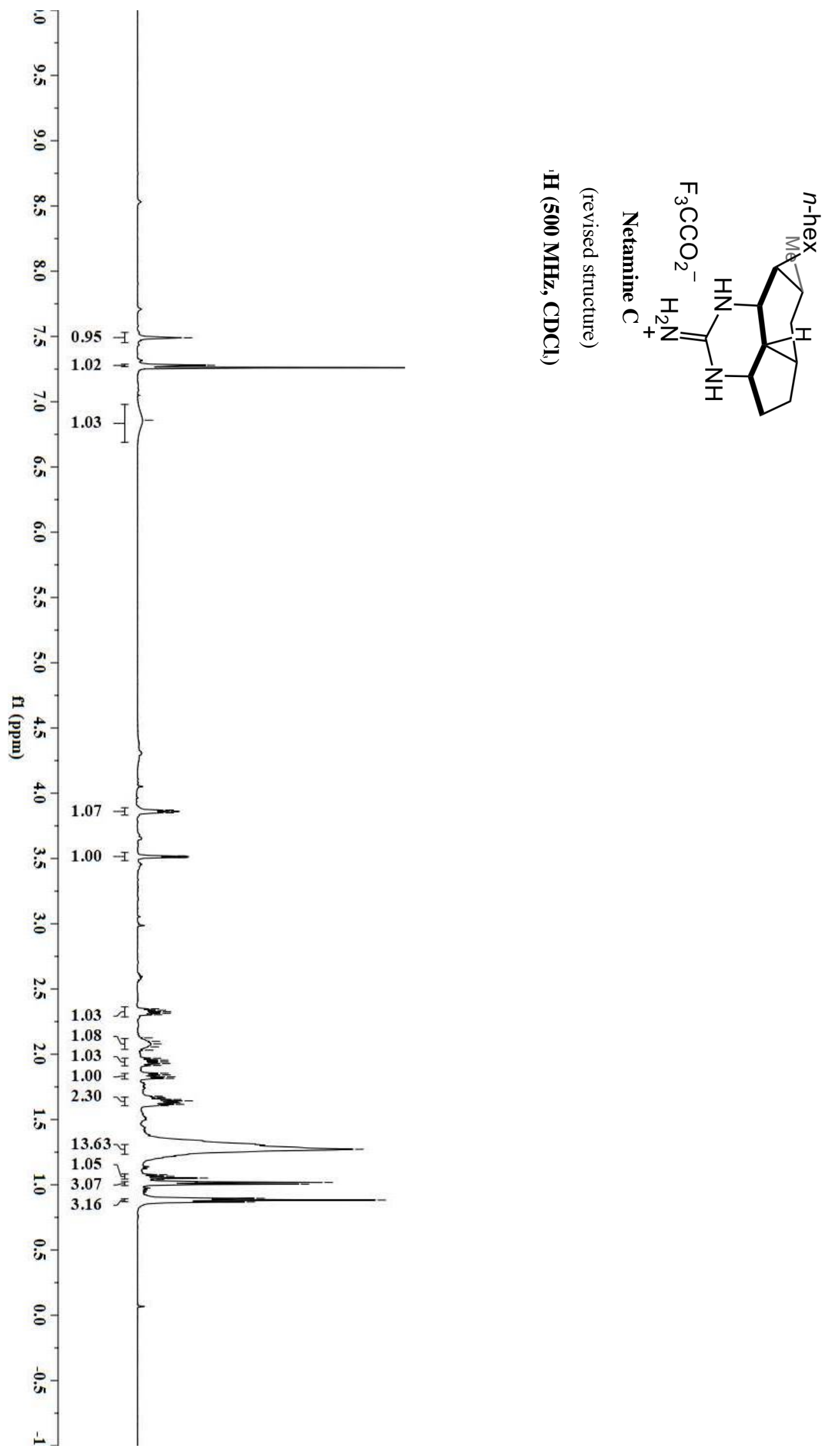


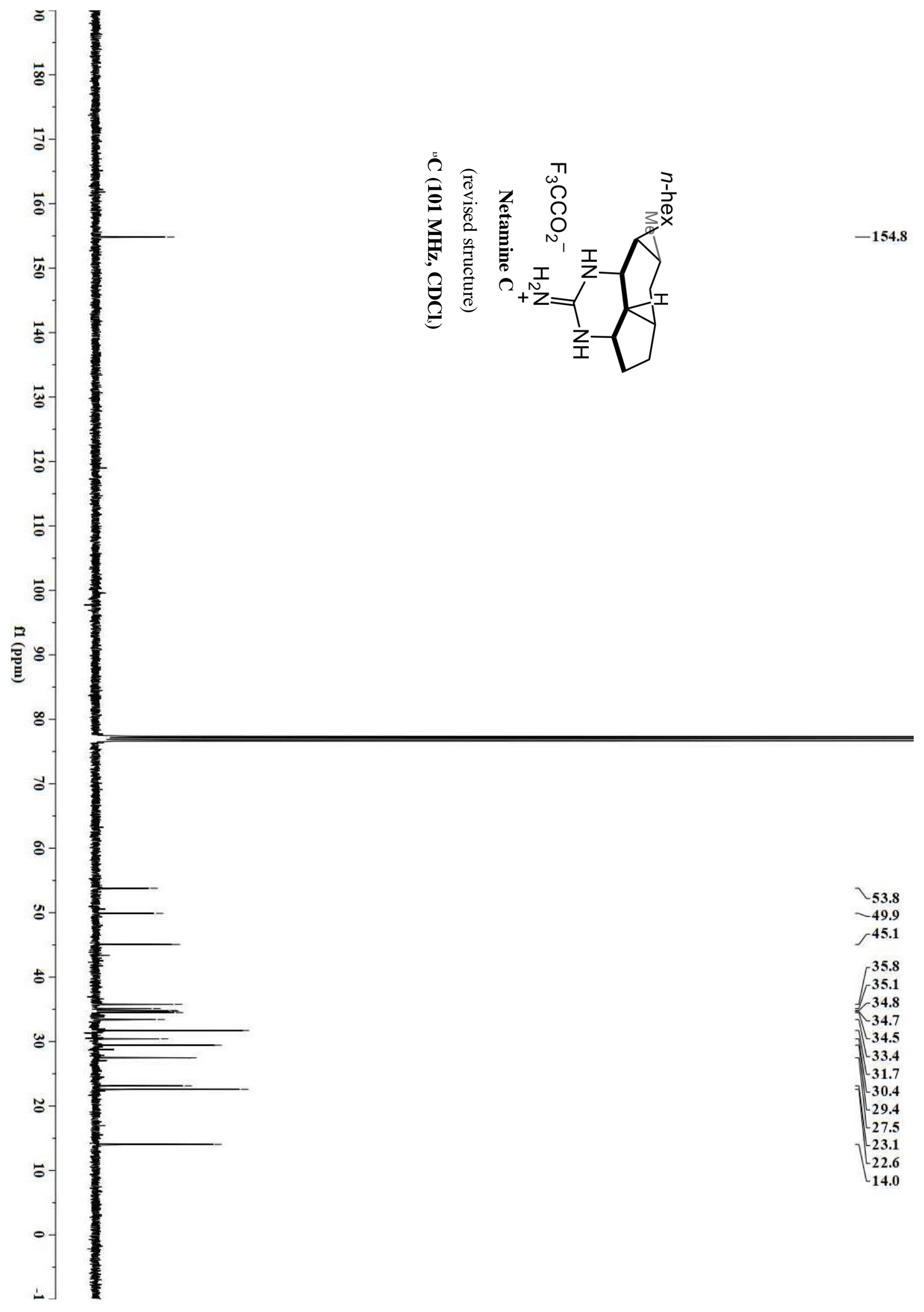



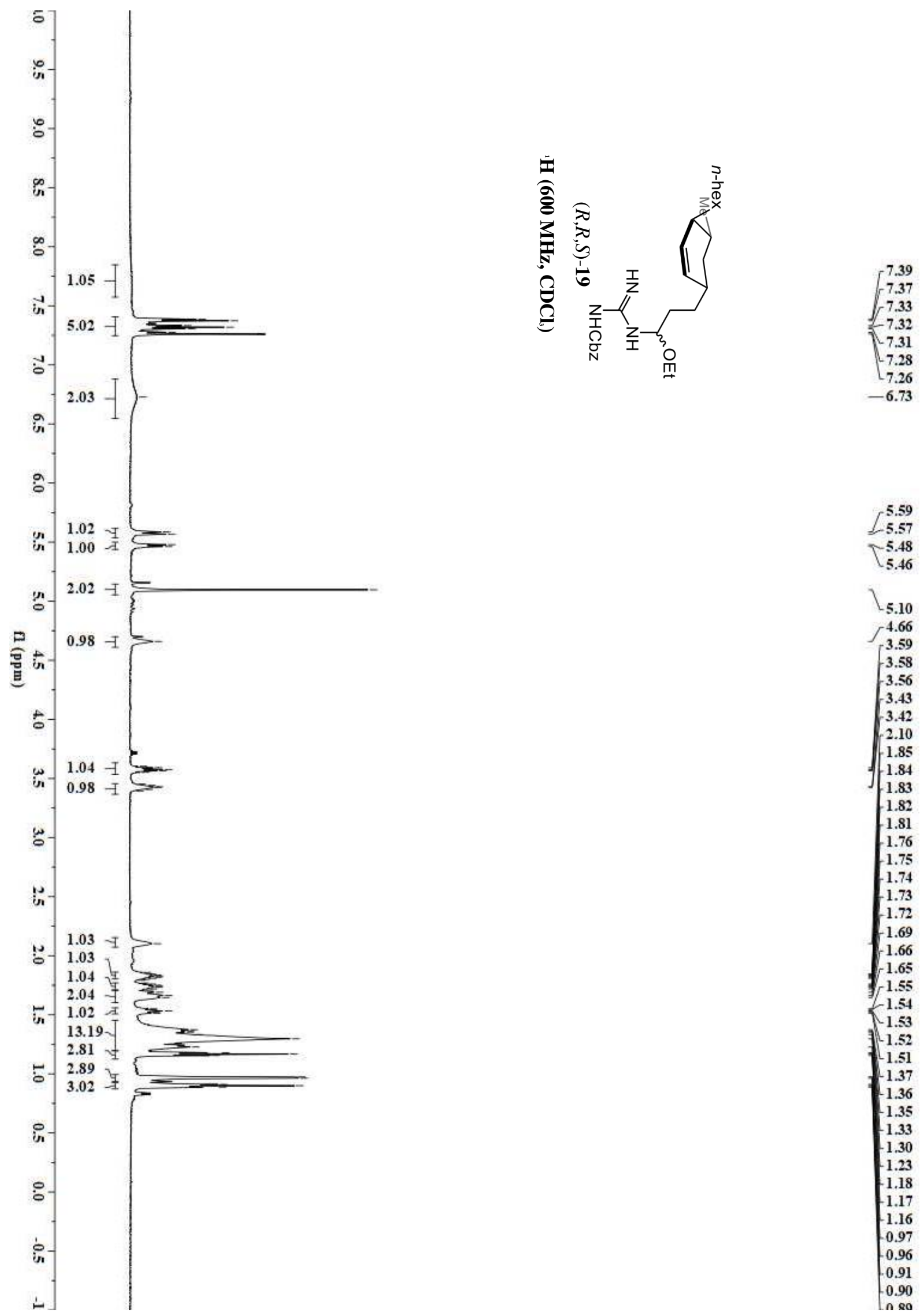


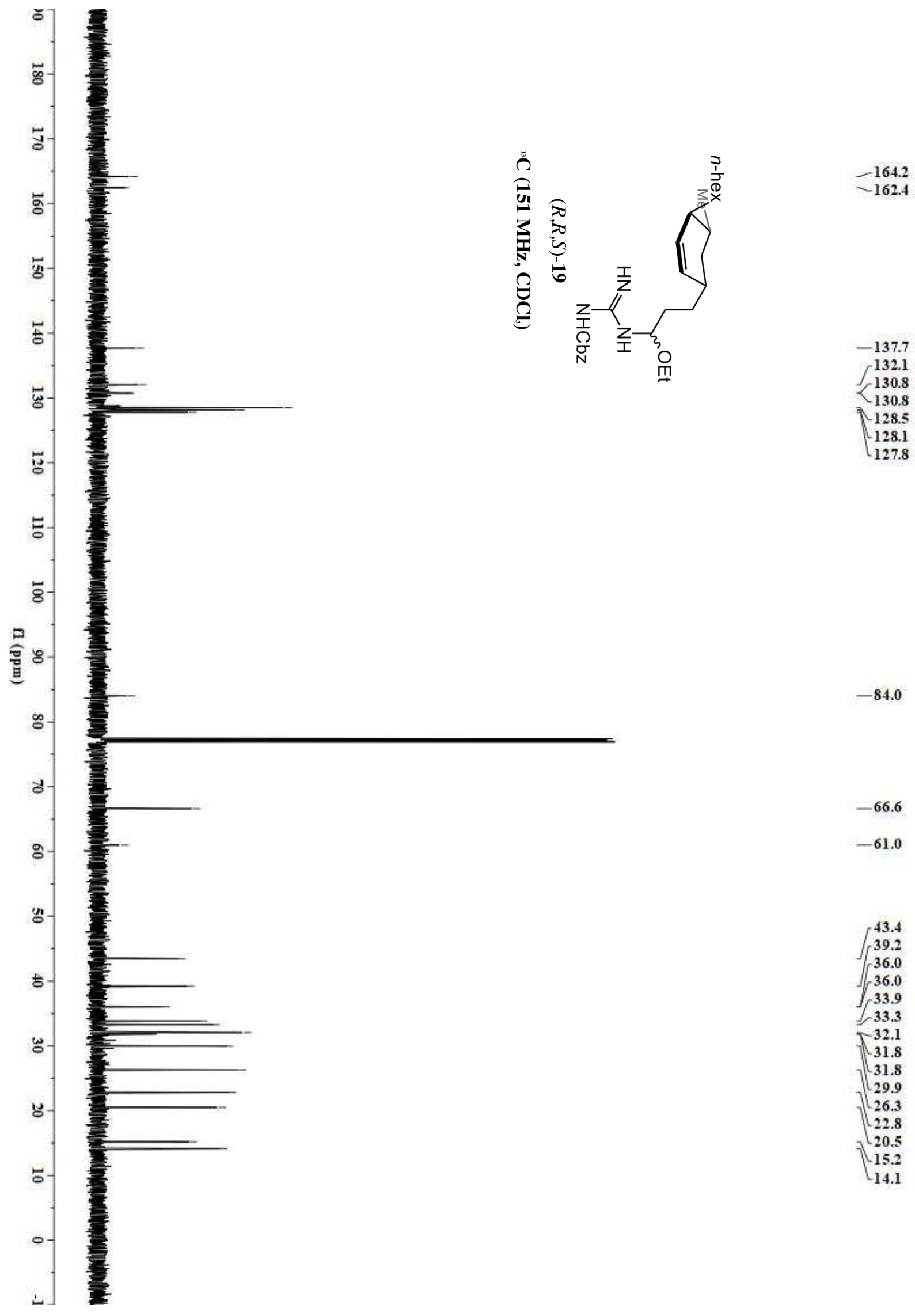




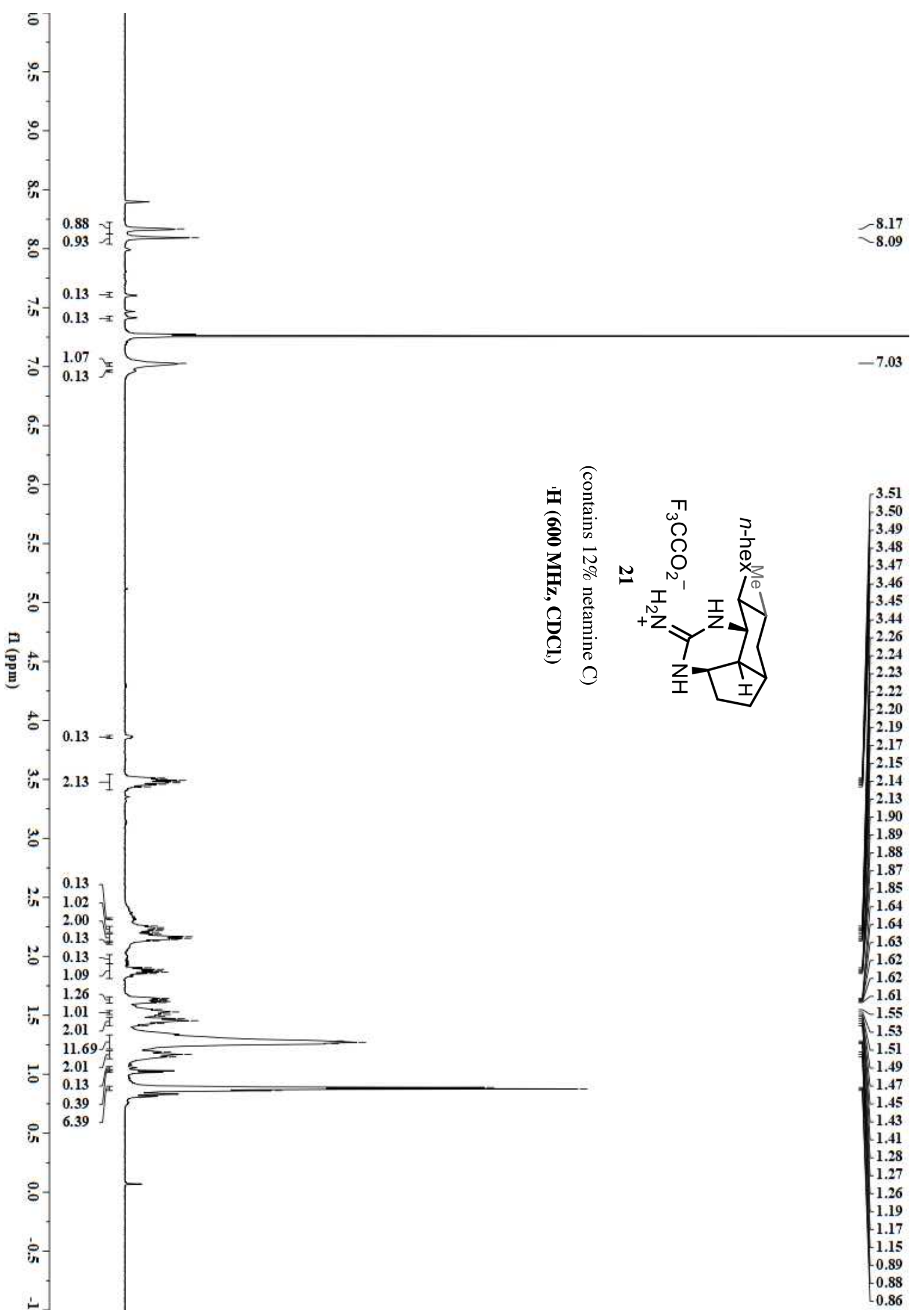




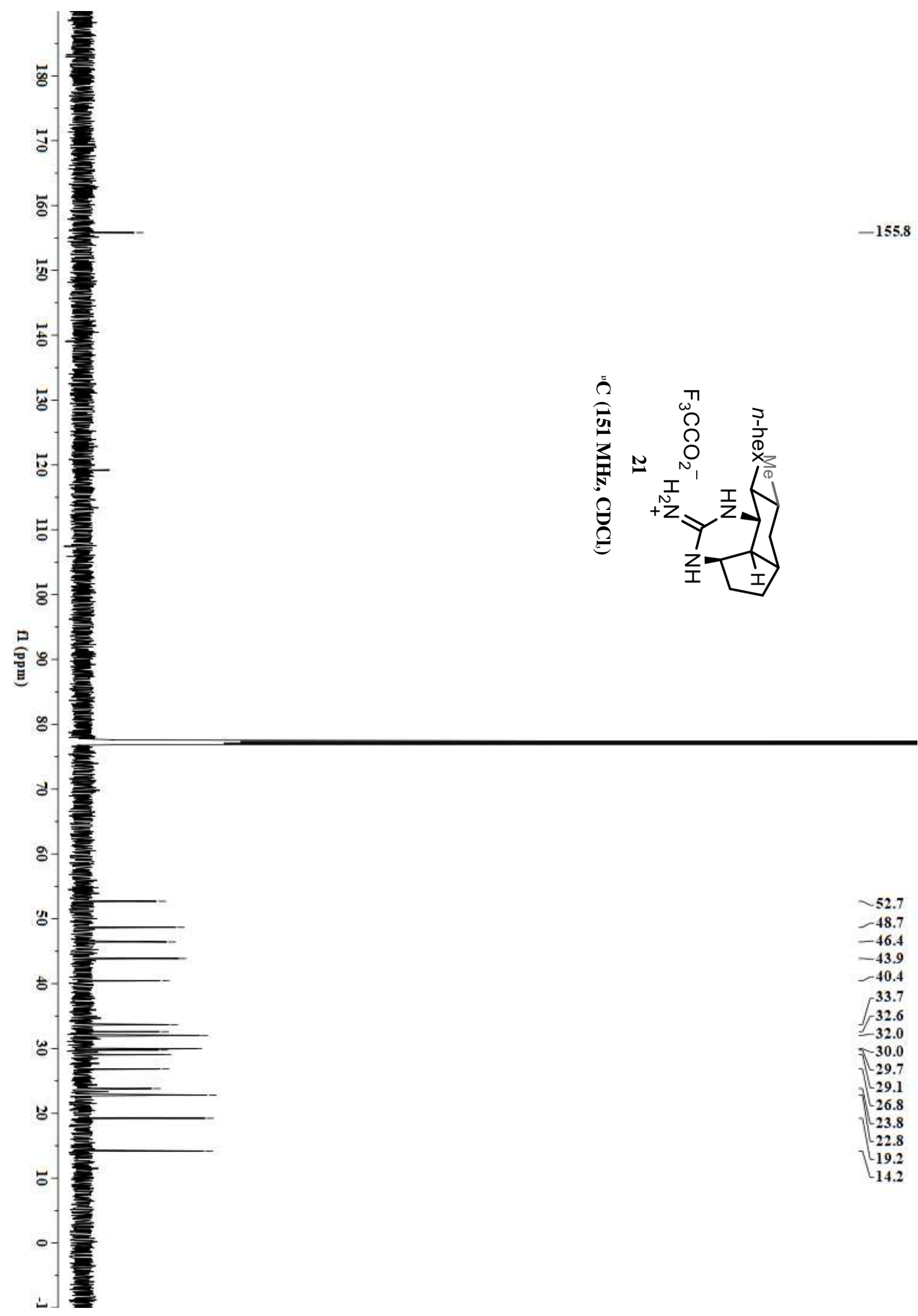



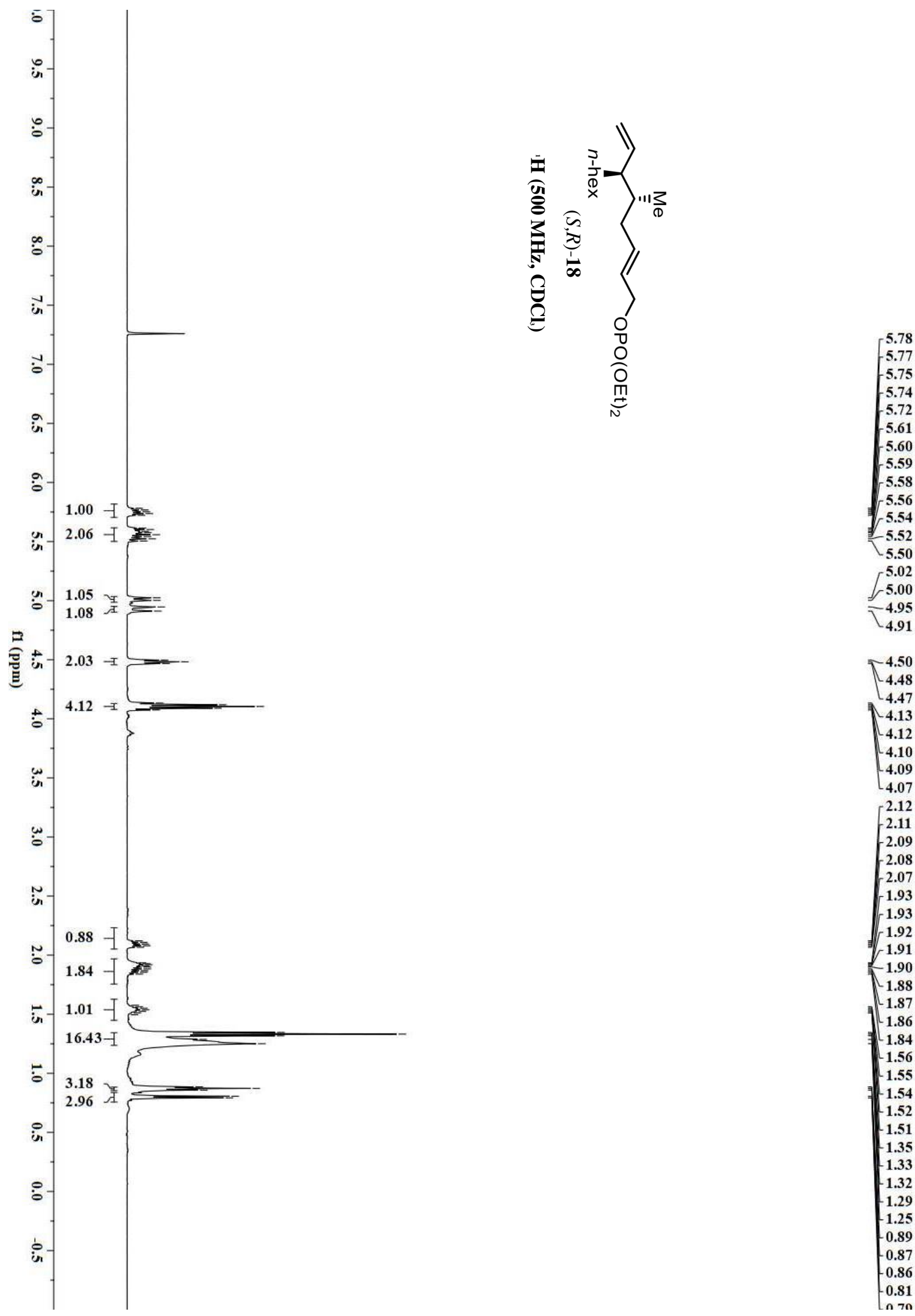

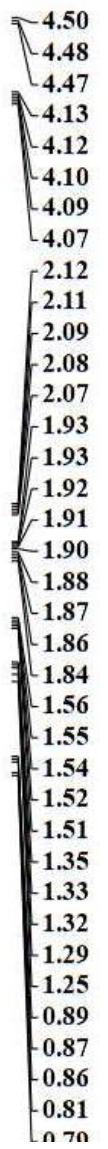



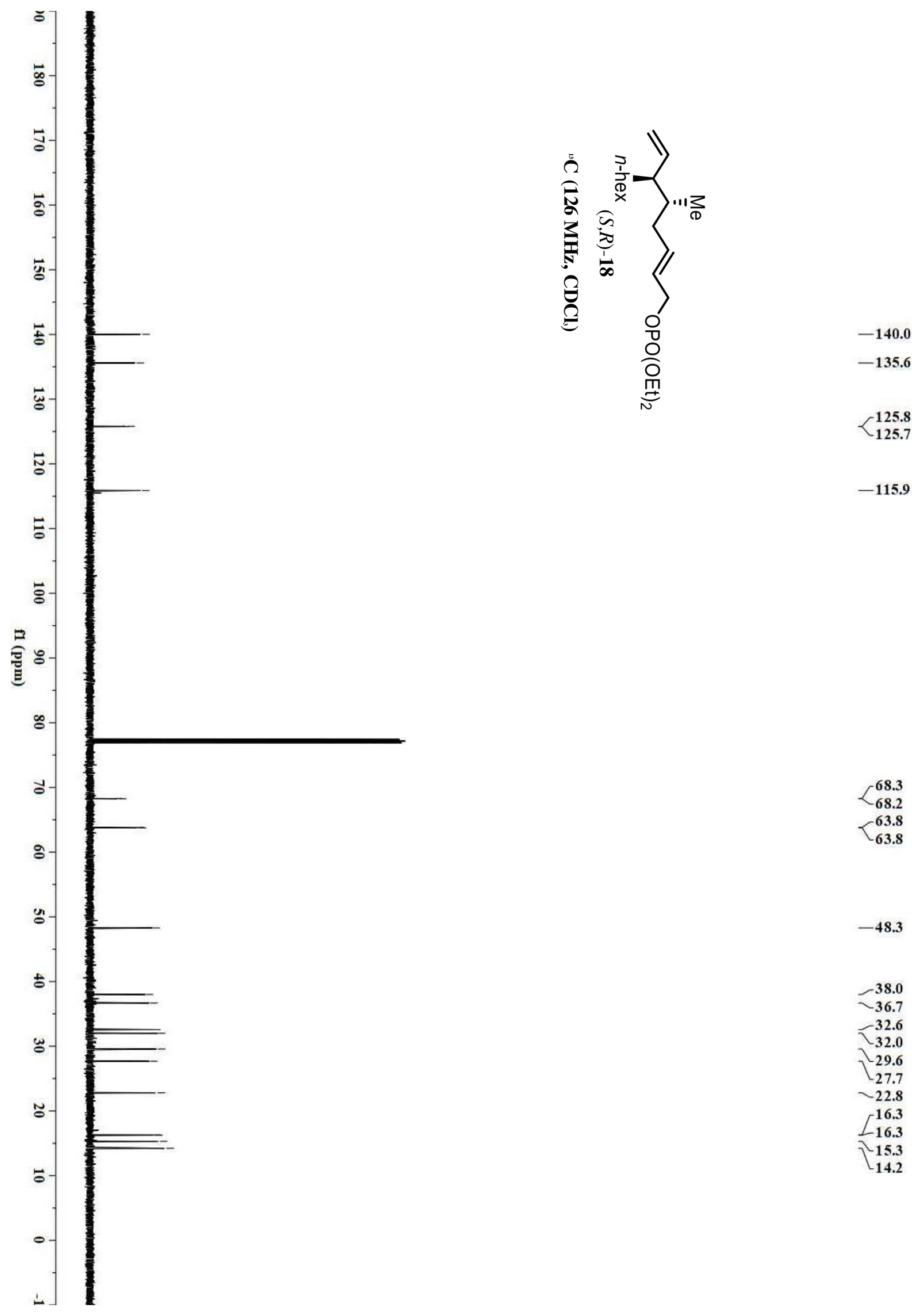

$-115.9$
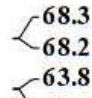

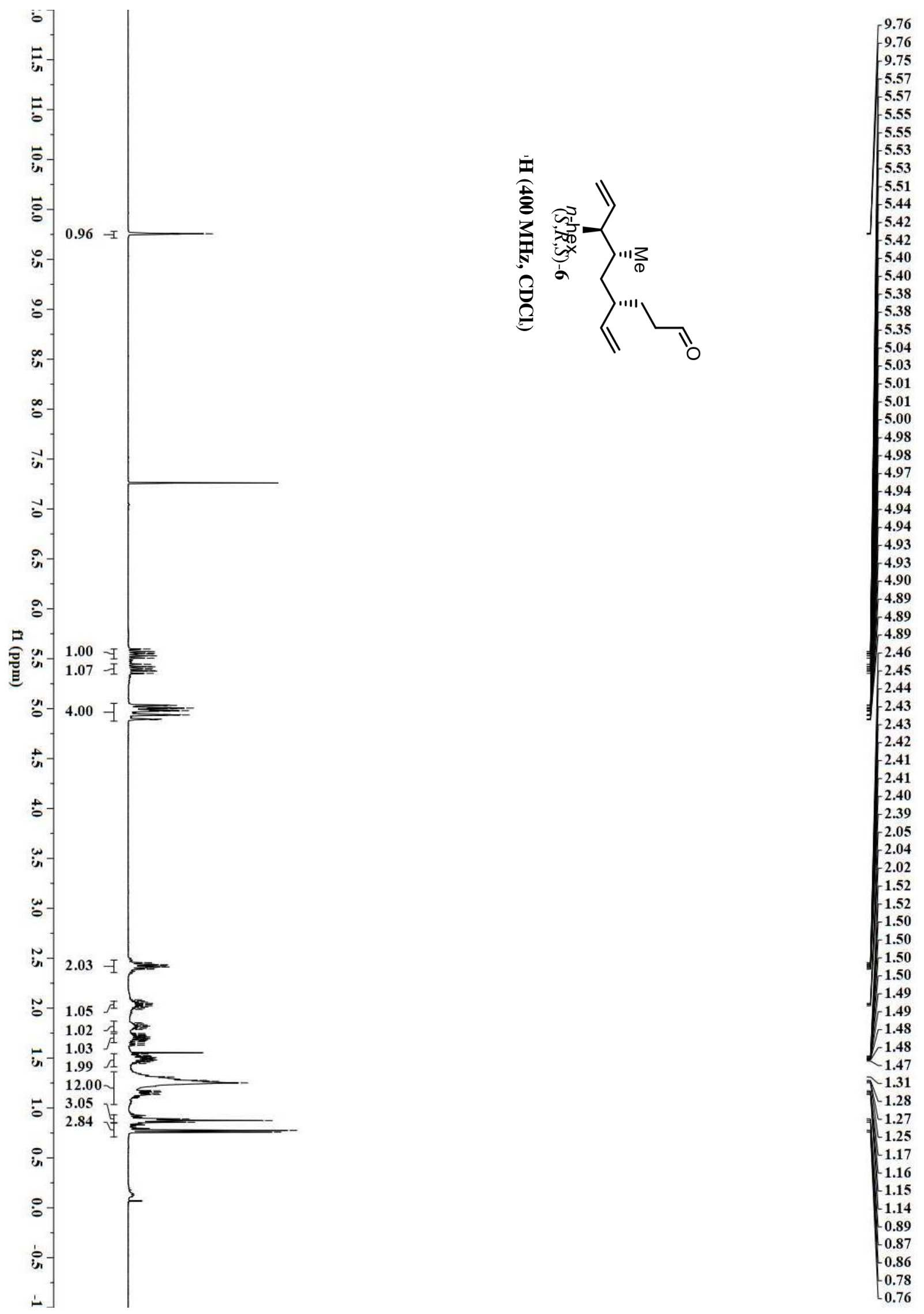


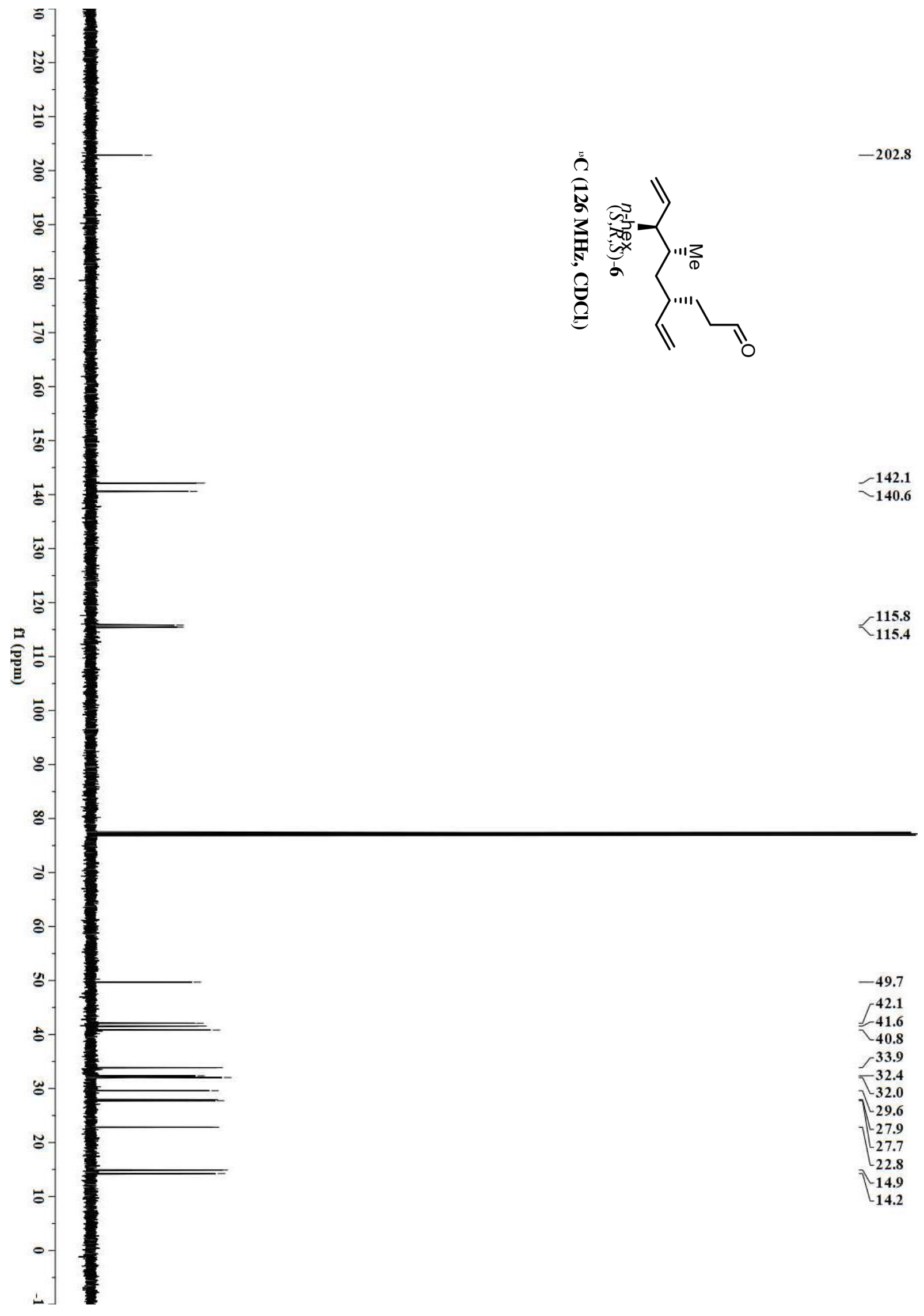



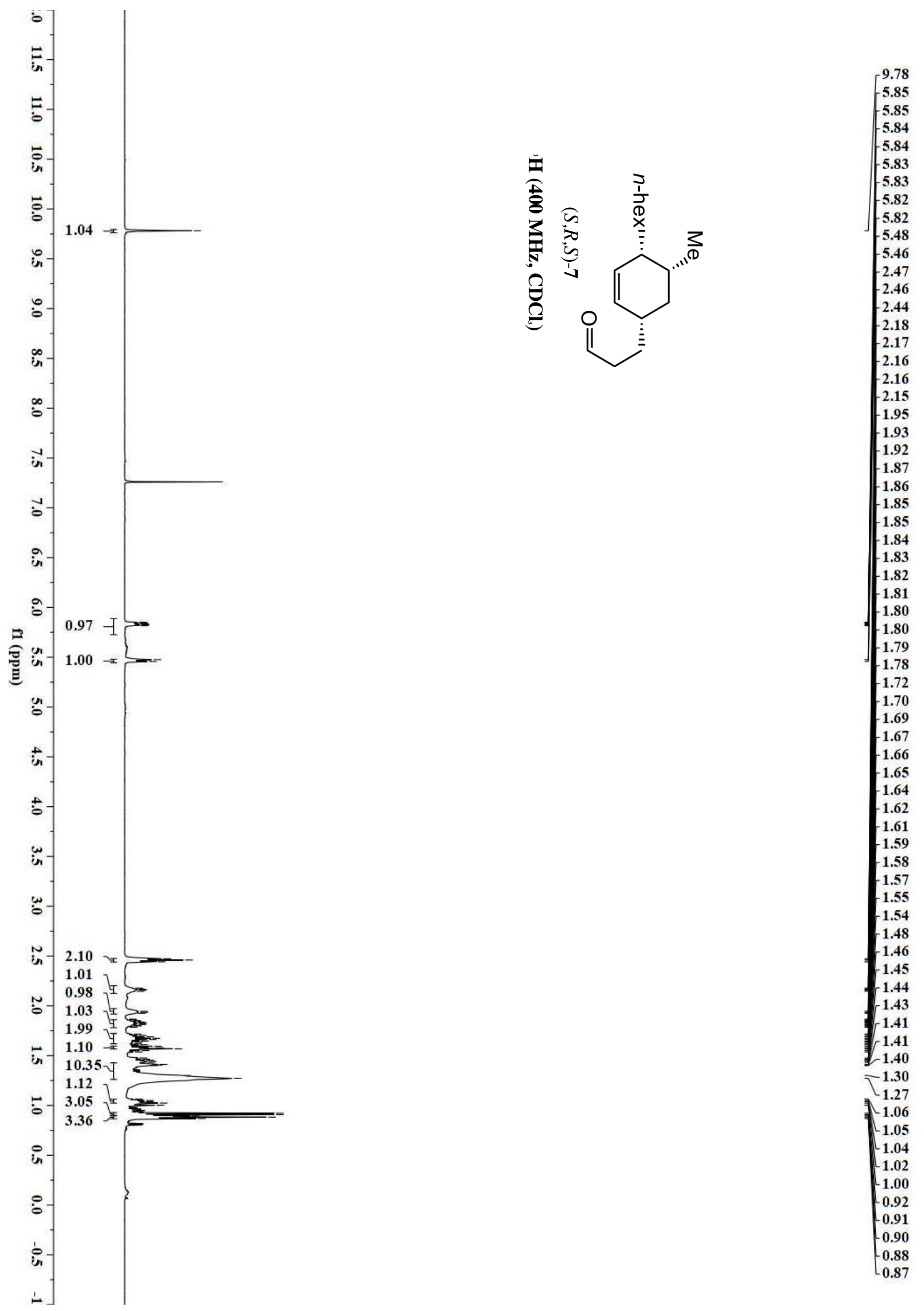


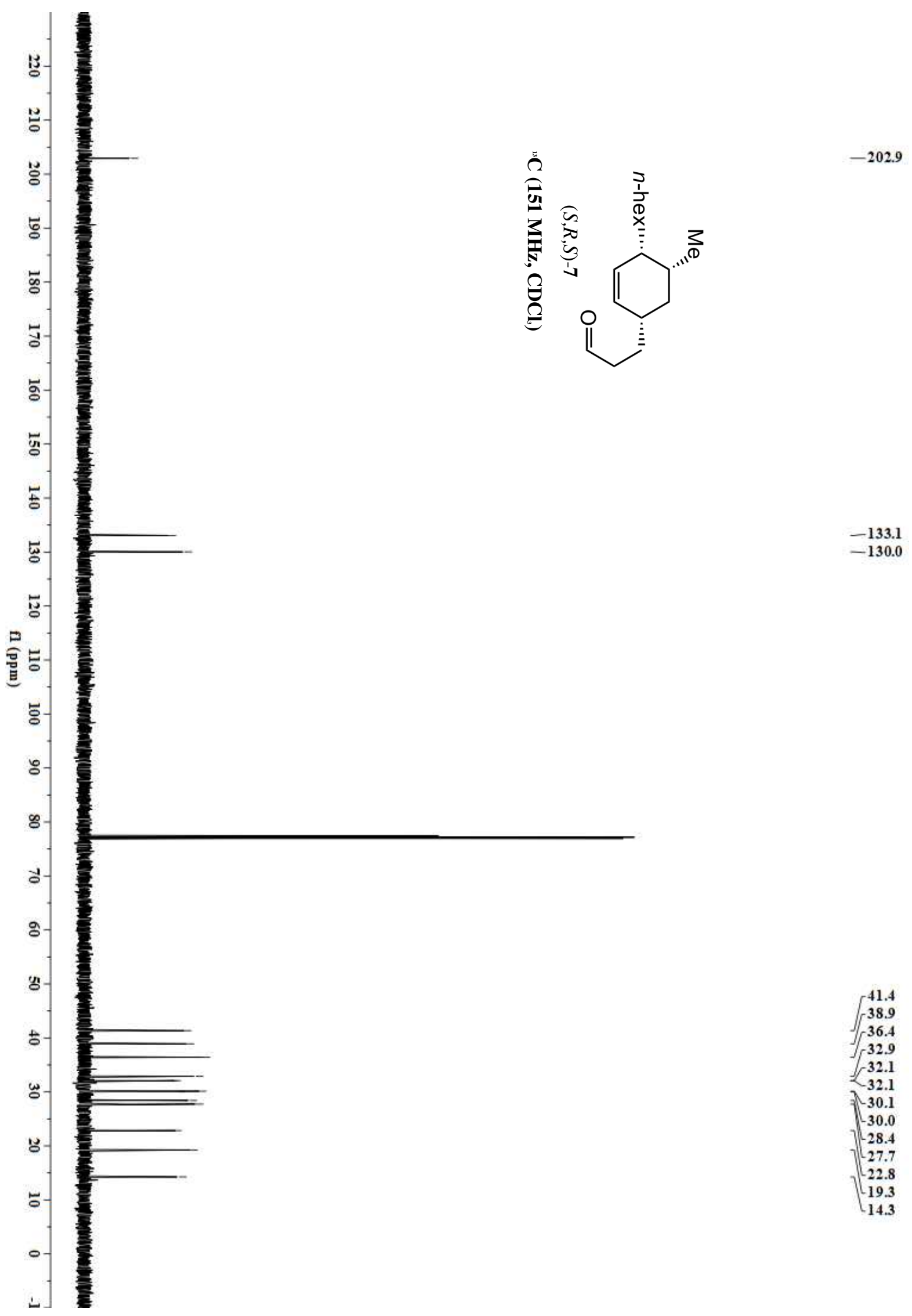




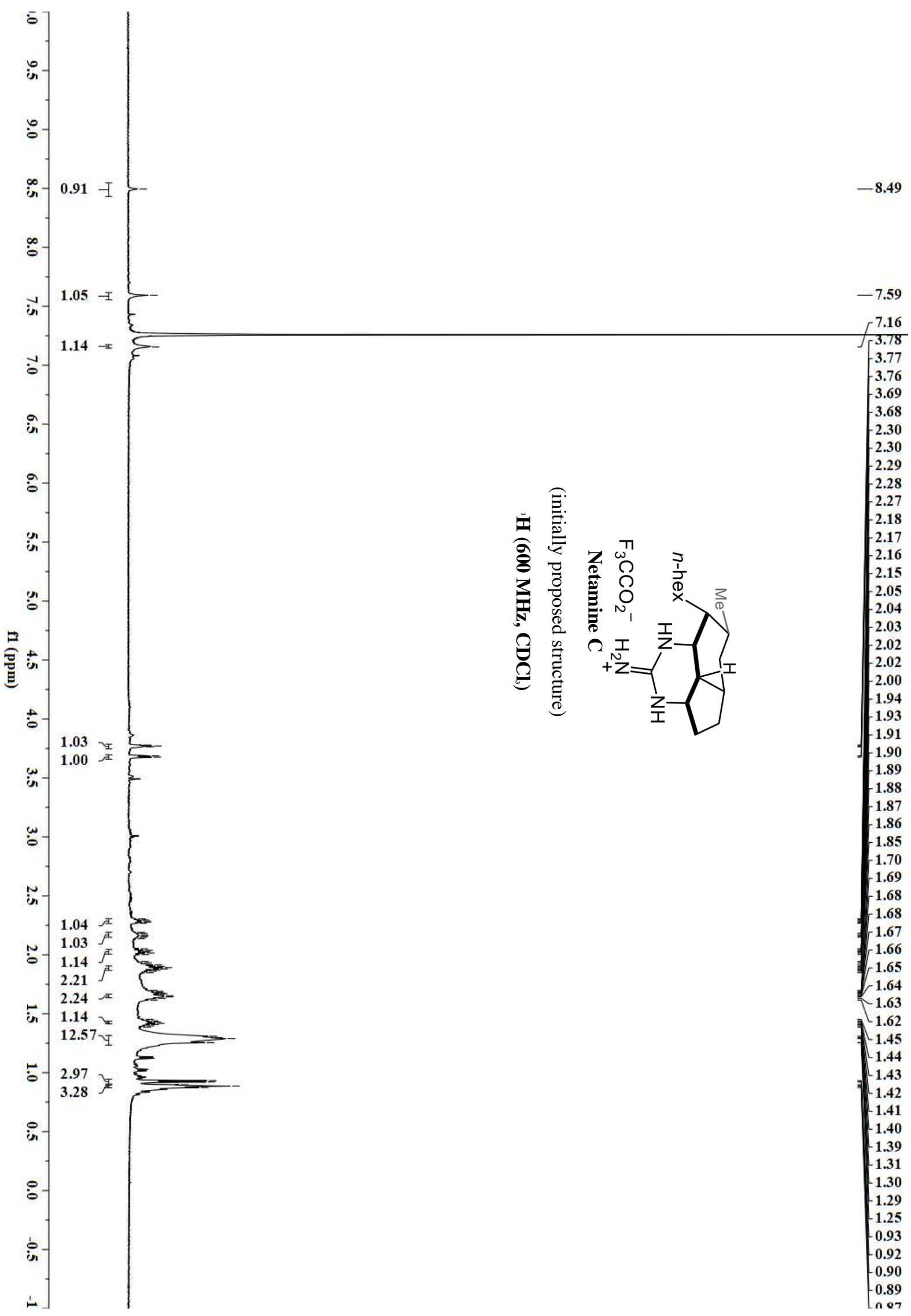




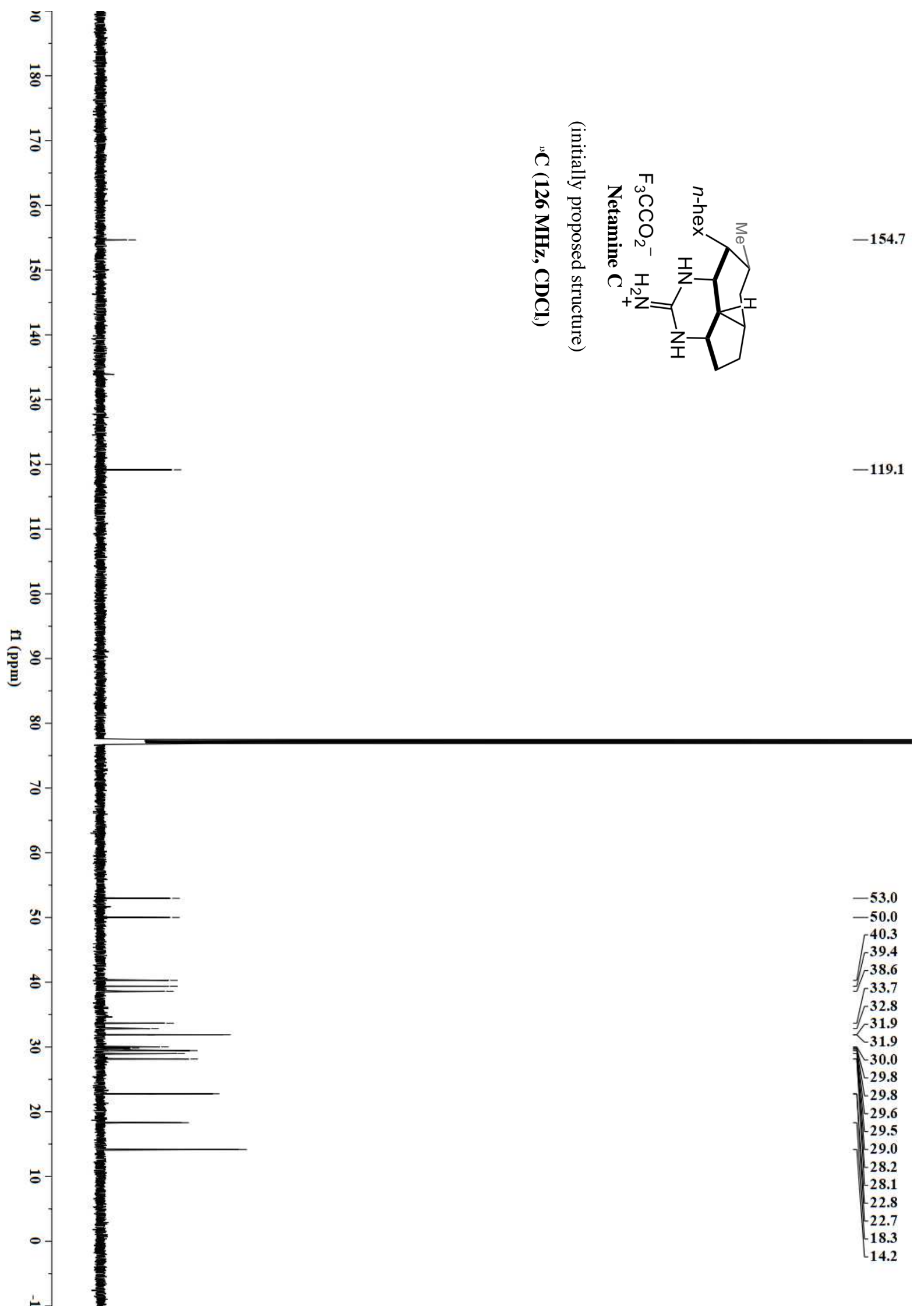




\section{X-Ray Structures}

\subsection{Structure of 8d}

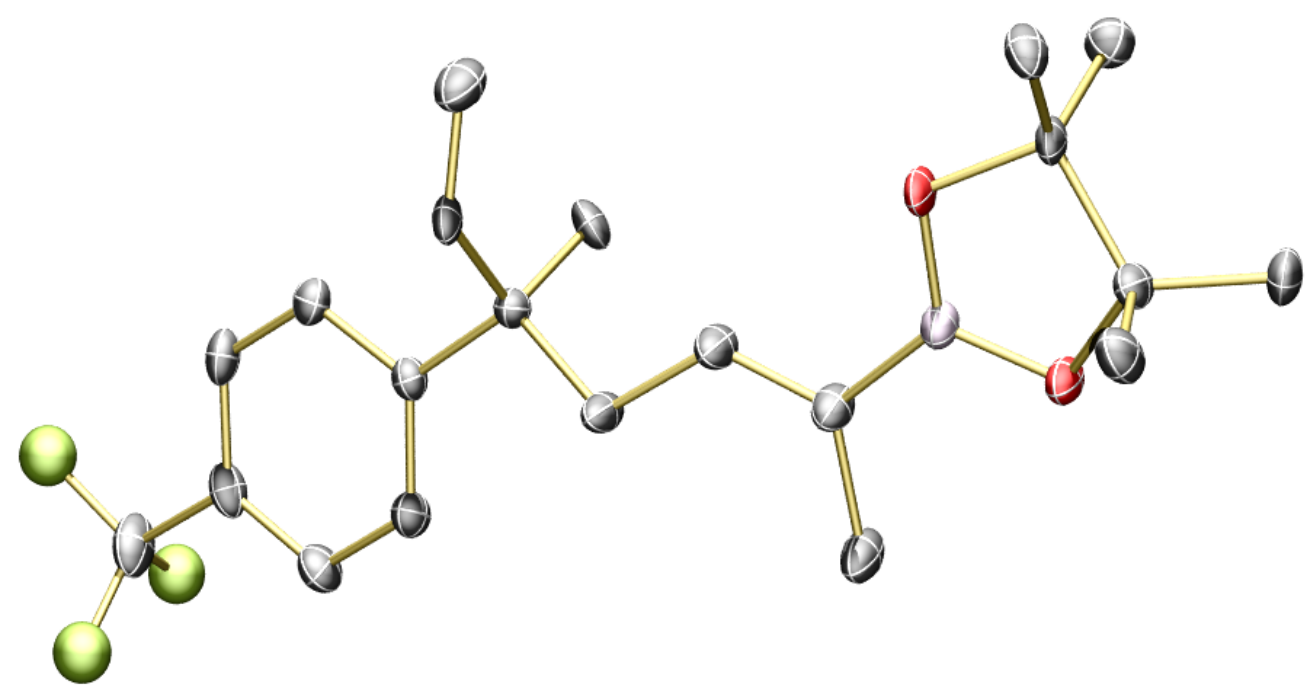

Table 3. Crystal data and structure refinement for $\mathrm{C}_{21} \mathrm{H}_{28} \mathrm{BF}_{3} \mathrm{O}_{2}$

Identification code

Empirical formula

Formula weight

Temperature

Wavelength

Crystal system

Space group

Unit cell dimensions

Volume

Z

Density (calculated)

Absorption coefficient

$\mathrm{F}(000)$

Crystal size

Theta range for data collection

Index ranges

Reflections collected

Independent reflections
$\mathrm{C} 21 \mathrm{H} 28 \mathrm{BF} 3 \mathrm{O} 2$

C21 H28 B F3 O2

380.24

100(2) K

$1.54178 \AA$

Triclinic

P1

$\mathrm{a}=6.7306(3) \AA$

$\mathrm{a}=95.475(2)^{\circ}$.

$\mathrm{b}=9.6620(5) \AA$

$\mathrm{b}=98.967(2)^{\circ}$.

$\mathrm{c}=16.8578(8) \AA$

$\mathrm{g}=106.855(2)^{\circ}$.
2

$1.232 \mathrm{Mg} / \mathrm{m}^{3}$

$0.790 \mathrm{~mm}^{-1}$

404

$0.460 \times 0.340 \times 0.100 \mathrm{~mm}^{3}$

2.683 to $66.717^{\circ}$.

$-8<=\mathrm{h}<=7,-11<=\mathrm{k}<=11,-20<=\mathrm{l}<=20$

19183

$6823[\mathrm{R}($ int $)=0.0234]$ 
Completeness to theta $=66.717^{\circ}$

Absorption correction

Max. and min. transmission

Refinement method

Data / restraints / parameters

Goodness-of-fit on $\mathrm{F}^{2}$

Final $R$ indices [I $>2 \operatorname{sigma}(\mathrm{I})]$

$\mathrm{R}$ indices (all data)

Absolute structure parameter

Extinction coefficient

Largest diff. peak and hole
$98.4 \%$

Semi-empirical from equivalents

0.7528 and 0.6605

Full-matrix least-squares on $\mathrm{F}^{2}$

6823 / 617 / 543

1.037

$\mathrm{R} 1=0.0468, \mathrm{wR} 2=0.1300$

$\mathrm{R} 1=0.0475, \mathrm{wR} 2=0.1308$

$0.01(10)$

$\mathrm{n} / \mathrm{a}$

0.456 and -0.219 e. $\AA^{-3}$

Table 4. Atomic coordinates $\left(\mathrm{x} 10^{4}\right)$ and equivalent isotropic displacement parameters $\left(\AA^{2} \times 10^{3}\right)$ for $\mathrm{C}_{21} \mathrm{H}_{28} \mathrm{BF}_{3} \mathrm{O}_{2}$. $\mathrm{U}(\mathrm{eq})$ is defined as one third of the trace of the orthogonalized $\mathrm{U}^{\mathrm{ij}}$ tensor

\begin{tabular}{|c|c|c|c|c|}
\hline & $\mathrm{x}$ & $\mathrm{y}$ & $\mathrm{z}$ & $\mathrm{U}(\mathrm{eq})$ \\
\hline $\mathrm{B}(1)$ & $7011(6)$ & $7086(4)$ & $3222(2)$ & $19(1)$ \\
\hline $\mathrm{B}(2)$ & $2645(6)$ & $3169(4)$ & $6777(2)$ & 19(1) \\
\hline$C(1)$ & $10086(6)$ & $6443(4)$ & $4120(2)$ & $29(1)$ \\
\hline$C(2)$ & $8245(5)$ & 7047(4) & $4072(2)$ & $22(1)$ \\
\hline$C(3)$ & 7741(5) & 7653(4) & $4731(2)$ & $24(1)$ \\
\hline$C(4)$ & $8863(5)$ & $7825(4)$ & $5596(2)$ & $23(1)$ \\
\hline$C(5)$ & $7452(5)$ & $7935(3)$ & $6227(2)$ & $18(1)$ \\
\hline$C(6)$ & $8617(5)$ & $8002(3)$ & 7091(2) & $18(1)$ \\
\hline$C(7)$ & $7689(5)$ & $8352(3)$ & $7745(2)$ & $21(1)$ \\
\hline $\mathrm{C}(8)$ & $8619(6)$ & $8387(4)$ & $8534(2)$ & $25(1)$ \\
\hline $\mathrm{C}(9)$ & $10520(6)$ & $8060(4)$ & $8698(2)$ & $24(1)$ \\
\hline$C(10)$ & 11466(6) & $7712(4)$ & $8075(2)$ & $25(1)$ \\
\hline$C(11)$ & $10521(5)$ & 7689(4) & $7274(2)$ & $22(1)$ \\
\hline$C(12)$ & $6305(5)$ & 6998(4) & 1851(2) & 19(1) \\
\hline$C(13)$ & $4543(5)$ & $7410(3)$ & $2234(2)$ & 19(1) \\
\hline$C(14)$ & $5498(6)$ & $5756(4)$ & $1137(2)$ & $26(1)$ \\
\hline$C(15)$ & 7873(5) & $8298(4)$ & $1618(2)$ & $26(1)$ \\
\hline$C(16)$ & $4055(6)$ & $8760(4)$ & 1974(2) & $23(1)$ \\
\hline$C(17)$ & $2496(5)$ & $6152(4)$ & $2124(2)$ & $25(1)$ \\
\hline $\mathrm{C}(18)$ & $5496(5)$ & $6558(3)$ & $6047(2)$ & $24(1)$ \\
\hline $\mathrm{C}(19)$ & 6870(5) & 9334(3) & $6178(2)$ & $19(1)$ \\
\hline $\mathrm{C}(20)$ & $4980(6)$ & $9457(4)$ & $5959(2)$ & $32(1)$ \\
\hline
\end{tabular}




\begin{tabular}{|c|c|c|c|c|}
\hline$C(21)$ & $11510(7)$ & 8093(4) & $9566(2)$ & $33(1)$ \\
\hline $\mathrm{F}(1)$ & $11415(10)$ & $9206(5)$ & $10058(2)$ & $48(1)$ \\
\hline $\mathrm{F}(2)$ & 13594(6) & $8156(7)$ & $9650(2)$ & $46(1)$ \\
\hline $\mathrm{F}(3)$ & 10623(9) & $6884(5)$ & $9862(2)$ & $53(1)$ \\
\hline $\mathrm{F}(1 \mathrm{X})$ & $9960(30)$ & $7380(20)$ & $9956(13)$ & $43(5)$ \\
\hline $\mathrm{F}(2 \mathrm{X})$ & $12290(30)$ & $9540(20)$ & 9924(14) & $32(5)$ \\
\hline $\mathrm{F}(3 \mathrm{X})$ & $12900(30)$ & $7600(20)$ & $9662(12)$ & $27(5)$ \\
\hline $\mathrm{F}(1 \mathrm{Y})$ & $10430(50)$ & $8610(40)$ & $10080(20)$ & $43(7)$ \\
\hline $\mathrm{F}(2 \mathrm{Y})$ & $13560(50)$ & $8940(40)$ & $9710(20)$ & $43(7)$ \\
\hline $\mathrm{F}(3 \mathrm{Y})$ & $11450(60)$ & $6890(40)$ & $9720(20)$ & $43(8)$ \\
\hline$C(22)$ & $-516(6)$ & $3675(4)$ & $5858(2)$ & $26(1)$ \\
\hline$C(23)$ & $1483(5)$ & $3240(3)$ & $5915(2)$ & $21(1)$ \\
\hline$C(24)$ & $2405(6)$ & $3019(4)$ & $5284(2)$ & $26(1)$ \\
\hline$C(25)$ & $1745(6)$ & $3204(4)$ & $4415(2)$ & $30(1)$ \\
\hline$C(26)$ & $2075(5)$ & $2070(4)$ & $3793(2)$ & $21(1)$ \\
\hline$C(27)$ & $1222(5)$ & $2252(3)$ & $2922(2)$ & $17(1)$ \\
\hline$C(28)$ & $2236(5)$ & 1984(3) & $2290(2)$ & $20(1)$ \\
\hline$C(29)$ & $1379(6)$ & 2018(3) & $1489(2)$ & $23(1)$ \\
\hline$C(30)$ & $-489(6)$ & $2344(3)$ & $1308(2)$ & $24(1)$ \\
\hline$C(31)$ & $-1511(5)$ & $2643(4)$ & $1932(2)$ & $23(1)$ \\
\hline$C(32)$ & $-662(5)$ & $2584(4)$ & $2724(2)$ & $21(1)$ \\
\hline $\mathrm{C}(33)$ & $3361(5)$ & $3315(3)$ & $8154(2)$ & 19(1) \\
\hline$C(34)$ & $5179(5)$ & 2938(3) & $7785(2)$ & $19(1)$ \\
\hline$C(35)$ & $1836(6)$ & 1987(5) & 8394(3) & $36(1)$ \\
\hline$C(36)$ & $4107(6)$ & $4560(4)$ & $8849(2)$ & $32(1)$ \\
\hline$C(37)$ & $5711(6)$ & $1597(4)$ & $8041(2)$ & $30(1)$ \\
\hline$C(38)$ & $7179(6)$ & $4221(4)$ & 7894(2) & $30(1)$ \\
\hline $\mathrm{C}(39)$ & $753(6)$ & $504(4)$ & $3913(2)$ & $28(1)$ \\
\hline $\mathrm{C}(40)$ & $4385(6)$ & 2204(4) & $3918(2)$ & $31(1)$ \\
\hline $\mathrm{C}(41)$ & $5245(6)$ & $1163(5)$ & $4089(2)$ & $34(1)$ \\
\hline $\mathrm{C}(42)$ & $-1427(7)$ & $2379(4)$ & $448(2)$ & $33(1)$ \\
\hline $\mathrm{F}(4)$ & $-306(11)$ & $3556(6)$ & 158(3) & $68(2)$ \\
\hline $\mathrm{F}(5)$ & $-1499(11)$ & $1215(6)$ & $-49(3)$ & $47(1)$ \\
\hline $\mathrm{F}(6)$ & $-3437(8)$ & $2433(8)$ & $342(2)$ & $50(1)$ \\
\hline $\mathrm{F}(4 \mathrm{X})$ & $170(40)$ & $2540(30)$ & $-27(17)$ & $46(6)$ \\
\hline $\mathrm{F}(5 \mathrm{X})$ & $-2710(50)$ & $990(30)$ & $110(20)$ & $51(7)$ \\
\hline $\mathrm{F}(6 \mathrm{X})$ & $-2390(40)$ & $3210(30)$ & $339(14)$ & $24(5)$ \\
\hline $\mathrm{F}(4 \mathrm{Y})$ & $-1060(30)$ & $3650(20)$ & $268(12)$ & $31(4)$ \\
\hline $\mathrm{F}(5 \mathrm{Y})$ & $-770(30)$ & $1550(20)$ & $-68(16)$ & $37(6)$ \\
\hline
\end{tabular}




\begin{tabular}{lcccc}
$\mathrm{F}(6 \mathrm{Y})$ & $-3530(30)$ & $1798(19)$ & $312(11)$ & $37(4)$ \\
$\mathrm{O}(1)$ & $7440(4)$ & $6513(2)$ & $2520(1)$ & $22(1)$ \\
$\mathrm{O}(2)$ & $5461(4)$ & $7736(2)$ & $3098(1)$ & $22(1)$ \\
$\mathrm{O}(3)$ & $2170(4)$ & $3727(3)$ & $7471(1)$ & $27(1)$ \\
$\mathrm{O}(4)$ & $4280(4)$ & $2599(3)$ & $6918(1)$ & $26(1)$ \\
\hline
\end{tabular}

Table 5. Bond lengths $(\AA)$ and angles $\left(^{\circ}\right)$ for $\mathrm{C}_{21} \mathrm{H}_{28} \mathrm{BF}_{3} \mathrm{O}_{2}$

\begin{tabular}{ll}
\hline $\mathrm{B}(1)-\mathrm{O}(2)$ & $1.365(5)$ \\
$\mathrm{B}(1)-\mathrm{O}(1)$ & $1.366(4)$ \\
$\mathrm{B}(1)-\mathrm{C}(2)$ & $1.550(5)$ \\
$\mathrm{B}(2)-\mathrm{O}(3)$ & $1.363(4)$ \\
$\mathrm{B}(2)-\mathrm{O}(4)$ & $1.365(5)$ \\
$\mathrm{B}(2)-\mathrm{C}(23)$ & $1.557(5)$ \\
$\mathrm{C}(1)-\mathrm{C}(2)$ & $1.510(5)$ \\
$\mathrm{C}(1)-\mathrm{H}(1 \mathrm{~A})$ & 0.9800 \\
$\mathrm{C}(1)-\mathrm{H}(1 \mathrm{~B})$ & 0.9800 \\
$\mathrm{C}(1)-\mathrm{H}(1 \mathrm{C})$ & 0.9800 \\
$\mathrm{C}(2)-\mathrm{C}(3)$ & $1.342(5)$ \\
$\mathrm{C}(3)-\mathrm{C}(4)$ & $1.503(4)$ \\
$\mathrm{C}(3)-\mathrm{H}(3 \mathrm{~A})$ & 0.9500 \\
$\mathrm{C}(4)-\mathrm{C}(5)$ & $1.548(4)$ \\
$\mathrm{C}(4)-\mathrm{H}(4 \mathrm{~A})$ & 0.9900 \\
$\mathrm{C}(4)-\mathrm{H}(4 \mathrm{~B})$ & 0.9900 \\
$\mathrm{C}(5)-\mathrm{C}(19)$ & $1.519(4)$ \\
$\mathrm{C}(5)-\mathrm{C}(6)$ & $1.528(4)$ \\
$\mathrm{C}(5)-\mathrm{C}(18)$ & $1.542(4)$ \\
$\mathrm{C}(6)-\mathrm{C}(11)$ & $1.396(5)$ \\
$\mathrm{C}(6)-\mathrm{C}(7)$ & $1.409(5)$ \\
$\mathrm{C}(7)-\mathrm{C}(8)$ & $1.372(5)$ \\
$\mathrm{C}(7)-\mathrm{H}(7 \mathrm{~A})$ & 0.9500 \\
$\mathrm{C}(8)-\mathrm{C}(9)$ & $1.398(5)$ \\
$\mathrm{C}(8)-\mathrm{H}(8 \mathrm{~A})$ & 0.9500 \\
$\mathrm{C}(9)-\mathrm{C}(10)$ & $1.374(5)$ \\
$\mathrm{C}(9)-\mathrm{C}(21)$ & $1.503(5)$ \\
$\mathrm{C}(10)-\mathrm{C}(11)$ & $1.395(5)$ \\
$\mathrm{C}(10)-\mathrm{H}(10 \mathrm{~A})$ & 0.9500 \\
$\mathrm{C}(11)-\mathrm{H}(11 \mathrm{~A})$ & 0.9500 \\
& \\
& \\
&
\end{tabular}




\begin{tabular}{|c|c|}
\hline $\mathrm{C}(12)-\mathrm{O}(1)$ & $1.454(4)$ \\
\hline$C(12)-C(15)$ & $1.516(5)$ \\
\hline$C(12)-C(14)$ & $1.526(5)$ \\
\hline$C(12)-C(13)$ & $1.563(4)$ \\
\hline $\mathrm{C}(13)-\mathrm{O}(2)$ & $1.456(4)$ \\
\hline$C(13)-C(16)$ & $1.521(5)$ \\
\hline$C(13)-C(17)$ & $1.522(4)$ \\
\hline $\mathrm{C}(14)-\mathrm{H}(14 \mathrm{~A})$ & 0.9800 \\
\hline $\mathrm{C}(14)-\mathrm{H}(14 \mathrm{~B})$ & 0.9800 \\
\hline $\mathrm{C}(14)-\mathrm{H}(14 \mathrm{C})$ & 0.9800 \\
\hline $\mathrm{C}(15)-\mathrm{H}(15 \mathrm{~A})$ & 0.9800 \\
\hline $\mathrm{C}(15)-\mathrm{H}(15 \mathrm{~B})$ & 0.9800 \\
\hline $\mathrm{C}(15)-\mathrm{H}(15 \mathrm{C})$ & 0.9800 \\
\hline $\mathrm{C}(16)-\mathrm{H}(16 \mathrm{~A})$ & 0.9800 \\
\hline $\mathrm{C}(16)-\mathrm{H}(16 \mathrm{~B})$ & 0.9800 \\
\hline $\mathrm{C}(16)-\mathrm{H}(16 \mathrm{C})$ & 0.9800 \\
\hline $\mathrm{C}(17)-\mathrm{H}(17 \mathrm{~A})$ & 0.9800 \\
\hline $\mathrm{C}(17)-\mathrm{H}(17 \mathrm{~B})$ & 0.9800 \\
\hline $\mathrm{C}(17)-\mathrm{H}(17 \mathrm{C})$ & 0.9800 \\
\hline $\mathrm{C}(18)-\mathrm{H}(18 \mathrm{~A})$ & 0.9800 \\
\hline $\mathrm{C}(18)-\mathrm{H}(18 \mathrm{~B})$ & 0.9800 \\
\hline $\mathrm{C}(18)-\mathrm{H}(18 \mathrm{C})$ & 0.9800 \\
\hline$C(19)-C(20)$ & $1.311(5)$ \\
\hline $\mathrm{C}(19)-\mathrm{H}(19 \mathrm{~A})$ & 0.9500 \\
\hline $\mathrm{C}(20)-\mathrm{H}(20 \mathrm{~A})$ & 0.9500 \\
\hline $\mathrm{C}(20)-\mathrm{H}(20 \mathrm{~B})$ & 0.9500 \\
\hline$C(21)-F(1)$ & $1.317(5)$ \\
\hline$C(21)-F(3)$ & $1.330(5)$ \\
\hline$C(21)-F(2)$ & $1.370(6)$ \\
\hline$C(22)-C(23)$ & $1.514(5)$ \\
\hline $\mathrm{C}(22)-\mathrm{H}(22 \mathrm{~A})$ & 0.9800 \\
\hline $\mathrm{C}(22)-\mathrm{H}(22 \mathrm{~B})$ & 0.9800 \\
\hline $\mathrm{C}(22)-\mathrm{H}(22 \mathrm{C})$ & 0.9800 \\
\hline C(23)-C(24) & $1.341(5)$ \\
\hline$C(24)-C(25)$ & $1.507(5)$ \\
\hline $\mathrm{C}(24)-\mathrm{H}(24 \mathrm{~A})$ & 0.9500 \\
\hline$C(25)-C(26)$ & $1.532(4)$ \\
\hline $\mathrm{C}(25)-\mathrm{H}(25 \mathrm{~A})$ & 0.9900 \\
\hline $\mathrm{C}(25)-\mathrm{H}(25 \mathrm{~B})$ & 0.9900 \\
\hline
\end{tabular}




\begin{tabular}{|c|c|}
\hline$C(26)-C(40)$ & $1.502(5)$ \\
\hline$C(26)-C(27)$ & $1.536(5)$ \\
\hline$C(26)-C(39)$ & $1.567(4)$ \\
\hline$C(27)-C(28)$ & $1.395(4)$ \\
\hline $\mathrm{C}(27)-\mathrm{C}(32)$ & $1.396(5)$ \\
\hline $\mathrm{C}(28)-\mathrm{C}(29)$ & $1.391(5)$ \\
\hline $\mathrm{C}(28)-\mathrm{H}(28 \mathrm{~A})$ & 0.9500 \\
\hline C(29)-C(30) & $1.378(5)$ \\
\hline $\mathrm{C}(29)-\mathrm{H}(29 \mathrm{~A})$ & 0.9500 \\
\hline $\mathrm{C}(30)-\mathrm{C}(31)$ & $1.396(5)$ \\
\hline$C(30)-C(42)$ & $1.495(5)$ \\
\hline $\mathrm{C}(31)-\mathrm{C}(32)$ & $1.381(5)$ \\
\hline $\mathrm{C}(31)-\mathrm{H}(31 \mathrm{~A})$ & 0.9500 \\
\hline $\mathrm{C}(32)-\mathrm{H}(32 \mathrm{~A})$ & 0.9500 \\
\hline $\mathrm{C}(33)-\mathrm{O}(3)$ & $1.453(4)$ \\
\hline C(33)-C(36) & $1.507(5)$ \\
\hline $\mathrm{C}(33)-\mathrm{C}(35)$ & $1.527(5)$ \\
\hline $\mathrm{C}(33)-\mathrm{C}(34)$ & $1.571(5)$ \\
\hline $\mathrm{C}(34)-\mathrm{O}(4)$ & $1.460(4)$ \\
\hline C(34)-C(38) & $1.515(5)$ \\
\hline $\mathrm{C}(34)-\mathrm{C}(37)$ & $1.524(5)$ \\
\hline $\mathrm{C}(35)-\mathrm{H}(35 \mathrm{~A})$ & 0.9800 \\
\hline $\mathrm{C}(35)-\mathrm{H}(35 \mathrm{~B})$ & 0.9800 \\
\hline $\mathrm{C}(35)-\mathrm{H}(35 \mathrm{C})$ & 0.9800 \\
\hline $\mathrm{C}(36)-\mathrm{H}(36 \mathrm{~A})$ & 0.9800 \\
\hline $\mathrm{C}(36)-\mathrm{H}(36 \mathrm{~B})$ & 0.9800 \\
\hline $\mathrm{C}(36)-\mathrm{H}(36 \mathrm{C})$ & 0.9800 \\
\hline $\mathrm{C}(37)-\mathrm{H}(37 \mathrm{~A})$ & 0.9800 \\
\hline $\mathrm{C}(37)-\mathrm{H}(37 \mathrm{~B})$ & 0.9800 \\
\hline $\mathrm{C}(37)-\mathrm{H}(37 \mathrm{C})$ & 0.9800 \\
\hline $\mathrm{C}(38)-\mathrm{H}(38 \mathrm{~A})$ & 0.9800 \\
\hline $\mathrm{C}(38)-\mathrm{H}(38 \mathrm{~B})$ & 0.9800 \\
\hline $\mathrm{C}(38)-\mathrm{H}(38 \mathrm{C})$ & 0.9800 \\
\hline $\mathrm{C}(39)-\mathrm{H}(39 \mathrm{~A})$ & 0.9800 \\
\hline $\mathrm{C}(39)-\mathrm{H}(39 \mathrm{~B})$ & 0.9800 \\
\hline C(39)-H(39C) & 0.9800 \\
\hline$C(40)-C(41)$ & $1.330(6)$ \\
\hline $\mathrm{C}(40)-\mathrm{H}(40 \mathrm{~A})$ & 0.9500 \\
\hline $\mathrm{C}(41)-\mathrm{H}(41 \mathrm{~A})$ & 0.9500 \\
\hline
\end{tabular}




\begin{tabular}{|c|c|}
\hline $\mathrm{C}(41)-\mathrm{H}(41 \mathrm{~B})$ & 0.9500 \\
\hline$C(42)-F(5)$ & $1.322(6)$ \\
\hline$C(42)-F(4)$ & $1.351(6)$ \\
\hline$C(42)-F(6)$ & $1.353(6)$ \\
\hline $\mathrm{O}(2)-\mathrm{B}(1)-\mathrm{O}(1)$ & $113.5(3)$ \\
\hline $\mathrm{O}(2)-\mathrm{B}(1)-\mathrm{C}(2)$ & $123.9(3)$ \\
\hline $\mathrm{O}(1)-\mathrm{B}(1)-\mathrm{C}(2)$ & $122.5(3)$ \\
\hline $\mathrm{O}(3)-\mathrm{B}(2)-\mathrm{O}(4)$ & $113.2(3)$ \\
\hline $\mathrm{O}(3)-\mathrm{B}(2)-\mathrm{C}(23)$ & $122.7(3)$ \\
\hline $\mathrm{O}(4)-\mathrm{B}(2)-\mathrm{C}(23)$ & $124.0(3)$ \\
\hline $\mathrm{C}(2)-\mathrm{C}(1)-\mathrm{H}(1 \mathrm{~A})$ & 109.5 \\
\hline $\mathrm{C}(2)-\mathrm{C}(1)-\mathrm{H}(1 \mathrm{~B})$ & 109.5 \\
\hline $\mathrm{H}(1 \mathrm{~A})-\mathrm{C}(1)-\mathrm{H}(1 \mathrm{~B})$ & 109.5 \\
\hline $\mathrm{C}(2)-\mathrm{C}(1)-\mathrm{H}(1 \mathrm{C})$ & 109.5 \\
\hline $\mathrm{H}(1 \mathrm{~A})-\mathrm{C}(1)-\mathrm{H}(1 \mathrm{C})$ & 109.5 \\
\hline $\mathrm{H}(1 \mathrm{~B})-\mathrm{C}(1)-\mathrm{H}(1 \mathrm{C})$ & 109.5 \\
\hline $\mathrm{C}(3)-\mathrm{C}(2)-\mathrm{C}(1)$ & $122.6(3)$ \\
\hline $\mathrm{C}(3)-\mathrm{C}(2)-\mathrm{B}(1)$ & $118.7(3)$ \\
\hline $\mathrm{C}(1)-\mathrm{C}(2)-\mathrm{B}(1)$ & $118.4(3)$ \\
\hline $\mathrm{C}(2)-\mathrm{C}(3)-\mathrm{C}(4)$ & $126.4(3)$ \\
\hline $\mathrm{C}(2)-\mathrm{C}(3)-\mathrm{H}(3 \mathrm{~A})$ & 116.8 \\
\hline $\mathrm{C}(4)-\mathrm{C}(3)-\mathrm{H}(3 \mathrm{~A})$ & 116.8 \\
\hline $\mathrm{C}(3)-\mathrm{C}(4)-\mathrm{C}(5)$ & $113.6(3)$ \\
\hline $\mathrm{C}(3)-\mathrm{C}(4)-\mathrm{H}(4 \mathrm{~A})$ & 108.8 \\
\hline $\mathrm{C}(5)-\mathrm{C}(4)-\mathrm{H}(4 \mathrm{~A})$ & 108.8 \\
\hline $\mathrm{C}(3)-\mathrm{C}(4)-\mathrm{H}(4 \mathrm{~B})$ & 108.8 \\
\hline $\mathrm{C}(5)-\mathrm{C}(4)-\mathrm{H}(4 \mathrm{~B})$ & 108.8 \\
\hline $\mathrm{H}(4 \mathrm{~A})-\mathrm{C}(4)-\mathrm{H}(4 \mathrm{~B})$ & 107.7 \\
\hline$C(19)-C(5)-C(6)$ & $108.3(2)$ \\
\hline $\mathrm{C}(19)-\mathrm{C}(5)-\mathrm{C}(18)$ & $112.6(3)$ \\
\hline $\mathrm{C}(6)-\mathrm{C}(5)-\mathrm{C}(18)$ & $107.6(2)$ \\
\hline $\mathrm{C}(19)-\mathrm{C}(5)-\mathrm{C}(4)$ & $108.0(2)$ \\
\hline$C(6)-C(5)-C(4)$ & $111.6(3)$ \\
\hline$C(18)-C(5)-C(4)$ & $108.8(3)$ \\
\hline$C(11)-C(6)-C(7)$ & $117.6(3)$ \\
\hline$C(11)-C(6)-C(5)$ & $123.9(3)$ \\
\hline$C(7)-C(6)-C(5)$ & $118.4(3)$ \\
\hline $\mathrm{C}(8)-\mathrm{C}(7)-\mathrm{C}(6)$ & $121.4(3)$ \\
\hline $\mathrm{C}(8)-\mathrm{C}(7)-\mathrm{H}(7 \mathrm{~A})$ & 119.3 \\
\hline
\end{tabular}




$\begin{array}{ll}\mathrm{C}(6)-\mathrm{C}(7)-\mathrm{H}(7 \mathrm{~A}) & 119.3 \\ \mathrm{C}(7)-\mathrm{C}(8)-\mathrm{C}(9) & 119.7(3) \\ \mathrm{C}(7)-\mathrm{C}(8)-\mathrm{H}(8 \mathrm{~A}) & 120.2 \\ \mathrm{C}(9)-\mathrm{C}(8)-\mathrm{H}(8 \mathrm{~A}) & 120.2 \\ \mathrm{C}(10)-\mathrm{C}(9)-\mathrm{C}(8) & 120.4(3) \\ \mathrm{C}(10)-\mathrm{C}(9)-\mathrm{C}(21) & 120.6(3) \\ \mathrm{C}(8)-\mathrm{C}(9)-\mathrm{C}(21) & 119.0(3) \\ \mathrm{C}(9)-\mathrm{C}(10)-\mathrm{C}(11) & 119.6(3) \\ \mathrm{C}(9)-\mathrm{C}(10)-\mathrm{H}(10 \mathrm{~A}) & 120.2 \\ \mathrm{C}(11)-\mathrm{C}(10)-\mathrm{H}(10 \mathrm{~A}) & 120.2 \\ \mathrm{C}(10)-\mathrm{C}(11)-\mathrm{C}(6) & 121.3(3) \\ \mathrm{C}(10)-\mathrm{C}(11)-\mathrm{H}(11 \mathrm{~A}) & 119.4 \\ \mathrm{C}(6)-\mathrm{C}(11)-\mathrm{H}(11 \mathrm{~A}) & 119.4 \\ \mathrm{O}(1)-\mathrm{C}(12)-\mathrm{C}(15) & 107.2(3) \\ \mathrm{O}(1)-\mathrm{C}(12)-\mathrm{C}(14) & 108.5(3) \\ \mathrm{C}(15)-\mathrm{C}(12)-\mathrm{C}(14) & 109.7(3) \\ \mathrm{O}(1)-\mathrm{C}(12)-\mathrm{C}(13) & 102.7(2) \\ \mathrm{C}(15)-\mathrm{C}(12)-\mathrm{C}(13) & 113.3(3) \\ \mathrm{C}(14)-\mathrm{C}(12)-\mathrm{C}(13) & 115.0(3) \\ \mathrm{O}(2)-\mathrm{C}(13)-\mathrm{C}(16) & 108.0(2) \\ \mathrm{O}(2)-\mathrm{C}(13)-\mathrm{C}(17) & 107.2(3) \\ \mathrm{C}(16)-\mathrm{C}(13)-\mathrm{C}(17) & 109.7(3) \\ \mathrm{O}(2)-\mathrm{C}(13)-\mathrm{C}(12) & 102.7(3) \\ \mathrm{C}(16)-\mathrm{C}(13)-\mathrm{C}(12) & 114.9(3) \\ \mathrm{C}(17)-\mathrm{C}(13)-\mathrm{C}(12) & 113.8(3) \\ \mathrm{C}(12)-\mathrm{C}(14)-\mathrm{H}(14 \mathrm{~A}) & 109.5 \\ \mathrm{C}(12)-\mathrm{C}(14)-\mathrm{H}(14 \mathrm{~B}) & 109.5 \\ \mathrm{H}(14 \mathrm{~A})-\mathrm{C}(14)-\mathrm{H}(14 \mathrm{~B}) & 109.5 \\ \mathrm{C}(12)-\mathrm{C}(14)-\mathrm{H}(14 \mathrm{C}) & 109.5 \\ \mathrm{H}(14 \mathrm{~A})-\mathrm{C}(14)-\mathrm{H}(14 \mathrm{C}) & 109.5 \\ \mathrm{H}(14 \mathrm{~B})-\mathrm{C}(14)-\mathrm{H}(14 \mathrm{C}) & 109.5 \\ \mathrm{C}(12)-\mathrm{C}(15)-\mathrm{H}(15 \mathrm{~A}) & 109.5 \\ \mathrm{C}(12)-\mathrm{C}(15)-\mathrm{H}(15 \mathrm{~B}) & 109.5 \\ \mathrm{H}(15 \mathrm{~A})-\mathrm{C}(15)-\mathrm{H}(15 \mathrm{~B}) & 109.5 \\ \mathrm{C}(12)-\mathrm{C}(15)-\mathrm{H}(15 \mathrm{C}) & 109.5 \\ \mathrm{H}(15 \mathrm{~A})-\mathrm{C}(15)-\mathrm{H}(15 \mathrm{C}) & 109.5 \\ & 109.5 \\ & \end{array}$




\begin{tabular}{|c|c|}
\hline $\mathrm{H}(16 \mathrm{~A})-\mathrm{C}(16)-\mathrm{H}(16 \mathrm{~B})$ & 109.5 \\
\hline $\mathrm{C}(13)-\mathrm{C}(16)-\mathrm{H}(16 \mathrm{C})$ & 109.5 \\
\hline $\mathrm{H}(16 \mathrm{~A})-\mathrm{C}(16)-\mathrm{H}(16 \mathrm{C})$ & 109.5 \\
\hline $\mathrm{H}(16 \mathrm{~B})-\mathrm{C}(16)-\mathrm{H}(16 \mathrm{C})$ & 109.5 \\
\hline $\mathrm{C}(13)-\mathrm{C}(17)-\mathrm{H}(17 \mathrm{~A})$ & 109.5 \\
\hline $\mathrm{C}(13)-\mathrm{C}(17)-\mathrm{H}(17 \mathrm{~B})$ & 109.5 \\
\hline $\mathrm{H}(17 \mathrm{~A})-\mathrm{C}(17)-\mathrm{H}(17 \mathrm{~B})$ & 109.5 \\
\hline $\mathrm{C}(13)-\mathrm{C}(17)-\mathrm{H}(17 \mathrm{C})$ & 109.5 \\
\hline $\mathrm{H}(17 \mathrm{~A})-\mathrm{C}(17)-\mathrm{H}(17 \mathrm{C})$ & 109.5 \\
\hline $\mathrm{H}(17 \mathrm{~B})-\mathrm{C}(17)-\mathrm{H}(17 \mathrm{C})$ & 109.5 \\
\hline $\mathrm{C}(5)-\mathrm{C}(18)-\mathrm{H}(18 \mathrm{~A})$ & 109.5 \\
\hline $\mathrm{C}(5)-\mathrm{C}(18)-\mathrm{H}(18 \mathrm{~B})$ & 109.5 \\
\hline $\mathrm{H}(18 \mathrm{~A})-\mathrm{C}(18)-\mathrm{H}(18 \mathrm{~B})$ & 109.5 \\
\hline $\mathrm{C}(5)-\mathrm{C}(18)-\mathrm{H}(18 \mathrm{C})$ & 109.5 \\
\hline $\mathrm{H}(18 \mathrm{~A})-\mathrm{C}(18)-\mathrm{H}(18 \mathrm{C})$ & 109.5 \\
\hline $\mathrm{H}(18 \mathrm{~B})-\mathrm{C}(18)-\mathrm{H}(18 \mathrm{C})$ & 109.5 \\
\hline$C(20)-C(19)-C(5)$ & $127.5(3)$ \\
\hline $\mathrm{C}(20)-\mathrm{C}(19)-\mathrm{H}(19 \mathrm{~A})$ & 116.3 \\
\hline $\mathrm{C}(5)-\mathrm{C}(19)-\mathrm{H}(19 \mathrm{~A})$ & 116.3 \\
\hline $\mathrm{C}(19)-\mathrm{C}(20)-\mathrm{H}(20 \mathrm{~A})$ & 120.0 \\
\hline $\mathrm{C}(19)-\mathrm{C}(20)-\mathrm{H}(20 \mathrm{~B})$ & 120.0 \\
\hline $\mathrm{H}(20 \mathrm{~A})-\mathrm{C}(20)-\mathrm{H}(20 \mathrm{~B})$ & 120.0 \\
\hline $\mathrm{F}(1)-\mathrm{C}(21)-\mathrm{F}(3)$ & 107.1(4) \\
\hline $\mathrm{F}(1)-\mathrm{C}(21)-\mathrm{F}(2)$ & $107.4(4)$ \\
\hline $\mathrm{F}(3)-\mathrm{C}(21)-\mathrm{F}(2)$ & $103.8(4)$ \\
\hline $\mathrm{F}(1)-\mathrm{C}(21)-\mathrm{C}(9)$ & 113.1(3) \\
\hline $\mathrm{F}(3)-\mathrm{C}(21)-\mathrm{C}(9)$ & $112.7(4)$ \\
\hline $\mathrm{F}(2)-\mathrm{C}(21)-\mathrm{C}(9)$ & $112.2(3)$ \\
\hline $\mathrm{C}(23)-\mathrm{C}(22)-\mathrm{H}(22 \mathrm{~A})$ & 109.5 \\
\hline $\mathrm{C}(23)-\mathrm{C}(22)-\mathrm{H}(22 \mathrm{~B})$ & 109.5 \\
\hline $\mathrm{H}(22 \mathrm{~A})-\mathrm{C}(22)-\mathrm{H}(22 \mathrm{~B})$ & 109.5 \\
\hline $\mathrm{C}(23)-\mathrm{C}(22)-\mathrm{H}(22 \mathrm{C})$ & 109.5 \\
\hline $\mathrm{H}(22 \mathrm{~A})-\mathrm{C}(22)-\mathrm{H}(22 \mathrm{C})$ & 109.5 \\
\hline $\mathrm{H}(22 \mathrm{~B})-\mathrm{C}(22)-\mathrm{H}(22 \mathrm{C})$ & 109.5 \\
\hline $\mathrm{C}(24)-\mathrm{C}(23)-\mathrm{C}(22)$ & $124.6(3)$ \\
\hline $\mathrm{C}(24)-\mathrm{C}(23)-\mathrm{B}(2)$ & $117.7(3)$ \\
\hline $\mathrm{C}(22)-\mathrm{C}(23)-\mathrm{B}(2)$ & $117.4(3)$ \\
\hline$C(23)-C(24)-C(25)$ & $127.8(3)$ \\
\hline $\mathrm{C}(23)-\mathrm{C}(24)-\mathrm{H}(24 \mathrm{~A})$ & 116.1 \\
\hline
\end{tabular}




\begin{tabular}{|c|c|}
\hline $\mathrm{C}(25)-\mathrm{C}(24)-\mathrm{H}(24 \mathrm{~A})$ & 116.1 \\
\hline$C(24)-C(25)-C(26)$ & $113.9(3)$ \\
\hline $\mathrm{C}(24)-\mathrm{C}(25)-\mathrm{H}(25 \mathrm{~A})$ & 108.8 \\
\hline $\mathrm{C}(26)-\mathrm{C}(25)-\mathrm{H}(25 \mathrm{~A})$ & 108.8 \\
\hline $\mathrm{C}(24)-\mathrm{C}(25)-\mathrm{H}(25 \mathrm{~B})$ & 108.8 \\
\hline $\mathrm{C}(26)-\mathrm{C}(25)-\mathrm{H}(25 \mathrm{~B})$ & 108.8 \\
\hline $\mathrm{H}(25 \mathrm{~A})-\mathrm{C}(25)-\mathrm{H}(25 \mathrm{~B})$ & 107.7 \\
\hline$C(40)-C(26)-C(25)$ & $109.0(3)$ \\
\hline $\mathrm{C}(40)-\mathrm{C}(26)-\mathrm{C}(27)$ & $111.6(3)$ \\
\hline $\mathrm{C}(25)-\mathrm{C}(26)-\mathrm{C}(27)$ & 111.1(3) \\
\hline $\mathrm{C}(40)-\mathrm{C}(26)-\mathrm{C}(39)$ & $110.2(3)$ \\
\hline $\mathrm{C}(25)-\mathrm{C}(26)-\mathrm{C}(39)$ & $108.9(3)$ \\
\hline $\mathrm{C}(27)-\mathrm{C}(26)-\mathrm{C}(39)$ & $105.9(3)$ \\
\hline $\mathrm{C}(28)-\mathrm{C}(27)-\mathrm{C}(32)$ & $117.6(3)$ \\
\hline$C(28)-C(27)-C(26)$ & $120.6(3)$ \\
\hline $\mathrm{C}(32)-\mathrm{C}(27)-\mathrm{C}(26)$ & $121.6(3)$ \\
\hline $\mathrm{C}(29)-\mathrm{C}(28)-\mathrm{C}(27)$ & $121.2(3)$ \\
\hline $\mathrm{C}(29)-\mathrm{C}(28)-\mathrm{H}(28 \mathrm{~A})$ & 119.4 \\
\hline $\mathrm{C}(27)-\mathrm{C}(28)-\mathrm{H}(28 \mathrm{~A})$ & 119.4 \\
\hline $\mathrm{C}(30)-\mathrm{C}(29)-\mathrm{C}(28)$ & 120.1(3) \\
\hline $\mathrm{C}(30)-\mathrm{C}(29)-\mathrm{H}(29 \mathrm{~A})$ & 119.9 \\
\hline $\mathrm{C}(28)-\mathrm{C}(29)-\mathrm{H}(29 \mathrm{~A})$ & 119.9 \\
\hline $\mathrm{C}(29)-\mathrm{C}(30)-\mathrm{C}(31)$ & 119.7(3) \\
\hline $\mathrm{C}(29)-\mathrm{C}(30)-\mathrm{C}(42)$ & $120.6(3)$ \\
\hline $\mathrm{C}(31)-\mathrm{C}(30)-\mathrm{C}(42)$ & 119.7(3) \\
\hline $\mathrm{C}(32)-\mathrm{C}(31)-\mathrm{C}(30)$ & 119.7(3) \\
\hline $\mathrm{C}(32)-\mathrm{C}(31)-\mathrm{H}(31 \mathrm{~A})$ & 120.2 \\
\hline $\mathrm{C}(30)-\mathrm{C}(31)-\mathrm{H}(31 \mathrm{~A})$ & 120.2 \\
\hline $\mathrm{C}(31)-\mathrm{C}(32)-\mathrm{C}(27)$ & 121.7(3) \\
\hline $\mathrm{C}(31)-\mathrm{C}(32)-\mathrm{H}(32 \mathrm{~A})$ & 119.2 \\
\hline $\mathrm{C}(27)-\mathrm{C}(32)-\mathrm{H}(32 \mathrm{~A})$ & 119.2 \\
\hline $\mathrm{O}(3)-\mathrm{C}(33)-\mathrm{C}(36)$ & $109.4(3)$ \\
\hline $\mathrm{O}(3)-\mathrm{C}(33)-\mathrm{C}(35)$ & $106.3(3)$ \\
\hline $\mathrm{C}(36)-\mathrm{C}(33)-\mathrm{C}(35)$ & $110.0(3)$ \\
\hline $\mathrm{O}(3)-\mathrm{C}(33)-\mathrm{C}(34)$ & $103.0(2)$ \\
\hline $\mathrm{C}(36)-\mathrm{C}(33)-\mathrm{C}(34)$ & $114.7(3)$ \\
\hline $\mathrm{C}(35)-\mathrm{C}(33)-\mathrm{C}(34)$ & $112.9(3)$ \\
\hline $\mathrm{O}(4)-\mathrm{C}(34)-\mathrm{C}(38)$ & $106.8(3)$ \\
\hline $\mathrm{O}(4)-\mathrm{C}(34)-\mathrm{C}(37)$ & $107.3(3)$ \\
\hline
\end{tabular}




\begin{tabular}{ll}
$\mathrm{C}(38)-\mathrm{C}(34)-\mathrm{C}(37)$ & $110.2(3)$ \\
$\mathrm{O}(4)-\mathrm{C}(34)-\mathrm{C}(33)$ & $102.3(2)$ \\
$\mathrm{C}(38)-\mathrm{C}(34)-\mathrm{C}(33)$ & $113.8(3)$ \\
$\mathrm{C}(37)-\mathrm{C}(34)-\mathrm{C}(33)$ & $115.5(3)$ \\
$\mathrm{C}(33)-\mathrm{C}(35)-\mathrm{H}(35 \mathrm{~A})$ & 109.5 \\
$\mathrm{C}(33)-\mathrm{C}(35)-\mathrm{H}(35 \mathrm{~B})$ & 109.5 \\
$\mathrm{H}(35 \mathrm{~A})-\mathrm{C}(35)-\mathrm{H}(35 \mathrm{~B})$ & 109.5 \\
$\mathrm{C}(33)-\mathrm{C}(35)-\mathrm{H}(35 \mathrm{C})$ & 109.5 \\
$\mathrm{H}(35 \mathrm{~A})-\mathrm{C}(35)-\mathrm{H}(35 \mathrm{C})$ & 109.5 \\
$\mathrm{H}(35 \mathrm{~B})-\mathrm{C}(35)-\mathrm{H}(35 \mathrm{C})$ & 109.5 \\
$\mathrm{C}(33)-\mathrm{C}(36)-\mathrm{H}(36 \mathrm{~A})$ & 109.5 \\
$\mathrm{C}(33)-\mathrm{C}(36)-\mathrm{H}(36 \mathrm{~B})$ & 109.5 \\
$\mathrm{H}(36 \mathrm{~A})-\mathrm{C}(36)-\mathrm{H}(36 \mathrm{~B})$ & 109.5 \\
$\mathrm{C}(33)-\mathrm{C}(36)-\mathrm{H}(36 \mathrm{C})$ & 109.5 \\
$\mathrm{H}(36 \mathrm{~A})-\mathrm{C}(36)-\mathrm{H}(36 \mathrm{C})$ & 109.5 \\
$\mathrm{H}(36 \mathrm{~B})-\mathrm{C}(36)-\mathrm{H}(36 \mathrm{C})$ & 109.5 \\
$\mathrm{C}(34)-\mathrm{C}(37)-\mathrm{H}(37 \mathrm{~A})$ & 109.5 \\
$\mathrm{C}(34)-\mathrm{C}(37)-\mathrm{H}(37 \mathrm{~B})$ & 109.5 \\
$\mathrm{H}(37 \mathrm{~A})-\mathrm{C}(37)-\mathrm{H}(37 \mathrm{~B})$ & 109.5 \\
$\mathrm{C}(34)-\mathrm{C}(37)-\mathrm{H}(37 \mathrm{C})$ & 109.5 \\
$\mathrm{H}(37 \mathrm{~A})-\mathrm{C}(37)-\mathrm{H}(37 \mathrm{C})$ & 109.5 \\
$\mathrm{H}(37 \mathrm{~B})-\mathrm{C}(37)-\mathrm{H}(37 \mathrm{C})$ & 109.5 \\
$\mathrm{C}(34)-\mathrm{C}(38)-\mathrm{H}(38 \mathrm{~A})$ & 109.5 \\
$\mathrm{C}(34)-\mathrm{C}(38)-\mathrm{H}(38 \mathrm{~B})$ & 109.5 \\
$\mathrm{H}(38 \mathrm{~A})-\mathrm{C}(38)-\mathrm{H}(38 \mathrm{~B})$ & 109.5 \\
$\mathrm{C}(34)-\mathrm{C}(38)-\mathrm{H}(38 \mathrm{C})$ & 109.5 \\
$\mathrm{H}(38 \mathrm{~A})-\mathrm{C}(38)-\mathrm{H}(38 \mathrm{C})$ & 109.5 \\
$\mathrm{H}(38 \mathrm{~B})-\mathrm{C}(38)-\mathrm{H}(38 \mathrm{C})$ & 109.5 \\
$\mathrm{C}(26)-\mathrm{C}(39)-\mathrm{H}(39 \mathrm{~A})$ & 109.5 \\
$\mathrm{C}(26)-\mathrm{C}(39)-\mathrm{H}(39 \mathrm{~B})$ & 109.5 \\
$\mathrm{H}(39 \mathrm{~A})-\mathrm{C}(39)-\mathrm{H}(39 \mathrm{~B})$ & 109.5 \\
$\mathrm{C}(26)-\mathrm{C}(39)-\mathrm{H}(39 \mathrm{C})$ & 109.5 \\
$\mathrm{H}(39 \mathrm{~A})-\mathrm{C}(39)-\mathrm{H}(39 \mathrm{C})$ & 109.5 \\
$\mathrm{H}(39 \mathrm{~B})-\mathrm{C}(39)-\mathrm{H}(39 \mathrm{C})$ & 109.5 \\
$\mathrm{C}(41)-\mathrm{C}(40)-\mathrm{C}(26)$ & $126.6(3)$ \\
$\mathrm{C}(41)-\mathrm{C}(40)-\mathrm{H}(40 A)$ & 116.7 \\
& 116.7 \\
$\mathrm{C}(41)-\mathrm{H}(40 \mathrm{~A})$ & 120.0 \\
& \\
\hline
\end{tabular}




$\begin{array}{ll}\mathrm{H}(41 \mathrm{~A})-\mathrm{C}(41)-\mathrm{H}(41 \mathrm{~B}) & 120.0 \\ \mathrm{~F}(5)-\mathrm{C}(42)-\mathrm{F}(4) & 106.6(5) \\ \mathrm{F}(5)-\mathrm{C}(42)-\mathrm{F}(6) & 105.5(4) \\ \mathrm{F}(4)-\mathrm{C}(42)-\mathrm{F}(6) & 105.8(5) \\ \mathrm{F}(5)-\mathrm{C}(42)-\mathrm{C}(30) & 112.5(4) \\ \mathrm{F}(4)-\mathrm{C}(42)-\mathrm{C}(30) & 111.9(3) \\ \mathrm{F}(6)-\mathrm{C}(42)-\mathrm{C}(30) & 114.0(3) \\ \mathrm{B}(1)-\mathrm{O}(1)-\mathrm{C}(12) & 107.4(3) \\ \mathrm{B}(1)-\mathrm{O}(2)-\mathrm{C}(13) & 107.4(3) \\ \mathrm{B}(2)-\mathrm{O}(3)-\mathrm{C}(33) & 107.9(3) \\ \mathrm{B}(2)-\mathrm{O}(4)-\mathrm{C}(34) & 108.2(3)\end{array}$

Symmetry transformations used to generate equivalent atoms:

Table 6. Anisotropic displacement parameters $\left(\AA^{2} \times 10^{3}\right)$ for $\mathrm{C}_{21} \mathrm{H}_{28} \mathrm{BF}_{3} \mathrm{O}_{2}$. The anisotropic displacement factor exponent takes the form: $-2 \mathrm{p}^{2}\left[\mathrm{~h}^{2} \mathrm{a}^{*} 2 \mathrm{U}^{11}+\ldots+2 \mathrm{~h} \mathrm{k} \mathrm{a}^{*} \mathrm{~b}^{*} \mathrm{U}^{12}\right]$

\begin{tabular}{lcccccc}
\hline & $\mathrm{U}^{11}$ & $\mathrm{U}^{22}$ & $\mathrm{U}^{33}$ & $\mathrm{U}^{23}$ & $\mathrm{U}^{13}$ & $\mathrm{U}^{12}$ \\
\hline $\mathrm{B}(1)$ & $24(2)$ & $21(2)$ & $15(2)$ & $2(1)$ & $4(2)$ & $10(1)$ \\
$\mathrm{B}(2)$ & $22(2)$ & $16(2)$ & $18(2)$ & $1(1)$ & $2(2)$ & $6(1)$ \\
$\mathrm{C}(1)$ & $38(2)$ & $40(2)$ & $17(2)$ & $3(1)$ & $4(2)$ & $25(2)$ \\
$\mathrm{C}(2)$ & $28(2)$ & $27(2)$ & $17(2)$ & $6(1)$ & $4(1)$ & $16(1)$ \\
$\mathrm{C}(3)$ & $26(2)$ & $35(2)$ & $16(2)$ & $4(1)$ & $2(1)$ & $17(1)$ \\
$\mathrm{C}(4)$ & $23(2)$ & $38(2)$ & $14(2)$ & $4(1)$ & $2(1)$ & $18(1)$ \\
$\mathrm{C}(5)$ & $17(2)$ & $21(2)$ & $16(2)$ & $2(1)$ & $3(1)$ & $6(1)$ \\
$\mathrm{C}(6)$ & $19(2)$ & $18(1)$ & $15(2)$ & $2(1)$ & $2(1)$ & $4(1)$ \\
$\mathrm{C}(7)$ & $25(2)$ & $18(2)$ & $20(2)$ & $1(1)$ & $6(1)$ & $6(1)$ \\
$\mathrm{C}(8)$ & $36(2)$ & $22(2)$ & $16(2)$ & $0(1)$ & $7(2)$ & $8(1)$ \\
$\mathrm{C}(9)$ & $32(2)$ & $20(2)$ & $15(2)$ & $4(1)$ & $-1(1)$ & $5(1)$ \\
$\mathrm{C}(10)$ & $25(2)$ & $30(2)$ & $20(2)$ & $4(1)$ & $-1(1)$ & $8(1)$ \\
$\mathrm{C}(11)$ & $23(2)$ & $27(2)$ & $16(2)$ & $2(1)$ & $4(1)$ & $7(1)$ \\
$\mathrm{C}(12)$ & $20(2)$ & $25(2)$ & $14(2)$ & $4(1)$ & $2(1)$ & $9(1)$ \\
$\mathrm{C}(13)$ & $24(2)$ & $22(2)$ & $10(2)$ & $-1(1)$ & $1(1)$ & $10(1)$ \\
$\mathrm{C}(14)$ & $32(2)$ & $31(2)$ & $16(2)$ & $-4(1)$ & $4(1)$ & $12(2)$ \\
$\mathrm{C}(15)$ & $24(2)$ & $34(2)$ & $18(2)$ & $4(1)$ & $2(1)$ & $5(1)$ \\
$\mathrm{C}(16)$ & $29(2)$ & $22(2)$ & $18(2)$ & $2(1)$ & $-2(1)$ & $11(1)$ \\
$\mathrm{C}(17)$ & $23(2)$ & $24(2)$ & $26(2)$ & $4(1)$ & $6(2)$ & $6(1)$ \\
$\mathrm{C}(18)$ & $22(2)$ & $23(2)$ & $18(2)$ & $-1(1)$ & $-5(1)$ & $2(1)$ \\
& & & & & \\
\end{tabular}




\begin{tabular}{|c|c|c|c|c|c|c|}
\hline C(19) & $27(2)$ & $20(1)$ & $10(1)$ & $-2(1)$ & $0(1)$ & $9(1)$ \\
\hline$C(20)$ & $38(2)$ & $38(2)$ & $27(2)$ & $6(2)$ & $7(2)$ & $23(2)$ \\
\hline $\mathrm{C}(21)$ & $50(2)$ & $34(2)$ & $16(2)$ & $3(1)$ & $2(2)$ & $18(2)$ \\
\hline $\mathrm{F}(1)$ & $82(4)$ & $49(2)$ & $11(2)$ & $-11(2)$ & $-13(2)$ & $37(3)$ \\
\hline $\mathrm{F}(2)$ & $38(2)$ & $70(3)$ & $21(2)$ & $2(2)$ & $-13(1)$ & $17(2)$ \\
\hline $\mathrm{F}(3)$ & $77(3)$ & $53(2)$ & $25(2)$ & $24(2)$ & $-3(2)$ & $12(2)$ \\
\hline$C(22)$ & $29(2)$ & $37(2)$ & $16(2)$ & $2(1)$ & $2(1)$ & $16(2)$ \\
\hline$C(23)$ & $23(2)$ & $20(2)$ & $17(2)$ & $0(1)$ & $-1(1)$ & $6(1)$ \\
\hline$C(24)$ & $30(2)$ & $31(2)$ & $19(2)$ & $2(1)$ & $1(1)$ & $17(1)$ \\
\hline$C(25)$ & $36(2)$ & $33(2)$ & $24(2)$ & $2(1)$ & $3(2)$ & $17(2)$ \\
\hline$C(26)$ & $23(2)$ & $28(2)$ & $14(2)$ & $3(1)$ & $2(1)$ & $10(1)$ \\
\hline $\mathrm{C}(27)$ & $21(2)$ & $10(1)$ & $18(2)$ & $1(1)$ & $4(1)$ & $0(1)$ \\
\hline$C(28)$ & $25(2)$ & $16(1)$ & $18(2)$ & $1(1)$ & $3(1)$ & $7(1)$ \\
\hline C(29) & $36(2)$ & $17(2)$ & $17(2)$ & $2(1)$ & $8(2)$ & $8(1)$ \\
\hline$C(30)$ & $38(2)$ & $16(2)$ & $14(2)$ & $0(1)$ & $3(1)$ & $5(1)$ \\
\hline $\mathrm{C}(31)$ & $25(2)$ & $23(2)$ & $19(2)$ & $3(1)$ & $2(1)$ & $8(1)$ \\
\hline$C(32)$ & $23(2)$ & $24(2)$ & $16(2)$ & $3(1)$ & $4(1)$ & $6(1)$ \\
\hline $\mathrm{C}(33)$ & $22(2)$ & $25(2)$ & $11(2)$ & $1(1)$ & $-1(1)$ & $9(1)$ \\
\hline$C(34)$ & $22(2)$ & $20(1)$ & $12(2)$ & $1(1)$ & $-1(1)$ & $7(1)$ \\
\hline$C(35)$ & $32(2)$ & $41(2)$ & $36(2)$ & $15(2)$ & 12(2) & $8(2)$ \\
\hline$C(36)$ & $33(2)$ & $39(2)$ & $22(2)$ & $-4(2)$ & $1(2)$ & $17(2)$ \\
\hline$C(37)$ & $36(2)$ & $32(2)$ & $27(2)$ & $5(2)$ & $3(2)$ & $18(2)$ \\
\hline C(38) & $25(2)$ & $33(2)$ & $33(2)$ & $1(2)$ & $9(2)$ & $9(2)$ \\
\hline C(39) & $30(2)$ & $24(2)$ & $26(2)$ & $4(1)$ & $1(1)$ & $6(1)$ \\
\hline $\mathrm{C}(40)$ & $30(2)$ & $36(2)$ & $26(2)$ & $5(1)$ & $8(1)$ & $6(1)$ \\
\hline $\mathrm{C}(41)$ & $29(2)$ & $54(2)$ & $27(2)$ & $8(2)$ & $8(2)$ & $24(2)$ \\
\hline $\mathrm{C}(42)$ & $48(2)$ & $31(2)$ & $17(2)$ & $1(1)$ & $-1(2)$ & $13(2)$ \\
\hline F(4) & $93(4)$ & $65(3)$ & $24(2)$ & $29(2)$ & $-3(2)$ & $-11(3)$ \\
\hline $\mathrm{F}(5)$ & $72(4)$ & $56(3)$ & $15(2)$ & $-12(2)$ & $-11(2)$ & $37(3)$ \\
\hline $\mathrm{F}(6)$ & $60(3)$ & $80(4)$ & $19(2)$ & $4(2)$ & $-7(2)$ & $46(3)$ \\
\hline $\mathrm{O}(1)$ & $26(1)$ & $28(1)$ & $14(1)$ & $2(1)$ & $3(1)$ & $15(1)$ \\
\hline $\mathrm{O}(2)$ & $28(1)$ & $30(1)$ & $9(1)$ & $-1(1)$ & $-1(1)$ & $16(1)$ \\
\hline $\mathrm{O}(3)$ & $26(1)$ & $44(1)$ & $14(1)$ & $5(1)$ & $1(1)$ & $20(1)$ \\
\hline $\mathrm{O}(4)$ & $31(1)$ & $39(1)$ & $14(1)$ & $3(1)$ & $2(1)$ & $20(1)$ \\
\hline
\end{tabular}


Table 7. Hydrogen coordinates $\left(\times 10^{4}\right)$ and isotropic displacement parameters $\left(\AA^{2} \times 10^{3}\right)$ for $\mathrm{C}_{21} \mathrm{H}_{28} \mathrm{BF}_{3} \mathrm{O}_{2}$

\begin{tabular}{|c|c|c|c|c|}
\hline & $\mathrm{x}$ & $\mathrm{y}$ & $\mathrm{z}$ & $\mathrm{U}(\mathrm{eq})$ \\
\hline $\mathrm{H}(1 \mathrm{~A})$ & 11348 & 7205 & 4052 & 44 \\
\hline $\mathrm{H}(1 \mathrm{~B})$ & 9751 & 5609 & 3689 & 44 \\
\hline $\mathrm{H}(1 \mathrm{C})$ & 10353 & 6124 & 4650 & 44 \\
\hline $\mathrm{H}(3 \mathrm{~A})$ & 6560 & 8007 & 4643 & 29 \\
\hline $\mathrm{H}(4 \mathrm{~A})$ & 10105 & 8717 & 5705 & 28 \\
\hline $\mathrm{H}(4 \mathrm{~B})$ & 9389 & 6979 & 5665 & 28 \\
\hline $\mathrm{H}(7 \mathrm{~A})$ & 6392 & 8569 & 7637 & 25 \\
\hline $\mathrm{H}(8 \mathrm{~A})$ & 7974 & 8633 & 8967 & 29 \\
\hline $\mathrm{H}(10 \mathrm{~A})$ & 12757 & 7489 & 8189 & 31 \\
\hline $\mathrm{H}(11 \mathrm{~A})$ & 11186 & 7456 & 6845 & 27 \\
\hline $\mathrm{H}(14 \mathrm{~A})$ & 4728 & 6067 & 681 & 39 \\
\hline $\mathrm{H}(14 \mathrm{~B})$ & 6699 & 5505 & 972 & 39 \\
\hline $\mathrm{H}(14 \mathrm{C})$ & 4549 & 4899 & 1299 & 39 \\
\hline $\mathrm{H}(15 \mathrm{~A})$ & 7161 & 8656 & 1167 & 40 \\
\hline $\mathrm{H}(15 \mathrm{~B})$ & 8435 & 9078 & 2086 & 40 \\
\hline $\mathrm{H}(15 \mathrm{C})$ & 9037 & 7999 & 1452 & 40 \\
\hline $\mathrm{H}(16 \mathrm{~A})$ & 3434 & 8566 & 1393 & 35 \\
\hline $\mathrm{H}(16 \mathrm{~B})$ & 3052 & 8999 & 2285 & 35 \\
\hline $\mathrm{H}(16 \mathrm{C})$ & 5364 & 9584 & 2077 & 35 \\
\hline $\mathrm{H}(17 \mathrm{~A})$ & 1831 & 5901 & 1548 & 37 \\
\hline $\mathrm{H}(17 \mathrm{~B})$ & 2807 & 5299 & 2319 & 37 \\
\hline $\mathrm{H}(17 \mathrm{C})$ & 1532 & 6445 & 2435 & 37 \\
\hline $\mathrm{H}(18 \mathrm{~A})$ & 5952 & 5688 & 6086 & 36 \\
\hline $\mathrm{H}(18 \mathrm{~B})$ & 4588 & 6620 & 6442 & 36 \\
\hline $\mathrm{H}(18 \mathrm{C})$ & 4704 & 6493 & 5498 & 36 \\
\hline $\mathrm{H}(19 \mathrm{~A})$ & 8007 & 10223 & 6322 & 23 \\
\hline $\mathrm{H}(20 \mathrm{~A})$ & 3782 & 8606 & 5809 & 38 \\
\hline $\mathrm{H}(20 \mathrm{~B})$ & 4807 & 10398 & 5951 & 38 \\
\hline $\mathrm{H}(22 \mathrm{~A})$ & -922 & 3883 & 5309 & 39 \\
\hline $\mathrm{H}(22 \mathrm{~B})$ & -263 & 4550 & 6252 & 39 \\
\hline $\mathrm{H}(22 \mathrm{C})$ & -1657 & 2873 & 5975 & 39 \\
\hline $\mathrm{H}(24 \mathrm{~A})$ & 3621 & 2707 & 5400 & 31 \\
\hline $\mathrm{H}(25 \mathrm{~A})$ & 2560 & 4193 & 4332 & 36 \\
\hline $\mathrm{H}(25 \mathrm{~B})$ & 229 & 3139 & 4317 & 36 \\
\hline $\mathrm{H}(28 \mathrm{~A})$ & 3536 & 1773 & 2408 & 24 \\
\hline
\end{tabular}




\begin{tabular}{lrrrl}
$\mathrm{H}(29 \mathrm{~A})$ & 2082 & 1817 & 1065 & 28 \\
$\mathrm{H}(31 \mathrm{~A})$ & -2785 & 2885 & 1813 & 27 \\
$\mathrm{H}(32 \mathrm{~A})$ & -1379 & 2775 & 3144 & 26 \\
$\mathrm{H}(35 \mathrm{~A})$ & 2569 & 1666 & 8856 & 54 \\
$\mathrm{H}(35 \mathrm{~B})$ & 632 & 2251 & 8548 & 54 \\
$\mathrm{H}(35 \mathrm{C})$ & 1326 & 1192 & 7934 & 54 \\
$\mathrm{H}(36 \mathrm{~A})$ & 4911 & 4283 & 9310 & 47 \\
$\mathrm{H}(36 \mathrm{~B})$ & 5014 & 5427 & 8678 & 47 \\
$\mathrm{H}(36 \mathrm{C})$ & 2882 & 4780 & 9011 & 47 \\
$\mathrm{H}(37 \mathrm{~A})$ & 6320 & 1788 & 8623 & 46 \\
$\mathrm{H}(37 \mathrm{~B})$ & 4419 & 757 & 7932 & 46 \\
$\mathrm{H}(37 \mathrm{C})$ & 6734 & 1383 & 7734 & 46 \\
$\mathrm{H}(38 \mathrm{~A})$ & 7836 & 4485 & 8471 & 46 \\
$\mathrm{H}(38 \mathrm{~B})$ & 8167 & 3951 & 7587 & 46 \\
$\mathrm{H}(38 \mathrm{C})$ & 6828 & 5058 & 7694 & 46 \\
$\mathrm{H}(39 \mathrm{~A})$ & -750 & 430 & 3830 & 42 \\
$\mathrm{H}(39 \mathrm{~B})$ & 964 & -229 & 3519 & 42 \\
$\mathrm{H}(39 \mathrm{C})$ & 1218 & 333 & 4465 & 42 \\
$\mathrm{H}(40 \mathrm{~A})$ & 5328 & 3124 & 3871 & 37 \\
$\mathrm{H}(41 \mathrm{~A})$ & 4370 & 223 & 4143 & 41 \\
$\mathrm{H}(41 \mathrm{~B})$ & 6733 & 1360 & 4157 & 41 \\
& & & & \\
\hline
\end{tabular}

Table 8. Torsion angles $\left(^{\circ}\right)$ for $\mathrm{C}_{21} \mathrm{H}_{28} \mathrm{BF}_{3} \mathrm{O}_{2}$

\begin{tabular}{lc}
\hline $\mathrm{O}(2)-\mathrm{B}(1)-\mathrm{C}(2)-\mathrm{C}(3)$ & $1.7(5)$ \\
$\mathrm{O}(1)-\mathrm{B}(1)-\mathrm{C}(2)-\mathrm{C}(3)$ & $179.1(3)$ \\
$\mathrm{O}(2)-\mathrm{B}(1)-\mathrm{C}(2)-\mathrm{C}(1)$ & $-173.2(3)$ \\
$\mathrm{O}(1)-\mathrm{B}(1)-\mathrm{C}(2)-\mathrm{C}(1)$ & $4.2(5)$ \\
$\mathrm{C}(1)-\mathrm{C}(2)-\mathrm{C}(3)-\mathrm{C}(4)$ & $-0.2(6)$ \\
$\mathrm{B}(1)-\mathrm{C}(2)-\mathrm{C}(3)-\mathrm{C}(4)$ & $-174.9(3)$ \\
$\mathrm{C}(2)-\mathrm{C}(3)-\mathrm{C}(4)-\mathrm{C}(5)$ & $-155.5(3)$ \\
$\mathrm{C}(3)-\mathrm{C}(4)-\mathrm{C}(5)-\mathrm{C}(19)$ & $-65.0(3)$ \\
$\mathrm{C}(3)-\mathrm{C}(4)-\mathrm{C}(5)-\mathrm{C}(6)$ & $176.1(3)$ \\
$\mathrm{C}(3)-\mathrm{C}(4)-\mathrm{C}(5)-\mathrm{C}(18)$ & $57.5(4)$ \\
$\mathrm{C}(19)-\mathrm{C}(5)-\mathrm{C}(6)-\mathrm{C}(11)$ & $-131.6(3)$ \\
$\mathrm{C}(18)-\mathrm{C}(5)-\mathrm{C}(6)-\mathrm{C}(11)$ & $106.5(3)$ \\
$\mathrm{C}(4)-\mathrm{C}(5)-\mathrm{C}(6)-\mathrm{C}(11)$ & $-12.8(4)$ \\
$\mathrm{C}(19)-\mathrm{C}(5)-\mathrm{C}(6)-\mathrm{C}(7)$ & $50.6(3)$
\end{tabular}




\begin{tabular}{|c|c|}
\hline$C(18)-C(5)-C(6)-C(7)$ & $-71.3(3)$ \\
\hline $\mathrm{C}(4)-\mathrm{C}(5)-\mathrm{C}(6)-\mathrm{C}(7)$ & $169.4(3)$ \\
\hline $\mathrm{C}(11)-\mathrm{C}(6)-\mathrm{C}(7)-\mathrm{C}(8)$ & $0.1(4)$ \\
\hline $\mathrm{C}(5)-\mathrm{C}(6)-\mathrm{C}(7)-\mathrm{C}(8)$ & $178.0(3)$ \\
\hline $\mathrm{C}(6)-\mathrm{C}(7)-\mathrm{C}(8)-\mathrm{C}(9)$ & $-0.5(5)$ \\
\hline $\mathrm{C}(7)-\mathrm{C}(8)-\mathrm{C}(9)-\mathrm{C}(10)$ & $0.4(5)$ \\
\hline $\mathrm{C}(7)-\mathrm{C}(8)-\mathrm{C}(9)-\mathrm{C}(21)$ & $-179.6(3)$ \\
\hline $\mathrm{C}(8)-\mathrm{C}(9)-\mathrm{C}(10)-\mathrm{C}(11)$ & $0.1(5)$ \\
\hline $\mathrm{C}(21)-\mathrm{C}(9)-\mathrm{C}(10)-\mathrm{C}(11)$ & $-179.9(3)$ \\
\hline $\mathrm{C}(9)-\mathrm{C}(10)-\mathrm{C}(11)-\mathrm{C}(6)$ & $-0.5(5)$ \\
\hline $\mathrm{C}(7)-\mathrm{C}(6)-\mathrm{C}(11)-\mathrm{C}(10)$ & $0.4(5)$ \\
\hline $\mathrm{C}(5)-\mathrm{C}(6)-\mathrm{C}(11)-\mathrm{C}(10)$ & $-177.4(3)$ \\
\hline $\mathrm{O}(1)-\mathrm{C}(12)-\mathrm{C}(13)-\mathrm{O}(2)$ & $24.7(3)$ \\
\hline $\mathrm{C}(15)-\mathrm{C}(12)-\mathrm{C}(13)-\mathrm{O}(2)$ & $-90.5(3)$ \\
\hline $\mathrm{C}(14)-\mathrm{C}(12)-\mathrm{C}(13)-\mathrm{O}(2)$ & $142.3(3)$ \\
\hline $\mathrm{O}(1)-\mathrm{C}(12)-\mathrm{C}(13)-\mathrm{C}(16)$ & 141.7(3) \\
\hline $\mathrm{C}(15)-\mathrm{C}(12)-\mathrm{C}(13)-\mathrm{C}(16)$ & $26.5(4)$ \\
\hline $\mathrm{C}(14)-\mathrm{C}(12)-\mathrm{C}(13)-\mathrm{C}(16)$ & $-100.7(3)$ \\
\hline $\mathrm{O}(1)-\mathrm{C}(12)-\mathrm{C}(13)-\mathrm{C}(17)$ & $-90.8(3)$ \\
\hline $\mathrm{C}(15)-\mathrm{C}(12)-\mathrm{C}(13)-\mathrm{C}(17)$ & $154.0(3)$ \\
\hline $\mathrm{C}(14)-\mathrm{C}(12)-\mathrm{C}(13)-\mathrm{C}(17)$ & $26.8(4)$ \\
\hline$C(6)-C(5)-C(19)-C(20)$ & $-123.2(3)$ \\
\hline $\mathrm{C}(18)-\mathrm{C}(5)-\mathrm{C}(19)-\mathrm{C}(20)$ & $-4.4(5)$ \\
\hline $\mathrm{C}(4)-\mathrm{C}(5)-\mathrm{C}(19)-\mathrm{C}(20)$ & $115.8(4)$ \\
\hline $\mathrm{C}(10)-\mathrm{C}(9)-\mathrm{C}(21)-\mathrm{F}(1)$ & $138.7(5)$ \\
\hline $\mathrm{C}(8)-\mathrm{C}(9)-\mathrm{C}(21)-\mathrm{F}(1)$ & $-41.3(6)$ \\
\hline $\mathrm{C}(10)-\mathrm{C}(9)-\mathrm{C}(21)-\mathrm{F}(3)$ & $-99.7(5)$ \\
\hline $\mathrm{C}(8)-\mathrm{C}(9)-\mathrm{C}(21)-\mathrm{F}(3)$ & $80.3(5)$ \\
\hline$C(10)-C(9)-C(21)-F(2)$ & $17.0(5)$ \\
\hline $\mathrm{C}(8)-\mathrm{C}(9)-\mathrm{C}(21)-\mathrm{F}(2)$ & $-163.0(4)$ \\
\hline $\mathrm{O}(3)-\mathrm{B}(2)-\mathrm{C}(23)-\mathrm{C}(24)$ & $162.9(3)$ \\
\hline $\mathrm{O}(4)-\mathrm{B}(2)-\mathrm{C}(23)-\mathrm{C}(24)$ & $-14.6(5)$ \\
\hline $\mathrm{O}(3)-\mathrm{B}(2)-\mathrm{C}(23)-\mathrm{C}(22)$ & $-12.2(5)$ \\
\hline $\mathrm{O}(4)-\mathrm{B}(2)-\mathrm{C}(23)-\mathrm{C}(22)$ & $170.3(3)$ \\
\hline $\mathrm{C}(22)-\mathrm{C}(23)-\mathrm{C}(24)-\mathrm{C}(25)$ & $2.6(6)$ \\
\hline $\mathrm{B}(2)-\mathrm{C}(23)-\mathrm{C}(24)-\mathrm{C}(25)$ & $-172.1(3)$ \\
\hline$C(23)-C(24)-C(25)-C(26)$ & $-143.6(3)$ \\
\hline $\mathrm{C}(24)-\mathrm{C}(25)-\mathrm{C}(26)-\mathrm{C}(40)$ & $-60.7(4)$ \\
\hline$C(24)-C(25)-C(26)-C(27)$ & $175.8(3)$ \\
\hline
\end{tabular}




\begin{tabular}{|c|c|}
\hline$C(24)-C(25)-C(26)-C(39)$ & $59.5(4)$ \\
\hline $\mathrm{C}(40)-\mathrm{C}(26)-\mathrm{C}(27)-\mathrm{C}(28)$ & $23.2(4)$ \\
\hline$C(25)-C(26)-C(27)-C(28)$ & 145.1(3) \\
\hline$C(39)-C(26)-C(27)-C(28)$ & $-96.7(3)$ \\
\hline$C(40)-C(26)-C(27)-C(32)$ & $-161.5(3)$ \\
\hline$C(25)-C(26)-C(27)-C(32)$ & $-39.6(4)$ \\
\hline $\mathrm{C}(39)-\mathrm{C}(26)-\mathrm{C}(27)-\mathrm{C}(32)$ & $78.6(4)$ \\
\hline $\mathrm{C}(32)-\mathrm{C}(27)-\mathrm{C}(28)-\mathrm{C}(29)$ & $-1.2(4)$ \\
\hline $\mathrm{C}(26)-\mathrm{C}(27)-\mathrm{C}(28)-\mathrm{C}(29)$ & 174.3(3) \\
\hline $\mathrm{C}(27)-\mathrm{C}(28)-\mathrm{C}(29)-\mathrm{C}(30)$ & $1.0(5)$ \\
\hline$C(28)-C(29)-C(30)-C(31)$ & $0.2(5)$ \\
\hline $\mathrm{C}(28)-\mathrm{C}(29)-\mathrm{C}(30)-\mathrm{C}(42)$ & $-179.8(3)$ \\
\hline $\mathrm{C}(29)-\mathrm{C}(30)-\mathrm{C}(31)-\mathrm{C}(32)$ & $-1.1(5)$ \\
\hline $\mathrm{C}(42)-\mathrm{C}(30)-\mathrm{C}(31)-\mathrm{C}(32)$ & $178.9(3)$ \\
\hline $\mathrm{C}(30)-\mathrm{C}(31)-\mathrm{C}(32)-\mathrm{C}(27)$ & $0.9(5)$ \\
\hline $\mathrm{C}(28)-\mathrm{C}(27)-\mathrm{C}(32)-\mathrm{C}(31)$ & $0.3(4)$ \\
\hline $\mathrm{C}(26)-\mathrm{C}(27)-\mathrm{C}(32)-\mathrm{C}(31)$ & $-175.2(3)$ \\
\hline $\mathrm{O}(3)-\mathrm{C}(33)-\mathrm{C}(34)-\mathrm{O}(4)$ & $-22.7(3)$ \\
\hline $\mathrm{C}(36)-\mathrm{C}(33)-\mathrm{C}(34)-\mathrm{O}(4)$ & $-141.5(3)$ \\
\hline $\mathrm{C}(35)-\mathrm{C}(33)-\mathrm{C}(34)-\mathrm{O}(4)$ & $91.5(3)$ \\
\hline $\mathrm{O}(3)-\mathrm{C}(33)-\mathrm{C}(34)-\mathrm{C}(38)$ & $92.1(3)$ \\
\hline $\mathrm{C}(36)-\mathrm{C}(33)-\mathrm{C}(34)-\mathrm{C}(38)$ & $-26.7(4)$ \\
\hline $\mathrm{C}(35)-\mathrm{C}(33)-\mathrm{C}(34)-\mathrm{C}(38)$ & $-153.7(3)$ \\
\hline $\mathrm{O}(3)-\mathrm{C}(33)-\mathrm{C}(34)-\mathrm{C}(37)$ & $-139.0(3)$ \\
\hline $\mathrm{C}(36)-\mathrm{C}(33)-\mathrm{C}(34)-\mathrm{C}(37)$ & $102.3(4)$ \\
\hline $\mathrm{C}(35)-\mathrm{C}(33)-\mathrm{C}(34)-\mathrm{C}(37)$ & $-24.7(4)$ \\
\hline$C(25)-C(26)-C(40)-C(41)$ & $120.9(4)$ \\
\hline $\mathrm{C}(27)-\mathrm{C}(26)-\mathrm{C}(40)-\mathrm{C}(41)$ & $-116.0(4)$ \\
\hline$C(39)-C(26)-C(40)-C(41)$ & $1.4(5)$ \\
\hline $\mathrm{C}(29)-\mathrm{C}(30)-\mathrm{C}(42)-\mathrm{F}(5)$ & $48.0(6)$ \\
\hline $\mathrm{C}(31)-\mathrm{C}(30)-\mathrm{C}(42)-\mathrm{F}(5)$ & $-132.0(5)$ \\
\hline $\mathrm{C}(29)-\mathrm{C}(30)-\mathrm{C}(42)-\mathrm{F}(4)$ & $-71.9(6)$ \\
\hline $\mathrm{C}(31)-\mathrm{C}(30)-\mathrm{C}(42)-\mathrm{F}(4)$ & $108.0(5)$ \\
\hline $\mathrm{C}(29)-\mathrm{C}(30)-\mathrm{C}(42)-\mathrm{F}(6)$ & $168.0(4)$ \\
\hline $\mathrm{C}(31)-\mathrm{C}(30)-\mathrm{C}(42)-\mathrm{F}(6)$ & $-12.0(5)$ \\
\hline $\mathrm{O}(2)-\mathrm{B}(1)-\mathrm{O}(1)-\mathrm{C}(12)$ & $9.0(4)$ \\
\hline $\mathrm{C}(2)-\mathrm{B}(1)-\mathrm{O}(1)-\mathrm{C}(12)$ & $-168.7(3)$ \\
\hline $\mathrm{C}(15)-\mathrm{C}(12)-\mathrm{O}(1)-\mathrm{B}(1)$ & $98.8(3)$ \\
\hline $\mathrm{C}(14)-\mathrm{C}(12)-\mathrm{O}(1)-\mathrm{B}(1)$ & $-142.9(3)$ \\
\hline
\end{tabular}




$\begin{array}{lc}\mathrm{C}(13)-\mathrm{C}(12)-\mathrm{O}(1)-\mathrm{B}(1) & -20.7(3) \\ \mathrm{O}(1)-\mathrm{B}(1)-\mathrm{O}(2)-\mathrm{C}(13) & 8.2(4) \\ \mathrm{C}(2)-\mathrm{B}(1)-\mathrm{O}(2)-\mathrm{C}(13) & -174.1(3) \\ \mathrm{C}(16)-\mathrm{C}(13)-\mathrm{O}(2)-\mathrm{B}(1) & -142.1(3) \\ \mathrm{C}(17)-\mathrm{C}(13)-\mathrm{O}(2)-\mathrm{B}(1) & 99.9(3) \\ \mathrm{C}(12)-\mathrm{C}(13)-\mathrm{O}(2)-\mathrm{B}(1) & -20.3(3) \\ \mathrm{O}(4)-\mathrm{B}(2)-\mathrm{O}(3)-\mathrm{C}(33) & -9.2(4) \\ \mathrm{C}(23)-\mathrm{B}(2)-\mathrm{O}(3)-\mathrm{C}(33) & 173.1(3) \\ \mathrm{C}(36)-\mathrm{C}(33)-\mathrm{O}(3)-\mathrm{B}(2) & 142.1(3) \\ \mathrm{C}(35)-\mathrm{C}(33)-\mathrm{O}(3)-\mathrm{B}(2) & -99.2(3) \\ \mathrm{C}(34)-\mathrm{C}(33)-\mathrm{O}(3)-\mathrm{B}(2) & 19.7(3) \\ \mathrm{O}(3)-\mathrm{B}(2)-\mathrm{O}(4)-\mathrm{C}(34) & -6.9(4) \\ \mathrm{C}(23)-\mathrm{B}(2)-\mathrm{O}(4)-\mathrm{C}(34) & 170.8(3) \\ \mathrm{C}(38)-\mathrm{C}(34)-\mathrm{O}(4)-\mathrm{B}(2) & -101.5(3) \\ \mathrm{C}(37)-\mathrm{C}(34)-\mathrm{O}(4)-\mathrm{B}(2) & 140.3(3) \\ \mathrm{C}(33)-\mathrm{C}(34)-\mathrm{O}(4)-\mathrm{B}(2) & 18.3(3)\end{array}$

Symmetry transformations used to generate equivalent atoms: 


\subsection{Structure of $\mathrm{Cu}$-allyl-1b (branched)}

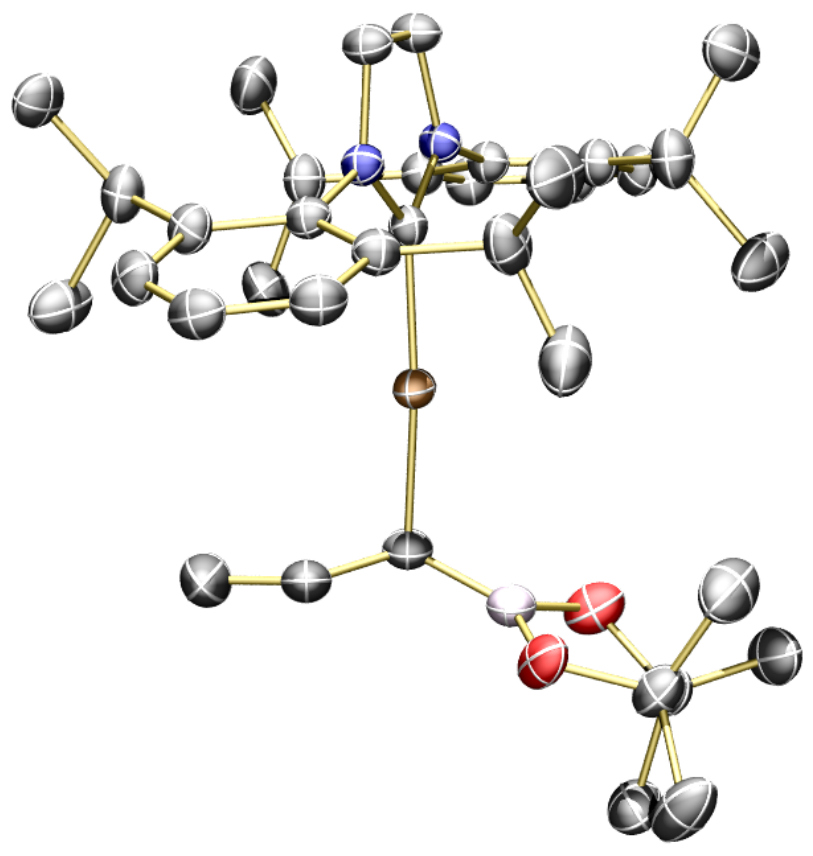

Table 9. Crystal data and structure refinement for $\mathbf{C u}-\mathbf{a l l y l}-\mathbf{1 b}$ (branched)

Identification code

Empirical formula

Formula weight

Temperature

Wavelength

Crystal system

Space group

Unit cell dimensions

Volume

$\mathrm{Z}$

Density (calculated)

Absorption coefficient

$\mathrm{F}(000)$

Crystal size

Theta range for data collection

Index ranges

Reflections collected

Independent reflections
$\mathrm{Cu}$-allyl-1b (branched)

C38 H57 B Cu N2 O2.50

656.20

100(2) K

$1.54178 \AA$

Monoclinic

$\mathrm{P} 2, / \mathrm{c}$

$\mathrm{a}=10.458(2) \AA$

$\mathrm{a}=90.00(3)^{\circ}$.

$\mathrm{b}=25.050(5) \AA$

$\mathrm{b}=107.96(3)^{\circ}$.

$c=15.770(3) \AA$

$\mathrm{g}=90.00(3)^{\circ}$.

3929.9(15) $\AA^{3}$

4

$1.109 \mathrm{Mg} / \mathrm{m}^{3}$

$1.025 \mathrm{~mm}^{-1}$

1412

$0.480 \times 0.100 \times 0.070 \mathrm{~mm}^{3}$

3.434 to $69.801^{\circ}$.

$-12<=\mathrm{h}<=12,-29<=\mathrm{k}<=29,0<=\mathrm{l}<=19$

14191

14191 [R(int) $=$ ?] 
Completeness to theta $=67.679^{\circ}$

Absorption correction

Max. and min. transmission

Refinement method

Data / restraints / parameters

Goodness-of-fit on $\mathrm{F}^{2}$

Final $R$ indices [I $>2 \operatorname{sigma}(\mathrm{I})]$

$\mathrm{R}$ indices (all data)

Extinction coefficient

Largest diff. peak and hole
$99.9 \%$

Semi-empirical from equivalents

0.7533 and 0.6319

Full-matrix least-squares on $\mathrm{F}^{2}$

14191 / 503 / 522

1.081

$\mathrm{R} 1=0.0482, \mathrm{wR} 2=0.1424$

$\mathrm{R} 1=0.0517, \mathrm{wR} 2=0.1455$

$\mathrm{n} / \mathrm{a}$

0.389 and -0.457 e. $\AA^{-3}$

Table 10. Atomic coordinates $\left(x 10^{4}\right)$ and equivalent isotropic displacement parameters $\left(\AA^{2} \times 10^{3}\right)$ for $\mathbf{C u}-\mathbf{a l l y l}-\mathbf{1 b}$ (branched). $\mathrm{U}(\mathrm{eq})$ is defined as one third of the trace of the orthogonalized $\mathrm{U}^{\mathrm{ij}}$ tensor

\begin{tabular}{|c|c|c|c|c|}
\hline & $\mathrm{X}$ & $\mathrm{y}$ & $\mathrm{Z}$ & $\mathrm{U}(\mathrm{eq})$ \\
\hline $\mathrm{Cu}(1)$ & $4713(1)$ & $3353(1)$ & $6355(1)$ & $49(1)$ \\
\hline $\mathrm{O}(1)$ & $3487(2)$ & $3722(1)$ & $8185(1)$ & $68(1)$ \\
\hline $\mathrm{O}(2)$ & $3935(2)$ & $4459(1)$ & 7501(1) & $73(1)$ \\
\hline $\mathrm{N}(1)$ & $4130(2)$ & $3253(1)$ & $4426(1)$ & $43(1)$ \\
\hline $\mathrm{N}(2)$ & $3953(2)$ & $2501(1)$ & $5016(1)$ & $42(1)$ \\
\hline $\mathrm{B}(1)$ & $4302(3)$ & 3939(1) & $7738(2)$ & $59(1)$ \\
\hline $\mathrm{C}(1)$ & $4222(2)$ & $3026(1)$ & $5223(1)$ & $41(1)$ \\
\hline $\mathrm{C}(2)$ & $3822(2)$ & $2879(1)$ & $3744(1)$ & $51(1)$ \\
\hline $\mathrm{C}(3)$ & $3709(2)$ & $2406(1)$ & $4118(1)$ & $50(1)$ \\
\hline $\mathrm{C}(4)$ & $4363(2)$ & $3810(1)$ & $4283(1)$ & $44(1)$ \\
\hline$C(5)$ & $5666(2)$ & $3968(1)$ & $4348(1)$ & $49(1)$ \\
\hline$C(6)$ & $5839(2)$ & $4498(1)$ & $4126(2)$ & $58(1)$ \\
\hline$C(7)$ & $4771(3)$ & $4846(1)$ & $3862(2)$ & $61(1)$ \\
\hline $\mathrm{C}(8)$ & $3504(2)$ & $4680(1)$ & $3826(2)$ & $60(1)$ \\
\hline $\mathrm{C}(9)$ & $3270(2)$ & $4158(1)$ & $4038(2)$ & $52(1)$ \\
\hline$C(10)$ & $6860(2)$ & $3593(1)$ & $4665(2)$ & $59(1)$ \\
\hline $\mathrm{C}(11)$ & $7859(3)$ & $3799(2)$ & $5518(2)$ & $94(1)$ \\
\hline$C(12)$ & $7538(3)$ & $3509(2)$ & $3949(2)$ & $92(1)$ \\
\hline$C(13)$ & $1875(2)$ & 3981(1) & $4041(2)$ & $65(1)$ \\
\hline$C(14)$ & $887(17)$ & $3918(11)$ & $3180(10)$ & $86(4)$ \\
\hline$C(15)$ & $1274(17)$ & $4395(7)$ & $4621(14)$ & $92(4)$ \\
\hline $\mathrm{C}(14 \mathrm{X})$ & $1595(11)$ & $4168(9)$ & $4811(7)$ & $103(4)$ \\
\hline$C(15 X)$ & $812(14)$ & $4131(6)$ & $3120(9)$ & $84(3)$ \\
\hline
\end{tabular}




\begin{tabular}{|c|c|c|c|c|}
\hline$C(16)$ & $3984(2)$ & 2084(1) & $5652(1)$ & $43(1)$ \\
\hline $\mathrm{C}(17)$ & $2834(2)$ & 1992(1) & $5900(1)$ & $50(1)$ \\
\hline$C(18)$ & 2874(2) & $1567(1)$ & $6479(2)$ & $57(1)$ \\
\hline$C(19)$ & 4004(3) & $1256(1)$ & $6800(2)$ & $59(1)$ \\
\hline $\mathrm{C}(20)$ & $5125(2)$ & 1362(1) & $6548(2)$ & $58(1)$ \\
\hline $\mathrm{C}(21)$ & $5149(2)$ & $1777(1)$ & 5961(2) & $50(1)$ \\
\hline $\mathrm{C}(22)$ & $1599(2)$ & $2345(1)$ & $5586(2)$ & $68(1)$ \\
\hline$C(23)$ & $1419(12)$ & 2704(5) & $6258(12)$ & $89(3)$ \\
\hline $\mathrm{C}(24)$ & 296(7) & 1967(8) & $5234(8)$ & $88(3)$ \\
\hline $\mathrm{C}(23 \mathrm{X})$ & $409(18)$ & $2112(7)$ & $5041(17)$ & $89(3)$ \\
\hline $\mathrm{C}(24 \mathrm{X})$ & $1430(20)$ & $2639(11)$ & $6453(13)$ & $89(5)$ \\
\hline$C(25)$ & 6392(2) & 1884(1) & $5694(2)$ & $59(1)$ \\
\hline$C(26)$ & $6720(30)$ & 1393(8) & $5263(14)$ & $65(4)$ \\
\hline $\mathrm{C}(27)$ & 7604(19) & $2020(12)$ & $6558(11)$ & $82(5)$ \\
\hline$C(26 X)$ & 7391(16) & $2213(7)$ & $6374(13)$ & $90(3)$ \\
\hline $\mathrm{C}(27 \mathrm{X})$ & $7030(20)$ & $1385(6)$ & $5403(14)$ & $80(4)$ \\
\hline $\mathrm{C}(28)$ & $5495(5)$ & $3731(2)$ & 7486(3) & $54(1)$ \\
\hline $\mathrm{C}(29)$ & $6208(5)$ & $3275(2)$ & 7990(3) & $74(2)$ \\
\hline $\mathrm{C}(30)$ & 7503(7) & $3141(4)$ & $8141(5)$ & $109(3)$ \\
\hline $\mathrm{C}(28 \mathrm{X})$ & $5355(8)$ & $3509(4)$ & $7660(5)$ & $49(2)$ \\
\hline $\mathrm{C}(29 \mathrm{X})$ & 6654(7) & $3724(3)$ & $7682(5)$ & $64(2)$ \\
\hline$C(30 X)$ & 7851(9) & $3484(6)$ & 7961(8) & $91(3)$ \\
\hline $\mathrm{C}(31)$ & $2459(8)$ & $4106(3)$ & $8160(4)$ & $62(1)$ \\
\hline $\mathrm{C}(32)$ & $3132(4)$ & $4627(1)$ & 8009(3) & $60(1)$ \\
\hline $\mathrm{C}(33)$ & $1232(4)$ & $3978(2)$ & 7361(4) & $96(1)$ \\
\hline$C(34)$ & $2090(6)$ & $4079(2)$ & $9010(3)$ & $96(2)$ \\
\hline$C(35)$ & $2240(6)$ & $5061(2)$ & 7486(4) & $90(1)$ \\
\hline$C(36)$ & 4052(4) & $4867(2)$ & $8890(3)$ & $82(1)$ \\
\hline$C(31 X)$ & 2444(9) & $4549(3)$ & $7635(6)$ & $45(2)$ \\
\hline $\mathrm{C}(32 \mathrm{X})$ & $2650(20)$ & $4150(8)$ & $8417(11)$ & $67(4)$ \\
\hline $\mathrm{C}(33 \mathrm{X})$ & $1340(11)$ & $4443(5)$ & $6824(7)$ & $75(3)$ \\
\hline $\mathrm{C}(34 \mathrm{X})$ & $2356(13)$ & $5124(4)$ & $7957(10)$ & $64(3)$ \\
\hline $\mathrm{C}(35 \mathrm{X})$ & $3452(15)$ & $4335(5)$ & $9319(8)$ & $90(1)$ \\
\hline $\mathrm{C}(36 \mathrm{X})$ & $1347(12)$ & $3844(5)$ & 8371(9) & $82(1)$ \\
\hline $\mathrm{C}(1 \mathrm{~S})$ & $2154(10)$ & $5173(4)$ & 1048(8) & $127(3)$ \\
\hline $\mathrm{C}(2 \mathrm{~S})$ & $945(9)$ & $4826(4)$ & $804(6)$ & $113(2)$ \\
\hline $\mathrm{O}(1 \mathrm{~S})$ & $130(10)$ & $5029(5)$ & $12(8)$ & $98(1)$ \\
\hline $\mathrm{C}(3 \mathrm{~S})$ & $-1081(8)$ & $4690(3)$ & $-380(6)$ & $104(2)$ \\
\hline $\mathrm{C}(4 \mathrm{~S})$ & $-1806(12)$ & $4946(5)$ & $-1323(8)$ & $133(3)$ \\
\hline
\end{tabular}


Table 11. Bond lengths $[\AA ̊]$ and angles $\left[^{\circ}\right]$ for $\mathbf{C u}$-allyl-1b (branched)

\begin{tabular}{|c|c|}
\hline $\mathrm{Cu}(1)-\mathrm{C}(1)$ & $1.884(2)$ \\
\hline $\mathrm{Cu}(1)-\mathrm{C}(28)$ & $1.962(5)$ \\
\hline $\mathrm{O}(1)-\mathrm{B}(1)$ & $1.376(3)$ \\
\hline $\mathrm{O}(1)-\mathrm{C}(31)$ & $1.434(9)$ \\
\hline $\mathrm{O}(2)-\mathrm{B}(1)$ & $1.377(3)$ \\
\hline $\mathrm{O}(2)-\mathrm{C}(32)$ & $1.392(4)$ \\
\hline $\mathrm{N}(1)-\mathrm{C}(1)$ & $1.356(2)$ \\
\hline $\mathrm{N}(1)-\mathrm{C}(2)$ & $1.387(3)$ \\
\hline $\mathrm{N}(1)-\mathrm{C}(4)$ & $1.445(2)$ \\
\hline $\mathrm{N}(2)-\mathrm{C}(1)$ & $1.364(2)$ \\
\hline $\mathrm{N}(2)-\mathrm{C}(3)$ & $1.381(2)$ \\
\hline $\mathrm{N}(2)-\mathrm{C}(16)$ & $1.443(2)$ \\
\hline $\mathrm{B}(1)-\mathrm{C}(28)$ & $1.513(6)$ \\
\hline$C(2)-C(3)$ & $1.343(3)$ \\
\hline $\mathrm{C}(2)-\mathrm{H}(2)$ & 0.9500 \\
\hline $\mathrm{C}(3)-\mathrm{H}(3)$ & 0.9500 \\
\hline$C(4)-C(5)$ & $1.393(3)$ \\
\hline $\mathrm{C}(4)-\mathrm{C}(9)$ & $1.394(3)$ \\
\hline$C(5)-C(6)$ & $1.398(3)$ \\
\hline$C(5)-C(10)$ & $1.519(3)$ \\
\hline$C(6)-C(7)$ & $1.376(3)$ \\
\hline $\mathrm{C}(6)-\mathrm{H}(6)$ & 0.9500 \\
\hline $\mathrm{C}(7)-\mathrm{C}(8)$ & $1.374(3)$ \\
\hline $\mathrm{C}(7)-\mathrm{H}(7)$ & 0.9500 \\
\hline $\mathrm{C}(8)-\mathrm{C}(9)$ & $1.390(3)$ \\
\hline $\mathrm{C}(8)-\mathrm{H}(8)$ & 0.9500 \\
\hline $\mathrm{C}(9)-\mathrm{C}(13)$ & $1.526(3)$ \\
\hline$C(10)-C(11)$ & $1.517(4)$ \\
\hline$C(10)-C(12)$ & $1.521(4)$ \\
\hline $\mathrm{C}(10)-\mathrm{H}(10)$ & 1.0000 \\
\hline $\mathrm{C}(11)-\mathrm{H}(11 \mathrm{~A})$ & 0.9800 \\
\hline $\mathrm{C}(11)-\mathrm{H}(11 \mathrm{~B})$ & 0.9800 \\
\hline $\mathrm{C}(11)-\mathrm{H}(11 \mathrm{C})$ & 0.9800 \\
\hline $\mathrm{C}(12)-\mathrm{H}(12 \mathrm{~A})$ & 0.9800 \\
\hline $\mathrm{C}(12)-\mathrm{H}(12 \mathrm{~B})$ & 0.9800 \\
\hline
\end{tabular}




\begin{tabular}{|c|c|}
\hline $\mathrm{C}(12)-\mathrm{H}(12 \mathrm{C})$ & 0.9800 \\
\hline$C(13)-C(14)$ & $1.439(15)$ \\
\hline$C(13)-C(15)$ & $1.630(11)$ \\
\hline $\mathrm{C}(13)-\mathrm{H}(13)$ & 1.0000 \\
\hline $\mathrm{C}(14)-\mathrm{H}(14 \mathrm{~A})$ & 0.9800 \\
\hline $\mathrm{C}(14)-\mathrm{H}(14 \mathrm{~B})$ & 0.9800 \\
\hline $\mathrm{C}(14)-\mathrm{H}(14 \mathrm{C})$ & 0.9800 \\
\hline $\mathrm{C}(15)-\mathrm{H}(15 \mathrm{~A})$ & 0.9800 \\
\hline $\mathrm{C}(15)-\mathrm{H}(15 \mathrm{~B})$ & 0.9800 \\
\hline $\mathrm{C}(15)-\mathrm{H}(15 \mathrm{C})$ & 0.9800 \\
\hline$C(16)-C(17)$ & $1.394(3)$ \\
\hline$C(16)-C(21)$ & $1.395(3)$ \\
\hline C(17)-C(18) & $1.396(3)$ \\
\hline$C(17)-C(22)$ & $1.517(3)$ \\
\hline$C(18)-C(19)$ & $1.374(4)$ \\
\hline $\mathrm{C}(18)-\mathrm{H}(18)$ & 0.9500 \\
\hline $\mathrm{C}(19)-\mathrm{C}(20)$ & $1.374(3)$ \\
\hline $\mathrm{C}(19)-\mathrm{H}(19)$ & 0.9500 \\
\hline$C(20)-C(21)$ & $1.399(3)$ \\
\hline $\mathrm{C}(20)-\mathrm{H}(20)$ & 0.9500 \\
\hline$C(21)-C(25)$ & $1.508(3)$ \\
\hline$C(22)-C(23)$ & $1.446(14)$ \\
\hline $\mathrm{C}(22)-\mathrm{C}(24)$ & $1.611(12)$ \\
\hline $\mathrm{C}(22)-\mathrm{H}(22)$ & 1.0000 \\
\hline $\mathrm{C}(23)-\mathrm{H}(23 \mathrm{~A})$ & 0.9800 \\
\hline $\mathrm{C}(23)-\mathrm{H}(23 \mathrm{~B})$ & 0.9800 \\
\hline $\mathrm{C}(23)-\mathrm{H}(23 \mathrm{C})$ & 0.9800 \\
\hline $\mathrm{C}(24)-\mathrm{H}(24 \mathrm{~A})$ & 0.9800 \\
\hline $\mathrm{C}(24)-\mathrm{H}(24 \mathrm{~B})$ & 0.9800 \\
\hline $\mathrm{C}(24)-\mathrm{H}(24 \mathrm{C})$ & 0.9800 \\
\hline$C(25)-C(26)$ & $1.495(18)$ \\
\hline$C(25)-C(27)$ & $1.587(16)$ \\
\hline $\mathrm{C}(25)-\mathrm{H}(25)$ & 1.0000 \\
\hline $\mathrm{C}(26)-\mathrm{H}(26 \mathrm{~A})$ & 0.9800 \\
\hline $\mathrm{C}(26)-\mathrm{H}(26 \mathrm{~B})$ & 0.9800 \\
\hline $\mathrm{C}(26)-\mathrm{H}(26 \mathrm{C})$ & 0.9800 \\
\hline $\mathrm{C}(27)-\mathrm{H}(27 \mathrm{~A})$ & 0.9800 \\
\hline $\mathrm{C}(27)-\mathrm{H}(27 \mathrm{~B})$ & 0.9800 \\
\hline $\mathrm{C}(27)-\mathrm{H}(27 \mathrm{C})$ & 0.9800 \\
\hline
\end{tabular}




\begin{tabular}{|c|c|}
\hline$C(28)-C(29)$ & $1.460(7)$ \\
\hline $\mathrm{C}(28)-\mathrm{H}(28)$ & 1.0000 \\
\hline $\mathrm{C}(29)-\mathrm{C}(30)$ & $1.343(8)$ \\
\hline $\mathrm{C}(29)-\mathrm{H}(29)$ & 0.9500 \\
\hline $\mathrm{C}(30)-\mathrm{H}(30 \mathrm{~A})$ & 0.9500 \\
\hline $\mathrm{C}(30)-\mathrm{H}(30 \mathrm{~B})$ & 0.9500 \\
\hline $\mathrm{C}(31)-\mathrm{C}(34)$ & $1.508(7)$ \\
\hline $\mathrm{C}(31)-\mathrm{C}(33)$ & $1.529(7)$ \\
\hline $\mathrm{C}(31)-\mathrm{C}(32)$ & $1.537(6)$ \\
\hline$C(32)-C(35)$ & $1.501(5)$ \\
\hline$C(32)-C(36)$ & $1.547(6)$ \\
\hline $\mathrm{C}(33)-\mathrm{H}(33 \mathrm{~A})$ & 0.9800 \\
\hline $\mathrm{C}(33)-\mathrm{H}(33 \mathrm{~B})$ & 0.9800 \\
\hline $\mathrm{C}(33)-\mathrm{H}(33 \mathrm{C})$ & 0.9800 \\
\hline $\mathrm{C}(34)-\mathrm{H}(34 \mathrm{~A})$ & 0.9800 \\
\hline $\mathrm{C}(34)-\mathrm{H}(34 \mathrm{~B})$ & 0.9800 \\
\hline $\mathrm{C}(34)-\mathrm{H}(34 \mathrm{C})$ & 0.9800 \\
\hline $\mathrm{C}(35)-\mathrm{H}(35 \mathrm{~A})$ & 0.9800 \\
\hline $\mathrm{C}(35)-\mathrm{H}(35 \mathrm{~B})$ & 0.9800 \\
\hline $\mathrm{C}(35)-\mathrm{H}(35 \mathrm{C})$ & 0.9800 \\
\hline $\mathrm{C}(36)-\mathrm{H}(36 \mathrm{~A})$ & 0.9800 \\
\hline $\mathrm{C}(36)-\mathrm{H}(36 \mathrm{~B})$ & 0.9800 \\
\hline $\mathrm{C}(36)-\mathrm{H}(36 \mathrm{C})$ & 0.9800 \\
\hline $\mathrm{C}(1 \mathrm{~S})-\mathrm{C}(2 \mathrm{~S})$ & $1.483(13)$ \\
\hline $\mathrm{C}(1 \mathrm{~S})-\mathrm{H}(1 \mathrm{~S} 1)$ & 0.9800 \\
\hline $\mathrm{C}(1 \mathrm{~S})-\mathrm{H}(1 \mathrm{~S} 2)$ & 0.9800 \\
\hline $\mathrm{C}(1 \mathrm{~S})-\mathrm{H}(1 \mathrm{~S} 3)$ & 0.9800 \\
\hline $\mathrm{C}(2 \mathrm{~S})-\mathrm{O}(1 \mathrm{~S})$ & $1.375(14)$ \\
\hline $\mathrm{C}(2 \mathrm{~S})-\mathrm{H}(2 \mathrm{~S} 1)$ & 0.9900 \\
\hline $\mathrm{C}(2 \mathrm{~S})-\mathrm{H}(2 \mathrm{~S} 2)$ & 0.9900 \\
\hline $\mathrm{O}(1 \mathrm{~S})-\mathrm{C}(3 \mathrm{~S})$ & $1.493(15)$ \\
\hline $\mathrm{C}(3 \mathrm{~S})-\mathrm{C}(4 \mathrm{~S})$ & $1.583(14)$ \\
\hline $\mathrm{C}(3 \mathrm{~S})-\mathrm{H}(3 \mathrm{~S} 1)$ & 0.9900 \\
\hline $\mathrm{C}(3 \mathrm{~S})-\mathrm{H}(3 \mathrm{~S} 2)$ & 0.9900 \\
\hline $\mathrm{C}(4 \mathrm{~S})-\mathrm{H}(4 \mathrm{~S} 1)$ & 0.9800 \\
\hline $\mathrm{C}(4 \mathrm{~S})-\mathrm{H}(4 \mathrm{~S} 2)$ & 0.9800 \\
\hline $\mathrm{C}(4 \mathrm{~S})-\mathrm{H}(4 \mathrm{~S} 3)$ & 0.9800 \\
\hline $\mathrm{C}(1)-\mathrm{Cu}(1)-\mathrm{C}(28)$ & $170.38(16)$ \\
\hline $\mathrm{B}(1)-\mathrm{O}(1)-\mathrm{C}(31)$ & $107.4(3)$ \\
\hline
\end{tabular}




\begin{tabular}{|c|c|}
\hline $\mathrm{B}(1)-\mathrm{O}(2)-\mathrm{C}(32)$ & $107.3(2)$ \\
\hline $\mathrm{C}(1)-\mathrm{N}(1)-\mathrm{C}(2)$ & $111.68(16)$ \\
\hline $\mathrm{C}(1)-\mathrm{N}(1)-\mathrm{C}(4)$ & $125.51(16)$ \\
\hline $\mathrm{C}(2)-\mathrm{N}(1)-\mathrm{C}(4)$ & $122.78(16)$ \\
\hline $\mathrm{C}(1)-\mathrm{N}(2)-\mathrm{C}(3)$ & $111.83(16)$ \\
\hline $\mathrm{C}(1)-\mathrm{N}(2)-\mathrm{C}(16)$ & $125.03(16)$ \\
\hline $\mathrm{C}(3)-\mathrm{N}(2)-\mathrm{C}(16)$ & $123.06(16)$ \\
\hline $\mathrm{O}(1)-\mathrm{B}(1)-\mathrm{O}(2)$ & $110.4(2)$ \\
\hline $\mathrm{O}(1)-\mathrm{B}(1)-\mathrm{C}(28)$ & $133.7(3)$ \\
\hline $\mathrm{O}(2)-\mathrm{B}(1)-\mathrm{C}(28)$ & $116.0(3)$ \\
\hline $\mathrm{N}(1)-\mathrm{C}(1)-\mathrm{N}(2)$ & $103.31(16)$ \\
\hline $\mathrm{N}(1)-\mathrm{C}(1)-\mathrm{Cu}(1)$ & $128.15(14)$ \\
\hline $\mathrm{N}(2)-\mathrm{C}(1)-\mathrm{Cu}(1)$ & $128.43(14)$ \\
\hline $\mathrm{C}(3)-\mathrm{C}(2)-\mathrm{N}(1)$ & $106.63(18)$ \\
\hline $\mathrm{C}(3)-\mathrm{C}(2)-\mathrm{H}(2)$ & 126.7 \\
\hline $\mathrm{N}(1)-\mathrm{C}(2)-\mathrm{H}(2)$ & 126.7 \\
\hline $\mathrm{C}(2)-\mathrm{C}(3)-\mathrm{N}(2)$ & $106.54(17)$ \\
\hline $\mathrm{C}(2)-\mathrm{C}(3)-\mathrm{H}(3)$ & 126.7 \\
\hline $\mathrm{N}(2)-\mathrm{C}(3)-\mathrm{H}(3)$ & 126.7 \\
\hline $\mathrm{C}(5)-\mathrm{C}(4)-\mathrm{C}(9)$ & $122.81(18)$ \\
\hline $\mathrm{C}(5)-\mathrm{C}(4)-\mathrm{N}(1)$ & $118.18(17)$ \\
\hline $\mathrm{C}(9)-\mathrm{C}(4)-\mathrm{N}(1)$ & $118.92(17)$ \\
\hline $\mathrm{C}(4)-\mathrm{C}(5)-\mathrm{C}(6)$ & $116.86(19)$ \\
\hline$C(4)-C(5)-C(10)$ & $122.23(18)$ \\
\hline$C(6)-C(5)-C(10)$ & $120.89(19)$ \\
\hline$C(7)-C(6)-C(5)$ & $121.4(2)$ \\
\hline $\mathrm{C}(7)-\mathrm{C}(6)-\mathrm{H}(6)$ & 119.3 \\
\hline $\mathrm{C}(5)-\mathrm{C}(6)-\mathrm{H}(6)$ & 119.3 \\
\hline $\mathrm{C}(8)-\mathrm{C}(7)-\mathrm{C}(6)$ & $120.1(2)$ \\
\hline $\mathrm{C}(8)-\mathrm{C}(7)-\mathrm{H}(7)$ & 119.9 \\
\hline $\mathrm{C}(6)-\mathrm{C}(7)-\mathrm{H}(7)$ & 119.9 \\
\hline $\mathrm{C}(7)-\mathrm{C}(8)-\mathrm{C}(9)$ & $121.0(2)$ \\
\hline $\mathrm{C}(7)-\mathrm{C}(8)-\mathrm{H}(8)$ & 119.5 \\
\hline $\mathrm{C}(9)-\mathrm{C}(8)-\mathrm{H}(8)$ & 119.5 \\
\hline $\mathrm{C}(8)-\mathrm{C}(9)-\mathrm{C}(4)$ & $117.68(19)$ \\
\hline $\mathrm{C}(8)-\mathrm{C}(9)-\mathrm{C}(13)$ & $120.9(2)$ \\
\hline $\mathrm{C}(4)-\mathrm{C}(9)-\mathrm{C}(13)$ & $121.40(19)$ \\
\hline $\mathrm{C}(11)-\mathrm{C}(10)-\mathrm{C}(5)$ & $110.6(2)$ \\
\hline$C(11)-C(10)-C(12)$ & $110.7(2)$ \\
\hline
\end{tabular}




\begin{tabular}{|c|c|}
\hline$C(5)-C(10)-C(12)$ & $111.4(2)$ \\
\hline $\mathrm{C}(11)-\mathrm{C}(10)-\mathrm{H}(10)$ & 108.0 \\
\hline $\mathrm{C}(5)-\mathrm{C}(10)-\mathrm{H}(10)$ & 108.0 \\
\hline $\mathrm{C}(12)-\mathrm{C}(10)-\mathrm{H}(10)$ & 108.0 \\
\hline $\mathrm{C}(10)-\mathrm{C}(11)-\mathrm{H}(11 \mathrm{~A})$ & 109.5 \\
\hline $\mathrm{C}(10)-\mathrm{C}(11)-\mathrm{H}(11 \mathrm{~B})$ & 109.5 \\
\hline $\mathrm{H}(11 \mathrm{~A})-\mathrm{C}(11)-\mathrm{H}(11 \mathrm{~B})$ & 109.5 \\
\hline $\mathrm{C}(10)-\mathrm{C}(11)-\mathrm{H}(11 \mathrm{C})$ & 109.5 \\
\hline $\mathrm{H}(11 \mathrm{~A})-\mathrm{C}(11)-\mathrm{H}(11 \mathrm{C})$ & 109.5 \\
\hline $\mathrm{H}(11 \mathrm{~B})-\mathrm{C}(11)-\mathrm{H}(11 \mathrm{C})$ & 109.5 \\
\hline $\mathrm{C}(10)-\mathrm{C}(12)-\mathrm{H}(12 \mathrm{~A})$ & 109.5 \\
\hline $\mathrm{C}(10)-\mathrm{C}(12)-\mathrm{H}(12 \mathrm{~B})$ & 109.5 \\
\hline $\mathrm{H}(12 \mathrm{~A})-\mathrm{C}(12)-\mathrm{H}(12 \mathrm{~B})$ & 109.5 \\
\hline $\mathrm{C}(10)-\mathrm{C}(12)-\mathrm{H}(12 \mathrm{C})$ & 109.5 \\
\hline $\mathrm{H}(12 \mathrm{~A})-\mathrm{C}(12)-\mathrm{H}(12 \mathrm{C})$ & 109.5 \\
\hline $\mathrm{H}(12 \mathrm{~B})-\mathrm{C}(12)-\mathrm{H}(12 \mathrm{C})$ & 109.5 \\
\hline $\mathrm{C}(14)-\mathrm{C}(13)-\mathrm{C}(9)$ & $115.9(7)$ \\
\hline $\mathrm{C}(14)-\mathrm{C}(13)-\mathrm{C}(15)$ & 108.1(7) \\
\hline$C(9)-C(13)-C(15)$ & $110.6(5)$ \\
\hline $\mathrm{C}(14)-\mathrm{C}(13)-\mathrm{H}(13)$ & 107.3 \\
\hline $\mathrm{C}(9)-\mathrm{C}(13)-\mathrm{H}(13)$ & 107.3 \\
\hline $\mathrm{C}(15)-\mathrm{C}(13)-\mathrm{H}(13)$ & 107.3 \\
\hline $\mathrm{C}(13)-\mathrm{C}(14)-\mathrm{H}(14 \mathrm{~A})$ & 109.5 \\
\hline $\mathrm{C}(13)-\mathrm{C}(14)-\mathrm{H}(14 \mathrm{~B})$ & 109.5 \\
\hline $\mathrm{H}(14 \mathrm{~A})-\mathrm{C}(14)-\mathrm{H}(14 \mathrm{~B})$ & 109.5 \\
\hline $\mathrm{C}(13)-\mathrm{C}(14)-\mathrm{H}(14 \mathrm{C})$ & 109.5 \\
\hline $\mathrm{H}(14 \mathrm{~A})-\mathrm{C}(14)-\mathrm{H}(14 \mathrm{C})$ & 109.5 \\
\hline $\mathrm{H}(14 \mathrm{~B})-\mathrm{C}(14)-\mathrm{H}(14 \mathrm{C})$ & 109.5 \\
\hline $\mathrm{C}(13)-\mathrm{C}(15)-\mathrm{H}(15 \mathrm{~A})$ & 109.5 \\
\hline $\mathrm{C}(13)-\mathrm{C}(15)-\mathrm{H}(15 \mathrm{~B})$ & 109.5 \\
\hline $\mathrm{H}(15 \mathrm{~A})-\mathrm{C}(15)-\mathrm{H}(15 \mathrm{~B})$ & 109.5 \\
\hline $\mathrm{C}(13)-\mathrm{C}(15)-\mathrm{H}(15 \mathrm{C})$ & 109.5 \\
\hline $\mathrm{H}(15 \mathrm{~A})-\mathrm{C}(15)-\mathrm{H}(15 \mathrm{C})$ & 109.5 \\
\hline $\mathrm{H}(15 \mathrm{~B})-\mathrm{C}(15)-\mathrm{H}(15 \mathrm{C})$ & 109.5 \\
\hline $\mathrm{C}(17)-\mathrm{C}(16)-\mathrm{C}(21)$ & $123.27(18)$ \\
\hline $\mathrm{C}(17)-\mathrm{C}(16)-\mathrm{N}(2)$ & $118.58(17)$ \\
\hline $\mathrm{C}(21)-\mathrm{C}(16)-\mathrm{N}(2)$ & $118.10(17)$ \\
\hline $\mathrm{C}(16)-\mathrm{C}(17)-\mathrm{C}(18)$ & $117.0(2)$ \\
\hline $\mathrm{C}(16)-\mathrm{C}(17)-\mathrm{C}(22)$ & $122.31(19)$ \\
\hline
\end{tabular}




\begin{tabular}{|c|c|}
\hline $\mathrm{C}(18)-\mathrm{C}(17)-\mathrm{C}(22)$ & $120.7(2)$ \\
\hline $\mathrm{C}(19)-\mathrm{C}(18)-\mathrm{C}(17)$ & $121.5(2)$ \\
\hline $\mathrm{C}(19)-\mathrm{C}(18)-\mathrm{H}(18)$ & 119.3 \\
\hline $\mathrm{C}(17)-\mathrm{C}(18)-\mathrm{H}(18)$ & 119.3 \\
\hline $\mathrm{C}(18)-\mathrm{C}(19)-\mathrm{C}(20)$ & $119.9(2)$ \\
\hline $\mathrm{C}(18)-\mathrm{C}(19)-\mathrm{H}(19)$ & 120.0 \\
\hline $\mathrm{C}(20)-\mathrm{C}(19)-\mathrm{H}(19)$ & 120.0 \\
\hline$C(19)-C(20)-C(21)$ & $121.7(2)$ \\
\hline $\mathrm{C}(19)-\mathrm{C}(20)-\mathrm{H}(20)$ & 119.2 \\
\hline $\mathrm{C}(21)-\mathrm{C}(20)-\mathrm{H}(20)$ & 119.2 \\
\hline$C(16)-C(21)-C(20)$ & $116.62(19)$ \\
\hline$C(16)-C(21)-C(25)$ & $122.73(19)$ \\
\hline $\mathrm{C}(20)-\mathrm{C}(21)-\mathrm{C}(25)$ & $120.6(2)$ \\
\hline $\mathrm{C}(23)-\mathrm{C}(22)-\mathrm{C}(17)$ & $114.4(6)$ \\
\hline$C(23)-C(22)-C(24)$ & $109.3(5)$ \\
\hline $\mathrm{C}(17)-\mathrm{C}(22)-\mathrm{C}(24)$ & $108.3(6)$ \\
\hline $\mathrm{C}(23)-\mathrm{C}(22)-\mathrm{H}(22)$ & 108.2 \\
\hline $\mathrm{C}(17)-\mathrm{C}(22)-\mathrm{H}(22)$ & 108.2 \\
\hline $\mathrm{C}(24)-\mathrm{C}(22)-\mathrm{H}(22)$ & 108.2 \\
\hline $\mathrm{C}(22)-\mathrm{C}(23)-\mathrm{H}(23 \mathrm{~A})$ & 109.5 \\
\hline $\mathrm{C}(22)-\mathrm{C}(23)-\mathrm{H}(23 \mathrm{~B})$ & 109.5 \\
\hline $\mathrm{H}(23 \mathrm{~A})-\mathrm{C}(23)-\mathrm{H}(23 \mathrm{~B})$ & 109.5 \\
\hline $\mathrm{C}(22)-\mathrm{C}(23)-\mathrm{H}(23 \mathrm{C})$ & 109.5 \\
\hline $\mathrm{H}(23 \mathrm{~A})-\mathrm{C}(23)-\mathrm{H}(23 \mathrm{C})$ & 109.5 \\
\hline $\mathrm{H}(23 \mathrm{~B})-\mathrm{C}(23)-\mathrm{H}(23 \mathrm{C})$ & 109.5 \\
\hline $\mathrm{C}(22)-\mathrm{C}(24)-\mathrm{H}(24 \mathrm{~A})$ & 109.5 \\
\hline $\mathrm{C}(22)-\mathrm{C}(24)-\mathrm{H}(24 \mathrm{~B})$ & 109.5 \\
\hline $\mathrm{H}(24 \mathrm{~A})-\mathrm{C}(24)-\mathrm{H}(24 \mathrm{~B})$ & 109.5 \\
\hline $\mathrm{C}(22)-\mathrm{C}(24)-\mathrm{H}(24 \mathrm{C})$ & 109.5 \\
\hline $\mathrm{H}(24 \mathrm{~A})-\mathrm{C}(24)-\mathrm{H}(24 \mathrm{C})$ & 109.5 \\
\hline $\mathrm{H}(24 \mathrm{~B})-\mathrm{C}(24)-\mathrm{H}(24 \mathrm{C})$ & 109.5 \\
\hline$C(26)-C(25)-C(21)$ & $108.6(9)$ \\
\hline$C(26)-C(25)-C(27)$ & $109.4(11)$ \\
\hline $\mathrm{C}(21)-\mathrm{C}(25)-\mathrm{C}(27)$ & 109.1(7) \\
\hline $\mathrm{C}(26)-\mathrm{C}(25)-\mathrm{H}(25)$ & 109.9 \\
\hline $\mathrm{C}(21)-\mathrm{C}(25)-\mathrm{H}(25)$ & 109.9 \\
\hline $\mathrm{C}(27)-\mathrm{C}(25)-\mathrm{H}(25)$ & 109.9 \\
\hline $\mathrm{C}(25)-\mathrm{C}(26)-\mathrm{H}(26 \mathrm{~A})$ & 109.5 \\
\hline $\mathrm{C}(25)-\mathrm{C}(26)-\mathrm{H}(26 \mathrm{~B})$ & 109.5 \\
\hline
\end{tabular}




\begin{tabular}{|c|c|}
\hline$H(26 A)-C(26)-H(26 B)$ & 109.5 \\
\hline $\mathrm{C}(25)-\mathrm{C}(26)-\mathrm{H}(26 \mathrm{C})$ & 109.5 \\
\hline$H(26 A)-C(26)-H(26 C)$ & 109.5 \\
\hline $\mathrm{H}(26 \mathrm{~B})-\mathrm{C}(26)-\mathrm{H}(26 \mathrm{C})$ & 109.5 \\
\hline $\mathrm{C}(25)-\mathrm{C}(27)-\mathrm{H}(27 \mathrm{~A})$ & 109.5 \\
\hline $\mathrm{C}(25)-\mathrm{C}(27)-\mathrm{H}(27 \mathrm{~B})$ & 109.5 \\
\hline $\mathrm{H}(27 \mathrm{~A})-\mathrm{C}(27)-\mathrm{H}(27 \mathrm{~B})$ & 109.5 \\
\hline $\mathrm{C}(25)-\mathrm{C}(27)-\mathrm{H}(27 \mathrm{C})$ & 109.5 \\
\hline $\mathrm{H}(27 \mathrm{~A})-\mathrm{C}(27)-\mathrm{H}(27 \mathrm{C})$ & 109.5 \\
\hline $\mathrm{H}(27 \mathrm{~B})-\mathrm{C}(27)-\mathrm{H}(27 \mathrm{C})$ & 109.5 \\
\hline $\mathrm{C}(29)-\mathrm{C}(28)-\mathrm{B}(1)$ & $116.8(4)$ \\
\hline $\mathrm{C}(29)-\mathrm{C}(28)-\mathrm{Cu}(1)$ & $96.7(3)$ \\
\hline $\mathrm{B}(1)-\mathrm{C}(28)-\mathrm{Cu}(1)$ & $105.0(3)$ \\
\hline $\mathrm{C}(29)-\mathrm{C}(28)-\mathrm{H}(28)$ & 112.4 \\
\hline $\mathrm{B}(1)-\mathrm{C}(28)-\mathrm{H}(28)$ & 112.4 \\
\hline $\mathrm{Cu}(1)-\mathrm{C}(28)-\mathrm{H}(28)$ & 112.4 \\
\hline $\mathrm{C}(30)-\mathrm{C}(29)-\mathrm{C}(28)$ & $127.6(6)$ \\
\hline $\mathrm{C}(30)-\mathrm{C}(29)-\mathrm{H}(29)$ & 116.2 \\
\hline $\mathrm{C}(28)-\mathrm{C}(29)-\mathrm{H}(29)$ & 116.2 \\
\hline $\mathrm{C}(29)-\mathrm{C}(30)-\mathrm{H}(30 \mathrm{~A})$ & 120.0 \\
\hline $\mathrm{C}(29)-\mathrm{C}(30)-\mathrm{H}(30 \mathrm{~B})$ & 120.0 \\
\hline $\mathrm{H}(30 \mathrm{~A})-\mathrm{C}(30)-\mathrm{H}(30 \mathrm{~B})$ & 120.0 \\
\hline $\mathrm{O}(1)-\mathrm{C}(31)-\mathrm{C}(34)$ & $109.9(5)$ \\
\hline $\mathrm{O}(1)-\mathrm{C}(31)-\mathrm{C}(33)$ & $108.3(5)$ \\
\hline $\mathrm{C}(34)-\mathrm{C}(31)-\mathrm{C}(33)$ & $110.1(5)$ \\
\hline $\mathrm{O}(1)-\mathrm{C}(31)-\mathrm{C}(32)$ & $101.5(5)$ \\
\hline $\mathrm{C}(34)-\mathrm{C}(31)-\mathrm{C}(32)$ & $115.5(5)$ \\
\hline $\mathrm{C}(33)-\mathrm{C}(31)-\mathrm{C}(32)$ & $111.0(5)$ \\
\hline $\mathrm{O}(2)-\mathrm{C}(32)-\mathrm{C}(35)$ & $106.6(3)$ \\
\hline $\mathrm{O}(2)-\mathrm{C}(32)-\mathrm{C}(31)$ & $102.6(4)$ \\
\hline $\mathrm{C}(35)-\mathrm{C}(32)-\mathrm{C}(31)$ & $117.6(5)$ \\
\hline $\mathrm{O}(2)-\mathrm{C}(32)-\mathrm{C}(36)$ & $108.4(3)$ \\
\hline $\mathrm{C}(35)-\mathrm{C}(32)-\mathrm{C}(36)$ & $108.8(3)$ \\
\hline $\mathrm{C}(31)-\mathrm{C}(32)-\mathrm{C}(36)$ & $112.3(4)$ \\
\hline $\mathrm{C}(31)-\mathrm{C}(33)-\mathrm{H}(33 \mathrm{~A})$ & 109.5 \\
\hline $\mathrm{C}(31)-\mathrm{C}(33)-\mathrm{H}(33 \mathrm{~B})$ & 109.5 \\
\hline $\mathrm{H}(33 \mathrm{~A})-\mathrm{C}(33)-\mathrm{H}(33 \mathrm{~B})$ & 109.5 \\
\hline $\mathrm{C}(31)-\mathrm{C}(33)-\mathrm{H}(33 \mathrm{C})$ & 109.5 \\
\hline $\mathrm{H}(33 \mathrm{~A})-\mathrm{C}(33)-\mathrm{H}(33 \mathrm{C})$ & 109.5 \\
\hline
\end{tabular}




\begin{tabular}{|c|c|}
\hline $\mathrm{H}(33 \mathrm{~B})-\mathrm{C}(33)-\mathrm{H}(33 \mathrm{C})$ & 109.5 \\
\hline $\mathrm{C}(31)-\mathrm{C}(34)-\mathrm{H}(34 \mathrm{~A})$ & 109.5 \\
\hline $\mathrm{C}(31)-\mathrm{C}(34)-\mathrm{H}(34 \mathrm{~B})$ & 109.5 \\
\hline $\mathrm{H}(34 \mathrm{~A})-\mathrm{C}(34)-\mathrm{H}(34 \mathrm{~B})$ & 109.5 \\
\hline $\mathrm{C}(31)-\mathrm{C}(34)-\mathrm{H}(34 \mathrm{C})$ & 109.5 \\
\hline $\mathrm{H}(34 \mathrm{~A})-\mathrm{C}(34)-\mathrm{H}(34 \mathrm{C})$ & 109.5 \\
\hline $\mathrm{H}(34 \mathrm{~B})-\mathrm{C}(34)-\mathrm{H}(34 \mathrm{C})$ & 109.5 \\
\hline $\mathrm{C}(32)-\mathrm{C}(35)-\mathrm{H}(35 \mathrm{~A})$ & 109.5 \\
\hline $\mathrm{C}(32)-\mathrm{C}(35)-\mathrm{H}(35 \mathrm{~B})$ & 109.5 \\
\hline $\mathrm{H}(35 \mathrm{~A})-\mathrm{C}(35)-\mathrm{H}(35 \mathrm{~B})$ & 109.5 \\
\hline $\mathrm{C}(32)-\mathrm{C}(35)-\mathrm{H}(35 \mathrm{C})$ & 109.5 \\
\hline $\mathrm{H}(35 \mathrm{~A})-\mathrm{C}(35)-\mathrm{H}(35 \mathrm{C})$ & 109.5 \\
\hline $\mathrm{H}(35 \mathrm{~B})-\mathrm{C}(35)-\mathrm{H}(35 \mathrm{C})$ & 109.5 \\
\hline $\mathrm{C}(32)-\mathrm{C}(36)-\mathrm{H}(36 \mathrm{~A})$ & 109.5 \\
\hline $\mathrm{C}(32)-\mathrm{C}(36)-\mathrm{H}(36 \mathrm{~B})$ & 109.5 \\
\hline $\mathrm{H}(36 \mathrm{~A})-\mathrm{C}(36)-\mathrm{H}(36 \mathrm{~B})$ & 109.5 \\
\hline $\mathrm{C}(32)-\mathrm{C}(36)-\mathrm{H}(36 \mathrm{C})$ & 109.5 \\
\hline $\mathrm{H}(36 \mathrm{~A})-\mathrm{C}(36)-\mathrm{H}(36 \mathrm{C})$ & 109.5 \\
\hline $\mathrm{H}(36 \mathrm{~B})-\mathrm{C}(36)-\mathrm{H}(36 \mathrm{C})$ & 109.5 \\
\hline $\mathrm{C}(2 \mathrm{~S})-\mathrm{C}(1 \mathrm{~S})-\mathrm{H}(1 \mathrm{~S} 1)$ & 109.5 \\
\hline $\mathrm{C}(2 \mathrm{~S})-\mathrm{C}(1 \mathrm{~S})-\mathrm{H}(1 \mathrm{~S} 2)$ & 109.5 \\
\hline $\mathrm{H}(1 \mathrm{~S} 1)-\mathrm{C}(1 \mathrm{~S})-\mathrm{H}(1 \mathrm{~S} 2)$ & 109.5 \\
\hline $\mathrm{C}(2 \mathrm{~S})-\mathrm{C}(1 \mathrm{~S})-\mathrm{H}(1 \mathrm{~S} 3)$ & 109.5 \\
\hline $\mathrm{H}(1 \mathrm{~S} 1)-\mathrm{C}(1 \mathrm{~S})-\mathrm{H}(1 \mathrm{~S} 3)$ & 109.5 \\
\hline $\mathrm{H}(1 \mathrm{~S} 2)-\mathrm{C}(1 \mathrm{~S})-\mathrm{H}(1 \mathrm{~S} 3)$ & 109.5 \\
\hline $\mathrm{O}(1 \mathrm{~S})-\mathrm{C}(2 \mathrm{~S})-\mathrm{C}(1 \mathrm{~S})$ & $105.0(8)$ \\
\hline $\mathrm{O}(1 \mathrm{~S})-\mathrm{C}(2 \mathrm{~S})-\mathrm{H}(2 \mathrm{~S} 1)$ & 110.7 \\
\hline $\mathrm{C}(1 \mathrm{~S})-\mathrm{C}(2 \mathrm{~S})-\mathrm{H}(2 \mathrm{~S} 1)$ & 110.7 \\
\hline $\mathrm{O}(1 \mathrm{~S})-\mathrm{C}(2 \mathrm{~S})-\mathrm{H}(2 \mathrm{~S} 2)$ & 110.7 \\
\hline $\mathrm{C}(1 \mathrm{~S})-\mathrm{C}(2 \mathrm{~S})-\mathrm{H}(2 \mathrm{~S} 2)$ & 110.7 \\
\hline $\mathrm{H}(2 \mathrm{~S} 1)-\mathrm{C}(2 \mathrm{~S})-\mathrm{H}(2 \mathrm{~S} 2)$ & 108.8 \\
\hline $\mathrm{C}(2 \mathrm{~S})-\mathrm{O}(1 \mathrm{~S})-\mathrm{C}(3 \mathrm{~S})$ & $112.0(9)$ \\
\hline $\mathrm{O}(1 \mathrm{~S})-\mathrm{C}(3 \mathrm{~S})-\mathrm{C}(4 \mathrm{~S})$ & $104.9(8)$ \\
\hline $\mathrm{O}(1 \mathrm{~S})-\mathrm{C}(3 \mathrm{~S})-\mathrm{H}(3 \mathrm{~S} 1)$ & 110.8 \\
\hline $\mathrm{C}(4 \mathrm{~S})-\mathrm{C}(3 \mathrm{~S})-\mathrm{H}(3 \mathrm{~S} 1)$ & 110.8 \\
\hline $\mathrm{O}(1 \mathrm{~S})-\mathrm{C}(3 \mathrm{~S})-\mathrm{H}(3 \mathrm{~S} 2)$ & 110.8 \\
\hline $\mathrm{C}(4 \mathrm{~S})-\mathrm{C}(3 \mathrm{~S})-\mathrm{H}(3 \mathrm{~S} 2)$ & 110.8 \\
\hline $\mathrm{H}(3 \mathrm{~S} 1)-\mathrm{C}(3 \mathrm{~S})-\mathrm{H}(3 \mathrm{~S} 2)$ & 108.8 \\
\hline $\mathrm{C}(3 \mathrm{~S})-\mathrm{C}(4 \mathrm{~S})-\mathrm{H}(4 \mathrm{~S} 1)$ & 109.5 \\
\hline
\end{tabular}




$\begin{array}{ll}\text { C(3S)-C(4S)-H(4S2) } & 109.5 \\ \text { H(4S1)-C(4S)-H(4S2) } & 109.5 \\ \text { C(3S)-C(4S)-H(4S3) } & 109.5 \\ \text { H(4S1)-C(4S)-H(4S3) } & 109.5 \\ \text { H(4S2)-C(4S)-H(4S3) } & 109.5\end{array}$

Symmetry transformations used to generate equivalent atoms:

Table 12. Anisotropic displacement parameters $\left(\AA^{2} \mathrm{x} 10^{3}\right)$ for $\mathbf{C u}$-allyl-1b (branched). The anisotropic displacement factor exponent takes the form: $-2 p^{2}\left[h^{2} a^{* 2} U^{11}+\ldots+2 h k a^{*} b^{*} U^{12}\right]$

\begin{tabular}{|c|c|c|c|c|c|c|}
\hline & $\mathrm{U}^{11}$ & $\mathrm{U}^{22}$ & $\mathrm{U}^{33}$ & $\mathrm{U}^{23}$ & $\mathrm{U}^{13}$ & $\mathrm{U}^{12}$ \\
\hline $\mathrm{Cu}(1)$ & $48(1)$ & $56(1)$ & $43(1)$ & $-10(1)$ & 11(1) & $1(1)$ \\
\hline $\mathrm{O}(1)$ & 101(1) & $46(1)$ & $68(1)$ & $13(1)$ & $41(1)$ & 21(1) \\
\hline $\mathrm{O}(2)$ & $100(1)$ & $56(1)$ & $76(1)$ & $-4(1)$ & $47(1)$ & $-14(1)$ \\
\hline $\mathrm{N}(1)$ & $50(1)$ & $38(1)$ & $40(1)$ & $-1(1)$ & $12(1)$ & $-3(1)$ \\
\hline $\mathrm{N}(2)$ & $49(1)$ & $38(1)$ & $41(1)$ & $-1(1)$ & $14(1)$ & $-2(1)$ \\
\hline $\mathrm{B}(1)$ & $62(1)$ & $66(2)$ & $46(1)$ & $-12(1)$ & $12(1)$ & $-1(1)$ \\
\hline $\mathrm{C}(1)$ & $40(1)$ & $41(1)$ & $42(1)$ & $0(1)$ & $12(1)$ & $0(1)$ \\
\hline $\mathrm{C}(2)$ & $65(1)$ & $48(1)$ & $39(1)$ & $-4(1)$ & $15(1)$ & $-8(1)$ \\
\hline$C(3)$ & $66(1)$ & $43(1)$ & $42(1)$ & $-6(1)$ & $17(1)$ & $-7(1)$ \\
\hline $\mathrm{C}(4)$ & $51(1)$ & $38(1)$ & $44(1)$ & $0(1)$ & $15(1)$ & $-3(1)$ \\
\hline$C(5)$ & $50(1)$ & $47(1)$ & $50(1)$ & $0(1)$ & $16(1)$ & $-3(1)$ \\
\hline$C(6)$ & $60(1)$ & $54(1)$ & $63(1)$ & $1(1)$ & $24(1)$ & $-12(1)$ \\
\hline$C(7)$ & $80(2)$ & $41(1)$ & $67(1)$ & $4(1)$ & $29(1)$ & $-4(1)$ \\
\hline $\mathrm{C}(8)$ & $68(1)$ & $47(1)$ & $66(1)$ & $7(1)$ & $22(1)$ & $10(1)$ \\
\hline $\mathrm{C}(9)$ & $52(1)$ & $47(1)$ & $56(1)$ & $3(1)$ & $17(1)$ & $1(1)$ \\
\hline$C(10)$ & 49(1) & $58(1)$ & $70(2)$ & $4(1)$ & 19(1) & $1(1)$ \\
\hline $\mathrm{C}(11)$ & $72(2)$ & $120(3)$ & $73(2)$ & $-6(2)$ & $-1(1)$ & $23(2)$ \\
\hline $\mathrm{C}(12)$ & $85(2)$ & $110(2)$ & $88(2)$ & $5(2)$ & $38(2)$ & $34(2)$ \\
\hline$C(13)$ & $50(1)$ & $63(2)$ & $83(2)$ & $12(1)$ & $20(1)$ & $4(1)$ \\
\hline $\mathrm{C}(14)$ & $60(6)$ & $126(14)$ & $75(5)$ & $-3(7)$ & $27(4)$ & $-11(7)$ \\
\hline$C(15)$ & $67(7)$ & 111(9) & $109(9)$ & $-39(7)$ & $42(7)$ & $-13(5)$ \\
\hline $\mathrm{C}(14 \mathrm{X})$ & $63(4)$ & 171(11) & $86(4)$ & $20(5)$ & $37(3)$ & $7(5)$ \\
\hline$C(15 X)$ & $53(3)$ & $102(7)$ & $90(4)$ & $12(5)$ & $10(3)$ & $14(5)$ \\
\hline$C(16)$ & $51(1)$ & $38(1)$ & $41(1)$ & $-2(1)$ & $16(1)$ & $-4(1)$ \\
\hline $\mathrm{C}(17)$ & $49(1)$ & $54(1)$ & $47(1)$ & $-3(1)$ & $16(1)$ & $-6(1)$ \\
\hline $\mathrm{C}(18)$ & $62(1)$ & $61(1)$ & $53(1)$ & $-2(1)$ & $26(1)$ & $-14(1)$ \\
\hline
\end{tabular}




\begin{tabular}{|c|c|c|c|c|c|c|}
\hline $\mathrm{C}(19)$ & $83(2)$ & $45(1)$ & $54(1)$ & $4(1)$ & $27(1)$ & $-7(1)$ \\
\hline $\mathrm{C}(20)$ & $69(1)$ & $44(1)$ & $62(1)$ & $8(1)$ & $22(1)$ & $8(1)$ \\
\hline $\mathrm{C}(21)$ & $54(1)$ & $40(1)$ & $58(1)$ & $1(1)$ & $22(1)$ & $0(1)$ \\
\hline $\mathrm{C}(22)$ & $49(1)$ & $86(2)$ & $70(2)$ & $12(1)$ & 21(1) & $4(1)$ \\
\hline $\mathrm{C}(23)$ & $66(4)$ & $76(4)$ & $118(7)$ & $-17(4)$ & 19(4) & $5(3)$ \\
\hline$C(24)$ & $45(2)$ & 124(8) & $95(5)$ & $-31(5)$ & $20(2)$ & $-10(3)$ \\
\hline$C(23 X)$ & $66(4)$ & $76(4)$ & $118(7)$ & $-17(4)$ & 19(4) & $5(3)$ \\
\hline$C(24 X)$ & $98(9)$ & $85(9)$ & 77(7) & $-8(6)$ & $17(5)$ & $50(7)$ \\
\hline$C(25)$ & $54(1)$ & $53(1)$ & $76(2)$ & $7(1)$ & $28(1)$ & $6(1)$ \\
\hline$C(26)$ & $54(8)$ & $84(7)$ & $68(5)$ & $-6(4)$ & $35(5)$ & $1(5)$ \\
\hline $\mathrm{C}(27)$ & $65(6)$ & $104(12)$ & $84(7)$ & $-30(7)$ & $35(5)$ & $-22(7)$ \\
\hline$C(26 X)$ & $69(5)$ & $74(6)$ & 134(9) & $-24(5)$ & $43(5)$ & $-13(4)$ \\
\hline$C(27 X)$ & $65(8)$ & $64(5)$ & 121(10) & $-19(5)$ & $43(6)$ & $-4(4)$ \\
\hline $\mathrm{C}(28)$ & $61(3)$ & $55(3)$ & $44(2)$ & $-9(2)$ & $14(2)$ & $-8(2)$ \\
\hline $\mathrm{C}(29)$ & $81(3)$ & $93(3)$ & $45(2)$ & $-11(2)$ & $12(2)$ & $21(2)$ \\
\hline$C(30)$ & $91(4)$ & $142(7)$ & $77(4)$ & $-26(4)$ & $0(3)$ & $41(4)$ \\
\hline$C(28 X)$ & $58(4)$ & $48(5)$ & $39(4)$ & $0(3)$ & 12(3) & $0(3)$ \\
\hline$C(29 X)$ & $61(4)$ & $74(5)$ & $56(4)$ & $-10(3)$ & $14(3)$ & $0(3)$ \\
\hline$C(30 X)$ & $61(5)$ & 120(9) & $87(7)$ & $-18(7)$ & $13(4)$ & $10(5)$ \\
\hline $\mathrm{C}(31)$ & $79(3)$ & $50(2)$ & $70(3)$ & $-2(2)$ & $39(2)$ & 2(2) \\
\hline $\mathrm{C}(32)$ & $81(2)$ & $43(2)$ & $61(2)$ & $5(1)$ & $27(2)$ & $10(2)$ \\
\hline $\mathrm{C}(33)$ & $72(2)$ & 104(3) & 113(4) & $-34(3)$ & $31(2)$ & $-17(2)$ \\
\hline $\mathrm{C}(34)$ & $145(4)$ & 74(3) & $100(3)$ & $18(2)$ & $83(3)$ & $21(3)$ \\
\hline $\mathrm{C}(35)$ & $124(4)$ & $68(3)$ & $75(3)$ & $14(2)$ & $24(3)$ & $33(2)$ \\
\hline$C(36)$ & $92(2)$ & $66(2)$ & $83(2)$ & $-18(2)$ & $22(2)$ & $6(2)$ \\
\hline$C(31 X)$ & $45(4)$ & $43(4)$ & $43(4)$ & $-3(3)$ & $7(3)$ & 1(3) \\
\hline$C(32 X)$ & $100(9)$ & $46(7)$ & $67(8)$ & 11(6) & $45(7)$ & $30(6)$ \\
\hline$C(33 X)$ & $69(6)$ & 79(7) & $67(6)$ & $-11(5)$ & $6(5)$ & $2(5)$ \\
\hline$C(34 X)$ & $80(7)$ & $38(5)$ & $77(8)$ & $-1(5)$ & $29(7)$ & 1(4) \\
\hline$C(35 X)$ & $124(4)$ & $68(3)$ & $75(3)$ & $14(2)$ & $24(3)$ & $33(2)$ \\
\hline$C(36 X)$ & $92(2)$ & $66(2)$ & $83(2)$ & $-18(2)$ & $22(2)$ & $6(2)$ \\
\hline
\end{tabular}

Table 13. Hydrogen coordinates $\left(\mathrm{x} 10^{4}\right)$ and isotropic displacement parameters $\left(\AA^{2} \mathrm{x} 10^{3}\right)$ for $\mathbf{C u}-\mathbf{a l l y l} \mathbf{- 1 b}$ (branched)

\begin{tabular}{lrrrr}
\hline & $\mathrm{x}$ & $\mathrm{y}$ & $\mathrm{z}$ & $\mathrm{U}(\mathrm{eq})$ \\
\hline $\mathrm{H}(2)$ & & & & \\
$\mathrm{H}(3)$ & 3712 & 2944 & 3132 & 61 \\
& 3501 & 2072 & 3822 & 60
\end{tabular}




\begin{tabular}{|c|c|c|c|c|}
\hline $\mathrm{H}(6)$ & 6713 & 4621 & 4159 & 69 \\
\hline $\mathrm{H}(7)$ & 4911 & 5203 & 3703 & 73 \\
\hline $\mathrm{H}(8)$ & 2777 & 4925 & 3654 & 72 \\
\hline $\mathrm{H}(10)$ & 6520 & 3239 & 4797 & 70 \\
\hline $\mathrm{H}(11 \mathrm{~A})$ & 8621 & 3552 & 5712 & 141 \\
\hline $\mathrm{H}(11 \mathrm{~B})$ & 8182 & 4152 & 5410 & 141 \\
\hline $\mathrm{H}(11 \mathrm{C})$ & 7421 & 3826 & 5983 & 141 \\
\hline $\mathrm{H}(12 \mathrm{~A})$ & 6877 & 3376 & 3405 & 138 \\
\hline $\mathrm{H}(12 \mathrm{~B})$ & 7908 & 3848 & 3824 & 138 \\
\hline $\mathrm{H}(12 \mathrm{C})$ & 8265 & 3248 & 4159 & 138 \\
\hline $\mathrm{H}(13)$ & 1978 & 3627 & 4347 & 78 \\
\hline $\mathrm{H}(14 \mathrm{~A})$ & 32 & 3805 & 3255 & 129 \\
\hline $\mathrm{H}(14 \mathrm{~B})$ & 762 & 4259 & 2860 & 129 \\
\hline $\mathrm{H}(14 \mathrm{C})$ & 1195 & 3648 & 2838 & 129 \\
\hline $\mathrm{H}(15 \mathrm{~A})$ & 1932 & 4444 & 5211 & 138 \\
\hline $\mathrm{H}(15 \mathrm{~B})$ & 1091 & 4740 & 4313 & 138 \\
\hline $\mathrm{H}(15 \mathrm{C})$ & 439 & 4250 & 4686 & 138 \\
\hline $\mathrm{H}(14 \mathrm{D})$ & 696 & 4050 & 4797 & 155 \\
\hline $\mathrm{H}(14 \mathrm{E})$ & 2263 & 4025 & 5343 & 155 \\
\hline $\mathrm{H}(14 \mathrm{~F})$ & 1632 & 4559 & 4825 & 155 \\
\hline $\mathrm{H}(15 \mathrm{D})$ & 1100 & 3983 & 2633 & 127 \\
\hline $\mathrm{H}(15 \mathrm{E})$ & -66 & 3982 & 3094 & 127 \\
\hline $\mathrm{H}(15 \mathrm{~F})$ & 744 & 4520 & 3062 & 127 \\
\hline $\mathrm{H}(18)$ & 2104 & 1490 & 6656 & 68 \\
\hline $\mathrm{H}(19)$ & 4010 & 969 & 7195 & 71 \\
\hline $\mathrm{H}(20)$ & 5904 & 1146 & 6779 & 69 \\
\hline $\mathrm{H}(22)$ & 1673 & 2564 & 5073 & 81 \\
\hline $\mathrm{H}(23 \mathrm{~A})$ & 604 & 2917 & 6005 & 133 \\
\hline $\mathrm{H}(23 \mathrm{~B})$ & 1333 & 2497 & 6765 & 133 \\
\hline $\mathrm{H}(23 \mathrm{C})$ & 2199 & 2942 & 6460 & 133 \\
\hline $\mathrm{H}(24 \mathrm{~A})$ & 415 & 1723 & 4779 & 132 \\
\hline $\mathrm{H}(24 \mathrm{~B})$ & 183 & 1760 & 5734 & 132 \\
\hline $\mathrm{H}(24 \mathrm{C})$ & -503 & 2188 & 4977 & 132 \\
\hline $\mathrm{H}(23 \mathrm{D})$ & -308 & 2380 & 4886 & 133 \\
\hline $\mathrm{H}(23 \mathrm{E})$ & 556 & 1976 & 4496 & 133 \\
\hline $\mathrm{H}(23 \mathrm{~F})$ & 149 & 1817 & 5361 & 133 \\
\hline $\mathrm{H}(24 \mathrm{D})$ & 2290 & 2792 & 6803 & 133 \\
\hline $\mathrm{H}(24 \mathrm{E})$ & 756 & 2923 & 6265 & 133 \\
\hline $\mathrm{H}(24 \mathrm{~F})$ & 1129 & 2379 & 6817 & 133 \\
\hline
\end{tabular}




\begin{tabular}{|c|c|c|c|c|}
\hline $\mathrm{H}(25)$ & 6227 & 2190 & 5266 & 71 \\
\hline $\mathrm{H}(26 \mathrm{~A})$ & 7527 & 1457 & 5086 & 98 \\
\hline $\mathrm{H}(26 \mathrm{~B})$ & 6884 & 1095 & 5686 & 98 \\
\hline $\mathrm{H}(26 \mathrm{C})$ & 5966 & 1305 & 4735 & 98 \\
\hline $\mathrm{H}(27 \mathrm{~A})$ & 7389 & 2342 & 6841 & 123 \\
\hline $\mathrm{H}(27 \mathrm{~B})$ & 7752 & 1721 & 6978 & 123 \\
\hline $\mathrm{H}(27 \mathrm{C})$ & 8420 & 2082 & 6391 & 123 \\
\hline $\mathrm{H}(26 \mathrm{D})$ & 8183 & 2274 & 6180 & 135 \\
\hline $\mathrm{H}(26 \mathrm{E})$ & 6986 & 2556 & 6443 & 135 \\
\hline $\mathrm{H}(26 \mathrm{~F})$ & 7660 & 2023 & 6946 & 135 \\
\hline $\mathrm{H}(27 \mathrm{D})$ & 6332 & 1184 & 4958 & 120 \\
\hline $\mathrm{H}(27 \mathrm{E})$ & 7725 & 1497 & 5145 & 120 \\
\hline $\mathrm{H}(27 \mathrm{~F})$ & 7429 & 1158 & 5923 & 120 \\
\hline $\mathrm{H}(28)$ & 6119 & 4023 & 7435 & 64 \\
\hline $\mathrm{H}(29)$ & 5697 & 3046 & 8241 & 89 \\
\hline $\mathrm{H}(30 \mathrm{~A})$ & 8064 & 3356 & 7907 & 131 \\
\hline $\mathrm{H}(30 \mathrm{~B})$ & 7858 & 2833 & 8482 & 131 \\
\hline $\mathrm{H}(28 \mathrm{X})$ & 5406 & 3189 & 8047 & 59 \\
\hline $\mathrm{H}(29 \mathrm{X})$ & 6652 & 4079 & 7471 & 77 \\
\hline $\mathrm{H}(30 \mathrm{C})$ & 7919 & 3128 & 8179 & 110 \\
\hline $\mathrm{H}(30 \mathrm{D})$ & 8634 & 3669 & 7940 & 110 \\
\hline $\mathrm{H}(33 \mathrm{~A})$ & 518 & 4237 & 7333 & 143 \\
\hline $\mathrm{H}(33 \mathrm{~B})$ & 1482 & 3998 & 6812 & 143 \\
\hline $\mathrm{H}(33 \mathrm{C})$ & 911 & 3618 & 7427 & 143 \\
\hline $\mathrm{H}(34 \mathrm{~A})$ & 1387 & 4343 & 8988 & 144 \\
\hline $\mathrm{H}(34 \mathrm{~B})$ & 1758 & 3721 & 9078 & 144 \\
\hline $\mathrm{H}(34 \mathrm{C})$ & 2885 & 4157 & 9518 & 144 \\
\hline $\mathrm{H}(35 \mathrm{~A})$ & 1653 & 5192 & 7819 & 136 \\
\hline $\mathrm{H}(35 \mathrm{~B})$ & 2795 & 5355 & 7387 & 136 \\
\hline $\mathrm{H}(35 \mathrm{C})$ & 1690 & 4918 & 6910 & 136 \\
\hline $\mathrm{H}(36 \mathrm{~A})$ & 3502 & 4987 & 9256 & 122 \\
\hline $\mathrm{H}(36 \mathrm{~B})$ & 4688 & 4594 & 9215 & 122 \\
\hline $\mathrm{H}(36 \mathrm{C})$ & 4549 & 5171 & 8757 & 122 \\
\hline $\mathrm{H}(33 \mathrm{D})$ & 1408 & 4076 & 6627 & 113 \\
\hline $\mathrm{H}(33 \mathrm{E})$ & 481 & 4489 & 6944 & 113 \\
\hline $\mathrm{H}(33 \mathrm{~F})$ & 1388 & 4692 & 6356 & 113 \\
\hline $\mathrm{H}(34 \mathrm{D})$ & 3103 & 5190 & 8501 & 6 \\
\hline $\mathrm{H}(34 \mathrm{E})$ & 2409 & 5376 & 7493 & 96 \\
\hline $\mathrm{H}(34 \mathrm{~F})$ & 1501 & 5173 & 8081 & 96 \\
\hline
\end{tabular}




\begin{tabular}{lrrrr}
$\mathrm{H}(35 \mathrm{D})$ & 2963 & 4618 & 9517 & 136 \\
$\mathrm{H}(35 \mathrm{E})$ & 3606 & 4036 & 9738 & 136 \\
$\mathrm{H}(35 \mathrm{~F})$ & 4318 & 4474 & 9297 & 136 \\
$\mathrm{H}(36 \mathrm{D})$ & 889 & 3739 & 7753 & 122 \\
$\mathrm{H}(36 \mathrm{E})$ & 1573 & 3524 & 8746 & 122 \\
$\mathrm{H}(36 \mathrm{~F})$ & 754 & 4074 & 8586 & 122 \\
$\mathrm{H}(1 \mathrm{~S} 1)$ & 2785 & 5050 & 1613 & 190 \\
$\mathrm{H}(1 \mathrm{~S} 2)$ & 2586 & 5156 & 579 & 190 \\
$\mathrm{H}(1 \mathrm{~S} 3)$ & 1888 & 5542 & 1114 & 190 \\
$\mathrm{H}(2 \mathrm{~S} 1)$ & 1191 & 4451 & 730 & 136 \\
$\mathrm{H}(2 \mathrm{~S} 2)$ & 489 & 4840 & 1269 & 136 \\
$\mathrm{H}(3 \mathrm{~S} 1)$ & -1678 & 4695 & 0 & 124 \\
$\mathrm{H}(3 \mathrm{~S} 2)$ & -819 & 4316 & -445 & 124 \\
$\mathrm{H}(4 \mathrm{~S} 1)$ & -2619 & 4742 & -1622 & 199 \\
$\mathrm{H}(4 \mathrm{~S} 2)$ & -2051 & 5317 & -1244 & 199 \\
$\mathrm{H}(4 \mathrm{~S} 3)$ & -1197 & 4940 & -1687 & 199 \\
& & & & \\
\hline
\end{tabular}

Table 14. Torsion angles $\left[{ }^{\circ}\right]$ for $\mathbf{C u}$-allyl-1b (branched)

\begin{tabular}{lc}
\hline $\mathrm{C}(31)-\mathrm{O}(1)-\mathrm{B}(1)-\mathrm{O}(2)$ & $5.8(3)$ \\
$\mathrm{C}(31)-\mathrm{O}(1)-\mathrm{B}(1)-\mathrm{C}(28)$ & $-176.0(4)$ \\
$\mathrm{C}(32)-\mathrm{O}(2)-\mathrm{B}(1)-\mathrm{O}(1)$ & $16.5(3)$ \\
$\mathrm{C}(32)-\mathrm{O}(2)-\mathrm{B}(1)-\mathrm{C}(28)$ & $-162.1(3)$ \\
$\mathrm{C}(2)-\mathrm{N}(1)-\mathrm{C}(1)-\mathrm{N}(2)$ & $-0.4(2)$ \\
$\mathrm{C}(4)-\mathrm{N}(1)-\mathrm{C}(1)-\mathrm{N}(2)$ & $-178.37(16)$ \\
$\mathrm{C}(2)-\mathrm{N}(1)-\mathrm{C}(1)-\mathrm{Cu}(1)$ & $176.12(14)$ \\
$\mathrm{C}(4)-\mathrm{N}(1)-\mathrm{C}(1)-\mathrm{Cu}(1)$ & $-1.9(3)$ \\
$\mathrm{C}(3)-\mathrm{N}(2)-\mathrm{C}(1)-\mathrm{N}(1)$ & $0.3(2)$ \\
$\mathrm{C}(16)-\mathrm{N}(2)-\mathrm{C}(1)-\mathrm{N}(1)$ & $177.22(16)$ \\
$\mathrm{C}(3)-\mathrm{N}(2)-\mathrm{C}(1)-\mathrm{Cu}(1)$ & $-176.23(14)$ \\
$\mathrm{C}(16)-\mathrm{N}(2)-\mathrm{C}(1)-\mathrm{Cu}(1)$ & $0.7(3)$ \\
$\mathrm{C}(1)-\mathrm{N}(1)-\mathrm{C}(2)-\mathrm{C}(3)$ & $0.4(2)$ \\
$\mathrm{C}(4)-\mathrm{N}(1)-\mathrm{C}(2)-\mathrm{C}(3)$ & $178.43(18)$ \\
$\mathrm{N}(1)-\mathrm{C}(2)-\mathrm{C}(3)-\mathrm{N}(2)$ & $-0.2(2)$ \\
$\mathrm{C}(1)-\mathrm{N}(2)-\mathrm{C}(3)-\mathrm{C}(2)$ & $0.0(2)$ \\
$\mathrm{C}(16)-\mathrm{N}(2)-\mathrm{C}(3)-\mathrm{C}(2)$ & $-177.06(17)$ \\
$\mathrm{C}(1)-\mathrm{N}(1)-\mathrm{C}(4)-\mathrm{C}(5)$ & $89.1(2)$ \\
$\mathrm{C}(2)-\mathrm{N}(1)-\mathrm{C}(4)-\mathrm{C}(5)$ & $-88.7(2)$ \\
&
\end{tabular}




\begin{tabular}{|c|c|}
\hline $\mathrm{C}(1)-\mathrm{N}(1)-\mathrm{C}(4)-\mathrm{C}(9)$ & $-94.4(2)$ \\
\hline $\mathrm{C}(2)-\mathrm{N}(1)-\mathrm{C}(4)-\mathrm{C}(9)$ & $87.8(2)$ \\
\hline$C(9)-C(4)-C(5)-C(6)$ & $-2.1(3)$ \\
\hline $\mathrm{N}(1)-\mathrm{C}(4)-\mathrm{C}(5)-\mathrm{C}(6)$ & $174.27(18)$ \\
\hline $\mathrm{C}(9)-\mathrm{C}(4)-\mathrm{C}(5)-\mathrm{C}(10)$ & $176.5(2)$ \\
\hline $\mathrm{N}(1)-\mathrm{C}(4)-\mathrm{C}(5)-\mathrm{C}(10)$ & $-7.1(3)$ \\
\hline $\mathrm{C}(4)-\mathrm{C}(5)-\mathrm{C}(6)-\mathrm{C}(7)$ & $0.4(3)$ \\
\hline$C(10)-C(5)-C(6)-C(7)$ & $-178.2(2)$ \\
\hline$C(5)-C(6)-C(7)-C(8)$ & $1.2(4)$ \\
\hline $\mathrm{C}(6)-\mathrm{C}(7)-\mathrm{C}(8)-\mathrm{C}(9)$ & $-1.2(4)$ \\
\hline$C(7)-C(8)-C(9)-C(4)$ & $-0.4(3)$ \\
\hline $\mathrm{C}(7)-\mathrm{C}(8)-\mathrm{C}(9)-\mathrm{C}(13)$ & $177.1(2)$ \\
\hline$C(5)-C(4)-C(9)-C(8)$ & $2.1(3)$ \\
\hline $\mathrm{N}(1)-\mathrm{C}(4)-\mathrm{C}(9)-\mathrm{C}(8)$ & $-174.24(19)$ \\
\hline $\mathrm{C}(5)-\mathrm{C}(4)-\mathrm{C}(9)-\mathrm{C}(13)$ & $-175.3(2)$ \\
\hline $\mathrm{N}(1)-\mathrm{C}(4)-\mathrm{C}(9)-\mathrm{C}(13)$ & $8.3(3)$ \\
\hline $\mathrm{C}(4)-\mathrm{C}(5)-\mathrm{C}(10)-\mathrm{C}(11)$ & $-117.5(3)$ \\
\hline $\mathrm{C}(6)-\mathrm{C}(5)-\mathrm{C}(10)-\mathrm{C}(11)$ & $61.0(3)$ \\
\hline $\mathrm{C}(4)-\mathrm{C}(5)-\mathrm{C}(10)-\mathrm{C}(12)$ & $118.8(3)$ \\
\hline $\mathrm{C}(6)-\mathrm{C}(5)-\mathrm{C}(10)-\mathrm{C}(12)$ & $-62.6(3)$ \\
\hline $\mathrm{C}(8)-\mathrm{C}(9)-\mathrm{C}(13)-\mathrm{C}(14)$ & $73.4(12)$ \\
\hline$C(4)-C(9)-C(13)-C(14)$ & $-109.2(12)$ \\
\hline $\mathrm{C}(8)-\mathrm{C}(9)-\mathrm{C}(13)-\mathrm{C}(15)$ & $-50.0(10)$ \\
\hline$C(4)-C(9)-C(13)-C(15)$ & $127.3(10)$ \\
\hline $\mathrm{C}(1)-\mathrm{N}(2)-\mathrm{C}(16)-\mathrm{C}(17)$ & $85.9(2)$ \\
\hline $\mathrm{C}(3)-\mathrm{N}(2)-\mathrm{C}(16)-\mathrm{C}(17)$ & $-97.5(2)$ \\
\hline $\mathrm{C}(1)-\mathrm{N}(2)-\mathrm{C}(16)-\mathrm{C}(21)$ & $-96.6(2)$ \\
\hline $\mathrm{C}(3)-\mathrm{N}(2)-\mathrm{C}(16)-\mathrm{C}(21)$ & $80.0(2)$ \\
\hline$C(21)-C(16)-C(17)-C(18)$ & $-0.8(3)$ \\
\hline $\mathrm{N}(2)-\mathrm{C}(16)-\mathrm{C}(17)-\mathrm{C}(18)$ & 176.61(18) \\
\hline$C(21)-C(16)-C(17)-C(22)$ & $177.4(2)$ \\
\hline $\mathrm{N}(2)-\mathrm{C}(16)-\mathrm{C}(17)-\mathrm{C}(22)$ & $-5.2(3)$ \\
\hline $\mathrm{C}(16)-\mathrm{C}(17)-\mathrm{C}(18)-\mathrm{C}(19)$ & $0.9(3)$ \\
\hline $\mathrm{C}(22)-\mathrm{C}(17)-\mathrm{C}(18)-\mathrm{C}(19)$ & $-177.3(2)$ \\
\hline $\mathrm{C}(17)-\mathrm{C}(18)-\mathrm{C}(19)-\mathrm{C}(20)$ & $-0.2(4)$ \\
\hline $\mathrm{C}(18)-\mathrm{C}(19)-\mathrm{C}(20)-\mathrm{C}(21)$ & $-0.7(4)$ \\
\hline$C(17)-C(16)-C(21)-C(20)$ & $-0.1(3)$ \\
\hline $\mathrm{N}(2)-\mathrm{C}(16)-\mathrm{C}(21)-\mathrm{C}(20)$ & $-177.44(19)$ \\
\hline$C(17)-C(16)-C(21)-C(25)$ & $-179.4(2)$ \\
\hline
\end{tabular}




$\begin{array}{lc}\mathrm{N}(2)-\mathrm{C}(16)-\mathrm{C}(21)-\mathrm{C}(25) & 3.3(3) \\ \mathrm{C}(19)-\mathrm{C}(20)-\mathrm{C}(21)-\mathrm{C}(16) & 0.8(3) \\ \mathrm{C}(19)-\mathrm{C}(20)-\mathrm{C}(21)-\mathrm{C}(25) & -179.9(2) \\ \mathrm{C}(16)-\mathrm{C}(17)-\mathrm{C}(22)-\mathrm{C}(23) & -105.2(7) \\ \mathrm{C}(18)-\mathrm{C}(17)-\mathrm{C}(22)-\mathrm{C}(23) & 72.9(7) \\ \mathrm{C}(16)-\mathrm{C}(17)-\mathrm{C}(22)-\mathrm{C}(24) & 132.6(5) \\ \mathrm{C}(18)-\mathrm{C}(17)-\mathrm{C}(22)-\mathrm{C}(24) & -49.3(6) \\ \mathrm{C}(16)-\mathrm{C}(21)-\mathrm{C}(25)-\mathrm{C}(26) & -121.8(10) \\ \mathrm{C}(20)-\mathrm{C}(21)-\mathrm{C}(25)-\mathrm{C}(26) & 58.9(10) \\ \mathrm{C}(16)-\mathrm{C}(21)-\mathrm{C}(25)-\mathrm{C}(27) & 119.0(12) \\ \mathrm{C}(20)-\mathrm{C}(21)-\mathrm{C}(25)-\mathrm{C}(27) & -60.3(13) \\ \mathrm{O}(1)-\mathrm{B}(1)-\mathrm{C}(28)-\mathrm{C}(29) & -20.1(6) \\ \mathrm{O}(2)-\mathrm{B}(1)-\mathrm{C}(28)-\mathrm{C}(29) & 158.1(3) \\ \mathrm{O}(1)-\mathrm{B}(1)-\mathrm{C}(28)-\mathrm{Cu}(1) & 85.6(4) \\ \mathrm{O}(2)-\mathrm{B}(1)-\mathrm{C}(28)-\mathrm{Cu}(1) & -96.2(3) \\ \mathrm{B}(1)-\mathrm{C}(28)-\mathrm{C}(29)-\mathrm{C}(30) & -153.3(5) \\ \mathrm{Cu}(1)-\mathrm{C}(28)-\mathrm{C}(29)-\mathrm{C}(30) & 96.2(5) \\ \mathrm{B}(1)-\mathrm{O}(1)-\mathrm{C}(31)-\mathrm{C}(34) & -145.7(4) \\ \mathrm{B}(1)-\mathrm{O}(1)-\mathrm{C}(31)-\mathrm{C}(33) & 93.9(4) \\ \mathrm{B}(1)-\mathrm{O}(1)-\mathrm{C}(31)-\mathrm{C}(32) & -174.1(9) \\ \mathrm{B}(1)-\mathrm{O}(2)-\mathrm{C}(32)-\mathrm{C}(35) & -23.0(4) \\ \mathrm{B}(1)-\mathrm{O}(2)-\mathrm{C}(32)-\mathrm{C}(31) & -154.0(3) \\ \mathrm{B}(1)-\mathrm{O}(2)-\mathrm{C}(32)-\mathrm{C}(36) & -29.8(4) \\ \mathrm{O}(1)-\mathrm{C}(31)-\mathrm{C}(32)-\mathrm{O}(2) & 89.1(3) \\ \mathrm{C}(34)-\mathrm{C}(31)-\mathrm{C}(32)-\mathrm{O}(2) & 32.1(4) \\ \mathrm{C}(33)-\mathrm{C}(31)-\mathrm{C}(32)-\mathrm{O}(2) & 150.9(5) \\ \mathrm{O}(1)-\mathrm{C}(31)-\mathrm{C}(32)-\mathrm{C}(35) & -82.8(6) \\ \mathrm{C}(34)-\mathrm{C}(31)-\mathrm{C}(32)-\mathrm{C}(35) & 148.6(4) \\ \mathrm{C}(33)-\mathrm{C}(31)-\mathrm{C}(32)-\mathrm{C}(35) & -92.5(6) \\ \mathrm{O}(1)-\mathrm{C}(31)-\mathrm{C}(32)-\mathrm{C}(36) & \\ \mathrm{C}(34)-\mathrm{C}(31)-\mathrm{C}(32)-\mathrm{C}(36) & \\ \mathrm{C}(33)-\mathrm{C}(31)-\mathrm{C}(32)-\mathrm{C}(36) & \\ \mathrm{C}(1 \mathrm{~S})-\mathrm{C}(2 \mathrm{~S})-\mathrm{O}(1 \mathrm{~S})-\mathrm{C}(3 \mathrm{~S}) & \\ \mathrm{C}(2 \mathrm{~S})-\mathrm{O}(1 \mathrm{~S})-\mathrm{C}(3 \mathrm{~S})-\mathrm{C}(4 \mathrm{~S}) & \\ & \\ & \\ & \end{array}$

Symmetry transformations used to generate equivalent atoms: 


\section{References}

1. Malachowski, W. P., Tie, C., Wang, K. \& Broadrup, R. L. J. Org. Chem. 67, 8962-8969 (2002).

2. Zhao, T. S. N., Yang, Y., Lessing, T. \& Szabó, K. J. J. Am. Chem. Soc. 136, 7563-7566 (2014).

3. Meng, F., McGrath, K. P. \& Hoveyda, A. H. Nature 513, 367-374 (2014).

4. Shi, Y., Jung, B., Torker, S. \& Hoveyda, A. H. J. Am. Chem. Soc. 137, 8948-8964 (2015).

5. Koh, M. J., Nguyen, T. T., Zhang, H., Schrock R. R. \& Hoveyda, A. H. Nature 531, 459-465 (2016).

6. Koh, M. J., Khan, R. K. M., Torker, S., Yu, M., Mikus, M. S. \& Hoveyda, A. H. Nature 517, 181-186 (2015).

7. Jung B. \& Hoveyda, A. H. J. Am. Chem. Soc. 134, 1490-1493 (2012).

8. Kacprzynski, M. A., May, T. L., Kazane, S. A. \& Hoveyda, A. H. Angew. Chem. Int. Ed. 46, 4554-4558 (2007).

9. Shi, Y. \& Hoveyda, A. H. Angew. Chem. Int. Ed. 55, 3455-3458 (2016).

10. Hojo, M., Sakuragi, R., Okabe, S. \& Hosomi, A. Chem. Commun. 4, 357-358 (2001).

11. Murahashi, S., Taniguchi, Y., Imada, Y. \& Tanigawa, Y. J. Org. Chem. 54, 3292-3303 (1989).

12. Akiyama, K., Gao, F. \& Hoveyda, A. H. Angew. Chem. Int. Ed. 49, 429-433 (2010).

13. Delvos, L. B., Vyas, D. J. \& Oestreich, M. Angew. Chem. Int. Ed. 52, 4650-4653 (2013).

14. Lee, J., Torker, S. \& Hoveyda, A. H. Angew. Chem. Int. Ed. 56, 821-826 (2017).

15. Spoehrle, S. S. M., West, T. H., Taylor, J. E., Slawin, A. M. Z. \& Smith, A. D. J. Am. Chem. Soc. 139, 11895-11902 (2017).

16. Chen, M. \& Hartwig, J. F. Angew. Chem. Int.Ed. 55, 11651-11655 (2016).

17. Shintani, R., Fujie, R., Takeda, M. \& Nozaki, K. Angew. Chem. Int. Ed. 53, 6546-6549 (2014).

18. Gao, F., McGrath, K. P., Lee, Y. \& Hoveyda, A. H. J. Am. Chem. Soc. 132, 14315-14320 (2010).

19. Takeda, M., Takatsu, K., Shintani, R. \& Hayashi, T. J. Org. Chem. 79, 2354-2367 (2014).

20. Takeda, M., Shintani, R. \& Hayashi, T. J. Org. Chem. 78, 50075017 (2013).

21. Yamamoto, Y. Adv. Synth. Catal. 352, 478-492 (2010).

22. Mankad, N. P., Laitar, D. S. \& Sadighi, J. P. Organometallics 23, 33693371 (2004).

23. Arakawa, Y., Goto, T., Kawase, K. \& Yushifuji, S. Chem. Pharm. Bull. Jpn. 43, 535-536 (1995).

24. Ishikawa, F., Kosasayama, A., Nakamura, S. \& Konno, T. Chem. Pharm. Bull. Jpn. 26, 3658-3665 (1978).

25. Cramer, C. J. \& Truhlar, D. G. Density functional theory for transition metals and transition metal chemistry. Phys.

Chem. Chem. Phys. 11, 10757-10816 (2009).

26. Grimme, S., Ehrlich, S. \& Goerigk, L. Effect of the damping function in dispersion corrected density functional theory.

J. Comp. Chem. 32, 1456-1465 (2011).

27. Peverati, R. \& Truhlar, D. G. Quest for a universal density functional: the accuracy of density functionals across a broad spectrum of databases in chemistry and physics. Phil. Trans. R. Soc. A 372, 20120476 (2014).

28. Frisch, M. J.; Trucks, G. W.; Schlegel, H. B.; Scuseria, G. E.; Robb, M. A.; Cheeseman, J. R.; Scalmani, G.; Barone, V.; Mennucci, B.; Petersson, G. A.; Nakatsuji, H.; Caricato, M.; Li, X.; Hratchian, H. P.; Izmaylov, A. F.; Bloino, J.; Zheng, G.; Sonnenberg, J. L.; Hada, M.; Ehara, M.; Toyota, K.; Fukuda, R.; Hasegawa, J.; Ishida, M.; Nakajima, T.; Honda, Y.; Kitao, O.; Nakai, H.; Vreven, T.; Montgomery, Jr., J. A.; Peralta, J. E.; Ogliaro, F.; Bearpark, M.; Heyd, J. J.; Brothers, E.; Kudin, K. N.; Staroverov, V. N.; Kobayashi, R.; Normand, J.; Raghavachari, K.; Rendell, A.; Burant, J. C.; Iyengar, S. S.; Tomasi, J.; Cossi, M.; Rega, N.; Millam, J. M.; Klene, M.; Knox, J. E.; Cross, J. B.; Bakken, V.; Adamo, C.; Jaramillo, J.; Gomperts, R.; Stratmann, R. E.; Yazyev, O.; Austin, A. J.; Cammi, R.; Pomelli, C.; Ochterski, J. W.; Martin, 
R. L.; Morokuma, K.; Zakrzewski, V. G.; Voth, G. A.; Salvador, P.; Dannenberg, J. J.; Dapprich, S.; Daniels, A. D.; Farkas, Ö.; Foresman, J. B.; Ortiz, J. V.; Cioslowski, J.; Fox, D. J. Gaussian 09, Revision D.01, Gaussian, Inc., Wallingford CT, 2009.

29. Neese, F. The ORCA program system. Wiley Interdisciplinary Reviews: Computational Molecular Science, 2, 73-78 (2012).

30. Mardirossian, N. \& Head-Gordon, M. $\omega$ B97M-V: A combinatorially optimized, range-separated hybrid, meta-GGA density functional with VV10 nonlocal correlation. J. Chem. Phys. 144, 214110 (2016).

31. Zhao, Y. \& Truhlar, D. G. Density Functionals with Broad Applicability in Chemistry. Acc. Chem. Res. 41, 157-167 (2008).

32. Weigend, F. \& Ahlrichs, R. Balanced basis sets of split valence, triple zeta valence and quadruple zeta valence quality for $\mathrm{H}$ to Rn: Design and assessment of accuracy. Phys. Chem. Chem. Phys. 7, 3297-3305 (2005).

33. Weigend, F. Accurate Coulomb-fitting basis sets for H to Rn. Phys. Chem. Chem. Phys., 8, 1057-1065 (2006).

34. Marenich, A. V., Cramer, C. J. \& Truhlar, D. G. J. Phys. Chem. B 113, 6378-6396 (2009).

35. Page, M. \& McIver Jr., J. W. J. Chem. Phys. 88, 922-935 (1988).

36. Page, M., Doubleday Jr., C. \& McIver Jr., J. W. J. Chem. Phys. 93, 5634-5642 (1990).

37. Weymuth, T., Couzijn, E. P. A., Chen, P. \& Reiher, M. J. Chem. Theory Comput. 10, 3092-3103 (2014).

38. Mardirossian, N. \& Head-Gordon, M. J. Chem. Theory Comput. 12, 4303-4325 (2016).

39. Brauer, B., Kesharwani, M. K., Kozuch, S. \& Martin, J. M. Phys. Chem. Chem. Phys. 18, 20905-20925 (2018).

40. Yu, H. S., He, X., Li, S. L. \& Truhlar, Chem. Sci. 7, 5032-5051 (2016).

41. Mardirossian, N. \& Head-Gordon, M. Molecular Physics 115, 2315-2372 (2017).

42. Goerigk, L., Hansen, A., Bauer, C., Ehrlich, S., Najibi, A. \& Grimme, S. Phys. Chem. Chem. Phys. 19, 32184-32215 (2017).

43. Torker, S., Merki, D. \& Chen. P. J. Am. Chem. Soc. 130, 4808-4814 (2008).

44. Minenkov, Y., Occhipinti, G., Singstad, A. \& Jensen, V. R. Dalton Trans. 41, 5526-5541 (2012).

45. Minenkov, Y., Occhipinti, G. \& Jensen, V. R. Organometallics 32, 2099-2111 (2013).

46. Khan, R. K. M., Torker, S. \& Hoveyda, A. H. J. Am. Chem. Soc. 136, 14337-14340 (2014).

47. Yang, L., Adam, C., Nichol, G. S. \& Cockroft, S. L. Nat. Chem. 5, 1006-1010 (2013).

48. Pollice, R., Bot, M., Kobylianskii, I. J., Shenderovich, I. \& Chen, P. J. Am. Chem. Soc. 139, 13126-13140 (2017).

49. Chai, J.-D. \& Head-Gordon, M. Phys. Chem. Chem. Phys., 10, 6615-6620 (2008).

50. Lichtenberger, D. L. \& Gladysz, J. A. Organometallics 33, 835-835 (2014).

51. Yoshikai, N. \& Nakamura, E. Chem. Rev. 112, 2339-2372 (2012).

52. Zhou, Y., Shi, Y., Torker, S. \& Hoveyda, A. H. J. Am. Chem. Soc. 140, 16842-16854 (2018).

53. Meng, F., Li, X., Torker, S., Shi, Y., Shen, X. \& Hoveyda, A. H. Nature 537, 387-393 (2016).

54. Li, X., Meng, F., Torker, S., Shi, Y. \& Hoveyda, A. H. Angew. Chem. Int. Ed. 55, 9997-10002 (2016).

55. Huang, Y., Torker, S., Li, X., del Pozo, J. \& Hoveyda, A. H. Angew. Chem. Int. Ed. 58, 2685-2691 (2018).

56. Iwamoto, H., Imamoto, T. \& Ito, H. Nat. Commun. 9, 2290-2299 (2018).

57. Jang, H., Filippo Romiti, F., Torker, S. \& Hoveyda, A. H. Nat. Chem. 9, 1269-1275 (2017).

58. Lee, J., Radomkit, S., Torker, S., del Pozo, J. \& Hoveyda, A. H. Nat. Chem. 9, 1269-1275 (2017).

59. Zhang, S., del Pozo, J., Romiti, F., Mu, Y., Torker, S., \& Hoveyda, A. H. Science 364, 45-51 (2019). 